
Andrea Bazarian Vosgueritchian

\section{INFRAESTRUTURA E PROJETOS DE REGENERAÇÃO URBANA}

Tese apresentada à Faculdade de Arquitetura e Urbanismo da Universidade de São Paulo para a obtenção do título de Doutor em Arquitetura e Urbanismo

Área de Concentração: Planejamento Urbano e Regional Orientador: Prof. Dr. Ricardo Toledo e Silva 
Autorizo a reprodução e divulgação total ou parcial deste trabalho, por qualquer meio convencional ou eletrônico, para fins de estudo e pesquisa, desde que citada a fonte.

e-mailda autora: bazarian@gmail.com

Exemplar revisado e alterado em relação à versão original, sob responsabilidade do autor e anuência do orientador. O original se encontra disponível na sede do programa.

São Paulo, 25 de novembro de 2015.

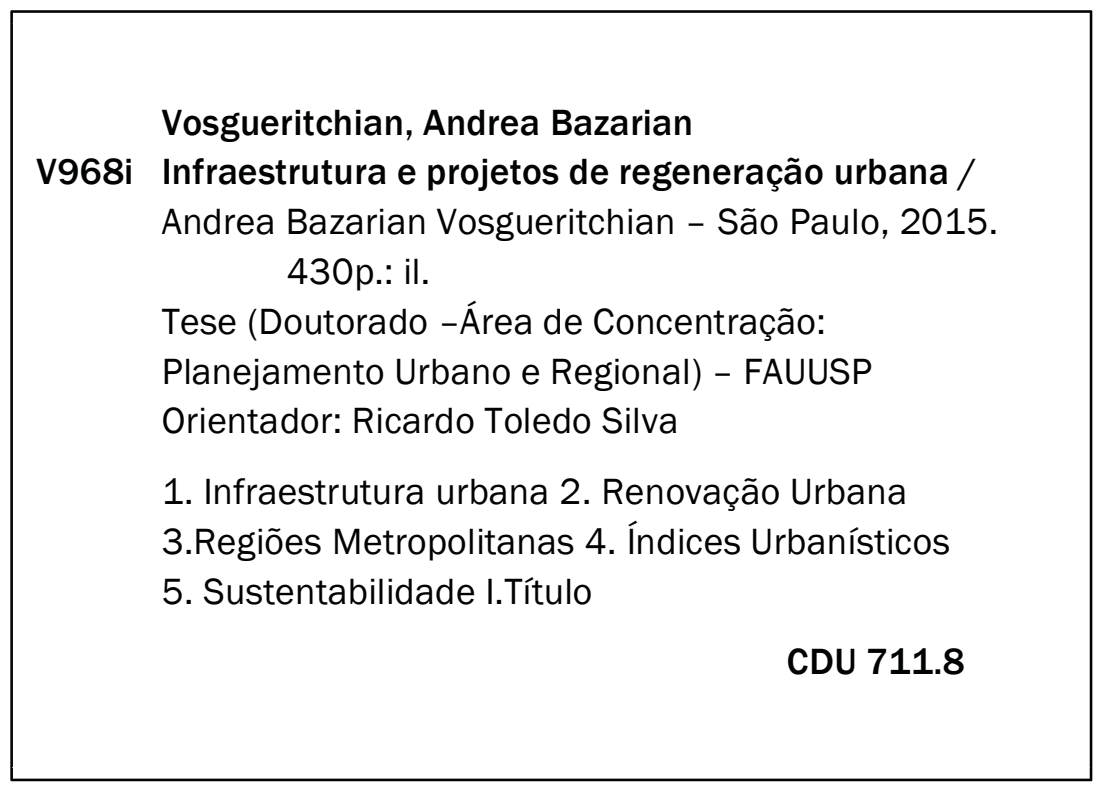




\section{BANCA EXAMINADORA}

Prof.Dr. Instituição Julgamento Assinatura

Prof.Dr. Instituição Julgamento Assinatura

Prof.Dr. Instituição Julgamento Assinatura

Prof.Dr. Instituição Julgamento Assinatura

Prof.Dr. Instituição Julgamento Assinatura

VOSGUERITCHIAN, A.B. Infraestrutura e projetos de regeneração urbana. Tese apresentada à Faculdade de Arquitetura e Urbanismo da Universidade de São Paulo para a obtenção do título de Doutor em Arquitetura e Urbanismo.

Aprovado em: 
Julia e Aldo 


\section{AGRADECIMENTOS}

Agradeço primeiramente ao Conselho Nacional de Desenvolvimento Científico e Tecnológico - CNPq, pelo apoio financeiro e técnico, sem o qual este trabalho não seria possível.

Ao meu orientador, Prof. Dr. Ricardo Toledo Silva, pelo constante incentivo, pelos direcionamentos técnico e acadêmico do mais alto rigor, pelo seu exemplo de profissionalismo, que levarei comigo sempre.

Aos professores Dra. Regina Meyer e Dr. Emílio Haddad, pelo tempo dedicado durante o processo da pesquisa e, principalmente, pelas valiosas sugestões na etapa de qualificação dessa pesquisa.

À Profa. Dra. Marta Dora Grostein e à Roberta Fontan Pereira Galvão, do Laboratório de Urbanismo da Metrópole, pelos esclarecimentos e direcionamentos técnicos durante o tratamento dos dados.

Ao Prof. Dr. Marcelo Giacaglia, pelos vários esclarecimentos, não só durante o atendimento de sua disciplina, mas até os últimos dias desta pesquisa, no campo de conhecimento dos Sistemas de Informação Geográfica, sem os quais o caminho teria sido mais tortuoso.

À pesquisadora e amiga Luciana Schwandner Ferreira e ao estudante Everson Silva, pelo suporte sério e consistente no processo de desenvolvimento desta tese. Além de expandirem o tempo para alcançarmos novos conteúdos, tornaram o dia a dia do trabalho bem menos solitário.

Ao CESAD, em especial ao recém-doutor Ricardo Nader, pelos inequívocos esclarecimentos durante o uso das ferramentas de georreferenciamento, mais precisamente no uso do software QuantumGis.

À Secretaria de Energia, em especial ao Prof. Ricardo Toledo e Silva, ao Sr. Henrique Ferraz, Henderson Querne e Jânio Souto, pelos longos esclarecimentos técnicos, pelo fundamental fornecimento de dados e sagazes direcionamentos quanto ao campo das redes de eletricidade da Região Metropolitana de São Paulo.

Também à Secretaria de Saneamento e Recursos Hídricos, em especial às longas entrevistas com o Dr. Ricardo Araújo, extremamente disponível e disposto a tratar os mais dificultosos temas na área de saneamento ambiental. 
À Sabesp, em especial à Nagip César Abrahão, pelo fundamental suprimento de dados e pelas didáticas e generosas explicações quanto ao setor de saneamento.

À Emplasa, em especial à diretora de Planejamento Rovena Negreiros e à diretora de Gestão de Projetos Diana Motta, pelas entrevistas instigantes no campo da problemática urbana da macrometrópole, assim como no campo da habitação de interesse social.

Aos entrevistados Eduardo Bernini, Cyro Vicente Boccuzzi, Prof. Aderbal de Arruda Penteado Júnior (Poli), Prof. Dr. José Sidnei Colombo Martini, Eduardo Tude (Teleco) e Prof. Wilson Ruggiero (Larc-Poli), pelo valioso tempo e pelas contribuições.

Aos colegas do LABAUT, especialmente a Joana Gonçalves, pelo incentivo logo no início desta pesquisa, e a Denise Duarte, Alessandra Prata e Mônica Marcondes, pelo apoio e amizade.

À Prof. Dra. Maria Lucia Refinetti Martins e aos funcionários da pós-graduação, especialmente à Isa e ao André, além de Cilda, Ivani e Dina.

Ao Tadzio Saraiva e a Sara Rodrigues, pela paciência e suporte na finalização gráfica desta tese. À Vivian Prado de Souza, pela revisão de texto.
A meu marido, Aldo Urbinati, e aos grandes amigos do Estudio Tupi, Rafael Ayres e Eduardo Pudenzi, que me acolheram nas etapas mais difíceis desta tese. Ao auxílio e ao afeto de Bruna Pogliessi.

Aos meus pais, Ivany e Mouses, por aquela grandeza de olhar, por acreditarem mesmo sem ter que entender, pelo amor panorâmico, por cuidarem pacientemente da nossa pequena quando eu e o Aldo precisávamos nos dedicar à pesquisa e ao trabalho.

À minha irmã de sangue e de alma, Simone, por ter parado para me ouvir enquanto tudo se movia, por ter feito aquelas perguntas difíceis de responder.

Novamente ao Aldo, por seu companheirismo, por sua generosidade, por sua intuição e perseverança, por tudo sem o qual não há - ontem, hoje e amanhã.

E finalmente à Julia, por ter escolhido nos conhecer durante esse processo duplamente intenso e importante de nossas vidas, por sua paciência inconsciente, por sua impaciência leviana, pela dádiva da sua alegria, por doar-me todo o significado do meu viver.

Ao final, esta tese pareceu ter feito algum sentido... 
As liberdades não são apenas os fins primordiais do desenvolvimento, mas também os meios principais. Amartya Sen 


\section{RESUMO}

VOSGUERITCHIAN, A.B. Infraestrutura e projetos de regeneração urbana. 2015. 430p. Tese (Doutorado) Faculdade de Arquitetura e Urbanismo, Universidade de São Paulo, São Paulo, 2015.

A demanda para a ampliação da cobertura das redes de infraestrutura em regiões metropolitanas e o consequente aumento de exigências por suas melhorias de qualidade especialmente em processo de desenvolvimento - permitem uma forma característica de compreensão a respeito de como certos benefícios e limitações físicas e econômicas acabam por regular o destino de áreas urbanizadas. Projetos de regeneração urbana, em geral, buscam responder por essa demanda por melhoramentos, não só no ambiente físico urbano, mas também na cobertura e qualidade dos serviços infraestruturais. Esses projetos objetivam reestruturar e reutilizar uma parte considerada decadente de uma área urbanizada no sentido de regular, reviver ou reinstalar maior vitalidade econômica no local em que se inserem. Dessa forma, esse renovado sistema urbano deve perdurar e ser capaz de permanecer diverso e produtivo através do tempo. Entretanto, a criação de guetos e enclaves diferenciados' em locais em geral carentes de infraestruturas fundamentais e em regiões onde estas são minimamente distribuídas no território urbano, tende a criar uma demanda que rapidamente é respondida e logo superada, com uma forte propensão a perder as qualidades intencionadas, que geraram a defasagem inicial em comparação ao tecido ordinário que os cercam. Contudo, o efeito perverso dessas iniciativas é a criação de uma superdemanda que acaba neutralizando os benefícios primeiros da iniciativa de regeneração urbana, como que configurando uma tendência a um efeito de dissolução dos enclaves diferenciados. $\mathrm{O}$ efeito resultante seria a homogeneização das carências, fazendo com que as limitações em escala e qualidade da operação de redes infraestruturais sejam replicadas e redistribuídas na malha urbana, sem que a solução localizada (no âmbito do perímetro da iniciativa de regeneração) efetivamente solucione o problema local e permaneça vantajoso através do tempo. Devido à heterogeneidade na rede de carências e benefícios no território da metrópole de São Paulo, soluções tópicas como as propostas em projetos de regeneração tenderiam rapidamente a ter suas qualidades e diferenças dissolvidas no grid urbano. Dessa forma, a hipótese desta pesquisa é a de que projetos de renovação urbana em cidades em desenvolvimento, que integram melhorias em relação à cobertura e qualidade de infraestrutura urbana - diferenciadas em relação ao entorno -, tendem a perder as qualidades intrínsecas que os diferenciam, sendo os seus benefícios atenuados e dissipados no território metropolitano. Por conseguinte, impõe-se como condição fundamental de preenchimento dos objetivos da regeneração, que se garantam condições equânimes de acesso à infraestrutura urbana na área de influência da intervenção.

\section{Palavras-chave}

Infraestrutura urbana. Renovação urbana. Regiões metropolitanas. Índices urbanísticos. Sustentabilidade. 


\section{ABSTRACT}

VOSGUERITCHIAN, A.B. Infraestrutura e projetos de regeneração urbana. 2015. 430p. Tese (Doutorado) Faculdade de Arquitetura e Urbanismo, Universidade de São Paulo, São Paulo, 2015.

The demand for the expansion of urban infrastructure coverage and the consequential increase of requests for quality improvements of networks in metropolitan areas, especially in developing countries, shapes a distinctive approach as to understand in what way certain benefits or limitations can eventually regulate the future of urban areas. Urban regeneration projects generally seek to account for the demand for network improvements, not only in the urban physical environment, but also in the coverage and quality of infrastructure services. These projects aim to restructure and reuse a part of an urban area that is considered decadent, so to regulate, revive or reinstall greater economic vitality in its location. Thus, this new urban system must subsist and be able to remain diverse and productive over time. However, the creation of distinguished enclaves in regions that generally lack basic infrastructure, and or where this is minimally distributed in the urban territory, tend to rapidly meet the demand and soon after surpass it, with a strong propensity to loose the qualities that generated their initial intentions. Nevertheless, the perverse effect of these initiatives is the creation of a 'super-demand' that neutralises the very first benefits of urban regeneration enterprises, as if setting a tendency of dissolution of these segregated enclaves. Where the limitations in scale and or quality of infrastructure networks are replicated and redistributed on the built environment, the net effect of these processes would be the dissemination of scarcity, making the purposes of the localised solution unattainable (within the perimeter of the regeneration initiative) and making it implausible to turn the enterprise advantageous over time. Due to the heterogeneity of the mesh of needs and benefits within the Metropolitan Region of São Paulo - the largest metropolis in South America - topical solutions such as those proposed in regeneration projects tend to have their qualities and differences rapidly dissolved in the urban grid. Thus, the hypothesis of this research is that urban renewal projects in developing cities that encompasses improvements over the coverage and quality of urban infrastructure - differentiated in relation to its surrounding environment - tend to lose its intrinsic qualities that would differentiate them in the first place, causing their expected benefits to be overcome and dissipated into the metropolitan territory. Therefore, a fundamental condition for completing urban regeneration objectives should ensure equitable conditions of access and quality of urban infrastructure in the area of influence of the intervention.

\section{Key Words}

Urban infrastructure. Urban regeneration. Metropolitan regions. Urban indicators. Sustainability. 


\section{LISTA DE FIGURAS}

Figura 1. Centro Pompidou e Les Halles. Na figura menor, base à esquerda: Les Halles é definida na área do retângulo maior à esquerda do desenho e, à direita, demarca-se o sítio do Centro Pompidou. Na imagem panorâmica do topo, o Centro Pompidou e seus arredores, sendo a imagem abaixo proveniente do quadrilátero Les Halles da década de 1980. 139

Figura 2. Mapa de Les Halles atual, mostrando as linhas de transporte público RER/Metrô 140

Figura 3. Maquete do projeto de Louis Arretche, 1980. 140

Figura 4. Seção transversal do projeto de Louis Arretche, 1980. 141

Figura 5. Transformações urbanas nas imediações de Les Halles. Situação em 1789, 1967 e 1980, da esquerda para a direita. 143

Figura 6. Proposta da equipe de Rem Koolhas/OMA. 149

Figura 7. Continuação. Proposta da equipe de Rem Koolhas/OMA...... 150

Figura 8. Proposta de equipe de Winy Mass/MVRDV. 152

Figura 9. Proposta da equipe de Jean Nouvel. 154

Figura 10. Proposta final de equipe de David Mangin (SEURA) - Galfetti ....................................................................................... 156

Figura 11. Proposta vencedora e modificada da equipe de David Mangin (SEURA) e Patrick Berger. 157

Figura 12 Imagens atuais do projeto vencedor. 158

Figura 13 Folder da iniciativa Better Bankside e a área de atuação.... 166

Figura 14. Ilustração mostrando as desconexões entre as franjas ativas e o interior isolado. 167

Figura 15. Áreas de intervenção propostas pelos arquitetos Witherford Watson Mann Architects. 171

Figura 16. Redes locais: relações espaciais entre os residentes e os locais 172
Figura 17. Mapa que indica as áreas de oportunidade para a geração de energia descentralizada. À esquerda, os limites da cidade de Londres. À direita, ampliação da área do south bank, das prefeituras de Lambeth e Southwark, ao sul do Rio Tâmisa. As linhas amarelas identificam as redes já instaladas, as vermelhas as redes potenciais, e os perímetros em roxo as áreas de oportunidade. 180

Figura 18. Mapas que identificam as oportunidades de áreas para a geração de energia distrital e linhas de conexão entre empreendimentos. Os círculos de diferentes proporções (maiores) identificam os empreendimentos com maior potencial de consumo e, por conseguinte, a geração de energia descentralizada. 180

Figura 19. 0 London Thames Gateway Heat Network. 182

Figura 20. Perímetro do Área de Intervenção do Projeto Nova Luz e os setores Nébias, Rio Branco, Triunfo e Mauá.

Figura 21. À esquerda, usos propostos para o pavimento térreo. À direita, de baixo para cima, áreas verdes, piso térreo e pisos superiores. 203

Figura 22. À esquerda, usos propostos para os pavimentos superiores. À direita, legenda dos usos. 204 


\section{LISTA DE MAPAS}

Mapa 1. Municípios de compõem a RMSP 227

Mapa 2. Limites municipais da RMSP sobre imagem de satélite. ........ 228

Mapa 3. Áreas de agregação dos setores censitários do Censo IBGE... 232

Mapa 4. Áreas de agregação das zonas OD do Metrô.

233

Mapa 5. Áreas de agregação das bacias de abastecimento da Sabesp. 234

Mapa 6. Áreas de agregação das bacias de esgotamento da Sabesp... 235

Mapa 7. Densidade populacional. 240

Mapa 8. Renda média em salários mínimos. 241

Mapa 9. Densidade de emprego 242

Mapa 10. Taxa de emprego. 243

Mapa 11. Domicílios com energia elétrica de companhia distribuidora. 252

Mapa 12. Duração das interrupções no fornecimento de energia elétrica. 253

Mapa 13. Duração das interrupções no fornecimento de energia elétrica. 254

Mapa 14. Duração das interrupções no fornecimento de energia elétrica.

Mapa 15. Frequência das interrupções no fornecimento de energia elétrica.

Mapa 16. Frequência das interrupções no fornecimento de energia elétrica.

Mapa 17. Frequência das interrupções no fornecimento de energia elétrica.
Mapa 18. Abrangência dos setores censitários interpolados por rede de gás canalizado.

Mapa 19. Rede de gás canalizado sobre área urbanizada da RMSP. ... 284

Mapa 20. Ampliação da rede de gás canalizado sobre área urbanizada da RMSP. 285

Mapa 21. Domicílios com abastecimento de água da rede geral. ........ 289

Mapa 22. Contingência dos sistemas de abastecimento de água da Sabesp em 2013. 290

Mapa 23. Índice de regularidade da adução da rede da Sabesp em 2013. ................................................................................. 295

Mapa 24. Índice de regularidade da distribuição de água da rede da Sabesp em 2013.

Mapa 25. Índice de reclamação de falta de água da rede da Sabesp em 2013.

Mapa 26. Domicílios com banheiros ligados à rede de esgoto............. 302

Mapa 27. Domicílios atendidos por coleta de lixo. ............................. 303

Mapa 28. Índice de coleta de esgoto municipal em 2013. ................. 304

Mapa 29. Índice de tratamento de esgoto municipal em 2013.

305

Mapa 30. Taxa de infiltração das bacias de esgotamento da rede da Sabesp em 2013.

Mapa 31. Melhor média anual de conexão de voz para o ano de 2013. 314

Mapa 32. Pior média anual de conexão de voz para o ano de 2013...... 315

Mapa 33. Melhor média anual de desconexão de voz para o ano de 2013. 316

Mapa 34. Pior média anual de desconexão de voz para o ano de 2013. 317

Mapa 35. Melhor média anual de conexão de dados para o ano de 2013. 318

Mapa 36. Pior média anual de conexão de dados para o ano de 2013. 319 
Mapa 37. Melhor média anual de desconexão de dados para o ano de 2013. 320

Mapa 38. Pior média anual de desconexão de dados para o ano de 2013.

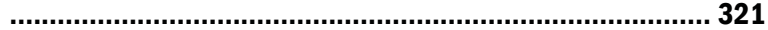

Mapa 39. Domicílios com pavimentação pública em seu entorno........ 326

Mapa 40. Domicílios com iluminação pública em seu entorno. ............ 327

Mapa 41. Paragens de transporte coletivo na RMSP. 334

Mapa 42. Rede de transportes ferroviário, metroviário e rodoviário da RMSP.

Mapa 43. Alcance do sistema de transportes coletivo e individual na RMSP.

Mapa 44. Densidade de viagens produzidas totais. 337

Mapa 45. Densidade de viagens atraídas totais 338

Mapa 46. Densidade de viagens produzidas por transporte coletivo. ... 339

Mapa 47. Densidade de viagens atraídas por transporte coletivo........ 340

Mapa 48. Densidade de viagens produzidas por transporte individual motorizado. 341

Mapa 49. Densidade de viagens atraídas por transporte individual motorizado.

Mapa 50. Paragens de transporte coletivo versus renda média domiciliar na área central da RMSP 343

Mapa 51. Densidade de viagens produzidas totais por motivo de trabalho. ......................................................................................... 349

Mapa 52. Densidade de viagens atraídas totais por motivo de trabalho. ......................................... 350

Mapa 53. Densidade de viagens produzidas totais por motivo de compras. 351

Mapa 54. Densidade de viagens atraídas totais por motivo de compras.

352
Mapa 55. Densidade de viagens produzidas totais por motivo de educação.

Mapa 56. Densidade de viagens atraídas totais por motivo de educação.

Mapa 57. Densidade de viagens produzidas totais por motivo de lazer. 355

Mapa 58. Densidade de viagens atraídas totais por motivo de lazer. ... 356

Mapa 59. Densidade de viagens produzidas totais por motivo de saúde.

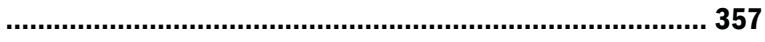

Mapa 60. Densidade de viagens atraídas totais por motivo de saúde. . 358

Mapa 61. 0 preço médio das unidades residenciais em 2010 362

Mapa 62. Renda média do responsável em 2010 363

Mapa 63. Ampliação da área central da RMSP indicando os lançamentos verticais (em branco) e horizontais (amarelo) 364

Mapa 64. A RMSP e os Projetos Estratégicos 367

Mapa 65. Identificação dos projetos urbanos OUCs e PPPs 375

Mapa 66. Identificação da OUC Água Branca. 376

Mapa 67. Identificação da OUC Água Espraiada. 377

Mapa 68. Identificação da OUC Centro e da área do Projeto Nova Luz. 378

Mapa 69. Identificação da OUC Faria Lima. 379

Mapa 70. Identificação da OUC São Bernardo do Campo. 380

Mapa 71. Identificação da área do projeto Arco do Tietê. 381

Mapa 72. Identificação da OUC Bairros do Tamanduateí. 382 Mapa 73. Identificação das PPPs Casa Paulista. 383

Mapa 74. Vetores de viagens produzidas por trabalho pela área da Luz. 393

Mapa 75. Principais vetores de viagens produzidas por trabalho pela área da Luz. 394 
Mapa 76. Vetores de viagens atraídas por trabalho para a área da Luz. 395

Mapa 77. Principais vetores de viagens atraídas por trabalho para a área da Luz.............................................................................. 396

Mapa 78. Vetores de viagens produzidas por educação para a área da Luz. ............................................................................................ 397

Mapa 79. Principais vetores de viagens produzidas por educação para a área da Luz.

Mapa 80. Vetores de viagens atraídas por educação para a área da Luz.

Mapa 81. Principais vetores de viagens atraídas por educação para a área da Luz. ............................................................................... 400

Mapa 82. Vetores de viagens produzidas por lazer para a área da Luz.. 401

Mapa 83. Principais vetores de viagens produzidas por lazer para a área da Luz. 402

Mapa 84. Vetores de viagens atraídas por lazer para a área da Luz...... 403

Mapa 85. Principais vetores de viagens atraídas por lazer para a área da Luz. 404

Mapa 86. Vetores de viagens atraídas por trabalho na OUC Água Branca. 405

Mapa 87. Principais vetores de viagens atraídas por trabalho na OUC Água Branca. 406 


\section{LISTA DE TABELAS}

Tabela 1. Evolução da população do 1er Arrondissement - Estatísticas e percentagem da população de Paris, de 1954 a 1999.......... 144

Tabela 2. Quadro sintético da área e população dos estudos de caso. . 187

Tabela 3. Diretrizes de desenvolvimento da infraestrutura do projeto Nova

Luz. 196

Tabela 4. Indicadores de qualidade de fornecimento de energia elétrica.

.................................................................................... 247

Tabela 5. Os quinze maiores consumidores de gás canalizado do Estado de São Paulo em 2013.

Tabela 6. Padrão de consumo de gás canalizado dos municípios da RMSP em 2013.

Tabela 7. Indicadores de qualidade do abastecimento de água. 299

Tabela 8. Indicadores de coleta e tratamento de esgoto.

Tabela 9. Indicadores de qualidade da telefonia móvel. 323

Tabela 10. Indicadores de qualidade do entorno.

Tabela 11. Síntese das zonas OD com maior densidade de viagens atraídas e produzidas........................................................................ 348

Tabela 12. As OUCs e o Quadro Socioeconômico. 384

Tabela 13. As OUCs e a Infraestrutura Urbana. 386

Tabela 14. Síntese dos fluxos de viagens atraídas e produzidas em relação à zona Santa Ifigênia. 392 


\section{LISTA DE SIGLAS}

\begin{tabular}{|c|c|}
\hline Aneel & Agência Nacional de Energia Elétrica \\
\hline Anatel & Agência Nacional de Telecomunicações \\
\hline Arsesp & $\begin{array}{l}\text { Agência Reguladora de Saneamento e Energia do Estado } \\
\text { de São Paulo }\end{array}$ \\
\hline BNDES & Banco Nacional do Desenvolvimento Econômico e Social \\
\hline BID & Business Improvement District \\
\hline CEAGESP & $\begin{array}{l}\text { Companhia de Entrepostos e Armazéns Gerais de São } \\
\text { Paulo }\end{array}$ \\
\hline CEM & Centro de Estudos da Metrópole \\
\hline CFQ & Características físico-químicas do gás \\
\hline CHP & Combined Heat and Power \\
\hline COGEP & Coordenadoria Geral de Planejamento \\
\hline Comgás & Companhia de Gás de São Paulo \\
\hline CPTM & Companhia Paulista de Trens Metropolitanos \\
\hline CSPE & Comissão de Serviços Públicos de Energia \\
\hline DEC & $\begin{array}{l}\text { Duração equivalente de interrupção por unidade } \\
\text { consumidora }\end{array}$ \\
\hline DIC & $\begin{array}{l}\text { Duração de interrupção individual por unidade } \\
\text { consumidora ou por ponto de conexão }\end{array}$ \\
\hline DICRI & $\begin{array}{l}\text { Duração da interrupção individual ocorrida em dia crítico } \\
\text { por unidade consumidora ou ponto de conexão }\end{array}$ \\
\hline DMIC & $\begin{array}{l}\text { Duração máxima de interrupção contínua por unidade } \\
\text { consumidora ou por ponto de conexão }\end{array}$ \\
\hline
\end{tabular}

DOPS

Departamento Estadual de Ordem Política e Social

EDS

Economic Development Strategy (Estratégia de Desenvolvimento Econômico)

\begin{tabular}{|c|c|}
\hline Embraesp & Empresa Brasileira de Patrimônio \\
\hline EMTU & $\begin{array}{l}\text { Empresa Metropolitana de Transportes Urbanos de São } \\
\text { Paulo }\end{array}$ \\
\hline Emplasa & Empresa Paulista de Planejamento Metropolitano SA. \\
\hline EUA & Estados Unidos da América \\
\hline FEC & $\begin{array}{l}\text { Frequência equivalente de interrupção por unidade } \\
\text { consumidora }\end{array}$ \\
\hline FIC & $\begin{array}{l}\text { Frequência de interrupção individual por unidade } \\
\text { consumidora ou ponto de conexão }\end{array}$ \\
\hline FME & Frequência média de atendimento de emergência \\
\hline IBGE & Instituto Brasileiro de Geografia e Estatística \\
\hline Inpe & Instituto Nacional de Pesquisas Espaciais \\
\hline IPTU & Imposto Predial e Territorial Urbano \\
\hline IRA & Índice de Regularidade de Adução \\
\hline IRD & Índice de Regularidade de Distribuição \\
\hline IRFA & Índice de Reclamações de Falta d’Água \\
\hline IVAZ & Índice de vazamentos no sistema de distribuição de gás \\
\hline LARC POLI & $\begin{array}{l}\text { Laboratório de Arquitetura e Redes de Computadores do } \\
\text { Departamento de Computação e Ciências Digitais da }\end{array}$ \\
\hline Limpurb & Departamento de Limpeza Urbana \\
\hline
\end{tabular}




\begin{tabular}{|c|c|c|c|}
\hline MDSP & Mapeamento Digital de São Paulo & PRE & Planos Regionais Estratégicos \\
\hline Metrô & Companhia do Metropolitano de São Paulo & Prodist & $\begin{array}{l}\text { Procedimentos de Distribuição de Energia Elétrica no } \\
\text { Sistema Elétrico Nacional }\end{array}$ \\
\hline MMP & Macrometrópole Paulista & PUB & Plano Urbanístico Básico \\
\hline MSP & Município de São Paulo & PUC & Pontifícia Universidade Católica \\
\hline NARUC & National Association of Regulatory Utilities Comissions & RMSP & Região Metropolitana de São Paulo \\
\hline OD & Origem e Destino & Sabesp & $\begin{array}{l}\text { Companhia de Saneamento Básico do Estado de São } \\
\text { Paulo }\end{array}$ \\
\hline ONU & Organização das Nações Unidas & SBEG & South Bank Employers'Group \\
\hline OU & Operação Urbana & Seade & Fundação Sistema Estadual de Análise de Dados \\
\hline OUBT & Operação Urbana Bairros do Tamanduateí & Sigao & Sistema de Gestão Operacional \\
\hline OUC & Operação Urbana Consorciada & SIGPlan & Sistema de Informações Gerenciais e de Planejamento \\
\hline PCS & Poder calorífico superior & SIOP & Sistema Integrado de Planejamento de Orçamento \\
\hline PDE & Plano Diretor Estratégico & SMI & Sistema Municipal de Informações \\
\hline PIB & Produto Interno Bruto & SNIS & Sistema Nacional de Informações sobre Saneamento \\
\hline PITU & Plano Integrado de Transportes Urbanos & SPTrans & São Paulo Transporte S.A. \\
\hline Planasa & Plano Nacional de Saneamento & TAE & Tempo de atendimento de emergência \\
\hline PPC & Porcentagem de perdas comerciais & TelComp & $\begin{array}{l}\text { Associação Brasileira de Serviços de Telecomunicações } \\
\text { Competitivas }\end{array}$ \\
\hline PPT & Porcentagem de perdas técnicas & Zeis & Zonas Especiais de Interesse Social \\
\hline PPTG & Porcentagem de perdas totais & & \\
\hline
\end{tabular}


SUMÁRIO

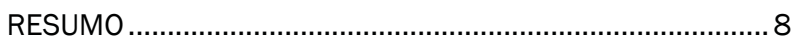

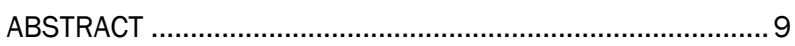

LISTA DE FIGURAS …...................................................... 10

LISTA DE MAPAS ..............................................................

LISTA DE TABELAS ............................................................ 14

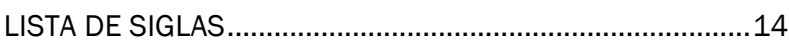

1. INTRODUÇÃO

1.1 Objeto e objetivo ........................................................... 19

1.2 Argumentos e hipótese .............................................. 22

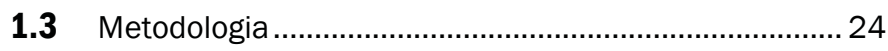

1.4 Estrutura de capítulos................................................. 32

\section{OS DISCURSOS E AS PRÁTICAS DO REFAZER URBANO...} 39

2.1 Definições e princípios desde o pós-guerra. 41

2.1.1 A natureza do prefixo re. .. .46

2.1.2 Da remoção de moradias impróprias à renovação ...51 2.1.3 A reabilitação, a revitalização e a requalificação.....57

2.1.4 A regeneração urbana. . .65

2.1.5 Conclusões parciais . .71

2.2 As redes de infraestrutura e a cidade 75

2.3 Implicações da privatização e a regulação dos serviços .88
2.4 Redes fragmentadas e redes integradas 102

2.5 Os enclaves diferenciados e os guetos ...................... 108

2.6 Políticas urbanas e instrumentos urbanísticos ........... 115

2.7 A estruturação metropolitana 128

2.8 O papel dos projetos urbanos na [re]estruturação metropolitana ........................................................... 132

2.9 As práticas da regeneração urbana ........................... 134

2.9.1. O Les Halles parisiense ........................................... 137

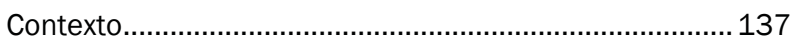

Último concurso .............................................................. 145

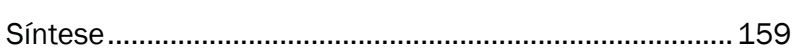

2.9.2. O south bank londrino ............................................. 163

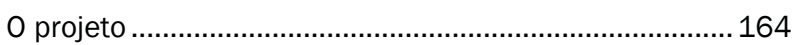

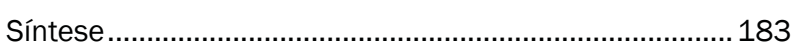

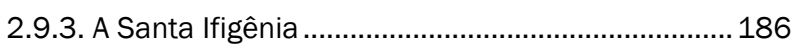

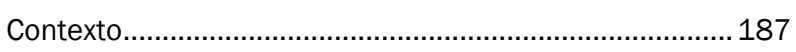

A Nova Luz ..................................................................... 191

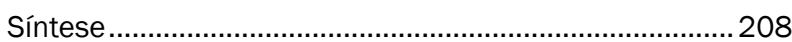

3. UMA RADIOGRAFIA DAS FORÇAS DA INFRAESTRUTURA URBANA E OS ARRANJOS ESPACIAIS DA METRÓPOLE .....211

3.1 O quadro da infraestrutura urbana na RMSP .............213

3.2 O desenho da infraestrutura urbana na RMSP .......... 224

Estatísticas básicas da RMSP............................................. 226

Formas de agregação de dados ........................................229

Método de classificação dos dados cartográficos .......... 236 
Dados socioeconômicos ..................................................... 237

3.2.1 A rede de energia .................................................... 244

A visão dos especialistas do setor de energia elétrica... 259

3.2.2 A rede de gás canalizado ........................................ 272

3.2.3 A rede de abastecimento de água .......................... 286

3.2.4 A rede de coleta e tratamento de esgoto ............... 298

3.2.5 A rede de telefonia móvel ........................................ 308

3.2.6 A rede de pavimentação e iluminação pública ..... 322

3.2.7 A rede de transportes............................................... 328

3.3 O espaço dos fluxos da RMSP.....................................344

3.3.1 As dinâmicas......................................................... 344

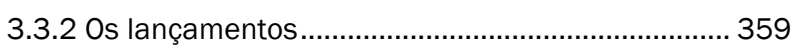

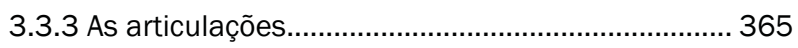

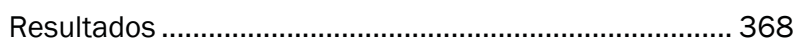

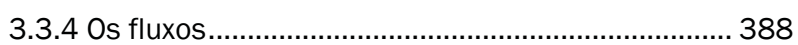

4. O ARQUIPÉLAGO, 0 GRIDE OS FLUXOS.................. 407

Efeitos da concentração e da dispersão .......................... 407

Justiça urbana ............................................................... 411

Interrupções e reprodução da desigualdade ................... 415

Os alcançes da autonomia e as perspectivas futuras.... 418

5. BIBLIOGRAFIA 


\section{INTRODUÇÃO}

\subsection{Objeto e objetivo}

São dois os objetos desta pesquisa: os projetos de regeneração urbana e a infraestrutura urbana. Ambos foram examinados primeiramente de forma teórica, por meio de revisão bibliográfica. Nesta 
foram definidos os conceitos e estabelecidas as bases metodológicas que estruturaram a investigação destes objetos.

Num segundo momento foram selecionados estudos de caso, de forma a permitir a análise mais específica dos projetos e práticas de regeneração urbana, sempre com foco em infraestrutura. Foram três os projetos estudados, um em Paris, um em Londres e um em São Paulo. A análise da infraestrutura urbana, posterior à revisão teórica, foi focada para o caso da Região Metropolitana de São Paulo - RMSP.

O objetivo principal desta pesquisa é o de evidenciar o potencial de transformação física e territorial provocado pelos melhoramentos na cobertura e qualidade das redes infraestruturais associados aos projetos de regeneração urbana. Por meio do estudo desses projetos e práticas, buscou-se tornar evidente o processo de regeneração urbana e suas relações com as redes de infraestrutura. A natureza dos espaços urbanos que funcionam como eixos de infraestrutura metropolitanos foi investigada de forma a demonstrar que projetos de intervenção, mesmo circunscritos, não trazem apenas benefícios e problemas diretamente ligados às suas imediações, mas são redistribuídos no território urbano.

Esta pesquisa mostra que projetos de intervenção, mesmo que minutos, podem causar impactos importantes não apenas locais, mas que geram efeitos no âmbito regional, desde que estejam conectados por uma agenda mais ampla que os circunscrevam numa rede infraestrutural de capacidade metropolitana. Ao contrário, também evidencia que projetos 
de intervenção herméticos em seu escopo, que não incoporem dentro de seus princípios os pontos críticos do local, tanto físicos quanto sociais, dificilmente conseguem gerar impactos positivos dentro de seu perímetro e no seu entorno.

Quanto a estrutura teórica, trabalhou-se, por um lado, a contextualização dos discursos que apoiaram os projetos de desenvolvimento urbano desde o pós-guerra (meados do século XX), tais como a revitalização, a renovação, a requalificação e, por último, a regeneração urbana, com o intuito de delinear suas similaridades e diferenças, por meio de uma abordagem histórica, teórica e conceitual. Por outro lado, identificaram-se os principais conceitos ligados ao campo da infraestrutura urbana no âmbito do planejamento urbano e regional, de forma a posicionar os argumentos desta pesquisa no panorama de discussão acadêmica nacional e internacional.

De forma a responder as perguntas desta tese, também foram levantadas as possibilidades de integração física, tecnológica, gerencial e econômica, dos diferentes campos de infraestrutura de serviços urbanos, assim como os possíveis efeitos dessa integração sobre a estrutura da oferta conjunta. Esta análise não exauriu o campo de possibilidade de integração, porém foi feita de forma a definir possíveis metodologias para promover uma avaliação integrada. 


\subsection{Argumentos e hipótese}

A demanda para a ampliação da cobertura das redes de infraestrutura em regiões metropolitanas e o consequente aumento de exigências por suas melhorias de qualidade - especialmente em processo de desenvolvimento - permitem uma forma característica de compreensão a respeito de como certos benefícios e limitações físicas e econômicas acabam por regular o destino de áreas urbanizadas.

Projetos de regeneração urbana, em geral, buscam responder por essa demanda por melhoramentos, não só no ambiente físico urbano, mas também na cobertura e qualidade dos serviços infraestruturais. Esses projetos objetivam reestruturar e reutilizar uma parte considerada decadente de uma área urbanizada no sentido de regular, reviver ou reinstalar maior vitalidade econômica no local em que se inserem. Dessa forma, esse renovado sistema urbano deve perdurar e ser capaz de permanecer diverso e produtivo através do tempo. Entretanto, a criação de guetos e enclaves diferenciados ${ }^{1}$, em locais em geral carentes de infraestruturas fundamentais e em regiões onde estas são minimamente 
distribuídas no território urbano, tende a criar uma demanda que rapidamente é respondida e logo superada, com uma forte propensão a perder as qualidades intencionadas, que geraram a defasagem inicial em comparação ao tecido ordinário que os cercam.

Contudo, o efeito perverso dessas iniciativas é a criação de uma superdemanda que acaba neutralizando os benefícios primeiros da iniciativa de regeneração urbana, como que configurando uma tendência a um efeito de dissolução dos enclaves diferenciados. O efeito resultante seria a homogeneização das carências, fazendo com que as limitações em escala e qualidade da operação de redes infraestruturais sejam replicadas e redistribuídas na malha urbana, sem que a solução localizada (no âmbito do perímetro da iniciativa de regeneração) efetivamente solucione o problema local e permaneça vantajoso através do tempo. Devido à heterogeneidade na rede de carências e benefícios no território da metrópole de São Paulo, soluções tópicas como as propostas em projetos de regeneração tenderiam rapidamente a terem suas qualidades e diferenças dissolvidas no grid urbano.

Dessa forma, a hipótese desta pesquisa é a de que projetos de renovação urbana em cidades em desenvolvimento, que integram melhorias em relação à cobertura e qualidade de infraestrutura urbana diferenciadas em relação ao entorno -, tendem a perder as qualidades intrínsecas que os diferenciam, sendo os seus benefícios atenuados e dissipados no território metropolitano. Por conseguinte, impõe-se como 
condição fundamental de preenchimento dos objetivos da regeneração que se garantam condições equânimes de acesso à infraestrutura urbana na área de influência da intervenção.

\subsection{Metodologia}

De forma a responder a hipótese desta pesquisa e preencher os objetivos estabelecidos, o trabalho teve como focos teóricos a revisão conceitual por meio da pesquisa bibliográfica e teórica relativa aos dois objetos principais de investigação: os projetos de regeneração urbana e a cobertura e qualidade das redes infraestruturais.

Após revisão conceitual e estabelecidos os fundamentos que suportam esta tese, foram definidos os estudos de caso. Foram examinados três projetos, um em Paris, um em Londres e um em São Paulo, todas são cidades de alta densidade populacional e que tiveram períodos históricos de crescimento extremos, seguidos de um processo de periferização. Os três projetos escolhidos estão localizados em polos centrais de infraestrutura e apresentam soluções distintas quanto às perspectivas traçadas na agenda da regeneração. Por meio do estudo dos projetos e práticas de regeneração urbana, buscou-se tornar evidente o 
processo de regeneração urbana e suas relações com os alicerces infraestruturais.

A análise dos estudos de caso foi feita mediante o levantamento de dados de projeto e também pelo levantamento de dados de cobertura e qualidade das redes de infraestrutura do local estudado. Sempre que possível, trabalhou-se sobre dados primários, muitas vezes provenientes das prefeituras responsáveis pelo desenvolvimento das iniciativas de regeneração.

A fim de compreender a natureza empírica da heterogeneidade ou homogeneidade do tecido urbano da Região Metropolitana de São Paulo, foram confrontados os dados socioeconômicos da RMSP em relação à cobertura infraestrutural no mesmo território. Todos os indicadores foram adquiridos por meio de uma intensa pesquisa de campo, de acordo com a disponibilidade e qualidade dos dados, e, importantemente, a relevância destes para responder a hipótese desta tese. Os dados empíricos foram trabalhados por meio de ferramentas computacionais que sistematizam as informações geográficas, mais especificamente com o uso do software QuantumGis (versão 2.8.1-Wien). Por meio da sistematização das informações e do relacionamento dos dados coletados, possíveis por operações geográficas utilizando a ferramenta de Sistemas de Informação Geográfica - SIG, foi possível evidenciar as discrepâncias na cobertura e qualidade de distribuição dos serviços por sub-regiões da RMSP. 
Para a análise das redes de infraestrutura, buscaram-se informações da rede de energia, gás, telecomunicações, abastecimento de água e esgotamento sanitário. Dados socioeconômicos da pesquisa do Censo também foram levantados e analisados, assim como a rede de transportes, pavimentação e iluminação, devido ao seu impacto nas análises urbanas.

Os dados primários foram levantados junto às concessionárias e às provedoras de serviços urbanos, como no caso da Sabesp (Companhia do Metropolitano de São Paulo), Metrô (Companhia do Metropolitano de São Paulo), SPTrans (São Paulo Transporte S.A.), entre outras. Quando não disponibilizadas, as informações foram buscadas por meio dos órgãos reguladores de serviços, como foi o caso da Aneel (Agência Nacional de Energia Elétrica), Anatel (Agência Nacional de Telecomunicações), Arsesp (Agência Reguladora de Saneamento e Energia do Estado de São Paulo) e o SNIS (Sistema Nacional de Informações sobre Saneamento). A pesquisa buscou identificar as diferenças de cobertura e qualidade da rede infraestrutural para áreas de agregação, as menores possíveis. Dessa forma, dependendo da fonte de dados, as áreas de agregação acabaram por definir delimitações territoriais distintas.

Os dados socioeconômicos analisados foram compilados por meio das informações disponibilizadas nas pesquisas do Censo do IBGE (Instituto Brasileiro de Geografia e Estatística), pesquisa origem e 
destino (OD) do Metrô, da Seade (Fundação Sistema Estadual de Análise de Dados) e do CEM (Centro de Estudos da Metrópole). Exemplos dos indicadores coletados incluíram: densidade da população, densidade de empregos, taxa de empregos, renda familiar média, renda do chefe de família, densidade de viagens, lançamentos imobiliários, preço médio dos lançamentos, entre outros.

Em relação à cobertura infraestrutural, os indicadores analisados em relação à rede de transportes incluíram: cobertura de transporte metropolitano - linhas de metrô, trem, corredores de ônibus e pontos de parada de todas as categorias anteriores (SPTrans, EMTU - Empresa Metropolitana de Transportes Urbanos de São Paulo -, Metrô e CPTM - Companhia Paulista de Trens Metropolitanos).

Quanto à rede de abastecimento de água, foram coletados os seguintes indicadores: domicílios atendidos por abastecimento de água da rede geral (Censo); índice de regularidade de adução e distribuição de água (Sabesp); índice de reclamação de falta d'àgua e a contingência dos sistemas de abastecimento de água (Sabesp).

Em relação à rede de esgoto, foram coletados os seguintes indicadores: domicílios com banheiros ligados à rede geral (Censo); domicílios com coleta de lixo (Censo); domicílios atendidos por coleta de lixo (Censo); índice de coleta e tratamento de esgoto (SNIS) e a taxa de infiltração das bacias de esgotamento (Sabesp). 
A rede de telefonia móvel foi analisada por meio dos seguintes indicadores: taxa de conexão e desconexão de chamadas de voz; e taxa de conexão e desconexão de dados - todas provenientes da Anatel.

Quanto à rede de energia, foram analisados os seguintes indicadores: domicílios com energia elétrica de companhia distribuidora (Censo) e índices de duração e frequência equivalente de interrupção de energia (Aneel).

A rede de gás canalizado foi analisada quanto à extensão da rede física e quanto ao número de consumidores por município, assim como os fins de uso do recurso (Arsesp). Também foram analisadas, brevemente, as características do entorno dos domicílios quanto à existência de iluminação pública e pavimentação, provenientes da pesquisa do entorno do Censo.

Também foram identificados, levantados e trabalhados dados de contaminação do solo e pontos de enchentes para a RMSP até uma etapa avançada de pesquisa, porém o processo de georreferenciamento dessas informações se mostrou extremamente dificultoso até o ponto de inviabilizar o progresso dos resultados a tempo do prazo limite desta pesquisa.

Todos os indicadores estudados são explicados em detalhe no capítulo 3, assim como as características das informações encontradas, como fonte, data, áreas de agregação dos dados, entre outras. 
Para que fosse possível a visualização geoespacial de algumas das características das redes, tais como a rede de gás canalizado, produziu-se, para esta pesquisa, uma nova imagem da área urbanizada da RMSP, por meio da justaposição e do tratamento de imagens de satélite disponibilizadas pelo Instituto Nacional de Pesquisas Espaciais (INPE) do tipo LANDSAT 5. Esse passo foi realizado devido às limitações das imagens disponíveis para a RMSP por meio de revisão bibliográfica, que, na grande maioria, acaba por desenhar a mancha urbanizada de acordo com a definiçãa de áreas urbanizadas da pesquisa do Censo do IBGE. Essa pesquisa partiu do pressuposto que a imagem de satélite representa, mais do que qualquer outra fonte, a área ocupada real, por ocupações regulares ou irregulares, independente do critério conceitual utilizado nas definições do Censo. A imagem produzida para essa pesquisa será disponibilizada a outros pesquisadores na área e deverá contribuir para futuras investigações no campo do planejamento urbano, geografia, e mais.

Foram realizadas entrevistas, formais e informais, para absorver a opinião dos especialistas que atuam na prática e na conceituação quanto ao conteúdo relativo aos dois objetos principais dessa pesquisa, as redes infraestruturais e os projetos de regeneração urbana. Assim, foram realizadas entrevistas com profissionais e acadêmicos, no sentido tanto de buscar esclarecimentos em relação à discussão teórica atual quanto para buscar auxílio no acesso de dados primários, o que pareceu bastante 
dificultado durante um período da pesquisa. Essas entrevistas se mostraram extremamente importantes, não só no sentido de ampliar a discussão proposta nesta tese, mas também de encontrar respostas muitas vezes impossibilitadas devido às dificuldades técnicas no acesso às informações e no tratamento dos dados.

A principal contribuição foi originada por especialistas na área de geração, transmissão, distribuição e inovação do setor elétrico. Por meio dessas discussões - resumidas no capítulo 3 -, foi possível obter um entendimento mais amplo e profundo em relação à problemática da rede infraestrutural de eletricidade, com claras conexões e aplicações junto a outras redes infraestruturais estudadas.

Devido à abrangente análise que englobou várias camadas de serviços infraestruturais, não foi possível realizar as entrevistas para todos os outros campos de conhecimento estudados, porém entendeu-se que as contribuições dadas por meio da discussão das redes de energia, tal como apresentado anteriormente, aplicam-se diretamente às outras redes pesquisadas.

Para além do desenho de redes, foram avaliados também os principais pontos de articulações da metrópole, definidos nos planos diretores municipais como áreas de interesse de desenvolvimento urbano e intituladas como áreas de operação urbana. Pontos de interesse imobiliários foram levantados por meio das pesquisas do Centro de Estudos da Metrópole, e as dinâmicas e os fluxos de intensidade entre os 
diversos espaços que compõem a RMSP foram analisados por meio dos dados da pesquisa origem destino do Metrô. Esses estudos foram determinantes não no sentido de buscar consequências de causa e efeito entre as dinâmicas estudadas, porém de buscar tendências na justaposição entre essas diversas condições estudadas.

As áreas de operações urbanas estudadas, as chamadas 'articulações', incluíram: a operação urbana Água Branca, Água Espraiada, Centro, projeto Nova Luz, Faria Lima, São Bernardo do Campo, projeto Arco do Tietê, Bairros do Tamanduateí, e as parcerias público-privadas Casas Paulista. Essas áreas foram sobrepostas a todos os mapas georreferenciados produzidos no início do capítulo 3 , o que incluiu os dados socioeconômicos e os dados de cobertura e qualidade das redes infraestruturais. O resultado da justaposição dessa vasta gama de informações foi organizado em duas matrizes, representadas nas Tabela 12 e Tabela 13.

Ainda neste capítulo, foi selecionada uma área para que se pudessem avaliar os fluxos decorrentes dos diversos motivos que levam as pessoas a se deslocarem entre as diferentes zonas incluídas da RMSP. Devido à complexidade do tratamento de dados nessa etapa do projeto, foi selecionada uma zona de pequeno tamanho, que pudesse representar a problemática descrita nos capítulos 2 e 3 , sendo escolhida assim a zona da Santa Ifigênia, que engloba o projeto Nova Luz (estudado no subcapítulo 2.9). Nessa etapa, foi possível demonstrar os impactos metropolitanos a 
partir do potencial de atração de determinadas zonas devido à oferta, ou carência, de empregos, comércio, educação e/ou lazer. Demonstraram-se também algumas tendências quanto à oferta ou carência de infraestrutura para essas mesmas áreas de articulação e fluxos estudadas.

Todos os campos de investigação examinados, que justapõem os dados infraestruturais, os dados de projetos de renovação urbana e as entrevistas, formaram uma base primária de dados empíricos fundamentais para a confrontação da hipótese inicial.

Por fim, no quarto e último capítulo, as partes conceituais e empíricas analisadas nesta tese foram contrapostas de forma a responder os argumentos e a hipótese desta, assim como se delinearam algumas perspectivas futuras de pesquisa no campo do planejamento urbano e regional quanto à infraestrura e aos projetos de regeneração urbana.

\subsection{Estrutura de capítulos}

A primeira parte desta tese tem como finalidade delinear os objeto e objetivos da pesquisa, assim como a metodologia e os argumentos e a hipótese que estruturaram a tese.

O segundo capítulo tem por objetivo contextualizar os discursos que apoiaram os projetos de desenvolvimento urbano desde o pós-guerra 
(meados do século $\mathrm{XX}$ ), tais como a revitalização, a renovação, a requalificação e, por último, a regeneração urbana, com o intuito de delinear suas similaridades e diferenças, por meio de uma revisão bibliográfica. Tem-se como principal argumento o pressuposto de que essas iniciativas, apesar das distintas designações e retóricas, produzem implicações urbanas de natureza semelhante, funcionando como espaços que mantêm ou reparam a capacidade e a eficiência dos sistemas de acumulação do capital, por meio da criação de espaços diferenciados. A demanda da população por melhoramentos urbanos, tanto por infraestruturas básicas quanto por serviços em maior quantidade e qualidade, tende tanto a ser cada vez mais exigente quanto a ser maior que a oferta, o que leva a produzir uma saturação quase imediata naqueles locais que sofrem intervenções positivas, diluindo sua capacidade e gerando maior necessidade de melhoramentos em outros locais.

De forma a complementar e superar a análise conceitual proposta no início do segundo capítulo, também se examinaram as práticas da regeneração urbana por meio da avaliação de três estudos de caso: o Les Halles em Paris, o Bankside Urban Forest em Londres e a Nova Luz em São Paulo. Mediante o estudo desses projetos, buscou-se tornar evidente o processo de regeneração urbana e suas relações com as redes de infraestrutura, assim como seus impactos no local, no entorno imediato e num contexto metropolitano. Essa investigação teve como 
objetivo incorporar problemáticas que dificilmente são discutidas no campo estritamente técnico da engenharia das redes de infraestrutura aprofundadas no terceiro capítulo.

O terceiro capítulo teve por finalidade organizar as informações levantadas na pesquisa empírica das redes de infraestrutura urbana para a Região Metropolitana de São Paulo, sempre com a intenção de representar os dados no campo territorial, de forma a possibilitar a identificação da diferenciação do espaço urbano com base na distribuição física e qualitativa das redes de infraestrutura urbana. Neste capítulo, pretendeu-se identificar quais indicadores poderiam melhor representar a diferença da qualidade das redes de serviços públicos entre setores censitários, zonas, distritos, ou municípios, assim como a consequente carência por melhorias por parte de seus residentes, trabalhadores, ou mesmo, visitantes. Para melhor identificação dessas diferenças, foram criados mapas de diferenciação, que pudessem evidenciar as discrepâncias na cobertura, qualidade de distribuição e, por vezes, consumo de recursos da Região Metropolitana de São Paulo. Foram analisados dados quanto aos serviços de infraestrutura de energia, gás canalizado, telecomunicações, transportes e saneamento, dentre estes, a rede de água e esgoto e coleta de lixo, e também dados de pavimentação e iluminação pública.

Assim, este terceiro capítulo processou uma radiografia das forças da infraestrutura urbana a fim de permitir que essas diferenças 
pudessem ser desenhadas no território da metrópole, o que, em outros campos de investigação do tema, por exemplo, no campo da sociologia, economia ou política, têm sido representadas apenas por meio de uma classificação socioeconômica, não sendo averiguados os possíveis efeitos ou consequências dos determinantes espaciais, territoriais.

Para além do desenho das 'veias' do território estudado, já descritas, procurou-se também representar quais as importantes articulações, os pontos de interesse imobiliários, as dinâmicas e os fluxos de intensidade entre os diversos espaços da metrópole. Esses estudos foram determinantes no sentido de buscar tendências quanto à justaposição entre essas diversas condições especuladas.

As chamadas 'articulações' urbanas foram sobrepostas a todos os mapas georreferenciados produzidos no início do capítulo 3, o que incluiu os dados socioeconômicos e os dados de cobertura e qualidade das redes infraestruturais. O resultado da justaposição dessa vasta gama de informações foi organizado em duas matrizes que relacionaram as Operações Urbanas Consorciadas (OUCs) ao quadro socioeconômico e as infraestruturas urbanas.

Ainda no capítulo 3, procurou-se demonstrar os impactos metropolitanos a partir do potencial de atração de determinadas zonas devido à oferta, ou carência, de empregos, comércio, educação e/ou lazer; por meio dos chamados 'fluxos metropolitanos'. Demonstraram-se 
também algumas tendências quanto à oferta ou carência de infraestrutura para essas mesmas áreas de articulação e fluxos estudadas.

Finalmente, o quarto e último capítulo teve a intenção de integrar os resultados dos capítulos anteriores (2 e 3), no sentido de dar uma contribuição mais ampla para o conhecimento no campo do planejamento urbano e regional. Nesta parte, buscou-se responder a hipótese desta tese, na qual projetos de renovação urbana em cidades em desenvolvimento que integram melhorias em relação à cobertura e à qualidade de infraestrutura urbana - diferenciadas em relação ao entorno - tendem por perder as qualidades intrínsecas que os diferenciam, sendo os seus benefícios superados e dissipados no território metropolitano. Por conseguinte, esperou-se evidenciar a importância do acesso à infraestrutura para assegurar os objetivos da regeneração urbana. Portanto, nessa conclusão, pretendeu-se demonstrar os efeitos de concentração e de dissolução dos melhoramentos urbanos, assim como a influência das interrupções infraestruturais na reprodução da desigualdade social.

Concluindo, no quarto capítulo, as condições da sociedade no sistema de redes infraestruturais foi novamente posto em questão, assim como discutidas as condições do desenvolvimento urbano em relação à integração ou à fragmentação territorial dos diferentes âmbitos de infraestrutura e serviços públicos. Os conceitos discutidos no início da tese foram revistos de forma a buscar perspectivas quanto às possíveis 
implicações provocadas pela privatização e regulação dos serviços infraestruturais públicos, assim como os processos de formação de guetos e enclaves diferenciados.

Dessa forma, foi possível evidenciar a heterogeneidade na rede de carências e benefícios no território da metrópole, compondo a defesa do argumento dos outros capítulos que compõem esta tese: que soluções tópicas na rede infraestrutural dificilmente respondem a demanda, sendo suas qualidades e diferenças dissolvidas no grid urbano. 


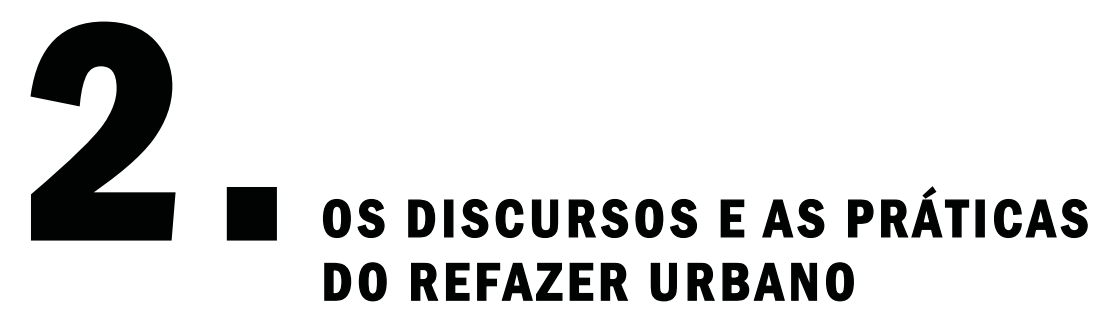

Este capitulo tem por objetivo contextualizar os discursos que apoiaram os projetos de desenvolvimento urbano desde o pós-guerra (meados do século XX), tais como a revitalização, renovação, requalificação e, por último, a regeneração urbana, com o intuito de delinear suas similaridades e diferenças, por meio de uma revisão bibliográfica. Tem-se como principal argumento o pressuposto de que essas iniciativas, apesar das distintas designações e retóricas, produzem implicações 
urbanas de natureza semelhantes, funcionando como engrenagens - ou arranjos espaciais ${ }^{2}$ - que mantêm ou reparam a capacidade e eficiência dos sistemas de acumulação do capital, por meio da criação de espaços diferenciados. A demanda da população por melhoramentos urbanos, tanto por infraestruturas básicas quanto por serviços em maior quantidade e qualidade, tende tanto a ser cada vez mais exigente quanto a ser maior que a oferta, o que leva a produzir uma saturação quase imediata naqueles locais que sofrem intervenções positivas, diluindo sua capacidade e gerando maior necessidade de melhoramentos em outros locais.

\footnotetext{
${ }^{2}$ Segundo Harvey (1990 ed. 2006), o conceito de arranjo especial, ou 'spatial fix', consiste na configuração espacial do ambiente construído, inclusive em termos de infraestrutura urbana, apropriada para as necessidades de acumulação de um dado período, que com o passar do tempo se torna obsoleta, passando a constituir um entrave - por meio das próprias deseconomias de aglomeração - devendo ser restruturada, reconfigurada, reconstruída, para dar as bases mais eficientes para o novo contexto. Para Harvey, a geografia adequada às necessidades da acumulação em dado momento histórico se torna eventualmente obsoleta em relação às exigências posteriores.
} 


\subsection{Definições e princípios desde o pós-guerra}

Desde meados do século XIX até o início da Primeira Guerra Mundial, a população das já maiores concentrações urbanas cresceu consideravelmente como resultado de imigrações em massa, principalmente proveniente da Europa. A maioria dos imigrantes pobres se concentrava em aglomerações étnicas, vivendo em habitações insalubres e superlotadas, já que, neste período, não havia programas de bem-estar social promovidos pelo governo (KEATING, 2001). São comuns as referências dessa época, em livros, filmes e documentários, a respeito das condições miseráveis que vivia grande parte da população, principalmente nas maiores concentrações urbanas, como em Nova York, Londres e Paris. Nos Estados Unidos, projetos de habitação social só surgiram na década de $1930^{3}$, após a Grande Depressão, décadas após a sua adoção em alguns países da Europa. A Depressão apenas exacerbou os profundos problemas existentes em áreas urbanas pobres, tema que passou a ser central para alguns líderes reformistas na área de habitação

3 Muitos desses projetos foram fruto do manifesto 'Carta de Atenas' para a 'cidade funcional', que se distinguia das cidades da Depressão pelo transporte especializado, autoestradas, edifícios altos, extensos espaços abertos e cidades dormitórios planejadas. 
social. Alguns programas nacionais de planejamento urbano ${ }^{4}$, sempre, de alguma forma, ligados aos programas de habitação social e de estabelecimento de códigos de zoneamento, passaram a surgir, porém fizeram muito pouco para aliviar os problemas de moradias precárias em favelas e cortiços. Devido à Segunda Guerra, esses primeiros programas foram interrompidos e, obviamente, os problemas exacerbados, exigindo um comprometimento dos governos nacionais a iniciarem programas de reconstrução para restaurar não apenas as estruturas físicas das cidades, mas também uma nova fundação ideológica:

Os anos após a Segunda Guerra Mundial viram uma enorme explosão da atividade do planejamento [urbano], especialmente na Europa: o grande plano estratégico para Londres, Copenhague, Estocolmo e, muito mais tarde, Paris. A motivação foi a de uma abrangente reconstrução do pós-guerra; porém, efetivamente representou uma continuidade ou conclusão dos movimentos de planejamento anteriores, após de um longo atraso devido a Depressão e a Guerra Mundial, agora fortemente associadas a uma agenda social mais ampla: a construção do Estado de Providência. (HALL, 2002, p.264)

\footnotetext{
4 Um panorama do Planejamento Urbano em 50 anos: Washington DC (1901); Chicago (1909); as inspiradas Cidades-Jardim de E. Howard: na Inglaterra Letcworth (1904) de Mumford, e Welwyn (1919) de Soissons; BoradCare CityDream (1930s) de Lloyd Wright's; Chandigarh (1947) de Le Corbusier e finalmente Brasília (1956) de Lúcio Costa.
} 
Após a década de 1950, a atividade de planejamento cresceu significativamente, evoluindo dos planos utópicos para a concreta implementação de programas, estabelecendo-se assim dentro do aparelho político do Estado de Providência. O discurso dominante era de que o planejamento urbano, com seus programas de desenvolvimento e redesenvolvimento urbanos, é uma atividade inequivocamente beneficente de governo: abrangente, tecnocrática, científica e socialmente progressiva, reformando as cidades para permanecerem mais saudáveis, eficientes, prósperas e bonitas (FREESTONE, 2001). Certamente, para que os planos de planejamento e desenvolvimento urbano tivessem prosseguimento, seu elemento principal - o uso e o valor da terra passaria de modo crescente a se tornar uma tecnologia na qual seu aperfeiçoamento se tornaria fundamental para propelir a economia urbana. O alvo destes programas era o de encontrar lugares obsoletos nas cidades, usualmente - mas nem sempre - áreas bombardeadas ou destruídas pela guerra, estabelecendo novos usos que fossem ao encontro à 'moderna' cidade industrial, frequentemente o fazendo a custo do tecido histórico da cidade e das comunidades existentes.

Em resposta a essas dinâmicas espaciais, o Estado passou gradativamente a intervir e controlar em maior grau as transformações urbanas, percebendo que os objetivos sociais mais amplos da sociedade não seriam atendidos isoladamente pelos mercados e atividades que transversalmente interferiam na divisão do espaço urbano, que, por sua 
vez, geravam impactos socioeconômicos profundos. Segundo Couch (1990, p.2), o Estado começou a controlar o traçado das vias e das redes de serviços públicos e a estabelecer normas mínimas para a habitação, tendo poderes para exigir a remoção de favelas e, até mesmo, construir novos edifícios habitacionais para substituí-las. Aos poucos, o Estado passou a estabelecer o papel de custear alguns dos passivos sociais agregados ao desenvolvimento e redesenvolvimento urbano, e até a envolver-se diretamente nesses projetos. Ao longo dos anos, tornou-se evidente que alguns aspectos do redesenvolvimento urbano não seriam facilmente manipulados pelo mercado, já que volumosos investimentos em infraestrutura, estes raramente rentáveis, seriam necessários antes que se pudessem desenvolver atividades rentáveis, como o desenvolvimento imobiliário. Estas redes essenciais de serviços passam a ser de responsabilidade do Estado, por meio de provisão direta ou de regulação sobre serviços delegados. De lá para cá, muita coisa mudou em relação aos principais promotores de investimentos nas redes de serviços infraestruturais básicos, o que não será aprofundado neste texto, senão apenas para demonstrar uma relação de atrelamento entre as responsabilidades e os interesses estatais e privados, e o acesso da sociedade a estas redes.

No caso específico de São Paulo, segundo Silva (2000), a relação entre o acesso à rede de serviços públicos e os processos específicos de exclusão social na escala urbana tem mudado consideravelmente. As 
relações econômicas e sociais estão sendo cada vez mais expostas a ajustes econômicos ligados à economia global, que exigem novas ferramentas analíticas, capazes de detectar novas formas de disparidade nas cidades em que - como em São Paulo - empresas, comércio e serviços têm substituído a atividade industrial como a fonte hegemônica de renda e emprego. Segundo ele:

Ao contrário de países industriais avançados, a nacionalização da oferta de redes de serviços no Brasil não foi capaz de superar todas as características de exclusão anterior - pré-1940 oferta privada e praticamente não regulamentada. As necessidades de uma demanda industrial crescente por serviços públicos tem precedência sobre as necessidades de reprodução social e as primeiras décadas do modelo estatal de fornecimento foram caracterizados por uma clara exclusão de grupos de baixa renda. (ibidem, p.162)

Sendo assim, parece adequado afirmar que o acesso desigual à infraestrutura básica cria espaços heterogêneos no tecido urbano, que, por sua vez, perdem ainda mais valor, já que perdem a capacidade de atrair o interesse de setores privados a realizarem seus investimentos em melhoramentos urbanos (lembrando o que foi exposto anteriormente, que a presença de serviços básicos é muitas vezes fator decisivo de atração de investimentos particulares).

Isso posto, por princípio, as iniciativas de desenvolvimento urbano buscam espaços previamente urbanizados, vantajosos e 
convenientes, no sentido de implantar, ou reimplantar, o crescimento econômico, enfatizando que "se a urbanização provoca o crescimento econômico ou crescimento econômico produz a urbanização, é indiscutível que os mesmos caminham juntos" (UN-HABITAT, 2010, p.43).

Sendo os projetos de desenvolvimento urbano iniciativas que, direta ou indiretamente, fomentam o restabelecimento de certa vitalidade econômica em uma localidade, este não teria sucesso sem o empreendimento de ações atreladas entre o estado e a sociedade de um período, sempre acompanhada de um discurso plausível. Os programas e discursos que objetivaram este refazer do tecido urbano serão aprofundados nos próximos tópicos, no sentido de se buscar um melhor entendimento de sua natureza, sua evolução, suas similitudes e diferenças.

\subsubsection{A natureza do prefixo re}

Dentro do campo do urbanismo, projetos com base no conceito de redesenvolvimento urbano objetivam reutilizar e reestruturar parte considerada decadente de uma parte da cidade, no sentido de regular, reviver ou reinstalar vitalidade econômica. Esse movimento contra a 
decadência de arredores urbanos tem bases, explícitas ou não, na ideia de sustentabilidade, na qual um sistema deve perdurar e ser capaz de permanecer diverso e produtivo através do tempo.

Evidências recentes ressaltam a importância de se repensar os espaços urbanos na atualidade, já que, em 2007, a população global urbana $^{5}$ se equivaleu à rural, ultrapassando-a rapidamente nos anos subsequentes. Em 2050, as projeções demográficas da Organização das Nações Unidas (ONU) indicam que a população mundial deverá ser de, aproximadamente, $70 \%$ urbana e seu crescimento deverá se concentrar no mundo em desenvolvimento (UNITED NATIONS, 2007). No Brasil, a população urbana é de aproximadamente $87 \%$ e, segundo projeções, chegará a 90\% em 2025 (UNITED NATIONS, 2009).

À medida que o mundo torna-se crescentemente mais urbano, é cada vez mais importante a compreensão dos processos que acompanham essa dinâmica: como as diferentes necessidades por recursos naturais, quanto aos impactos físicos, econômicos, sociais e culturais que transformam a sociedade, que, por sua vez, como em um

5 Segundo a UN Urban STATS

(Disponível em: <http://unstats.un.org/unsd/demographic/sconcerns/densurb/

Defintion_of\%20Urban.pdf>), a definição difere de país para país, e mesmo entre regiões do mesmo país. Porém, para o caso do Brasil, a definição de populações urbanas se refere àquelas de zonas urbanas e suburbanas de centros administrativos de distritos e municípios. 
circuito, também produz e modifica o espaço em que habita. $\mathrm{O}$ processo de urbanização crescente referido, no entanto, não tem a expansão territorial como premissa. As áreas urbanas são dinâmicas, constantemente alterando sua forma e seus processos; estas se expandem, se contraem, ou se reestruturam internamente em resposta a mudanças econômicas e sociais. É importante ressaltar que o crescimento demográfico urbano foi mais intenso após a Revolução Industrial e, em países e regiões desenvolvidos, principalmente na Europa Ocidental e Estados Unidos, este não mais exerce a mesma pressão ocorrida após as duas grandes guerras (1 $1^{\underline{a}}$ e $2^{\underline{a}}$ Guerras Mundiais). Nesse contexto, hoje a maior parte das transformações que afeta áreas urbanas resulta de ajustes graduais das atividades econômicas e de movimentos populacionais entre bairros ou entre cidades, e seus efeitos no espaço urbano.

Estas transformações sociais e econômicas modificam as demandas espaciais, podendo levar à intensificação da utilização de algumas áreas, em detrimento de outras. Essas dinâmicas geram a necessidade de demolir propriedades, recuperá-las, alterar seu uso e ocupação, criar novos empreendimentos ou, até mesmo, abandoná-los, alterando assim constantemente o tecido material das cidades. Além disso, essas demandas trazem consigo a necessidade de reconfigurações na prestação de serviços públicos e infraestruturais, não só em sua conformação física, mas também em sua operação e gestão. Este repensar da evolução das cidades está diretamente ligado ao desafio contínuo da 
economia global, junto às suas variações demográficas, devido à busca de melhores condições de trabalho e moradia e qualidade de vida, que, combinados, invocam um pensamento quase calamitoso, de que todo o território do planeta possa se tornar uma cidade interminável ${ }^{6}$. $\mathrm{O}$ empenho contra a então decadência de espaços urbanos consome vastos esforços, especialmente largas somas de capital, justificado como uma reforma necessária para despertar o motor econômico.

A ideia de promover iniciativas de desenvolvimento urbano em lugares considerados deteriorados parte de um pressuposto de que a decadência, a disfunção e o descontrole devem ser eliminados do tecido urbano, devendo ser regenerados. Do grande mapa da cidade de Londres, ao menos um quinto da extensão da cidade é destacada pela prefeitura como passível de projetos de regeneração urbana, definidos como áreas de empobrecimento por critérios como carência em termos de renda, emprego, saúde, educação, crime, moradia, serviços e meio ambiente. Pelo mapa, fica claro que estes problemas não estão homogeneamente distribuídos, e, sim, concentrados em diversas partes da cidade. De acordo com a referência, 26\% de Londres estão entre 20\% das áreas mais desfavorecidas de toda a Inglaterra (INDEX OF MULTIPLE DEPRIVATION, 2013). No caso de São Paulo, segundo pesquisa de Alves 
(2006) do Centro de Estudos da Metrópole, o território da metrópole também apresenta uma profunda heterogeneidade no que se refere aos grupos de vulnerabilidade social. Segundo Alves (idem), dentro do grupo de alta vulnerabilidade também existem diferenças significativas nas condições socioeconômicas e demográficas, relacionadas às categorias de vulnerabilidade ambiental. Desta forma, a vulnerabilidade social é agravada por situações de risco e degradação ambiental, que, por também apresentarem maior concentração de crianças e jovens, revelam a existência de áreas críticas, nas quais justamente os grupos sociais com maiores níveis de pobreza e privação social - e, portanto, com menor capacidade de reação às situações de risco - vão residir. Portanto, esta sobreposição e cumulatividade de riscos e problemas sociais e ambientais representam um grande desafio para as políticas públicas, que, na maioria das vezes, são compartimentalizadas segundo áreas de intervenção setorial.

As propostas de redesenvolvimento possuem a capacidade de trazer inúmeros benefícios aos locais de vulnerabilidades múltiplas: a provisão de habitação social, o reúso de áreas degradadas, o aumento de densidade e, consequentemente, a redução da expansão urbana, além das melhorias na acessibilidade, na valorização da paisagem, entre outros aspectos. No entanto, essas ações geralmente envolvem em destruição de construções e paisagens de interesse histórico, poluição, perda de espaços públicos, perda de biodiversidade e, prioritariamente, realocação de 
pessoas de baixa renda, na maior parte das vezes devido à valorização das propriedades da região - objeto de investimentos e afluência de população de classe média. Projetos de redesenvolvimento urbano devem, pois, enfrentar o desafio de trabalhar nessas diferentes 'camadas' e escalas, ao mesmo tempo.

$\mathrm{Na}$ tentativa de criar um entendimento mais claro e crítico dos discursos e manifestações do redesenvolvimento urbano, serão analisadas algumas das primeiras iniciativas internacionais do século XX, principalmente nos EUA e na Europa.

\subsubsection{Da remoção de moradias impróprias à renovação urbana}

Como apresentado anteriormente, as condições impróprias e intoleráveis de moradia em bairros já consolidados em cidades do pósguerra (pincipalmente americanas e europeias em crescimento), junto à aspiração de se fazer 'melhor' uso do solo em áreas urbanas centrais, deram início à implementação de massivas remoções de populações pobres e destruição de moradias consideradas impróprias. Internacionalmente, essa fase é designada de Slum Clearance, ou mesmo, Era of the Bulldozer, por sua imposição física e agressiva como a de uma 'escavadeira' (do inglês bulldozer), acompanhada de uma 'liberação' ou 'limpeza' (do inglês clearance) destes espaços físicos, para a instauração 
de outros usos. De forma geral, em seu impacto quantitativo, diz-se que as populações europeias removidas foram, em sua maior parte, realojadas pelo Estado. Em contrapartida, as norte-americanas, devido à construção de novas habitações sociais estarem nas mãos de empreendedores privados, estes não acompanharam o número de remoções promovido pelo governo, o que gerou um grande déficit. Além disso, é relevante a segregação infundida na ocupação daqueles dos edifícios habitacionais construídos nos locais das remoções, na maioria das vezes destinados às famílias brancas com mais recursos socioeconômicos, em detrimento das mais carentes.

Independentemente do país em que estes projetos foram implantados, a resposta foi de insatisfação generalizada por parte das populações forçosamente removidas, acarretando em altos custos em suas estruturas sociais, e muitas vezes, em um progressivo processo de empobrecimento. Os locais desses novos empreendimentos eram comumente remotos e isolados e as estruturas físicas propostas pelos arquitetos do 'novo espírito moderno' não refletiam a maneira de morar dessas famílias, sendo esses empreendimentos considerados frios e desumanos. Dessa forma, é possível caracterizar esta fase pela ênfase no ambiente construído e por um determinismo físico na construção de melhores estruturas materiais para essas áreas degradadas. Apesar da produção de habitações mais seguras e higiênicas em comparação com as moradias precárias a que substituíram, essa abordagem 'retroescavadeira' 
produziu uma má reputação, sendo gradativamente substituída pelos discursos da renovação urbana e reabilitação de vizinhanças. Segundo Couch, Fraser e Percy (2003), a renovação urbana na década de 1960 foi dirigida pelo setor público e, principalmente, preocupada com a reconstrução em grande escala de áreas de moradias precárias superlotadas e situadas em localidades centrais nas grandes cidades.

A reação mais notável destes projetos de desenvolvimento urbano de larga escala, e talvez a primeira desta robustez, foi verbalizada pela jornalista norte-americana Jane Jacobs, por meio de seu livro, Morte e Vida das Grandes Cidades, publicado em 1961. Nesse livro, Jacobs faz uma crítica severa desse tipo de empreendimento, realçando seus impactos negativos na vida diária das comunidades e na vitalidade dos bairros. Institucionalmente, a Lei dos Direitos Civis Americanos só foi instituída em 1964 e teve como intenção remover as restrições raciais em habitação para tentar reverter a severa segregação de bairros residenciais. É importante ressaltar que a segregação e a discriminação racial norteamericana aumentaram de intensidade nesse período por conta da prática chamada de redlining (marcações em vermelho), na qual instituições bancárias, imobiliárias, ou mesmo, de prestação de comércio, de serviços e saúde passaram a delinear áreas na cidade em que não se instalariam ou investiriam seus recursos. Credores, seguradoras e corretores de imóveis evitariam, assim, os bairros com populações expressivamente de minoria, com base de que sua malvista presença 
ameaçasse o interesse imobiliário, causando a evasão de moradores de melhor status. O conjunto desses fatores explodiu nos tumultos que varreram as cidades norte-americanas entre os anos de 1965-1967, evento relevante nos estudos de justiça social e geografia de David Harvey.

Estudos posteriores também observam os sistemas de governo deste período pelas técnicas disciplinadoras e reguladoras que interferiam na forma urbana por meio de iniciativas de desenho e redesenho de áreas urbanas. Como observado por Focault (1975, ed. 2003), as habitações produzidas para a classe operária do século XIX são representações de técnicas disciplinadoras e reguladoras de sistemas de governo:

Podemos facilmente verificar como o próprio 'grid', a própria configuração espacial, de propriedades articuladas em uma espécie de forma perpendicular, torna-se um mecanismo disciplinar que controla o corpo [...]. O fato de que indivíduos tornam-se visíveis, junto a normalização de comportamentos, significou uma espécie de policiamento ou controle espontâneos gerados pela configuração espacial próprias da cidade. É fácil identificar uma série de mecanismos disciplinadores em propriedades de habitações da classe operária [...] que aplicam-se a população e que incentivam padrões de economias relacionados à habitação, o arrendamento de acomodações, e em alguns casos sua compra." (ibidem).

Um dos mentores dos projetos de redesenvolvimento urbano de larga escala, que se denominam de renovação urbana, foi o urbanista norte-americano Robert Moses, comparado por críticos ao Baron 
Hausmman do século XX, ou The Power Broker. Conhecido por seu grande poder de persuasão e influência política, um dos primeiros passos de Moses foi suspender o projeto em andamento do Plano de Zoneamento de Nova York, ganhando assim liberdade para implementar seu plano ambicioso de, literalmente, refazer a cidade. Moses ganhou proeminência e influência política após a Segunda Guerra Mundial, quando a maioria de suas propostas urbanas foi concedida pelos sucessivos prefeitos de Nova York no período, entre 1945-1960. Moses se tornou público por dar prioridade à construção de autoestradas e pontes emblemáticas, promovendo o uso de automóveis, além da construção de quase trinta mil unidades habitacionais, praticamente o mesmo número de demolições de habitações consideradas precárias e construções de parques públicos distantes do centro da cidade ${ }^{7}$. Apenas uma curiosidade, em 1969, dez anos depois, a ponte Rio-Niterói seria construída, medindo aproximadamente dez vezes a extensão da média das construídas por Moses.

A reputação de Moses passou a ser cada vez mais questionada, à medida que seus projetos devastavam bairros e comunidades históricos para a abertura de vias expressas, deslocando milhares de residentes de

${ }^{7}$ Por exemplo, Long Island (Robert Moses State Park), um de seus parques mais proeminentes, podendo ser acessado apenas por automóvel, por meio da recémconstruída Robert Moses Causeway. 
locais proeminentes, assim como pela decadência dos transportes públicos, apontada pelos cidadãos nova-iorquinos por seu desinvestimento no setor. Uma passagem que ilustra a visão de Moses pode ser esboçada por uma entrevista de Robert Caro ${ }^{8}$ com um dos engenheiros de Moses, Sidney M. Shapiro, descrita em um artigo de autoria de Joerges (1999, p.416):

Moses havia restringido o uso de parques estaduais por famílias pobres e de classe médiabaixa, limitando o acesso por meios de transporte rápidos (público); ele havia vetado a proposta de construção de um ramal da Estrada Long Island Rail à praia Jones por este motivo. Agora ele passou a limitar o acesso por ônibus, instruindo Shapiro (um de seus engenheiros) a construir uma ponte bem baixa sobre a nova via - muito baixa para que ônibus possam passar.

Além desses fatores, o imaginário de uma parte da população foi machucado com sua oposição e a destruição de muitos dos edifícios e atividades de recreação do parque de diversões popular Coney Island, considerados por ele de 'mau gosto'. Da mesma forma, projetos de renovação urbana ao redor do mundo tiveram sua reputação protestada por seus impactos ambiciosos no tecido físico e social da cidade, sendo debatidos até hoje, ao mesmo tempo criticados e louvados por diversos setores da sociedade.

${ }^{8}$ Autor do livro The Power Broker: Robert Moses and the Fall of New York (New York: Alfred Knopf, 1974, p.318). 


\subsubsection{A reabilitação, a revitalização e a requalificação urbana}

O sucesso econômico de alguns dos projetos de renovação urbana da década de 1950, como o Golden Triangle em Pittsburgh, no qual grande parte do centro da cidade foi demolida e reconstruída com edifícios de escritórios, parques e uma arena de esportes, pode ser reconhecido, já que a cidade era célebre por ser uma das mais sujas e economicamente deprimidas dos Estados Unidos. Porém, como notado anteriormente, essas iniciativas de renovação, apesar de seus melhoramentos, não conseguiram 'abafar' a insatisfação crescente de milhões de moradores pobres e desfavorecidos que eram deslocados de seus endereços. Na década de 1960, não só os moradores, mas também a opinião pública passaram a se voltar contra esses projetos. Como exposto no influente livro de Jacobs (1961), críticos e acadêmicos ressaltavam a importância da diversidade na vida urbana - de bairros, edifícios e pessoas -, argumentando que os centros das cidades deveriam ser uma trama de atividades interligadas, que juntas trabalhassem para criar um centro mais amplo e forte. Dessa forma, antes da implementação de qualquer plano de planejamento, projetos deveriam ser estudados caso a caso, criteriosamente, e deveriam levar em consideração a opinião e participação dos afetados na tomada de decisões, tornando-se uma parte competente no processo de planejamento. 
A nova retórica que tomou forma com o slogan 'War on Poverty' do novo presidente americano Lyndon Johnson, em 1964, em vez de promover o Slum Clearance, investiria então em educação, saúde, formação profissional, segurança pública, e na reabilitação dos bairros existentes. Outro importante slogan da época denominava-se 'maximum feasible participation' ${ }^{9}$, termo que ironicamente já manifesta as contingências do que era na época considerada uma participação 'possível' ou 'exequível' das comunidades locais. Os programas de reabilitação foram uma série de atividades que visavam, em vez de demolirem as habitações existentes, melhorarem estas estruturas e seus ambientes, ao mesmo tempo em que promovesse o tratamento de problemas sociais, provendo serviços e melhorando sua qualidade.

Em 1966, depois de tantas iniciativas liberais abortadas anteriormente, o Congresso Americano aprovou uma legislação indispensável para estabelecer novos programas de renovação urbana: as Demonstration Cities (cidades-modelo) e o Programa de Desenvolvimento Metropolitano. O objetivo era o de acabar com a técnica bulldozer de reconstrução urbana, concentrando-se na reabilitação das habitações existentes, em reconhecimento de que o

\footnotetext{
${ }^{9}$ Ver Rubin (1969). Maximum Feasible Participation: The origins, implications, and Present Status. The ANNALS of the American Academy of Political and Social Science. September, 1969. vol. 385. no. 1, p.14-29.
} 
complexo de atividades urbanas constitui uma unidade orgânica, devendo incluir uma abordagem cuidadosa de planejamento para revitalizar todo o espectro de serviços à comunidade e de oportunidades econômicas, junto com a melhoria da estrutura física. Dessa forma, escolas, centros de saúde, lazer, serviços sociais, negócios locais, capacitação para o trabalho, centros policiais e de proteção contra incêndios e transportes deveriam ser simultaneamente implantados nos bairros marcados pelas formas mais graves da patologia urbana (CONDIT, 1974).

Segundo Carmon e Baron (1994), apesar da abundância de boa vontade e das grandes somas de recursos gastas em diversos países, a avaliação com ênfases sociais desses programas mostrou-se frequentemente negativa. Muitos programas não foram implementados e as verbas disponíveis gastas em locais e em questões que não faziam parte dos planos oficiais. No que foram implementados, os programas frequentemente beneficiaram os moradores locais, mas não seus entornos e seus bairros, não podendo alterar assim a sua reputação e a imagem negativa destes 'guetos', a fim de trazer benefícios mais amplos.

A crise financeira e a desaceleração da economia na década de 1970, aliada à crescente crítica por projetos de larga escala com as características anteriores, mudaram o foco do desenvolvimento - e redesenvolvimento - urbano. De forma geral, os governos recuaram seu envolvimento com projetos em áreas deterioradas, passando a 'oferecer' 
essas áreas a iniciativas privadas em troca de sanções especiais em impostos e benefícios financeiros, ambos 'a favor do bem comum'. Parcerias como essas tinham a forma de uma ligação direta do Estado com os moradores locais, ou de parcerias público-privadas. No primeiro caso, os indivíduos investiam em sua propriedade com recursos próprios, recebendo alguns incentivos de entidades voluntárias e/ou públicas. No entanto, a forma mais comum destas parcerias público-indivíduo foi o incentivo dos municípios, por meio de permissões legais específicas e deduções fiscais, de promover a atração de moradores de classe média ou média alta em bairros de baixa renda, geralmente próximos de centros de serviços atraentes, provocando o deslocamento de moradores menos avantajados para outros locais. Esse processo é conhecido como gentrificação, segundo Lees, Slater e Wyly (2007) “[...] a transformação de uma área da classe trabalhadora ou vacante dos centros de cidades, para o uso residencial e/ou comercial da classe média”.

Há um enorme debate em relação à promoção deliberada de processos de gentrificação: de um lado seus defensores justificam ser este um mal necessário para lidar com regiões decadentes, trazendo tanto melhorias físicas nas estruturas dos edifícios e bairros quanto aumentando o potencial para gerar vitalidade econômica nessas localidades, além, é claro, de gerar novas receitas - seus maiores defensores são obviamente os próprios governos municipais e os moradores vizinhos mais prósperos. Por outro lado, seus críticos se 
amparam no arcabouço da justiça urbana e na defesa da consolidação dos laços das comunidades locais - na justificativa de que a revitalização das áreas degradadas deveria ser feita pela promoção de programas de educação e inclusão, com foco na criação de empregos locais e geração de atividades econômicas locais e de pequena escala - e seus defensores seriam claramente os residentes locais que não conseguem arcar com os crescentes aumentos nos aluguéis e nos inalcançáveis valores das propriedades.

No caso das parcerias público-privadas, que enfatizam lucros e investimentos financeiros para fins de 'interesse público', estas são geralmente viabilizadas por extensas incorporações imobiliárias, em que seus promotores recebem, em troca, sanções especiais das autoridades locais, como isenções de impostos ou acréscimos na capacidade construtiva. Um exemplo emblemático desse último tipo de parceria foi o projeto de London Docklands no Reino Unido, que será explorado com mais profundidade em outro tópico desta pesquisa.

Um segmento específico do mercado unilateral privado anteriormente descrito, e em crescimento na década de 1980, foi o de planos de revitalização de centros urbanos, com o desenvolvimento de novos centros corporativos. Essa passagem foi ocasionada pela transição da economia industrial para aquela baseada em serviços, provocando um crescimento sem precedentes na construção de grandes complexos empresariais para fornecerem espaço para os serviços financeiros, 
administrativos e profissionais - expansão necessária para acomodar o progresso da nova economia global. Grandes plantas industriais passaram a ser desativadas ou realocadas para regiões periféricas das cidades, em que o valor da terra se encontrava menos valorizado, o que deixou vastas áreas centrais inativas e sem função, com potencial para serem revertidas em outros usos - de serem requalificadas - para acompanharem a nova economia, no caso, usos corporativos ou residenciais mais venturosos. Nos Estados Unidos, a quantidade de espaços de escritório disponíveis quase duplicou em pouco mais de uma década, atraindo um grande número de jovens profissionais de volta aos centros da cidade. Ao mesmo tempo, a atividade imobiliária que se apropriou dessas oportunidades de revalorização de localidades na produção de novos espaços comerciais e residenciais para a classe média passou a construir acima da capacidade de absorção do mercado, criando ciclos de expansão e contração de negócios refletidos nas recessões americanas das décadas de 1980, 1990 e 2000. É importante ressaltar que o modelo de investimento privado durante este período se mostrou limitado em sua capacidade de prever e prover espaços que respondessem as legítimas deficiências de cada bairro, não que este tivesse o objetivo de ir de encontro às demandas socioeconômicas locais, mas sim por sua oportunidade de alavancar negócios em áreas menos saturados.

A promoção da chamada requalificação urbana na forma de parcerias público-privadas, ao contrário do desenvolvimento urbano 
promovido unilateralmente pela iniciativa privada, teria então maior possibilidade de promover e assegurar uma melhor coordenação entre os objetivos econômicos - foco do setor privado - para as mais abrangentes políticas urbanas: sociais, econômicas e ambientais. Esse estilo mais 'comercial' de redesenvolvimento urbano evidente na década de 1980 reflete um conjunto de mudanças na natureza e estrutura do controle e da filosofia política (ROBERTS; SYKES, 1999). Outra questão que passa crescentemente a fazer parte dos novos discursos de desenvolvimento urbano desde a década de 1970 é o paradigma da sustentabilidade, com foco nas consequências ambientais provocadas pelo anterior desenvolvimento industrial e na economia capitalista de consumo. $\mathrm{O}$ argumento defendido é de que, nesse modelo de desenvolvimento, há limites naturais de capacidade dos ecossistemas para sustentar a vida humana sem significativa degradação ambiental. A expansão territorial suburbana, reflexo do crescimento da maioria das cidades pósindustriais, é vista como insustentável devido à sua ocupação excessiva sobre áreas naturais que exerceriam funções vitais no ecossistema do planeta. Nesse sentido, a consequência da excessiva suburbanização e da expansão urbana é vista como uma das promotoras de um novo declínio urbano, passando, então, a revitalização e o adensamento de áreas centrais a ser cada vez mais defendido como um meio para redirecionar o crescimento de subúrbios. 
Desde os anos 1970, a paisagem física dos centros urbanos também se alterou radicalmente até a década de 1980, refletindo a demarcada setorização proposta pelos códigos de zoneamento modernistas e dominada por uma arquitetura homogênea e funcionalista. Esses espaços foram marcados pelo legado de planejamento do pósguerra (visto anteriormente) e foram caracterizados por ambientes físicos pobres, sistemas de tráfego bastante hostis para os pedestres, espaços comerciais decadentes e economias dominadas pelos serviços, levando áreas inteiras das cidades a tornarem-se desertos culturais após o horário comercial. Desde então, a paisagem urbana das grandes cidades e os seus centros têm sido foco de novos investimentos e desenvolvimentos urbanos (ibidem). A década de 1980 viu uma 'reimaginação' dos centros urbanos na qual se envolveu uma combinação de aprimoramentos físicos e de uma valoração de espaços culturais emblemáticos que pudessem transformar a imagem das cidades. Esta 'reimaginação' foi, no campo da arquitetura, expressa por elementos pós-modernos, incluindo elementos do patrimônio histórico e do imaginário cultural coletivo, festivo e nostálgico, assim como a gentrificação, para dar nova vida a esses espaços (HALL, 2006). Esta combinação de elementos em decorrência da desindustrialização deu origem a novas políticas de redesenvolvimento urbano, que, em meados das décadas de 1980 e 1990, passa a denominarse regeneração urbana. 


\subsubsection{A regeneração urbana}

Sendo esta 'atividade' de regeneração urbana uma prática mais recente, dos últimos 20-30 anos, é possível perceber que este entendimento ainda está se consolidando, estando pouco maduro. A busca de definições acadêmicas faz-se necessária, assim como a dos outros termos estudados, mas percebe-se que esta última ainda se encontra superficial e pouco crítica. Dando um passo para trás e relembrando a definição do termo 'gerar' de acordo com dicionário Oxford, em que significa 'dar existência, produzir, evoluir'. Regenerar é 'gerar mais uma vez, ter a existência renovada':

Quando falamos de regeneração urbana estamos a falar de algo mais do que a renovação urbana: da reutilização e reinvestimento na estrutura física de áreas urbanas existentes. Estamos falando de um processo econômico que faz aumentar o que diminuiu: em ampliar o investimento onde ele retrocedeu, em aumentar o emprego onde este diminuiu, aumentar o gasto do consumidor e aumentar a população, em essência, estamos falando de crescimento econômico. (COUCH, 1990, p.75)

Procurando-se compreender a diferença no uso das terminologias 'renovação' e 'regeneração urbana', Couch (ibidem) procura esclarecer que a renovação urbana é o resultado inevitável da ação de forças econômicas e sociais sobre áreas urbanas, vista como a mudança física ou a mudança no uso ou intensidade do uso do solo e dos 
edifícios. Segundo ele, uma distinção deve ser feita entre o processo de renovação, essencialmente uma transformação física, e o processo de regeneração urbana, em que a comunidade ou o estado procura trazer de volta, ao local, investimentos, emprego e consumo, além de melhorar a qualidade de vida dentro de uma área urbana.

Segundo Roberts e Sykes (1999), a regeneração urbana pode ser vista como o resultado de uma interação entre vários processos, assim como uma resposta a oportunidades e desafios que são apresentados pela 'degeneração urbana' de determinado lugar em um momento específico no tempo. Isso não deve ser entendido como uma sugestão que todos os problemas urbanos são exclusivos de uma determinada cidade, ou que as soluções defendidas e apresentadas no passado têm pouca relevância para as circunstâncias de hoje, mas é o caso de que cada desafio urbano provavelmente irá exigir a construção e implementação de uma resposta específica. Entretanto, a regeneração urbana seria uma visão e ação integradora e abrangente que leva à resolução de problemas urbanos, e que procura trazer melhorias duradouras nas condições econômicas, físicas, sociais e ambientais de uma área que tenha sido sujeita a mudanças. Esta é uma atividade primeiramente intervencionista, porém de ações coordenadas entre os setores público, privado, voluntário e comunitário; de formar a criar um meio de mobilizar o esforço coletivo e fornecer a base para a negociação de soluções adequadas. 
As perspectivas acima mostram uma tendência a se reintroduzir a perspectiva estratégica de planejamento urbano, com uma visão coordenada entre a ação local e as ações no nível regional, com um avanço direcionado a políticas e práticas mais abrangentes com ênfase em análises integradas, que não deixem de levar em consideração o patrimônio e a conservação, assim como a sustentabilidade ambiental.

Por outro lado, segundo Turok (2005), a regeneração urbana é dificilmente, se alguma vez já a foi, inclusiva, podendo fazer com que os problemas urbanos abordados não sejam na prática resolvidos, pois estes podem estar entre os problemas mais difíceis ou 'detestáveis' da sociedade.

Segundo Couch (1990), o principal impulso da política governamental nos últimos anos tem sido o de estimular a regeneração urbana por meio de várias formas de subsídios, mantendo apenas os mecanismos de nível tático de planejamento e controle urbano. Porém, seus efeitos tendem a levar a uma renovação urbana fragmentada e descoordenada, tendo consequências que prejudicam a eficiência entre os recursos utilizados e a eficácia com que os objetivos sociais possam ser alcançados. Os resultados são aparentes, por exemplo: na cidade de Londres, em que altos níveis de investimento combinados a uma multiplicidade de órgãos responsáveis e sem um controle e coordenação adequados levaram à aprovação de propostas como Canary Wharf, Broadgate, e a remodelação de Kings Cross, com pouca consideração em 
seu impacto sobre o meio ambiente, emprego e padrões de deslocamento, investimentos imobiliários e demandas habitacionais da cidade.

A regeneração urbana passou a ser sinônimo de gentrificação (LEES; SLATER; WYLY, 2007). Segundo Andersen (2003), a gentrificação indiretamente promove a decadência urbana, já que as pessoas de poucos recursos são deslocadas das áreas gentrificadas, concentrando-se em outras partes da cidade, em que a sucessão e a decadência se aceleram. Dessa forma, a gentrificação pode levar ao aumento da segregação e à decadência urbana nas cidades, dependendo do grau em que as áreas gentrificadas são substituídas para os subúrbios ou para outros bairros nas cidades. Também há indicações de que a gentrificação nos EUA pode ser relativamente temporária, na medida em que registros de Nova York (MARCUSE, 1997) indicam que processos de decadência começaram a aparecer em alguns dos bairros gentrificados/regenerados - movimento chamado de de-gentrificação. A regeneração, tanto nos EUA quanto em outras partes do mundo, poderia, portanto, em certa medida, ser um fenômeno pertencente a um determinado período histórico, desaparecendo com a mudança de 'gostos' e novas condições econômicas.

Mais recentemente, Couch, Sykes e Börstinghaus (2011) fizeram uma avaliação da regeneração urbana no Reino Unido, Alemanha e França, identificando questões e temas comuns dentro da arena política nos três países, particularmente no equilíbrio a ser alcançado entre 
iniciativas e estratégias que visavam garantir o desenvolvimento ou 'renascimento' das metrópoles enquanto cumpriam a aspiração de reconectar áreas e populações excluídas da dinâmica funcional a que pertenciam. Esses países têm em comum a visão de cidade como um motor de desenvolvimento econômico e reconhecem a importância das 'cidades competitivas' como fatores inerentes na política urbana. No entanto, esse ponto de vista não significa necessariamente que as tensões entre os objetivos visavam, de um lado, maximizar o desenvolvimento econômico e, de outro, minimizar a privação social e ambiental, esta muitas vezes incompatíveis. Dessa forma, os governos de cada país devem constantemente manter um equilíbrio entre o que é politicamente aceitável ou tolerável, contra essas diferentes medidas de sucesso.

As discussões anteriores apontam fortemente para o contexto de um caminho de dependência que moldou os fundamentos de regeneração urbana nos países e estados considerados, tanto nas questões quanto nas formas com que as políticas urbanas têm sido tratadas. $\mathrm{Na}$ França, é a difícil questão da exclusão social, particularmente em zonas habitacionais periféricas, que consome o pensar da inovação política. $\mathrm{Na}$ Alemanha, é a questão do desequilíbrio regional e os desafios demográficos que têm sido dominante na prática política. No Reino Unido (especialmente na Inglaterra, devido a sua alta densidade populacional), é a agenda que foi definida pelo governo Thatcher de reutilização e revalorização de recursos econômicos urbanos 
'desperdiçados' e subutilizados. Assim, a utilização de terrenos abandonados, a contenção da expansão urbana e a gentrificação de bairros foram as marcas da política da regeneração inglesa. Dessa forma, é evidente que os programas de regeneração urbana em cada país têm se desenvolvido de acordo com suas as normas e prioridades institucionais, sendo razoável concluir que há também a evolução da política de regeneração urbana de que cada um siga um caminho de dependência de diferentes graus (ibidem).

Independentemente dos termos utilizados nos programas de desenvolvimento e redesenvolvimento, estes respondem às prioridades da geração que os criou, apropriando-se das possibilidades que a arena política pôde oferecer, no limite da aceitação e tolerância do público. Regeneração urbana, revitalização, renovação e renascimento estão entre a infinidade de frases e chavões que tendem a ser usados pela mídia, governo e, até mesmo, acadêmicos como termos passíveis de serem intercambiáveis, essencialmente relacionados com o mesmo processo (TALLON, 2009).

Portanto, por meio das reflexões anteriores, sugere-se que as últimas iniciativas de regeneração urbana não chegam a alcançar os seus objetivos discursivos mais amplos, pois trabalham com as prioridades e resoluções de problemas mais emergentes para cada contexto, sem que a aspirada estratégia integrada possa ser desenvolvida, assim como os instrumentos de implementação e avaliação imparciais, necessários para a constatação de seu sucesso. 


\subsubsection{Conclusões parciais}

Em paralelo às políticas urbanas estudadas e suas iniciativas de redesenvolvimento com foco social, econômico e, às vezes, ambiental, é importante ressaltar o contexto dos indicadores de desigualdade de renda que, de maneira geral nos países desenvolvidos e em nível nacional, aumentou entre meados dos anos 1980 e 2005 - período em que os projetos de regeneração urbana passaram a ser implementados. Nos Estados Unidos, 1\% das famílias mais ricas ganham, hoje, mais de 72 vezes a média da renda do quinto populacional mais pobre e 23 vezes mais do que o quinto populacional médio ${ }^{10}$, enquanto em 1978, essa diferença era de aproximadamente oito vezes (MERRIFIELD, 2013). Em alguns países em desenvolvimento, como o Brasil, esta desigualdade vem diminuindo, apesar de ser uma das mais altas do mundo, mas a desigualdade é mais acentuada nas áreas urbanas do que nas áreas rurais (UN-HABITAT, 2010). Apesar de ser complexo estabelecer uma relação direta entre estes indicadores e as políticas urbanas contemporâneas que

10 Fontes indicadas pela UN-Habitat (2010): Gini data from the U.S. Census Bureau, 2006 American Community Survey; index of dissimilarity data from CensusScope, based on 2000 U.S. Census data. Sources: Beauregard, 2008; CensusScope, n.d.; Katz, 2002; Kneebone \& Berube, 2008; Massey \& Fischer, 2000; Massey \& Fischer, 2003; McCarthy, 1999; OECD, 2008; Schill \& Wachter, 1995; Sherman, 2009; Steffel Johnson, 2006; Von Hoffman, 2009 
implementam processos de regeneração urbana que, por sua vez, produzem efeitos na sociedade e nos espaços construídos, a aproximação pura destes fatos para efeitos discursivos parece racional se analisadas conjuntamente com os argumentos expostos neste artigo.

Observando estes argumentos, pode-se deduzir que o crescimento urbano nunca dependeu tão fortemente da criação de novos mecanismos para lidar com o capital financeiro e o crédito, fazendo-os 'girar' sob novos aparelhos desregulamentados e subscritos pelo Estado, transformando o capital excedente em especulação imobiliária. A acumulação do capital não se faz mais de tal maneira pela produção, mas pela espoliação e expropriação (MERRIFIELD, 2013).

Lembrando-se de um dos principais casos deste artigo, quando o programa de renovação urbana federal dos Estados Unidos (os 'Housing Acts' de 1949 e 1954) foi estabelecido, as 'cidades', ou melhor, suas administrações se habilitaram para poderem usar do domínio eminente de tomar posse de propriedades ${ }^{11}$, e, em seguida, leiloá-las a agentes privados, que as renovariam de acordo com os regulamentos de cada cidade. Como caso típico, o governo federal pagou à cidade de New Haven dois terços dos custos para compra, limpeza e revenda das 
propriedades de terra, enquanto ela reembolsava as pessoas cujas casas foram tomadas pelo, então, determinado valor de mercado imobiliário. Aproximadamente 25 mil pessoas foram obrigadas a se deslocarem ao longo dos programas de renovação urbana da prefeitura de Richard Lee, que duraram 17 anos - entre 1953 a 1970. Alguns permaneceram em New Haven, enquanto muitos se mudaram para os subúrbios. O processo de expulsão e o testemunho das demolições das antigas residências, às vezes de quadras ou bairros inteiros em nome da construção de grandes centros comerciais (hoje decadentes), provaram ser um período difícil de esquecer (THE ARGUMENTS OF URBAN RENEWAL, 2013; DEWIT, 2005). Dessa forma, para que o modelo econômico possa ser perpetuado:

O capitalismo não pode prescindir dos 'arranjos espaciais'. Mais uma vez ele voltou-se para a reorganização geográfica (através de expansão e intensificação) como uma solução parcial contra suas crises e impasses. O capitalismo, assim, constrói e reconstrói a geografia à sua própria imagem. Ele constrói uma paisagem geográfica distintiva, um espaço produzido de transportes e comunicações, de infraestruturas e de organização territorial, que facilita a acumulação de capital durante uma fase de sua história, para que o tenha demolido e reconfigurado para abrir caminho para uma nova acumulação em uma fase posterior, (HARVEY, 2000, p.54)

Como prognosticou Harvey (ibidem, p.78), diferenças geográficas estão perpetuamente sendo reproduzidas, sustentadas, prejudicadas, e reconfiguradas por processos político-econômicos e 
socioecológicos que ocorrem no presente. Por meio de apoio financeiro internacional, especuladores procuram maximizar seus ganhos pelo aumento de renda fundiária, radicalmente remodelando inteiros espaços metropolitanos em Shangai e Moscou, assim como em Londres e Nova York. A busca por rendas diferenciadas muitas vezes acentuam as discrepâncias geográficas na intensidade de investimentos de capital, fazendo com que regiões ricas fiquem mais ricas, enquanto regiões pobres fiquem mais pobres.

Mesmo assim, as iniciativas estudadas não deixam de inspirar uma expectativa por um futuro mais justo. Todas elas têm conotações semelhantes, relativas ao renascimento, à renovação e à reconstituição. A regeneração, por suas raízes na religião, teoria social e medicina, é uma palavra inspirada na esperança religiosa ${ }^{12}$. Talvez um presságio que demonstre o limite do real, a contradição de se tentar obter uma solução lógica dentro deste mesmo modelo que gera suas próprias incoerências.

Por todos os motivos apresentados acima, é possível afirmar que os projetos de regeneração partem do princípio de que as áreas urbanas consideradas degradadas podem ter o ser destino transformado mediante a implementação de uma agenda multidisciplinar que consiga disseminar 
uma dinâmica econômica favorável para a comunidade local, seu entorno imediato e seus efeitos na cidade.

Dessa forma, estabelece-se no cerne desses projetos de regeneração um compromisso de atenuação das desigualdades sociais, econômicas e ambientais, que, diferentemente dos projetos caracterizados como de renovação, reabilitação e requalificação urbana, são resumidos basicamente ao processo de transformação física das cidades.

\subsection{As redes de infraestrutura e a cidade}

A revisão e a definição dos conceitos mais debatidos quanto às redes e ao significado do termo infraestrutura se faz necessária para que se possa configurar uma estruturação teórica que sustente a discussão levantada nesta tese. Os conceitos selecionados para compor essa discussão foram aqueles diretamente aplicados ao campo das análises urbanas, mesmo que trazidos por teóricos ou profissionais de distintas formações, como sociologia, geografia, economia, engenharia e arquitetura. Dessa forma, procura-se responder, neste capítulo, à questão: quais as características que tornam os ambientes urbanos passíveis de serem representados pelo conceito de rede; assim como responder a 
pergunta: como a demanda da sociedade por distintos serviços urbanos acaba por configurar o ambiente físico conformado pelo sistema infraestrutural de uma cidade.

Segundo análise de Castells (apud PFLIEGER et al., 2008, p.215), a cidade em rede possui quatro características básicas: a primeira referese ao uso, às interligações e aos deslocamentos permanentes e contínuos entre o local e o global, entre lugares e fluxos; a segunda refere-se a transformações de estilo de vida associados à sociedade em rede, e os desafios que eles geram em termos de mobilidade espacial, residencial e social; a terceira característica básica da cidade em rede se dá em consequência dos processos sociais e programas políticos que juntos acabam por reorganizar a morfologia social e a geografia de diferenciação social - isto se reflete na quebra gradual das solidariedades de comunidades, que, por sua vez, se reflete em uma certa desqualificação dos lugares da vida cotidiana; e o último aspecto se refere aos processos políticos que possuem a capacidade de estruturar a cidade em rede, de repensar o planejamento moderno, as tomadas de decisão e de distribuição de poderes.

Em comentário a respeito do livro The Network Society: a new context for planning (ALBRECHTS; MANDELBAUM, 2005), Dupuy procura desafiar o tradicional paradigma do planejamento urbano por meio de uma abordagem de redes: 
A Rede (a possibilidade de uma sociedade organizada em rede) uma vez alimentou sonhos utópicos do espaço urbano não diferenciado, sem centros nem periferias. Assim o espaço seria, não importando onde este se localizaria [...]. As Redes iriam prover instantaneamente a todos com os mesmos serviços. E o que se quer dizer com Redes? Estas são sistemas técnicos projetados para fornecer convenientemente aos cidadãos os serviços que se tornaram cruciais para a vida urbana moderna: água encanada, esgotamento, energia, transportes, comunicações. Estas vieram a ser chamadas de 'redes' por causa de sua estrutura espacial - fios, tubulações, trilhos, e assim por diante, organizados por malhas ou ramificações dependendo do caso. (DUPUY, 2005, p.120, tradução nossa).

Em contrapartida, os autores ${ }^{13}$ da seção 'Impacts of Physical Networks' sugerem que a cidade, ou a sociedade urbana, continua a se desenvolver em direção a um modelo com alto grau de diferenciação, sendo que qualquer tentativa de impedir este caminho seria inútil, já que centros e periferias urbanas não se assemelham entre si; como também não servem às mesmas populações, nem mesmo às mesmas atividades.

A análise de Coutard (1999) a respeito do aclamado artigo 'Réseaux de communications. Marchés et territoires' de Dupuy e Curien 
(1997) nos relembra a metodologia de análise das redes de comunicação em relação aos seus impactos no território, por meio do conhecimento da morfologia e da topologia de redes. Nesta análise, a morfologia é analisada do ponto de vista formal de três camadas - a infraestrutura (tanto a robusta quanto a de telecomunicações), a 'info-estrutura' e os serviços. Esta versão é transposta e adaptada às necessidades de análise econômica do modelo de descrição de sistemas de teleinformática. A primeira camada - a infraestrutura - é definida como aquela que contém todos os equipamentos que suportam e asseguram a função de interconexão de redes. A segunda - a 'info-estrutura' - consiste no sistema de controle de quem opera os serviços, estes, os mais otimizados possíveis, que transitam através de um fluxo por meio da infraestrutura. Por último, a terceira camada é referente aos serviços prestados às diferentes categorias de cliente, sendo, por sua vez, diferenciados e adaptados à condição específica.

O estudo de topologia de redes, na visão de Dupuy e da linha editorial da Revista Flux, teria como objetivo evidenciar a organização territorial implicada pela presença de uma rede, a organização descontínua marcada por pontos, nós, origens, destinos e linhas que se cruzam sem que se fundam fronteiras ou espaços inteiros, sem 'osmose', pela palavra do autor (CURIEN; DUPUY, 1997). Conforme aplicável, as relações entre redes e territórios são baseadas na geografia topológica, que se refere à nodalidade das redes, apontando para o território servido, 
a geografia temporal (spatial anamorphoses) ou uma geografia tarifária (por exemplo, análise de distâncias e custos). Essencialmente, este estudo é fundamentado na teoria matemática de grafos, por meio da qual se define dois indicadores essenciais: a conectividade e as conexões de rede.

Curien e Dupuy (1997) também discutem processos conjuntos de privatização, liberalização e transposição caracterizadores da regulamentação, e desregulação, das redes. As redes técnicas são avaliadas de uma forma precisa, como um sistema de controle que organiza as relações entre todos os diversos agentes cuja interação determina o funcionamento do mercado: a autoridade pública, o serviço de regulação, as empresas ativas de mercado, os acionistas da empresa dominantes, os credores destas empresas etc.

Efeitos dessas redes deveriam considerar, por exemplo, modalidades como o club effect (efeito de clube), efeito no qual os benefícios proporcionados para clientes individuais acabam por aumentar o número total de usuários.

Também devem ser consideradas as externalidades das redes: positivas e negativas, diretas e indiretas, setoriais (abastecimento que afeta a demanda da rede) ou extrassetoriais (afetando outras economias). Um exemplo recorrente de uma externalidade seria o congestionamento, com características de externalidade negativa, direta e setorial, efeito este possível de ser gerado em todas as redes de infraestrutura. Um quadro de cooperação entre as diferentes redes e suas possíveis intermediações 
poderia configurar possibilidades de se engendrar externalidades positivas e extrassetoriais.

Coutard (1999) nota no artigo supracitado que o modelo morfológico das três camadas, já discutido, assim como as questões de subsídios cruzados, efeitos de clube e a importância da regulação, podem ser aplicados a muitas atividades, ressaltando o paradoxo intrínseco da aferição generalizante: “Se tudo é rede, nada é rede?” (CURIEN; DUPUY, 1997, p.168, tradução nossa).

É de difícil superação a análise abstrata e imperfeita entre duas abordagens de diferentes profundidades: a da evolução econômica amarrada a teorias robustas e a da microeconômica, na qual os desenvolvimentos territoriais são analisados à luz de uma teoria do espaço que se encontra em um nível de consolidação inferior. Também é criticada a insistente recomendação de se criar um papel independente do regulador, tanto do corpo político quanto dos atores de mercado, já que esta característica seria extremamente difícil de encontrar na prática.

Uma vez definida e demonstrada uma estrutura de rede num determinado setor econômico, ainda assim ele deve assegurar que os componentes da presente estrutura não são puros artifícios intelectuais, mas correspondem às categorias realmente significativas para os atores envolvidos, mais precisamente, eles assumem importância para os formuladores de políticas envolvidos, determinam suas interações, estratégias e ações. (CURIEN; DUPUY, 1997, p.168, tradução nossa). 
Esta entremeada argumentação no campo da economia, matemática, sociologia e política passa a ter um caráter crescentemente abstrato, perdendo de vista a abordagem e as circunscrições materiais que interferem na práxis da estrutura física dos ambientes urbanos. Assim, percebe-se a importância e a necessidade de aprofundar o campo conceitual e técnico do termo infraestrutura, como a possibilidade de materialização dos sistemas de rede nas cidades.

A palavra infraestrutura é de origem do século XX na França e derivada da junção do prefixo infra, anatomia inferior, abaixo ou sob a parte de um corpo; e estrutura, substantivo que denota as relações entre as partes ou elementos de algo complexo, ou um edifício ou objeto construído a partir de diversas partes. A definição de infraestrutura remete a estruturas e instalações físicas (estradas, redes de energia elétrica, redes de saneamento etc.) necessárias ao funcionamento da sociedade ou de uma corporação (OXFORD DICTIONARY OF ENGLISH, 2010, tradução nossa).

Olhar para as cidades sob as lentes da análise sobre a forma com que fios, dutos, túneis, cabos, ruas e outras redes se entrelaçam e alimentam as cidades, é uma maneira de ver o urbanismo moderno como um processo sociotécnico complexo e dinâmico, no qual o modo de vida urbano se revela, como uma articulação incessante e móvel. Cidades e regiões urbanas tornam-se pontos estáticos em meio a um fluxo perpétuo de infraestruturas mediadas por fluxos, movimentos e trocas; surgindo 
como processos que ligam distantes funções - como o abastecimento de água e o despejo de esgoto e resíduos - ao movimento dos recursos, internamente ao ambiente físico da cidade. As cidades através da história não deixaram de ser os centros primários de troca e distribuição de produtos e mercadorias em uma escala transnacional, sendo também vitais na articulação dos movimentos de trabalhadores, migrantes e turistas pelos sistemas múltiplos de transporte físico (GRAHAM, 2000b).

Segundo Graham (ibidem), a conexão dialética entre as redes de infraestrutura e a natureza do urbanismo moderno denota que a análise das redes deve adotar uma perspectiva interdisciplinar e multidimensional, na qual pelo menos três elementos-chaves devem ser considerados. O primeiro deles é que as redes infraestruturais constituem uma porção significativa do tecido material, econômico e geopolítico das cidades contemporâneas; neste sentido, as redes de infraestrutura só podem promover suas funções, e a aceleração de seus fluxos, por meio de uma inserção física e espacial, pela produção de novas configurações territoriais que acabam por controlar os processos sociais (HARVEY, 1985; SWYNGEDOUW, 1993). O segundo elemento significativo é que as redes de infraestrutura e o aparato sociotécnico que as envolvem estruturam e delineiam as experiências da cultura urbana; neste sentido, não é possível se pensar em uma cultura urbana da modernidade sem que sejam ofertados os serviços tecnológicos que proveem energia, água, comunicações, iluminação etc. O último elemento-chave diz respeito à 
capacidade das redes de infraestrutura em exercerem uma influência nas geografias sociotécnicas de poder; neste sentido, é por meio destas redes que as pessoas, organizações e instituições expandem suas capacidades e influências no tempo e no espaço.

As redes infraestruturais são necessariamente tanto sociais quanto técnicas, representando geografias ao mesmo tempo de capacitações e de restrições. Assim, a significação do termo infraestrutura no campo do pensamento do planejamento urbano deve ser renovada e reproblematizada, devendo considerar, para além das estruturas físicas e tecnológicas, seus efeitos sociais, políticos e discursivos. As 'caixas-pretas' escondidas no subterrâneo das cidades devem ser 'reabertas'. Humphrey (2003) argumenta que hoje as cidades são unidas por uma dependência comum de suas comunidades em relação às suas infraestruturas, o que pode se tornar uma ameaça, caso os seus provedores sejam movidos por interesses particulares. Dessa forma, a preocupação da sociedade vai além da confiabilidade na provisão dos serviços essenciais tão somente; essas tecnologias implicam numa relação entre tempo e riscos e, além disso, em uma perda 'moral' que pode, consequentemente, mover a revolta social. Segundo a autora, a variante marxista do conceito de infraestrutura é de que esta constitui a base econômica para a reprodução social. Nessa corrente, a política, a religião e a cultura são elementos superestruturais mais elevados, sob os quais atua a base fundamental da infraestrutura (sendo esta última determinada pelo caráter das primeiras). 
Como explorado anteriormente, as redes infraestruturais alimentaram sonhos utópicos de um espaço urbano não diferenciado, sem centralidades nem periferias, destacado da localidade, em que as redes proveriam serviços instantaneamente a todos. Entretanto, paradoxalmente, a sociedade e a cidade mostram evidências de cursarem a direção de um grau crescente de diferenciação, já que centros e periferias não se assemelham e não acomodam as mesmas populações nem as mesmas atividades. (ALBRECHTS; MANDELBAUM, 2005).

Em complemento a tal observação, percebe-se uma fragmentação dos objetivos de acesso universal - ao menos retórico - aos serviços públicos estabelecidos na maior parte dos países principalmente no final do século XIX e na primeira metade do século XX. Regimes políticos e regulatórios que apoiaram monopólios padronizados de infraestruturas públicas que sustentaram coberturas no acesso de energia, transporte, comunicações e saneamento básico estão deixando de ser formas hegemônicas de gestão de infraestrutura, como resultado predominante da liberalização e privatização dos serviços (GRAHAM, 2000a).

Como explorado mais acima, as redes de infraestrutura são indispensáveis para garantir a produção econômica e, ao mesmo tempo, responder as necessidades de reprodução social. Porém, basicamente, o modelo econômico que subsidia a oferta de serviços depende de resultados positivos de geração de riqueza, para que possa garantir sua 
distribuição. Países desenvolvidos que atingiram a cobertura universal antes de se abrirem para a privatização dos serviços não encontrariam grandes problemas no segundo binômio - o atendimento social; porém, ao contrário, países capitalistas em desenvolvimento, que ainda não puderam atingir a maturidade de suas redes, e, ao mesmo tempo, ainda buscaram a desregulação dos serviços básicos, encontrariam problemas na homogeneidade de cobertura de suas redes. Nesse último caso, o interesse de garantir a produção e o consumo diferenciados por parte de companhias privadas é primordial, e não necessariamente irá garantir um reinvestimento de seu capital excedente para responder às demandas sociais, principalmente na falta de regulação adequada.

Não se pode esquecer que, no período mais exuberante de privatizações de serviços essenciais ao redor do mundo, década de 198090, o capital privado também encontrava no setor imobiliário seus maiores rendimentos. Esta combinação entre oferta de infraestrutura e desenvolvimento imobiliário passou a direcionar o investimento destes setores em territórios urbanos que assegurassem o interesse das camadas da sociedade mais dispostas a investirem o seu capital, naturalmente as mais ricas e localizadas nos bairros mais valorizados. Dessa forma, a concentração de melhorias, tanto dos serviços infraestruturais nos subterrâneos quanto em melhorias no ambiente urbano nas superfícies, acabou por acirrar a desigualdade de acesso no território urbano. De acordo com Graham (2000a): 
[...] é o surgimento de um desigual número de espaços de rede de infraestrutura 'premium': novas ou adaptadas redes de transportes, telecomunicações, energia ou água que são personalizadas com precisão às necessidades dos usuários e espaços mais prestigiosos, enquanto ignorando usuários e espaços mais carentes.

O surgimento generalizado de tais espaços premium parece estar intimamente ligado a uma tendência ao parcelamento físico e socioeconômico do tecido de muitas cidades contemporâneas (BADCOCK, 1997). Em muitos casos, a produção desigual de conectividade que decorre da expansão de espaços premium parece combinar com uma tendência paradoxal em direção ao reforço de fronteiras locais (EZECHIELI, 1998; CASTELLS, 1996), o que fortalece a tendência de criação de outros enclaves diferenciados, que, por sua vez, definem a heterogeneidade e a fragmentação do tecido urbano, assim como a diferenciação na cobertura e qualidade das redes infraestruturais. Segundo Graham (2000a), o surgimento de redes com as características de infraestrutura premium é suportado em particular por quatro processos de mudanças políticas, econômicas e sociotécnicas: (1) a 'divisão' da provisão de infraestrutura urbana, a evolução das organizações capitalistas e a formação de escala; (2) a erosão de um planejamento urbano abrangente e a construção de novos espaços de consumo, criando o crescimento de um planejamento urbano 'empresarial' e fragmentado; (3) o surgimento do 'consumo' de 
infraestrutura; (4) e a dispersão de núcleos e extensão de paisagens de regiões urbanas. Tais espaços transcendem as limitadas percepções das padronizadas e monopolistas redes de energia, água, comunicações e transportes estabelecidas durante a metade do século passado.

A tese de Graham e Marvin (2001) de nome Splintering Urbanism (que poderia ser traduzido como Urbanismo Fragmentado) se desenvolve em torno da observação central de que a fragmentação organizacional, institucional, econômica e técnica atual de sistemas de infraestrutura tem reformulado as relações sociais e espaciais nas cidades, assim como a relação entre as cidades e as suas infraestruturas. Os autores argumentam que atualmente os sistemas de infraestrutura estão seletivamente sendo reorganizados em torno de novas lógicas, tecnologias, relações sociais e - acima de tudo - de novos espaços. A grande maioria dos exemplos citados no livro refere-se a situações de cidades altamente desenvolvidas e de capitalismo avançado, em que a demanda por serviços de infraestrutura é alta, e em crescimento. Dessa forma, a grande questão é, geralmente, sobre como atender a essa alta demanda por serviços - básicos ou personalizados - sob novas condições institucionais, econômicas e tecnológicas. No entanto, neste trabalho seminal (e referência básica para esta pesquisa de doutoramento) há pouca menção de situações aplicadas a países em desenvolvimento, ou naqueles em que o uso demandado se encontra em declínio. Além disso, apresentam-se breves referências à vulnerabilidade da infraestrutura por 
obsolescência em períodos de transformação social e econômica, assim como abreviadas explorações dos problemas que podem surgir a partir da trajetória crescente de dependência de sistemas de infraestrutura. Esses aspectos são abordados ao longo desta tese.

\subsection{Implicações da privatização e a regulação dos serviços públicos}

A implantação dos sistemas infraestruturais e de oferta de serviços no Brasil remonta ao século XIX, com a implementação de uma rede de esgoto sanitário na cidade do Rio de Janeiro pelo Imperador D. Pedro II, a partir de 1853. D. Pedro II contratou serviços de projeto de esgotamento sanitário e pluvial na Inglaterra e instituiu a Lei 719/1853, autorizando o governo a contratar serviços estrangeiros ou outro qualquer para realizarem o serviço de limpeza das casas e do esgoto das águas pluviais. Após trinta anos, foi instalada a iluminação pública na mesma cidade. A rede ferroviária também passou a ser instalada por volta dos anos 1850, atingindo em trinta anos a extensão de cerca de $5.600 \mathrm{~km}$ entre Rio de Janeiro e São Paulo. De igual importância é a construção da usina hidrelétrica de Parnaíba, a partir de 1899, que possibilita energizar a 
iluminação pública e os bondes da cidade de São Paulo (GOMES, 1986; SILVA 1988).

Vale notar que estas iniciativas de extrema importância histórica para o país dependeram desde o princípio de suporte técnico e de capital estrangeiro. É da época do imperador Pedro II que se implantaram as primeiras parcerias público-privadas, tais como as conhecemos hoje, por meio da construção das ferrovias brasileiras. Segundo o Banco Nacional do Desenvolvimento Econômico e Social - BNDES (2008), o Tesouro assumia "o compromisso com o concessionário de cada ferrovia de lhe gerar uma rentabilidade anual de pelo menos 7\% ao ano em ouro", dispositivo contratual esse chamado de 'Cláusula do ouro'. Diz-se que a consequência destes mecanismos no ambiente físico do território brasileiro foi a criação de um traçado bastante sinuoso, assim como a multiplicação de estações, de forma a garantir maior rentabilidade em ouro, em detrimento de originar um traçado racional 'euclidiano'.

Assim, desenham-se as origens da construção e ampliação das primeiras infraestruturas de serviço de utilidade pública, que, a partir do século XIX, passa por díspares fases de desenvolvimento. Até a década de 1940, a oferta por serviços caracterizava-se prioritariamente por um perfil privado, sendo explicitamente não regulada. A partir dos anos de 1970 e 1980, o poder estatal busca dar impulso a uma cobertura homogeneizante da oferta de serviços, de forma a tentar suprir as carências básicas das populações desde o princípio excluídas dos benefícios infraestruturais 
disponibilizados em rede, e que, por sua vez, apresentavam um crescimento demográfico jamais visto no país. A progressiva industrialização brasileira dependia de uma oferta de infraestrutura garantida, de forma a assegurar uma produção crescente em detrimento da provisão de condições básicas (abastecimento de água, coleta de esgoto, provisão de energia elétrica) à população, igualmente crescente e suas consequentes (im)possibilidades de reprodução social.

O efeito deste descompasso geraria as condições que, no presente, cobrem o território brasileiro e, por consequência disso, caracterizam a natureza desigual do acesso social aos serviços de utilidade pública.

Nos anos 1990, o país passou a criar mecanismos e ferramentas oficiais que impulsionaram a privatização dos serviços, a desestatização, que rapidamente aliaram-se à expansão dos mercados de capital estrangeiros. Assim, empresas estatais federais passaram a abrir seus capitais no mercado de ações e, em alguns casos, admitir controle majoritário por terceiros, em um processo de participação crescente do capital privado em setores de interesse público, tais como o elétrico, o ferroviário, o rodoviário, o portuário, o de telecomunicações, entre outros, estes estritamente ligados aos objetos desta pesquisa. Mais adiante (ainda neste capítulo) discute-se a formação e a influência das agências de regulação que acompanham este período. 
Nesse contexto, os processos de privatização referem-se à transferência de ativos e de responsabilidades operacionais do setor público para o setor privado, por uma variedade de acordos contratuais para construir e gerir infraestrutura em nome do setor público. Isto se dá por meio da reformulação das instituições de gestão, do estabelecimento de regras, normas e fiscos, e da introdução de técnicas de estimulação de mercado e de tomadas de decisão; o que implica fortemente no deslocamento de princípios keynesianos de bem-estar social por princípios neoliberais de mercado na formulação de políticas.. O elemento-chave da comercialização de serviços é a liberalização e a desregulação projetadas para estimularem a concorrência de mercado (BAKKER, 2003).

Assim, enfatiza-se a transferência para a esfera privada não só do domínio material sobre os serviços, mas principalmente do domínio normativo e de sistematização gerencial, que geram expectativas para que os 'marcos regulatórios' setoriais possam salvaguardar o interesse público. (SILVA, 2000)

O papel destas privatizações indica, pelos princípios da economia capitalista, o agravamento de disparidades no acesso social aos benefícios produzidos pela rede de utilidades, já que a tendência do capital privado é de, declaradamente, buscar as áreas mais rentáveis para manterem-se competitivos. Ao mesmo tempo, a inclusão de regras de regulação às empresas privadas busca manter os princípios de acesso público 
universal, o que cria um jogo de tensões que implicam e projetam no desenvolvimento urbano suas expressões mais explícitas.

Poucos exemplos parecem ir contra a lógica do capital descrita anteriormente. A instituição do Código das Águas ${ }^{14}$, por sua vez, parece ter se tornado um exemplo para o país, por trazer desde a sua concepção um balanço de interesses entre a racionalidade econômica, a garantia de acesso e o desenvolvimento tecnológico. Em contrapartida, pode-se generalizar que a estrutura de oferta dos serviços de infraestrutura no país tem sido historicamente determinada a partir das estratégias de financiamento que seguem a lógica do capital, em subordinação a outros dois aspectos imprescindíveis para o progresso desta rede de benefícios: o desenvolvimento tecnológico e o institucional (ibidem).

A natureza da universalidade e o acesso social às redes de infraestrutura urbana passam a configurar um ambiente de avaliação das políticas de governo, como forma de caracterizar, ou não, a agenda democrática de determinada gestão. A avaliação do controle social por meio da conectividade dos serviços passa, assim, a representar um desafio complexo de pesquisa, devendo compor formas profundas de análise que

14 O Código das Águas - Decreto n² 24.643, de 10/07/1934, foi a primeira norma legal que disciplinou o aproveitamento industrial das águas e o aproveitamento e a exploração da energia hidráulica. Trata-se de um texto legal ainda vigente, embora muito alterado e revogado por leis posteriores (COSTA FREIRIA, 2015) 
superem apenas as características de cobertura ou presença de uma rede próxima a um território. Essa análise deve buscar, para além do alcance a determinado serviço, a disponibilidade e a garantia de qualidade do mesmo. O aprofundamento destas propriedades encontram-se no subcapítulo 2.9.

Bakker (2003) estabelece uma distinção entre a privatização e a comercialização, na primeira haveria a implicação de uma mudança organizacional, e na segunda, uma mudança institucional. A autora coloca ênfase na inter-relação entre a mudança de regulamentação dos sistemas de abastecimento de água entre a gestão pública e a privada, comparando o uso e o acesso à água e às paisagens urbanas em cidades do hemisfério Norte e Sul. As últimas, comparadas às primeiras mais homogêneas, podem ser consideradas mais multidimensionais em seus processos de privatização. Nesse contexto, a metáfora da 'rede' seria aplicada às cidades mais desenvolvidas e não caberia àquelas cidades em desenvolvimento, nas quais seria mais pertinente a metáfora do 'arquipélago'. Baseando-se nestas duas metáforas, e em resposta ao dualismo 'público-privado' frequentemente evocado em estudos de privatização, o estudo de Bakker coloca em primeiro plano os conceitos de territorialização dos poderes corporativos como um meio de entender a articulação entre a privatização e os processos de urbanização.

Segundo a autora, não é possível saber se os processos de privatizações em cidades em desenvolvimento conseguirão converter 
arquipélagos em redes, já que existem poucos exemplos que têm sistematicamente rebatido a diferenciação espacial de acesso de abastecimento de água em áreas urbanas. As privatizações continuam a ser um processo altamente ambivalente para os usuários, particularmente os menos favorecidos, dada as reformulações dos procedimentos e direitos no abastecimento de água. As análises de privatização dos setores de abastecimento de água em cidades em desenvolvimento devem abordar essa transformação multidimensional, em que o envolvimento do setor privado na gestão do abastecimento de água implicaria em um processo que reconfiguraria não só a regulamentação do abastecimento e as paisagens urbanas, mas também os direitos dos usuários e a prática democrática da experiência diária de todos os que usam o recurso. Segundo ela, deve-se lembrar de que mesmo aqueles que possuem acesso a serviços de rede podem ter problemas com baixa qualidade e confiabilidade: a água pode fluir de forma intermitente, algumas horas por dia, ou apenas algumas horas por semana. (ibidem)

É importante notar que a noção de 'arquipélago' apresentada anteriormente por Bakker (2003) não pode ser aplicada diretamente às redes de água da metrópole paulista, assim como nas demais metrópoles brasileiras. Devido ao Plano Nacional de Saneamento - Planasa instituído pelo governo na década de 1970, a cobertura dos serviços de abastecimento de água pôde se ampliar vastamente em grande parte das concentrações urbanas brasileiras. 
Estudando um paralelo dos problemas gerados pelas privatizações de serviços essenciais na Grã-Bretanha, Speak e Graham (2000) relatam que esses processos fizeram com que bairros e grupos sociais menos abastados se encontrassem hoje com acesso limitado a serviços privados. Em seu estudo, analisou-se o acesso a energia, telecomunicações, serviços financeiros e varejo de alimentos em dois bairros marginalizados, Benwell em Newcastle upon Tyne e Netherly em Liverpool. Os autores desta pesquisa argumentam que o acesso a esses serviços providos pelo setor privado devem ser considerados essenciais para que haja plena participação da sociedade contemporânea, e a falha no reconhecimento dessa importância deve minar estratégias de regeneração correntes, levando ao agravamento da exclusão dos bairros mais desfavorecidos. A base empírica deste trabalho foi realizada por entrevistas com mais de quarenta famílias e uma série de grupos foco, assim como dados quantitativos sobre a reestruturação do setor privado e de uso dos serviços. Identificou-se a extensão e os efeitos da retirada de serviços do setor privado nas duas áreas de estudo de caso; explorando as dificuldades que surgiram na consideração de clientes de 'alto risco e baixo lucro', e as estratégias de enfrentamento utilizadas pela comunidade excluída; considerando-se assim quais as possibilidades políticas e formas de reconectar as lacunas que existem entre aqueles socialmente excluídos e os serviços do setor privado, muitas vezes, inacessíveis. 
As principais conclusões deste estudo identificaram que projetos de regeneração (objeto de estudo desta tese) continuam por ignorar a importância dos serviços providos pelo setor privado no processo de declínio destas áreas, sendo provável que a retirada destes serviços acabaria por minar as áreas de regeneração e, assim, contribuir para a desestabilização de comunidades. Percebeu-se que há diálogo insuficiente entre as equipes de regeneração da área e aqueles que entregam os serviços dos setores privados: quando estes estão envolvidos como parceiros nos projetos de regeneração, seu envolvimento é tangente à entrega dos seus serviços.

No contexto internacional, os projetos de regeneração têm um papel a desempenhar na negociação dos 'melhores negócios' para os moradores. Isso pode incluir a negociação de prêmios de seguros mais baixos para combater as práticas de redlining (descritas no subcapítulo 2.1) quando certas empresas se recusam a lidar com famílias provenientes de bairros desfavorecidos. Verificou-se também, nestes estudos de caso, que estratégias comunitárias não conseguem oferecer serviços alternativos adequados. Dessa forma, uma ênfase sobre a comunidade de autoajuda parece improvável como estratégia de sucesso sem que haja um apoio considerável do governo e da iniciativa privada. Entretanto, essa analogia não pode ser aplicada no Brasil, aonde não há a prática generalizada de seguros residenciais, sendo o exemplo relevante apenas para ilustrar possíveis conflitos em ambientes políticos diversos. 
Enquanto o governo estaria a pressionar o setor privado para que volte a se envolver com os indivíduos e as comunidades menos abastadas, há um número de maneiras pelas quais o setor privado poderia contribuir, por exemplo, pela criação de bancos e cooperativas de crédito, sem que, necessariamente, estas entidades privadas devam reativar seus serviços nestas áreas por si próprios. Dessa forma, reforça-se que os projetos de regeneração possuiriam um papel fundamental a desempenhar no sentido de aproximar estes dois lados da questão (ibidem).

Junto às privatizações dos anos 1990, soma-se a implantação dos processos de regulação, modelados sob o formato de agências reguladoras, porém de forma ainda bastante incipiente. Naqueles setores em que a maior parte das concessões de prestação dos serviços permaneceu sob a égide das empresas estatais, como no caso do saneamento básico, a regulação alcançou somente 13\% das concessões de todo o país, até o ano de 2006 (JUNIOR; CASTRO; PAGANINI, 2009). É importante ressaltar que a fragmentação das políticas públicas, a falta de capacidade político-administrativa dos municípios, conjuntamente à má aplicação de recursos públicos, assim como a insuficiência de instrumentos de regulação e regulamentação no país acabaram por definir um quadro de cobertura de infraestrutura básica bastante deficitária no país. 
A regulação pública da infraestrutura e dos serviços em rede tem papel central na criação de oportunidades de desenvolvimento urbano e regional, interferindo diretamente sobre o ambiente natural e construído que constitui patrimônio de todos (SILVA, 2000). Assim ressalta-se a importância desses instrumentos para defender os interesses da sociedade perante esses serviços, à medida que os últimos se tornam cada vez mais especializados e espacialmente segregados.

Cabe aqui a definição do conceito de regulação descrita por Junior, Castro e Paganini (2009, p.81) como:

[...] a intervenção do Estado nas ordens econômica e social com a finalidade de se alcançarem eficiência e equidade, traduzidas como universalização na provisão de bens e serviços públicos de natureza essencial por parte de prestadores de serviços estatais e privados.

De acordo com os autores, deve-se dividir a regulação de serviços públicos como sendo de natureza estrutural, de condutas e de qualidade. A primeira delas aborda as condições de entrada e de saída das empresas de interesse público nas quais sobrevêm os setores regulados e as medidas para separação vertical de segmentos da prestação dos serviços, o que permite a atuação de várias empresas nas diferentes fases da cadeia produtiva. Dessa forma, faz-se muito importante a regulação estrutural, para que se definam as condições de participação destas empresas em diferentes posições na escala de produção de um serviço. A segunda forma, a de condutas, regula o comportamento das empresas 
dentro do mercado, englobando preços, qualidade e investimentos. Nesta, os principais procedimentos utilizados são a fixação de preços, com as consequentes problemáticas de precificação da taxa de retorno e possíveis desinvestimentos futuros caso mal-calculados. A terceira forma de regulação, a da qualidade, tem como objetivo fixar condições e parâmetros de qualidade dos serviços prestados de forma que se torne possível sua verificação. (PINHEIRO; SADDI, 2005; JOURAVLEV, 2001; JUNIOR; CASTRO; PAGANINI, 2009). Os parâmetros de qualidade estabelecidos pelas reguladoras de infraestrutura urbana foram analisados no capítulo 3 desta tese.

Segundo Williams, Borrows e Daly (1998), os reguladores devem definir os seus objetivos de regulação desde o princípio de suas atividades, a fim de estabelecer uma verdadeira abordagem programática para a regulação da água ou, neste caso, de um recurso natural necessário para suprir as necessidades das pessoas. Deve-se levar em consideração seu papel na prestação de serviços, no escopo dos seus objetivos e na ênfase relativa que pretendem dar na relação de eficiência entre equidade e comércio. No relatório do NARUC - National Association of Regulatory Utilities Comissions -, são descritas as diferentes formas de organização e níveis de autonomia decisória das entidades reguladoras de serviços de abastecimento de água nos Estados Unidos, definindo-se uma escala baseada no papel reativo ou proativo das entidades em relação à intensidade de compromisso com respeito ao caráter público dos serviços prestados. 
Nesta escala, os requisitos são cumulativos, não havendo como atingir um nível de desempenho sem que se atinja o anterior. Para os padrões norte-americanos, espera-se que as reguladoras atinjam o grau de pró-atividade máximo, porém reconhece-se que o mesmo incide em maiores recursos e capacitação. Em relação à necessidade desses últimos, recursos e capacitações, o NARUC define três níveis principais:

1. o primeiro demanda capacitações de auditoria financeira e fiscal, com um breve acompanhamento de qualidade, sendo aplicadas àquelas entidades reativas e centradas em questões tarifarias;

2. o segundo grupo demanda capacitações adicionais em técnicas de operação e gestão dos serviços, sendo aplicadas àquelas entidades que operam os serviços regulados;

3. o terceiro requer, além das categorias anteriores, capacitações em planejamento e longo prazo, acompanhamento amplo do estado da arte da indústria para além de sua jurisdição, monitoramento da demanda e promoção de iniciativas legislativas em articulação com os outros reguladores, sendo aplicado àquelas entidades proativas que se envolvem direta e indiretamente a política, como exemplo, a de abastecimento de água.

A escala que mensura o papel das entidades reguladoras de acordo com o NARUC identifica cinco categorias crescentes em nível de proatividade e compromisso para com a utilização dos recursos: 
1. a Entidade Reguladora atende, conforme regulamentos, a solicitações de serviço encaminhadas pela companhia e pelos usuários;

2. a Entidade Reguladora acompanha por iniciativa própria os serviços das companhias reguladas;

3. a Entidade Reguladora supervisiona a operação das companhias reguladas, inclusive a eficiência nas atividades de operação e planejamento;

4. a Entidade Reguladora é ativa em (todos os) os assuntos ligados à indústria privada da água, inclusive legislação, estrutura da indústria e padrões de qualidade de outras agências;

5. a Entidade Reguladora é ativa em todos os assuntos relacionados ao abastecimento de água e não se limita ao escopo dos serviços ofertados pelas companhias hoje reguladas (tradução livre).

As iniciativas identificadas no relatório NARUC podem, em algumas circunstâncias, fornecer melhorias significativas no desempenho das empresas de água, assim como nas empresas de outros escopos, porém essas iniciativas são apenas exemplos dos tipos de ações que devem ser tomadas para que se assegure a continuidade e confiabilidade no abastecimento de água potável (ibidem).

É importante que cada agência de utilidades, como no exemplo de abastecimento de água, reveja seus objetivos de acordo com o melhor uso do recurso, para que seja assegurada sua disponibilidade através do 
tempo. Somente será possível atingir os objetivos do interesse público por uma autoavaliação crítica no nível programático da regulação das indústrias que interferem diretamente nos recursos básicos necessários para suprir as atividades urbanas.

\subsection{Redes fragmentadas e redes integradas}

Como vimos no subcapítulo anterior, a regulação pública da infraestrutura e dos serviços em rede possui um papel fundamental no desenvolvimento urbano e regional, balizando assim as potencialidades de determinada localidade em relação à sua capacidade de articulação para com o entorno e para com outras localidades do contexto urbano. A avaliação da organização material de um espaço urbano por sua capacidade de assegurar um espaço fluido de trocas de informação e movimentação permite criar uma metodologia que identifique e pondere os níveis de fragmentação, dispersão, descontinuidades e desarticulações espaciais de uma conurbação.

Remete-se aí a conceituação do 'espaço dos fluxos' aprofundado por Castells (1999) relativo àquele que tem a capacidade de assegurar a articulação entre trechos urbanos aparentemente descontínuos e 
desarticulados. Essa ideia é explicitada no livro São Paulo Metrópole, conforme trecho destacado a seguir:

O novo padrão de organização do território metropolitano está intrinsicamente associado à mobilidade e é comandado, em grande parte, por seus novos atributos - dispersão e continuidade. Esse novo modelo espacial requer uma infraestrutura de transportes cuja eficiência repousa na capacidade de integrar as atividades dispersas no território metropolitano e criar fortes e eficientes polos articuladores locais. $\mathrm{O}$ reconhecimento desses 'polos de convergência' é hoje um dos focos de planejamento e projeto urbano. (MEYER; GROSTEIN; BIDERMAN; 2014, p.242)

Em contraste com este conceito (o espaço dos fluxos), pode-se observar a contradição estabelecida em alguns trechos urbanos consolidados com capacidade de infraestrutura instalada, em que é possível identificar uma queda na aptidão de atração de populações, causando assim o esvaziamento de população residente. Esse fenômeno, identificado em períodos históricos distintos em bairros do Município de São Paulo (MSP), como a Barra Funda, o Brás, o Pari, a Mooca, a Bela Vista, a Liberdade, os Campos Elíseos, o Cambuci etc., será discutido no capítulo 3 .

Outros processos urbanísticos que podem ilustrar mecanismos que vão na contramão da criação de um espaço de fluxos contínuos são aqueles caracterizados pelas áreas periféricas dos municípios e da RMSP como um todo. Ao possuírem valores imobiliários mais baixos, e 
normalmente em situação precária em relação ao acesso de infraestrutura básica, estas áreas apresentam características de distritos-dormitório, os quais concentram uma alta densidade populacional de baixa renda e baixa oferta de empregos. Esses distritos (ao exemplo de Franco da Rocha, Francisco Morato, Poá, Itaquaquecetuba, Ferraz de Vasconcelos, Carapicuíba etc.) podem ser identificados nos mapas apresentados no capítulo 3.

Outro fator refere-se à insuficiência na alocação populacional de baixa renda aliada à situação de precariedade no acesso aos serviços básicos de infraestrutura, o que acaba por gerar um aumento na quantidade e na dispersão de núcleos de domicílios subnormais (favelas), na maior parte das vezes sendo deslocados para áreas residuais da cidade e/ou em áreas de fragilidade ambiental (como exemplo a Represa de Guarapiranga e Billings e a Área de Proteção Ambiental do Tietê). Esse fenômeno pode ser revertido por meio de projetos apropriados de (re)urbanização de favelas (tais como o de Heliópolis e Paraisópolis), prioritariamente pelos mecanismos de regularização fundiária, implantação de infraestrutura e equipamentos sociais.

O sistema de transporte, neste caso o rodoviário, também contribui intensamente para o isolamento de áreas urbanizadas, criando adensamento residencial e empresarial dos mais diversos padrões por meio da ilusão de proximidade física, porém esta, na maior parte das vezes, sempre próxima ou em processo de saturação. Este é o caso, por 
exemplo, ocorrido no adensamento residencial de Granja Viana em Cotia, de Alphaville em Barueri, de Tamboré em Santana do Parnaíba, de Arujá, propiciados pela abertura e/ou alargamento das Rodovias Raposo Tavares, Castelo Branco etc.

Núcleos empresariais e comerciais que representam este fenômeno ocorreram em áreas como a reconfiguração da Avenida Nova Faria Lima, Marginal Pinheiros, Hélio Pelegrino, Vila Olímpia, Berrini, Rua Verbo Divino, Avenida Água Espraiada, entre outros.

Esses núcleos residenciais, comerciais e empresariais acabam por configurar áreas urbanas autônomas excepcionalmente circunscritas, com pouquíssimas relações funcionais com os municípios do entorno, gerando enclaves fortificados e diferenciados assim como definidos no subcapítulo 2.5. Um processo de natureza complexa, a gentrificação discutida no início desta pesquisa -, acaba por impactar ainda mais a diferenciação social no território da RMSP, por meio da substituição da população de um determinado local por população de maior poder aquisitivo, como o que vem ocorrendo em diversas áreas como Pinheiros, Tatuapé, Mooca, Moema, Jardim Anália Franco, Vila Prudente, Itaim etc.

O efeito discutido acima seria revertido caso o sistema estrutural de transporte fosse aquele que buscasse maior mobilidade no menor uso do espaço físico, aquele que se configura como o transporte coletivo de massa: trem, metrô, ônibus; causando maior integração do território e 
maior acesso social, o que pode ser verificado pelo argumento colocado por Meyer, Grostein e Biderman (2014, p.240):

A presença de grandes infraestruturas urbanas, com ênfase nos sistemas de transporte de massa e na mobilidade, vem funcionando como elemento capaz de atender à expansão excessiva da mancha urbana e produzir maior coesão nos territórios metropolitanos. Sua função é organizar os sistemas e subsistemas urbanos que leva à consolidação ou expansão da malha urbana. Seu impacto positivo sobre o território está diretamente associado à sua capacidade de gerar ou anunciar continuidade urbana. Seus aspectos negativos já foram examinados em outras dinâmicas e se relacionam, sobretudo, com as alterações do preço da terra quando incidem sobre zonas habitadas por moradores com baixo poder aquisitivo.

Do ponto de vista do efeito positivo em relação à geração de um espaço físico fluido, observa-se a consolidação dos municípios que se configuram como subcentros regionais que apresentam acelerado processo de transformação urbana devido ao crescimento de atividades industriais, comércio e serviços, aliados ao alto crescimento populacional. A consolidação desses subcentros manifesta o papel potencial de reconfiguração territorial de regiões que passam a oferecer à população serviços com maior qualidade em relação a outros subcentros que acabam por não exercerem características de polos econômicos regionais. 
A reorganização funcional de antigos centros industriais - que passam a exercer atividades terciárias, como Santo André, São Bernardo do Campo, São Caetano do Sul e Diadema; e ao mesmo tempo a concentração de novos polos industriais em Osasco, Cotia, Arujá e São Paulo - acaba por gerar alternativas para responder às demandas muitas vezes saturadas em regiões mais tradicionais. Nesta mesma direção, está a criação ou o alargamento de polos de impacto nacional e internacional, como centros logísticos, aeroportos, centro de convenções, centros de compras, centros de cultura e polos turísticos.

Por esta resumida análise, é clara a necessidade de projetos estratégicos que possam ser ao mesmo tempo abrangentes e sistêmicos, que englobem a escala metropolitana e macrometropolitana. A exemplo disso, deve-se listar o Anel ferroviário, o Hidroanel, o Rodoanel, o Arco do Tietê, assim como Projetos Urbanos, tais como as Operações Urbanas (OU). Essas últimas também têm o potencial de transformar áreas urbanizadas no sentido de reestruturar e aprimorar as dinâmicas urbanas de áreas especiais coordenadas pelo poder municipal e viabilizadas por meio de contrapartidas financeiras e da flexibilização dos índices de uso e ocupação do solo.

Exemplos dessas Operações Urbanas Consorciadas (OUCs), que incluem as existentes e previstas, são: a Faria Lima, a Água Espraiada, a Água Branca, o Centro; assim como o bairro do Tamanduateí com suas diferentes sub-áreas; a Operação Urbana de São Bernardo do Campo e o 
Projeto de Habitação Estadual denominado Parceria Público Privada Casa Paulista. Esses projetos têm sido bastante criticados ${ }^{15}$ por trazerem benefícios em áreas a priori privilegiadas, não possibilitando a redistribuição das benfeitorias para regiões realmente precárias e necessitárias. Estes serão discutidos no subcapítulo 2.9.

\subsection{Os enclaves diferenciados e os guetos}

A tendência a uma urbanização crescente de caráter especialmente dividido, com uma rápida expansão de condomínios fechado, com núcleos de riqueza extensamente protegidos, e ao mesmo tempo com o aumento da periferização e da expansão de áreas urbanizadas segregadas, tem sido verificada por diversos estudos científicos citados ao longo deste texto, incluindo o relatório da Organização das Nações Unidas - Habitat 2010.

Fundamentalmente, aqueles que possuem mais recursos acabam por concentrar não só maiores extensões de terras, como também a ter

\footnotetext{
${ }^{15}$ Ver artigos de Fix, M.; Samora P.; Hirata M.; Rolnik, R..
} 
acesso a mais serviços públicos; sendo diferenciados da população excluída e estigmatizada, percebida como 'não civilizada'. Tendência evidente nos processos de urbanização em Dubai, os condomínios residenciais fechados são construídos para atrair investidores internacionais de classe alta; realidade esta que mascara a realidade de milhares de trabalhadores imigrantes sem acesso a direitos básicos, sujeitos a extensas jornadas de trabalho e alojados em acampamentos precários e periféricos (UN-HABITAT, 2010).

Essa tendência, marcada por Teresa Caldeira em seu livro Cidade de muros, 2000, é demonstrada pela multiplicação dos lançamentos de condomínios fechados em São Paulo, que insere a classe de renda superior a uma espécie de condição de isolamento, criando um contraste entre o considerado seguro e familiar - no interior dos muros - e o sentido como uma ameaça, um estranhamento - no espaço fora das fronteiras muradas.

É importante assim rever e definir quais as categorias que comporiam as diversas áreas de concentração social e econômica no território urbano; de forma a elucidar quais os diferentes fenômenos que poderiam ser identificados no território da RMSP por meio dos estudos empíricos realizados.

A principal referência teórica neste campo é Peter Marcuse, advogado alemão radicado nos Estados Unidos e professor emérito em planejamento urbano e regional. Marcuse (1997) identifica o 
desenvolvimento urbano do período posterior aos anos de 1970 como tendo passado por três evoluções intimamente conectadas, e que se reforçam mutuamente. São elas:

1. as transformações dos guetos raciais e de classe em áreas urbanas segregadas e excluídas da cidade por conta de barreiras sociais, econômicas e muitas vezes físicas;

2. um período de desenvolvimento suburbano, em que cidades são criadas nos subúrbios, combinando áreas residenciais, empresariais, sociais e culturais, e que deslocadas das áreas centrais e sobrepostas a padrões anteriores de urbanização, acaba por representar uma dramática forma de enclave excludente;

3. a transformação de áreas totalizantes da elite, contendo residências luxuosas e de classe alta (assim como instalações sociais, culturais e empresariais), chamadas de comunidades fortificadas, cada vez mais separadas das outras partes da cidade por distinções sociais, econômicas e também, muitas vezes, barreiras físicas.

Marcuse (1977) alerta que a discussão acadêmica do período foca nas discussões mais genéricas em relação à cidade global e à posição de cada cidade em um ranking de desenvolvimento internacional, sendo o ambiente físico das cidades de certa forma similares de acordo com sua posição nesse ranking. O autor demonstra que, para além dessa categorização da cidade global, muitas estruturas urbanas sofreriam as 
três evoluções descritas anteriormente, sendo estas um fenômeno não necessariamente resultante das mudanças globais, porém resultantes de uma tendência à suburbanização decorrente do desenvolvimento urbano per si.

[...] É a natureza das fronteiras - muradas, a distância espacial, a separação social - a característica que define essas diversas formas de desenvolvimento espacial, ou é o fato de uma população residente ser excluída ou segregada, ou a qualidade da natureza desta população, ou as atividades que ocorrem dentro delas, que as definem? (MARCUSE, 1997, p.314, tradução nossa).

O gueto seria uma área espacialmente concentrada usada para separar e limitar involuntariamente um grupo, normalmente racial, considerado inferior pela sociedade dominante. Dois seriam os grupos decorrentes desta categoria: o gueto tradicional, aquele confinamento que é desejado pela sociedade dominante como uma forma de controle de suas atividades, com adicionais interesses econômicos; e o gueto 'novo', no qual a área de concentração combina raça e classe e é segregada em relação às atividades econômicas da sociedade, que as confina por medo de que as atividades realizadas na área possam pôr em perigo a paz dominante.

Um enclave é uma área espacialmente concentrada em que a população de um determinado grupo, autodefinido por etnia, religião ou outros, se reúne como um meio de reforçar suas atividades econômicas, 
sociais, políticas e culturais. Essa categoria subdivide-se em enclaves de imigrantes, culturais ou de exclusão (exemplo: cidadelas).

O que é comum entre estas áreas de concentração é seu confinamento por um muro, por um limite, uma demarcação. Em um gueto, essas limitações podem ocorrer devido à presença de uma estrada, de uma condição topográfica acidentada, devido à presença de uma linha férrea ou uma mudança de tipologias do ambiente construído, por exemplo.

O subúrbio totalizante é aquela área de concentração que acontece fora das áreas centrais, em que atividades empresariais, centros de emprego e instalações comerciais e culturais são combinados com áreas estritamente residenciais, permitindo diversidade, porém sem que se incluam os mais ricos e os mais pobres da hierarquia econômica. Seriam consideradas áreas totalizantes, que se propõem a abranger todas as funções e atividades necessárias do dia a dia, porém ainda dependentes dos centros econômicos principais - industriais, financeiros, empresariais.

Estas são de fato cidadelas na sua forma clássica: lugares onde seus moradores possam viver isoladamente e protegidos do mundo exterior por meses a fio, em que todas as suas necessidades podem ser fornecidas internamente nos espaços em que estão concentrados. A parte luxuosa da cidade particionada se tornou uma cidade de luxo inteira para si. Esta, é claro, continua a precisar dos serviços de uma gama de 
trabalhadores pouco qualificados para manter as suas tarefas diárias, mas estes vêm quando necessário e ficam de fora quando não; certamente não vivendo dentro de seus limites. E, tanto quanto possível, os seus serviços são substituídos por dispositivos tecnologicamente sofisticados, portões de entrada que funcionam com cartão, transporte automatizado, máquinas de limpeza especializadas e alimentos congelados. (MARCUSE, 1997, p.319, tradução nossa).

No estudo de Smets e Salman (2008), foram examinadas três estratégias políticas para resolver ou atenuar os efeitos negativos da segregação urbana: a primeira delas visa misturar distintos grupos populacionais direta ou indiretamente por meio de uma oferta diferenciada de habitação; a segunda visa fixar as comunidades ocupando áreas isoladas para evitar que estas se deteriorem ainda mais ou causem tensões sociais; e por último uma estratégia de reverter a segregação por meio da participação econômica.

A ideia de supostamente melhorar as condições e as oportunidades das pessoas em desvantagem pela mescla de populações de diferentes rendas parece ser hoje uma medida largamente incutida nas agendas de planejamento do mundo ocidental. Resta saber se essa ideia reflete um ideal utópico ou se realmente há como se obter resultados concretos no sentido de uma mais justa distribuição de renda.

A segunda estratégia pode ser considerada uma tática escapista, pois parte do princípio de que se devem delinear áreas problemáticas para 
que estas, sendo contidas, por exemplo, em um enclave fortificado, sejam mais simples de serem controladas ou evitadas. Devido às tendências recentes de agravamento na distribuição da renda, estas estratégias são mais e mais aparentes nas cidades, não só por meio de delimitações físicas robustas, mas também por sistemas de vigilância virtuais que fazem o controle intensivo do ambiente construído, assegurando a 'qualidade' do público que ali transita. Um efeito desta segregação, já comentada no subcapítulo anterior (2.4):

[...] é o corte deliberado de ligações com o resto do conglomerado urbano. Isto não só é realizado espacialmente, mas também em termos das dimensões sociais e culturais de 'pertencimento' à cidade [...]. A cidade perde assim a qualidade de uma 'comunidade imaginada' para tornar-se um conjunto de grupos com interesses próprios, ignorando e rejeitando a identidade do outro. Os indivíduos, assim, deixam de se sentir pertencidos a um todo. $\mathrm{O}$ resultado final não é apenas uma cidade arquipélago, mas um arquipélago mutualmente hostil. As políticas de integração acabam perdendo sua legitimidade, tornando-se irrelevantes para promover o bemestar dos residentes. (SMETS; SALMAN, 2008, p.1.323, tradução nossa)

A terceira estratégia que busca reverter a segregação por meio da participação econômica é diretamente relacionada a uma tática de contrapor a informalidade, não apenas fundiária, mas incluindo todos os seus reflexos, já que a falta de titularidade acaba por impossibilitar a inserção desses indivíduos na sociedade: “portanto, estes não podem 
estabelecer contratos lucrativos com estranhos, não podem obter crédito, seguros ou serviços urbanos. Eles são dependentes de suas famílias e de seus vizinhos" (DE SOTO, 2001, p.55, tradução nossa).

Assim, pretende-se verificar nos próximos capítulos, se os projetos de regeneração urbana, por meio dos projetos centrados no poder público - OUCs e PPPs (parceria público-privada) -, pretendem, por suas mais fundamentais intenções, gerar uma agenda que tenha a potencialidade de criar espaços de maior acesso às mais diversas camadas da sociedade ou, ao contrário, não passam de ferramentas que acabam por alavancar espaços exclusivos, impossibilitando a redistribuição de melhoramentos para regiões mais carentes.

\subsection{Políticas urbanas e instrumentos urbanísticos}

Compreender as políticas urbanas e os instrumentos urbanísticos que incidem no desenvolvimento urbano do território que compõe a RMSP se faz necessário, não apenas no sentido de apreender o contexto político em questão, mas também tentar desvencilhar quais os principais empecilhos que podem desestimular projetos mais ousados. 
As políticas urbanas correspondem ao conjunto das políticas e ações do poder público que incidem sobre os processos urbanos, representando um conjunto de metas, diretrizes e procedimentos que orientam a ação do poder público em relação a um conjunto de relações, necessidades ou demandas sociais que ocorrem em nível local e afetam diretamente na vida cotidiana da população que reside em aglomerados urbanos. Dessa forma, as políticas urbanas orientam as ações do poder público dirigidas à organização e ordenação do território das cidades, à produção e distribuição de espaços, infraestruturas, serviços e equipamentos públicos, e à regulamentação das atividades e das construções públicas e privadas no espaço urbano (ALVIM; CASTRO, 2010).

A Constituição Federal de 1988 define 'política urbana' como a 'política de desenvolvimento urbano executada pelo poder público municipal', como parte da ordenação econômica e financeira do Estado. Nessa concepção, atribuí-se aos municípios a competência da implementação dos objetivos da política urbana de ordenação das funções sociais da cidade e da propriedade e a garantia do bem-estar de seus habitantes.

$\mathrm{O}$ atendimento das demandas das populações urbanas englobam as mais diversas exigências no âmbito da educação, habitação, transporte, saúde, segurança, assistência social, esporte, lazer, cultura, meio ambiente etc.; que, por sua vez, dependem de uma complexa rede infraestrutural 
urbana que englobe um eficiente conglomerado composto pelo sistema viário, rede de coleta e tratamento de água e esgoto, rede de gás canalizado, iluminação pública, coleta de resíduos sólidos, telecomunicações, entre outros. O cenário crescente de mundialização dos mercados de bens e serviços acaba por intervir diretamente nas conformações urbanas, o que confere ao território a escala espacial na qual a disputa para a procura e para a distribuição de recursos em diferentes escalas possa acontecer.

As relações entre estes diversos setores de atuação implicam em um conflito de interfaces nas esferas de responsabilidade políticas - do âmbito federal, regional, estadual e municipal -, o que, em contrapartida, exige uma dificultosa coordenação, articulação e integração para a obtenção de sinergias que possam beneficiar a maior parte dos habitantes. Obviamente, o que se quer evitar por meio do processo da construção das políticas e ações que respondam as demandas urbanas são as interferências que provocam efeitos negativos em um ou mais processos, as chamadas externalidades.

Não se espera aqui fazer uma revisão histórica de todos os processos políticos e institucionais que possibilitaram o avanço das políticas urbanas e da criação dos instrumentos urbanísticos desenvolvidos até o dia de hoje, mas, sim, marcar os pontos mais relevantes para que se possa contextualizar a problemática dos projetos urbanos. Nesse sentido, não se poderia deixar de lado o importante passo 
de reforma institucional impulsionada pela Constituição Federal do Brasil em 1988, da Lei Orgânica Municipal do Município de São Paulo ${ }^{16}$ de 1990 e do Estatuto da Cidade (Lei Federal no 10.257/2001), que, articulados, levaram à introdução de novos padrões de gestão local. Assim, os municípios brasileiros passariam a assumir um novo papel na produção do espaço urbano, por meio da descentralização fiscal, dos processos de redemocratização e da constituição de uma esfera pública renovada como função social da cidade e da propriedade urbana.

O Estatuto da Cidade regulamenta o capítulo 'Política Urbana' da Constituição Brasileira, tendo como princípios o planejamento participativo e a função social da propriedade. O principal instrumento do Estatuto é o Plano Diretor Estratégico (PDE), obrigatório para municípios conturbados ${ }^{17}$ ou com mais de vinte mil habitantes. Este, por sua vez, institucionaliza o instrumento urbanístico da Operação Urbana (OU) no município, dentre outros explorados a seguir.

O PDE de São Paulo atual (Lei no 16.050 de julho de 2014 que revoga a Lei no 13.430 de 2002) tem como principal objetivo "humanizar e reequilibrar São Paulo, aproximando moradia e emprego e enfrentando 
as desigualdades socioterritoriais". Para atingir esses objetivos, o plano cria diretrizes gerais ${ }^{18}$ para:

combater a terra ociosa, que não cumpre a função social; implantar a política habitacional para quem precisa; valorizar o meio ambiente; orientar o crescimento da cidade nas proximidades do transporte público; qualificar a vida urbana na escala de bairro; promover o desenvolvimento econômico na cidade; preservar o patrimônio e valorizar as iniciativas culturais; e fortalecer a participação popular nas decisões dos rumos da cidade." (SÃO PAULO, Lei no 16.050, 2014)

Dessa forma, a Política de Desenvolvimento Urbano Ambiental de cada subprefeitura deve, a princípio, atender às diretrizes do PDE, que tem como principais objetivos:

Art. $6^{\circ}$ A Política de Desenvolvimento Urbano e o Plano Diretor Estratégico se orientam pelas seguintes diretrizes:

I - justa distribuição dos benefícios e ônus do processo de urbanização;

II - retorno para a coletividade da valorização de imóveis decorrente dos investimentos públicos $\mathrm{e}$ das alterações da legislação de uso e ocupação do solo;

III - distribuição de usos e intensidades de ocupação do solo de forma equilibrada, para evitar ociosidade ou sobrecarga em relação à 
infraestrutura disponível, aos transportes e ao meio ambiente, e para melhor alocar os investimentos públicos e privados; IV - compatibilização da intensificação da ocupação do solo com a ampliação da capacidade de infraestrutura para atender as demandas atuais e futuras;

[...]

VII - utilização racional dos recursos naturais, em especial da água e do solo, de modo a garantir uma cidade sustentável para as presentes e futuras gerações; [...] (SÃO PAULO, Lei no 16.050, 2014, p.3).

O PDE deve-se articular com o planejamento metropolitano e com os planos dos demais municípios da Região Metropolitana (SÃO PAULO, Lei no 16.050, 2014, art. 2º) e criar a Macroárea de Estruturação Metropolitana, definindo territórios considerados estratégicos na relação entre São Paulo e os demais municípios da metrópole; por meio de 'espaços destinados a projetos específicos que tem como um dos principais objetivos requalificar os espaços públicos reaproximando a cidade das suas águas' (Ibidem).

O PDE de São Paulo precedente já havia sido definido como “o instrumento básico da política de desenvolvimento e expansão urbana” (SÃO PAULO, Lei no $13.430,2002$, art. 40), instituindo um plano urbanístico ambiental e a adoção de instrumentos urbanísticos por meio 
da participação popular e da votação da Câmara dos Vereadores ${ }^{19}$. Os instrumentos urbanísticos criados instituíram parâmetros voltados à função social da propriedade, como o parcelamento, o uso e a ocupação do solo, o Imposto Predial e Territorial Urbano (IPTU) progressivo e a desapropriação com pagamento de títulos da dívida pública. Também instituiu instrumentos voltados para recuperação de mais-valias geradas por ações públicas e coletivas, financiamento das infraestruturas e realização de intervenções urbanas em áreas delimitadas na cidade, viabilizadas por meio de parcerias entre o setor público e o privado. Além destes, também incluiu instrumentos de preservação e gestão ambiental e urbanística, e também de instrumentos para viabilizar políticas habitacionais para a população de baixa renda, as chamadas 'Zonas Especiais de Interesse Social - Zeis'.

A Lei no 13.399/2002 dispõe sobre a criação das subprefeituras do município de São Paulo e prevê a transferência gradual de órgãos e funções da Administração Direta Municipal. Assim, atribuí-se às subprefeituras a responsabilidade que tange o impacto na rede infraestrutural da metrópole, tais como descritos abaixo: 
I - constituir-se em instância regional de administração direta com âmbito intersetorial e territorial;

II - instituir mecanismos que democratizem a gestão pública e fortalecer as formas participativas que existam em âmbito regional;

III - planejar, controlar e executar os sistemas locais, obedecidas as políticas, diretrizes e programas fixados pela instância central da administração;

IV - coordenar o Plano Regional e Plano de Bairro, Distrital ou equivalente, de acordo com as diretrizes estabelecidas pelo Plano Estratégico da Cidade;

V - compor com Subprefeituras vizinhas, instâncias intermediárias de planejamento e gestão, nos casos em que o tema, ou o serviço em causa, exijam tratamento para além dos limites territoriais de uma Subprefeitura;

VI - estabelecer formas articuladas de ação planejamento e gestão com as Subprefeituras e Municípios limítrofes a partir das diretrizes governamentais para a política municipal de relações metropolitanas;

VII - atuar como indutoras do desenvolvimento local, implementando políticas públicas a partir das vocações regionais e dos interesses manifestos pela população;

VIII - ampliar a oferta, agilizar e melhorar a qualidade dos serviços locais, a partir das diretrizes centrais;

IX - facilitar o acesso e imprimir transparência aos serviços públicos tornando-os mais próximos dos cidadãos;

X - facilitar a articulação intersetorial dos diversos segmentos e serviços da Administração Municipal que operam na região. (SÃO PAULO, Lei no 13.399 , 2002) 
A Lei de Zoneamento (Lei $\mathrm{n}^{-}$13.885/2004) estabelece normas complementares ao PDE, mesmo após a sua revisão em 2004. Essa lei institui os Planos Regionais Estratégicos (PRE) das Subprefeituras, dispõe sobre o parcelamento e a disciplina e ordena o Uso e Ocupação do Solo do Município de São Paulo. A Parte I da Lei refere-se às Normas Complementares ao Plano Diretor Estratégico; a Parte II da Lei, aos Planos Regionais Estratégicos das Subprefeituras; e a Parte III trata da Disciplina e Ordenação do Parcelamento, Uso e Ocupação do Solo. Após a revisão do PDE em 2014, os Planos Regionais das Subprefeituras devem ser revistos no prazo de 360 dias $^{20}$ de forma articulada à Lei de Parcelamento, Uso e Ocupação do Solo, devendo ser articulados aos planos diretores dos municípios vizinhos, podendo buscar a participação dos Consórcios Intermunicipais da RMSP.

Os PREs, no âmbito de cada subprefeitura, estabelecem objetivos e diretrizes de desenvolvimento urbano e ambiental, os quais devem se concretizar nas propostas para os elementos estruturadores ${ }^{21} \mathrm{e}$

\footnotetext{
${ }^{20}$ Da vigência do PDE, Lei no 16.050 , de 31 de julho de 2014.

${ }^{21}$ Os elementos estruturantes são definidos como o arcabouço permanente da cidade: a rede hídrica estrutural, a rede viária estrutural, a rede estrutural de transporte público coletivo e a rede estrutural de eixos e polos de centralidade. (SÃO PAULO, 2004)
} 
integradores ${ }^{22}$ do PDE. Os PREs seguem como referência os coeficientes de aproveitamento e as zonas criadas pelo PDE, contudo, outras interpretações das propostas do PDE acabam por diferenciar-se no domínio de cada subprefeitura, o que dificulta o caráter integrador na esfera municipal e, por consequência, na esfera metropolitana.

Integram os PREs as disposições e propostas do plano municipal de habitação e do plano municipal de circulação viária e de transportes, assim como os instrumentos de outorga Onerosa do Direito de Construir, Operações Urbanas Consorciadas, Transferência do Direito de Construir e as Áreas de Intervenção Urbana. Também são definidas nessa escala, as Zonas Especiais de Interesse Urbanístico, as Zonas Especiais de Preservação Ambiental, as Zonas Especiais de Preservação Agrícola, os Estudos de Impactos de Vizinhança e os Estudos Prévios de Impacto Ambiental.

É importante ressaltar alguns detalhes da Política de Desenvolvimento Urbano Ambiental e Regional da Lei de Zoneamento supracitada, na qual:

Art. 50. O Plano Regional Estratégico de cada Subprefeitura considera as desigualdades

${ }^{22}$ Os elementos integradores são constituídos pelo tecido urbano que permeia os eixos estruturantes e abriga as atividades em geral: habitação, equipamentos sociais, áreas verdes, os espaços públicos e os espaços de comércio, serviços e indústrias. (SÃO PAULO, 2004) 
regionais e tem em vista a inclusão social, em função de sua localização e das articulações inter e intra-urbanas e de suas especificidades, estabelecendo na sua Política de Desenvolvimento Regional as interações com o Plano Diretor Estratégico do Município de São Paulo. (SÃO PAULO, Lei no 13.885 , 2004, cap. II, art. 50)

Art. 54. Os Planos Regionais Estratégicos de cada Subprefeitura, atendendo às diretrizes estabelecidas na Seção II Do Macrozoneamento, do Capítulo II - Do Uso e Ocupação do Solo, do Título III - Do Plano Urbanístico Ambiental, do PDE, apresentam diretrizes urbanísticas e ambientais visando à correção das desigualdades sociais e regionais específicas de cada distrito que compõe a Subprefeitura inserida nas diferentes 'Macroáreas e Macrozonas'.

$\S 1^{\circ}$ - Cada Subprefeitura, em função de suas especificidades, delimita Áreas de Intervenção Urbana - AIU, Projetos Estratégicos de Intervenção Urbana - PEIU e Operações Urbanas Consorciadas - OUC, com seus respectivos programas, objetivos e diretrizes, de forma a atender às necessidades do desenvolvimento regional, coadunados com as diretrizes do PDE.

$\S 2^{\circ} \quad$ - Cada Subprefeitura identifica equipamentos de caráter internacional, nacional, estadual, metropolitano e intraurbano presentes na região, integrando-os aos programas e às diretrizes específicas das Áreas de Intervenção Urbana e das Operações Urbanas Consorciadas de cada Subprefeitura. (SÃO PAULO, Lei no $13.885,2004$, cap. II, art. 54) 
Por fim, ressaltam-se os objetivos do instrumento das Operações Urbanas estabelecidos pelo PDE e pela Política de Desenvolvimento

Urbano e Ambiental:

Art. 138. As Operações Urbanísticas Consorciadas têm por finalidade:

I - otimizar a ocupação das áreas subutilizadas, por meio de intervenções urbanísticas;

II - implantar equipamentos estratégicos para o desenvolvimento urbano;

III - ampliar e melhorar o sistema de transporte coletivo, as redes de infraestrutura e o sistema viário estrutural;

IV - promover a recuperação ambiental de áreas contaminadas e áreas passíveis de inundação;

$\mathrm{V}$ - implantar equipamentos públicos sociais, espaços públicos e áreas verdes;

VI - promover Empreendimentos de Habitação de Interesse Social e urbanizar e regularizar assentamentos precários;

VII - proteger, recuperar e valorizar o patrimônio ambiental, histórico e cultural;

VIII - promover o desenvolvimento econômico e a dinamização de áreas visando à geração de empregos. (SÃO PAULO, Lei no $16.050,2014$, art. 138)

No que diz respeito à exploração das empresas privadas envolvidas nas Concessões Urbanísticas:

$\S 3^{\circ}$ A concessionária poderá obter sua remuneração mediante exploração:

I - dos terrenos;

II - do potencial construtivo a ser utilizado na implantação do Projeto de Intervenção Urbana; 
III - das edificações destinadas a usos privados que resultarem da obra realizada;

IV - da renda derivada da exploração de espaço públicos;

$\mathrm{V}$ - das receitas acessórias, nos termos que forem fixados no respectivo edital de licitação e contrato de concessão urbanística. (SÃO PAULO, Lei no ${ }^{-}$16.050, 2014, art. 144)

De acordo com a revisão anterior, é possível identificar a natureza bastante recente com que a legislação urbanística tem tentado incluir objetivos e parâmetros de intervenção que, de certa forma, consigam englobar a complexidade territorial presente nas diferentes escalas geográficas atuantes na problemática urbana da metrópole. Mesmo assim, também se verifica um sistema de informações que ainda apresenta muitas vezes uma linguagem vaga e generalista, assim como lacunas quanto às formas de integração e implementação dos instrumentos e ferramentas urbanísticas que objetivem a melhor distribuição de oportunidades e evite as acirradas desigualdades regionais da RMSP.

Dessa forma, conclui-se que mesmo as versões mais atuais dos Planos Diretores Estratégicos Municipais, assim como os Instrumentos Urbanísticos revistos acima, não abordam de forma clara e objetiva as práticas de regeneração urbana nos termos definidos nesta tese. Consequentemente, os objetivos destes instrumentos se aproximam mais àqueles determinados pelos projetos de requalificação e renovação urbana que intervêm prioritariamente na transformação física das cidades. 


\subsection{A estruturação metropolitana}

A estruturação institucional hoje vigente da região estudada foi estabelecida oficialmente por meio do Conselho e Agência de Desenvolvimento Regional da Região Metropolitana de São Paulo, mediante a Lei Complementar no 1.139, de 16 de junho de 2011. Não obstante, a Região Metropolitana, formada pelos mesmos 39 municípios que hoje a compõem, foi criada muito antes, pela Lei Complementar Federal no 14, de 8 de junho de 1973. A regulamentação presente decorre dos princípios da Constituição de 1988, que transferiu a institucionalização das regiões metropolitanas à esfera estadual.

A urbanização do Brasil contemporâneo tende a reverter alguns quadros desenvolvimentistas impressos na década de 1950, como a que se apresentou na construção de Brasília. Nas políticas públicas atuais, vide Estatuto da Cidade implementado em 2001 e instrumentos como o Plano Diretor Estratégico, fala-se de produção de igualdade social na tentativa de se reverter padrões de irregularidade, degradação e desigualdade por meio da proposta de participação popular no processo de tomada de decisão governamental.

Como explicado no subcapítulo anterior, o Estatuto criou instrumentos de dois tipos: o primeiro ligado à gestão e o segundo, à 
regularização da propriedade urbana. As duas principais inovações do primeiro são a participação popular na formulação e implementação de políticas e a ideia de que a urbanização deve ser produzida por meio de uma cooperação entre organizações públicas e privadas.

Segundo Caldeira (apud KEINER et al., 2005), o Estatuto também criou alguns mecanismos paradoxais em que a democratização e a neoliberalização se entrelaçaram na construção da cidade. A São Paulo dos últimos 15-20 anos é uma cidade na qual o investidor privado interveio decisivamente, às vezes, em parceria com o governo, para beneficiar as áreas de seu investimento com o objetivo claro de obter um aumento significativo no valor de seus imóveis. O resultado disso foi a consolidação de um novo padrão de segregação baseado na proliferação de 'enclaves fortificados', espaços privados, monitorados por segurança privada para áreas residenciais, de consumo, entretenimento e trabalho.

Ainda na contramão dos processos de consolidação da democracia participativa, e contrariando o desejo da sociedade civil, o prefeito da cidade de São Paulo, no ano de 2011, anunciou providências que resultaram na redução do poder de autonomia das subprefeituras, autonomia que lhes havia sido outorgada na descentralização iniciada em 2001. A exemplo da questão ambiental em gestão de resíduos na sessão anterior, o serviço de limpeza pública, que havia sido transferido para as subprefeituras, foi devolvido ao controle do Limpurb - Departamento Limpeza Urbana (prefeitura), o que inclui a fiscalização das caçambas. No 
entanto, deve-se lembrar que a região metropolitana de São Paulo gera 17.000 toneladas de resíduos por dia, de quase vinte milhões de habitantes, quase a população da Austrália (21 milhões). Obviamente há de se pensar numa redistribuição de responsabilidades efetiva entre os níveis de governo para que se chegue a uma solução mais sustentável.

Conforme Lei Complementar $\mathrm{n}^{\circ}$. 14 de 1973 e legislação sucessiva, a Região Metropolitana de São Paulo é composta por 39 municípios, 5 sub-regiões, 127 distritos, e abriga, como já foi dito, quase vinte milhões de habitantes. Com uma área de aproximadamente 8.000 $\mathrm{km}^{2}$, a região ocupa um pouco mais de $3 \%$ do território paulista. De acordo com as últimas estimativas, um em cada dez brasileiros reside na região, que a cada hora ganha trinta novos habitantes. Cinco dos nove municípios do Estado de São Paulo com mais de quinhentos mil habitantes se localizam na região metropolitana: São Paulo, Guarulhos, São Bernardo do Campo, Santo André e Osasco.

A RMSP é o maior polo de riqueza nacional, com um produto interno bruto (PIB) de $\mathrm{R} \$ 572,2$ bilhões (57\% do total estadual e 18,9\% do PIB brasileiro), responsável pelo recolhimento de um quarto dos impostos no país (SECRETARIA DE DESENVOLVIMENTO URBANO, 2001).

São claros a importância e o desafio que a região apresenta na gestão de recursos, tanto naturais quanto administrativos, em um campo de claras desigualdades entre municípios. Com o intuito de promover a 
cooperação articulada entre diferentes níveis de governo para garantir melhor aproveitamento de recursos públicos, naturais, proteção do meio ambiente e redução de desigualdades, o governador do Estado de São Paulo sancionou a Lei Complementar n ${ }^{\circ} .1 .139$ de 2011. Essa Lei cria um novo sistema de gestão ancorado no planejamento metropolitano que busca o desenvolvimento sustentável e o bem-estar dos habitantes da Região Metropolitana de São Paulo.

A lei estabelece o Conselho de Desenvolvimento Regional, a Agência Metropolitana e o Fundo de Desenvolvimento Metropolitano, englobando os 39 municípios do Estado, com instrumentos de planejamento e um fundo que administra os recursos financeiros das prefeituras, do Estado e do Governo Federal, podendo inclusive receber financiamentos externos (como os do Banco Interamericano de Desenvolvimento).

Teoricamente, segundo a Secretaria de Desenvolvimento Urbano (2001), este instrumento integraria os objetivos das prefeituras, tornando possível resolver problemas urbanos importantes do ponto de vista do planejamento, como o Bilhete Único Metropolitano, o combate às enchentes, a recuperação do Rio Tietê, o tratamento e a destinação de resíduos sólidos, a expansão da rede de Metrô e CPTM, entre outros.

Em geral, a iniciativa parece adequada, porém deve-se verificar com o tempo se uma agenda de compromissos clara se consolidará, junto a definições mais transparentes na responsabilidade de cada instância 
política, para que problemas que abranjam uma diversa gama de jurisdições, sejam resolvidos de forma constante e duradoura e não acabem sendo apenas uma solução paliativa.

Para efeito do objeto desta tese é importante constatar que a Lei Complementar $n^{\circ} .1 .139$ de 2011, conforme artigo $3^{\circ}$, tem por objetivo promover a integração do planejamento e da execução das funções públicas de interesse comum, porém não fica claro de que forma essas funções devem ser executadas quanto a titularidade integrada ${ }^{23}$ das redes e serviços de infraestrutura.

\subsection{O papel dos projetos urbanos na [re]estruturação metropolitana}

Dentro dos instrumentos que podem exercer a capacidade de articulação entre a agenda estratégica de desenvolvimento das regiões metropolitanas e dos objetivos locais de um distrito, há os projetos

\footnotetext{
${ }^{23}$ Caberia aqui uma discussão mais aprofundada quanto a governança metropolitana e o pacto federativo, à respeito do controle da constitucionalidade e titularidade da prestação de serviços, porém o foco desta tese acabaria por ampliar-se sobremaneira.
} 
urbanos. Essa capacidade de promover transformações em escalas diversas - local, municipal, regional - por meio do desenho funcional e qualitativo de infraestruturas urbanas em locais estratégicos evidencia o papel reestruturador e articulador de projetos 'regenerativos'.

A conexão de tecidos disfuncionais e dispersos do território poderiam então se dar não só pela escolha de pontos nodais de convergência de fluxos entre demandas e ofertas, mas também pela disposição de sistemas infraestruturais que garantam um nível de flexibilidade que acomode os crescentes padrões de exigência das relações de produção da economia global.

Assim, a rede articulada de pontos nodais representada pelos projetos articuladores metropolitanos e seus diversos raios de influências acabaria por criar uma rede de alcance cada vez maior, configurando, por sua vez, o espaço macrometropolitano, até cruzar as fronteiras nacionais, de forma a integrar-se na dinâmica da economia global. Não que o espaço intersticial entre os polos nodais não acabe por sofrer situações de segregação, consequência básica dos processos da economia capitalista. Porém, pergunta-se: pode a determinação de infraestruturas urbanas tornar-se a força integradora que articula pontos nodais, tornando-se o principal elemento de estímulo das dinâmicas metropolitanas?

A reposta não seria possível sem se estudar alguns casos específicos que se apresentaram como possíveis soluções articuladoras entre a escala local e regional, e que, em algum nível, mostrassem a 
necessidade de conjugar planejamento e projeto urbano. Assim, no próximo capítulo, verificam-se as possibilidades e/ou capacidades dos projetos em ultrapassarem planos superficiais transformando-se em capacitores concretos com capacidade de atuar nos problemas de uma localidade específica, transmutando seus efeitos exponencialmente no território.

\subsection{As práticas da regeneração urbana}

Por meio do estudo dos projetos e práticas de regeneração urbana, buscou-se tornar evidente tal processo de regeneração e suas relações com os alicerces infraestruturais. Assim, foram estudados três projetos, um em Paris, um em Londres e um em São Paulo, sendo todas cidades de alta densidade populacional e que tiveram períodos históricos de crescimento extremos, seguidos de um processo de periferização. Os três projetos escolhidos estão localizados em polos centrais de infraestrutura e apresentam soluções distintas quanto às perspectivas traçadas na agenda da regeneração.

No estudo de caso de Les Halles, em Paris, esses processos foram expostos por meio de uma abordagem histórica, teórica e conceitual, 
porém resumidos na versão final ${ }^{24}$ desta tese, de forma a manter apenas as informações mais relevantes. As diversas transformações urbanas de Les Halles expõem o desafio que muitos espaços urbanos enfrentam ao adaptarem-se a seus tempos. Devido à natureza de espaços que funcionam como eixos infraestruturais metropolitanos, como o Les Halles, esperou-se demonstrar que projetos de intervenção circunscritos não trazem apenas benefícios e/ou problemas para a população das imediações do projeto, mas que, sim, são redistribuídos no território urbano.

O projeto Bankside Urban Forest, em Londres, apresenta uma forma inovadora de conceber um projeto de regeneração urbana, no qual não se tem um masterplan rígido, que estabelece parâmetros de uso e ocupação do solo tal como usualmente. O projeto fundamenta-se na criação de uma agenda de pequenas intervenções estratégicas que podem envolver pequenas e grandes corporações locais, assim como residentes de todas as idades e grupos da região. Pode-se demonstrar neste estudo que projetos de intervenção, mesmo que minutos, podem causar impactos importantes não apenas locais, mas que geram impulsos no âmbito regional, se estiverem conectados por uma agenda mais ampla

${ }^{24} \mathrm{O}$ estudo completo foi apresentado na qualificação desta tese, e pode ser disponibilizado caso interesse do leitor. 
que os circunscrevam numa rede infraestrutural de capacidade metropolitana.

Por fim, o projeto Nova Luz torna evidente as complexidades dos processos que objetivam a regeneração urbana, e evidencia que projetos de intervenção herméticos em seu escopo, que não incorporem dentro de seus princípios os pontos críticos do local, tanto físicos quanto sociais, dificilmente conseguem gerar impactos positivos dentro de seu perímetro e no seu entorno. As identificações de um perímetro específico de projeto e de uma agenda prescritiva de usos, neste caso, se opõem à liberdade construída na agenda de intervenções menores do projeto londrino. 


\subsubsection{Les Halles parisiense}

Este estudo tem o intuito de tornar evidente o processo de regeneração urbana e seus produtos e concretizações, pelo estudo de caso de Les Halles em Paris, por meio de uma abordagem histórica, teórica e conceitual. O estudo das diversas transformações urbanas do Les Halles representa o desafio que muitos espaços urbanos enfrentam ao adaptarem-se a seus tempos. Devido à natureza de espaços que funcionam como eixos infraestruturais metropolitanos, como Les Halles, procurou-se demonstrar que projetos de intervenção circunscritos não trazem apenas benefícios e problemas para a população das imediações do projeto, e que, sim, são redistribuídos no território urbano. Dessa forma, políticas urbanas que tratem apenas de questões espaço-temporais imediatas devem encontrar, subitamente, uma nova ferida exposta, a qual se deve regenerar.

\section{Contexto}

Desde o início da desocupação do mercado em 1969 até as suas demolições em 1971, houve uma busca quase constante por uma definição do que se fazer no sítio original: abriu-se o tempo e o espaço para que contínuas discussões, convocatórias de concursos, debates públicos, e até exibições de 'teatro revolucionário' ocupassem o Trou de 
Paris. O ministro da Cultura André Marlaux foi bastante influente na ocasião, considerado o 'profeta' da arte e cultura, pregou a ideia de um novo centro cultural que acomodasse num único lugar as diversas formas de expressão da arte e cultura francesa. Outra demanda que podia aliar-se ao fortalecimento da imagem cultural francesa foi a construção de uma robusta biblioteca pública. No entanto, a controvérsia não iria, ainda dessa vez, preencher o 'buraco' exposto de Les Halles. Em 1968, o presidente Charles de Gaulle anunciou que seria no Platô Beaubourg o local da nova biblioteca, onde eram acomodados os veículos de transporte e material de refugo do mercado, assim como a favela SaintMerri. Em 1969, o novo presidente Georges Pompidou adotou o projeto de Malraux e de Gulle, e o Platô Beaubourg foi demolido, sendo objeto de concurso para o novo museu multicultural, o que futuramente iria se transformar no famoso Centro Pompidou, concebido pelos, então estudantes de arquitetura, Renzo Piano e Richard Rogers. O Centro Pompidou foi desenhado e construído entre os anos de 1971 e 1977, quando inaugurado junto com a nova estação de trem RER, nos subsolos do sítio Les Halles (ver Figuras 1, 2, 3 e 4). Enquanto isso, o vazio do terreno seria ocupado por estacionamentos, sendo seus arredores abandonados por mais quase uma década. 

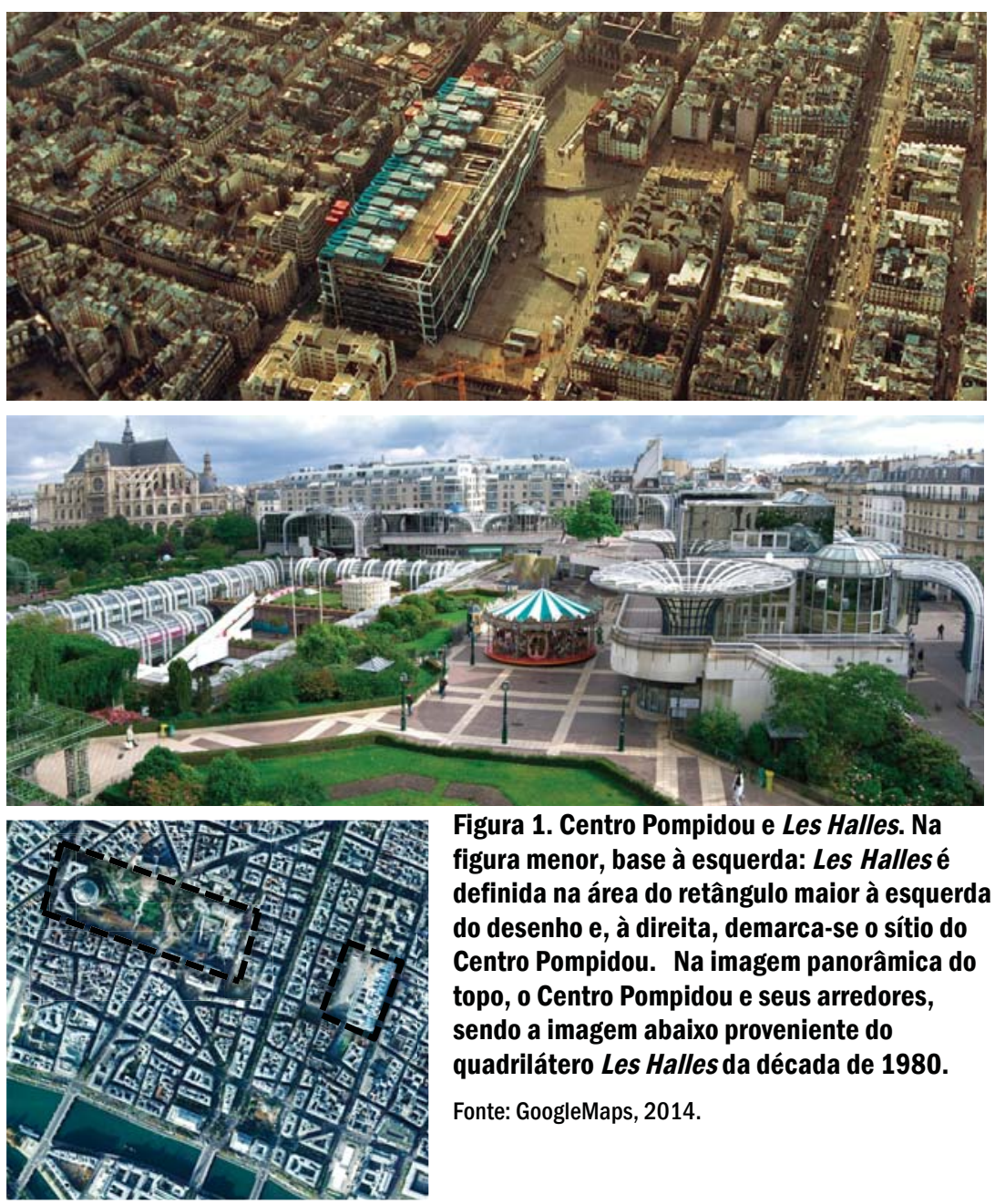

Figura 1. Centro Pompidou e Les Halles. Na figura menor, base à esquerda: Les Halles é definida na área do retângulo maior à esquerda do desenho e, à direita, demarca-se o sítio do Centro Pompidou. Na imagem panorâmica do topo, o Centro Pompidou e seus arredores, sendo a imagem abaixo proveniente do quadrilátero Les Halles da década de 1980.

Fonte: GoogleMaps, 2014. 


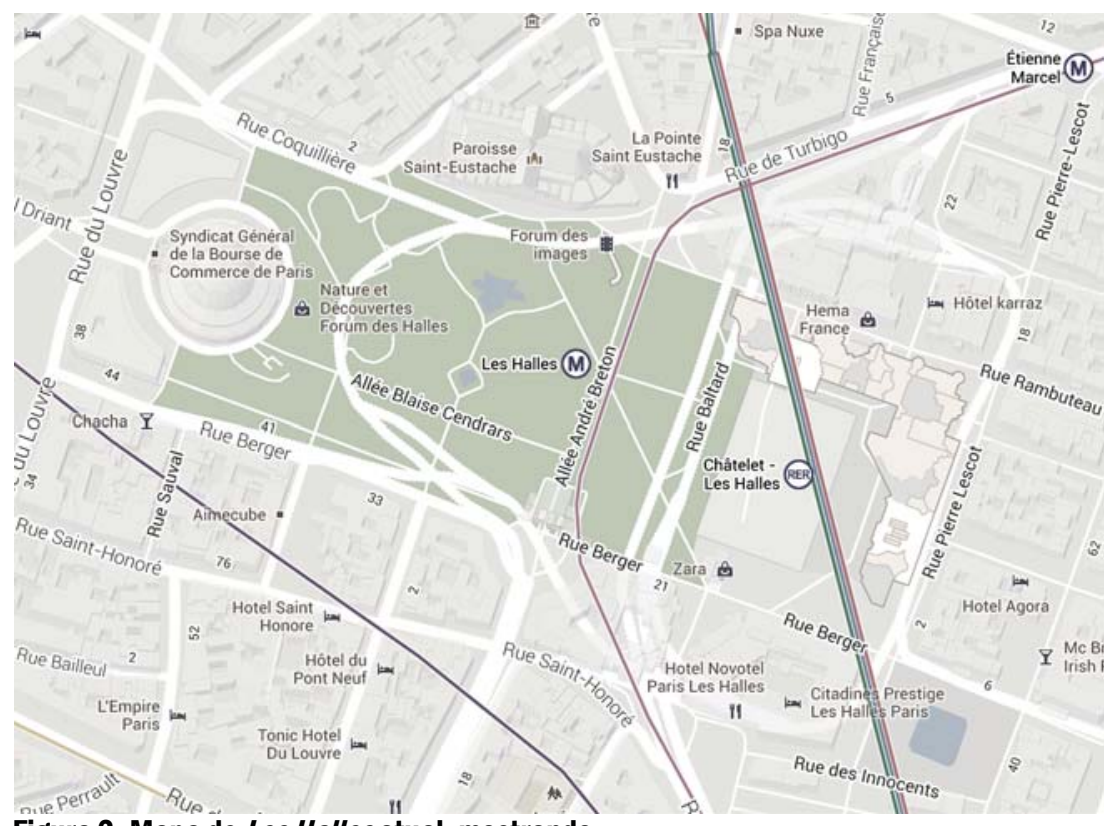

Figura 2. Mapa de Les Halles atual, mostrando as linhas de transporte público RER/Metrô .

Fonte: GoogleMaps, 2014.

Figura 3. Maquete do projeto de Louis Arretche, 1980. Fonte: Dupont, 2004.

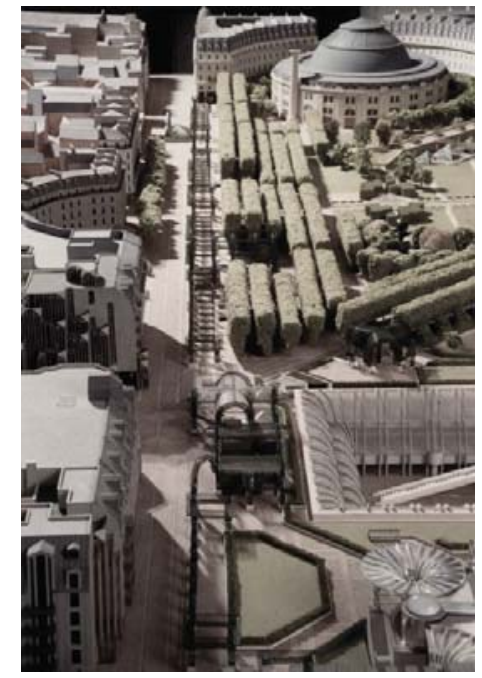




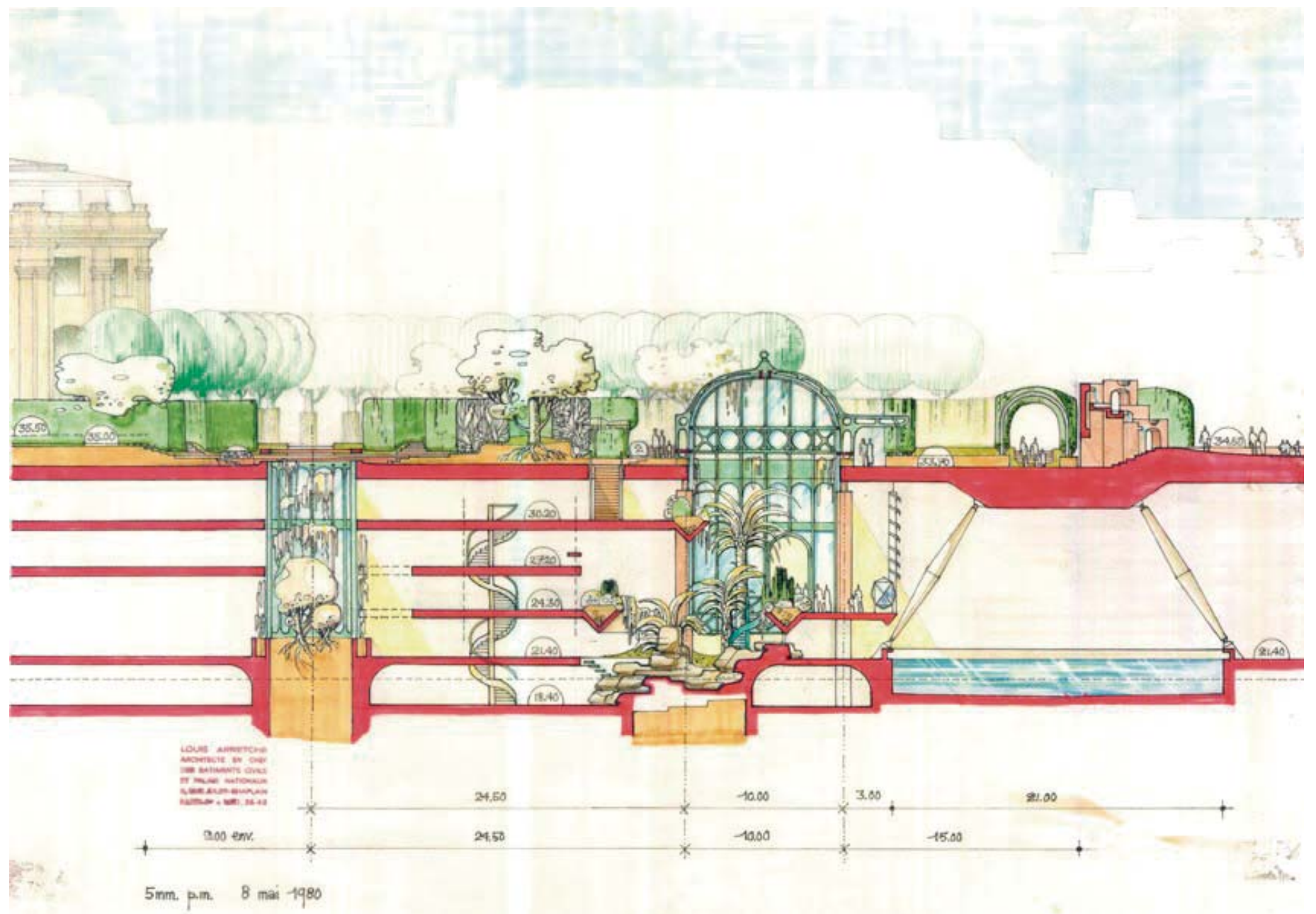

Figura 4. Seção transversal do projeto de Louis Arretche, 1980.

Fonte: Dupont, 2004. 
É importante notar que a natureza da concentração populacional é hoje distinta do período anterior, quando uma boa proporção das pessoas que trabalhavam no mercado morava no entorno. De acordo com o relatório oficial do Atelier Parisien d'Urbanisme (VELA, 2005), de 1954 para 1999, a população residente no $1^{\circ}$. Distrito (1er Arrondissemment) diminuiu consideravelmente, quase 44\%, e transformou-se numa população mais jovem (ver Tabela 1). Hoje, a maior proporção de pessoas está de passagem pelo local e, devido ao importante $h u b$ central de transporte Châtelet-Les-Halles, estas fazem uma 'pausa' entre seus trabalhos e suas residências. Um dos grupos que é mais atraído ao shopping center, bares e restaurantes e praças do entorno é, hoje, composto de jovens de menos de 25 anos (40\%) e uma boa parte dos transeuntes vem dos subúrbios (45\%). A reputação do local é ruim, como em outros tempos. Les Halles é vista como agressiva, decadente e perigosa. Segundo Chevalier (1994), 2/3 das lojas do fórum tinha sido assaltada na década de 1980, além do sabido tráfico e consumo de drogas, exibições pornográficas e prostituição, e os mais graves casos de estupro e morte: uma visão do ambiente de desafeto que ocupou a região. 


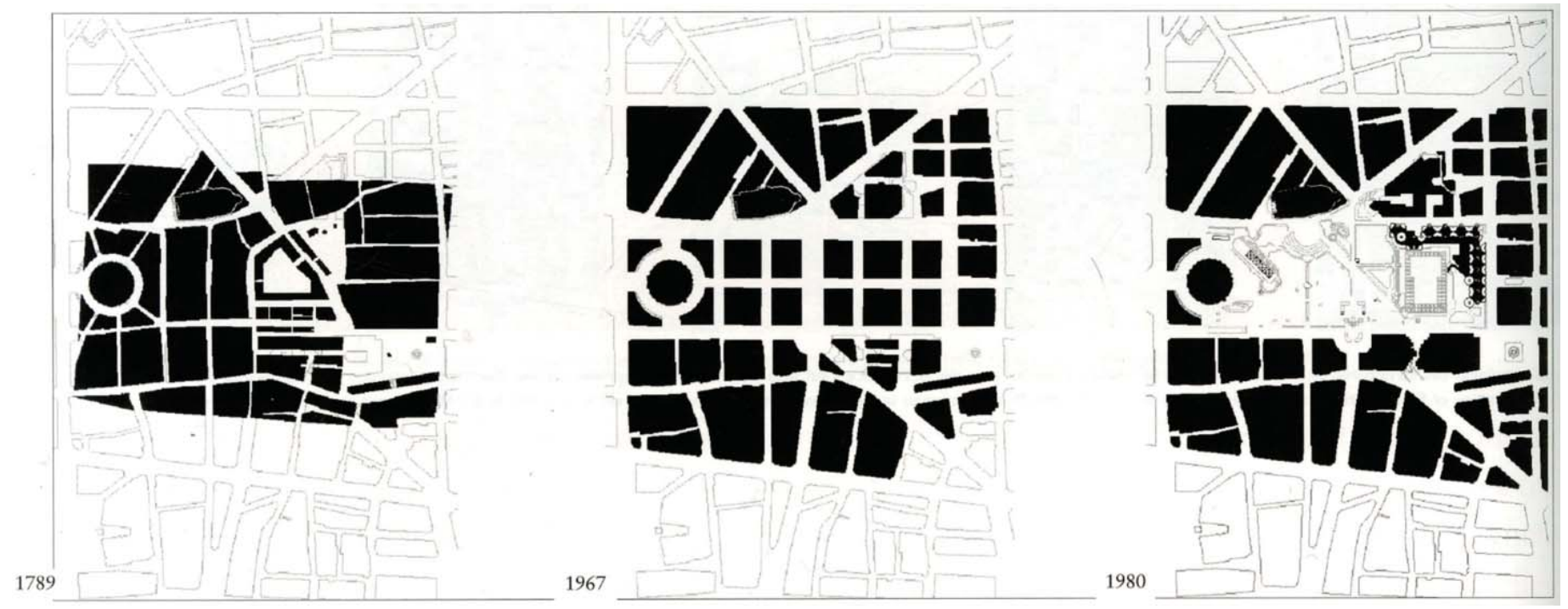

Figura 5. Transformações urbanas nas imediações de Les Halles. Situação em 1789, 1967 e 1980, da esquerda para a direita. Fonte: Dupont, 2004 
Tabela 1. Evolução da população do 1er Arrondissement - Estatísticas e percentagem da população de Paris, de 1954 a 1999. Fonte: Adaptado de Vela, 2005.

\begin{tabular}{|c|c|c|c|c|c|c|c|c|c|c|c|c|c|c|c|c|}
\hline \multirow{2}{*}{$11^{\circ}$ DISTRITO } & \multicolumn{2}{|c|}{1954} & \multicolumn{2}{|c|}{1962} & \multicolumn{2}{|c|}{1968} & \multicolumn{2}{|c|}{1975} & \multicolumn{2}{|c|}{1982} & \multicolumn{2}{|c|}{1990} & \multicolumn{2}{|c|}{1999} & \multicolumn{2}{|c|}{ EVOLUÇĀO EM \% } \\
\hline & & $\%$ & & $\%$ & & $\%$ & & $\%$ & & $\%$ & & $\%$ & & $\%$ & $\begin{array}{l}1982 . \\
1990\end{array}$ & $\begin{array}{l}1990 . \\
1999\end{array}$ \\
\hline $\begin{array}{l}\text { POPULAÇĀO } \\
\text { TOTAL }\end{array}$ & 38.849 & 100,0 & 36.622 & 100,0 & 32.343 & 100,0 & 22.350 & 100,0 & 19.000 & 100,0 & 18.365 & 100,0 & 16.895 & 100,0 & $-3,3$ & $-8,0$ \\
\hline \multicolumn{17}{|c|}{ POPULAÇĀO POR SEXO } \\
\hline Homens & 17.439 & 44,9 & 16.966 & 46,3 & 15.068 & 46,6 & 10.505 & 47,0 & 8.808 & 46,4 & 8.902 & 48,5 & 8.370 & 49,5 & 1.1 & $-6,0$ \\
\hline \multicolumn{17}{|l|}{ ATIVIDADE } \\
\hline Homens ativos & 12.511 & 32,4 & 11.354 & 31,0 & 9.989 & 30,9 & 6.560 & 29,4 & 5.500 & 28,8 & 5.649 & 30,8 & 5.384 & 35,6 & 2,7 & $-4,7$ \\
\hline Mulheres ativas & 10.739 & 27,8 & 9.861 & 26,9 & 8.568 & 26,5 & 5.955 & 26,6 & 4.784 & 25,1 & 4.793 & 26,1 & 4.511 & 29,8 & 0,2 & $-5,9$ \\
\hline Totais ativos & 23.250 & 60,1 & 21.215 & 57,9 & 18.557 & 57,4 & 12.515 & 56,0 & 10.284 & 53,9 & 10.442 & 56,9 & 9.895 & 65,4 & 1,5 & $-5,2$ \\
\hline Homens inativos & 4.813 & 12,4 & 5.612 & 15,3 & 5.079 & 15,7 & 3.945 & 17,7 & 3.380 & 17,7 & 3.253 & 17,7 & 2.074 & 13,7 & $-3,8$ & $-36,2$ \\
\hline Totais inativos & 15.419 & 39,9 & 15.407 & 42,1 & 13.786 & 42,6 & 9.835 & 44,0 & 8.788 & 46,1 & 7.923 & 43,1 & 5.230 & 34,6 & $-9,8$ & $-34,0$ \\
\hline \multicolumn{17}{|l|}{ NACIONALIDADE } \\
\hline Franceses & 36.543 & 94,1 & 33.331 & 91,0 & 28.404 & 87,8 & 19.020 & 85,1 & 15.468 & 81,4 & 15.298 & 83,3 & 14.579 & 86,3 & $-1,1$ & $-4,7$ \\
\hline Estrangeiros & 2.306 & 5,9 & 3.291 & 9,0 & 3.939 & 12,2 & 3.330 & 14,9 & 3.532 & 18,6 & 3.067 & 16,7 & 2.316 & 13,7 & $-13,2$ & $-24,5$ \\
\hline \multicolumn{17}{|l|}{ FAIXA ETÁRIA } \\
\hline 0 a 4 anos & 2.002 & 5,2 & 1.551 & 4,2 & 1.352 & 4,2 & 760 & 3,4 & 632 & 3,3 & 650 & 3,5 & 604 & 3,6 & 2,8 & $-7,1$ \\
\hline 5 a 14 anos & 3.609 & 9,3 & 3.482 & 9,5 & 2.740 & 8,5 & 1.705 & 7,6 & 1.492 & 7,9 & 1.305 & 7,1 & 1.166 & 6,9 & $-12,5$ & $-10,7$ \\
\hline 15 a 24 anos & 4.438 & 11,4 & 4.846 & 13,2 & 5.152 & 15,9 & 2.970 & 13,3 & 2.628 & 13,8 & 2.379 & 13,0 & 1.973 & 11,7 & $-9,5$ & $-17,1$ \\
\hline 25 a 34 anos & 6.863 & 17,7 & 5.844 & 16,0 & 4.937 & 15,3 & 3.665 & 16,4 & 3.488 & 18,4 & 3.770 & 20,5 & 4.117 & 24,4 & 8,1 & 9,2 \\
\hline 35 a 64 anos & 17.279 & 44,5 & 15.856 & 43,3 & 13.043 & 40,3 & 8.760 & 39,2 & 7.324 & 38,5 & 7.288 & 38,7 & 6.453 & 38,2 & $-0,5$ & $-11,5$ \\
\hline $\begin{array}{l}\text { a partir de } \\
75 \text { anos }\end{array}$ & 1.299 & 3,3 & 1.732 & 4,7 & 1.800 & 5,6 & 1.665 & 7,4 & 1.604 & 8,4 & 1.579 & 8,6 & 1.293 & 7,7 & $-1,6$ & $-18,1$ \\
\hline
\end{tabular}


Atualmente o local é mais policiado, porém a sensação de tensão e de ambiente 'desagradável' permanece contrário ao modo de vida idealizado pelos franceses e a maior parte dos cidadãos de grandes metrópoles. Mais uma vez o intuito da regeneração urbana se torna motivo para que, em 2003, o prefeito Bertrand Delanoë anunciasse a abertura de um novo concurso de ideias para Les Halles.

\section{Último concurso}

Por meio da visibilidade produzida na história controversa de renovação de Les Halles, Bertrand Delanoë pretendeu criar um novo sinal promovido pela esquerda socialista: o de abrir o debate ao público quanto ao futuro da área e, assim, desfazer as tradições autoritárias de planejamento urbano da França. Os principais objetivos do plano seriam os de resolver o congestionamento da região e renovar o layout de todo o empreendimento, assim como dar uma nova aparência a todo conjunto. O projeto foi liderado pelo diretor de urbanismo, Jean-Pierre Caffet, e prefeito do primeiro Arrondissement (distrito), Jean-François Legaret, e dirigido por uma parceria entre a Prefeitura de Paris, a agência de transportes RATP e o grupo comercial que administra o shopping Fórum Les Halles; devendo ser implementado pela Diretoria de Urbanismo da Câmara Municipal junto à entidade público-privada SEM Paris Centre. 
Apesar da importância do projeto, o número de arquitetos inscritos nem se comparou à ocasião precedente, nos anos 1980. Possivelmente a oportunidade de, de fato, se repensar o futuro do local não tenha sido oferecida, e uma agenda já orientada para uma 'reforma' para manter o mesmo programa comercial tenha sido notada. De fato, houve um envolvimento maior da sociedade por meio da exposição do projeto ao público, a partir das quatro equipes finalistas selecionadas pelo júri. As preferências dos visitantes foram apuradas, funcionando como um termômetro quanto a sua aceitação em relação as propostas, porém não contando oficialmente como voto. No site oficial do plano, o título 'O novo coração de Paris’ anuncia:

Les Halles será reorganizada e modernizada para tornar o bairro mais acolhedor para os visitantes, e se tornará mais coesa, mais aberta à cidade e melhor integrada ao ambiente urbano. E, graças à redução dos congestionamentos, os visitantes poderão respirar mais livremente e poderão acessar todas as instalações e fazer o seu caminho com facilidade e num ambiente mais agradável. (PARIS LES HALLES, 2013)

Os quatro finalistas foram as equipes de Rem Koolhaas (OMA), Winy Maas (MVRDV), Jean Nouvel e David Mangin (SEURA), sendo o último projeto o escolhido por gerar menos controvérsias e por propor a mais simples implementação. Para um melhor entendimento, as quatro 
propostas foram abaixo descritas, de acordo com o material produzido e publicado em domínios públicos (websites e revistas oficiais).

De acordo com a equipe chefiada por Rem Koolhaas (OMA), a história de destruição de Les Halles produziu uma neurose em relação à questão dos projetos de grande porte, tornando a atividade de planejamento da cidade moderna em uma atividade complexa e suspeita aos olhos da sociedade, produzindo uma perda de convicção em relação ao projeto moderno. Dessa forma, o objetivo principal da equipe foi o de tentar reinventar uma paisagem urbana moderna para Paris, que pudesse, até certo ponto, produzir uma coexistência entre o tradicional e o moderno, que incluísse o discurso da consciência ambiental e que conseguisse romper com a ideia de um gesto unificador e definitivo em grande escala. Decidiu-se por testar o conceito de uma 'cultura moderna acumulativa', por meio da acumulação de intervenções específicas e precisas, contextuais e delicadas, que, juntas, pudessem redefinir o extenso território de Les Halles. O projeto (ver Figura 6 e Figura 7 ) consistiu num grupo de edifícios que, por vezes, emerge da superfície e, por vezes, penetra no subterrâneo, com a perspectiva de que esse conceito pudesse acabar com a 'esquizofrenia' que existe entre o subsolo e a superfície do terreno. Além disso, propôs-se uma superfície de áreas verdes, coberta por um campo de círculos de diferentes espécies vegetais que pudesse definir e atrair uma série de atividades de lazer. Essa multiplicidade de utilizações seria o resultado de, ao mesmo tempo em que se propõe uma 
variedade de plantas, propor uma variedade de arquiteturas em relação ao sítio inteiro. $O$ discurso da equipe foi de que essa combinação entre arquitetura e artefato, proposta de forma global, tornaria-os inseparáveis, o que poderia definir um caminho possível para a paisagem urbana moderna na França. Nesse sentido, a equipe busca 'Reinventar a modernidade de Paris'. (OMA, 2013) 

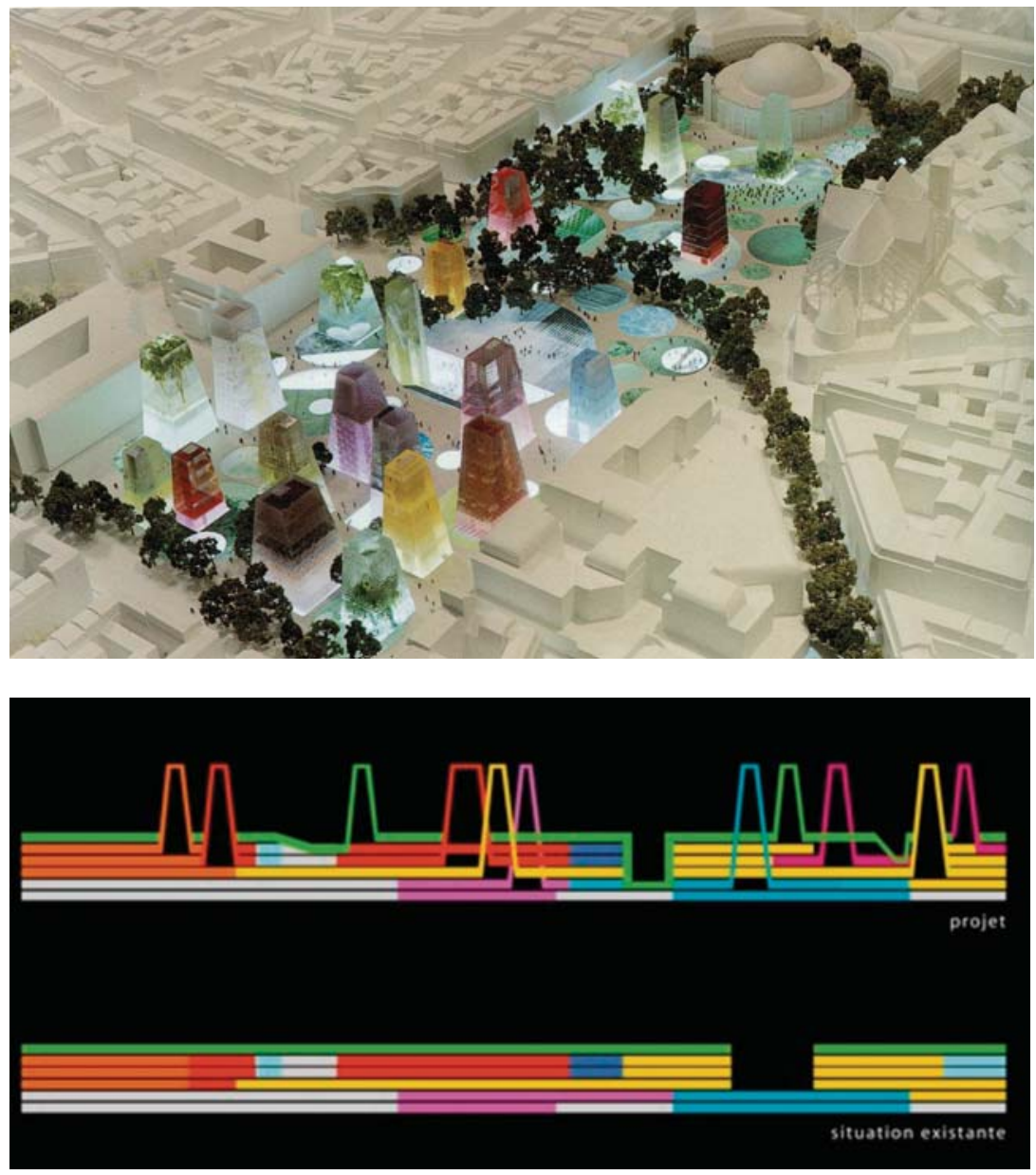

Figura 6. Proposta da equipe de Rem Koolhas/OMA.

Fonte: OMA, 2013 

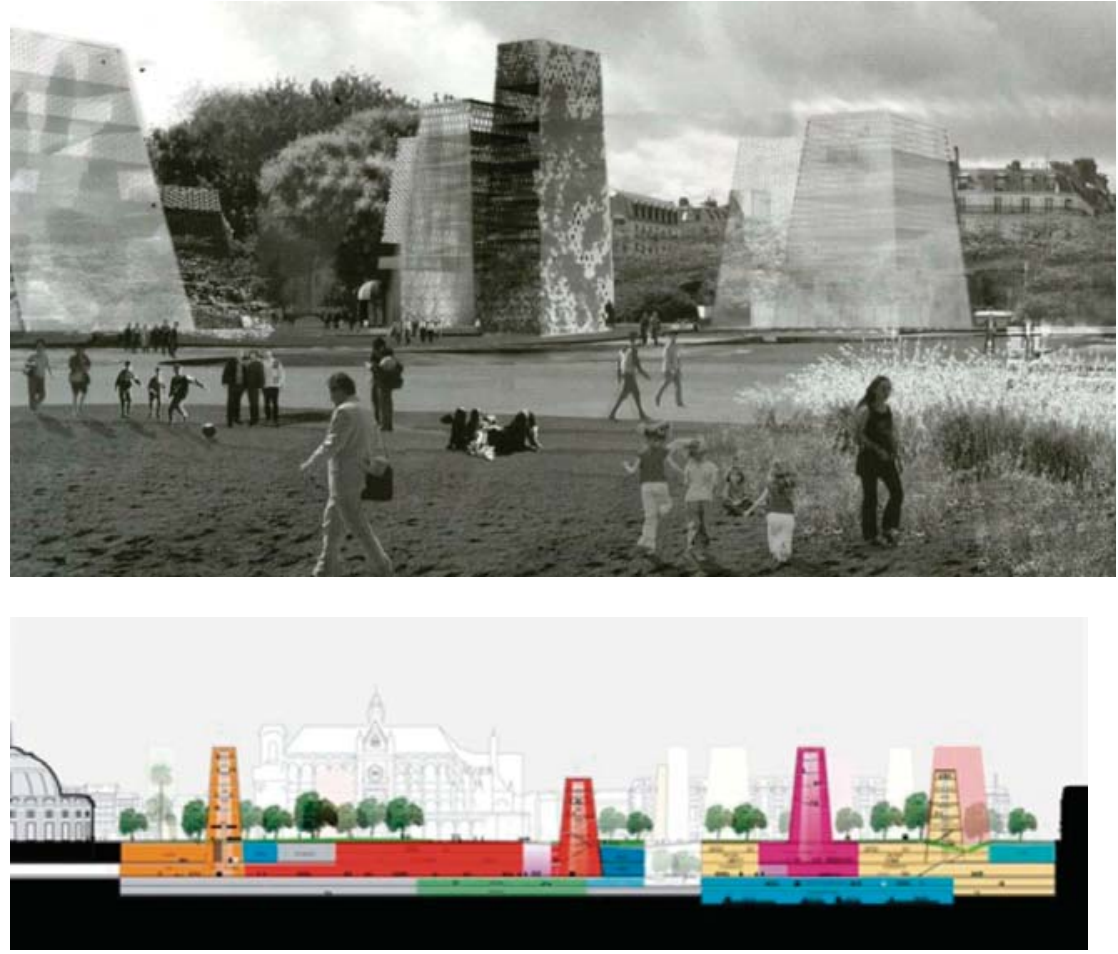

Figura 7. Continuação. Proposta da equipe de Rem Koolhas/OMA.

Fonte: OMA, 2013. 
A equipe de Winy Maas (MVRDV) propôs a remodelação do Fórum Les Halles por meio de uma série de intervenções precisas que, juntas, eventualmente, resultaria num grande projeto icônico no centro de Paris. O projeto (ver Figura 8) para o fórum incluiria a abertura da estação de metro à luz natural, assim como melhorias nas instalações vizinhas, equipamentos culturais, vias comerciais, circulações e paradas do metrô e os estacionamentos no fórum, centrando-os em torno de um vale subterrâneo coberto por uma gigantesca rosácea. A crítica da equipe em relação ao projeto original é a de que, apesar da dimensão programática e seu uso intenso, ele não criou uma 'grandeza', não possuía 'alma', nem se transformou em um ícone para a cidade. O centro de compras está escondido e escuro, a estação superlotada - escura e claustrofóbica - e o parque não possui um caráter forte. A equipe levantou questões como: de que maneira podemos viver com o antagonismo de uma época que busca, ao mesmo tempo, o protecionismo e o cosmopolitismo? Outra questão levantada diz respeito à possibilidade de se realizar ambições em larga escala, por meio de intervenções em pequena escala. Essa intervenção diz ter procurado combinar os desejos das partes envolvidas - o sistema de transporte da RATP, o setor comercial e a Prefeitura de Paris - e de tentar 'colar' essa série de intervenções de diferentes natureza, personalidade e orçamento, de forma a transformar o espaço num ambiente de colaboração rico e diferenciado. A ideia da equipe foi a de compor 'com grandeza' pequenos pedaços, como num vitral. (MVRDV, 2013) 

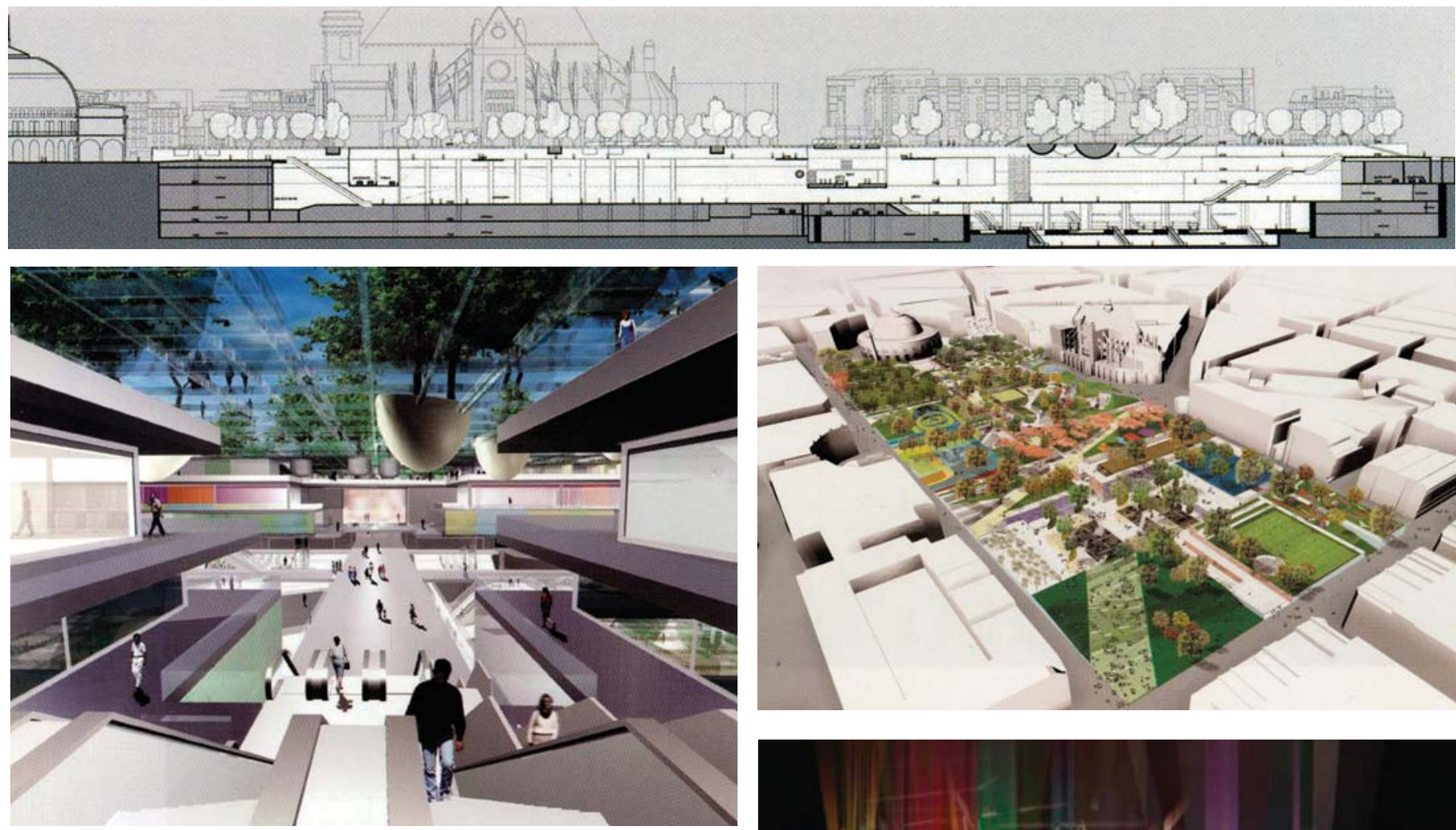

Figura 8. Proposta de equipe de Winy Mass/MVRDV Fonte: MVRDV, 2013.

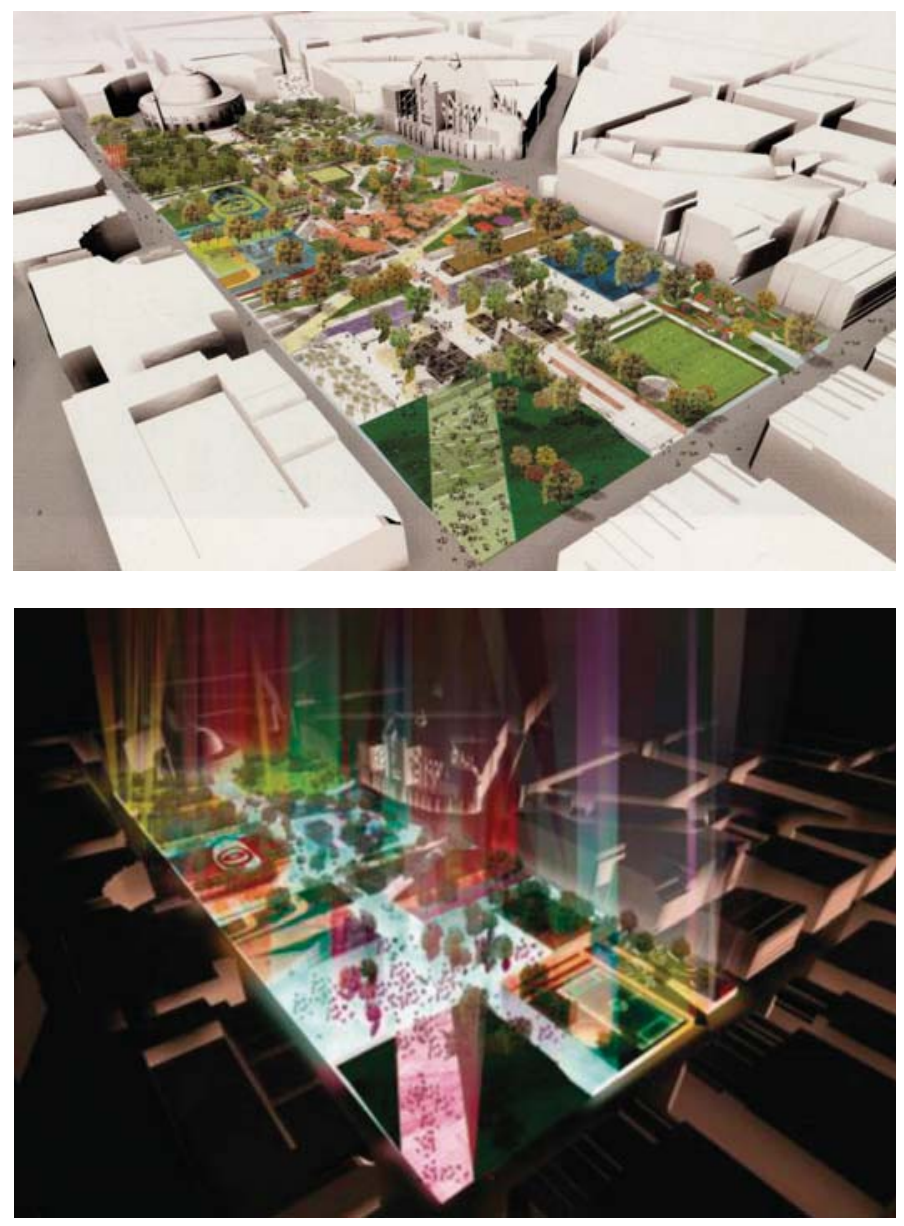


A equipe de Jean Nouvel, por sua vez, defendeu que, com o seu projeto (ver Figura 9), o local recuperaria sua dignidade e afirmaria a sua vocação como um bairro extraordinário no centro de Paris. Este carregaria a 'imagem e o mito da capital em harmonia com a história de Paris, e reconciliaria a felicidade dos habitantes à vida natural no centro de Paris'. O projeto melhoraria a rotina das pessoas que vivem no bairro, oferecendo novos espaços para a sua fruição, assim como para as suas necessidades, garantindo a sua tranquilidade, o seu conforto e sua segurança por meio da definição clara de ruas, praças e jardins. O jardim existente, muito desordenado, seria substituído por um novo jardim, com a nitidez herdada das grandes tradições dos jardins arquetípicos de Paris: Palais Royal, Tuileries etc., permitindo que se abrisse para as ruas e praças adjacentes. O discurso de Nouvel propôs redefinir o conceito de modernidade com a defesa de que, segundo suas próprias palavras, 'ser moderno hoje é saber onde se está', e continua: 'ser moderno é modificar a leitura do território enquanto o respeita'. (ATELIER JEAN NOUVEL, 2013). 

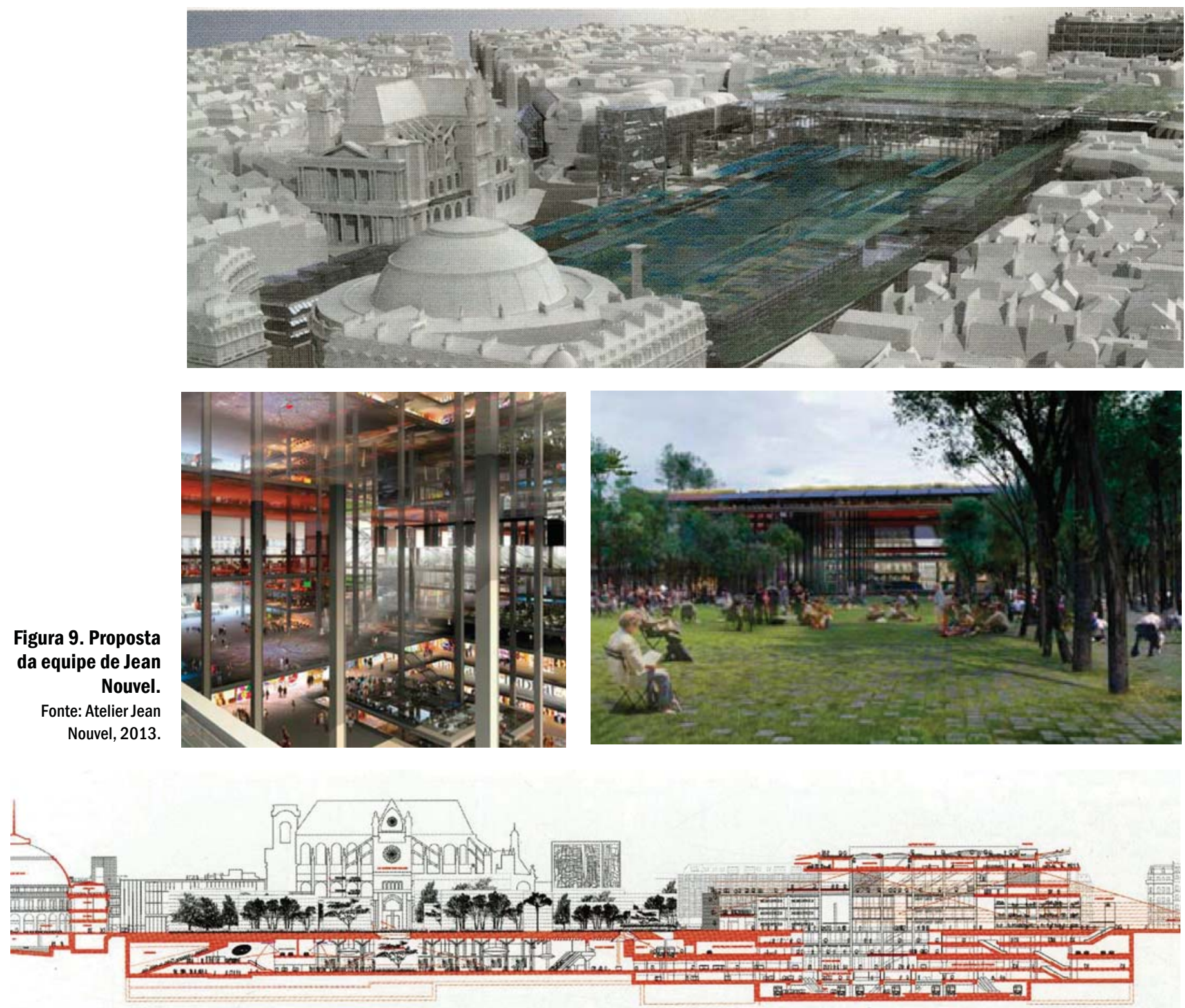
Por fim, o projeto vencedor da equipe de David Mangin e Aurelio Golfetti (SEURA) propôs uma solução fundamentalmente urbana, que recomendou restaurar os caminhos urbanos destinados aos pedestres, desde o Beaubourg ao Louvre, aos Grands Boulevards e ao Rio Sena (ver Figura 10). Procurou-se reorganizar o sítio e estabelecer uma nova relação entre os espaços subterrâneos e a cidade, entre o RER, o comércio, o fórum e os jardins. Um grande espaço público aberto foi proposto, a fim de inscrever-se na concatenação dos principais espaços de Paris, as Tuileries, Cour Carré, o Palais Royal, o Beaubourg e a Place des Vosges. Mangin defendeu sua proposta como racional 'buscando os mínimos meios para causar os maiores efeitos' (SEURA, 2013).

Apesar de vencedor, pouco tempo depois, o prefeito Delanoë resolveu alterar o projeto arquitetônico do Fórum Les Halles, mudando sua autoria para uma figura mais conhecida na França, Patrick Berger, diferentemente de Mangin, até aquele momento desconhecido. Mangin ficou com a coordenação do projeto, fazendo um papel de liderança do masterplan (ver Figura 11). Essa nova mudança pôde mostrar, mais uma vez no tempo, a dificuldade de se trabalhar em uma área tão vital, em que o conflito de interesses se mostra mais exposto. O projeto que se encontra praticamente finalizado, pode ser visualizado na Figura 12. 

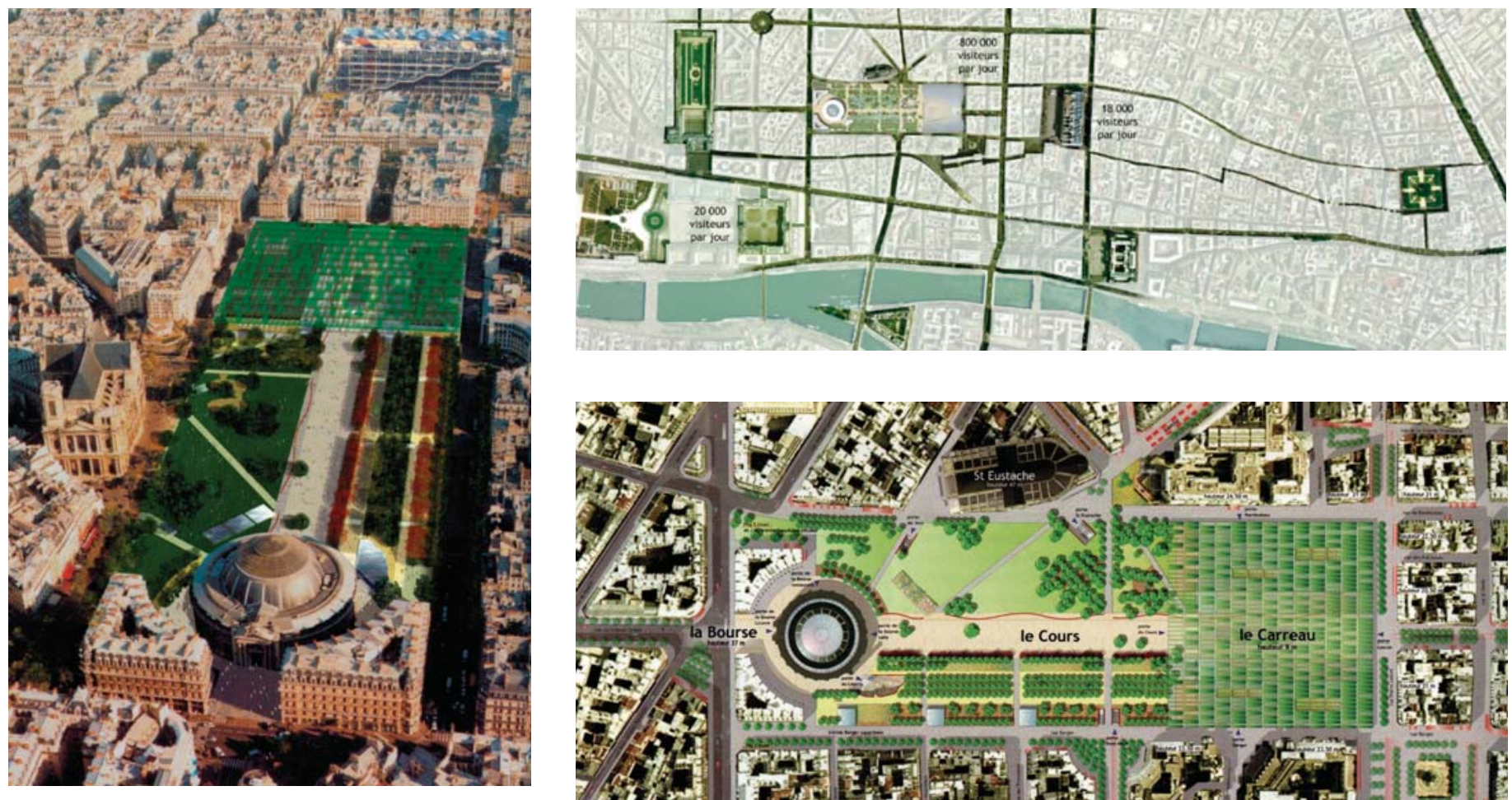

Figura 10. Proposta final de equipe de David Mangin (SEURA) - Galfetti

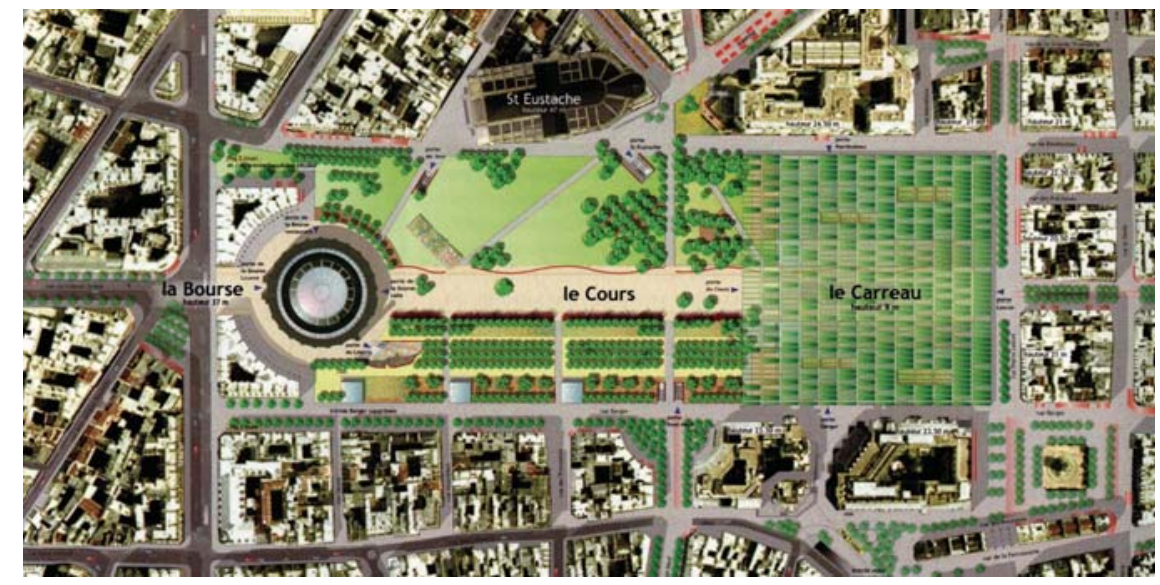
Fonte: SEURA, 2013.

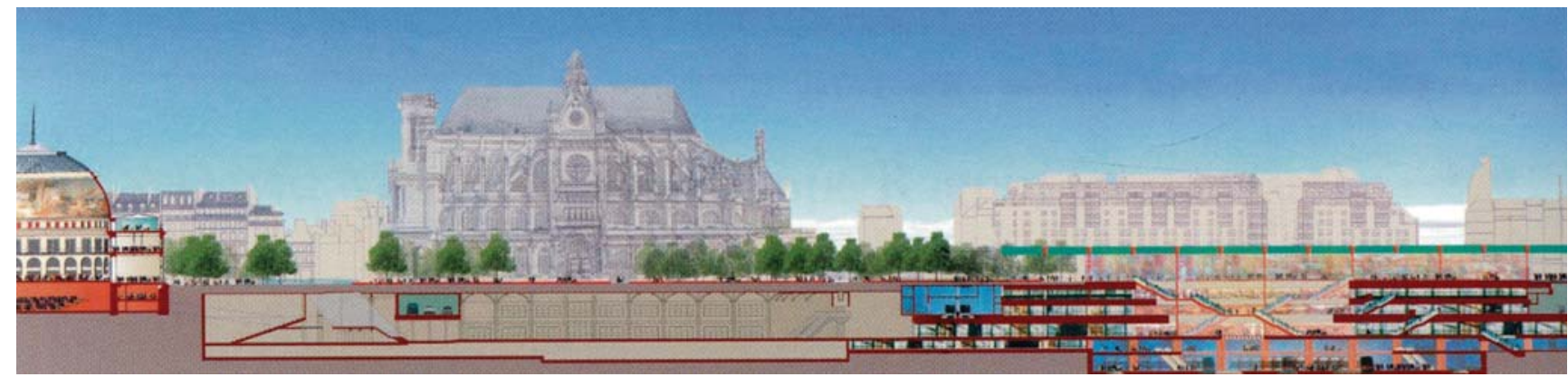



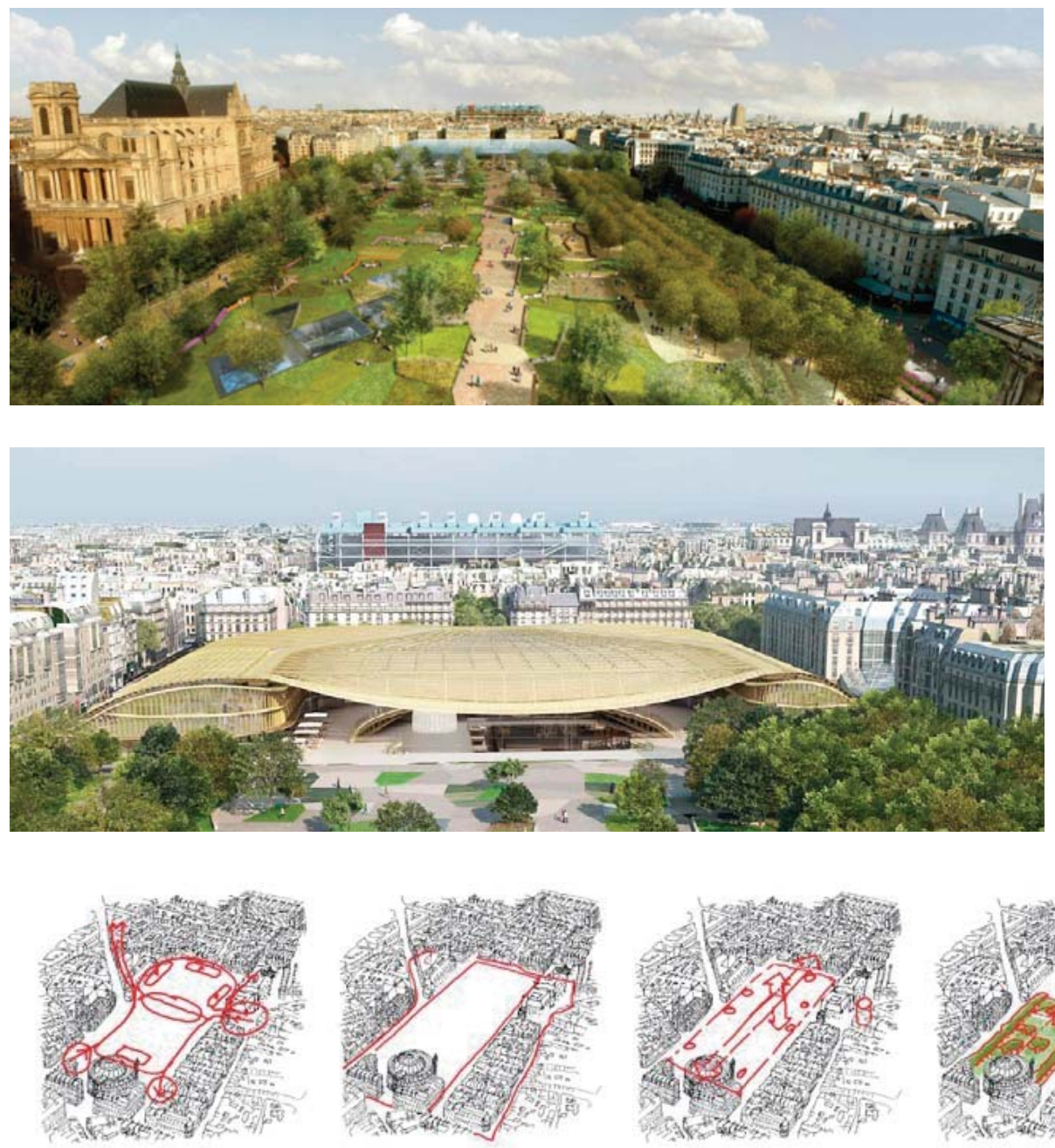

l'infrastructure routière

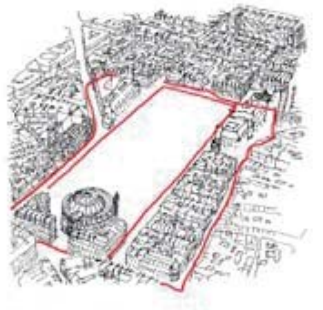

l'espace public

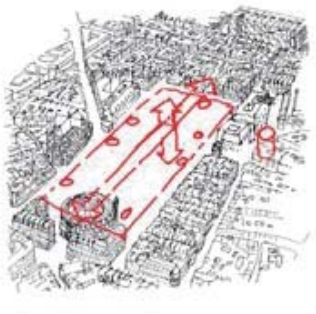

les tiaisons verticales

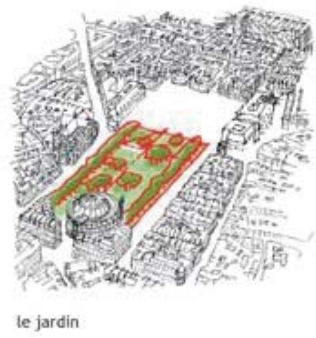

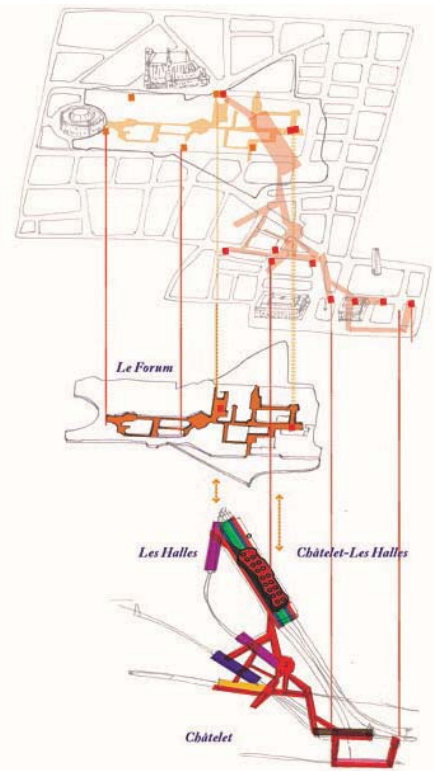

M1 M4 M7 M 11 M14 RERA AERB RERD

Figura 11. Proposta vencedora e modificada da equipe de David Mangin (SEURA) e Patrick Berger.

Fonte: SEURA, 2015. 


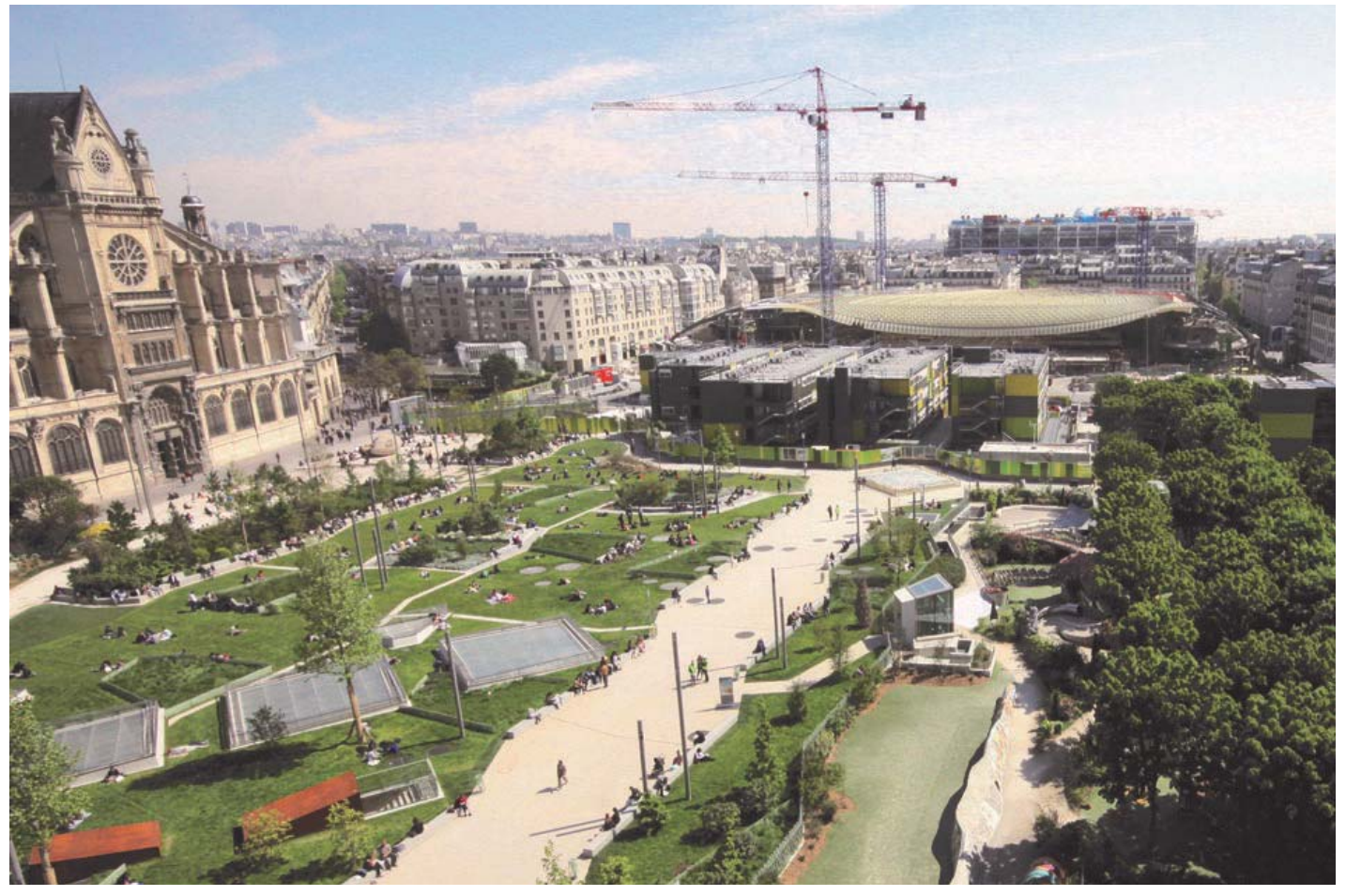

Figura 12 Imagens atuais do projeto vencedor.

Fonte: SEURA, 2015
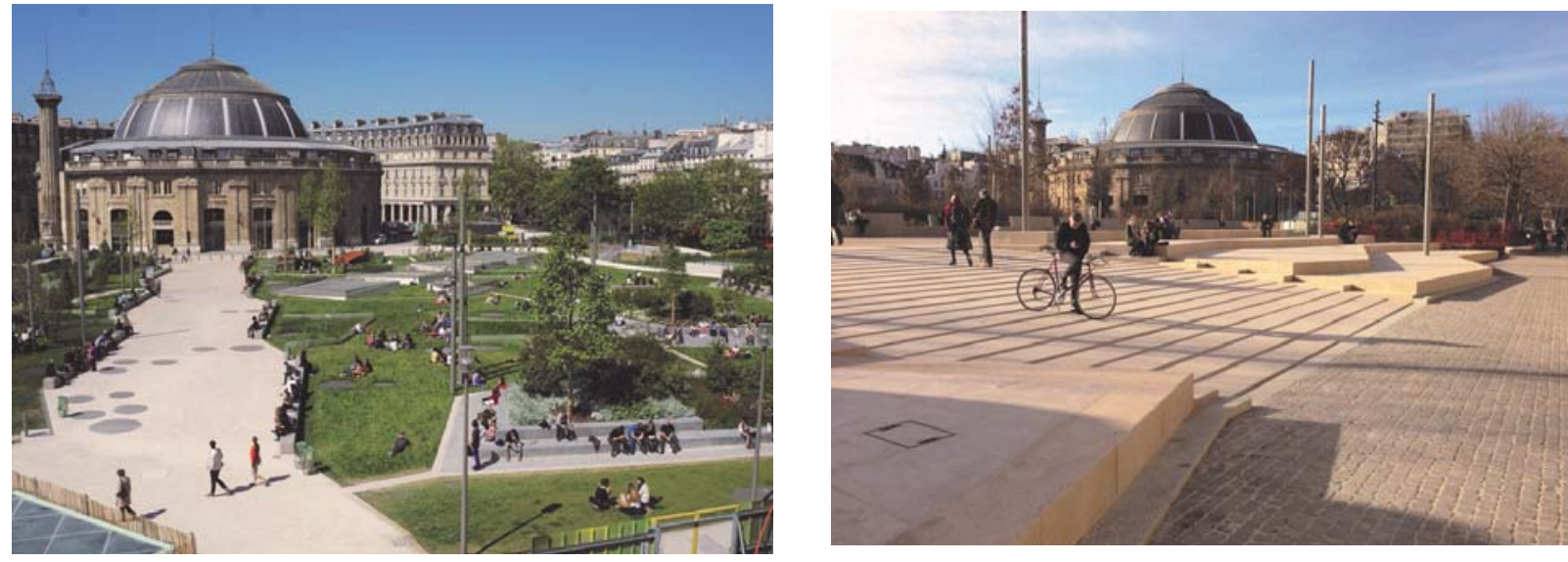


\section{Síntese}

Em relação às propostas do último concurso de 2004, é possível perceber que todas as quatro equipes propuseram melhoramentos nas interfaces entre as áreas subterrâneas e o nível da rua, o que mostra um diagnóstico comum da necessidade e capacidade de transformar o fluxo de pessoas e o futuro comercial do shopping, por meio da exposição das áreas anteriormente ocultadas nos níveis inferiores. As propostas francesas de Mangin e Nouvel tiveram um caráter mais urbanístico em sua linguagem de intervenção, sendo a 'arquitetura' focada no edifício comercial - o antigo Fórum Les Halles - que conecta a estação RER, localizada diametralmente no eixo oposto da cúpula da Bolsa de Comércios, liberando todo o restante para passeios e áreas ajardinadas.

Por outro lado, as propostas dos outros dois arquitetos holandeses, Koohlaas e Maas, idealizaram uma disposição de objetos arquitetônicos de diversos tamanhos e cores de forma dispersa, ocupando o território disponível. Essas diferenças de partido também foram abordadas pela crítica de arquitetura francesa, Françoise Fromonot, em sua análise do concurso de 2004 (FROMONOT, 2005), na qual ela repreende a proposta vencedora de Mangin por quase anular a sua intenção, propondo uma neutralidade 'monótona' e agradando ao público com uma resposta pouco audaciosa e retrógrada. A reflexão de Bretch nunca coube melhor: “A exaltação da natureza é gerada nas 
cidades que são inabitáveis" (BRETCH apud SOWA, 2004), de forma que o projeto de Mangin, de um grande jardim, oferece à sociedade o que esta idealiza para áreas urbanas densas: o de um parque, um respiro, um vazio, que possa anular os malefícios humanos e a precariedade dos centros urbanos. A intervenção no coração do inconsciente coletivo mostra a abrangência das palavras do prefeito Delanoë na abertura do concurso:

A intervenção de Les Halles se refere não somente aos que residem no local, mas a todos os parisienses, a toda a população da Ile-deFrance e também aos turistas, porque este é o coração da cidade. (SOWA, 2004, tradução nossa)

Segundo Sowa (ibidem), a retórica e a metáfora emocional do coração escondem o fato de que o verdadeiro problema em Les Halles diz respeito à otimização do fluxo de pessoas, veículos e mercadorias. Nenhum 'retoque', segundo ele, mudará a lógica da área, que foi projetada e é gerida de acordo com três imperativos: 'Venha, consuma e siga em frente!'.

A visão de Dupont (2004) é a de que qualquer intervenção nesse lugar deve levar em consideração o fato de que Les Halles se situa no ponto de cruzamento de duas lógicas territoriais: uma é produto da lógica dos anéis concêntricos a partir do qual se fez o crescimento da cidade de Paris, em torno do antigo mercado central; e a outra lógica é a das redes 
que produzem as transformações espaço-temporais no coração de uma área urbana que se adapta ao fluxo de milhões de habitantes. Dessa forma, distinguem-se duas entidades espaciais associadas às necessidades e funções específicas: o subsolo, inteiramente produto da infraestrutura, de trocas entre meios de transporte e trocas comerciais; e o tecido urbano, acima do solo, o qual deve ser reparado e reabilitado.

Certamente, o que governa o destino desse local é o nó de infraestrutura localizado no 'buraco' de Les Halles, que, de certa forma, 'suga' a energia das superfícies e as esvazia, quase como um 'ralo' (ver Figura 5). Por causa da natureza desse polo infraestrutural, novos projetos no local não trariam apenas benefícios e problemas para seus residentes, e sim seriam redistribuídos no espaço da metrópole. Portanto, políticas urbanas que apenas queiram tratar dos problemas imediatos, tanto no tempo quanto no espaço, devem encontrar em pouco espaço de tempo uma nova ferida exposta, a qual deve se regenerar.

De toda forma, o processo de destruição criativa e reconstrução não deixaram de encontrar em Les Halles o espaço e o material necessário para se renovar e se reinventar. Como pôde ser visto, Les Halles é um dos mais interessantes laboratórios de ideias de regeneração urbana conhecido, um espaço que, por suas transformações físicas, materializa a dialética entre as visões ideais e utópicas em problemas de natureza prática de cada tempo. O estudo da transformação urbana desse local 
representa o desafio que os espaços urbanos enfrentam ao adaptarem-se a seus tempos.

O projeto para o novo Les Halles amplia em $50 \%$ os espaços de conexão para o complexo da estação Châtelet-Le Halles, além de criar três novos acessos ao mesmo. O vasto programa, que inclui uma grande área comercial de varejo, um conservatório musical, um centro de hip-hop e um centro cultural para as pessoas com deficiência visual e auditiva, aliados a múltipla acessibilidade de transporte público, enfatizam ainda mais a importância do local em relação a região parisiense. Concluindo, os objetivos de reorganização espacial e funcional e de redução do congestionamento, aliados a esse vasto programa de funções e atividades proposto na área sublinham o papel de polo de acesso e integração de redes infraestruturais no contexto regional da grande Paris. 


\subsubsection{0 south bank londrino}

A escolha do projeto Bankside Urban Forest (Londres, Reino Unido) se deu, inicialmente, pela importante localização; próxima de um eixo infraestrutural ${ }^{25}$ importante da cidade, a estação London Bridge, a leste, a proximidade da estação de metrô de Southwark, a oeste ${ }^{26}$, e o Rio Tâmisa, a norte. Além disso, a forma inovadora de conceber um projeto de regeneração urbana tal como este foi um fator indiscutível para desenvolver um estudo mais detalhado da área. O projeto fundamenta-se na criação de uma agenda de pequenas intervenções estratégicas que pudessem envolver pequenas e grandes corporações locais, assim como residentes de todas as idades e grupos da região. Assim, não se trata de um masterplan rígido que estabelece parâmetros de uso e ocupação do solo tal como usualmente. Demonstra-se por esse estudo de caso que, projetos de intervenção, mesmo que de pequena escala, podem causar impactos importantes não apenas locais, mas também que gerem efeitos no âmbito regional, desde que estejam conectados por uma agenda mais

\footnotetext{
${ }^{25}$ A estação London Bridge conecta duas linhas importantes de metrô, a Northen Line e a Jubilee Line, assim como linhas de trem. Também é uma estação terminal de ônibus que distribuem passageiros para inúmeras regiões da cidade.

${ }^{26}$ Além do grande polo de transportes da Estação Waterloo.
} 
ampla que os circunscrevam numa rede infraestrutural de capacidade metropolitana.

\section{0 projeto}

O Bankside Urban Forest (Londres, Reino Unido) é um projeto de iniciativa da comunidade local que buscou preservar o caráter da área, ao mesmo tempo em que respeita a chegada de novas instituições como resultado da valorização imobiliária do entorno, assim como trazer melhorias para os moradores e visitantes. Em 2006, uma série de estudos foi realizada na região para tentar capturar a identidade desse perímetro, coordenada pelos arquitetos da Witherford Watson Mann. Estes desenvolveram a ideia de uma floresta urbana para criar uma super estrutura que pudesse alinhar os diferentes projetos vislumbrados em diversos pontos da região, mantendo, assim, uma linguagem única, mesmo em se tratando de áreas e programas distintos. Essa iniciativa para compreender e traçar a identidade do local foi realizada por meio de uma série de consultas públicas para identificar as áreas de maior interesse dos moradores, e, ao mesmo tempo, de oportunidades para captar investimentos.

A intenção de alinhar diversos projetos numa iniciativa única visou fazer o melhor uso de uma ferramenta de planejamento chamada 
Section 106 - Planning Gain, que tem o intuito de facilitar investimentos cruzados e criar uma melhor integração entre os projetos, fazendo com que os resultados e os benefícios possam ser infiltrados para os agentes da comunidade.

O projeto localiza-se na margem sul do Rio Tâmisa, em Londres, sendo delimitado ao norte pelo rio, ao sul pelo bairro de Elephant and Castle, e ao leste pelas ruas Blackfriars e Borough High Street (ver Figura 13). As franjas que delimitam a área de intervenção são de uma intensa atividade, tanto comercial quanto de turismo, que contrastam com o interior, que apresenta menor conectividade com o entorno e possui baixa atividade e pouca visitação (Figura 14). 


\section{Better Bankside at a glance}

Better Bankside is a non-profit company run by and for its members. It provides services that improve

the local area for commercial activity and is funded by an annual contribution from all eligible businesses in the area.
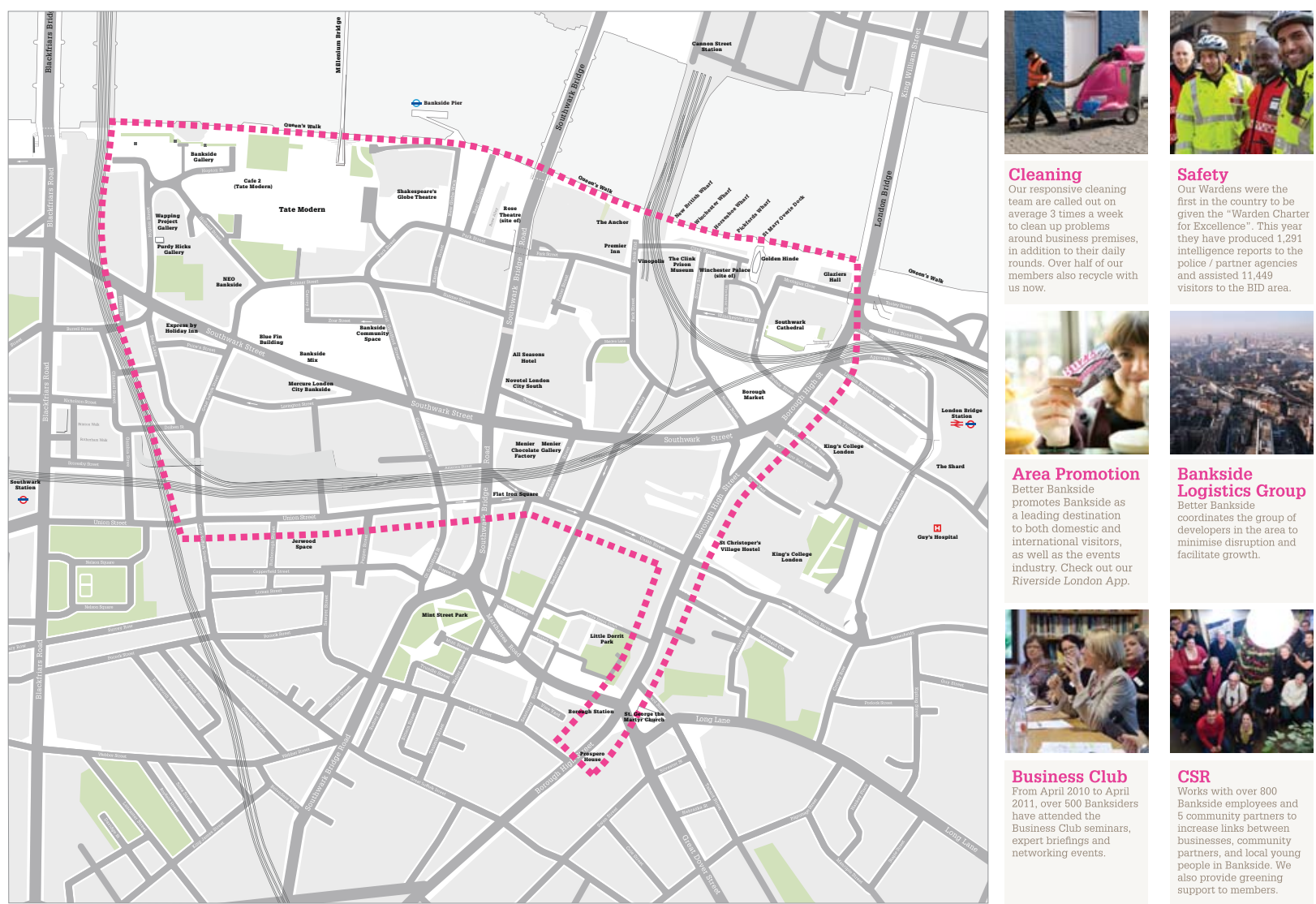

promotes Bankside
a leading destination
to both domestic and

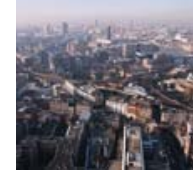

Bankside

Logistics Group

coordinates the group

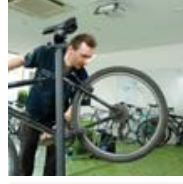

Travel Planning international visitors,
as well as the events
ndustry. Check out our
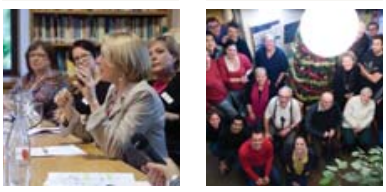

Business Club From April 2010 to April
2011 , over 500 Banksiders
have attended the

CSR

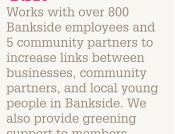

last year and trained over We also run the secure
cycle park on Hopton Business Club seminars
expert brieflngs and

See our website or speak to one of the team to hear more about our services, or how to get involved. Visit www.betterbankside.co.uk or call 02079283998

Figura 13 Folder da iniciativa Better Bankside e a área de atuação.

Fonte: Better Bankside, 2015. 


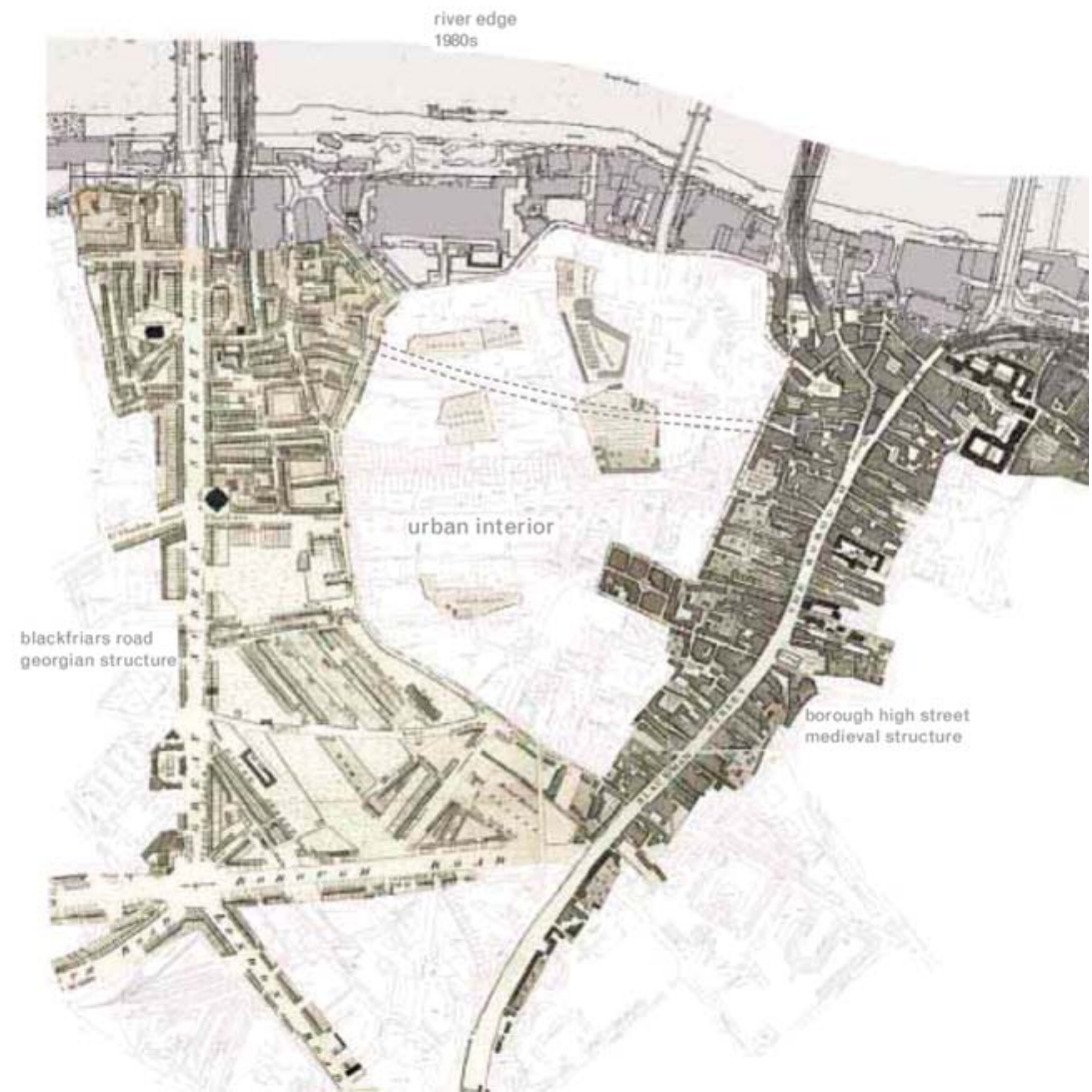

Figura 14. llustração mostrando as desconexões entre as franjas ativas e o interior isolado.

Fonte: Southwark Council, 2015.

Copyright Witherford Watson Mann Architects based upon Ordinance Survey mapping with the permission of the controller of her Majesty's Stationary Office. Unauthorised reproduction infringes Crown copyright 010010252 and may lead to prosecution or civil proceedings. 
Percebido como um projeto razoavelmente tímido em suas proporções, essa iniciativa conseguiu identificar e englobar diversos projetos de pequena escala que pudessem gerar um grande impacto na qualidade de vida da comunidade local e dos visitantes da área. Exemplos dessas iniciativas incluíram: controle de tráfego; arte pública; mobiliário urbano; plantio de árvores; faixas de pedestres; ciclovias mais seguras; e a identificação de alguns equipamentos que pudessem ser transformados em algumas âncoras de interesse especial, criando, assim, uma identidade específica para o local. (LITTLEFIELD, 2012)

Com custos na faixa de $£ 6,4$ milhões de libras esterlinas (o que é considerado baixo para projetos de regeneração urbana na Inglaterra), as principais fontes de financiamento vieram de uma ampla variedade de atores, incluindo a Agência de Desenvolvimento de Londres, o Better Bankside e outras contribuições do London Borough of Southwark e o Transport for London.

A concepção do projeto foi baseada em três ideias centrais (HALL, 2010):

- trabalhar com a experiência tanto de grandes quanto de pequenas organizações na área, que variam de grupos comunitários a grandes empresas;

- enfatizar o papel das pequenas intervenções, muitas das quais suportam os espaços existentes;

- estabelecer um processo gradual de entregas e revisões de projeto, em que as lições aprendidas nos primeiros projetos possibilitam o refinamento dos próximos. 
O projeto foi considerado bastante viável, por ser estruturado por diversos pequenos orçamentos que poderiam ser facilmente acessados por procedimentos pouco burocráticos; além da ordem desses diversos projetos estar sempre aberta a mudanças de prioridades.

Como já descrito, o projeto enfatiza o papel da pequena escala e das propostas graduais e é sustentado por três estratégias principais (HALL, 2010):

- a concepção de pequenos projetos que catalisam a formação de novos projetos por meio da participação ativa dos usuários, muitas vezes associada aos espaços públicos existentes. Esses pequenos projetos são conceituados como 'sementes' que podem multiplicar as redes de espaços, pessoas e atividades. As 'sementes' do projeto são tanto espaciais quanto organizacionais, tornando a inclusão social possível por meio do desenho do lugar numa variedade de formas. Exemplos dessas intervenções são ilustrados na Figura 15. As iniciativas são encabeçadas por diferentes organizações, sob a égide do Better Bankside;

- a produção de um quadro abrangente de projeto para direcionar os investimentos ao longo do tempo. Os projetos precisam estabelecer uma reputação que desafie as convenções de como corporate landscapes são entregues, assim como o envolvimento das pequenas e grandes organizações na 'ativação' e na transformação de seus respectivos espaços. Os mecanismos espaciais e sociais para tornar os padrões de projetos em exemplos não foram totalmente estabelecidos, sendo desenvolvidos junto com a entrega dos primeiros projetos; 
- o papel dos pontos de intercâmbio (identificados no estudo que produziu a Figura 16), incluindo espaços de reuniões locais ou mais amplos. As intervenções na esfera pública também são usadas para influenciar o que acontece nas bordas associadas às áreas privadas de projeto. Esses locais de intercâmbio têm o objetivo de equilibrar a oferta de espaços públicos ativos com altos fluxos do público geral, incluindo os turistas, com a valorização de espaços, muitas vezes, reprimidos, reivindicados por pequenos grupos locais. Os projetos iriam melhorar o movimento de pedestres por meio da desaceleração do tráfego. Os locais de projeto, muitas vezes situados em cruzamentos principais, também deveriam melhorar a identificação dos pedestres para com o seu posicionamento na região. No entanto, o projeto também reconheceu a necessidade de criar mais espaços escondidos, muitas vezes localizados numa camada interna, em torno de espaços públicos importantes.

O projeto urbanístico Bankside Urban Forest foi concebido e é hoje administrado por três entidades: a Prefeitura de Southwark (ao sul de Londres), o Design for London e o Better Bankside. Esse último é constituído por uma empresa sem fins lucrativos e sem capital aberto, definida como um Business Improvement District (BID), representada por uma área geográfica na qual um grupo de empresas locais vota por investir num conjunto de objetivos comuns que visa promover benfeitorias ao local e à comunidade; por esses instrumentos, essas empresas oferecem os serviços identificados como prioritários para o melhoramento do distrito, por exemplo, segurança, limpeza urbana, reciclagem, logística, planejamento de mobilidade, entre outros. 


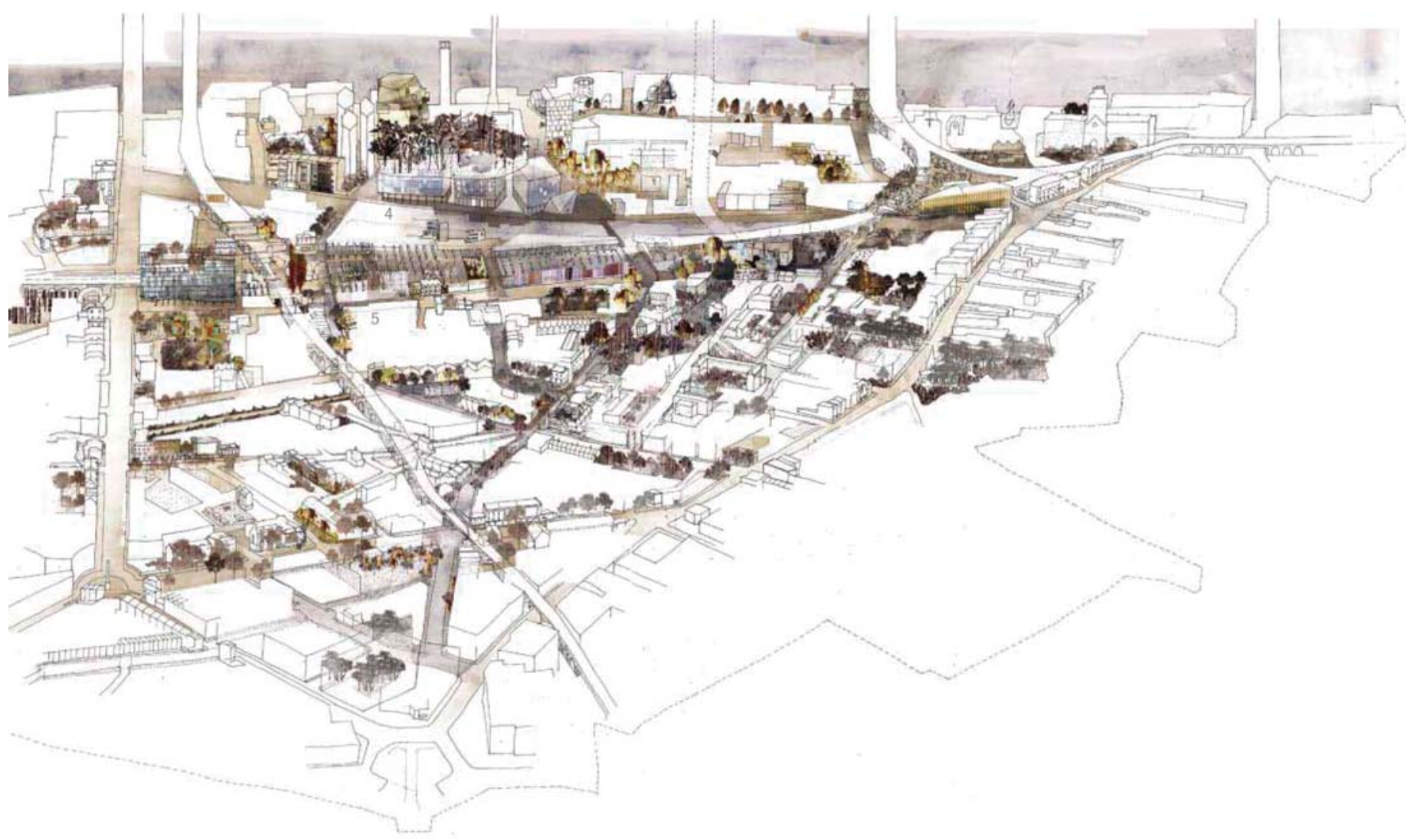

Figura 15. Áreas de intervenção propostas pelos arquitetos Witherford Watson Mann Architects.

Fonte: Southwark Council, 2015. Ilustração: Witherford Watson Mann Architects 


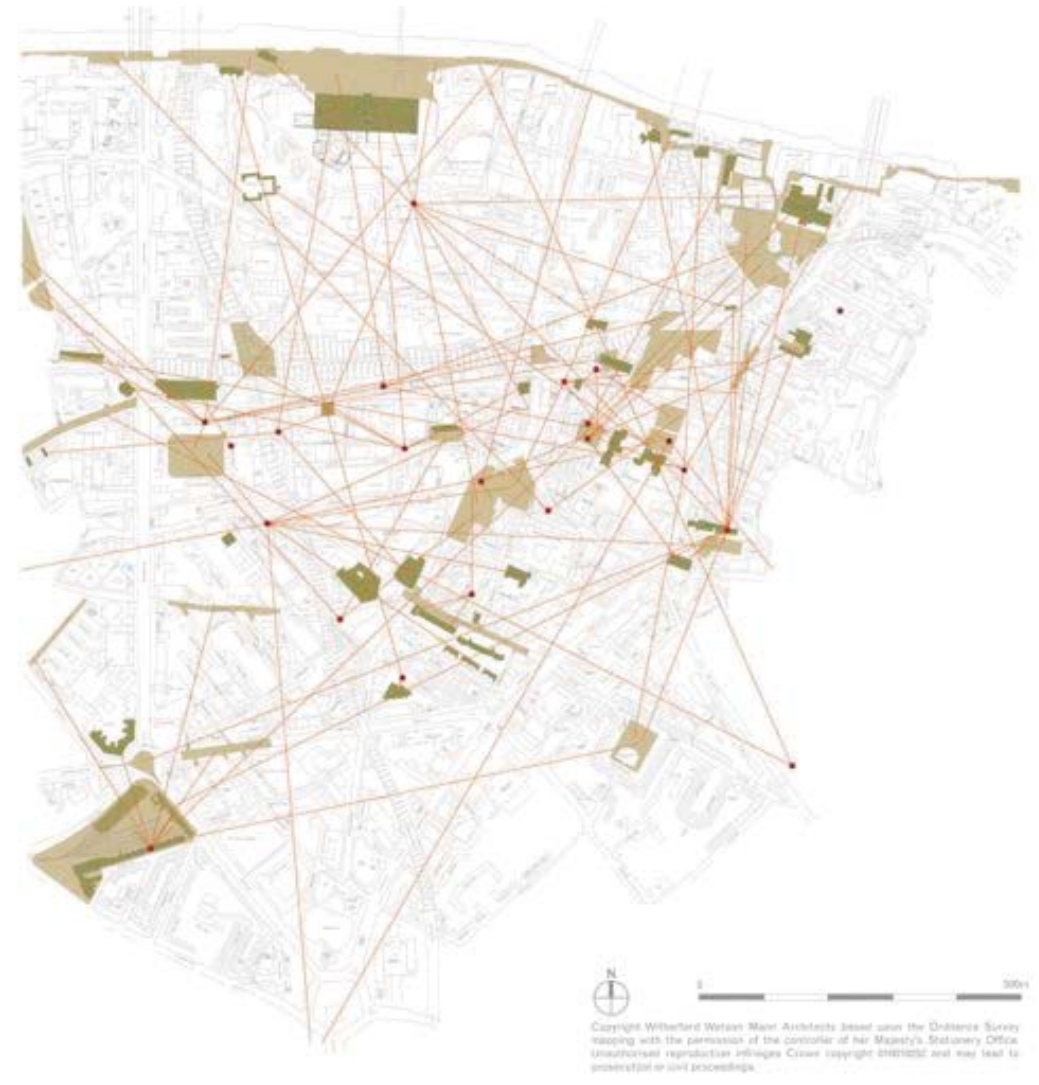

Figura 16. Redes locais: relações espaciais entre os residentes e os locais

\section{que frequentam.}

Fonte: Southwark Council, 2015. Ilustração: Witherford Watson Mann ArchitectsCopyright Witherford

Watson Mann Architects based upon Ordinance Survey mapping with the permission of the controller of her

Majesty's Stationary Office. Unauthorised reproduction infringes Crown copyright 010010252 and may

lead to prosecution or civil-proceedings. 
É importante ressaltar a importância do papel dos BIDs para a articulação de empresas locais na criação de um senso de lugar, sendo essas iniciativas incluídas e encorajadas tanto na Economic Development Strategy - EDS (Estratégia de Desenvolvimento Econômico) quanto no London Plan (Plano para Londres), ambos da Prefeitura de Londres. Há regras para o estabelecimento desse instrumento local, no qual as empresas que queiram ter poder de voto no projeto devem estar inseridas no perímetro da iniciativa, devem contribuir com uma base anual mínima de contribuições fiscais (£ 17.500,00) e não serem de serviços como estacionamento de veículos, empresas de publicidade, nem estações de comunicação (por exemplo, antenas de celular).

Dentre os benefícios 'empresariais' dos BIDS estão incluídos:

- o reinvestimento das somas arrecadadas obrigatoriamente na mesma área;

- a direção e as decisões dos objetivos são estabelecidos pela própria sociedade comercial local;

- redução de custos, por exemplo, devido à contratação de serviços 'em conjunto';

- mediação com 'Subprefeituras' e outros órgãos públicos, como transporte e polícia;

- maior atração de consumidores e retenção de pessoal;

- promoção dos serviços locais;

- oportunidades de networking entre empresas vizinhas.

Assim, conjuntamente às entidades envolvidas no projeto Bankside Urban Forest, também incluísse uma variedade de parceiros, 
como a Cross River Partnership (parceria público-privada originalmente fundada para realizar projetos de infraestrutura ligados às transposições do Rio Tâmisa), a Tate Modern (museu de arte moderna), a Land Securities (incorporadora imobiliária), a Architecture Foundation (fundação independente de arquitetura sem fundos lucrativos) e a Transport for London (órgão governamental responsável pelo sistema de transportes da Grande Londres). Por meio da participação desses parceiros de vulto, foi possível perceber o nível de articulação política e administrativa estabelecido devido a essa iniciativa para fazer fluir os incentivos financeiros, de aprovação de projetos, de suporte e integração da comunidade, mobilidade, entre outros.

Pode-se dizer assim que o Bankside Urban Forest não se trata de um projeto, mas de um programa mais complexo que envolve diversos projetos tópicos. Dentre estes, estariam a criação de um parque infantil no entorno da Tate Modern e de tratamento paisagístico que pudesse criar uma identidade que permeasse toda a área do programa, ao mesmo tempo em que produz uma rede de pontos nodais de interesse e alcance do pedestre, possibilitando, assim, maior interação e maior nível de atividades transversalmente ao território.

Segundo Worpole (2015), a noção de cidade como uma floresta baseia-se no passado, na base da criação de um novo espaço público que possa ser reino da liberdade individual (Stadtluft macht frei - city air makes you free), e também de novos imperativos ecológicos, para tornar 
as cidades econômica, social e ambientalmente mais sustentáveis. Segundo o autor, mesmo com a extrema inovação tecnológica atual, ainda há um limiar simbólico entre 'civilização' e 'floresta'. Mitologicamente, a primeira era um lugar de alquimia e transformação: as mulheres tornavam-se homens e os homens, mulheres, as crianças se transformavam em feras. No mundo moderno, no entanto, a cidade é que providencia o papel da floresta, como um espaço no qual as pessoas podem aparecer e desaparecer à vontade, escolher seus relacionamentos, seu estilo de vida, sua crença.

Assim, o autor defende o caráter do projeto Bankside Urban Forest, que vai contra o excesso de definições e prescrições que deixam de fora do perímetro do projeto os reais conflitos da área, e organizam a área regenerada por padrões de uso e consumo das pessoas. O modelo prescritivo dos projetos de regeneração urbana vai contra o senso 'errático' e aberto que pode acontecer efemeramente no espaço público. Assim, o projeto procura resistir ao excesso de imposições no campo territorial. Ao adotar uma abordagem mais ecológica às estratégias do espaço urbano, mais oportunidades de apoio a economias locais e possível conservação de padrões e conectividades históricas podem acontecer: 'A ideia da floresta não é baseada em economias centroperiferia e hierarquias espaciais, mas em redes equitativas de subsistência e de intercâmbio. Ela incorpora muitas associações históricas com a liberdade e a justiça social.' (WORPOLE, 2015, tradução nossa) 
O 'espaço florestal' adquiriu nos últimos tempos um conjunto de significados com associações a um espaço aberto e permeável, que oferece uma multiplicidade de caminhos, no qual um terreno pode ser acessado por qualquer ponto de suas bordas, onde o espaço é dinamicamente reconfigurado ao longo do movimento de seus transeuntes. Segundo o arquiteto Alvar Aalto (apud WORPOLE, 2015, tradução nossa), "Uma pessoa deve ser capaz de caminhar por uma floresta a caminho de casa para o trabalho".

Fazendo uma analogia da simbologia da floresta à infraestrutura, o primeiro objeto desta tese ${ }^{27}$, a multiplicidade de caminhos possíveis para o suprimento dos serviços infraestruturais, seria de igual importância. Nesse sentido, poderiam se abrir caminhos para uma gestão da oferta e demanda de recursos que pudessem incorporar princípios mais sustentáveis. Segundo o relatório London Heat Network Manual (MAYOR OF LONDON, 2014), a energia térmica (calor) ainda é a razão principal para a produção e o uso de energia na nossa sociedade, ultrapassando a quantidade de energia utilizada para transporte ou eletricidade. A geração de calor é produzida pela queima de combustíveis fósseis e é responsável por cerca de 1/3 das emissões de dióxido de carbono no Reino Unido. Segundo o relatório, para que o país faça a sua 
parte no combate às mudanças climáticas, os edifícios devem deixar de ser responsáveis pela emissão de dióxido de carbono até 2050, o que força uma série de iniciativas para tornar a rede de energia mais eficiente.

Um dos caminhos mais estudados no Reino Unido, e com várias instalações já em uso na cidade de Londres, visa transformar uma parte do suprimento de energia na geração por fontes descentralizadas por meio da conformação de distritos de energia. A meta da Prefeitura de Londres é de produzir $25 \%$ do suprimento de energia por meio de fontes descentralizadas até o ano de 2025, diminuindo em mais de $35 \%$ as emissões de gases efeito estufa até esse ano (ibidem).

A energia descentralizada pode ser produzida em três diferentes escalas:

- pequena escala: quando a energia é gerada e distribuída por e para apenas um empreendimento (podendo este ser composto por apenas um ou por uma série de edifícios) que sirva aproximadamente até três mil consumidores domésticos. $\mathrm{O}$ sistema pode ou não ser de propriedade e operação dos usuários de energia. Normalmente, projetos dessa escala configuram-se em pequenas centrais de energia térmica que servem um empreendimento comunitário. Esse tipo de sistema aplica-se, por exemplo, a conjuntos habitacionais;

- média escala: quando a energia é suprida para mais de um empreendimento e mais de um lote, configurando necessariamente numa rede que serve uma gama ampliada de usuários, por volta de vinte mil, podendo incluir setores residenciais, edifícios públicos e consumidores comerciais. 
Normalmente, o suprimento desses serviços são realizados e operados por meio de uma empresa contratada. Essa escala de projeto será mais aprofundada a seguir, por meio do estudo realizado para a área de projeto do Bankside Urban Forest;

- grande escala: esses projetos envolvem redes com vários quilômetros de extensão, podendo suprir mais de cem mil usuários por meio da conexão em série de várias estações de energia e vários geradores de calor. Esses projetos envolvem um alto custo e, geralmente, são desdobrados em várias operadoras que se responsabilizam por partes do sistema. Um exemplo de extrema importância nessa escala é o London Thames Gateway Heat Network, que será brevemente apresentado a seguir.

Enquanto a meta do governo para a implementação desses esquemas está prioritariamente focada na redução de emissões, proprietários, empreendedores e incorporadores são motivados pelo aumento da eficiência do uso de energia, menores custos, redução de custos operacionais e menor espaço de instalação de sistemas nos edifícios. O foco no atendimento à redução das emissões de $\mathrm{CO}_{2}$, por parte dos empreendedores, visa atender a política de planejamento energético da Prefeitura de Londres.

Um cenário atual que identifica as potencialidades de confluência entre os diversos empreendimentos da cidade de Londres, construídos ou em processo de aprovação, foi produzido pelo governo britânico e pode ser visualizado em GIS por meio do London Heat Map (MAYOR OF LONDON, 2015). Essa excelente iniciativa demonstra o 
nível complexo da pesquisa, de natureza não só acadêmica, mas também muito aplicada, no sentido não só de identificar aquelas experiências já instaladas, mas no de indicar futuras áreas de confluência para o desenvolvimento de redes descentralizadas. Por meio do estudo dessa iniciativa, foi possível identificar que a área de projeto do Bankside Urban Forest está inserida numa área de extremo potencial quanto às possibilidades de geração de energia descentralizada, como identificados nas Figura 17 e Figura 18. 

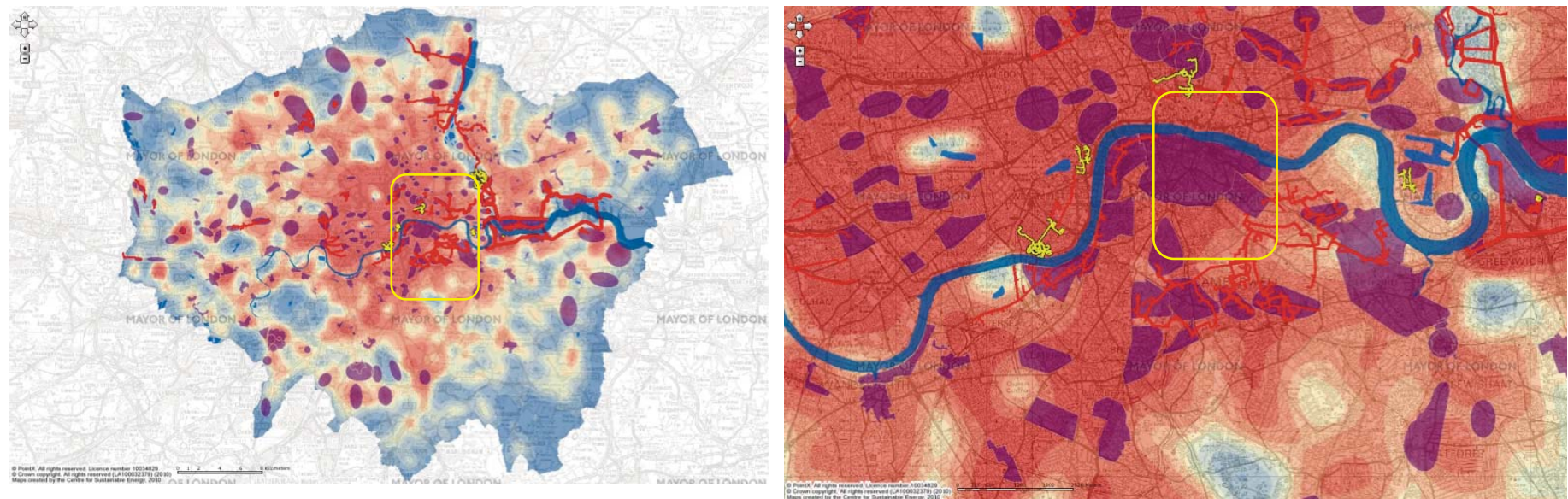

Figura 17. Mapa que indica as áreas de oportunidade para a geração de energia descentralizada. À esquerda, os limites da cidade de Londres. À direita, ampliação da área do south bank, das prefeituras de Lambeth e Southwark, ao sul do Rio Tâmisa. As linhas amarelas identificam as redes já instaladas, as vermelhas as redes potenciais, e os perímetros em roxo as áreas de oportunidade.

Fonte: Mayor of London, 2015.
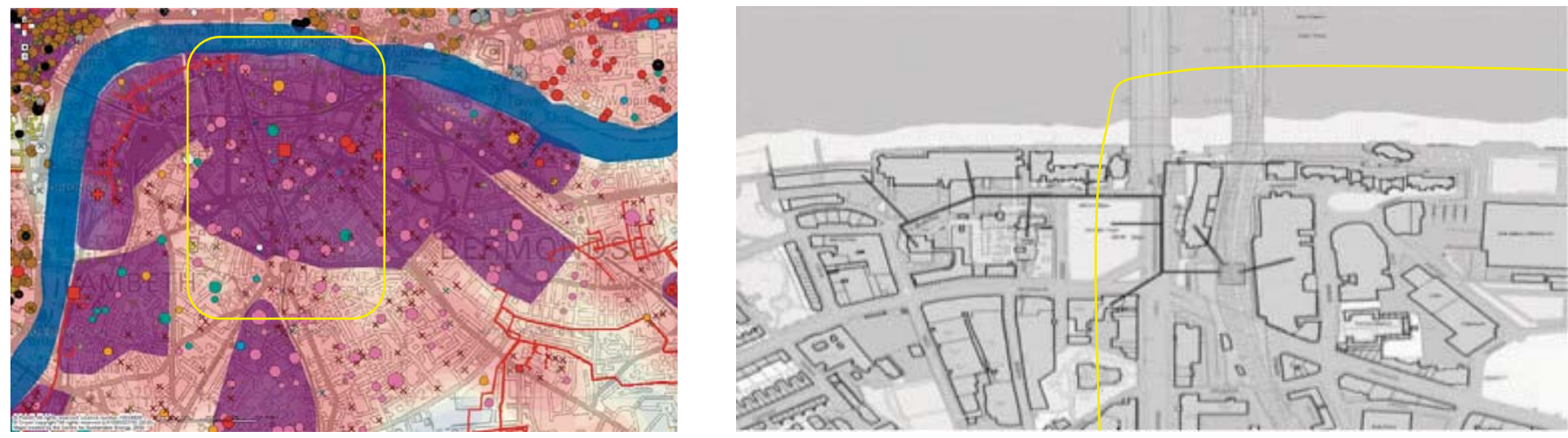

Figura 18. Mapas que identificam as oportunidades de áreas para a geração de energia distrital e linhas de conexão entre empreendimentos. 0 s círculos de diferentes proporções (maiores) identificam os empreendimentos com maior potencial de consumo e, por conseguinte, a geração de energia descentralizada.

Fonte: Mayor of London, 2015 
Essas oportunidades são não apenas encorajadas pelo governo, mas também impostas às prefeituras de Londres, por meio do London Plan (instrumento da mesma natureza do Plano Diretor de São Paulo). Esse último impõe às prefeituras ao menos a incorporação de políticas e propostas locais quanto à criação de oportunidades para o incentivo de geração de energia descentralizada, particularmente com foco nas redes de energia térmica.

Possibilidades de produção combinada de calor e eletricidade, conhecida como a cogeração (do inglês Combined Heat and Power CHP), também foram analisadas em 2009 por meio da iniciativa conjunta liderada pelo grupo South Bank Employers'Group (SBEG), a pela London South Bank University (LSBU) e a Agência de Desenvolvimento de Londres, London Development Agency. Nesta pesquisa, 120 edifícios foram identificados como potenciais para o uso da cogeração. As conclusões dessa pesquisa confirmam a forte tendência de aplicação real dessas inovações aos novos empreendimentos, não necessariamente de forma isolada, mas por meio da ligação desses em, inicialmente, agrupamentos (distritos), e, numa segunda etapa estratégica, da ligação em rede desses distritos.

Nessa última análise, é importante ressaltar o projeto de grande escala citado anteriormente, o London Thames Gateway Heat Network, ilustrado na Figura 19. Esse projeto enfatiza o caráter quase monumental de implementação de uma rede contingencial, autônoma e independente 
em relação àquela fornecida pelas concessionárias tradicionais, indicando uma nova configuração territorial da infraestrutura de energia. Nesse novo modelo, colocam-se geração, transmissão e distribuição no mesmo local do consumo final, o que configura um enclave de serviços produzidos e controlados pelo empreendimento, e diferenciados em relação ao entorno. Esses enclaves, por sua vez, têm como destino favorecer-se de um suporte ainda maior, já que, desde o princípio, se estrutura num plano estratégico que prevê a conexão a outros enclaves diferenciados na cidade.

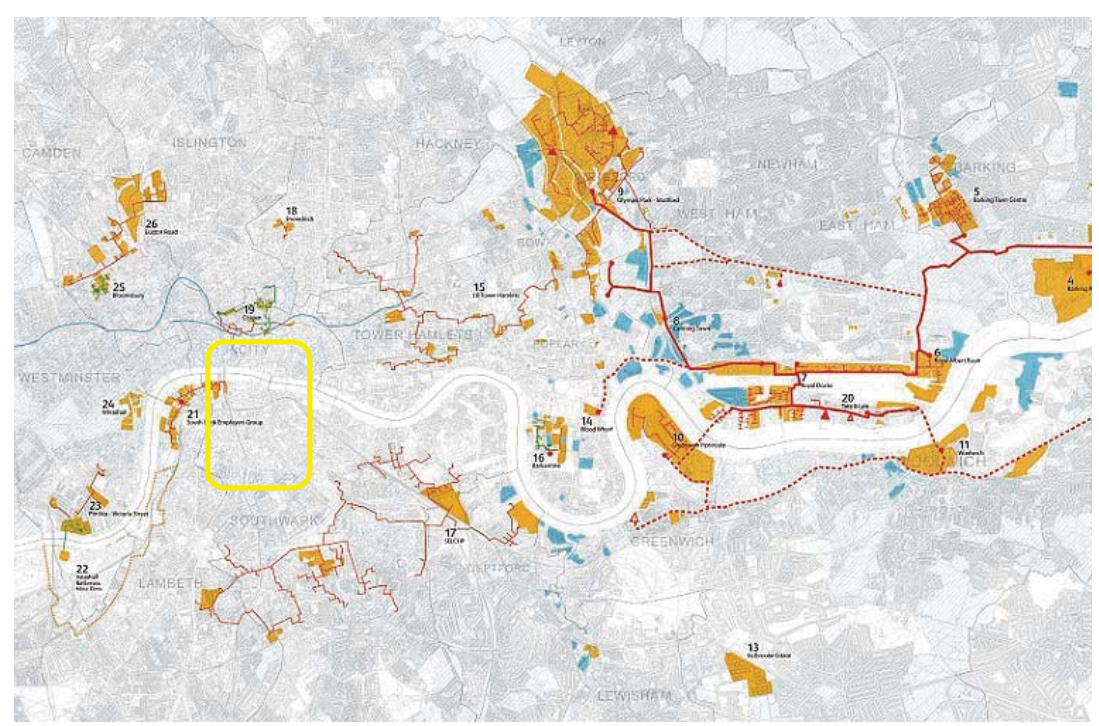

Figura 19. 0 London Thames Gateway Heat Network

Fonte: ARUP, 2015. 


\section{Síntese}

Desse modo, diferentemente do exemplo de projeto anterior Les Halles, a estratégia premiada do Bankside Urban Forest de desenvolvimento de uma floresta urbana contrasta com a primeira, a de um parque. O termo parque origina-se do latim parricus ou de parc, em francês, significando clausura, invólucro ou recinto. Os parques europeus originais eram propriedades reais para caça, estritamente policiados, enquanto as florestas eram consideradas como um lugar de liberdade, sem fronteiras.

Como analisado anteriormente, apesar das facilidades oferecidas devido a muito bem servida localização, promover soluções nessa região também apresentava desafios. Muitas eram as críticas aos projetos de desenvolvimento da área, que acusaram o mercado imobiliário de promover a destruição do espaço público em nome da 'regeneração', enquanto beneficiava apenas aqueles mais abastados, que podiam pagar para se localizar nos enclaves mais bem servidos de benefícios infraestruturais. Os que defendiam os valores exorbitantes do metro quadrado na área se ampararam nas dificuldades técnicas de construir num entremeio de túneis de metrô e trem. Devido a esse fator, as construções são mais onerosas, pois devem vencer grandes vãos estruturais, ao mesmo tempo em que não podem crescer excessivamente em altura para compensar seus custos com a produção de mais área 
construída, já que há limitações impostas pelo patrimônio histórico quanto às vistas protegidas do Palácio de Westminster e do Parlamento, entre outras. (WOODMAN, 2013)

Segundo Littlefield (2012, p.9, tradução nossa):

o desenvolvimento imobiliário não é a mesma coisa que regeneração. Também não é a mudança. [...] a regeneração no contexto do ambiente construído tipicamente incorpora mudanças e construções, em certa medida, mas esses termos não devem ser confundidos como sinônimos.

Há também de se ser cauteloso com as considerações que veem essas áreas 'regeneradas' das cidades como 'organismos vivos'. Segundo Mike Batty da UCL - University College London (apud LITTLEFIELD, 2012), as cidades podem ser consideradas como entidades vivas e seus processos complexos podem ser modelados e previstos com muita precisão e utilidade. No entanto, deve-se lembrar de que, para as cidades realmente poderem ser 'curadas' ou 'regeneradas', estas devem contar com os agentes propriamente ativos: as pessoas e os formuladores de políticas, que realmente podem provocar mudanças dentro do organismo vivo das cidades.

Independentemente dessas observações, fica impossível negar, que, do ponto de vista da análise infraestrutural, ou seja, da economia dos serviços que estruturam e nutrem os diversos tecidos da cidade, soluções 
estratégicas como as propostas neste caso (tanto por meio da agenda de projeto de regeneração quanto o da agenda de provisão de serviços descentralizados estudadas) ampliam as liberdades de desenvolvimento territorial e social, e, certamente, se mostram mais sustentáveis no tempo e no espaço.

O projeto do Bankside Urban Forest em comparação com o Les Halles apresenta diferenças importantes do ponto de vista do acesso e da integração das redes de infraestrutura. Primeiramente, as áreas apresentam contornos de natureza diferente; o Bankside não possue um perímetro definido (analogia à floresta), sendo que o Les Halles (analogia ao parque) é conformado por limites espaciais bastante claros. A questão da demarcação dos limites físicos dos projetos foi identificada nessa pesquisa como um fator que influencia o alcance das agendas de infraestrutura e regeneração urbana. Aferindo-se a analogia da simbologia da floresta, o que se deve esperar em relação ao suprimento de serviços provenientes das redes de infraestrutura urbana é uma multiplicidade de alternativas de forma a abrir caminhos para uma gestão da oferta e demanda de recursos que possam incorporar princípios mais sustentáveis. Nesse sentido, verifica-se um maior grau de autonomia no Bankside Urban Forest, por exemplo com as possibilidades de geração de energia distribuída, apenas possível no contexto de um entorno urbano amadurecido, que não apresenta carências fundamentais e que pode oferecer alternativas que suplantam o alcance das tecnologias tradicionais. 


\subsubsection{A Santa Ifigênia}

Tal como os estudos de caso anteriores, Les Halles e Bankside Urban Forest, a área de projeto Nova Luz localiza-se num espaço de intensa centralidade quanto ao acesso à rede de transporte coletivo (metrô, trem e ônibus), além de ser excepcionalmente servido por infraestrutura de serviços urbanos. Esse estudo tem o intuito de tornar evidente a complexidade dos processos que objetivam a regeneração urbana, e evidencia que projetos de intervenção herméticos em seu escopo, que não incorporem dentro de seus princípios os pontos críticos do local, tanto físicos quanto sociais, dificilmente conseguem gerar impactos positivos dentro de seu perímetro e no seu entorno.

A identificação de um perímetro específico de projeto e de uma agenda prescritiva de usos, nesse caso, se opõe à liberdade construída na agenda de intervenções menores do projeto londrino estudado anteriormente. Não somente isso, as dinâmicas financeiras provenientes de instrumentos urbanísticos promovidos pelas parcerias públicoprivadas nos últimos dois casos mostram rumos opostos em relação à longa vida das intervenções. No caso paulista, o projeto foi cancelado, e, no caso londrino, mesmo após crise financeira, houve uma estruturação mais sólida e independente que pôde manter as propostas de intervenção da área, tanto para os investidores quanto para os residentes. Isso não significa que, nos dois casos, o resultado disso não tenha provocado, em 
algum nível, um processo de gentrificação, porém isso é um assunto que vai além do escopo desta pesquisa e deve ser certamente aprofundado no futuro. A falta de identidade do público para com a intervenção do projeto de regeneração, desde sua concepção, incapacita as possibilidades de desenvolvimento da área, assim como a probabilidade de interferir nas redes de intercâmbio construídas tanto para beneficiar a economia local quanto a regional.

Tabela 2. Quadro sintético da área e população dos estudos de caso.

Tabela elaborada pela própria autora.

Fonte: Censo da França, 1999; Censo da Inglaterra e País de Gales, 2011; PREFEITURA DE SÃO PAULO DESENVOLVIMENTO URBANO, 2011.

\begin{tabular}{|l|c|c|}
\hline & Área [hectares] & População aproximada \\
\hline Quartier Les Halles & 41 & 8.980 \\
\hline Bankside Urban Forest & 21 & 2.097 \\
\hline Nova Luz & 50 & 12.000 \\
\hline
\end{tabular}

\section{Contexto}

A primeira forma de intervenção que teve como objetivo a renovação da área da Santa Ifigênia, com foco na Luz, foi desenvolvida pela então Coordenadoria Geral de Planejamento - COGEP, pela Lei de Zoneamento de $1^{\text {o }}$ de novembro de 1974, que delimita o bairro da Luz. Fundamentalmente, a proposta desenvolvida pela COGEP e pelo escritório Rino Levi Arquitetos Associados, por meio de um diagnóstico evidenciando a dinâmica do bairro, propôs resolver o conflito entre 
produzir o adensamento das funções residenciais, comerciais e de serviços enquanto melhorava a qualidade ambiental da área por meio da recuperação de áreas deterioradas e do melhor aproveitamento do espaço público (MEZA, 2007). Nesse estudo, a deterioração é entendida como a obsolescência das edificações, a falta de conservação destas, a incidência de habitações subnormais e a predominância de usos industriais. (CESAR; FRANCO; BRUNA, 1977)

Na década de 1970, os planos urbanísticos apontavam como principal deficiência o baixo aproveitamento dos equipamentos urbanos existentes e propunham coeficientes de aproveitamentos mais altos em relação a outras áreas por meio de alterações no zoneamento, não tendo como foco a concepção de obras de infraestrutura. Nesse período, essas propostas não foram incorporadas pela legislação vigente, o que manteve as áreas centrais estagnadas e descompassadas em relação ao desenvolvimento urbano que ocorria em outras regiões.

Na década de 1980, foi desenvolvido, pela Secretaria Estadual da Cultura, o projeto Luz Cultural (entre 1984 e 1986), que pretendia dinamizar a área por meio do aproveitamento integrado dos equipamentos e atividades culturais da região. Esse projeto teve como o objetivo criar uma estratégia para valorizar o potencial cultural pela divulgação das atividades da região e a incorporação destas na vida cotidiana dos moradores, de maneira a gerar um movimento de envolvimento e participação das comunidades residentes no entorno da 
área. Segundo Meza (2007), devido ao curto espaço de tempo de promoção dessas atividades, essas iniciativas não conseguiram gerar uma força política representativa da comunidade local, assim como não conseguiu aproximar o setor privado para realizar investimentos que pudessem promover a reabilitação da região. A captação de investimentos privados seria vital para o sucesso do projeto, que, como outros de mesma natureza, seria totalmente subsidiado pelo governo estadual.

Devido ao projeto de Integração Centro (parte do Plano Integrado de Transportes Urbanos - PITU 2020), a conexão das linhas da CPTM desde a zona leste às estações da Luz, Brás e Barra Funda e a linha 4 do Metrô pôde ser viabilizada, em 1995, o que gerou um efeito positivo sobre a dinâmica de transportes coletivos e a mobilidade dos passageiros de toda a metrópole. Ao mesmo tempo, a década de 1990 foi um período, por assim dizer, de favorecimento da reprodução do capital por meio da alteração das atividades existentes na região e da substituição das populações residentes e que trabalhavam na área central.

De forma a usufruir dessas melhorias na integração da rede de transportes e dar continuidade à dinâmica econômica instalada, o chamado 'Polo Luz' buscou captar investimentos da iniciativa privada, de forma a aliviar os gastos do governo do estado em equipamentos que pudessem atrair públicos de outras localidades, principalmente por meio de atividades culturais. Dessa forma, projetos como a Pinacoteca, a Sala São Paulo, a Estação da Luz e a Estação Pinacoteca, assim como 
intervenções menores, como o Jardim da Luz, o Mosteiro da Luz, o Museu de Arte Sacra e o antigo edifício do Departamento Estadual de Ordem Política e Social - DOPs foram concebidos e concretizados.

Contudo, apesar da vasta divulgação das benfeitorias e investimentos privados de empreiteiras de renome na área, muito se discutiu em relação ao real alcance da captação desses recursos. Segundo Wisnik et al. (2001), esses investimentos não passaram da ordem de 4\%, diferentemente das grandezas divulgadas na mídia, sendo, concretamente, o Estado a principal fonte de recursos para a realização desses projetos. Outra crítica em relação aos programas desse período foi a de que esses importantes equipamentos acabam por relacionarem-se melhor com a esfera metropolitana do que diretamente com a escala local, não pulverizando, dessa forma, os benefícios no entorno imediato dos projetos culturais implantados. Um exemplo autêntico que ilustra este julgamento pode ser obtido pelos projetos do Programa Monumenta, que conseguiu executar obras de restauro e conservação de alguns edifícios e monumentos históricos - no entanto, os investimentos diretamente aplicados para a melhora do entorno e do sítio urbano não foram realizados como estabelecido nos objetivos iniciais do programa. 


\section{A Nova Luz}

O projeto urbanístico de nome Nova Luz, foi criado pelo viceprefeito de São Paulo Gilberto Kassab, como um plano de renovação urbana do bairro Santa Ifigênia ${ }^{28}$. O projeto foi implementado por meio do Projeto Urbanístico Específico - PUE e Estudos Complementares para fins de realização de Concessão Urbanística no perímetro de intervenção, definido na Lei $\mathrm{n}^{\circ}$ 14.918, de 07 de maio de 2009 (PROJETO NOVA LUZ, 2011). O projeto foi aprovado pela Câmara Municipal com horizonte de implantação de 15 anos, dividido em cinco fases, porém este foi cancelado em 2013, pelo atual prefeito, Fernando Haddad.

Segundo relatório da Secretaria de Desenvolvimento Urbano (PROJETO NOVA LUZ, 2012), o plano teve como princípio alterações de uso e ocupação do solo com a finalidade de alcançar os seguintes objetivos:

- o incremento da área destinada para o uso residencial, propiciando o aumento da densidade demográfica de no mínimo 350 hab/ha, com objetivo de permitir que mais cidadãos possam usufruir das vantagens locacionais desse setor da cidade;

${ }^{28} \mathrm{O}$ bairro é até os dias de hoje popularmente chamado de Cracolândia, devido ao grande número de usuários de crack que ocupam a região, que também é conhecida como ponto de tráfico de drogas. 
- a diversificação dos empregos por meio da alocação de espaços que permitam a instalação de empresas de porte variado e que possam atrair aproximadamente vinte mil novos postos de trabalho;

- a consolidação de uma área destinada à habitação de interesse social, indicada como Zeis 3 no Plano Diretor Estratégico, com a produção de mais de 1.500 unidades habitacionais;

- a criação de uma rede de espaços públicos capazes de recepcionar melhor os usuários da região, tanto moradores quanto trabalhadores, com a indicação de alternativas de acabamentos para pavimentação, iluminação, paisagismo e mobiliário urbano;

- a criação de parâmetros de ocupação de lotes privados que, em conjunto com a legislação urbanística, determinariam a volumetria final do projeto;

- a preservação e recuperação do patrimônio histórico.

As determinações do Plano Diretor Estratégico do período de concepção do projeto, com a delimitação de um perímetro de Zeis 3, consolidava a possibilidade de produção de habitação de interesse social na área central associado a um projeto de transformação urbana. As determinações do instrumento da Lei de Concessão Urbanística (14.917/09) aplicadas a esse projeto reforçava os incentivos existentes para o uso residencial e para a restauração dos imóveis tombados e objetivados na elaboração da Operação Urbana Centro. Segundo definição do relatório do Projeto Nova Luz (2012a), a Concessão Urbanística é: 
um contrato administrativo por meio do qual o Município, por meio de licitação, transfere a pessoa(s) jurídica(s) a execução de obras de urbanização ou reurbanização de interesse público, obras estas a serem executadas por conta e risco da(s) pessoa(s) jurídica(s) então contratadas, com base em projeto urbanístico específico previamente definido pelo Poder Público Municipal (ibidem, p.239).

A área de intervenção do projeto localiza-se na região central da cidade de São Paulo e próxima de importantes polos de transporte público: estações de trem e metrô. A área é consolidada e inteiramente edificada, possuindo aproximadamente 50 hectares e 45 quadras, sendo delimitada pela Av. Duque de Caxias, Rua Mauá, Av. Cásper Líbero, Av. Ipiranga e Av. São João (ver Figura 20). Equipamentos culturais de valor histórico encontram-se no entorno da área de projeto, como a Pinacoteca do Estado, a Sala São Paulo (Estação Júlio Prestes) e o Museu da Língua Portuguesa (na Estação da Luz), incluindo 88 bens tombados na região, além de outros nas áreas adjacentes dos bairros República, Bom Retiro e Sé.

Segundo Alejandra Devecchi (in STICA, 2011), arquiteta e urbanista do projeto Nova Luz, encontram-se na região duas grandes economias de aglomeração: na Santa Ifigênia, o comércio de eletrônicos, e na General Osório, o comércio de motocicletas. $\mathrm{Na}$ região, há moradia com densidade de 260 hab/ha, 12.000 moradores e 20.000 empregos, sendo os objetivos da intervenção os de dobrar o número de moradores e empregos. 
Segundo dados do IBGE, no período de concepção do projeto, a população residente da área girava em torno de 12.000 pessoas, o que representava menos da metade da população residente do local nos anos 1970 (de aproximadamente quarenta mil pessoas). Em 2011, segundo relatório da prefeitura, a região apresentava aproximadamente dois empregos por habitante e concentrava uma população residente com densidade demográfica bruta equivalente a 220 hab/ha.

Quanto à existência de rede física e serviços infraestruturais, a área é dotada de cobertura de abastecimento de água, esgoto sanitário, drenagem urbana, energia e iluminação pública, telecomunicações (rede de telefonia e fibra ótica) e rede de gás. Porém, devido ao aumento quase dobrado da população projetada, todas essas redes físicas infraestruturais se apresentariam limitadas em sua capacidade, além de já apresentarem problemas (como desordenamento espacial, vazamentos etc.). Mesmo com a previsão de um uso mais eficiente dos recursos (como água e energia), a necessidade de readequação na alimentação e ampliação da capacidade das redes seria fundamental para o suporte ao aumento da população. As diretrizes de desenvolvimento da infraestrutura do projeto Nova Luz foram sintetizadas na Tabela 3. 


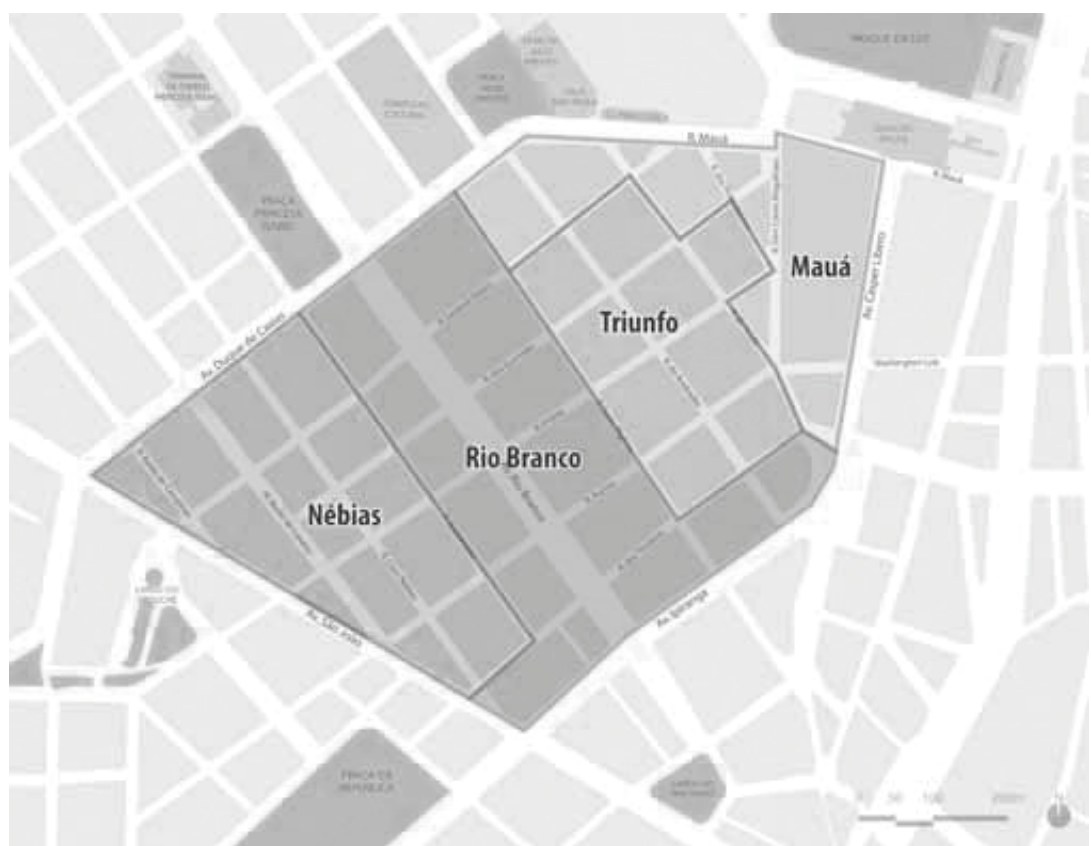

Figura 20. Perímetro do Área de Intervenção do Projeto Nova Luz e os setores Nébias, Rio Branco, Triunfo e Mauá.

Fonte: Projeto Nova Luz, 2011 
Tabela 3. Diretrizes de desenvolvimento da infraestrutura do projeto Nova Luz.

Fonte: Adaptado de Projeto Nova Luz, 2011

\begin{tabular}{|c|c|c|c|}
\hline ESPECIALIDADE & $\begin{array}{l}\text { ABRANGENNCIA } \\
\text { DO ESTUDO }\end{array}$ & RESPONSÁVEL & SIINTESE DAS SOLUÇÕES \\
\hline \multirow{3}{*}{$\begin{array}{l}\text { ABASTECIMENTO } \\
\text { DE ÁGUA }\end{array}$} & $\begin{array}{l}\text { Distribuição de água } \\
\text { potável }\end{array}$ & $\begin{array}{l}\text { SABESP / } \\
\text { Concessionário }\end{array}$ & $\begin{array}{l}\text { Substituição e ordenamento da rede de distribuição de água - cerca de } 12 \mathrm{~km} \text { de vias } \\
\text { na área de projeto }\end{array}$ \\
\hline & $\begin{array}{l}\text { Uso racional - } \\
\text { dispositivos } \\
\text { economizadores }\end{array}$ & $\begin{array}{l}\text { Concessionário / } \\
\text { proprietário / } \\
\text { ocupante }\end{array}$ & $\begin{array}{l}\text { Instalação dos dispositivos economizadores - solução a ser adotada no âmbito do } \\
\text { projeto de novos empreendimentos e nas edificações existentes }\end{array}$ \\
\hline & $\begin{array}{l}\text { Sistema integrado - } \\
\text { aproveitamento de } \\
\text { águas pluviais }\end{array}$ & Concessionário & $\begin{array}{l}\text { Sistema integrado de água predial (coleta, tratamento e armazenamento, } \\
\text { separação do sistema) - solução a ser adotada no âmbito do projeto de novos } \\
\text { empreendimentos }\end{array}$ \\
\hline \multirow{2}{*}{$\begin{array}{l}\text { ESGOTAMENTO } \\
\text { SANITÁRIO }\end{array}$} & $\begin{array}{l}\text { Rede pública - coleta } \\
\text { e tratamento na ETE } \\
\text { Barueri }\end{array}$ & $\begin{array}{l}\text { SABESP / } \\
\text { Concessionário }\end{array}$ & $\begin{array}{l}\text { Substituição e ordenamento da rede de coleta de esgotos - cerca de } 12 \mathrm{~km} \text { de via na } \\
\text { área de projeto }\end{array}$ \\
\hline & & Concessionário & $\begin{array}{l}\text { Sistema integrado de água predial - adoção de solução para tratamento "in loco" } \\
\text { com reuso no âmbito do projeto de novos empreendimentos }\end{array}$ \\
\hline \multirow{3}{*}{$\begin{array}{l}\text { DRENAGEM } \\
\text { URBANA }\end{array}$} & Sistema superficial & $\begin{array}{l}\text { SIURB - Proj } 4 \text { / } \\
\text { Concessionário }\end{array}$ & $\begin{array}{l}\text { Readequação do alinhamento horizontal da geometria das vias, correção de pontos } \\
\text { baixos e implantação de novo sistema de guias e sarjetas no sistema viário }\end{array}$ \\
\hline & Dispositivos & $\begin{array}{l}\text { SIURB - Proj } 4 / \\
\text { Concessionário }\end{array}$ & $\begin{array}{l}\text { Implantação de dispositivos usuais e inovadores nas calçadas, compreendendo piso } \\
\text { permeável e jardins de chuva }\end{array}$ \\
\hline & Sistema enterrado & $\begin{array}{l}\text { SIURB - Proj } 4 \text { e } \\
\text { Concessionário }\end{array}$ & Redimensionamento e substituição da rede subterrânea por novas tubulações \\
\hline
\end{tabular}




\begin{tabular}{|c|c|c|c|}
\hline ESPECIALIDADE & $\begin{array}{l}\text { ABRANGÊNCIA } \\
\text { DO ESTUDO }\end{array}$ & RESPONSÁVEL & SÍNTESE DAS SOLUÇÕES \\
\hline \multirow{6}{*}{$\begin{array}{l}\text { ENERGIA E } \\
\text { ILUMINAÇÃO } \\
\text { PÚBLICA }\end{array}$} & $\begin{array}{l}\text { Distribuição de } \\
\text { energia - rede pública }\end{array}$ & $\begin{array}{l}\text { ELETROPAULO / } \\
\text { Concessionário }\end{array}$ & $\begin{array}{l}\text { Adequação da alimentação, ordenamento e ampliação da capacidade das redes e } \\
\text { distribuição de energia no padrão ELETROPAULO }\end{array}$ \\
\hline & $\begin{array}{l}\text { Geração local de } \\
\text { energía }\end{array}$ & $\begin{array}{l}\text { ELETROPAULO / } \\
\text { Concessionário }\end{array}$ & $\begin{array}{l}\text { Geração local de energia alternativa através de painéis fotovoltáicos nas coberturas } \\
\text { dos novos empreendimentos }\end{array}$ \\
\hline & \multirow{2}{*}{$\begin{array}{l}\text { Sistema de } \\
\text { conservação e } \\
\text { eficiência energética }\end{array}$} & Concessionário & $\begin{array}{l}\text { Recomenda-se a adoção de novas tecnologias no projeto de novos empreendimentos } \\
\text { - Recomenda-se seguir os parâmetros de eficiência PROCEL EDIFICA }\end{array}$ \\
\hline & & $\begin{array}{l}\text { Concessionário / } \\
\text { Proprietário }\end{array}$ & $\begin{array}{l}\text { Recomenda-se a adoção de novas tecnologias nas edificações existentes - previsão } \\
\text { no Programa de Gestão para Sustentabilidade (EIA - Rima) }\end{array}$ \\
\hline & $\begin{array}{l}\text { Iluminação pública - } \\
\text { rede pública }\end{array}$ & $\begin{array}{l}\text { ILUME / } \\
\text { Concessionário }\end{array}$ & $\begin{array}{l}\text { Adequação e ordenamento da alimentação e ampliação do sistema de iluminação } \\
\text { pública e utilização de postes/luminárias conforme padrões requeridos por ILUME }\end{array}$ \\
\hline & Sinalização viária & $\begin{array}{l}\text { CET / SIURB / } \\
\text { Concessionário }\end{array}$ & Adequação e ordenamento da alimentação do sistema de sinalização viário vertical \\
\hline \multirow{2}{*}{$\begin{array}{l}\text { TELECOMUNICA- } \\
\text { ÇÕES - REDE DE } \\
\text { TELEFONIA E } \\
\text { FIBRAS ÓTICAS }\end{array}$} & $\begin{array}{l}\text { Cabeamento } \\
\text { telefônico - áreas } \\
\text { públicas }\end{array}$ & $\begin{array}{l}\text { Telefônica / } \\
\text { Concessionário }\end{array}$ & Ordenamento das redes e ampliação da capacidade \\
\hline & $\begin{array}{l}\text { Fibras óticas - áreas } \\
\text { públicas }\end{array}$ & $\begin{array}{l}\text { Empresa de } \\
\text { Telecom / } \\
\text { Concessionário }\end{array}$ & Ordenamento das redes e ampliação da capacidade \\
\hline REDE DE GÁS & $\begin{array}{l}\text { Gás canalizado - } \\
\text { áreas públicas }\end{array}$ & $\begin{array}{l}\text { COMGÁs / } \\
\text { Concessionário }\end{array}$ & $\begin{array}{l}\text { Ordenamento das redes existentes e renovação das antigas conforme padrão da } \\
\text { COMGÁS }\end{array}$ \\
\hline
\end{tabular}




\begin{tabular}{|c|c|c|c|}
\hline ESPECIALIDADE & $\begin{array}{l}\text { ABRANGÊNCIA } \\
\text { DO ESTUDO }\end{array}$ & RESPONSÁVEL & SÍNTESE DAS SOLUÇÕES \\
\hline \multirow{4}{*}{$\begin{array}{l}\text { GESTÃO DE } \\
\text { RESÍDUOS }\end{array}$} & $\begin{array}{l}\text { Resíduos domésticos } \\
\text { - não recicláveis }\end{array}$ & $\begin{array}{l}\text { LIMPURB } \\
\text { Concessionário / } \\
\text { Proprietário / } \\
\text { Ocupante }\end{array}$ & $\begin{array}{l}\text { Coleta e disposição dos resíduos conforme contrato vigente com LIMPURB e } \\
\text { implantação e uso de estratégia otimizada para localização de containers }\end{array}$ \\
\hline & $\begin{array}{l}\text { Resíduos domésticos } \\
\text { - recicláveis }\end{array}$ & $\begin{array}{l}\text { LIMPURB } \\
\text { Concessionário / } \\
\text { Proprietário / } \\
\text { Ocupante }\end{array}$ & $\begin{array}{l}\text { Coleta e disposição dos resíduos conforme contrato vigente com LIMPURB e } \\
\text { implantação e uso de estratégia otimizada para localização de containers }\end{array}$ \\
\hline & $\begin{array}{l}\text { Resíduos domésticos } \\
\text { - orgânicos }\end{array}$ & $\begin{array}{l}\text { Concessionário / } \\
\text { Proprietário / } \\
\text { Ocupante }\end{array}$ & $\begin{array}{l}\text { Implantação de estratégia otimizada de coleta e transporte para local de } \\
\text { armazenamento e compostagem }\end{array}$ \\
\hline & $\begin{array}{l}\text { Resíduos de } \\
\text { demolição e } \\
\text { construção civil }\end{array}$ & $\begin{array}{l}\text { Concessionário / } \\
\text { Construtor }\end{array}$ & $\begin{array}{l}\text { Implantação de Centro de triagem e processamento no canteiro de obras com } \\
\text { retorno dos materiais para uso na obra }\end{array}$ \\
\hline
\end{tabular}


Como já indicado anteriormente, a infraestrutura de transportes coletivos na região é servida pela estrutura ferroviária da CPTM, possuindo quatro linhas que atendem diretamente área:

- Linha 7 - Rubi, com destino a Jundiaí;

- Linha 8 - Diamante, com destino a Itapevi;

- Linha 10 - Turquesa, com destino a Rio Grande da Serra; e

- Linha 11 - Coral, com destino a Estudantes na zona leste.

Somam-se a isso mais três linhas de Metrô:

- Linha 1 - Azul;

- Linha 3 - Vermelha;

- Linha 4 - Amarela (na época em obras).

A Estação da Luz encontra-se lindeira ao perímetro do projeto Nova Luz, sendo o modal mais importante para a região.

O projeto foi concebido para utilizar da ferramenta de nome Concessão Urbanística, prevista no Plano Diretor Estratégico de São Paulo em 2002, na gestão da prefeita Marta Suplicy. O uso da Concessão Urbanística autoriza, por meio de licitação, uma concessionária a executar obras de urbanização de interesse público, obtendo remuneração mediante às explorações da mais-valia do solo, dos terrenos e das edificações destinadas ao uso privado.

Por meio desse instrumento, o plano urbanístico, chancelado pelo Poder Municipal, transfere à concessionária a responsabilidade e os custos da execução e os pagamentos de desapropriações e indenizações dos terrenos, ficando também com os lucros da valorização mobiliária, 
que, na maior parte dos casos, é produzida no processo de renovação urbana. Devido a flexibilizações na legislação urbanística das OUCs, a área construída computável máxima para uso residencial seria de seis vezes a área do terreno, e para uso não residencial de 2,5 ou 4, lembrando que, nesse caso, o projeto Nova Luz estaria contido no perímetro da OUC Centro. Esse incremento na área construída é um dos fatores que viabiliza o interesse das iniciativas privadas em parcerias com o estado ou a Prefeitura. De acordo com a divisão organizacional gerada pela Concessão Urbanística, esse projeto foi estruturado por uma parceria público-privada entre a Prefeitura de São Paulo e a concessionária formada pela AECOM, a Cia. City, a Fundação Getúlio Vargas e a Concremat. Segundo relatório do Projeto Nova Luz (2012a) é importante notar que, diferentemente do processo de desenvolvimento imobiliário que remunera uma atividade econômica com ciclo bem definido, iniciando-se com a compra de terrenos até a venda dos imóveis para o mercado, a categoria de negócio da concessão urbanística envolve um período de aproximadamente 15 anos, composto pela implantação de todas as obras públicas, entrega das unidades HIS, gestão dos programas socioambientais e viabilização dos empreendimentos imobiliários. Desta maneira, a remuneração do concessionário se dá pelo valor adicional que decorre da implantação do projeto urbanístico, que refletido na exploração dos empreendimentos imobiliários, se transfere para o valor dos terrenos da região. Essa lógica é explicitada a seguir: 
Para determinação deste valor, o modelo tem em si implícito o conceito de que o valor do terreno captura os ganhos gerados com a incorporação e desenvolvimento imobiliário. O modelo utiliza o método involutivo para estimar o valor do terreno, que parte de um empreendimento paradigma seguindo as diretrizes de cada quadra definidas no PUE, e calcula o valor possível a ser atribuído a ele, partindo da receita de venda das unidades imobiliárias, subtraindo todos os custos de construção, incorporação e o resultado imobiliário, de forma que o empreendimento seja economicamente viável. A diferença entre o valor atual do terreno e o valor atribuído a ele pelo método involutivo é o "valor decorrente da implantação do projeto", valor este a ser capturado pelo concessionário. Desta maneira, a receita estimada do concessionário urbanístico, que é composta pela receita das unidades comerciais do Programa Renova Luz e do valor decorrente da implantação do projeto, deveria ser suficiente para fazer frente aos custos das obras e intervenções previstas no PUE e PU- ZEIS, bem como para remunerar o seu capital investido. Como este valor não é suficiente, o presente estudo estima o patrocínio do município necessário para compor a receita do concessionário. (ibidem, p.241)

Deste modo, a Prefeitura de São Paulo, por meio de processo licitatório, é responsável por delegar a obrigação da implantação do PUE, PUZEIS e serviços a um ente privado - o concessionário, que obtém sua remuneração por meio da exploração dos empreendimentos imobiliários previamente definidos no projeto urbanístico (ibidem).

Os custos totais projetados para a implantação do Projeto Urbanístico Específico - PUE, do Plano de Urbanização da ZEIS PUZEIS e dos programas de compensações e programas sócioambientais, em julho de 2012 seriam de aproximadamente 607 milhões de reais. Desses, 87 milhões seriam ligados à infraestrutura e áreas verdes, 
51 milhões para custos de construção de equipamentos públicos, 110 milhões para o programa de renovação de unidades residenciais, 296 milhões para a construção de unidades HIS (adicionalmente a 113 milhões para a aquisição de terrenos), sendo os restantes estimados para custos adicionais de aquisição, demolição, limpeza e remoção, regularização de terrenos etc. (PROJETO NOVA LUZ, 2012). Um dos motivos divulgados pelo atual prefeito em 2015, Fernando Haddad, para a paralisação do projeto foi o seu alto custo.

A principal virtude promulgada na concepção do projeto foi a de constituir uma importante frente de expansão e adensamento urbano, tendo como preceito básico a melhor utilização de um setor da cidade com amplas vantagens locacionais associadas à infraestrutura de transporte. Essa operação urbana localizada ao longo dos trilhos do trem constituiria assim em um novo padrão de expansão urbana. Outros benefícios esperados seriam a consolidação de um padrão de ocupação em que os pavimentos térreos seriam destinados ao comércio (tal como acontece em alguns setores da área) e os pavimentos superiores seriam setorizados entre o uso residencial e de escritórios, sendo esses últimos concentrados ao longo da Av. Rio Branco, conforme pode ser observado nas Figuras 21 e Figuras 22. 

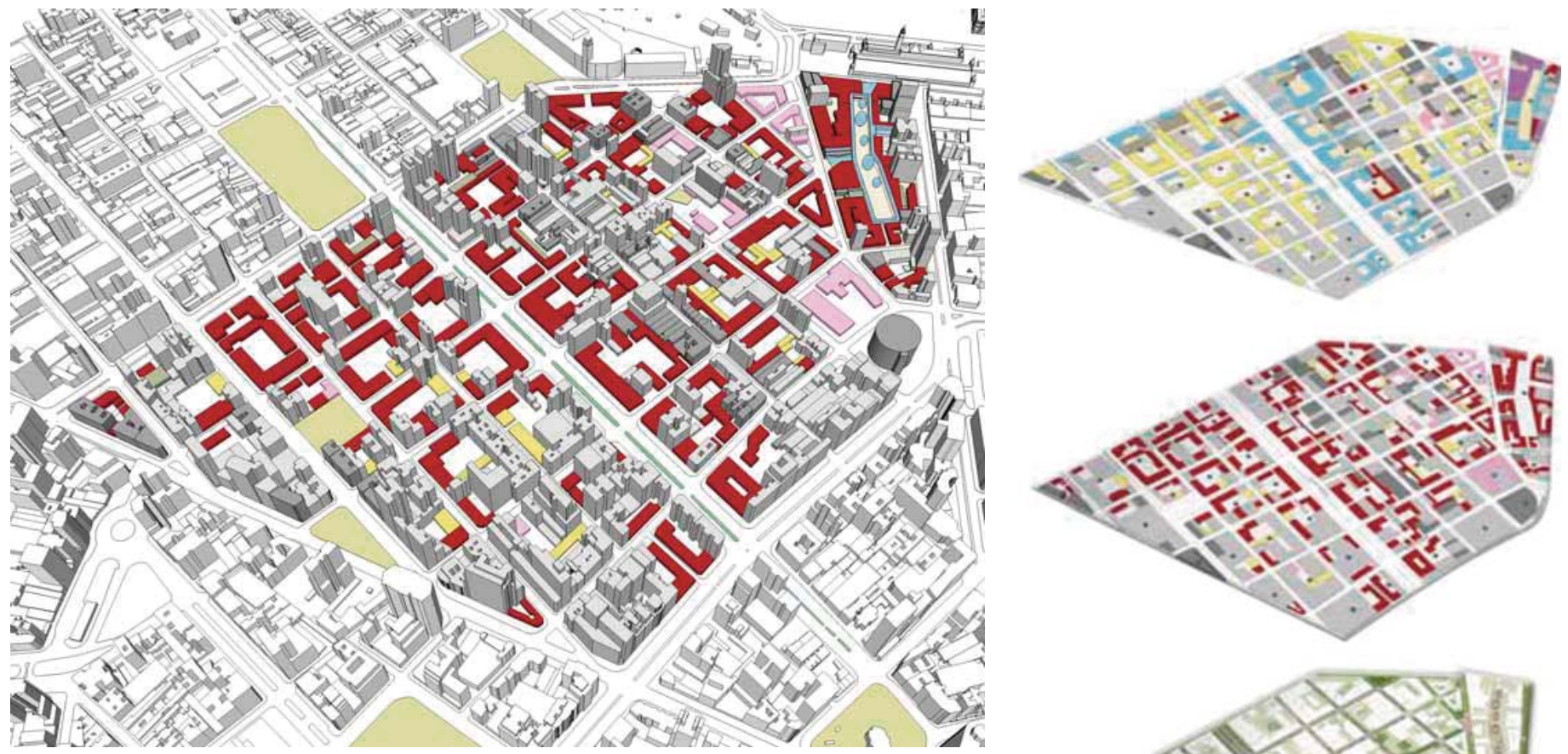

Figura 21. À esquerda, usos propostos para o pavimento térreo. À direita, de baixo para cima, áreas verdes, piso térreo e pisos superiores.

Fonte: Projeto Nova Luz, 2011

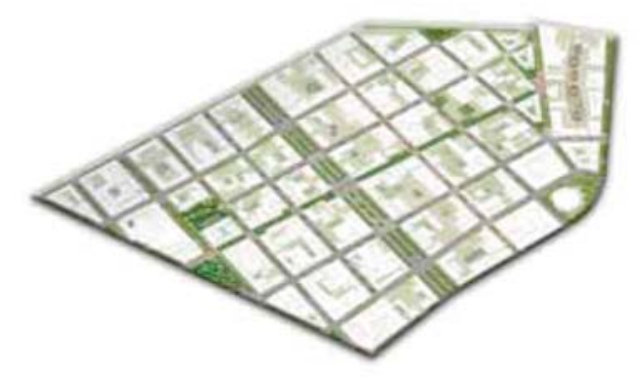




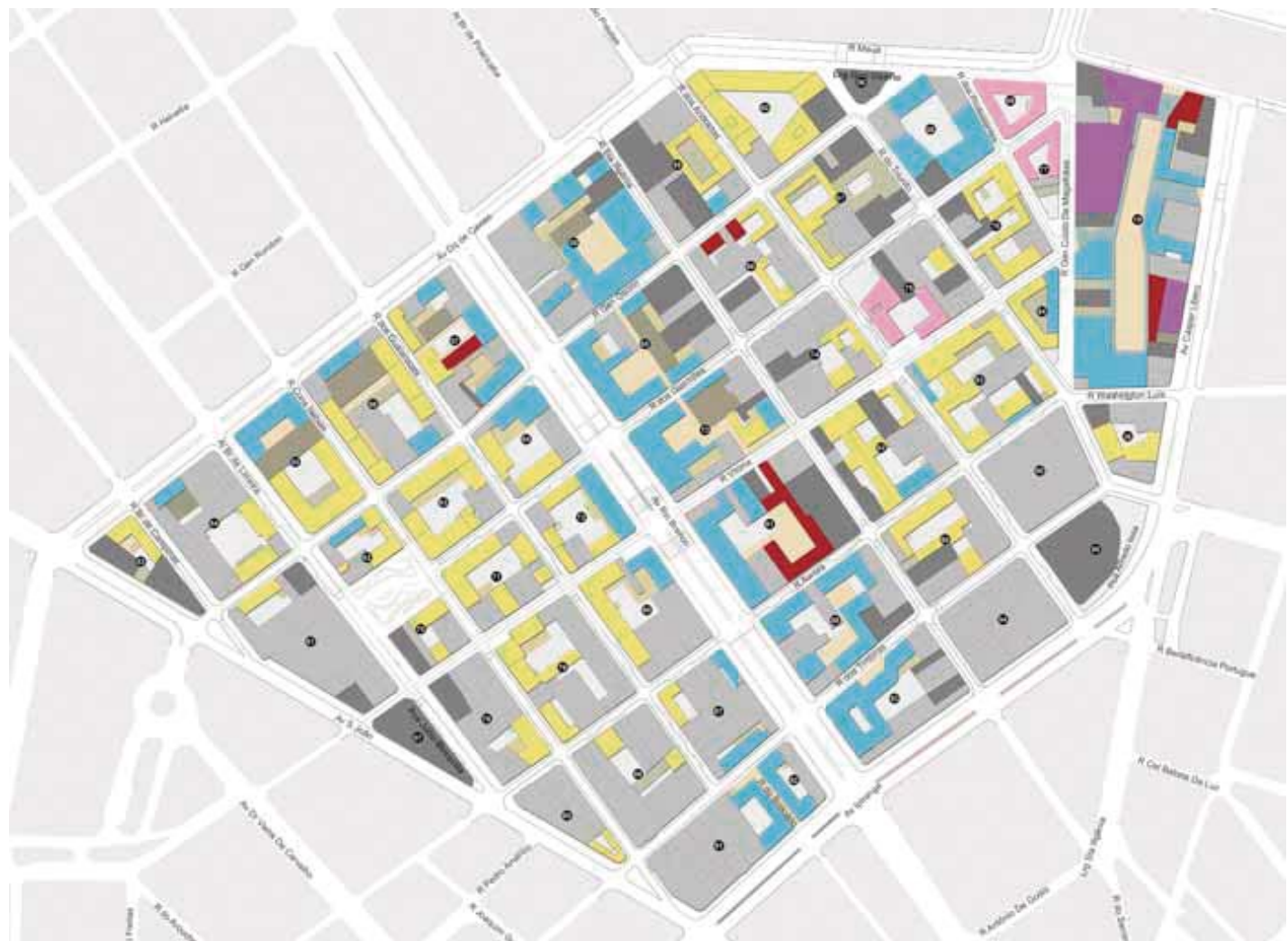

\begin{tabular}{|c|}
\hline Serviços \\
\hline Residencial \\
\hline Comercial \\
\hline Entretenimento \\
\hline Institucional \\
\hline Patrimônio histórico \\
\hline Prédios mantidos \\
\hline $\begin{array}{l}\text { Espaços livres } \\
\text { (Pavimentadas) }\end{array}$ \\
\hline $\begin{array}{l}\text { Espaços livres } \\
\text { (Verde) }\end{array}$ \\
\hline Áreas de serviços \\
\hline
\end{tabular}

Figura 22. À esquerda, usos propostos para os pavimentos superiores. À direita, legenda dos usos.

Fonte: Projeto Nova Luz, 2011 
O ponto mais polêmico do projeto foi exatamente o elemento que desde o princípio o viabilizaria, o uso da ferramenta da Concessão Urbanística, que estaria beneficiando as concessionárias nos trâmites de indenizações e desapropriações dos terrenos. Estes, em vez de serem realizados apenas como instrumento legal de interesse público e social, estariam gerando lucros para as mesmas empresas privadas, sem que os benefícios dos investimentos públicos na região pudessem ser repartidos pela sociedade como um todo. Segundo Paula Ribas, presidente da AMOLUZ:

Ali na Rua Vitória, já temos notícia de que uma grande construtora comprou meio quarteirão, quer dizer, mesmo o projeto não concluído a especulação imobiliária já começou há muito tempo, porque estão comprando por preço de Cracolândia, e vendendo por preço de Nova Luz. [E ainda:] Não tem uma linha no projeto preliminar que fale sobre como vai ser balanceado esse impacto estrutural com o impacto social, não tem nenhum plano para falar sobre a remoção das famílias que serão desapropriadas, para onde essas pessoas vão, a garantia de que elas voltarão para os imóveis delas, não tem! [...] Enquanto eu não ver [sic] isso na lei, enquanto eu não ver [sic] isso no Diário Oficial, eu não vou ficar sossegada. (in STICA, 2011)

Conforme explicado anteriormente, a Lei de Concessão Urbanística (14.917/09) é um instrumento presente no Plano Diretor de 
São Paulo que permite transferir para um terceiro, como a iniciativa privada, a implementação de obras de urbanização. A remuneração se daria por meio da exploração dos terrenos localizados no perímetro definido para essa finalidade, pelos processos de desapropriação, que, no Brasil, deve ser feita por interesse público ou social. Assim, como assegurar esses objetivos no caso desta ser feito por iniciativa privada? No caso das concessões, por exemplo, cedidas para empresas para o abastecimento de água, assegura-se o direito da sociedade a esse recurso básico; no caso de uma concessão de uma rodovia, a empresa privada se responsabiliza pela sua manutenção. Pergunta-se aqui, quais os serviços públicos que estariam sendo prestados para a sociedade por meio de uma concessão urbanística?

Outras críticas levantadas dizem respeito à ampla previsão de demolição da área, na ordem de grandeza de $270.609 \mathrm{~m}^{2}$, sendo $34.168 \mathrm{~m}^{2}$ de área residencial e $236.441 \mathrm{~m}^{2}$ de área não residencial, o que afetaria 321 unidades habitacionais que teriam que ser renovadas ou suas famílias deslocadas para que essas pudessem se manter no local (PROJETO NOVA LUZ, 2012). Segundo Rolnik (RAQUELROLNIK, 2015a), as garantias e os procedimentos para a realocação dos moradores da área de intervenção que constam nas Diretrizes do Plano Urbanístico da Zona Especial de Interesse Social - Zeis 3, não foram nem sequer citadas durante a aprovação do Plano Urbanístico da Zeis 3 na área de Santa Ifigênia, que é inserida na área do projeto Nova Luz. 
A falta de transparência, de um processo democrático, de interlocução entre os diferentes grupos que seriam afetados pelo projeto, da participação dos moradores e comerciantes da Santa Ifigênia na concepção do projeto, no estabelecimento de diretrizes e de um programa de ações para a área, também foram extremamente criticados. Esses problemas no cerne do processo do projeto da Nova Luz comprometeriam, então, o produto, o projeto urbanístico, fazendo com que este estivesse dissociado, sem comprometimento algum com o processo social. Segundo Kazuo Nakano, arquiteto e urbanista do Instituto Pólis:

Essas imagens que são utilizadas para se apresentar esses grandes projetos urbanos traduzem uma situação ali muito sedutora, com muitas cores, são imagens, e são fantasmagorias, porque aquilo está completamente oco, está completamente esvaziado de um processo real na sociedade, você vê que aquilo está artificializado completamente. (in STICA, 2011)

Em contrapartida, segundo Luís Octávio da Silva, arquiteto e urbanista da Secretaria Municipal de Habitação, uma forma de assegurar o acesso social dos moradores da região já é prevista pelas Zeis:

Para isso existem Zeis, existem mecanismos, existem programas de habitação em área central. [...] A Zeis é uma zona especial de interesse social, são parcelas do território, do município, é um instrumento que existe em vários outros municípios no país, é um instrumento para 
garantir que justamente as melhorias que o poder público vier a empreender numa determinada área sejam retidas e sejam mantidas por uma população de baixa renda. (in STICA, 2011)

Fator este que não garante que as famílias que residem em situações precárias na região possam ser realocadas na mesma área.

\section{Síntese}

Assim, dando força ao movimento contrário ao projeto, muitos comerciantes e residentes reclamaram que a caracterização perversa da área, cruelmente chamada de 'cracolândia', não passou de um instrumento publicitário para desvalorizar ainda mais a área, de forma a permitir a desapropriação dos lotes demarcados pela prefeitura com valores ainda mais desvalorizados. Relembrando o slogan criado por Andrea Matarazzo na época, Paulo Garcia, presidente da Associação dos Comerciantes da Santa Ifigênia aponta: "Para acabar com a cracolândia temos que fazer a Nova Luz". Elias Obeid, comerciante local alega: "não é cracolândia, é 'lojolândia', pagamos impostos, compramos mercadorias, vai lá na Rua Santa Ifigência, não tem crack [...], ele quer falar que é cracolândia para desapropriar a preço de banana”. Sakar Obeid, comerciante da mesma família, afirma: "Hoje a cracolândia só existe na frente da polícia metropolitana, na rua Couto de Magalhães, na frente da 
Rua dos Gusmões, nós não temos dúvidas que a degradação da região foi fomentada, ela não aconteceu por acaso". (in STICA, 2011)

Desse modo, verifica-se, através dos olhos dos mais diversos atores, que visam os mais distintos interesses, que a tensão pelos direitos de residirem, trabalharem e, até mesmo, especularem na área da Santa Ifigênia se faz, sobretudo, devido ao fato desse espaço ser servido por uma grande oferta de empregos, serviços, equipamentos culturais e, principalmente, oferta de infraestrutura das mais diversas naturezas ${ }^{29}$.

Tal como visto na Tabela 3, apesar da oferta de infraestrutura na região, a área carece de investimentos para a ampliação da oferta e para uma melhor gestão da demanda, não só para promover o uso mais eficiente da água, gás e energia, por exemplo, mas para prever soluções inovadoras que possam integrar esses diferentes recursos (tanto provenientes de entradas quanto de saídas de sistemas de energia, água, efluentes) numa forma de uso mais atenta, eficiente e engenhosa.

Em comparação com os projetos de Les Halles e Bankside Urban Forest, o projeto Nova Luz, do ponto de vista do acesso e da integração das redes de infraestrutura possui, a princípio, um forte potencial. A localização se insere em um polo de transporte coletivo e possui boa cobertura e

${ }^{29}$ A infraestrutura de transportes foi muito citada no documentário 'Um lugar ao centro' de Stica (2011) 
qualidade da rede de serviços infraestruturais, o que é verificado e aprofundado no Capítulo 3. Porém, devido aos limitantes da agenda de regeneração urbana da Nova Luz e a falta de projetos complementares que ampliem o escopo limitado de um desenho de transformação urbana tão-somente física, a produção de soluções de gestão da oferta e demanda de recursos infraestruturais não se consolida. Além disso, a natureza do entorno urbano, que, no caso da Nova Luz, apresenta carências, acaba por dificultar o desenvolvimento de soluções integradas que promovam um reequilíbrio regional. Neste caso, a solução local facilmente acabaria por gerar uma super demanda, de forma a atrair um público carente de serviços e atividades provenientes de outras áreas da metrópole. Assim, apesar do potencial do local, a concretização de agendas alternativas quanto ao acesso e integração das redes infraestruturais se mostra complexa.

Com o intuito de compreender a condição das redes de infraestrutura no âmbito dos impactos e efeitos metropolitanos, parte-se do contexto da Região Metropolitana de São Paulo, e sua caracterização em relação a cobertura e qualidade da rede de serviços infraestruturais. Além disso, são estudadas as dinâmicas, as articulações e os fluxos da metrópole, à partir das Operações Urbanas Municipais, de forma a gerar uma melhor compreensão dos processos de transformação urbana no território da Metrópole. 


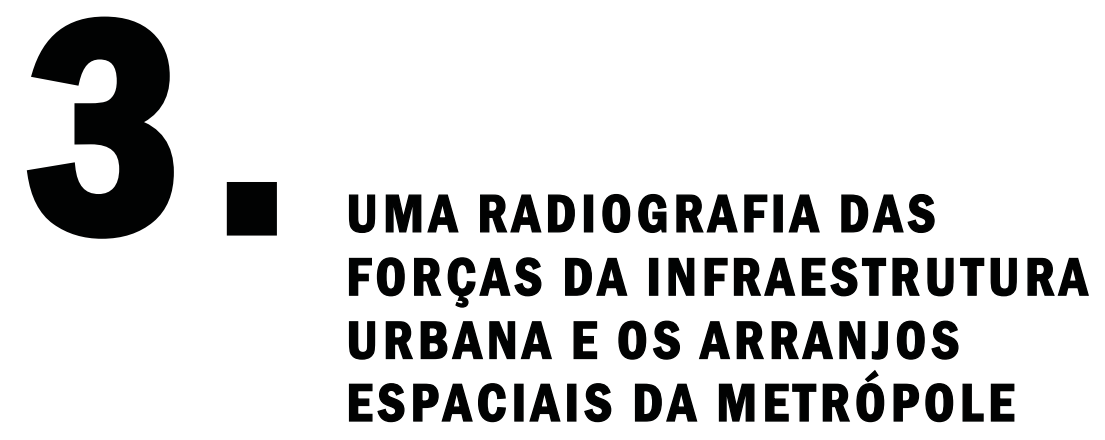

Esta parte da pesquisa envolveu a avaliação de uma base empírica que possibilitou a identificação de processos que poderiam gerar a diferenciação do espaço urbano com base na distribuição física e qualitativa das redes de infraestrutura urbana, buscando identificar quais as causas e agentes que promoviam essa severa diferença entre os distritos, e a consequente avidez por melhorias por parte de seus moradores, trabalhadores, ou mesmo, visitantes. Para melhor identificação dessas diferenças, foram criados mapas de diferenciação, 
evidenciando as discrepâncias na cobertura, qualidade de distribuição e consumo de recursos da Região Metropolitana de São Paulo. Foram incluídos dados quanto aos serviços de infraestrutura de energia, gás canalizado, telecomunicações, transportes e saneamento, dentre estes, a rede de água e esgoto.

Este capitulo estruturou a base empírica da pesquisa por meio de um tripé: do quadro, do desenho e da condição da infraestrutura urbana na RMSP. Neste capitulo, também foram expostas as principais ideias discutidas nas entrevistas com profissionais especialistas nas áreas de infraestrutura e projetos de renovação urbana.

Dessa forma, pretendeu-se evidenciar a heterogeneidade na rede de carências e benefícios no território da metrópole, compondo a defesa do argumento dos outros capítulos que compõem esta tese: que soluções tópicas na rede infraestrutural dificilmente respondem a demanda, sendo suas qualidades e diferenças dissolvidas no grid urbano. 


\subsection{0 quadro da infraestrutura urbana na RMSP}

Apesar da generalidade do tema, infraestrutura urbana, tratado no capítulo anterior, para a análise deste trabalho, abordaram-se as problemáticas infraestruturais relativas às redes técnicas de abastecimento de água potável, esgotamento sanitário, drenagem e manejo das águas pluviais urbanas, rede de abastecimento de energia elétrica e gás e rede de telecomunicações; ou seja, aquelas estruturas que se constituem em estruturas físicas ligadas em rede e consolidadas no tecido urbano da cidade. Não se incluem as estruturas básicas para o manejo de resíduos sólidos e limpeza urbana, assim como não são abordados os equipamentos institucionais, sociais e culturais, os quais são frequentemente referidos na literatura como equipamentos infraestruturais urbanos.

Por meio de estudos em teoria da modernização (por exemplo, as de Walt Rostow 1960 e John Friedmann 1966), compreende-se que a infraestrutura é parte integrante dos processos de modernização das cidades dos pós-guerra, sendo evidente a intenção de acelerar o desenvolvimento de cidades por uma transição industrial e de crescente modernização, que se tornaria evidente em melhoras nas condições e 
padrões de vida. O papel de uma base infraestrutural confiável, por exemplo, nos setores de energia, transporte e abastecimento de água, é essencial para garantir a produção e a circulação dos produtos e pessoas, fundamental para o modelo de desenvolvimento moderno. Esperava-se, por essas teorias de modernização, que, por questões de eficientização econômica, esses investimentos em infraestruturas seriam inicialmente concentrados em uma ou duas centralidades urbanas, sendo ampliadas por um movimento de 'vazamento', ou 'gotejamento', em direção às periferias, e, neste processo, progressivamente provocariam a mudança nos modos de vida e de produção e nos padrões de pobreza. Dessa forma, de início, os centros tenderiam a drenar todos os investimentos e concentrariam os recursos e as maiores competências; porém, esperava-se que, uma vez que as deseconomias do crescimento urbano superassem os benefícios da concentração, a perspectiva mudaria a favor da difusão da modernidade para outras formas institucionais e infraestruturais. Então, a desigualdade era vista como o mal necessário, porém que teria duração limitada; já que as últimas ambições da modernidade seriam a de promover por fim a homogeneidade espacial (GRAHAM, 2001).

Os processos de formação das culturas de modernidade urbana e de oferta da infraestrutura e serviços em rede no Brasil foram explorados por Silva (2007), entre o fim do século XIX e a década de 1930. Verificouse, neste estudo, que as propostas tecnológicas e reguladoras dos sistemas de infraestrutura e serviços públicos deste período apresentavam maior 
capilaridade urbana e social que as propostas de melhorias urbanas, em geral restritas às áreas centrais e aos bairros de elite. As conclusões apontaram para uma convergência das metas sociais e das estratégias básicas para atingi-las, da parte tanto dos planos setoriais das duas primeiras décadas de 1900 quanto do aparato regulador estabelecido no início da década de 1930.

Segundo Schiffer (2002), a produção do espaço no Brasil é um dos mecanismos centrais utilizados pela elite brasileira para garantir o seu domínio, por meio da criação de áreas segregadas de alta renda - seja para moradia ou para o emprego qualificado - com o suporte do Estado para a instalação de equipamentos urbanos e infraestrutura. Segundo a autora, a segregação urbana na maioria das cidades brasileiras, e principalmente na Região Metropolitana de São Paulo, é resultado da segregação de classes, embora ela também aponte que, até a década de 1940, a segregação étnica tenha sido causada pela imigração, ambas causando efeitos na estrutura espacial das cidades. Schiffer (ibidem) aponta que a forma espacial metropolitana reflete dois processos: (1) o primeiro é o processo histórico local, que basicamente começou com o crescimento da industrialização depois de 1955, sendo este seguido pela reestruturação econômica dos anos 1970, particularmente no setor manufatureiro; (2) e o segundo, o processo subsequente provocado pelos ajustes econômicos resultantes do reflexo do atual padrão de acumulação global. Dessa forma, a metrópole teria evoluído de uma orientação 
industrial para a economia terciária, caracterizada por uma elevada concentração de serviços avançados e indústrias financeiras, tendo São Paulo se consolidado como a principal sede de empresas nacionais e estrangeiras e principal centro econômico brasileiro. Ao mesmo tempo, a cidade sofreu efeitos colaterais negativos, como o desemprego crescente, enorme crescimento no número de habitantes de moradias precárias, a disseminação de enclaves 'fortificados' e a violência social, efeitos que vão ao caminho oposto da melhora de qualidade de vida da população. Essas deficiências comprometeriam a atratividade da cidade, causando o efeito oposto do almejado.

Porém, para além da discussão do poder de atratividade global de cada cidade como efeito do processo de segregação urbana dirigidos pelas minorias, é fundamental estabelecer quais as considerações no plano local, em relação ao acesso, ou a falta de acesso, por parte de setores da sociedade agrupados em territórios específicos; aprofundando, assim, a discussão quanto à cobertura de infraestrutura no contexto brasileiro. Segundo Silva (2000), a exclusão social envolveria não apenas a mais evidente falta de acesso direto aos bens e serviços básicos que caracterizam a pobreza, mas também a falta de acesso a serviços públicos que, em um mercado de trabalho em mutação, são indispensáveis para garantir um grau mínimo de sobrevivência na economia urbana. Segundo Silva (ibidem, p.39): 
O mercado de trabalho que resulta da lógica de uma economia global é, em grande parte, excludente em si mesmo; a sobrevivência à margem da atividade econômica contemporânea depende, em grande medida, do acesso aos serviços públicos em quantidade e qualidade adequados. $\mathrm{O}$ acesso básico à água $\mathrm{e}$ ao saneamento básico - os fundamentos da infraestrutura social nas cidades - é uma condição necessária para superar a pobreza urbana, assim como as conexões de energia elétrica e coleta de lixo, mas não são condições suficientes para superar a pobreza. $\mathrm{O}$ acesso a facilidades de comunicação é hoje um requisito básico para entrar no mercado de trabalho às margens das modernas empresas globais incluindo empresas de pequeno porte $e$ produção descentralizada desde a residência - o que faz com que a funcionalidade da própria residência e do bairro seja condições fundamentais para as atividades econômicas. Serviços de rede, mais do que serem minimamente disponíveis para a sobrevivência biológica, devem ser entregues em quantidade, regularidade e qualidade suficientes para apoiarem essas atividades. E essa nova inserção dos serviços implica em uma revisão conceitual das condições de acesso a redes de serviços infraestruturais.

$\mathrm{O}$ acesso às políticas de infraestrutura urbana tem um papel fundamental na conformação do espaço urbano e na distribuição heterogênea dos benefícios públicos entre os diversos segmentos da população e entre as diferentes áreas da cidade de São Paulo, 
consequentemente, contrastando ainda mais o histórico de segregação urbana da cidade colonial e seu impacto sobre a qualidade de acesso das populações. Em seu trabalho, Bischir (2009) define a segregação como a separação dos grupos sociais no espaço, gerando, ao mesmo tempo, relativa homogeneidade social interna e heterogeneidade em relação aos grupos sociais do entorno. Seus resultados demonstram que a cobertura das redes físicas infraestruturais é até considerada alta, mas, novamente, indicam que a tendência é que áreas de relativa homogeneidade social interna tendem agora para maior heterogeneidade, de acesso e de qualidade, mesmo em áreas periféricas da cidade de São Paulo.

Este trabalho confirma as evidências analisadas por Silva em 2000, que revelam que a cobertura das redes de infraestrutura tende a englobar a maior parte das principais concentrações urbanas - incluindo bairros pobres. Porém, mais importantemente, isso não contrariaria o caráter excludente do desenvolvimento urbano, que - apesar da cobertura aparentemente homogênea - disfarçaria diferenças qualitativas no acesso aos produtos destes serviços e a dimensão estratégica do controle social sobre as redes. Dessa forma, a localização específica de saídas concentradas de serviços de rede no espaço urbano define realmente quem são e onde estão os incluídos, em oposição a uma população crescente de excluídos.

Portanto, há bases sólidas que demonstram que a relação entre o acesso à rede de serviços públicos e os processos específicos de exclusão 
social estão mudando na escala urbana, assim como a maior parte das relações econômicas e sociais estão sendo cada vez mais expostas a ajustes econômicos ligados a chamada economia global (SILVA, 2000, p.61):

Ao contrário de países industriais avançados, a nacionalização da oferta de redes de serviços no Brasil não foi capaz de superar todas as características de exclusão anterior - pré-1940 oferta privada e praticamente não regulamentada. As necessidades de uma demanda industrial crescente por serviços públicos têm precedência sobre as necessidades de reprodução social e as primeiras décadas do modelo estatal de fornecimento foram caracterizadas por uma clara exclusão de grupos de baixa renda. Durante os anos 80 , no entanto, a cobertura da maior parte das redes de utilidades urbanas aumentou dramaticamente, resultando em um grau de perversidade nunca antes visto no Brasil. Porém, essa tendência à cobertura universal coincidiu com uma situação em que a maioria das concessionárias sofria fortes restrições de investimento em suas capacidades centrais para a produção, resultando em um descompasso entre seus suprimentos globais e as capacidades de distribuição recentemente reforçadas. Como consequência, o acesso desigual à infraestrutura se refletiu em uma fonte não confiável e de baixa qualidade na periferia dos principais sistemas, ao invés de domicílios totalmente desconectados.

A discussão e a procura de soluções concretas quanto ao descompasso sociotécnico provocado pela falta de abrangência e interligação das redes de serviços públicos na metrópole têm se mostrado 
descontínua, com períodos mais ou menos intensos. Um momento importante de culminação desses objetivos aconteceu em 2006 por uma iniciativa intitulada de "Cadastro Único" (Instituto de Engenharia, 2006). Contudo, essa excelente iniciativa não encontrou campo férteis para a sua evolução, sendo interrompida devido a vários fatores indicados pelas diferentes partes interessadas. Esses estão relacionados nos parágrafos que se seguem.

No auge das iniciativas de integração entre os diferentes órgãos e operadoras, públicas e privadas, que compõem o universo da rede de serviços de infraestrutura, a porta-voz do grupo - a Secretaria Municipal de Infraestrutura e Obras - expôs a sua preocupação em promover a 'manutenção' da cidade com planos de curto e médio prazo. O caráter temporal apresentado demonstra prontamente a dificuldade de efetivação de um plano complexo de integração que visava a totalidade das redes, que, sem dúvida, não seria possível de ser executada tão rapidamente.

Do ponto de vista do Departamento de Controle de Uso das Vias Públicas - Convias, a preocupação se dá pelos custos envolvidos nas obras e nos conflitos ocasionados nas vias públicas. Assim, na ocasião a mesma defendeu a cobrança de taxas para cobrir despesas com obras.

O Canal de articulação entre o poder público municipal e as concessionárias de serviços públicos - CEC, ofereceu apoio ao quadro de 
gestão do uso e ocupação das vias públicas, de forma a facilitar essas operações.

A Sabesp expôs que suas operações já desenvolviam levantamentos cartográficos e a criação de base de dados com o GIS, que caminharia para abranger informações de várias concessionárias.

A Comgás na época já contava com levantamento em GIS de $100 \%$ de sua rede, e criticou que $65 \%$ dos problemas de suas redes são provocados por terceiros. Na ocasião existia um plano de prevenção de danos entre a Comgás e a Sabesp, para a troca de informações sobre as mesmas redes. A Eletropaulo apresentou que seu cadastro estaria progredindo para uma sistematização geográfica em GIS.

No campo das telecomunicações, a Telefônica ratificou que possui um sistema - SAGRE - de cadastro de rede externa, que possibilita o gerenciamento e a manutenção automatizada do sistema. A associação Telcomp arguiu que a troca de informações entre as concessionárias era muito frágil, sendo necessário um planejamento integrado entre todos os agentes. Essa levantou a dificuldade de criar uma linguagem unificada para a criação de uma base georeferenciada comum, atentando para a complexidade de se mapear redes de alcance nacional, como é o caso da rede de telecomunicações. 
O Metrô, atentou para a grande demora na coleta de informações sobre as redes e solicitou um maior comprometimento das operadoras com os cronogramas de projetos e obras.

O mais importante instrumento apresentado na iniciativa de integração das redes infraestruturais foi realizado pela Secretaria de Estado de Economia e Planejamento. O SIGPLAN - instrumento de planejamento das políticas públicas - teria o intuito de evitar o conflito entre as obras. Esse instrumento propunha o georeferenciamento no nível das três regiões metropolitanas de São Paulo, de forma a sistematizar as principais redes e equipamentos existentes, as suas obras de expansão, assim como informações socioeconômicas, urbanísticas e ambientais. Após essa data, o SIGPLAN foi substituído pelo Sistema Integrado de Planejamento de Orçamento - o SIOP, e ainda se encontra em desenvolvimento.

A Secretaria Municipal de Planejamento - MDSP - apresentou a iniciativa de realizar o mapeamento digital de São Paulo, que faria o levantamento e a identificação de todos os aspectos existentes na cidade (não fica claro quais seriam ' todos esses aspectos' ). Estes dados coletados se comunicariam com outros sistemas, como o da Prefeitura, o que constituiria, assim, o Sistema Municipal de Informações - SMI.

Por último, a Secretaria de Energia, Recursos Hídricos e Saneamento do Estado de São Paulo atenta para um grande problema que 
dificulta a ampliação e interligação das redes, a malha informal da cidade. Nesse sentido, a informalidade estaria causando um grande impacto nas operações e nos rendimentos dos serviços de infraestrutura, que, por sua vez, a deixa aquém dos padrões necessários para que se pudessem desenvolver projetos mais ousados. Do ponto de vista da Secretaria, por conseguinte, deveria ser privilegiada a manutenção preventiva das infraestruturas já existentes.

No momento não é possível dizer que exista uma iniciativa e um instrumento concreto e operante, que tenha conseguido dissolver as tensões existentes dentre todas as partes, os setores de planejamento, as associações de classe, as operadoras e concessionárias.

Dessa forma, é imperativo que a conectividade do território urbano seja hoje avaliada em uma perspectiva que vá além das ligações físicas entre as propriedades e as instalações infraestruturais, de forma a ampliar a visibilidade das representações políticas e as suas aproximações, ou não, dos objetivos democráticos. Nessa perspectiva, devem-se incluir a análise da qualidade e da gestão das redes de serviços, elementos estes que têm a capacidade de modificar o destino do material visível acima das superfícies da cidade. 


\subsection{0 desenho da infraestrutura urbana na RMSP}

Esta parte da pesquisa tem por finalidade organizar as informações levantadas na pesquisa empírica das redes de infraestrutura urbana para a Região Metropolitana de São Paulo, com a intenção de representar os dados no campo territorial, de forma a possibilitar a identificação da diferenciação do espaço urbano com base na distribuição física e qualitativa das redes de infraestrutura urbana.

Aqui, identificaram-se quais indicadores poderiam melhor representar a diferença da qualidade das redes de serviços públicos entre setores censitários, zonas, distritos, ou municípios, assim como a consequente carência por melhorias por parte de seus residentes, trabalhadores, ou mesmo, visitantes. Para melhor identificação dessas diferenças, foram criados mapas de diferenciação, que pudessem evidenciar as discrepâncias na cobertura, qualidade de distribuição e, por vezes, consumo de recursos da Região Metropolitana de São Paulo. Foram analisados dados quanto aos serviços de infraestrutura de energia, gás canalizado, telecomunicações, transportes e saneamento, dentre estes, a rede de água e esgoto e coleta de lixo, e também dados de pavimentação e iluminação pública.

Uma radiografia das forças da infraestrutura urbana foi delineada, a fim de permitir que essas diferenças pudessem ser desenhadas no território da metrópole, o que, em outros campos de 
investigação do tema, por exemplo, no campo da sociologia, economia ou política, têm sido representadas apenas por meio de uma classificação socioeconômica, não sendo averiguados os possíveis efeitos ou consequências dos determinantes espaciais, territoriais.

Para além do desenho das 'veias' do território estudado, já descritas, identificaram-se as importantes articulações, os pontos de interesse imobiliários, as dinâmicas e os fluxos de intensidade entre os diversos espaços da metrópole. Esses estudos foram determinantes no sentido de buscar tendências quanto à justaposição entre essas diversas condições especuladas.

As chamadas 'articulações' urbanas foram sobrepostas a todos os mapas georreferenciados produzidos no início do capítulo 3, o que incluiu os dados socioeconômicos e os dados de cobertura e qualidade das redes infraestruturais. $\mathrm{O}$ resultado da justaposição dessa vasta gama de informações foi organizado em duas matrizes que relacionaram as OUCs ao quadro socioeconômico e as infraestruturas urbanas.

No subcapítulo 3.3 demonstraram-se os impactos metropolitanos a partir do potencial de atração de determinadas zonas devido à oferta, ou carência, de empregos, comércio, educação e/ou lazer; por meio dos chamados 'fluxos metropolitanos'. Aqui também comprovaram-se algumas tendências quanto à oferta ou carência de infraestrutura para essas mesmas áreas de articulação e fluxos estudadas. 


\section{Estatísticas básicas da RMSP}

A fim de ilustrar o espaço metropolitano estudado nessa pesquisa, apresentam-se à seguir algums mapas gerais que configuram o território da RMSP.

Conforme apresentado no item 2.7 (A estruturação metropolitana), a RMSP é composta por 39 municípios (Mapa 1): Arujá, Barueri, Biritiba-Mirim, Caieiras, Cajamar, Carapicuíba, Cotia, Diadema, Embu, Embu-Guaçu, Ferraz de Vasconcelos, Francisco Morato, Franco da Rocha, Guararema, Guarulhos, Itapecerica da Serra, Itapevi, Itaquaquecetuba, Jandira, Juquitiba, Mairiporã, Mauá, Mogi das Cruzes, Osasco, Pirapora do Bom Jesus, Poá, Ribeirão Pires, Rio Grande da Serra, Salesópolis, Santa Isabel, Santana do Parnaíba, Santo André, São Bernardo do Campo, São Caetano do Sul, São Lourenço da Serra, São Paulo, Suzano, Taboão da Serra e Vargem Grande Paulista.

Os limites dos municípios que compõem a RMSP podem ser visualizados na sobreposição destes com a imagem de satélite mais atual produzida para essa pesquisa. No Mapa 2 tem-se um entendimento importante da região em relação a composição de áreas urbanizadas (tons em vermelho), áreas de cobertura vegetal (tons de verde) e áreas de recursos hídricos (tons azul escuro). Basicamente, a mancha urbanizada tem uma forma radial concêntrica, com centro no MSP, e é circundada por áreas rurais ou de proteção ambiental. 


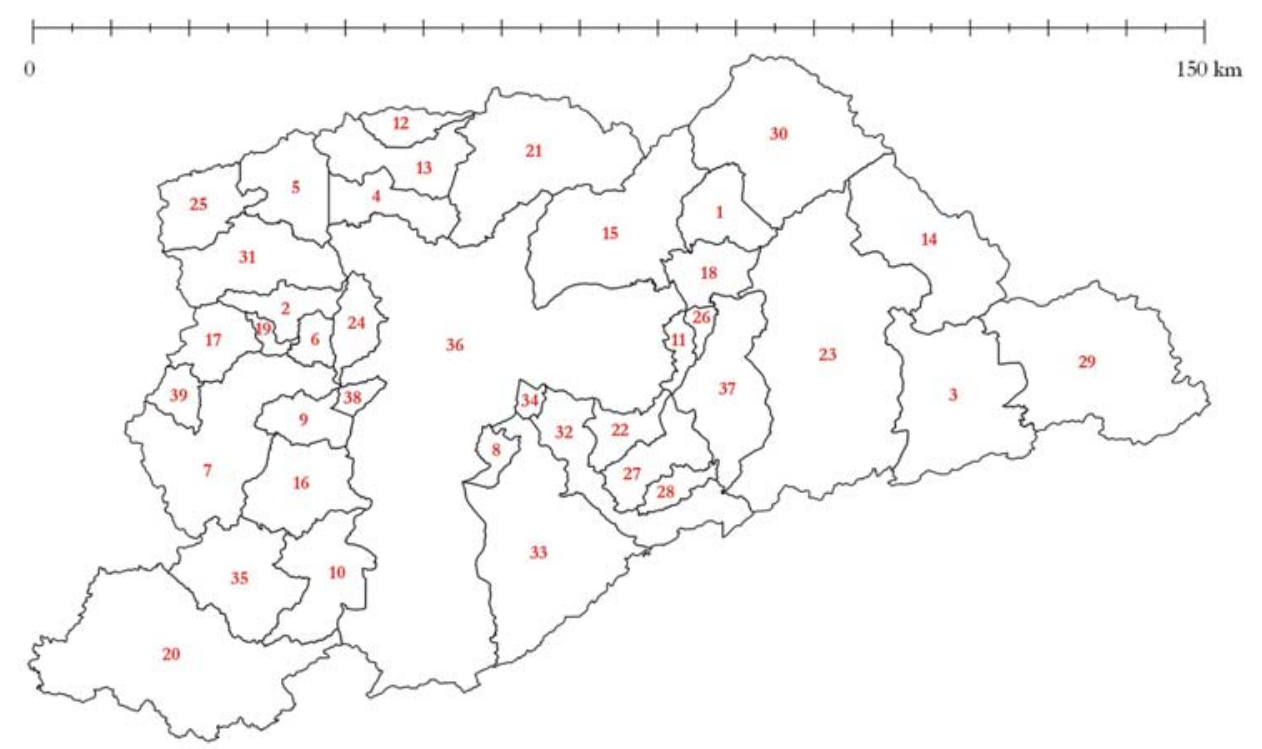

$\begin{array}{ll}1 & \text { Arujá } \\ 2 & \text { Barueri } \\ 3 & \text { Biritiba-Mirim } \\ 4 & \text { Caieiras } \\ 5 & \text { Cajamar } \\ 6 & \text { Carapicuíba } \\ 7 & \text { Cotia } \\ 8 & \text { Diadema } \\ 9 & \text { Embu } \\ 10 & \text { Embu-Guaçu } \\ 11 & \text { Ferrraz de Vasconcelos } \\ 12 & \text { Francisco Morato } \\ 13 & \text { Franco da Rocha }\end{array}$

14 Guararema

15 Guarulhos

16 Itapecerica da Serra

17 Itapevi

18 Itaquaquecetuba

19 Jandira

20 Juquitiba

21 Mairiporã

22 Mauá

23 Mogi das Cruzes

24 0sasco

25 Pirapora do Bom Jesus

26 Poá

27 Ribeirão Pires

28 Rio Grande da Serra

29 Salesópolis

30 Santa Isabel

31 Santana de Parnaíba

32 Santo André

33 São Bernardo do Campo

34 São Caetano do Sul

35 São Lourenço da Serra

36 São Paulo

37 Suzano

38 Taboão da Serra

39 Vargem Grande Paulista

Mapa 1. Municípios de compõem a RMSP.

Mapa elaborado pela própria autora.

Fonte: CEM, 2007b. 


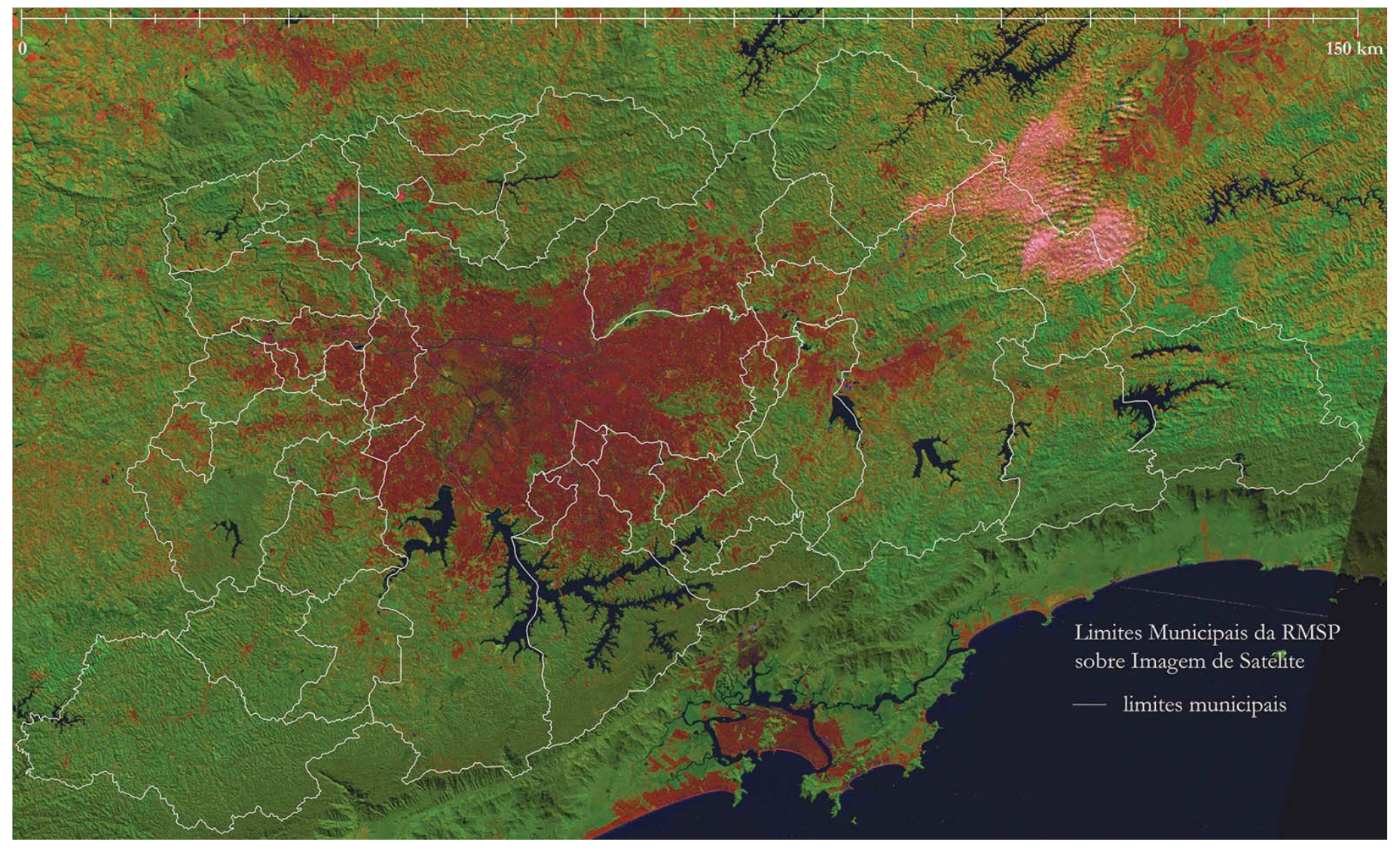

Mapa 2. Limites municipais da RMSP sobre imagem de satélite.

Mapa elaborado pela própria autora.

Fonte: CEM, 2007b; LANDSAT TM 5: imagem de satélite. São José dos Campos: Instituto Nacional de Pesquisas Espaciais, 2011. 3 fotografias aéreas. Canais 3,4, 5 e composição colorida 5,4 e 3 . 


\section{Formas de agregação de dados}

De forma a caracterizar a diferenciação do espaço metropolitano por seus diversos aspectos, distintas fontes de dados foram compostas para possibilitar a leitura de um cenário abrangente. Dessa forma, a coleta de informações dependeu de um esforço de compatibilização de diversas formas de agregação de dados, estes, por sua vez, definidos na origem da fundamentação metodológica de cada base infraestrutural.

Primeiramente, foi empregada nesta pesquisa a forma de agregação de dados do Censo, referentes aos setores censitários, que representa: "a menor unidade territorial, formada por área contínua, integralmente contida em área urbana ou rural, com dimensão adequada à operação de pesquisas e cujo conjunto esgota a totalidade do Território Nacional [...]" (IBGE, 2011, p.4). Quanto a sua base territorial:

O setor censitário é a unidade territorial de controle cadastral da coleta, constituída por áreas contíguas, respeitando-se os limites da divisão político-administrativa, do quadro urbano e rural legal e de outras estruturas territoriais de interesse, além dos parâmetros de dimensão mais adequados à operação de coleta. (ibidem, p.9) 
O desenho destes setores pode ser visualizado no Mapa 3. Por meio da pesquisa de dados do Censo de 2010, foi possível cruzar os dados do cadastro alfanumérico com as representações espaciais, criando, assim, uma base de dados geoespaciais ${ }^{30}$.

As bases da coleta de dados que utilizaram a característica de agregação de dados dos setores censitários foram todas aquelas que usaram como dados primários a pesquisa do Censo: o número de domicílios com cobertura de energia elétrica de concessionária; os domicílios com abastecimento de água da rede geral; os domicílios com coleta de lixo; os dados do entorno dos domicílios com ou sem pavimentação e iluminação pública.

Na pesquisa Origem e Destino do Metrô de 2007, as variáveis foram agregadas por zonas, sendo a RMSP dividida em 460 zonas e o MSP, composto por 96 distritos, em 320 zonas de pesquisa. Segundo o relatório síntese da pesquisa OD:

\footnotetext{
${ }^{30}$ É necessário destacar que, apesar destes dados serem divulgados e possivelmente utilizados em todo o território nacional, a compatibilização dessas bases com o objetivo de compreender os dados básicos socioeconômicos e a cobertura de infraestrutura na RMSP se mostrou extremamente dificultosa, levando três vezes o tempo planejado para tal. As consultas ao IBGE devem ser obrigatoriamente realizadas por e-mail, e demoram, em média, 15 dias corridos para o retorno de uma dúvida, sem que esta seja esclarecida. Esse demorado processo chegou a quase inviabilizar a publicação deste conteúdo, apenas possível por meio do auxílio de pesquisadores da FAU USP, que passaram pelos mesmos problemas anteriormente.
} 
Os critérios para definição do zoneamento de 2007 foram os seguintes: comparabilidade com o zoneamento da Pesquisa Origem e Destino 1997, compatibilidade com os limites de municípios e de distritos no município de São Paulo, consideração dos limites de setores censitários de 2000 do IBGE [...]. Foram ainda considerados no zoneamento o sistema de transporte, os equipamentos urbanos, as barreiras físicas e as áreas vazias. (SÃO PAULO - ESTADO, 2007, p.7)

A geografia das zonas OD pode ser observada no Mapa 4. Os dados desta pesquisa, que utilizaram esse tipo de agregação por zonas $\mathrm{OD}$, foram aqueles referentes aos dados socioeconômicos quanto a população, renda, emprego e número de viagens por diferentes motivos (trabalho, educação e lazer) e modos (transporte coletivo ou transporte individual motorizado).

A agregação dos dados de telecomunicações, assim como os do SNIS, de coleta e tratamento de esgoto, é representada pelo nível municipal, sendo assim, muito agregados. O desenho dos limites territoriais dos municípios pode ser visto no Mapa 1.

Os dados de saneamento, mais especificamente de abastecimento de água e infiltração das bacias de esgotamento provenientes da Sabesp, utilizaram, tal como diz o nome, a agregação dos setores de abastecimento e das bacias de esgotamento, que respeita as características hidrológicas desses recursos. Respectivamente, os limites territoriais dessas bacias podem ser visualizados nos Mapa 5 e Mapa 6. 


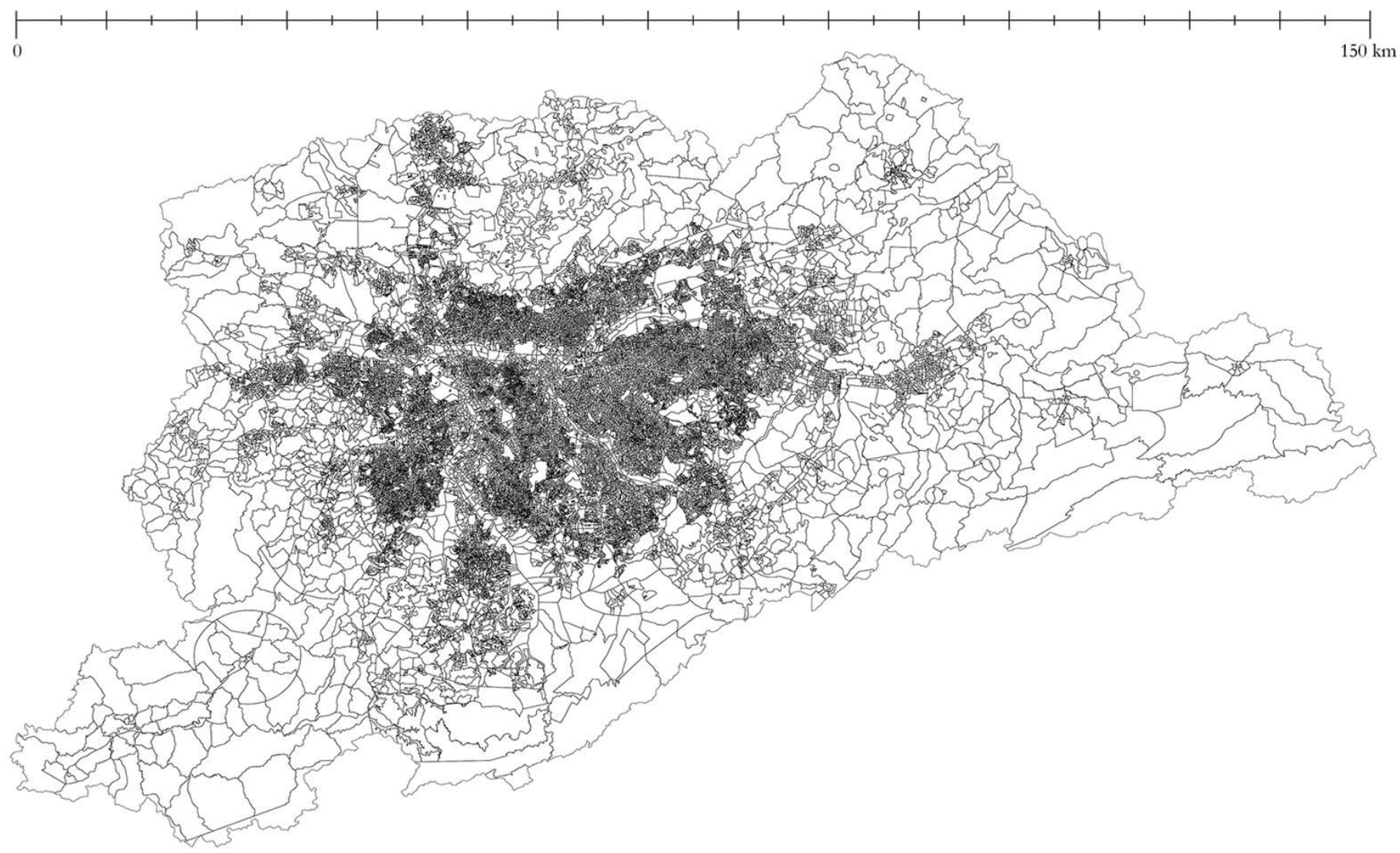

Mapa 3. Áreas de agregação dos setores censitários do Censo IBGE.

Setores censitários

Mapa elaborado pela própria autora.

Fonte: IBGE, 2010.

áreas de agregação 


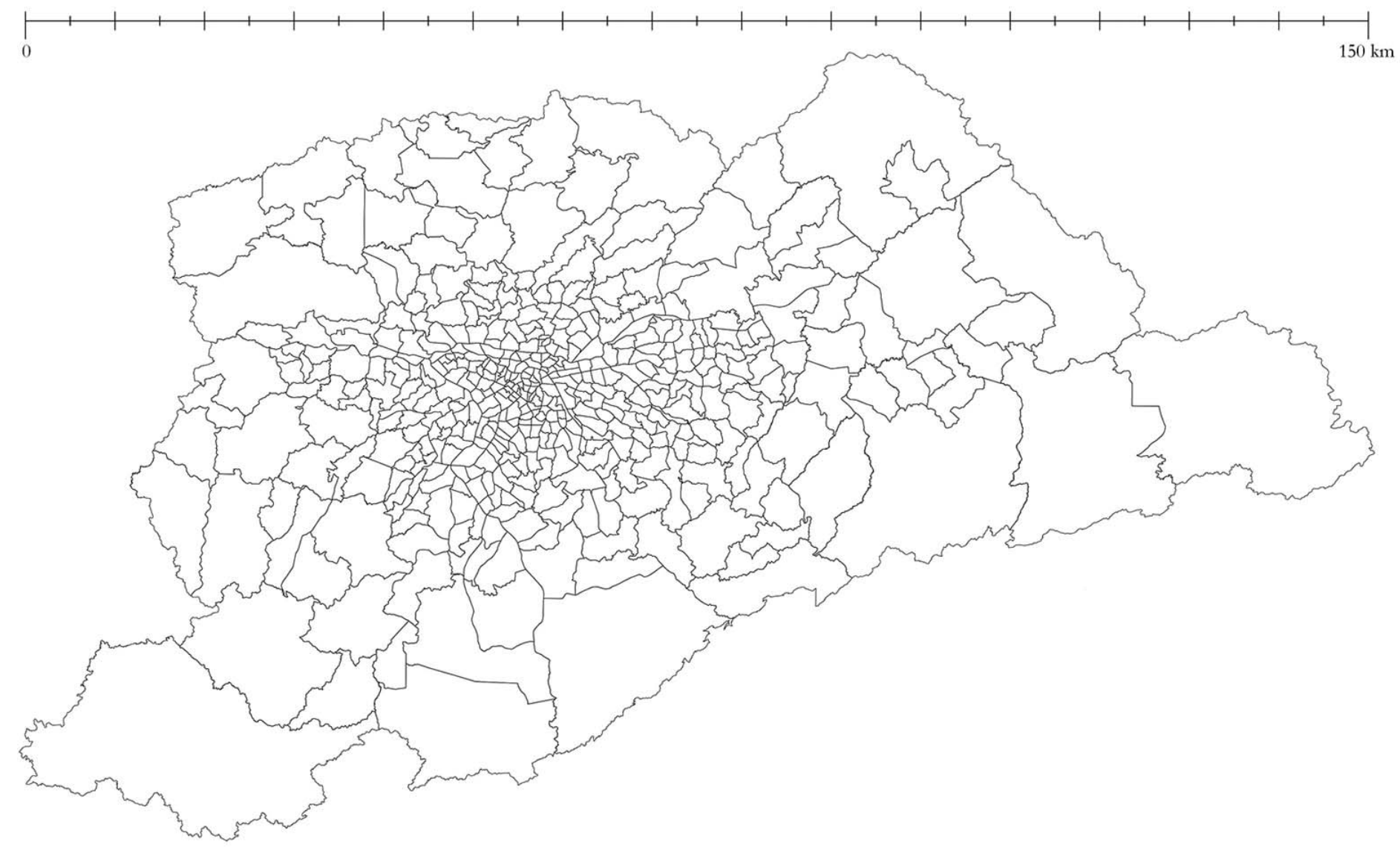

Mapa 4. Áreas de agregação das zonas OD do Metrô.

Mapa elaborado pela própria autora.

Fonte: SÃO PAULO (ESTADO), METRO, 2007.

Zonas OD

áreas de agregação 


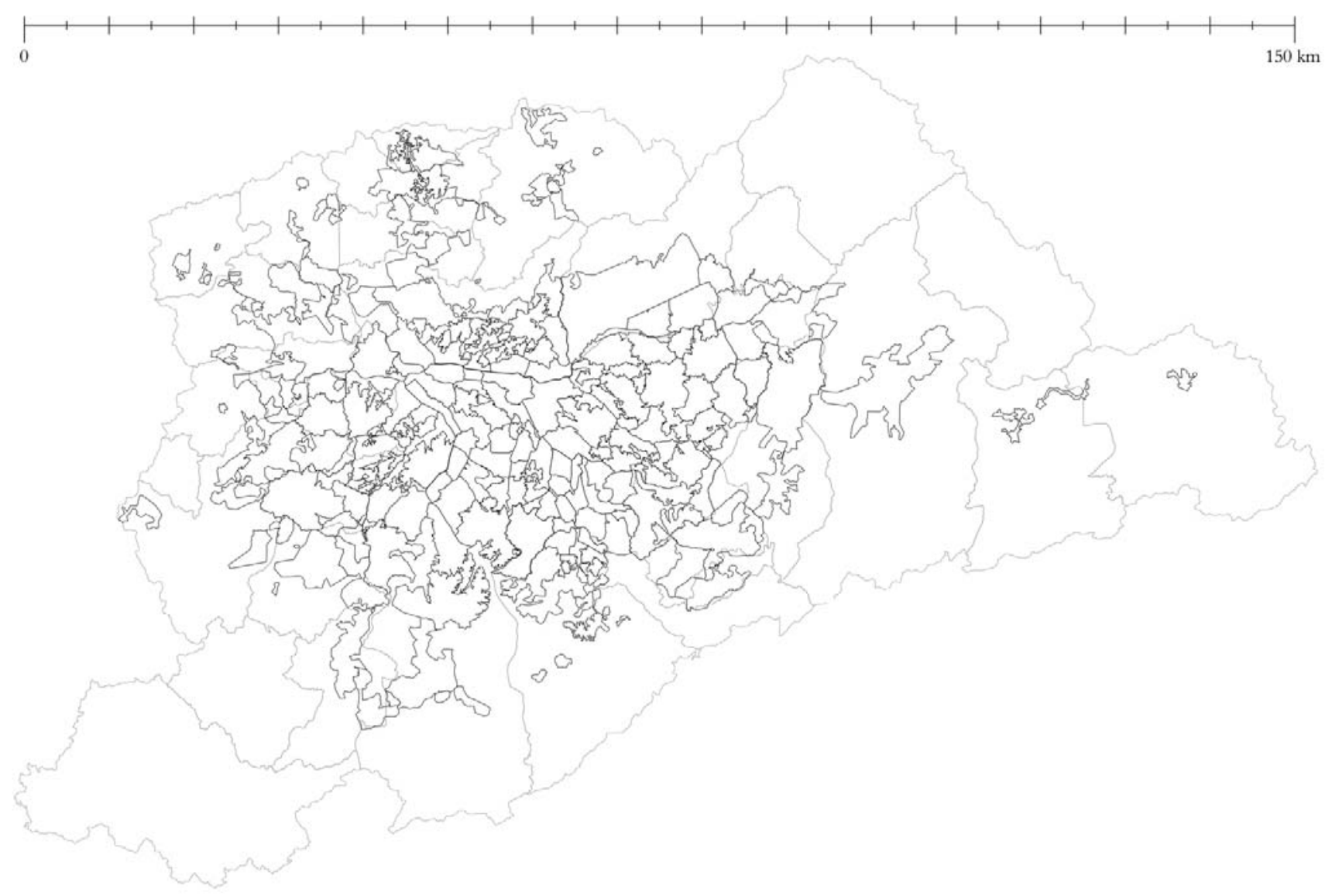

Bacias de abastecimento

Mapa 5. Áreas de agregação das bacias de abastecimento da Sabesp.

Mapa elaborado pela própria autora.

áreas de agregação

Fonte: SÃO PAULO (ESTADO), SABESP, 2015; CEM, 2007b.

limites municipais 


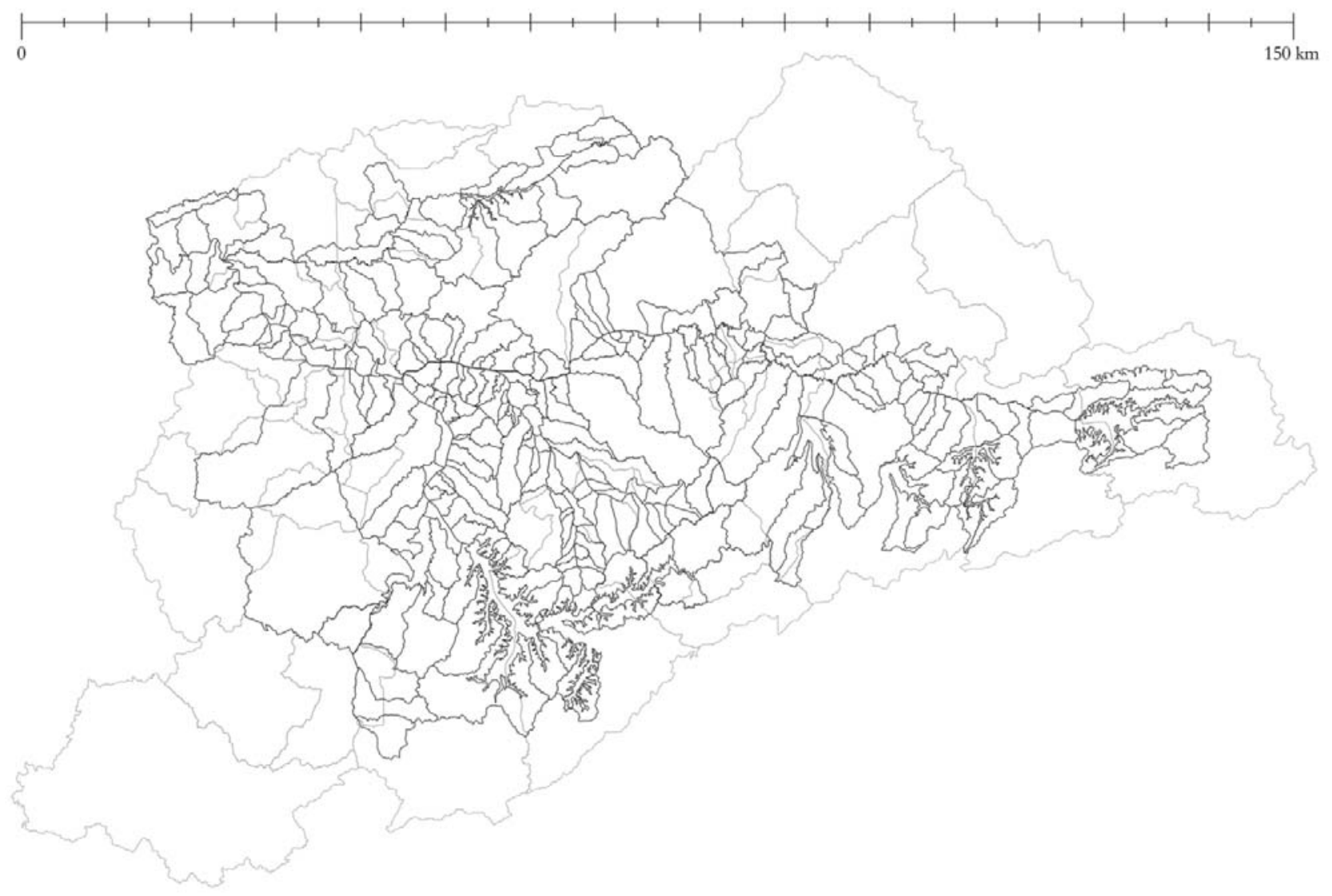

Mapa 6. Áreas de agregação das bacias de esgotamento da Sabesp.

Mapa elaborado pela própria autora.

Bacias de esgotamento

áreas de agregação

limites municipais 
A verificação dos dados de cobertura e qualidade dos serviços infraestruturais no território, apresentada nesta etapa da pesquisa, foi fundamental para a caracterização do espaço metropolitano de São Paulo, e, dessa forma, para a demonstração do argumento e hipótese desta tese: a de que projetos de renovação urbana em cidades em desenvolvimento, que integram melhorias em relação à cobertura e qualidade de infraestrutura urbana - diferenciadas em relação ao entorno -, tendem a perder as qualidades intrínsecas que os diferenciam, sendo os seus benefícios atenuados e dissipados no território metropolitano.

\section{Método de classificação dos dados cartográficos}

Devido ao grande volume dos dados quantitativos coletados e mapeados, houve a necessidade de classificá-los de forma a facilitar tanto a descrição quanto a ilustração dos mesmos. O tratamento estatístico das bases diferiu quanto aos modos de classificação de resultados empregados, devido às diversas naturezas de informações e a necessidade de mais justa interpretação dos resultados.

Os dados coletados que possuíam uma referência de eficiência definida pela agência reguladora foram graduados de acordo com as classes estabelecidas pelas mesmas. Estes foram os casos das bases da Anatel (telecomunicações), Sabesp (abastecimento de água e taxas de 
infiltração das bacias de esgotamento), Aneel (fornecimento de energia) e Arsesp (gás).

Em relação às bases de dados do Censo do IBGE, os resultados foram graduados por 'intervalos iguais' constantes, que atribui intervalos constantes e iguais para cada classe, sendo assim, as classes de porcentagem de mesmo 'tamanho' de forma a avaliar a cobertura de determinada infraestrutura. Este também foi o caso do tratamento de dados do SNIS (esgoto).

As bases de dados da pesquisa OD foram graduadas pelo modo Quantil, no qual o total do conjunto dos dados é subdividido em um número de classes, em que cada uma tem o mesmo número de observações. Após diversos testes, esse método se mostrou a melhor forma de promover a igual interpretação dos resultados, já que o universo da análise da pesquisa era muito amplo.

\section{Dados socioeconômicos}

A geografia da densidade populacional da RMSP pode ser visualizada no Mapa 7, no qual é possível identificar polos de densidade (100 - 309 hab/ha), concentrados no núcleo da região. As zonas mais adensadas são a Treze de Maio (309 hab/ha), o Bixiga (263 hab/ha) e Higienópolis (259 hab/ha). Há áreas de pouca densidade (18 - 100 hab/ha) entre estes polos, mais baixas quando confluentes com os rios 
Pinheiros e Tietê, e de baixíssima densidade ( 0 - 18 hab/ha) nas largas margens que delimitam a região com o entorno.

Vale lembrar que a densidade residencial analisada a partir dos dados da OD representam a densidade bruta, definida como aquela que resulta da divisão entre a população residencial pela área da zona OD onde essa população reside, incluindo-se neste caso, as áreas livres e áreas de vias. Contudo, seria adequado reproduzir em um mapa os valores de densidade líquida, aquela que relaciona a população residente com a área relativa apenas aos terrenos ocupados por residências. Devido a dificuldade de composição e tratamento de dados geoespaciais, não foi possível a finalização desse mapa a tempo da conclusão dessa tese. Entretanto, deve-se alertar para o fato significativo de que a densidade líquida permitiria uma compreensão mais fiel quanto ao nível de concentração ou dispersão da população, o que representa um cenário bem distinto daquele ilustrado no Mapa 7. O que veríamos no caso da densidade líquida seria um quadro de densidade muito alta nas periferias, onde a quantidade de pessoas por cômodo e/ou residência é bem maior do que nas áreas centrais, ao contrário do ilustrado no Mapa 7.

A composição da renda média (renda total dividida pelo número de domicílios totais) em salários mínimos da RMSP pode ser visualizada no Mapa 8, em que é possível identificar raros polos de renda superior (acima de 8 salários mínimos), concentrados principalmente na região 
oeste do MSP, que engloba bairros como o Alto de Pinheiros, a Chácara Flora, o Jardim Europa, Moema, Pacaembu, Real Parque e Vila Nova Conceição. A maior área territorial da RMSP apresenta rendas médias entre 1,5 a 3 salários mínimos, sendo que a maior parte da área urbanizada (ver Mapa 2) apresenta rendas entre 3 e 5 salários mínimos.

Quanto à densidade de empregos (empregos/ha), vemos no Mapa 9 a clara concentração das maiores densidades no núcleo do MSP, basicamente englobando as zonas que circundam a região da Sé até confrontar com o Rio Tietê ao norte e o Rio Pinheiros a oeste. As maiores densidades se encontram nas zonas da Sé (1.623 emp/ha), República (1.524 emp/ha) e Consolação (706 emp/ha). Neste núcleo descrito acima, o pior resultado se encontra no Pacaembu, com apenas $27 \mathrm{emp} / \mathrm{ha}$. Há importantes polos de emprego representados pelas zonas de Guarulhos, Osasco e Santo André, assim como eixos importantes ao sul da MSP, como Brooklin - Granja Julieta - Santo Amaro, e zona leste Pari - Belém - Tatuapé. $\mathrm{Na}$ análise da taxa de empregos, em que se considera o número de empregos por população residente, é possível identificar com ainda mais clareza, no Mapa 10, quais são aquelas regiões nitidamente desprovidas de oferta nas localizações que apresentam densidades populacionais consideráveis (ver novamente Mapa 7. Densidade populacional.). Este é o caso, ao norte, de Francisco Morato e Franco da Rocha, a oeste, Itapevi, ao sul, Itapecerica da Serra e Grajaú, e a leste, Vila Ema, Parque São Lucas e Sapopemba, para citar alguns exemplos. 


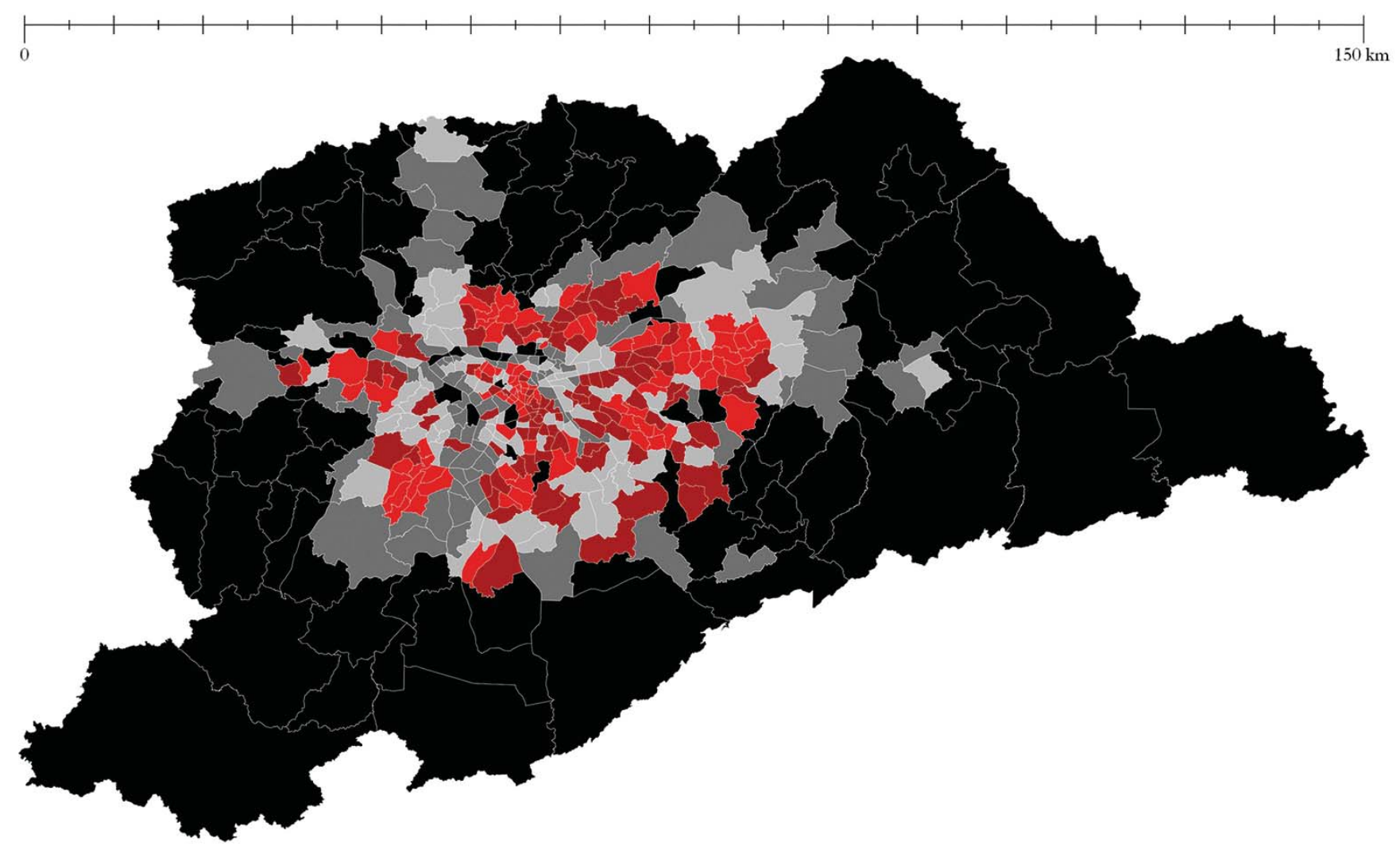

Densidade populacional

[hab/ha]

0-18

18-60

60-100

Mapa 7. Densidade populacional.

Mapa elaborado pela própria autora.

100-150

Fonte: SÃO PAULO (ESTADO), METRO, 2007.

150-309 


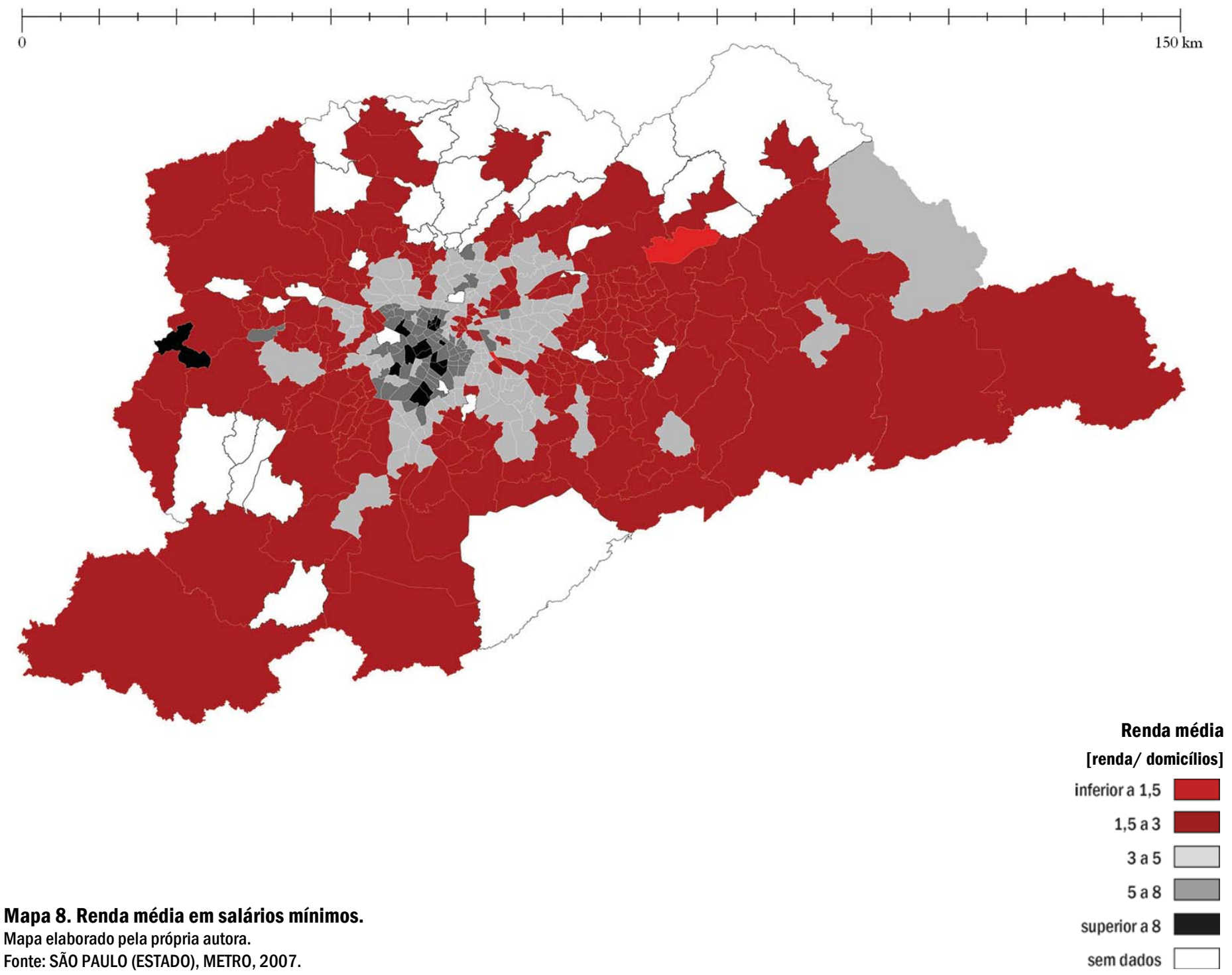




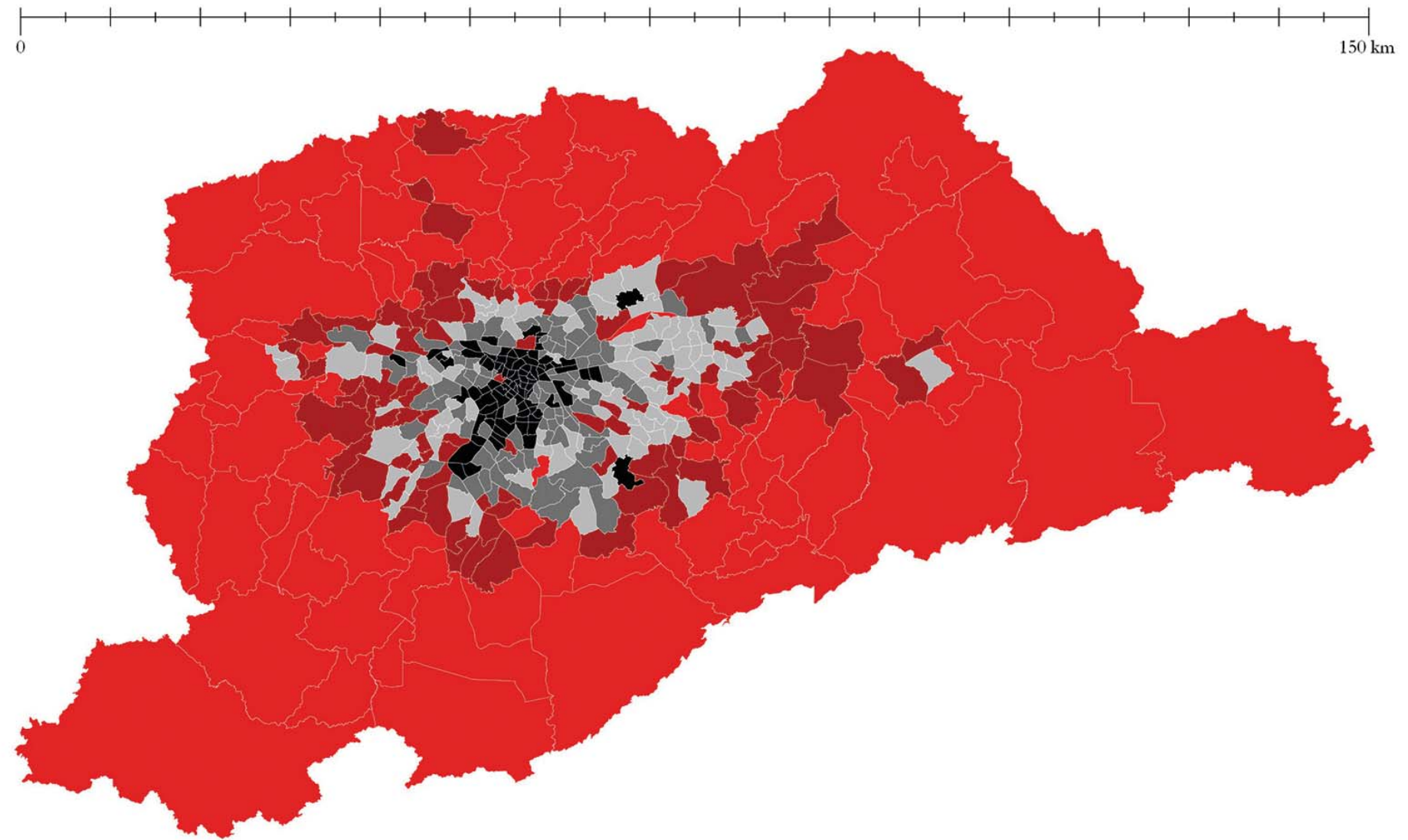

Densidade de emprego

[empregos/ha]

0 - 9

$9-32$

32 a 52

Mapa 9. Densidade de emprego.

Mapa elaborado pela própria autora.

52 a 104

Fonte: SÃO PAULO (ESTADO), METRO, 2007.

104 - 1.624

sem dados 


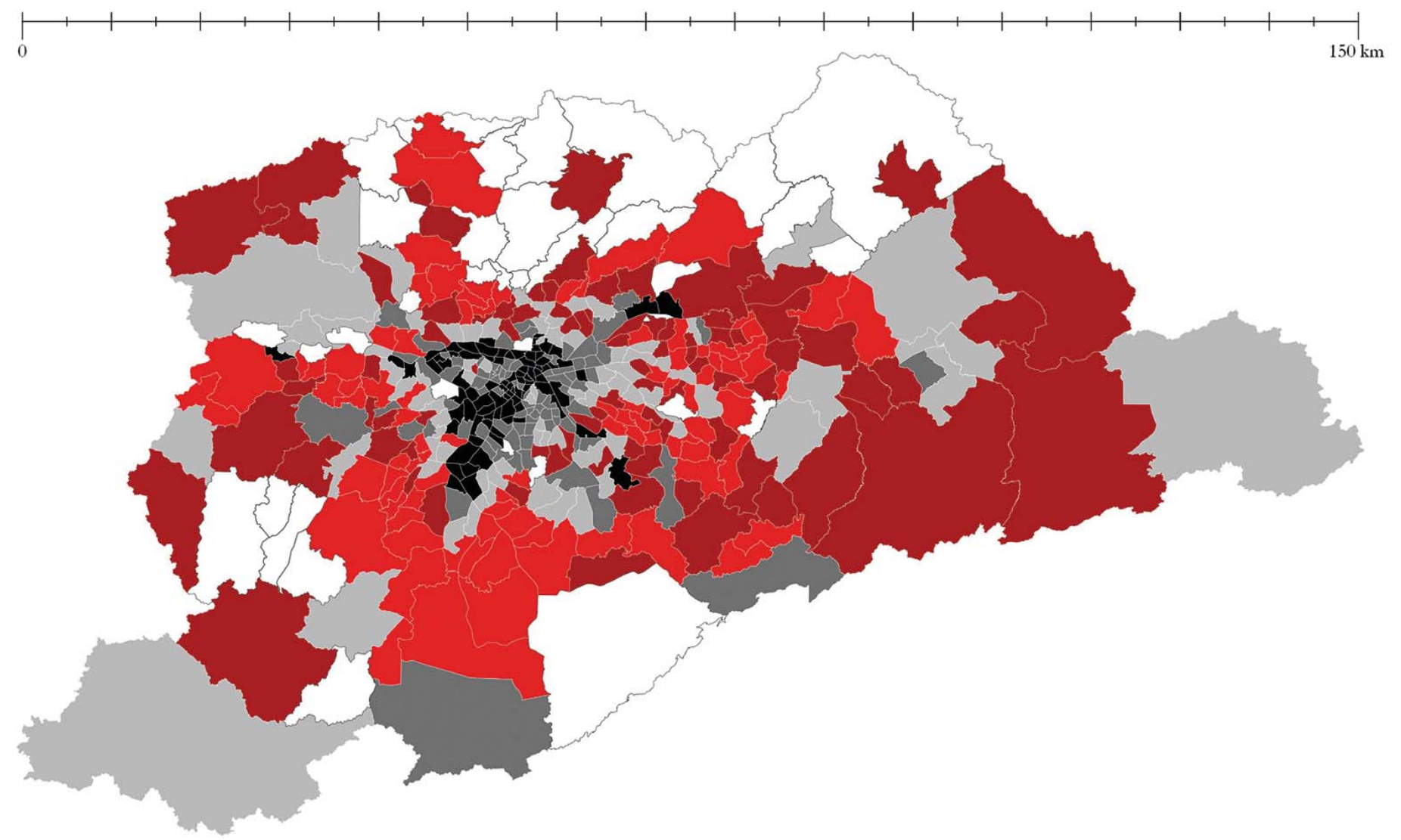

Taxa de emprego

[empregos/residentes]

$0-0,22$

$0,22 \cdot 0,34$

$0,34-0,62$

$0,62-1,60$

$1,60-39,08$

Mapa 10. Taxa de emprego.

Mapa elaborado pela própria autora.

Fonte: SÃO PAULO (ESTADO), METRO, 2007.

sem dados 


\subsubsection{A rede de energia}

De acordo com a discussão nos capítulos anteriores, viu-se que, além da heterogeneidade ou homogeneidade da cobertura de uma rede de infraestrutura, a qualidade desta interfere no futuro do desenvolvimento de cada distrito ou subdistrito de uma região. Percebeu-se também que dados de qualidade são de difícil aquisição, visto que estes representam informações que, inclusive, induzem a implicações em níveis judiciais, o que exporia a vulnerabilidade das empresas concessionárias: públicas, privadas ou na combinação de ambas.

No caso desta pesquisa, na parte de energia elétrica, procurou-se o contato de profissionais especialistas na área de infraestrutura, para que estes pudessem discutir a hipótese e, quando pertinente, questões mais específicas desta tese. Estas discussões estão sintetizadas ao fim desta seção. Mais precisamente no campo da energia, depois de longas discussões com ex-presidentes e vice-presidentes da Eletropaulo e de agências reguladoras no setor, foi possível localizar dados de qualidade do setor que são raramente discutidos no campo da arquitetura e urbanismo. Mais interessante ainda é que estes dados incluem todos os subdistritos que, em conjunto, englobam toda a RMSP, o que veio ao encontro do intuito de analisar a heterogeneidade do território na escala da metrópole.

De acordo com entrevista realizada com o Prof. Dr. Aderbal de Arruda Penteado Junior (2012), foram obtidos os primeiros dados 
analisados na pesquisa, conforma as regras de regulamentação para supervisão, avaliação e controle da regularidade no serviço de fornecimento de energia, item 5 do Módulo 8 dos Procedimentos de Distribuição de Energia Elétrica no Sistema Elétrico Nacional - Prodist, aprovado pelo instrumento da Aneel: Resolução Normativa no 469/2011 de 01/02/2012. Após esta data, o diagnóstico foi refeito de forma a atualizar os dados (para o ano de 2013) e a legislação vigente: Resolução Normativa no 641/2014. O diagnóstico foi realizado pelos Indicadores de Continuidade dos serviços públicos de energia elétrica, nos seus aspectos de duração e frequência, a serem observados pelas concessionárias e permissionárias de serviço público de distribuição e de transmissão de energia elétrica, nas unidades consumidoras e nos pontos de conexão.

Os dados coletivos foram denominados como:

- DEC - duração equivalente de interrupção por unidade consumidora;

- FEC - frequência equivalente de interrupção por unidade consumidora.

$\mathrm{E}$ os individuais como:

- DIC - duração de interrupção individual por unidade consumidora ou por ponto de conexão;

- FIC - frequência de interrupção individual por unidade consumidora ou ponto de conexão; 
- DMIC - duração máxima de interrupção contínua por unidade consumidora ou por ponto de conexão;

- DICRI - duração da interrupção individual ocorrida em dia crítico por unidade consumidora ou ponto de conexão.

DEC, DIC, DMIC e DICRI são expressos em horas e centésimos de hora e FEC e FIC, em número de interrupções e centésimos do número de interrupções, sendo calculados para períodos de apuração mensais, trimestrais e anuais, com exceção do indicador DICRI, que deve ser apurado por interrupção ocorrida em dia crítico. Os dados avaliados nesta tese foram sintetizados na Tabela 4 . 
Tabela 4. Indicadores de qualidade de fornecimento de energia elétrica.

Tabela elaborada pela própria autora.

Fonte: Arsesp.

\begin{tabular}{|c|c|c|c|}
\hline ÍNDICE & DESCRIÇÃO & REFERÊNCIA & CLASSIFICAÇÃO \\
\hline \multirow{5}{*}{ [CENSO] } & \multirow{5}{*}{$\begin{array}{l}\text { Domicílios com energia } \\
\text { elétrica de companhia } \\
\text { distribuidora }\end{array}$} & 0 a $\mathbf{2 0} \%$ & Crítico \\
\hline & & 21 a $40 \%$ & Ruim \\
\hline & & 41 a $60 \%$ & Regular \\
\hline & & 61 a $80 \%$ & Aceitável \\
\hline & & 81 a $100 \%$ & Bom \\
\hline $\begin{array}{c}\text { DEC } \\
\text { [ANEEL] }\end{array}$ & $\begin{array}{l}\text { Duração equivalente de } \\
\text { interrupção por unidade } \\
\text { consumidora }\end{array}$ & $\begin{array}{l}\text { Variável de } \\
\text { acordo com o } \\
\text { número de } \\
\text { consumidores } \\
\text { por conjunto } \\
\text { elétrico }\end{array}$ & $\begin{array}{l}\text { Observar limites } \\
\text { máximos de } \\
\text { referência } \\
\text { estabelecidos pelo } \\
\text { PRODIST }\end{array}$ \\
\hline $\begin{array}{c}\text { FEC } \\
\text { [ANEEL] }\end{array}$ & $\begin{array}{l}\text { Frequência equivalente de } \\
\text { interrupção por unidade } \\
\text { consumidora }\end{array}$ & $\begin{array}{l}\text { Variável de } \\
\text { acordo com o } \\
\text { número de } \\
\text { consumidores } \\
\text { por conjunto } \\
\text { elétrico }\end{array}$ & $\begin{array}{l}\text { Observar limites } \\
\text { máximos de } \\
\text { referência } \\
\text { estabelecidos pelo } \\
\text { PRODIST }\end{array}$ \\
\hline
\end{tabular}


Devido à dificuldade na obtenção dos dados individuais e, mesmo quando possivelmente adquiridos, na intricada aplicabilidade no tratamento destes, decidiu-se trabalhar com os dados coletivos DEC e FEC, representando, assim, os dados para todos os conjuntos elétricos (base de agregação dos dados em energia) para toda a RMSP.

Os dados foram adquiridos por meio dos relatórios de acompanhamento da Agência Nacional de Energia Elétrica - Aneel, englobando as três concessionárias que servem a RMSP: Eletropaulo, Bandeirante e Elektro. A base de dados foi coletada para o ano-base de 2013, e trabalhada para que pudesse ser referenciada geograficamente de forma a tornar possível a leitura clara da heterogeneidade entre as distintas microrregiões que compõem a RMSP. Os valores que compuseram a amostra desta análise incorporaram os DEC/FEC sem $\operatorname{expurgo}^{31}$, de forma a eliminar desvios que pudessem interferir na

31 O Módulo 8 do Prodist define os critérios para expurgo no conjunto de leituras. Um exemplo advém da ocorrência de variações temporárias de tensão ou de interrupções de longa duração, quando o intervalo de medição de dez minutos deverá ser expurgado e substituído por igual número de leituras válidas. Outros exemplos de expurgo incluem interrupções de origem externa ao sistema de distribuição, situações consideradas de emergência, interrupções vinculadas em dias considerados críticos, em dias de racionamento ou alívio de carga etc. Estes expurgos (DEC/FEC Apurados) não foram considerados nesta pesquisa, pois acabam por encobrir a realidade sofrida pelos usuários quando em uma interrupção concreta, além de poderem ser usados pelas concessionárias para, de alguma forma, mascarar seus indicadores de qualidade. 
compreensão dos dados. A comparação entre os valores finais DEC e FEC e os valores de referência limite (dependente do número de consumidores para determinado conjunto elétrico) para cada unidade territorial (conjunto elétrico) foi realizada de duas maneiras.

$\mathrm{Na}$ primeira delas, é possível visualizar os valores finais DEC e FEC no território por meio de duas barras de cores distintas, dispostas ao lado da referência limite (Mapa 13 e Mapa 16). Na segunda metodologia, o território compreendido pelo alcance dos conjuntos elétricos foi graduado de forma a expor sua adequação, ou não, aos limites estabelecidos pela reguladora (Mapa 12 e Mapa 15). O limitante desta última metodologia foi o fato de apenas ter sido possível identificar o alcance dos conjuntos elétricos no território para aqueles servidos pela AES Eletropaulo, não podendo ser identificadas as áreas das outras duas concessionárias. Por meio dessas duas metodologias, pode-se facilitar a visualização dos diferentes índices encontrados transversalmente na amostra. Os resultados ampliados para a região central do MSP podem ser visualizados nos Mapas 14 e 17.

O diagnóstico dos indicadores DEC (Mapa 12, Mapa 13 e Mapa 14) para o ano de 2013 mostra que praticamente toda a RMSP esteve fora do limite de referência, e, não timidamente, muitas vezes excedendo em quase cinco vezes o marco regulatório. Em consequência disso, não só as concessionárias sofrem implicações do ponto de vista imposto pelas reguladoras por meio da 
imposição de penalidades (como o pagamento de multas), mas, prioritariamente, os consumidores, que recebem os seus serviços com qualidade muito aquém das estabelecidas por lei. Raramente os últimos conhecem seus direitos quanto aos serviços que consomem, e quando muito, solicitam e ulteriormente recebem o ressarcimento de seus prejuízos.

O mesmo ocorre para os índices FEC (Mapa 15, Mapa 16 e Mapa 17), contudo, as diferenças entre o número de interrupções de fornecimento e os valores limite são de menor escala. Em geral, os dados são críticos para a maior parte da RMSP, exceto para algumas subestações de localizações mais centrais no MSP, que podem ser alcançadas por, muitas vezes, outras subestações em períodos críticos.

Assim, as piores médias anuais de durações equivalentes de interrupção por unidade consumidora foram medidas no conjunto elétrico Imigrantes, sendo aproximadamente de 69 horas (limite de 11 horas), Vargem Grande, 69 horas (limite de 18 horas), e Parelheiros, 45 horas (limite de 20 horas). Estes também apresentaram índices críticos de frequência equivalente de interrupção, constando, respectivamente, 26 ocorrências (limite de 9 ocorrências), 27 ocorrências (limite de 15) e 17 ocorrências (limite de 16).

Os melhores índices DEC para o mesmo período ocorreram no Centro, sendo quase nulo com 0,04 horas (limite de 3 horas), Brigadeiro, 1 hora (limite de 3) e sistema reticulado Bandeirantes (vias aterradas), com interrupção de aproximadamente 2 horas (limite de 3). Os dados 
FEC para os mesmos conjuntos seguem a boa performance destes, sendo respectivamente nulo (limite de 2 ocorrências), 2 ocorrências (limite de 2) e 1 ocorrência (limite de 2).

As piores e melhores localidades apresentadas acima acompanharam o histórico diagnosticado no momento da qualificação desta tese, permitindo dizer que há um panorama bastante consolidado da diferenciação tecnológica associada aos territórios da RMSP.

A diferença entre estes índices mostra que, apesar da homogeneidade da cobertura da rede elétrica, ilustrada no Mapa 11, há uma destacada heterogeneidade de qualidade dos serviços de provisão de energia elétrica. Contudo, mais importante do que estes resultados per si são suas implicações para o desenvolvimento urbano destas regiões que apresentam os piores índices, que normalmente se localizam em áreas mais periféricas da metrópole.

Há uma relação direta entre estes índices e a relação de confiabilidade para com os serviços de eletricidade, principalmente para aqueles setores que são eletricamente intensivos, o que acaba se constituindo em um fator desestimulante para atrair indústrias, comércios e serviços que dependem de bons índices. Além disso, por meio da divulgação destes indicadores, pela resolução da Aneel comentada anteriormente, muitas empresas eletrointensivas, em locais hoje assumidamente contingentes, alertam para a possibilidade de mudarem seus endereços (para mais informações ver Anexos: Entrevistas), o que claramente tem consequências socioeconômicas para as localidades em que se inserem (emprego-renda). 


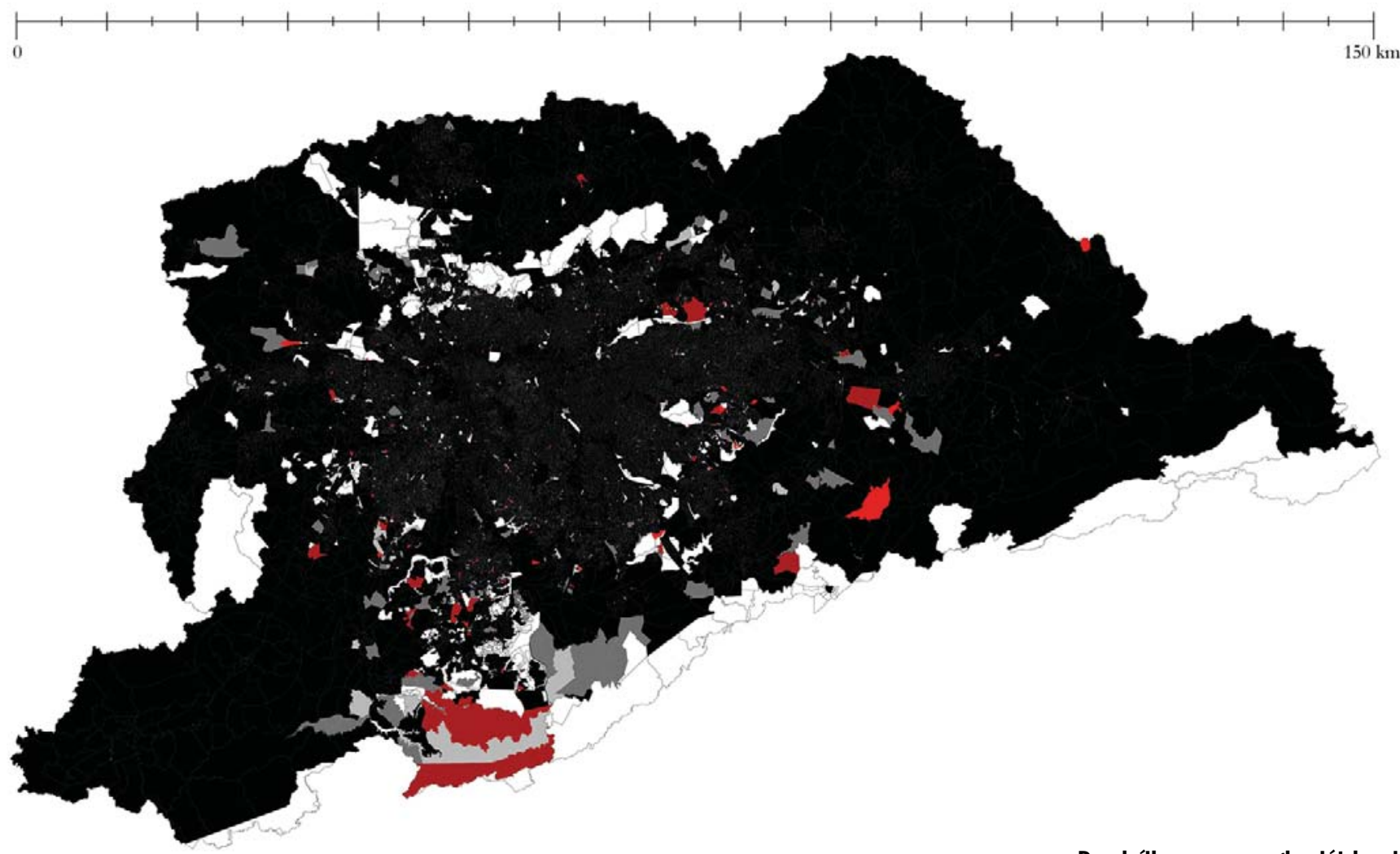

Domicílios com energia elétrica de companhia distribuidora $[\%]$

$$
0-20
$$$$
20 \text { a } 40
$$$$
40 \text { a } 60
$$

Mapa 11. Domicílios com energia elétrica de companhia distribuidora.

Mapa elaborado pela própria autora.

80 a 100

sem dados

Fonte: IBGE, 2010; CEM, 2007b. 


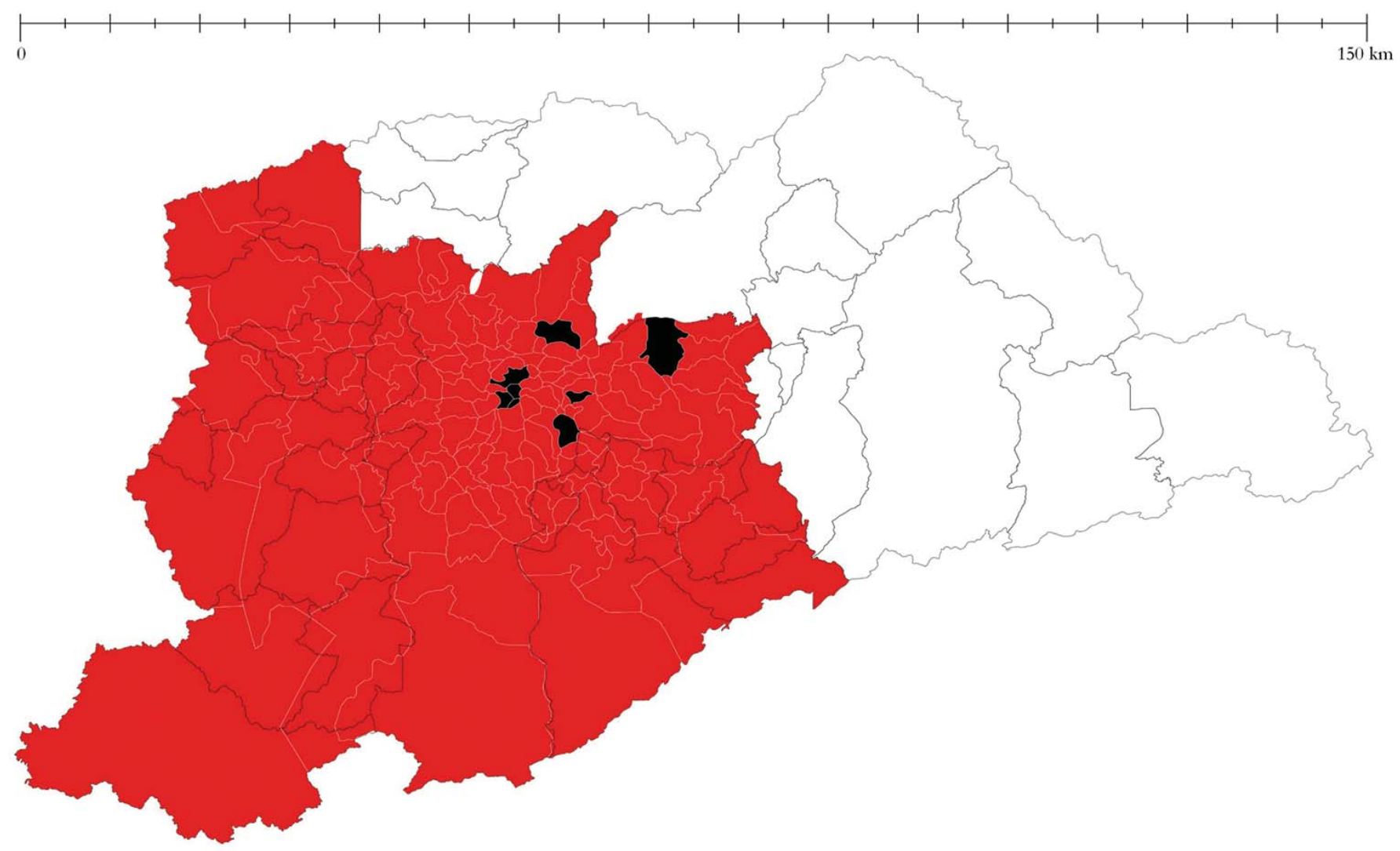

Duração das interrupções no fornecimento de energia elétrica [DEC][número de interrupções] DEC inferior ao limite

Mapa 12. Duração das interrupções no fornecimento de energia elétrica.

Mapa elaborado pela própria autora.

Fonte: BRASIL, 2014b; CEM, 2007b.

DEC superior ao limite

limites municipais 


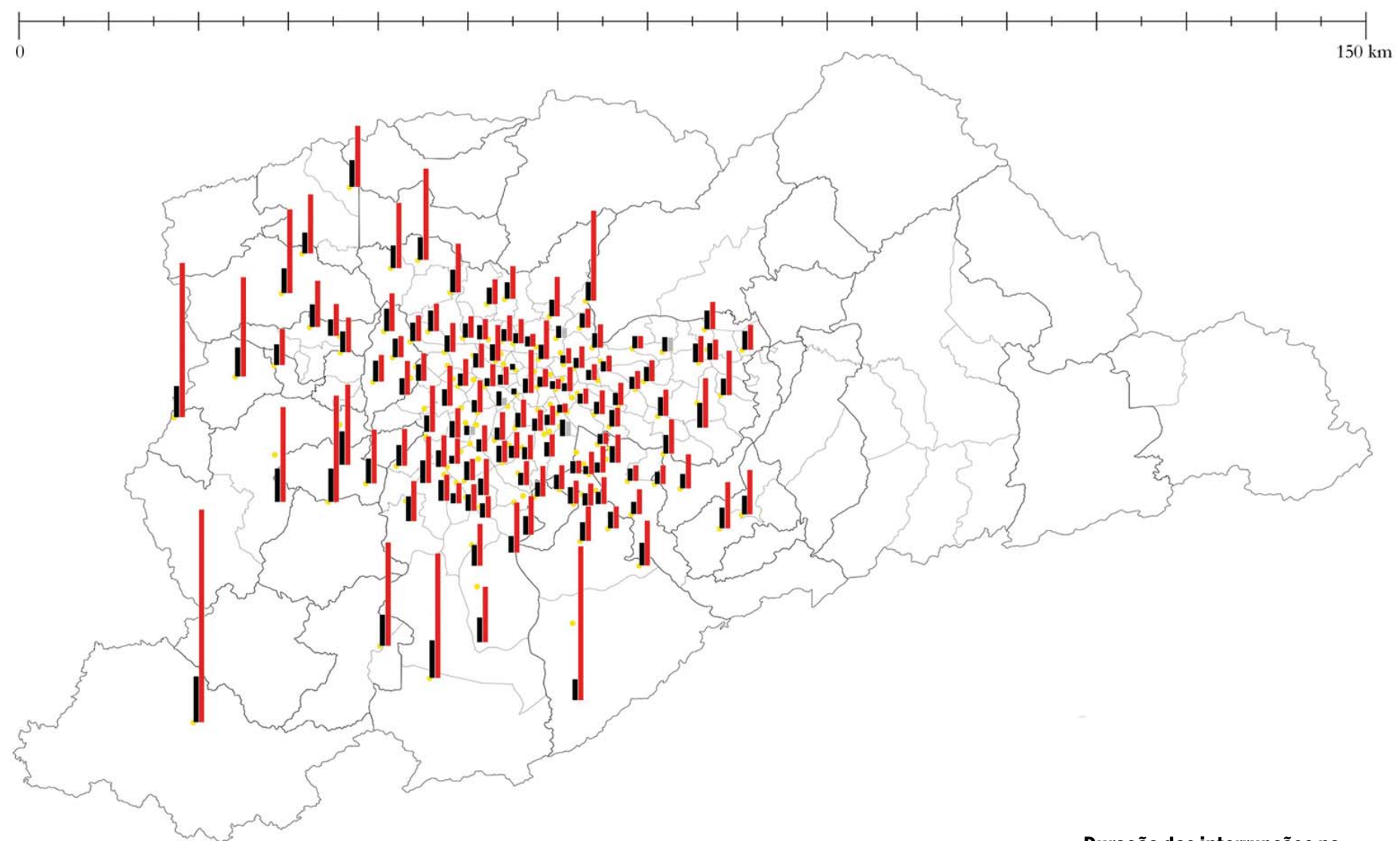

Duração das interrupções no fornecimento de energia elétrica [DEC][horas] subestações limites distritais

limites municipais DEC inferior ao limite

Mapa 13. Duração das interrupções no fornecimento de energia elétrica.

Mapa elaborado pela própria autora.

DEC superior ao limite 


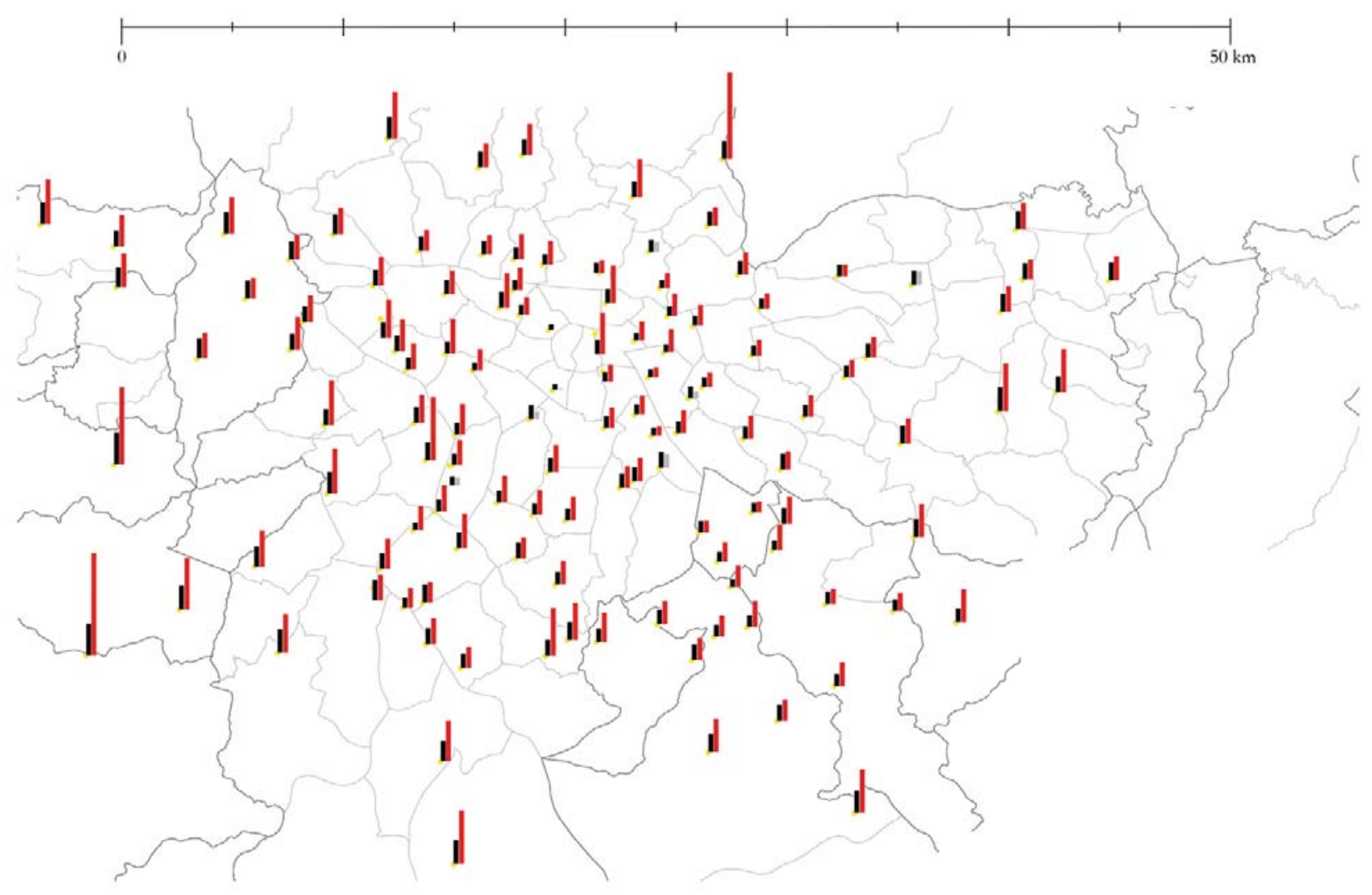

Duração das interrupções no fornecimento de energia elétrica [DEC][horas]

Mapa 14. Duração das interrupções no fornecimento de energia elétrica. Aproximação à área central do MSP.

Mapa elaborado pela própria autora.

Fonte: BRASIL, 2014b; CEM, 2007b; CEM,2007a. 


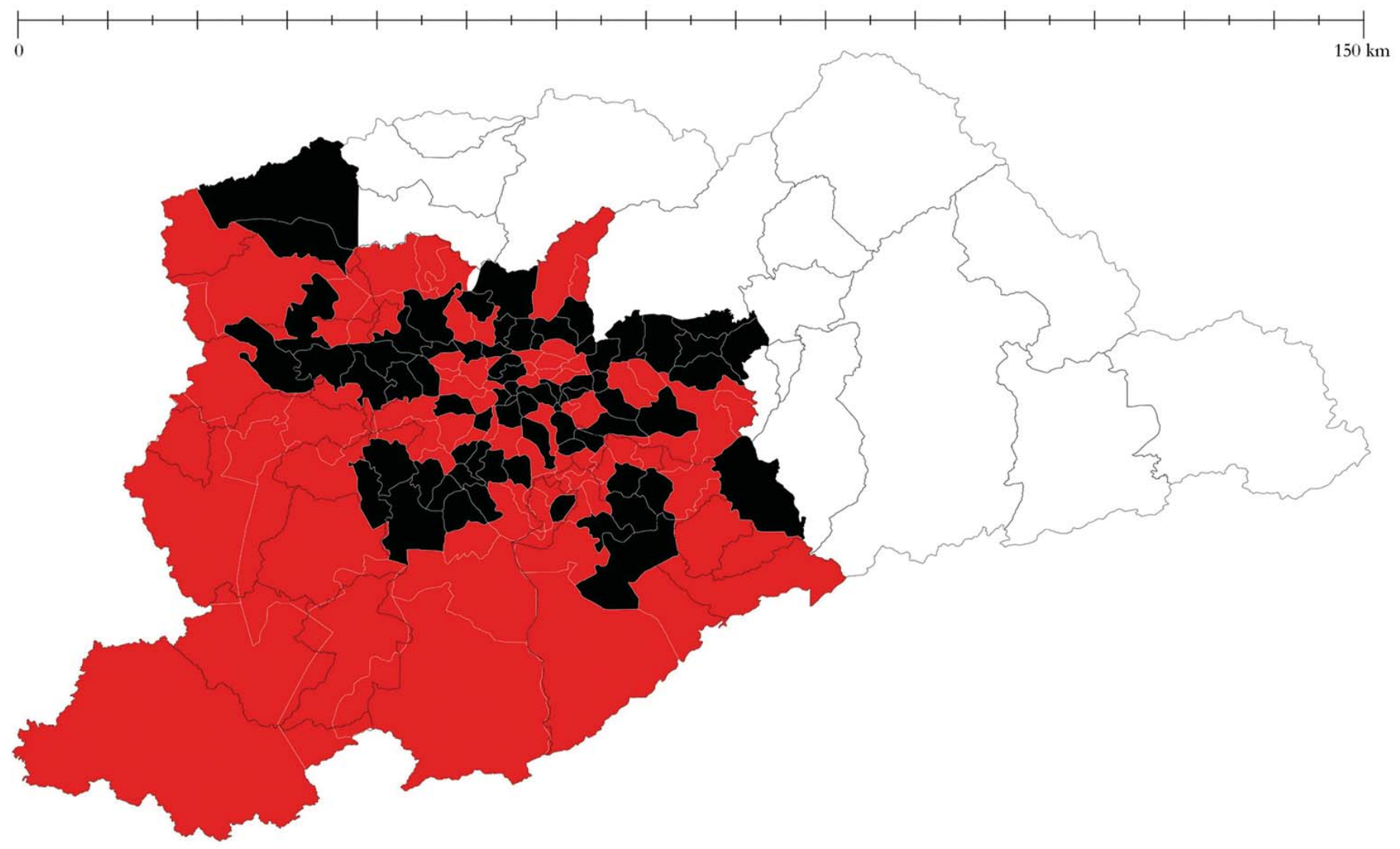

Frequência das interrupcões no fornecimento de energia elétrica

[FEC][número de interrupções] DEC inferior ao limite

Mapa 15. Frequência das interrupções no fornecimento de energia elétrica.

Mapa elaborado pela própria autora.

DEC superior ao limite

Fonte: BRASIL, 2014b; CEM, 2007b.

limites municipais 


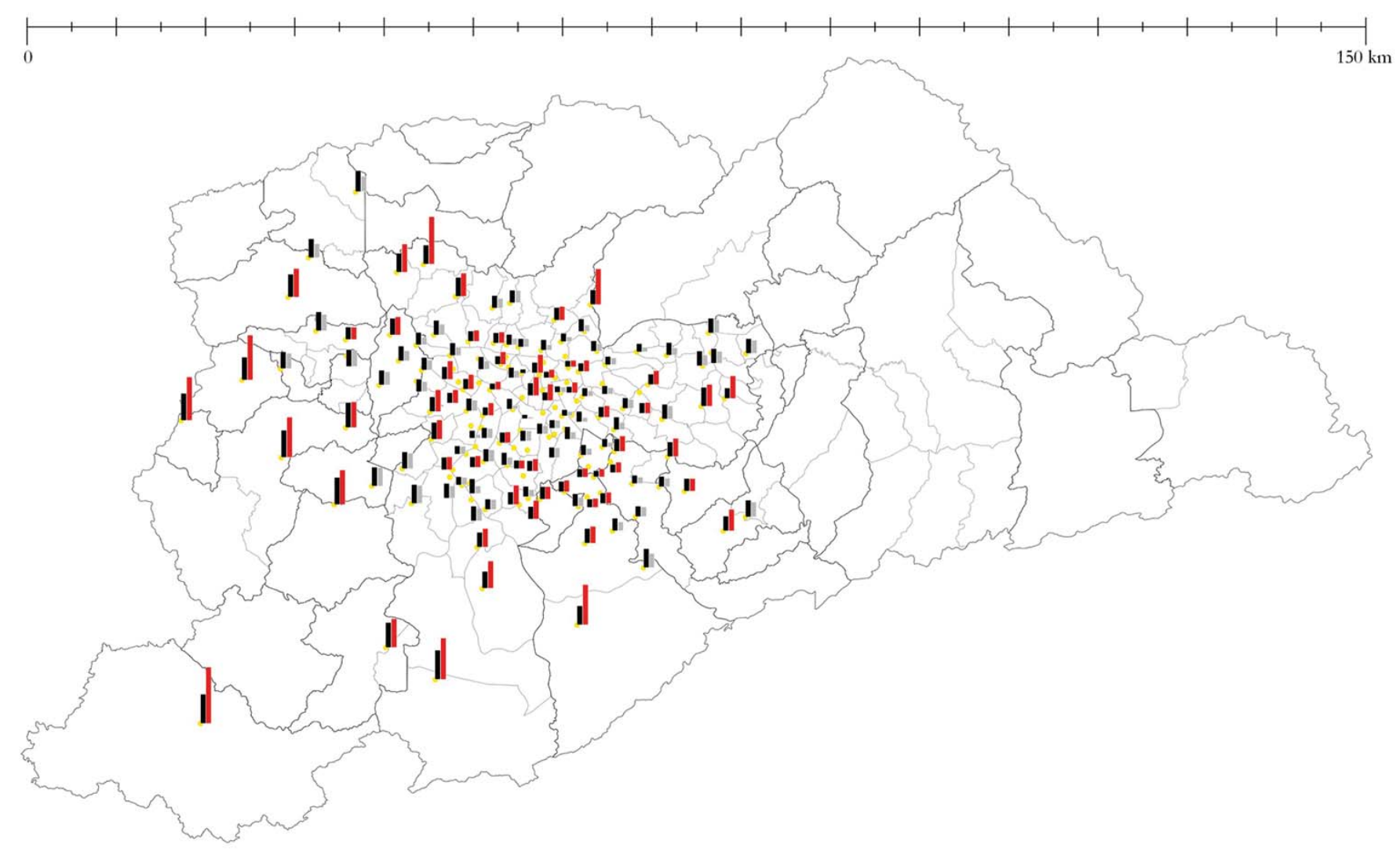

Frequência das interrupções no fornecimento de energia elétrica [FEC][número de interrupções] subestações limites distritais limites municipais FEC inferior ao limite

Mapa 16. Frequência das interrupções no fornecimento de energia elétrica. Mapa elaborado pela própria autora.

FEC supprior ao limite

Fontes: BRASIL, 2014b; CEM, 2007b; CEM,2007a. 


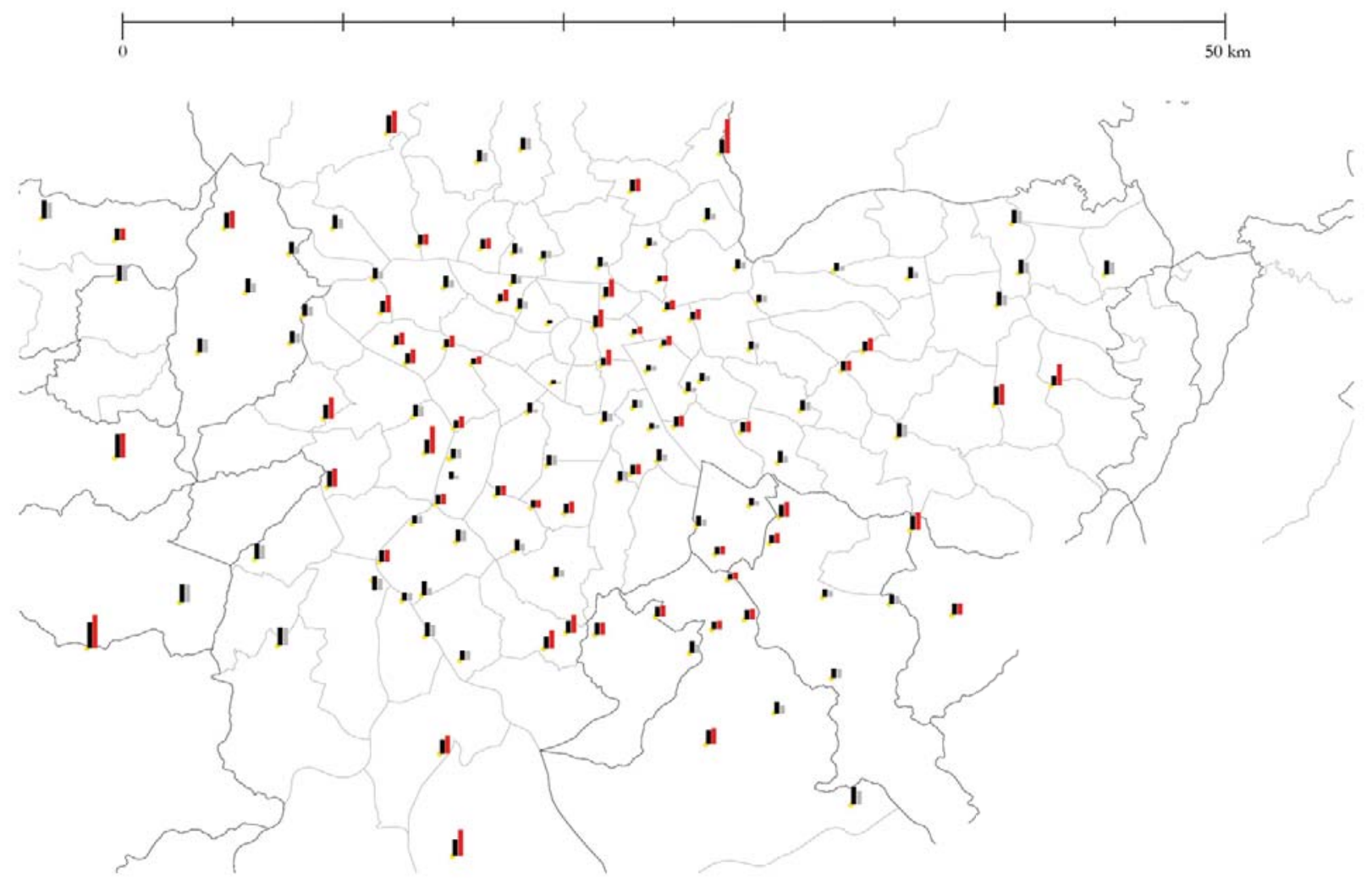

Frequência das interrupções no fornecimento de energia elétrica [FEC][número de interrupções] subestações limites distritais limites municipais FEC inferior ao limite Aproximação à área central do MSP.

Mapa elaborado pela própria autora.

Fonte: BRASIL, 2014b; CEM, 2007b; CEM,2007a.

FEC superior ao limite 
De acordo com a análise dos dados e mapas apresentados, verifica-se que os piores indicadores DEC e FEC tendem a localizar-se nas áreas periféricas onde os dados socioeconômicos são mais precários (ver subcapítulo - Dados socioeconômicos). Assim, as disparidades de continuidade no fornecimento de energia podem inviabilizar planos e projetos urbanos que recomendem a descentralização de atividades produtivas. Pode-se concluir que torna-se inviável a localização de atividades econômicas que dependam de maior carga e continuidade de energia, por exemplo call-centres e afins, em partes do território que não apresentem os atributos satisfatórios, a menos que sua melhoria faça parte explícita e materializável do plano ou projeto em questão.

\section{A visão dos especialistas do setor de energia elétrica}

De forma a aprofundar a discussão quanto aos objetos e objetivos desta tese, foram realizadas quatro entrevistas com profissionais do setor de infraestrutura urbana, todos com uma vasta experiência: tanto na implementação de soluções tecnológicas quanto na implementação de políticas e regulação do setor. Os entrevistados foram:

- (1) Eduardo Bernini: ex-presidente da AES sócio-diretor da Tempo Giusto Consultoria Empresarial; 
- (2) Cyro Vicente Boccuzzi: ex-vice-presidente da AES e CEO \& presidente do Latin American Smart Grid Forum e da ECOEE;

- (3) Dr. Aderbal de Arruda Penteado Junior: diretor da Arsesp Agência Reguladora de Saneamento e Energia do Estado de São Paulo, professor no Departamento de Engenharia de Energia e Automação Elétricas da Escola Politécnica da USP;

- (4) Dr. José Sidnei Colombo Martini: prefeito do campus da

Cidade Universitária da USP, professor e chefe do Departamento de Engenharia de Computação e Sistemas Digitais da Escola Politécnica da USP - as considerações quanto a essa entrevista serão incluídas nas próximas etapas da pesquisa;

Essas discussões auxiliaram na maior compreensão quanto às potencialidades, às fraquezas, às oportunidades e aos riscos em relação à análise dos cenários da infraestrutura urbana na RMSP. No caso destas discussões, a rede de eletricidade - cobertura, tecnologia, qualidade e controle - teve mais relevância do que outras redes infraestruturais, principalmente devido à experiência dos profissionais. A seguir serão expostos os pontos considerados mais relevantes e que influenciaram na delimitação e confirmação dos argumentos desta tese.

Um assunto evidenciado nas discussões, foi a dependência da sociedade hoje em relação às redes infraestruturais, primordialmente a rede de eletricidade, já que as outras têm uma relação direta ou indireta para com a primeira (bombeamento da rede de abastecimento de água, 
rede de transporte eletrificado, telecomunicações). Dessa forma, por se tratar de um serviço cada vez mais essencial, a tolerância da sociedade para a sua indisponibilidade tem se tornando cada vez mais reduzida:

[...] já que cada vez mais dependemos de energia, seja para pagar uma conta neste restaurante, seja para descer de um elevador de um prédio, seja para poder andar de transporte eletrificado, o metrô, enfim, o nosso nível de dependência é crescente. Todos os sistemas de vários processos, de todo o mercado financeiro, de todas as atividades comerciais hoje são suportadas por processadores, que muitas vezes não funcionam se não houver energia. (BOCCUZZI, 2013)

Portanto, reconhece-se a capacidade das redes infraestruturais de imporem uma série de economias e deseconomias que não são facilmente percebidas nem quantificadas. A percepção da sociedade em relação às redes, de certa forma, ocorre apenas na interrupção de luz, água, internet, uma vez que já se tem o acesso àquelas. Bernini (2012) levanta o aspecto da falta de estima da população quando a rede em que se tem acesso é degradada, o que não acontece na mesma simetria em relação a sua disponibilidade e valorização. Refletindo sobre este aspecto, Bernini comenta sobre a dimensão da cidadania que é incorporada nos equipamentos urbanos, adicionando que a presença e o bom estado destes interferem no comportamento da sociedade. Quando presidente da AES, ele comenta que um processo contínuo de 'busca de autoestima' era despertado quando ocorria a regularização dos serviços de 
eletricidade nas áreas precárias, sendo novas demandas ligadas à cidadania imediatamente cobradas das comunidades, como saneamento, gestão de lixo etc. Dessa forma, a questão da infraestrutura urbana não se detêm à tecnologia de um setor isolado, como o energético, e deve ser compreendida como uma rede de serviços compartilhados e combinados.

Bernini destaca os riscos das linhas físicas de energia que muitas vezes passam por sobre comunidades que não são regularmente alimentadas, mas que, contudo, ilegalmente, se servem destas estruturas sem o conhecimento e a segurança necessária, causando acidentes, não raros, fatais, porém não comentados nos veículos de comunicação. Outra dificuldade refere-se à saturação das linhas físicas que hoje estruturam as redes de eletricidade e telecomunicações, esta última envolvendo a telefonia, a fibra ótica, a tevê a cabo. Esse limite se dá, segundo ele, devido à conformação dessas redes em vias áreas convencionais, configurados por cabos ligados por postes. Essa rede é configurada em camadas: a primeira é prioridade da companhia de energia elétrica, que é 'dona' do poste, pelo qual passa a rede primária e se localiza o equipamento de transformação. A segunda camada é da rede de telecomunicações, que paga para as empresas de energia por ponto, para poder se 'apoiar' nos postes das concessionárias; o que acontece é que as empresas mais poderosas passam cabos até chegarem ao limite físico de sustentação dos postes, criando um monopólio, já que outras companhias não encontram espaço para poderem competir por igual. Dessa forma, a melhora da 
qualidade desses serviços também é prejudicada, já que não há espaço para competição, o que gera uma consequência econômica importante. Essa atividade, apesar de teoricamente regulada pela Embratel, Anatel, Aneel, não é na realidade controlada (ibidem).

Portanto, Bernini defende a substituição das vias aéreas por subterrâneas, que, apesar de serem exponencialmente mais caras, regulariam o mercado de infraestrutura e possibilitariam uma melhor interligação entre os diferentes setores, assim como se adaptariam melhor as distintas demandas de qualidade. Do ponto de vista da viabilidade desses sistemas, ele defende a modalidade de concessão, parceria públicoprivada, ou na forma de outorga de concessões dentro do que estabelece a Lei 8.987: concessões públicas por exploração de prestações de serviços, que se assemelha a uma rodovia pedagiada. Essas redes já foram implementadas em alguns pontos da cidade, porém, como destacado nas primeiras sessões deste trabalho, de forma a atenderem apenas clientes preferenciais. Conforme destacado por Bernini durante a entrevista:

Com isso algumas áreas como Vila Olímpia conseguiram se viabilizar como vocação para a instalação de 'dot-hubs', porque essas empresas levaram fibra ótica, conexão de alta velocidade, para aquele cluster (Av. Paulista, Av. Faria Lima, pedacinho da Berrini), mas não como uma coisa organizada, eles foram só para atender clientes ou cluster muito especializados. (ibidem)

No caso da implementação das redes subterrâneas implementadas na Rua Oscar Freire (endereço do comércio de luxo de 
São Paulo), a iniciativa se deu por meio da organização dos lojistas, que tinham o interesse de atrair maior número de clientes por meio do melhoramento da paisagem, com a 'limpeza' dos intrincados cabos e postes, e o 'embelezamento' das calçadas. Houve uma negociação com a Eletropaulo, na qual os lojistas arcariam com um valor proporcional à testada de suas lojas e a prefeitura com a outra metade. Devido aos altos custos, os moradores ou o comércio de diferente padrão em outro trecho da mesma rua não pôde arcar com os custos, sendo assim os melhoramentos foram interrompidos, e localizados apenas no trecho mais valorizado. Segundo Bernini, 'cheguei à conclusão de que o enterramento da rede visto como uma ação isolada não resolve o problema'. Então, há que se pensar na economia da infraestrutura como parte de um cenário integrador de todos os serviços públicos, indissociável aos equipamentos urbanos. (ibidem)

Conforme Boccuzzi (2013), o enterramento das redes não se viabilizou, pois o serviço em primeiro momento não era universalizado $\mathrm{e}$ o número de crescimento da demanda era brutal. Como o Brasil ainda é um país que cresce a taxas maiores do que a média no mundo, não se justifica o enterramento das redes, movimento este que só deveria ser realizado, segundo ele, numa etapa de maturação, quando se atinge certo limite de estabilidade. Essa estabilidade, claramente, poderia ter sido determinada pelo próprio uso do solo, no entanto esta ferramenta é razoavelmente prematura na política urbana brasileira. Para exemplificar 
esta lógica, ele cita a malha subterrânea da área central de São Paulo, implantada nos anos 1960/70, devido à previsão de limite de saturação destas áreas segundo o planejamento das companhias nesse período.

Não há como negar a importância destes serviços para o desenvolvimento urbano, e, no sentido inverso, a do planejamento urbano em sua capacidade de sinalizar um direcionamento para a ocupação do solo e o zoneamento da metrópole, que leva em conta os conflitos assinalados anteriormente. $\mathrm{O}$ embate de competências entre as concessionárias e os municípios assinala a importância da governança para a resolução de conflitos. Exemplos de projetos de lei que buscaram resolver estes conflitos, por exemplo, sugeriram a cobrança de IPTU sobre a área ocupada pelo poste e a área projetada pelos cabos no passeio público; porém, estas iniciativas não tiveram sucesso.

Como sugestão para esta pesquisa, Bernini (2012) concorda que estudos de casos de regeneração urbana que exponham os impactos dos melhoramentos de infraestrutura urbana, e que também incluam os efeitos das redefinições de vocação econômica, sejam altamente informativos, no sentido de poderem alimentar as políticas públicas para direcionarem uma dinâmica de transformação mais sustentável.

Discutiu-se também a importância de interferências infraestruturais em menores escalas (de um lote ou conjunto de lotes para fins de desenvolvimento urbano) por sua capacidade de possibilitar um benefício em uma dimensão maior, na escala, por exemplo, da metrópole. 
Neste sentido, segundo Boccuzzi (2013), hoje é possível se pensar na questão da geração de energia de microescala, que, produzindo energia localmente, teria a capacidade de aliviar a demanda das concessionárias, por meio de um sistema de processamento computacional que trocaria dados com a rede para controlar os fluxos de importação e exportação de energia, o chamado smart grid (rede inteligente). Nesse sentido, a importância da descentralização da geração de energia para benefício não só da rede de eletricidade, mas também para a minimização de impactos ambientais, é defendida por Boccuzzi (ibidem):

[...] é [a descentralização] a única forma concreta de você atender aos requisitos de confiabilidade e continuidade que a sociedade atual demanda. A energia é cada vez mais cara, e nós a vamos buscar cada vez mais longe. As melhores fontes não tão distantes, e com maior potencial de produção, já foram as primeiras a serem aproveitadas. Hoje estamos chegando na fronteira da Amazônia, com impactos ambientais questionáveis, construindo usinas monstruosas que não têm um potencial de geração, porque elas não podem mais ser construídas com aquele largo. São usinas que chamamos de fio d'água, com reservatórios (área inundada) muito pequenos, devido às preocupações com mudanças climáticas, biodiversidade etc. Então essas usinas tem esse impacto monstruoso em termos ambientais, custos altíssimos, as linhas de transmissão que trazem essa energia são longuíssimas, são projetos caros. 
Assim como a inovação tecnológica das redes subterrâneas apresentada por Bernini, a inovação dos smart grids apresentada por Boccuzzi (ibidem) também aposta na iniciativa privada para a sua viabilização, como apontado:

[...] a indústria, os shoppings, os grandes empreendimentos vão ser o vetor pelo qual essas tecnologias [smart grids] vão começar a tomar [forma], porque são os clientes que gastam energia, porque quem gasta quer melhorar o seu custo. Nesse primeiro momento, as empresas de energia vão ficar assustadas, pois vão achar que o mercado cativo delas, que é de concessão, vai estar sendo perdido.

Desta forma, verifica-se que, pela experiência de Boccuzzi, o vetor de transformação da qualificação dos serviços infraestruturais seria realizado por meio da apropriação dos investimentos privados, devido ao seu retorno face à confiabilidade e ao custo de energia. Além desses fatores, é evidenciado o papel da atratividade destas soluções no mercado imobiliário, e na tendência destes benefícios de serem rapidamente ampliados para as camadas mais humildes da população, como discutido:

[...] e até ao marketing que este tipo de abordagem pode proporcionar: um local seguro, que tenha boa infraestrutura, um local diferenciado. A tecnologia vai avançar muito rápido, não vai dar para confinar estes lugares por esses benefícios, vai ser que nem o telefone celular, massificado. (ibidem) 
Nesse último quesito, o efeito de 'gotejamento', explorado no item 3.1 deste trabalho, é esperado por Boccuzzi. Nele, os investimentos em infraestruturas inicialmente concentrados em enclaves diferenciados (como shopping centers) vão sendo ampliados por meio do 'vazamento' destes benefícios em direção às periferias, porém não fica claro como este efeito tomaria forma.

Penteado (2013) confirma esta tendência de se obter serviços beneficiados primeiramente em enclaves diferenciados, quando comenta que:

[...] a concessionária tem um mapa de regiões, que são as regiões críticas e prioritárias. A região toda do Morumbi etc. Por ter o Palácio, por ter gente influente é uma região prioritária. $\mathrm{Na}$ região da Berrini, a concessionária sabe que tem uma carga que está crescendo bastante, então ela se provisiona. Ela faz isso porque ela tem um planejamento e é obrigada a comprar energia antes para suprir o crescimento vegetativo, que ela julga que vai acontecer. Ela faz uma previsão, ela tem que afinar os instrumentos de planejamento dela de forma a comprar aquilo que ela atende hoje mais um pouco para atender o crescimento vegetativo ou em regiões localizadas, o crescimento pontual, a explosão que ela sabe que vai ocorrer porque vão colocar um supershopping numa região, aí ela sabe que o resto vai crescer, daí ela tem que se provisionar $[\ldots]$.

Todavia, segundo Penteado (ibidem), o real catalisador das transformações urbanas é dado pelo vetor do transporte. Este teria 
predominância em relação a todas as outras redes infraestruturais, sendo não só a solução, mas o grande problema de São Paulo. Nesse caso, ele sugere que, no caso de se trabalhar nesta tese com um grupo de indicadores em infraestrutura, estes devem ser ponderados de maneira que o transporte tenha um peso preponderante em relação aos outros. Interessantemente, também se discutiu a questão da governança no sentido de atender os gargalos infraestruturais, que nem sempre são de origem da falta de atendimento da concessionária, sendo competência da prefeitura, como é o caso, por exemplo, da iluminação pública.

Também de relevância para esta pesquisa foi a discussão quanto ao processo de negociação com as concessionárias no caso do desenvolvimento de grandes projetos. É importante notar que, ao contrário do que se tem no senso comum das discussões sobre a expansão de cidades, não deve se pensar que um projeto numa área consolidada da cidade deve ter como premissa a despreocupação em relação a sua ligação com as redes de infraestrutura. Naturalmente, projetos de masterplan em regiões centrais propõem o crescimento do adensamento, o que, consequentemente, mesmo em cenários de eficiência energética e sustentabilidade, cria uma demanda infraestrutural aumentada. O aumento da demanda em energia, abastecimento de água, maior carga no destino e tratamento de esgoto, entre outros, são tratados como já resolvidos, já que os sítios em áreas consolidadas estão dentro de áreas de cobertura. Porém, como discutido anteriormente, a presença de 
cobertura não significa que a superação da demanda irá se resolver de forma facilitada e regular.

Segundo Penteado (ibidem), quando se propõe um novo projeto que tenha uma escala de consumo além do considerado trivial (que atinja 5 MVA - 10 MVA), a concessionária deve verificar se os alimentadores naquela região têm a capacidade de abastecer a nova carga nos limites da rede física existente. A avaliação e os melhoramentos no aumento do suprimento são rotineiramente realizados, já que isso significa maior comercialização de energia, o elemento-chave do negócio das concessionárias, além de considerados uma obrigação moral e ética. Porém, é importante notar que, ao contrário da suposição de recurso infinito, existe um limite físico dessas redes, em que algumas regiões já se encontram por falta de disponibilidade de espaço para passagem de cabos, de estruturas físicas que permitiriam a energia chegar com maior volume. Outro possivelmente limite se dá devido a imprecisões no planejamento da demanda energética, realizada para um horizonte de 7-8 anos, de acordo com um estudo das taxas de crescimento vegetativas acrescidas de fatores pontuais que possam mudar o perfil de alguma região, como a expansão do metrô.

Entretanto, o maior problema se daria na configuração da rede física de eletricidade, que, devido a sua topologia - em São Paulo é radial (one-way) e não possui duplicidade - faz com que seja muito difícil redistribuir toda a carga transmitida num ramal em outro sentido, o que 
causa as grandes interrupções e apagões ocorridos em todo o país (ibidem). Segundo Penteado (ibidem), trabalhos para contornar esses problemas estão sendo planejados e implementados, porém, não alcançam a demanda, como apontado por ele:

[...] quando está tudo autorizado, devido ao crescimento naquela região, quando a subestação entra em operação, já está quase saturada, pois demorou tanto para ser feito. [...] - e continua 'não temos contingência, é como andar com pneus novinhos só que sem o estepe.

Dessa forma, como já explorado anteriormente, a falta de confiabilidade em suprimento de energia acaba sendo um desestimulante para atrair indústrias que dependem de bons índices, o que certamente gera impactos irreparáveis no modelo econômico vigente.

Então, como tratado anteriormente, considerou-se importante a análise empírica desses índices para a análise da diferenciação territorial da metrópole de São Paulo, objeto desta tese, sem que se considerasse a grande diferenciação desses dados se analisados no contexto maior da nação. Na escala federal, os índices de interrupção são ainda mais gritantes, o que torna mais relevante o argumento que combina o contexto da provisão da infraestrutura, do desenvolvimento urbano e, consequentemente, do desenvolvimento econômico, que juntos desenham a topografia da heterogeneidade do território brasileiro.

Nesse contexto, a importância de um planejamento urbano integrado - que considere como parte indissociável de seu corpo as fontes 
que geram os recursos naturais que alimentam a cidade e as veias que distribuem estes recursos, tanto por vias aéreas quanto nas suas camadas mais subterrâneas - se faz fundamental no sentido de apontar para o desenvolvimento de cidades mais democráticas e sustentáveis.

\subsubsection{A rede de gás canalizado}

Em consulta direta à Arsesp, esta informou que a 27ำ subcláusula dos Contratos de Concessão para Exploração de Serviços Públicos de Distribuição de Gás Canalizado no Estado de São Paulo estabelece que as concessionárias obrigam-se a manter e melhorar os níveis de continuidade e qualidade do fornecimento de gás canalizado, assim como a observar os demais indicadores constantes do Anexo II - Projeto de Qualidade desses Contratos, aplicando-se, quando for o caso, a legislação superveniente. De acordo com a consulta, esclareceu-se que os indicadores são válidos por áreas de concessão, não havendo valores diferenciados entre distritos, bairros, ou mesmo, municípios.

No caso da RMSP, a recomendação da agência foi a de que se deveriam verificar os dados com a Companhia de Gás de São Paulo Comgás, que atende a região. Esta não nos forneceu seus dados de qualidade, também inacessíveis por meio da agência reguladora, que pôde apenas oferecer relatórios anuais que apresentaram resultados agregados aos valores de todas as concessionárias para o Estado de São Paulo, como 
um todo. Devido a esse fator, foi apenas possível identificar quais os indicadores utilizados para acompanhamento e controle, assim como seus valores de referência. Por meio da Comgás, houve a disponibilização do desenho da rede de gás canalizado, o que, para efeito do entendimento da cobertura física do sistema na RMSP, tornou possível a identificação da sua abrangência territorial.

Os indicadores referentes às concessionárias (como um todo e cada um de seus grupos de usuários) devem ser expressos por valores diários, mensais e/ou anuais, e enviados periodicamente à Comissão de Serviços Públicos de Energia - CSPE, hoje Arsesp. Mediante estudos e análises específicas já definidos pela CSPE, os procedimentos para controle de indicadores e, particularmente, a metodologia para o cálculo das perdas comerciais, técnicas e totais de gás são utilizadas para a determinação das respectivas porcentagens de perdas. Os indicadores de controle estão relacionados a seguir:

- pressão;

- PCS: poder calorífico superior;

- CFQ: características físico-químicas do gás; Acompanham-se a esses indicadores aqueles que as concessionárias devem registrar em relação ao volume de gás comprado e ao volume total de gás faturado, assim como ao volume de gás produzido e ao consumo próprio. São estes: 
- PPC: porcentagem de perdas comerciais [não há padrão ainda definido];

- PPT: porcentagem de perdas técnicas [não há padrão ainda definido];

- PPTG: porcentagem de perdas totais [não há padrão ainda definido].

Também devem ser acompanhados indicadores de segurança no fornecimento do gás, sendo estes representados pelos seguintes:

- Odorização: odor e concentração de odorante no gás [COG], expressa em $\mathrm{mg}$ por $\mathrm{m}^{3}$ de gás;

- IVAZ: índice de vazamentos no sistema de distribuição de gás;

- TAE: tempo de atendimento de emergência;

- FME: frequência média de atendimento de emergência [não há padrão definido].

Também existentes são aqueles indicadores de qualidade do atendimento comercial, que, por não serem diretamente relacionados com a qualidade de infraestrutura técnica e física, não foram incluídos na análise desta tese.

Como vimos, não foi possível relacionar os dados de qualidade específicos para a RMSP, desagregados por setores que pudessem identificar a diferenciação destes resultados geograficamente, já que os dados são disponíveis para o Estado como um todo. Assim, para efeito da análise dessa pesquisa, foram observados os dados de cobertura física da 
rede de gás canalizado, assim como o número de consumidores por atividade residencial, comercial, industrial, automotivo, para fins de cogeração e termogeração (ver Tabela 5 e Tabela 6). Esses últimos dados foram organizados por município da RMSP, porém, devido a restrições de recursos não foi possível gerar uma mapa georeferenciado até a data de finalização dessa pesquisa.

Em relação aos dados disponíveis quanto à cobertura da rede na RMSP, a verificação se deu por dois métodos.

A primeira análise se deu pela interpolação entre o desenho da rede e os setores censitários que compõem a RMSP. Assim, quando houve um ramal que cruzasse ou estivesse contido em um setor censitário, ele foi graduado com uma cor vermelha. Os setores sem nenhuma interpolação foram graduados com a cor cinza. Essa análise pode ser visualizada no Mapa 18. Abrangência dos setores censitários interpolados por rede de gás canalizado. Devido ao fato de os setores censitários localizados nas franjas da RMSP serem de maior área, estes acabam demonstrando um tipo de erro de leitura da informação, já que acabam sendo coloridos por inteiro mesmo que apenas um ramal de gás seja contido ou cruze o setor. Esse método também impossibilita a análise da porosidade interna do sistema, um segundo problema para o que se pretende analisar nesta pesquisa. 
Tabela 5. Os quinze maiores consumidores de gás canalizado do Estado de São Paulo em 2013.

Fonte: Secretaria de Energia, 2013.

\begin{tabular}{|c|c|c|c|c|c|c|c|}
\hline \multicolumn{8}{|l|}{2013} \\
\hline MUNICÍPIOS & RESIDENCIAL & COMERCIAL & INDUSTRIAL & AUTOMOTIVo & COGERAÇÃO & TERMOGERAÇÃO & TOTAL $\left(M^{3}\right)$ \\
\hline São Paulo & 174.326 .194 & 89.868 .049 & 317.668 .123 & 111.232 .996 & 4.315 .275 & 768.623 .452 & $1.466 .034 .08 \mathrm{~g}$ \\
\hline Cubatão & 133.056 & 0 & 320.830 .640 & 2.855 .787 & 0 & 0 & 323.819 .483 \\
\hline Santo André & 3.107 .064 & 1.808 .672 & 293.157.824 & 8.625 .837 & 0 & 0 & 306.699 .397 \\
\hline Santa Gertrudes & 0 & 0 & 280.661 .065 & 0 & 0 & 0 & 280.661 .065 \\
\hline Jacareí & 436 & 42.481 & 140.907 .524 & 2.900 .254 & 120.167 .675 & $\mathbf{0}$ & 264.018.370 \\
\hline Paulínia & 0 & 0 & 249.618 .500 & 554.708 & 0 & 0 & 250.173.208 \\
\hline Suzano & 111.124 & 433.961 & 229.350 .710 & 2.090 .576 & 0 & 0 & 231.986.371 \\
\hline Alumínio & 13.877 & 22.183 & 231.247.935 & 0 & 0 & 0 & 231.283.995 \\
\hline Mogi Guaçu & $\mathbf{0}$ & 24.528 & 43.742 .590 & 941.138 & 119.518 .684 & $\mathbf{0}$ & 164.226 .940 \\
\hline Piracicaba & 602.249 & 278.226 & 159.049 .444 & 2.005 .096 & 0 & 0 & 161.935 .015 \\
\hline Limeira & 189.066 & 221.441 & 156.148 .746 & 1.959 .282 & $\mathbf{0}$ & 0 & 158.518.535 \\
\hline Cordeirópolis & 0 & 0 & 156.777 .704 & 375.847 & 0 & 0 & 157.153 .551 \\
\hline Guarulhos & 5.985 .544 & 3.003 .730 & 93.133 .526 & 16.381 .486 & 3.637 .536 & 0 & 122.141 .822 \\
\hline Rio Claro & 0 & 5.816 & 117.422 .866 & 1.794 .037 & 0 & 0 & 119.222 .719 \\
\hline $\begin{array}{c}\text { São Bernardo do } \\
\text { Campo }\end{array}$ & 7.720 .283 & 2.452 .706 & 90.292 .957 & 6.466 .574 & 54.003 & 0 & 106.986 .523 \\
\hline
\end{tabular}


Tabela 6. Padrão de consumo de gás canalizado dos municípios da RMSP em 2013.

Fonte: Adaptado de Secretaria de Energia, 2013.

\begin{tabular}{|c|c|c|c|c|c|c|c|c|c|c|c|c|c|c|}
\hline & & $\begin{array}{l}\text { 을 } \\
\text { 용 } \\
\text { 용 }\end{array}$ & 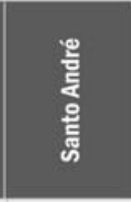 & $\begin{array}{l}\text { 옳 } \\
\text { 今 }\end{array}$ & $\begin{array}{l}\text { 을 } \\
\text { 言 } \\
\text { 空 }\end{array}$ & 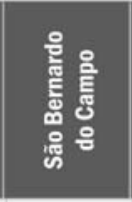 & 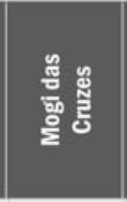 & 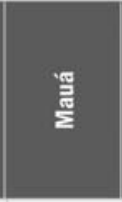 & 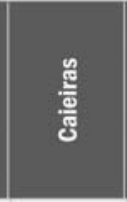 & 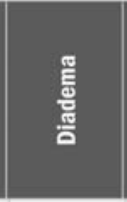 & $\begin{array}{l}\text { \&్ } \\
\text { gू } \\
\text { gू }\end{array}$ & 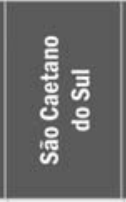 & ' & 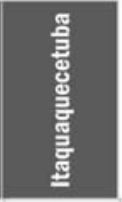 \\
\hline \multirow{2}{*}{ 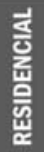 } & $\begin{array}{c}\text { Consumo } \\
\text { aprox. }\end{array}$ & 174.326 .194 & 3.107.064 & 111.124 & 5.985 .544 & 7.720 .283 & 2.328 .529 & 0 & 0 & 888.594 & 4.423 .801 & 3.355 .808 & 0 & 0 \\
\hline & $\begin{array}{l}\text { Consu- } \\
\text { midores }\end{array}$ & 664.837 & 10.686 & 368 & 25.553 & 42.208 & 15.022 & 0 & 1 & 7.015 & 26.217 & 7.870 & 0 & 0 \\
\hline \multirow{2}{*}{ 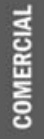 } & consumo & 89.868 .049 & 1.808 .672 & 433.961 & 3.003 .730 & 2.452 .706 & 510.957 & 124.597 & 178.414 & 4.270 .043 & 2.111 .200 & 866.228 & 0 & 397.855 \\
\hline & $\begin{array}{l}\text { Consu- } \\
\text { midores }\end{array}$ & 9.708 & 130 & 15 & 143 & 298 & 131 & 2 & 3 & 48 & 185 & 95 & 0 & 1 \\
\hline \multirow{2}{*}{ 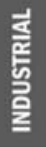 } & consumo & 317.668 .123 & 293.157.824 & 229.350 .710 & 93.133.526 & 90.292 .957 & 70.187 .557 & 66.356 .475 & 5 26.966.977 & 20.814.311 & 9.245.252 & 18.217.221 & 18.446 .597 & 15.365 .136 \\
\hline & $\begin{array}{l}\text { Consu- } \\
\text { midores }\end{array}$ & 268 & 26 & 23 & 69 & 55 & 22 & 25 & 8 & 35 & 8 & 11 & 6 & 16 \\
\hline \multirow{2}{*}{ 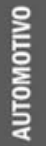 } & consumo & 111.232 .996 & 8.625 .837 & 2.090 .576 & 16.381 .486 & 6.466 .574 & 5.446 .967 & 3.401 .497 & 1.495 .036 & 2.465 .826 & 10.244 .809 & 1.655 .458 & 3.050 .513 & 1.599 .621 \\
\hline & $\begin{array}{l}\text { Consu- } \\
\text { midores }\end{array}$ & 154 & 8 & 2 & 15 & 11 & 5 & 3 & 1 & 3 & 10 & 4 & 1 & 1 \\
\hline \multirow{2}{*}{ 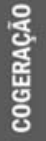 } & consumo & 4.315 .275 & 0 & 0 & 3.637 .536 & 54.003 & 0 & 2.085 .479 & 0 & 0 & 0 & 0 & 0 & 0 \\
\hline & $\begin{array}{l}\text { Consu- } \\
\text { midores }\end{array}$ & 6 & 0 & 0 & 4 & 1 & 0 & 1 & 0 & 0 & 0 & 0 & 0 & 0 \\
\hline \multirow{2}{*}{ 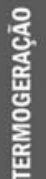 } & consumo & 768.623 .452 & 0 & 0 & 0 & 0 & 0 & 0 & 0 & 0 & 0 & 0 & 0 & 0 \\
\hline & $\begin{array}{l}\text { Consu- } \\
\text { midores }\end{array}$ & 0 & 0 & 0 & 0 & 0 & 0 & 0 & 0 & 0 & 0 & 2 & 0 & 0 \\
\hline \multirow{2}{*}{ 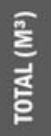 } & consumo & 1.466 .034 .089 & 306.699.397 & 231.986.371 & 122.141.822 & 106.986 .523 & 78.474 .010 & 71.968 .048 & B 28.640.427 & 28.438.774 & 26.025 .062 & 24.094 .715 & 21.497.110 & 17.362 .612 \\
\hline & $\begin{array}{c}\text { Consumi- } \\
\text { dores }\end{array}$ & 674.973 & 10.850 & 408 & & 42.573 & 15.180 & 31 & 13 & 7.101 & 26.420 & 7.982 & 7 & 18 \\
\hline
\end{tabular}




\begin{tabular}{|c|c|c|c|c|c|c|c|c|c|c|c|c|}
\hline 嗑 & $\begin{array}{l}\text { 举 } \\
\text { 恶 }\end{array}$ & 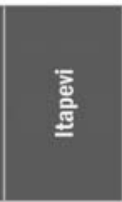 & 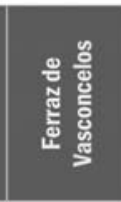 & 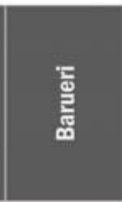 & 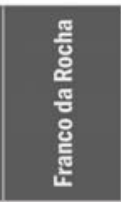 & 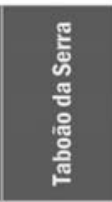 & 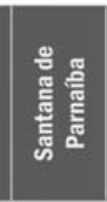 & 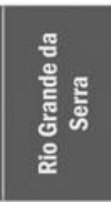 & 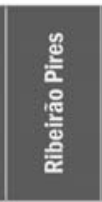 & $\begin{array}{l}\text { 总 } \\
\text { 莺 }\end{array}$ & 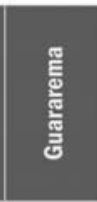 & 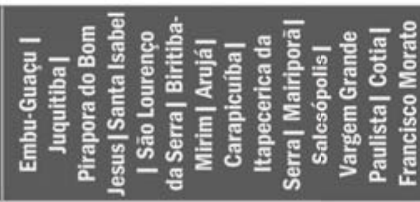 \\
\hline 0 & 0 & 0 & 0 & 1.311 .770 & 0 & 1.177 .323 & 557.048 & 0 & 0 & 12.598 & 0 & 0 \\
\hline 0 & 0 & 0 & 0 & 1.528 & 0 & 7.129 & 217 & 0 & 0 & 159 & 0 & 0 \\
\hline 0 & 0 & 0 & 0 & 759.342 & 0 & 235.349 & 5.138 & 0 & 0 & 0 & 0 & 0 \\
\hline 0 & 0 & 0 & 0 & 26 & 0 & 20 & 1 & 0 & 0 & 0 & 0 & 0 \\
\hline 16.974 .347 & 13.020 .163 & 10.343 .325 & 10.990 .764 & 4.632 .715 & 10.126 .215 & 3.957 .024 & 2.759 .255 & 1.263 .833 & 725.225 & 659.852 & 606.953 & 0 \\
\hline 8 & 10 & 8 & 15 & 4 & 2 & 4 & 1 & 1 & 1 & 3 & 1 & 0 \\
\hline 0 & 858.113 & 1.300 .586 & 0 & 3.771 .889 & 0 & 1.978 .332 & 0 & 0 & 0 & 0 & 0 & 0 \\
\hline 0 & 1 & 1 & 0 & 3 & 0 & 1 & 0 & 0 & 0 & 0 & 0 & 0 \\
\hline 0 & 0 & 0 & 0 & 0 & 0 & 1.186 .120 & 0 & 0 & 0 & 0 & 0 & 0 \\
\hline 0 & 0 & 0 & 0 & 0 & 0 & 1 & 0 & 0 & 0 & 0 & 0 & 0 \\
\hline 0 & 0 & 0 & 0 & 0 & 0 & 0 & 0 & 0 & 0 & 0 & 0 & 0 \\
\hline 0 & 0 & 0 & 0 & 0 & 0 & 0 & 0 & 0 & 0 & 0 & 0 & 0 \\
\hline 16.974 .347 & 13.878 .276 & 11.643 .911 & 10.990 .764 & 10.475 .716 & 10.126 .215 & 8.534 .148 & 3.321 .441 & 1.263 .833 & 725.225 & 672.450 & 606.953 & 0 \\
\hline 8 & 11 & 9 & 15 & 1.561 & 2 & 7.155 & 219 & 1 & 1 & 162 & 1 & 0 \\
\hline
\end{tabular}




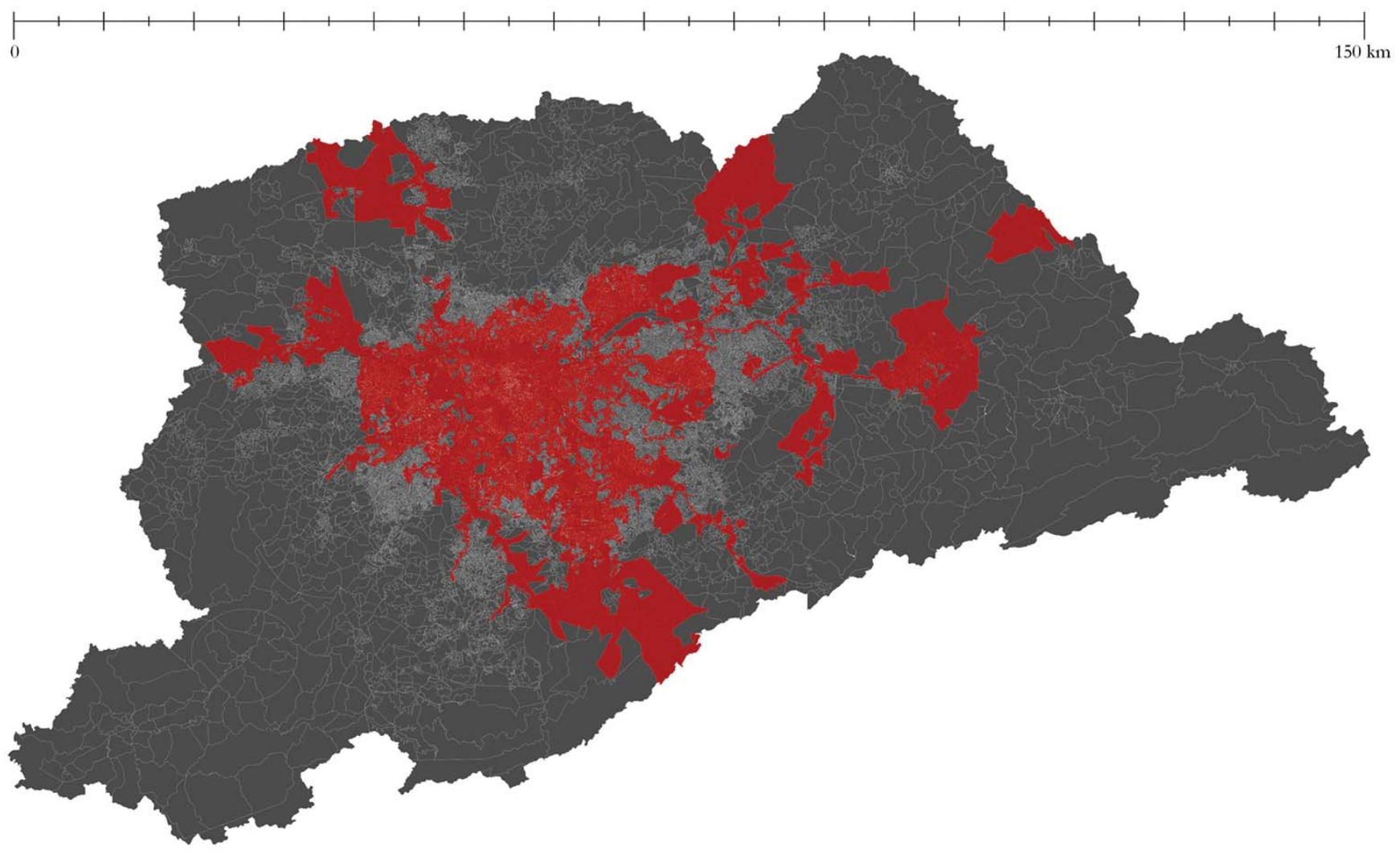

Abrangência da rede de gás [setores censitários interpolados por rede de

Mapa 18. Abrangência dos setores censitários interpolados por rede de gás canalizado.

Mapa elaborado pela própria autora.

Fonte: COMGÁs, 2015; IBGE, 2010.

interpolados

não interpolados 
Devido aos problemas encontrados na primeira análise, foi realizada uma segunda análise, efetuada pela sobreposição da malha de gás canalizado sobre a imagem de satélite composta para cobrir toda a RMSP. Nesta imagem, é possível identificar as áreas urbanizadas e as áreas verdes, criando um quadro bastante oportuno de avaliação com relação à presença da rede infraestrutural em áreas urbanizadas. Esta opção foi considerada mais adequada por representar um quadro mais concreto quanto à heterogeneidade da cobertura, como é possível visualizar no Mapa 19. Pode-se observar uma diferenciação quanto à cobertura com maior abrangência nas área mais centrais da RMSP, como o município de São Paulo e aqueles municípios lindeiros, assim como uma porosidade do sistema no interior de áreas a princípio 'cobertas'.

Em um mapa ampliado do sistema (Mapa 20), vê-se que mesmo as áreas de localização bastante centrais da RMSP, no centro do MSP, estas ainda não são alcançadas pelo sistema, como é o caso dos lotes próximos a marginais e linhas de trem (Barra Funda, Água Branca), ou bairros como Vila Leopoldina, Lapa, Sumaré e Butantã. Obviamente, existem aquelas áreas em que não há sistema devido à presença de um parque, de um cemitério, do CEAGESP - Companhia de Entrepostos e Armazéns Gerais de São Paulo, da Cidade Universitária etc., porém, muitas áreas urbanizadas, de médio ou baixo adensamento não são alcançadas pela rede. Além destes, devido à natureza material do sistema, 
é possível que áreas inundáveis ou de alta declividade acabem por ser de difícil instalação do sistema.

Apesar dessa pesquisa não ter como foco uma compreensão histórica do desenvolvimento das redes de infraestrutura urbana, é importante notar que, em específico para o uso do gás natural, esse recurso tem ganhado um espaço crescente na matriz energética do país e do estado de São Paulo. O recurso é uma alternativa para a produção de eletricidade, seja por meio de usinas termelétricas ou por cogeração.

Há controvérsias ambientais quanto a produção de energia por termoelétricas, devido a queima de combustíveis fósseis não renováveis e pelo alto teor de poluentes lançados na atmosfera. Além disso, as termoelétricas apresentam um alto custo de operação, devido ao grande volume de combustível necessário para a produção de energia. O ponto positivo do uso dessa fonte, é que as usinas podem ser construídas próximas da fonte consumidora, o que evita as grandes perdas na transmissão de eletricidade.

Outra alternativa de uso de gás natural de grande potencial e de alta eficiência, é o processo de cogeração, que permite a produção simultânea de energia elétrica e térmica, na forma de vapor e água quente. $\mathrm{O}$ interessante dessa alternativa, é que o usuário final pode ser o próprio fornecedor de energia, podendo dessa forma garantir uma segurança maior quanto a qualidade de fornecimento do recurso, e 
evitando assim as oscilações tão presentes no sistema distribuidor da RMSP, estudadas no subcapítulo anterior - A rede de energia. Além disso, caso haja excedente na produção de energia, essa pode ser vendida às concessionárias que operam na região.

Em atividades industriais e comerciais, a segurança de continuidade pode representar grandes economias, principalmente quando se tem uma alternativa de fornecimento nos horários de pico, quando as tarifas são mais caras. Aos benefícios desses sistemas alternativos também somam-se o curto prazo para implantação dos projetos, além do fornecimento da quantidade de energia elétrica e térmica na medida necessária para as atividades do usuário. Além disso, a energia é gerada na tensão e frequência desejada, reduzindo os riscos de blecaute e chegando a ciclos de rendimento de até $85 \%$.

A aplicação da cogeração nos setores de comércio e serviços se torna interessante quando os estabelecimentos possuem, por exemplo, centrais de aquecimento de água ou de condicionamento de ar, como hospitais, supermercados, shopping centers, hotéis e edifícios comerciais. Exemplos dessas aplicações na RMSP são: o complexo hospitalar Clínicas, a rede Sonda supermercados, os Shopings Interlagos e Tabõao da Serra, o hotel Sofitel e o centro empresarial Rochaverá, entre outros.

Do ponto de vista da indústria, a cogeração se torna interessante nos processos produtivos que utilizam vapor ou resfriamento, como os 
setores de alimentos e bebidas, produção de borracha, setor têxtil e papel e celulose, com diversos exemplos na RMSP, que incluem: a Corn products em Mogi Guaçu, a Inapel e a Levorin em Guarulhos, a Radici fibras em São José dos Campos.

Por todos os motivos acima expostos, fica evidente a importância de uma boa cobertura e qualidade da rede de gás canalizado para permitir soluções de geração distribuída de eletricidade, não só para aliviar a carga dos sistemas de distribuição mais saturados, como também para ampliar a segurança de fornecimento. Essas alternativas podem vir a viabilizar intervenções urbanas de regeneração em locais com indicadores deficitários de DEC e FEC de fornecimento de energia elétrica. 


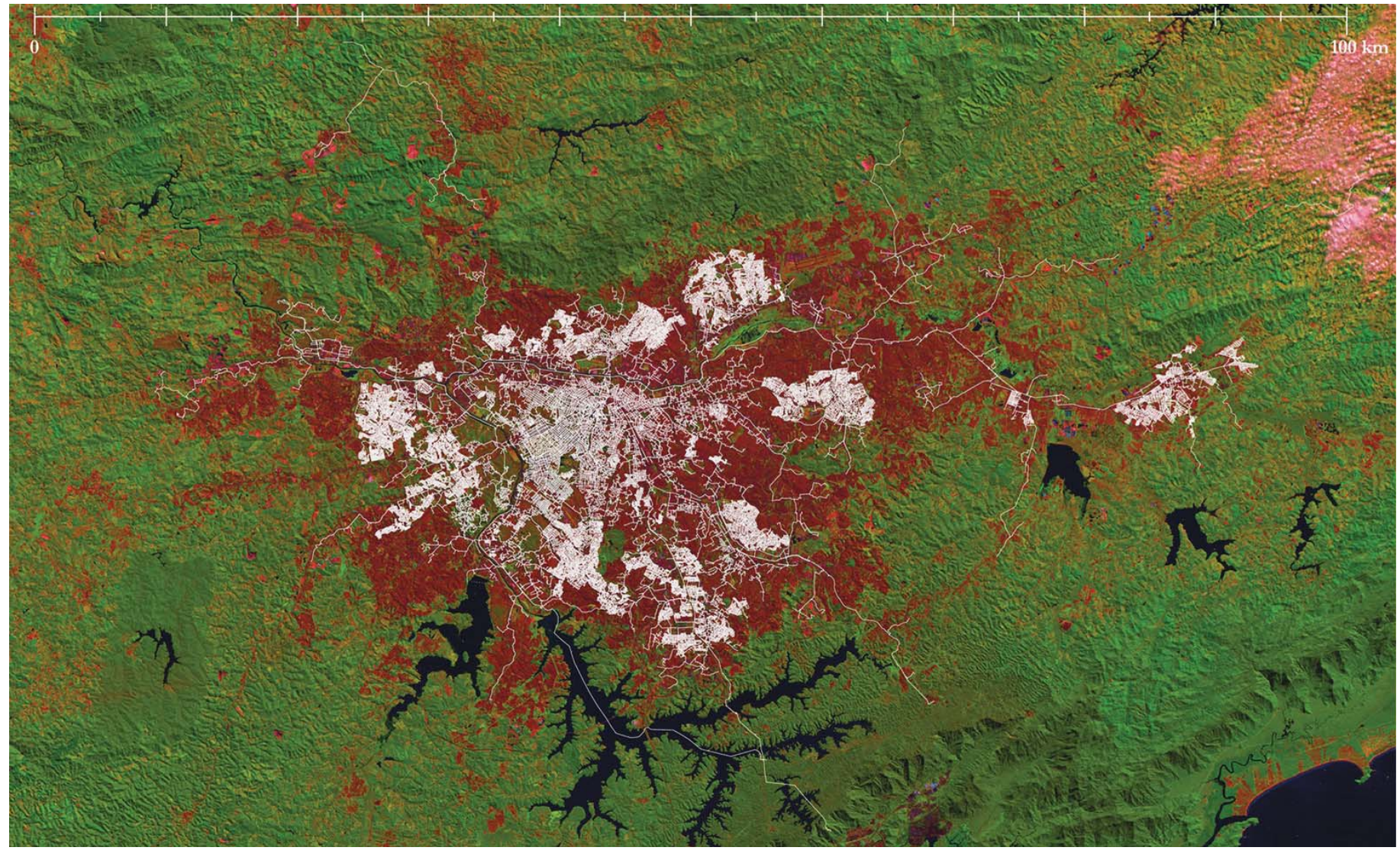

Mapa 19. Rede de gás canalizado sobre área urbanizada da RMSP.

Mapa elaborado pela própria autora.

Fonte: COMGÁS, 2015; LANDSAT TM 5: imagem de satélite. São José dos Campos: Instituto Nacional de Pesquisas Espaciais, 2011. 2 fotografias aéreas. Canais 3,4,5 e composição colorida 5,4 e 3 . 


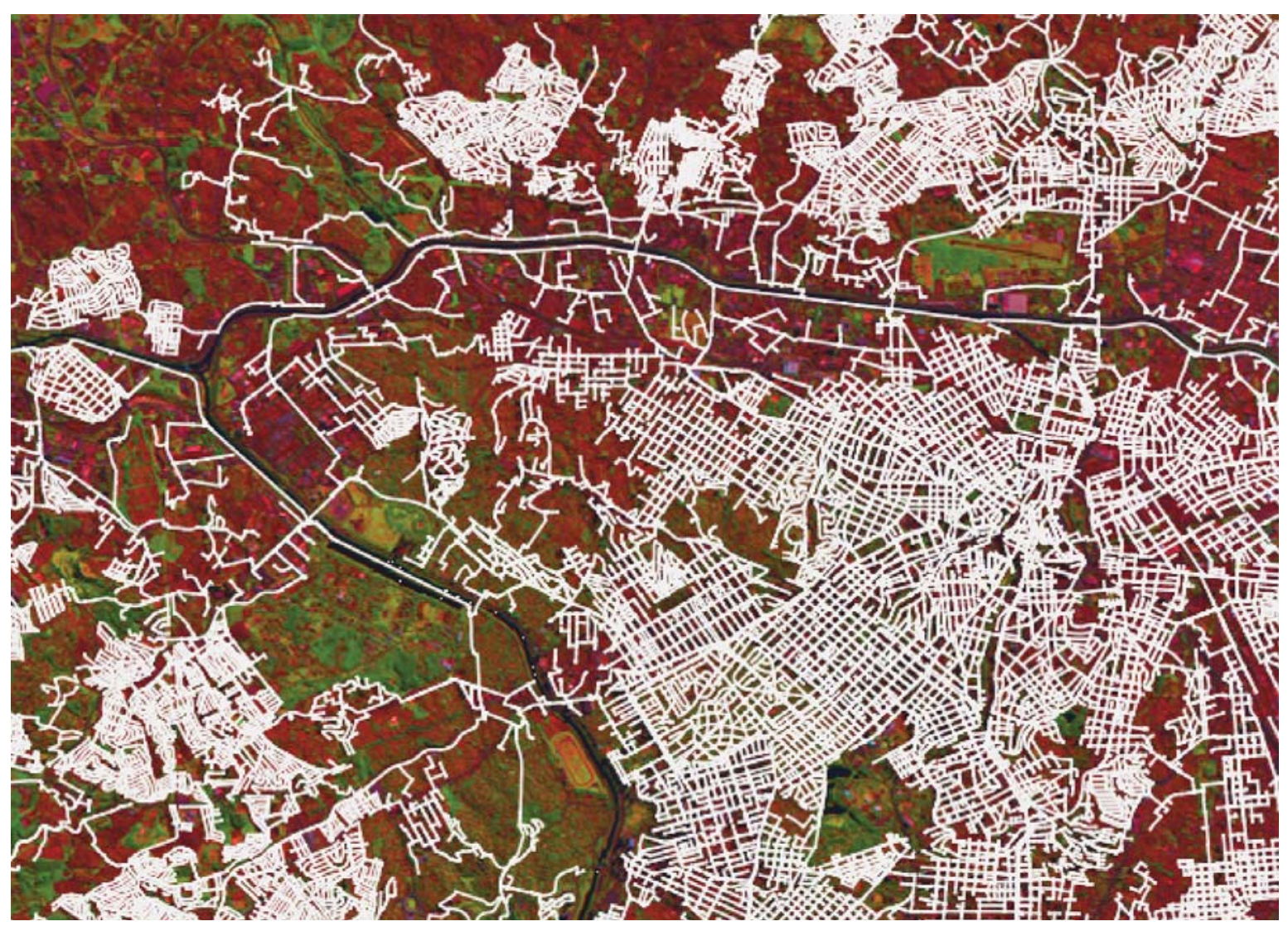

Mapa 20. Ampliação da rede de gás canalizado sobre área urbanizada da RMSP.

Mapa elaborado pela própria autora.

Fonte: COMGÁs, 2015; LANDSAT TM 5: imagem de satélite. São José dos Campos: Instituto Nacional de Pesquisas Espaciais, 2011. 2 fotografias aéreas. Canais 3,4,5 e composição colorida 5,4 e 3 . 


\subsubsection{A rede de abastecimento de água}

A caracterização da rede de abastecimento de água se deu por meio do georreferenciamento dos dados disponíveis na pesquisa do Censo (IBGE, 2010) e dos dados primários requisitados para o Departamento de Desenvolvimento e Gestão Metropolitana da Companhia de Saneamento Básico do Estado de São Paulo - Sabesp referentes ao ano de 2013. Os indicadores analisados neste capítulo foram:

- domicílios com abastecimento da rede geral [\%];

- $\quad$ índice de regularidade de adução - IRA [\%];

- $\quad$ índice de regularidade de distribuição - IRD [\%];

- $\quad$ índice de reclamação de falta d'água -IRFA [\%]; e

- contingência dos sistemas de abastecimento.

Esses foram sistematizados na Tabela 7. 
Tabela 7. Indicadores de qualidade do abastecimento de água.

Tabela elaborada pela própria autora.

Fonte: Sabesp, 2015; IBGE 2010.

\begin{tabular}{|c|c|c|c|}
\hline ÍNDICE & DESCRIÇÃO & REFERÊNCIA & CLASSIFICAÇÃO \\
\hline \multirow{5}{*}{$\begin{array}{c}\text { IRA } \\
\text { [SABESP] }\end{array}$} & \multirow{5}{*}{ Índice de regularidade de adução } & Inferior a $\mathbf{7 0} \%$ & Péssimo \\
\hline & & Entre $\mathbf{7 0} \%$ e $\mathbf{9 0} \%$ & Ruim \\
\hline & & Entre $90 \%$ e $95 \%$ & Regular \\
\hline & & Entre $95 \%$ e $98 \%$ & Bom \\
\hline & & Superior a $98 \%$ & Ótimo \\
\hline \multirow{5}{*}{$\begin{array}{c}\text { IRD } \\
\text { [SABESP] }\end{array}$} & \multirow{5}{*}{ Índice de regularidade de distribuição } & Inferior a $\mathbf{7 0} \%$ & Péssimo \\
\hline & & Entre $\mathbf{7 0} \%$ e $\mathbf{9 0} \%$ & Ruim \\
\hline & & Entre $90 \%$ e $95 \%$ & Regular \\
\hline & & Entre $95 \%$ e $98 \%$ & Bom \\
\hline & & Superior a $\mathbf{9 8 \%}$ & Ótimo \\
\hline \multirow{3}{*}{$\begin{array}{l}\text { IRFA } \\
\text { [SABESP] }\end{array}$} & \multirow{3}{*}{ Índice de reclamação de falta d'água } & < 10 reclamações / 1000 ligações & Normal \\
\hline & & $10>20$ reclamações / 1000 ligações & Atenção \\
\hline & & > 20 reclamações / 1000 ligações & Crítico \\
\hline \multirow{5}{*}{ [CENSO] } & \multirow{5}{*}{$\begin{array}{l}\text { Domicílios com abastecimento } \\
\text { da rede geral }\end{array}$} & 0 a $20 \%$ & Crítico \\
\hline & & 21 a $40 \%$ & Ruim \\
\hline & & 41 a $60 \%$ & Regular \\
\hline & & 61 a $80 \%$ & Aceitável \\
\hline & & 81 a $100 \%$ & Bom \\
\hline \multirow{3}{*}{ [SABESP] } & \multirow{3}{*}{$\begin{array}{l}\text { Contingência dos sistemas de } \\
\text { abastecimento }\end{array}$} & abastecido por 1 sistema & Bom \\
\hline & & abastecido por 2 sistemas & Ótimo \\
\hline & & abastecido por 3 sistemas & Excelente \\
\hline
\end{tabular}


É importante notar que, quanto aos mapas da Sabesp, os setores de abastecimento que possuíam valores nulos, descritos no mapa como 'sem dados', não são operados pela Sabesp, referindo-se àqueles municípios chamados permissionários, como é o caso de Guarulhos, São Caetano, Santo André, Mogi das Cruzes e Mauá, além de Diadema (em 2013, esta era permissionária).

De acordo com a pesquisa do Censo, os domicílios de maior porcentagem de ligação com a rede de abastecimento de água da rede geral (Mapa 21) convergem com as áreas de maior adensamento populacional, conforme visto no Mapa 7. Nesse sentido, de modo geral, o cruzamento das informações desses dois mapas demonstra uma cobertura uniforme e positiva, em que a maior parte dos domicílios é coberta pelo sistema público. Porém, tal como os outros indicadores estudados, resumir o índice de cobertura do Censo é insuficiente para configurar a geografia da acessibilidade social concreta ao acesso do recurso, no caso água, apenas a partir da ligação do domicílio ao sistema.

Muitos são os problemas que inviabilizam o acesso ao serviço, e vão além da capacidade de um domicílio de estar conectado à rede. O principal, sem a menor dúvida, é a disponibilidade de água nos reservatórios, assim como a regularidade de adução e distribuição da rede de abastecimento. Para efeito do diagnóstico desses indicadores, essas informações foram coletadas mediante autorização da Sabesp e georreferenciadas para que fosse possível a visualização da informação no território estudado. 


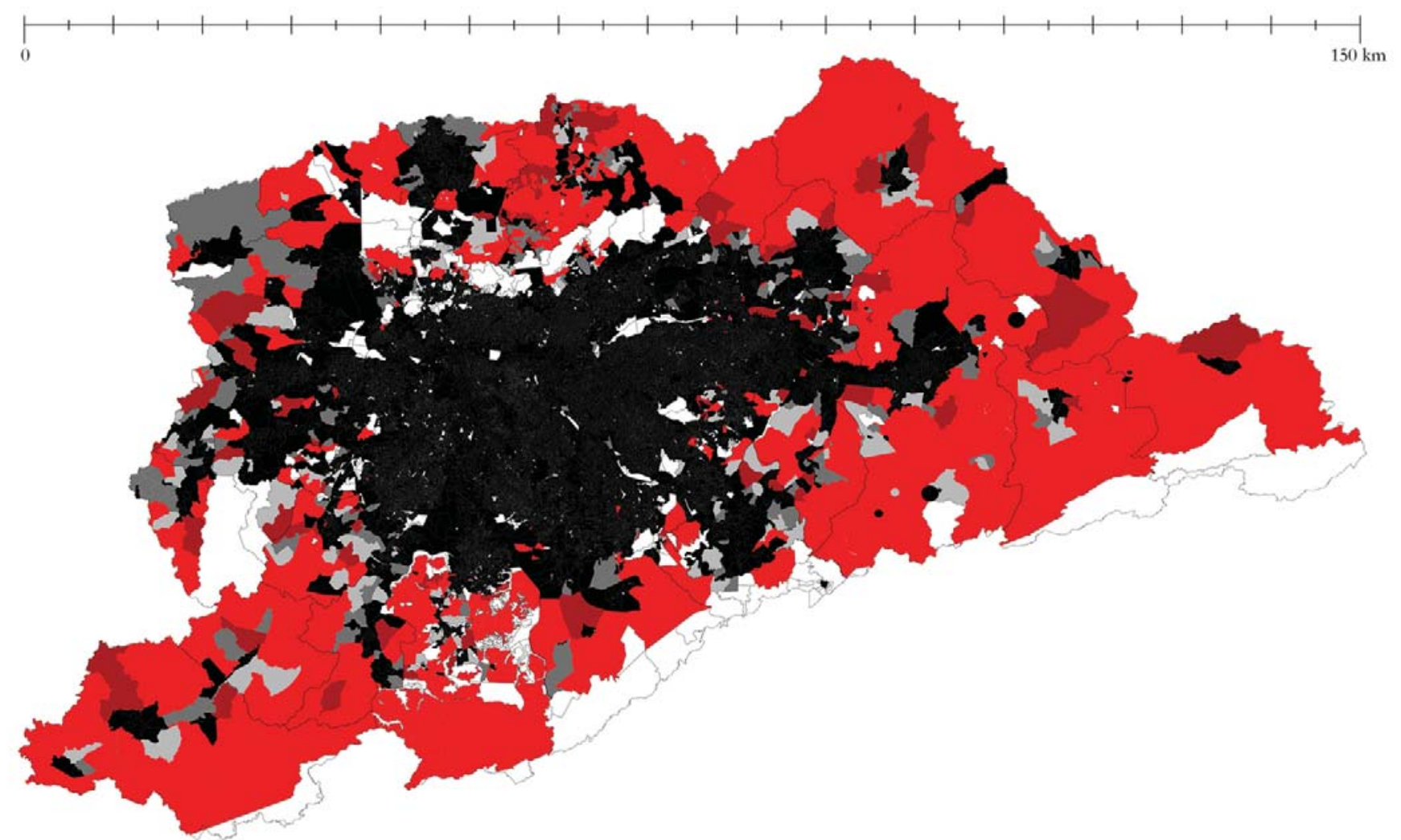

Domicílios com abastecimento de água da rede geral [\%]

0 - $20 \square$
20 a 40
40 a $60 \square$
60 a $80 \square$
80 a $100 \square$
sem dados $\square$

Mapa 21. Domicílios com abastecimento de água da rede geral.

Mapa elaborado pela própria autora.

Fonte: IBGE, 2010; CEM, 2007b.

limites municipais 


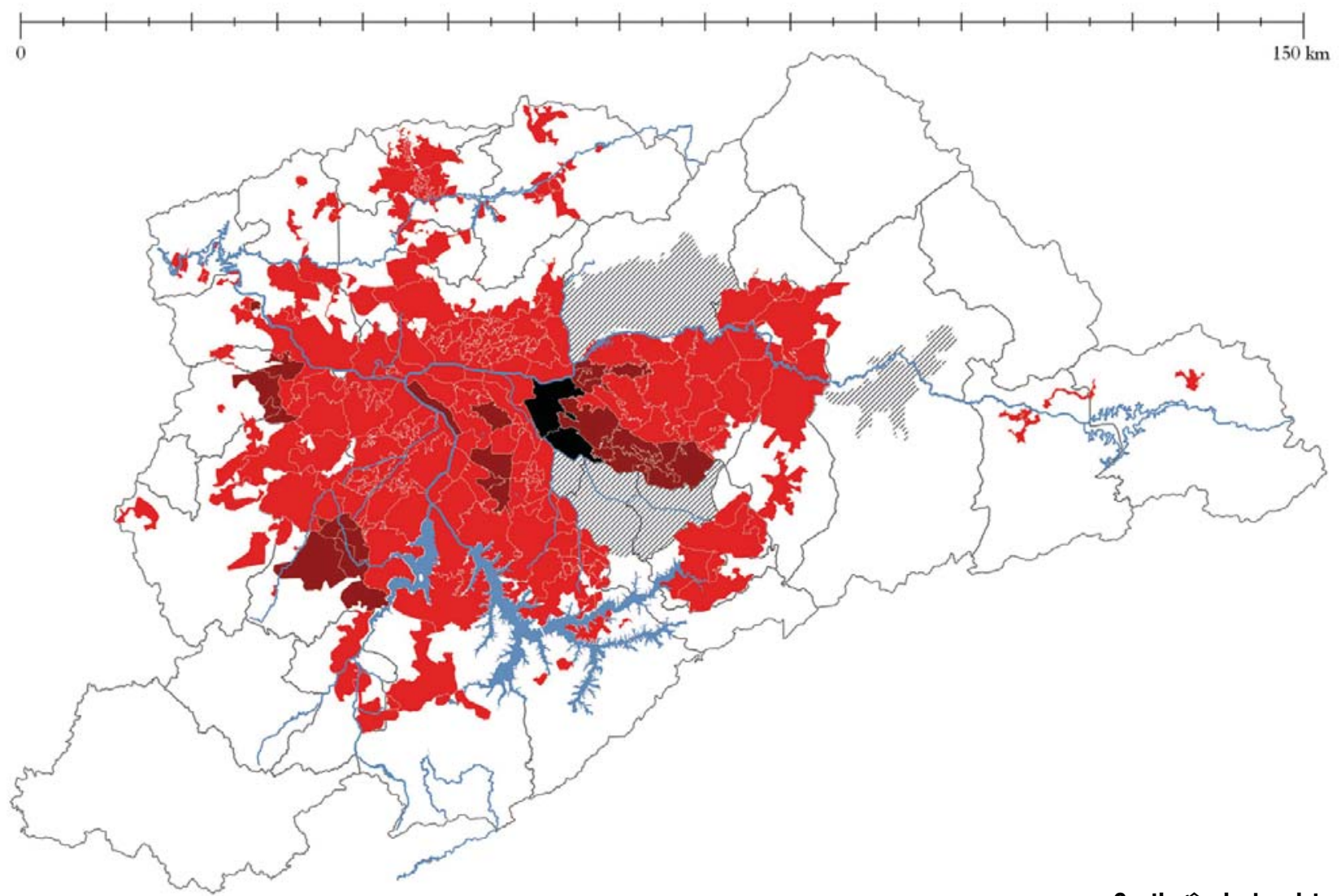

Contingência dos sistemas de abastecimento

abastecimento por um sistema

abastecimento por dois sistemas

abastecimento por três sistemas

Mapa 22. Contingência dos sistemas de abastecimento de água da Sabesp em 2013.

Mapa elaborado pela própria autora.

Fonte: SÃO PAULO (ESTADO),SABESP, 2015;EMPLASA,2015; CEM, 2007b.

sem dados

hidrografia

limites municipais 
A concessionária (Sabesp) disponibilizou dados dos sistemas que abastecem a RMSP, e também informações que possibilitaram a verificação de áreas que pudessem, em 2013, ser ligadas a sistemas secundários, em caso de racionamento do recurso no sistema principal. Assim, para efeito desta pesquisa, foi criado um mapa que pudesse demonstrar a contingência de uma localização de forma a demonstrar a possibilidade de uma área ser servida por outros sistemas em tempos de crise, mostrando, assim, a capacidade, ou os limites de capacidade, de integração dos sistemas de abastecimento.

Com a crise hídrica, de 2014 e 2015, várias áreas passaram a operar nesse esquema alternativo, na possibilidade de flexibilidade no abastecimento. Porém, devido a problemas tanto geográficos quanto de foco de investimentos, muitas áreas que não apresentam este tipo de flexibilidade acabaram, como ainda o fazem, por sofrer as consequências de um racionamento de forma mais severa. No Mapa 22, é possível identificar as áreas que desfrutam de maior adaptabilidade em períodos de anormalidade.

Como explicado, também foram analisados geograficamente os dados IRA, o indicador que exprime a eficiência da entrega de água nos pontos de reservação do sistema adutor metropolitano, permitindo avaliar a performance da adução. O IRA representa a porcentagem de tempo em que os reservatórios de distribuição trabalharam com níveis superiores aos limites mínimos operacionais estabelecidos, sendo esse 
indicador capaz de traduzir as falhas operacionais e o déficit de abastecimento nos diversos subsistemas da concessionária.

Várias são as causas que resultam em índices IRA inferiores, como a insuficiência de produção, a insuficiência na distribuição, a insuficiência de recalque, o rodízio, alguma manutenção do sistema (programada ou não), uma falha na operação, ou mesmo, a falta de energia elétrica.

O diagnóstico do IRA para o ano de 2013, conforme Mapa 23, indica que, a partir da região sul do MSP caminhando sentido horário, passando por todos os municípios abastecidos pela Sabesp que beiram a borda da RMSP, os valores são considerados 'péssimos', inferiores a 70\%. A área 'interna' do conjunto de setores de abastecimento estudados encontra valores em geral 'ótimos'.

O IRD é um indicador que exprime a eficiência da entrega de água ao consumidor. Este é representado por uma porcentagem de tempo em que o cliente teve o produto entregue, em volume e pressão adequados ao seu consumo. É calculado tendo como variáveis: a quantidade total de horas do mês medido, a quantidade de horas sem abastecimento e o total de clientes afetados (na forma de economias ativas), resultado dos diversos eventos de descontinuidade da distribuição de água (intermitências e falta d'água), durante este mesmo mês.

A análise do IRD, conforme o Mapa 24, indica menos áreas 'péssimas', porém um grande número de conjunto com resultados 
'regulares'. Diferentemente do caso anterior (IRA), no qual os conjuntos apresentavam valores 'ótimos', estes apresentam, na maior parte, resultados 'bons', sendo os resultados em geral mais homogêneos do que podemos constatar no anterior. Naquele, a segregação entre o número de setores com qualidade de distribuição 'péssimos' contrastam com um também grande número de setores ‘ótimos’.

Por fim, o IRFA é um indicador que avalia as reclamações dos clientes em relação à falta d'água e a intermitência no abastecimento. Essas reclamações são provenientes da Central de Atendimento Telefônico da Sabesp e são registradas no Sistema de Gestão Operacional - SIGAO da empresa. O indicador é processado mensalmente por setor de abastecimento e expresso em 'número de reclamações por mil ligações de água’. Os valores de referência para os três indicadores estudados, IRA, IRD e IRFA, podem ser consultados na Tabela 7.

A análise do IRFA, conforme Mapa 25, indica claramente um grande número de setores localizados a oeste da RMSP, apresentando mais de vinte reclamações a cada mil ligações, o que é considerado crítico.

Com obviedade, existe uma convergência nos setores que apresentam IRFA críticos quando analisados os outros dois indicadores, IRA e IRD. Para esses mesmos casos, o nível de integração das bacias de abastecimento é baixo, com pouca contingência, sendo abastecidos por 
apenas um sistema. Essas análises demonstram que, na grande maioria dos casos, setores de abastecimento que apresentam um indicador crítico também tendem a apresentar resultados péssimos ou regulares nos outros quesitos - e vice-versa -, setores ótimos em um indicador também tendem a apresentar resultados ótimos, bons, ou terem maiores níveis de contingência em outros quesitos.

Verfica-se que os sistemas de abastecimento de água operam em situação limítrofe. As áreas que apresentam os piores índices são, em geral, espaços periféricos e sujeitos a expansão urbana. No caso de planos e projetos de regeneração que possivelmente venham a se localizar nas principais falhas dos sistemas de abastecimento de água, verifica-se um grande risco de redistribuição de complicações, já que nessas localizações dificilmente há oferta de fontes alternativas quando do aumento da demanda por recursos. 


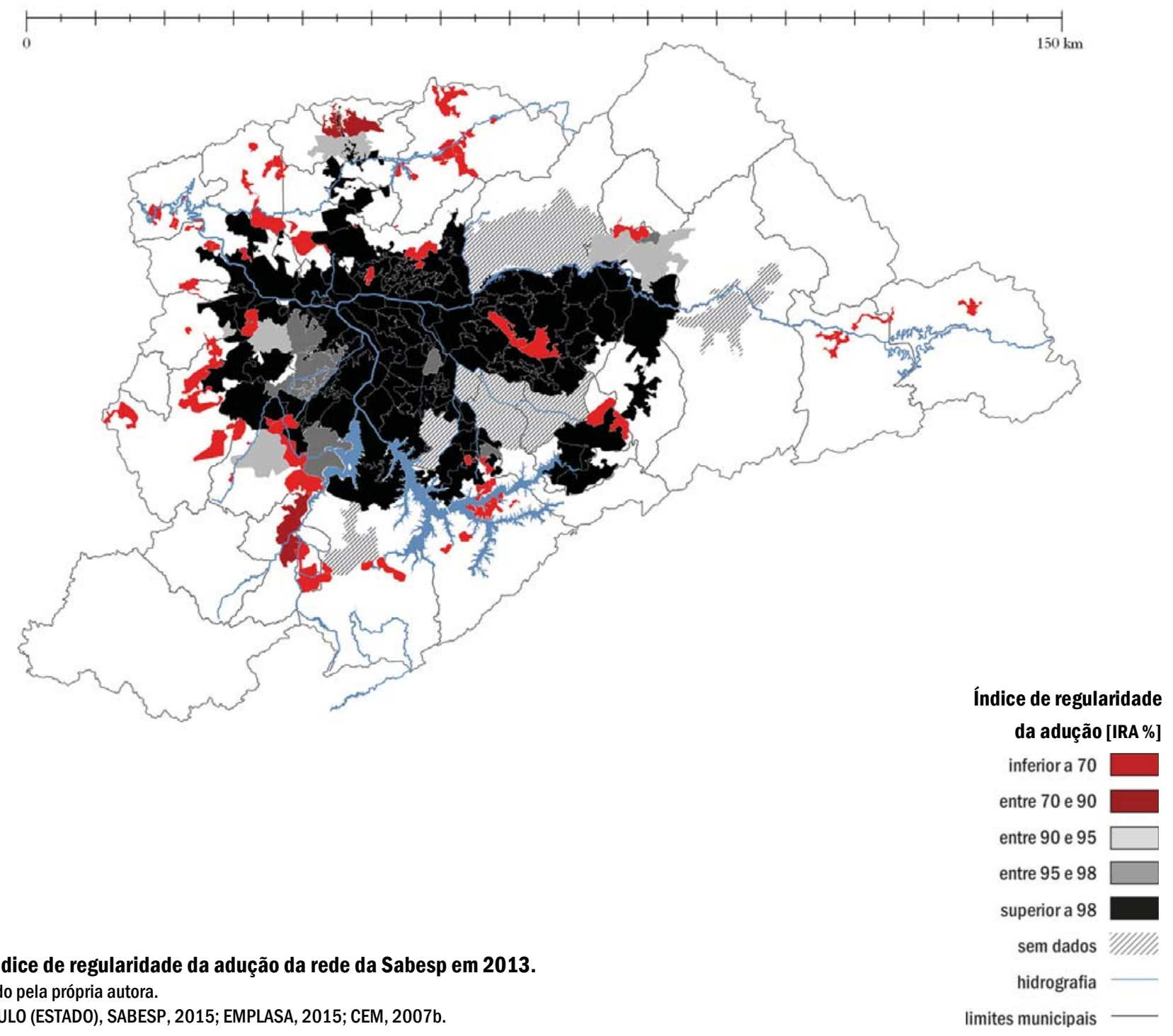

Mapa 23. Índice de regularidade da adução da rede da Sabesp em 2013.

Mapa elaborado pela própria autora.

Fonte: SÃO PAULO (ESTADO), SABESP, 2015; EMPLASA, 2015; CEM, 2007b. 


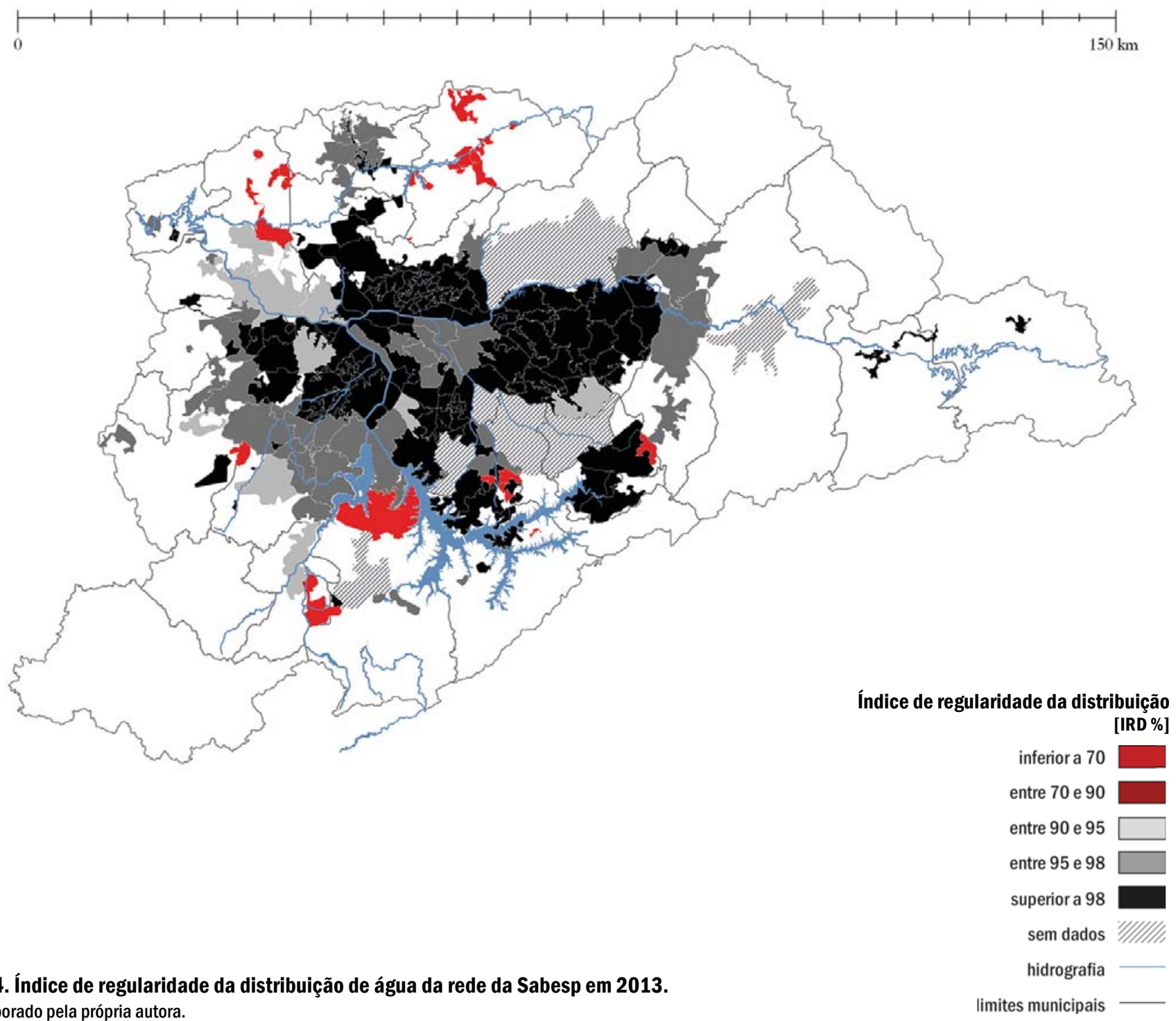

Mapa 24. Índice de regular

Mapa elaborado pela própria autora.

limites municipais

Fonte: SÃO PAULO (ESTADO), SABESP, 2015; EMPLASA, 2015; CEM, $2007 \mathrm{~b}$. 


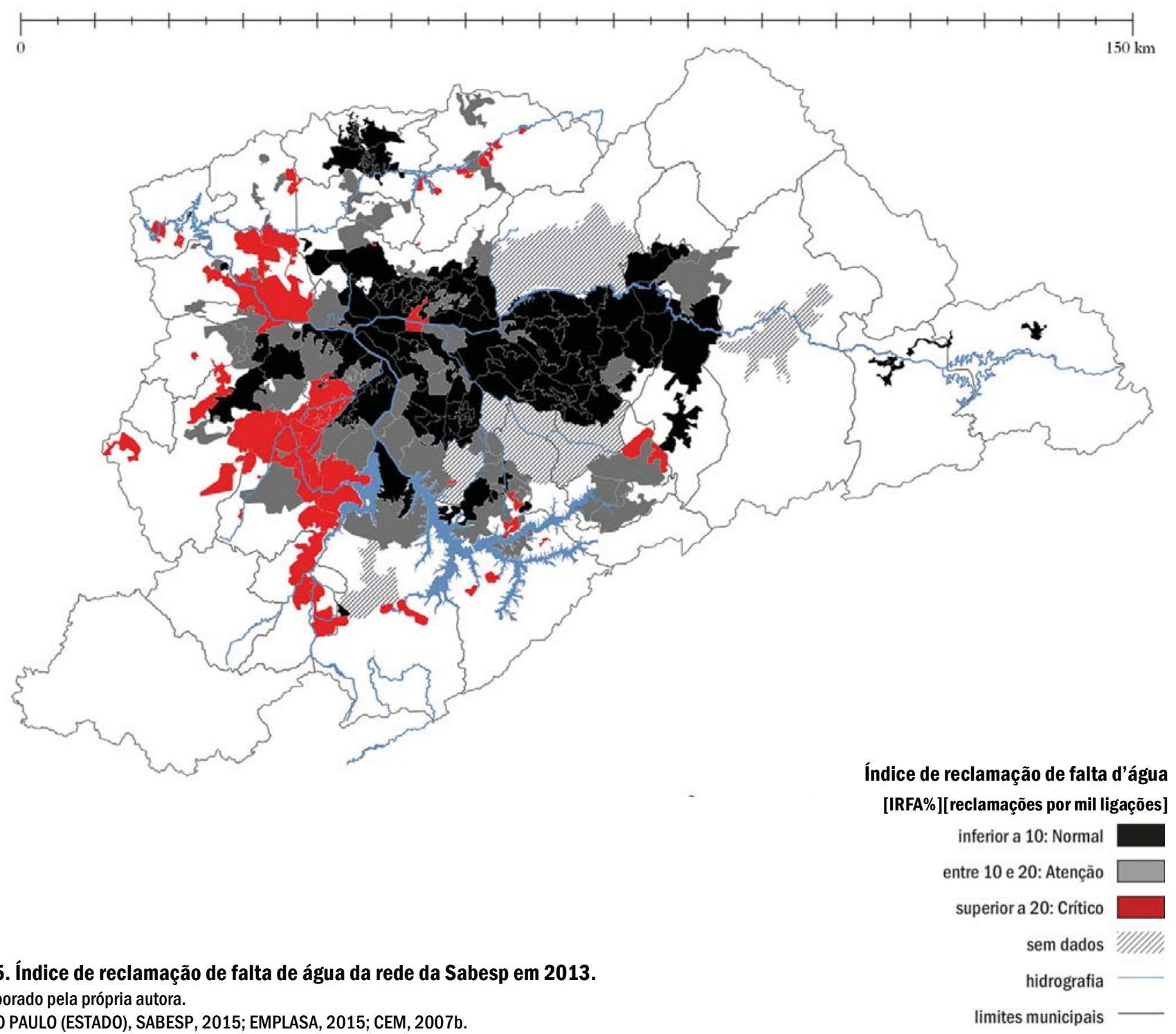

Mapa elaborado pela própria autora.

Fonte: SÃO PAULO (ESTADO), SABESP, 2015; EMPLASA, 2015; CEM, 2007b. 


\subsubsection{A rede de coleta e tratamento de esgoto}

A rede de coleta e tratamento de esgoto, tal como a rede de abastecimento de água, foi representada por meio do georreferenciamento dos dados disponíveis na pesquisa do Censo (IBGE, 2010) e dos dados primários requisitados para o Departamento de Desenvolvimento e Gestão Metropolitana da Companhia de Saneamento Básico do Estado de São Paulo - Sabesp (referentes ao ano de 2013), assim como dados levantados na pesquisa do Ministério das Cidades por meio do Sistema Nacional de Informações sobre Saneamento - SNIS. Aos indicadores estudados, nesta pesquisa incluíram-se:

- domicílios com banheiros ligados à rede geral [\%];

- domicílios atendidos por coleta de lixo [\%];

- $\quad$ índice de coleta de esgoto [\%];

- índice de tratamento de esgoto [\%];

- taxa de infiltração das bacias de esgotamento [1/s/km].

O quadro síntese destes indicadores contém os seus valores de referência, conforme Tabela 8 . 
Tabela 8. Indicadores de coleta e tratamento de esgoto.

Tabela elaborada pela própria autora.

Fonte: Sabesp, 2015; IBGE, 2010; BRASIL, MINISTÉRIO DAS CIDADES, 2013.

\begin{tabular}{|c|c|c|c|}
\hline ÍNDICE & DESCRIÇÃOO & REFERÊNCIA & CLASSIFICAÇÃO \\
\hline \multirow{5}{*}{$\begin{array}{c}\text { TI } \\
\text { [Sabesp] }\end{array}$} & \multirow{5}{*}{$\begin{array}{l}\text { Taxa de infiltração das bacias de esgotamento } \\
\qquad[\mathrm{l} / \mathrm{s} / \mathrm{km}]\end{array}$} & 0,40 a 0,46 & Crítico \\
\hline & & 0,33 a 0,40 & Ruim \\
\hline & & 0,28 a 0,33 & Regular \\
\hline & & 0,24 a 0,28 & Aceitável \\
\hline & & 0,20 a 0,24 & Bom \\
\hline \multirow{5}{*}{ [Censo] } & \multirow{5}{*}{ Domicílios com banheiros ligados à rede geral } & 0 a $20 \%$ & Crítico \\
\hline & & 21 a $40 \%$ & Ruim \\
\hline & & 41 a $60 \%$ & Regular \\
\hline & & 61 a $80 \%$ & Aceitável \\
\hline & & 81 a $100 \%$ & Bom \\
\hline \multirow{5}{*}{ [Censo] } & \multirow{5}{*}{ Domicílios atendidos por coleta de lixo } & 0 a $20 \%$ & Crítico \\
\hline & & 21 a $40 \%$ & Ruim \\
\hline & & 41 a $60 \%$ & Regular \\
\hline & & 61 a $80 \%$ & Aceitável \\
\hline & & 81 a $100 \%$ & Bom \\
\hline \multirow{5}{*}{ [SNIS] } & \multirow{5}{*}{ Índice de coleta de esgoto } & 0 a $20 \%$ & Crítico \\
\hline & & 21 a $40 \%$ & Ruim \\
\hline & & 41 a $60 \%$ & Regular \\
\hline & & 61 a $80 \%$ & Aceitável \\
\hline & & 81 a $100 \%$ & Bom \\
\hline \multirow{5}{*}{ [SNIS] } & \multirow{5}{*}{ Índice de tratamento de esgoto } & 0 a $20 \%$ & Crítico \\
\hline & & 21 a $40 \%$ & Ruim \\
\hline & & 41 a $60 \%$ & Regular \\
\hline & & 61 a $80 \%$ & Aceitável \\
\hline & & 81 a $100 \%$ & Bom \\
\hline
\end{tabular}


Os dados do Censo, desagregados por setor censitário, apresentam resultados bastante díspares, o que acompanha as informações de densidade populacional (Mapa 7. Densidade populacional.); se por um lado a cobertura é de até $20 \%$, por outro, é de 80 a $100 \%$. No núcleo composto pelo centro urbanizado do MSP, São Caetano, Santo André e São Bernardo do Campo, no eixo leste até Mogi das Cruzes, no eixo Guarulhos/Arujá e no eixo oeste Osasco/Barueri, o nível de cobertura é bastante alto, como ilustrado no Mapa 26. A cobertura de atendimento por coleta de lixo já é bem mais abrangente (Mapa 27), o que pode ser explicada prioritariamente por uma questão de acesso físico por via superficial da malha viária, diferentemente da primeira, que exige a instalação física da infraestrutura no subsolo do território. É importante ressaltar aqui uma das mais fundamentais questôes que definem o problema da cobertura da infraestrutura na RMSP, que é a dificuldade da regularização fundiária em áreas ocupadas por domicílios subnormais, principalmente em áreas de proteção ambiental. Este problema será discutido no Capítulo 4.

Infelizmente, apesar de vastos esforços, os dados de cobertura de domicílios quanto à coleta e ao tratamento de esgoto desagregados por distritos ainda não estão disponíveis. Para este fim, a melhor fonte de dados foi a do SNIS, apesar de que estas informações são agregadas com abrangência municipal, o que pode mascarar amplas heterogeneidades de indicadores que representam o problema do saneamento no país. Mesmo 
assim, a diferenciação na cobertura e no tratamento de esgoto no território da RMSP é clara, conforme visualizado nos Mapa 28 e Mapa 29.

Como ilustrado nesses mapas, quase $1 / 4$ dos municípios apresentam cobertura entre 20 e $40 \%$, sendo que $1 / 6$ deles não chegam a ter nem $20 \%$ de tratamento de esgoto, o que demonstra a clara deficiência da região como um todo. 


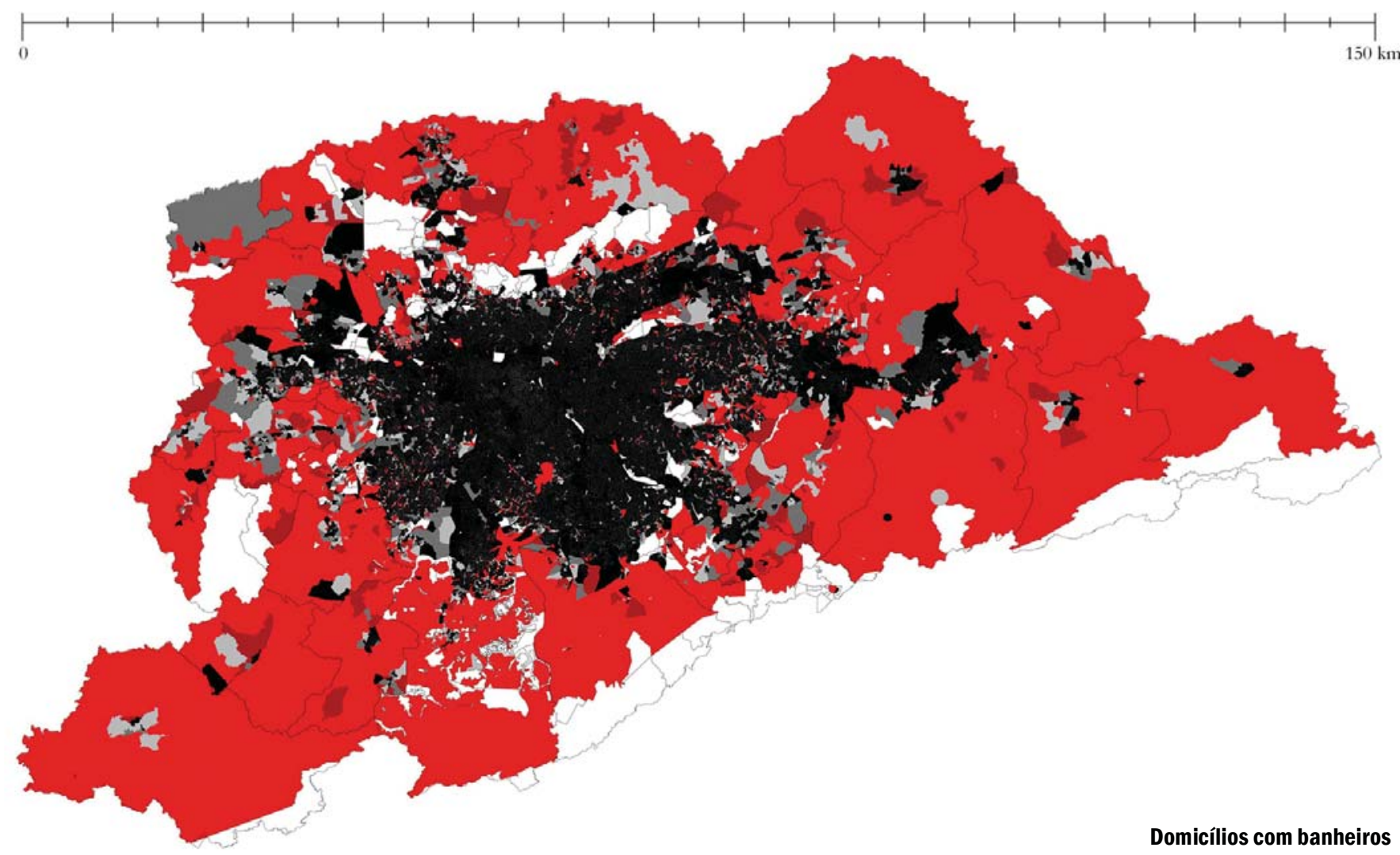

ligados à rede de esgoto [\%]

$$
0-20
$$$$
20 \text { a } 40
$$$$
40 \text { a } 60
$$$$
60 \text { a } 80
$$

Mapa 26. Domicílios com banheiros ligados à rede de esgoto.

Mapa elaborado pela própria autora.

sem dados

Fonte: IBGE, 2010; CEM, 2007b.

limites municipais 

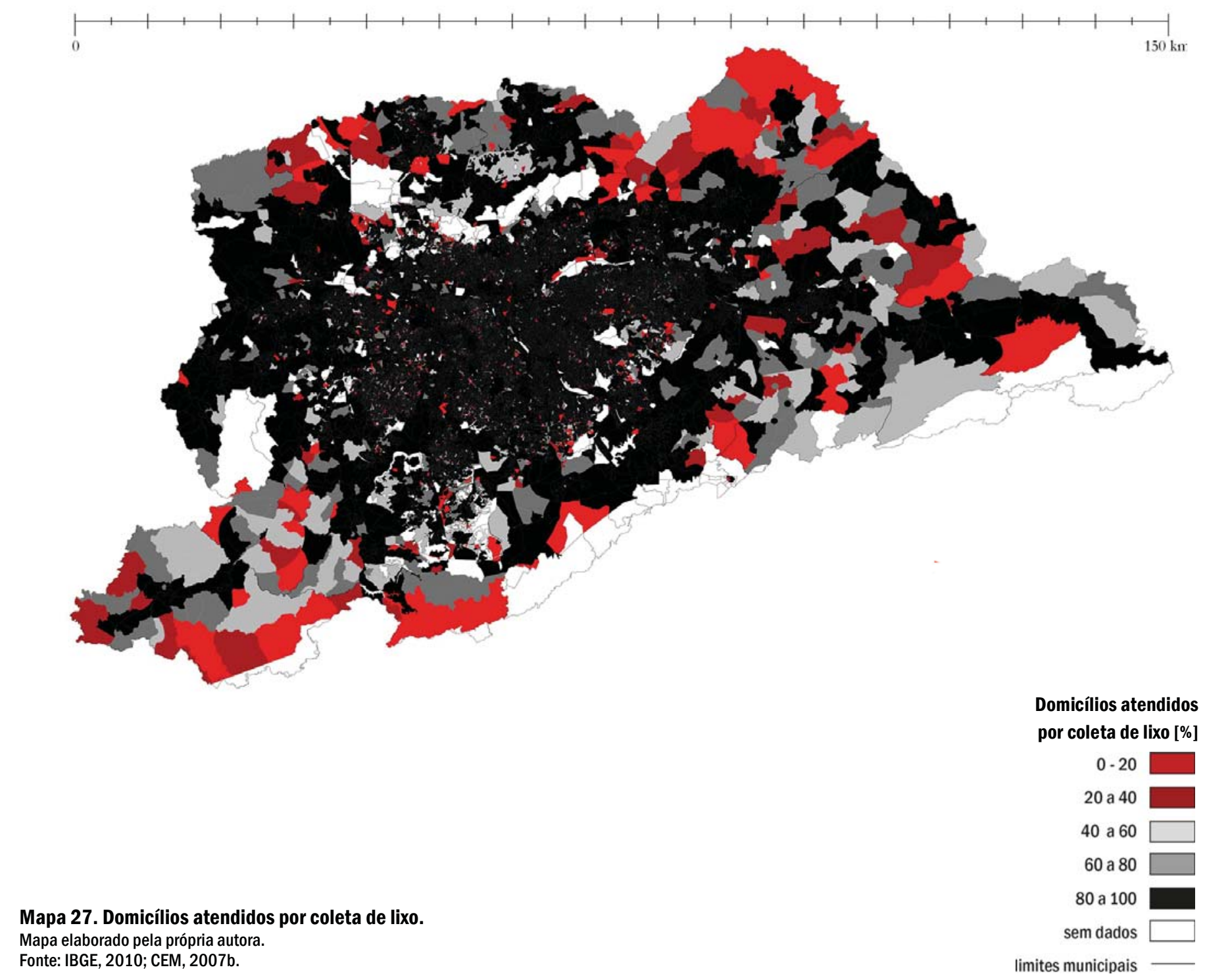


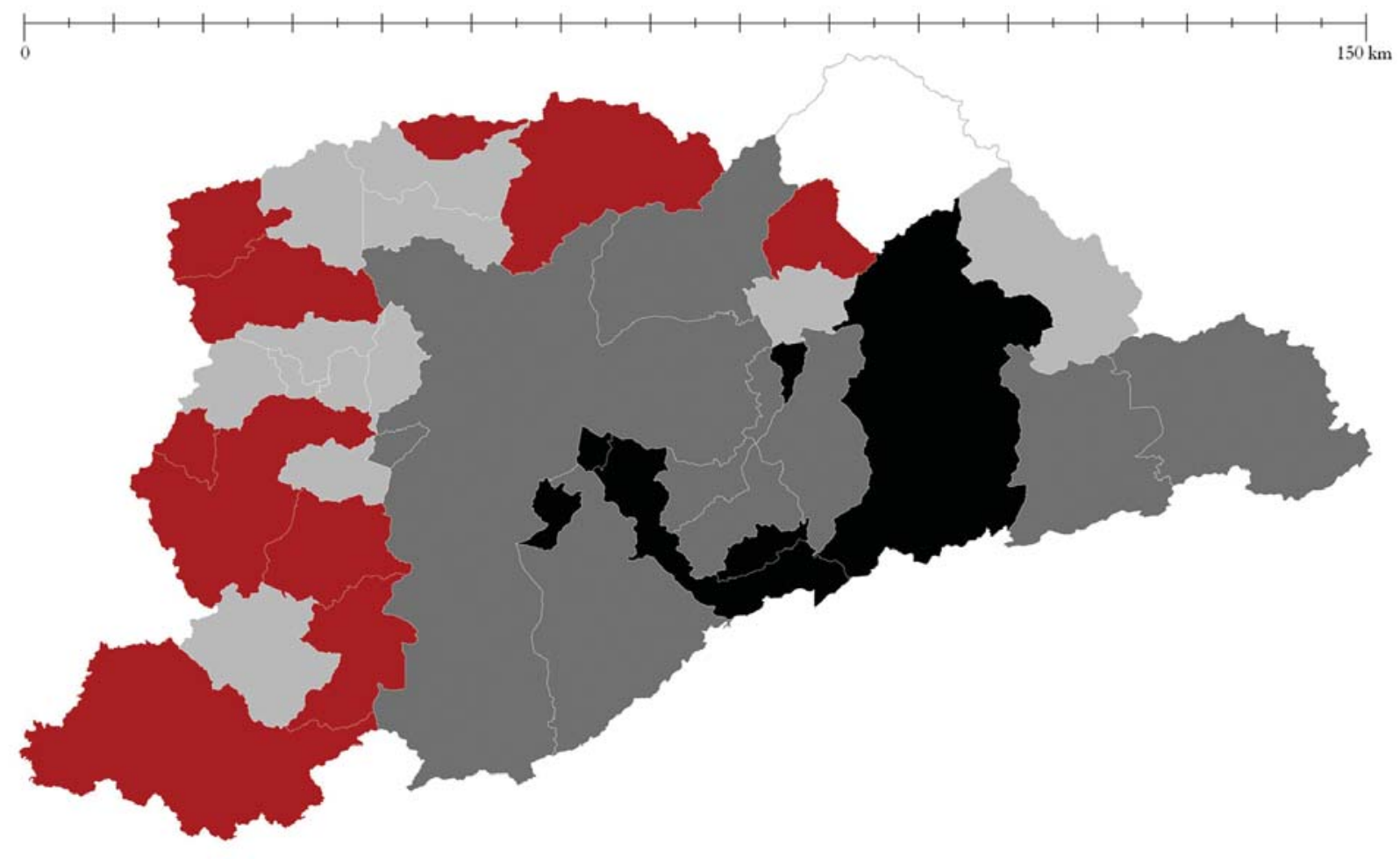

Índice de coleta de esgoto

Mapa 28. Índice de coleta de esgoto municipal em 2013.

Mapa elaborado pela própria autora.

80 a 100

Fonte: BRASIL, MINISTÉRIO DAS CIDADES, 2013; CEM, 2007b.

sem dados 


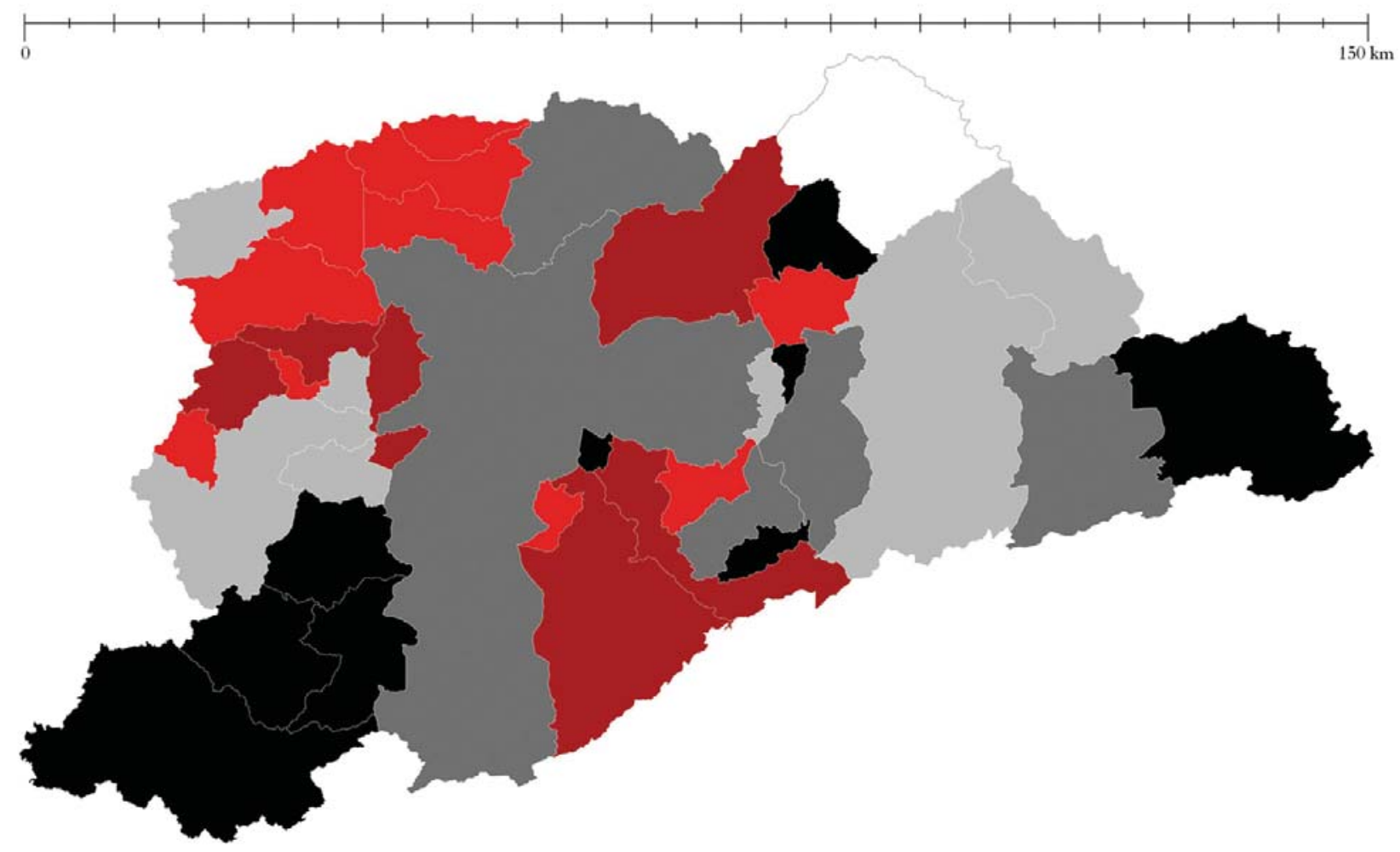

Mapa 29. Índice de tratamento de esgoto municipal em 2013.

Mapa elaborado pela própria autora.

Fonte: BRASIL, MINISTÉRIO DAS CIDADES, 2013; CEM, 2007b.

Índice de tratamento de esgoto

$0-20$

20 a 40

40 a 60

60 a 80

80 a 100

sem dados 


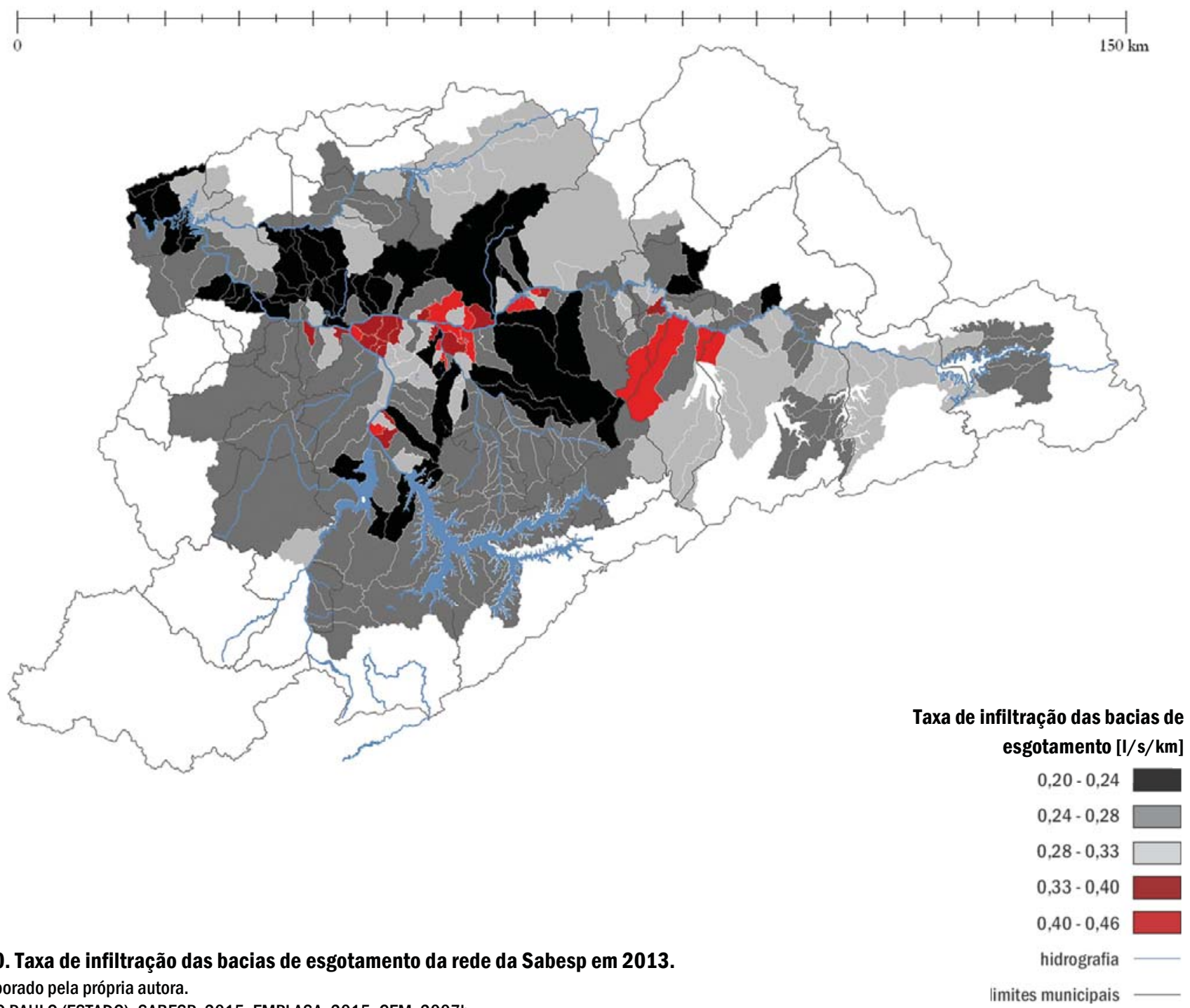

Mapa elaborado pela própria autora.

Fonte: SÃO PAULO (ESTADO), SABESP, 2015; EMPLASA, 2015; CEM, 2007b.

limites municipais 
A taxa de infiltração das bacias de esgotamento indica a quantidade de água do sistema pluvial que infiltra nas redes coletoras de esgoto dessa bacia, medida em litros por segundo por quilômetro. Num sistema perfeito, essa taxa seria zero, porém, como há deficiências estruturais nas redes, uma taxa de água pluvial acaba percolando nas redes coletoras, e, por sua vez, o esgoto das redes coletoras também acaba percolando para redes de drenagem, sendo assim, esse coeficiente serve para calcular um acréscimo de vazão na bacia provocado pelas infiltrações. De acordo com a Sabesp, a determinação destes coeficientes se dá por meio de estudos específicos e bastante sofisticados, e, por isso, são realizados aproximadamente a cada dez anos.

Como se pode notar (Mapa 30), áreas de várzea, como as lindeiras ao Rio Tietê, principalmente, e ao Rio Pinheiros (Vila Leopoldina, Lapa, Barra Funda, Bom Retiro, Limão) apresentam taxas bastante altas de infiltração, assim como a área de confluência entre os municípios de Poá, Ferraz de Vasconcelos e Suzano, nas imediações de onde passa o Rio Guaió e trecho leste do Rodoanel. Se fôssemos sobrepor os pontos de alagamentos, aqueles primeiros trechos próximos às marginais também seriam coincidentes.

Assim, é importante notar que, mesmo em locais que possuem bons índices de banheiros ligados à rede de esgoto, ou seja, locais urbanizados consolidados da RMSP, há vulnerabilidade em relação aos problemas de alagamento e às taxas de infiltração. Isto demonstra que 
falar apenas da questão da abrangência de um sistema, no caso coleta e tratamento de efluentes, não é suficiente para representar a realidade da qualidade desta rede infraestrutural fundamental, que ainda é, literalmente, tão cheia de furos.

\subsubsection{A rede de telefonia móvel}

A rede de telefonia móvel foi selecionada para compor a base de infraestruturas examinadas nesta pesquisa por causar um efeito direto no cotidiano das pessoas e, consequentemente, comprometer a sua inserção na sociedade e na capacidade própria de exercer atividades de diferentes naturezas, principalmente trabalho e manutenção de relações pessoais. Atualmente, a rede de telefonia fixa não é mais suficiente para inserir o indivíduo na rede de facilidades da sociedade contemporânea, tornandose indiretamente um item essencial, sem o qual um indivíduo pode se notar excluído da comunidade que o cerca.

Para compor os dados de cobertura e abrangência da rede de telecomunicações, foram contatadas a Agência Nacional de Telecomunicações - Anatel, a empresa de consultoria Teleco, a Associação Brasileira de Serviços de Telecomunicações Competitivas TelComp e o Laboratório de Arquitetura e Redes de Computadores do Departamento de Computação e Ciências Digitais da Escola Politécnica da Universidade de São Paulo - LARC POLI. 
O acesso aos dados para caracterização da cobertura e qualidade da rede foi de extrema dificuldade, como no caso da pesquisa em saneamento. Devido ao número elevado de prestadoras deste serviço e a ausência de uma base de informações que possa ser geograficamente referenciada em unidades territoriais de menor agregação que o nível municipal, constatou-se uma alta fragmentação de subsídios para compor os objetivos deste capítulo. Esta fragmentação pode ser vista como intencional do ponto de vista mercadológico, já que há uma alta competitividade no setor, não sendo do interesse das prestadoras evidenciar as particularidades de sua rede de serviços.

Entretanto, foi criada uma metodologia de análise para os dados levantados por meio dos indicadores da Anatel de acompanhamento do plano de melhoria do serviço móvel pessoal - telefonia móvel celular com dados dos indicadores de rede consolidados por município. Como os dados disponibilizados pela Anatel são disponibilizados por município e divididos por prestadoras por meio de taxas mensais e anuais de cada uma delas, foi realizada uma avaliação que pudesse representar, dentre todas elas, quais as melhores e piores médias de resultados por município em um ano específico, nesse caso, 2013 (já que a maior parte dos dados nesta pesquisa acompanhou este ano de corte). Assim, não houve a intenção de expor quais as melhores ou as piores prestadoras de telefonia móvel, e, sim, a de apresentar quais os melhores e os piores índices que se diferenciam no espaço da metrópole. 
Os indicadores estudados foram criados por meio da compilação de dados coletados 24 horas por dia, todos os dias do mês, e foram representados pelas seguintes taxas, conforme apresentado na Tabela 9:

- de conexão de voz: total de chamadas completadas dividido pelo total de tentativas [Referência $\geq 95 \%$ ];

- de desconexão de chamada de voz: total de chamadas interrompidas dividido pelo total de chamadas [Referência $\leq$ $2 \%]$

- de conexão de dados: total de conexões de dados dividido pelo total de tentativas [Referência $\geq 98 \%$ ];

- de queda de conexão de dados: total de conexões de dados interrompidos dividido pelo total de conexões [Referência $\leq$ $5 \%$. 
Tabela 9. Indicadores de qualidade da telefonia móvel.

Tabela elaborada pela própria autora.

Fonte: BRASIL, 2014a.

\begin{tabular}{|c|c|c|c|}
\hline ÍNDICE & DESCRIÇÃOO & REFERÊNCIA & CLASSIFICAÇÃOO \\
\hline [Anatel] & $\begin{array}{c}\text { Taxa de conexão de voz: } \\
\text { total de chamadas } \\
\text { completadas / total de } \\
\text { tentativas }\end{array}$ & $\geq 95 \%$ & $\begin{array}{l}\text { Observar limites } \\
\text { máximos de } \\
\text { referência } \\
\text { estabelecidos pela } \\
\text { Anatel }\end{array}$ \\
\hline [Anatel] & $\begin{array}{l}\text { Taxa de desconexão de } \\
\text { chamada de voz: total de } \\
\text { chamadas interrompidas } \\
\text { / pelo total de chamadas }\end{array}$ & $\leq 2 \%$ & $\begin{array}{l}\text { Observar limites } \\
\text { máximos de } \\
\text { referência } \\
\text { estabelecidos pela } \\
\text { Anatel }\end{array}$ \\
\hline [Anatel] & $\begin{array}{l}\text { Taxa de conexão de } \\
\text { dados: total de conexões } \\
\text { de dados / total de } \\
\text { tentativas }\end{array}$ & $\geq 98 \%$ & $\begin{array}{l}\text { Observar limites } \\
\text { máximos de } \\
\text { referência } \\
\text { estabelecidos pela } \\
\text { Anatel }\end{array}$ \\
\hline [Anatel] & $\begin{array}{l}\text { Taxa de queda de conexão } \\
\text { de dados: total de } \\
\text { conexões de dados } \\
\text { interrompidas / total de } \\
\text { conexões }\end{array}$ & $\leq 5 \%$ & $\begin{array}{l}\text { Observar limites } \\
\text { máximos de } \\
\text { referência } \\
\text { estabelecidos pela } \\
\text { Anatel }\end{array}$ \\
\hline
\end{tabular}


Esses indicadores foram georreferenciados de forma a tornar possível a visualização dos resultados na região metropolitana. Percebe-se que as piores taxas de conexão e desconexão de voz, e de conexão e desconexão de dados, seguem uma forte tendência de ocorrerem nos municípios mais periféricos da RMSP. Apesar das exigências mínimas estipuladas pela reguladora - ANATEL - não é raro encontrar médias muito aquém das taxas de referência, o que representa padrões de qualidade bastante inferiores às normas.

As piores taxas médias de conexão de voz foram identificadas nos município de Embu, Cajamar e Guararema (Mapa 32), sendo as piores taxas médias de desconexão de voz em Mairiporã, São Lourenço da Serra e novamente Cajamar (Mapa 34). Em relação à conexão de dados, é importante notar que mesmo as melhores médias se encontram abaixo dos valores de referência, o que indica uma condição bastante insatisfatória na provisão destes serviços (Mapa 35). As piores taxas médias de conexão de dados (Mapa 36) se encontram nos municípios de Embu, Vargem Grande Paulista, Pirapora de Bom Jesus, Itaquaquecetuba, Poá e Rio Grande da Serra. As piores taxas de desconexão de dados (Mapa 38) estão nos municípios de Biritiba-Mirim, Guararema e Ribeirão Pires.

Dessa forma, apesar da agregação de dados de natureza incipiente para análise territorial da heterogeinedade da prestação de serviços, que resulta em áreas de abrangência municipais, é fácil perceber 
que as piores médias de todos os indicadores de qualidade para chamadas e conexões de dados de telefonia móvel analisados localizam-se nos municípios às franjas da RMSP. Inversamente, também é claro perceber que as melhores condições de telefonia móvel são encontradas nos municípios mais ricos e de posição mais central na RMSP. 


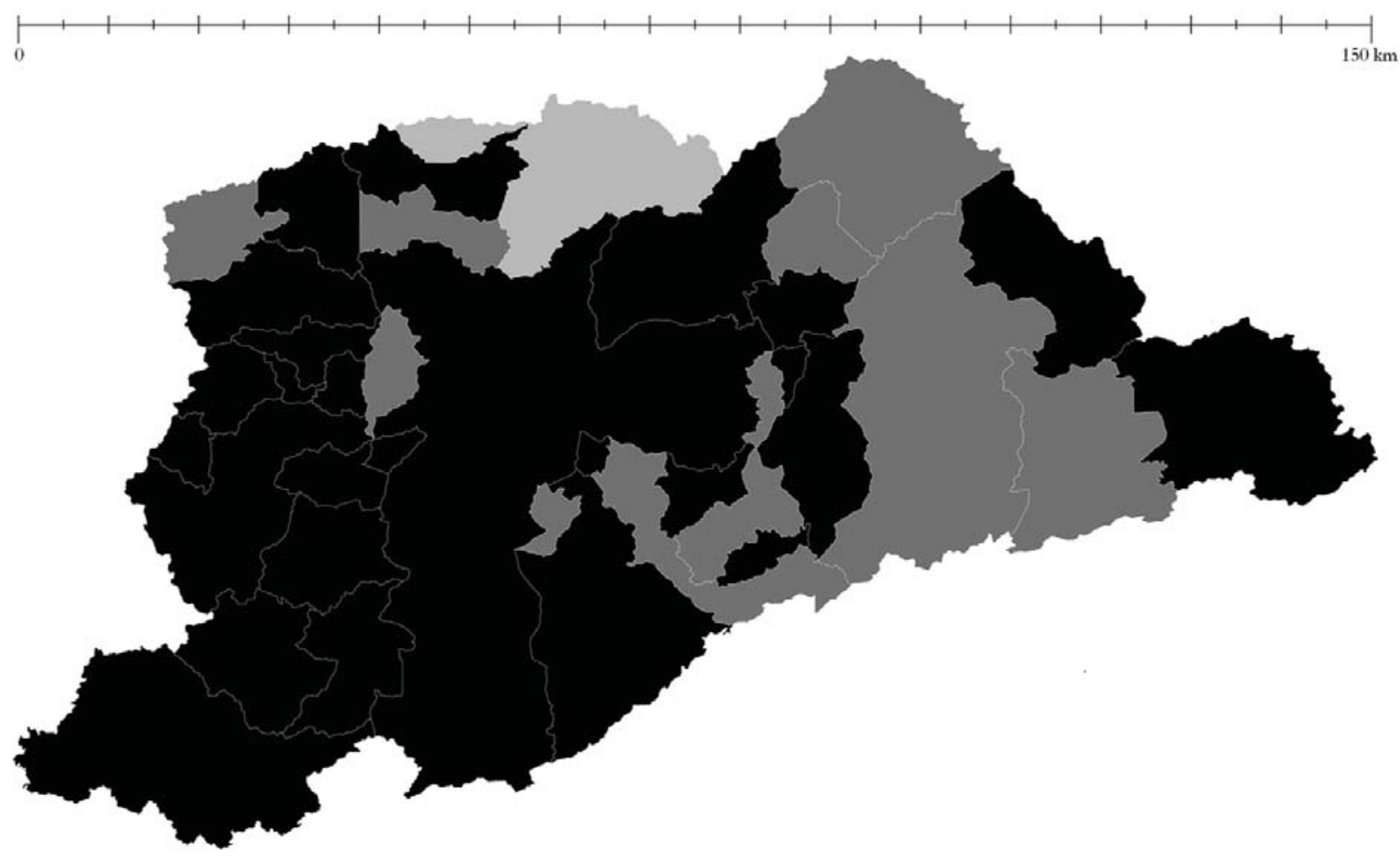

Taxa de conexão de voz Melhor média anual [referência $\geq 95 \%$ ] [total de chamadas completadas/total de tentativas]

Mapa 31. Melhor média anual de conexão de voz para o ano de 2013.

97 a $98 \%$

Mapa elaborado pela própria autora.

98 a $99 \%$

Fonte: BRASIL, 2014a; CEM, 2007b.

99 a $100 \%$ 


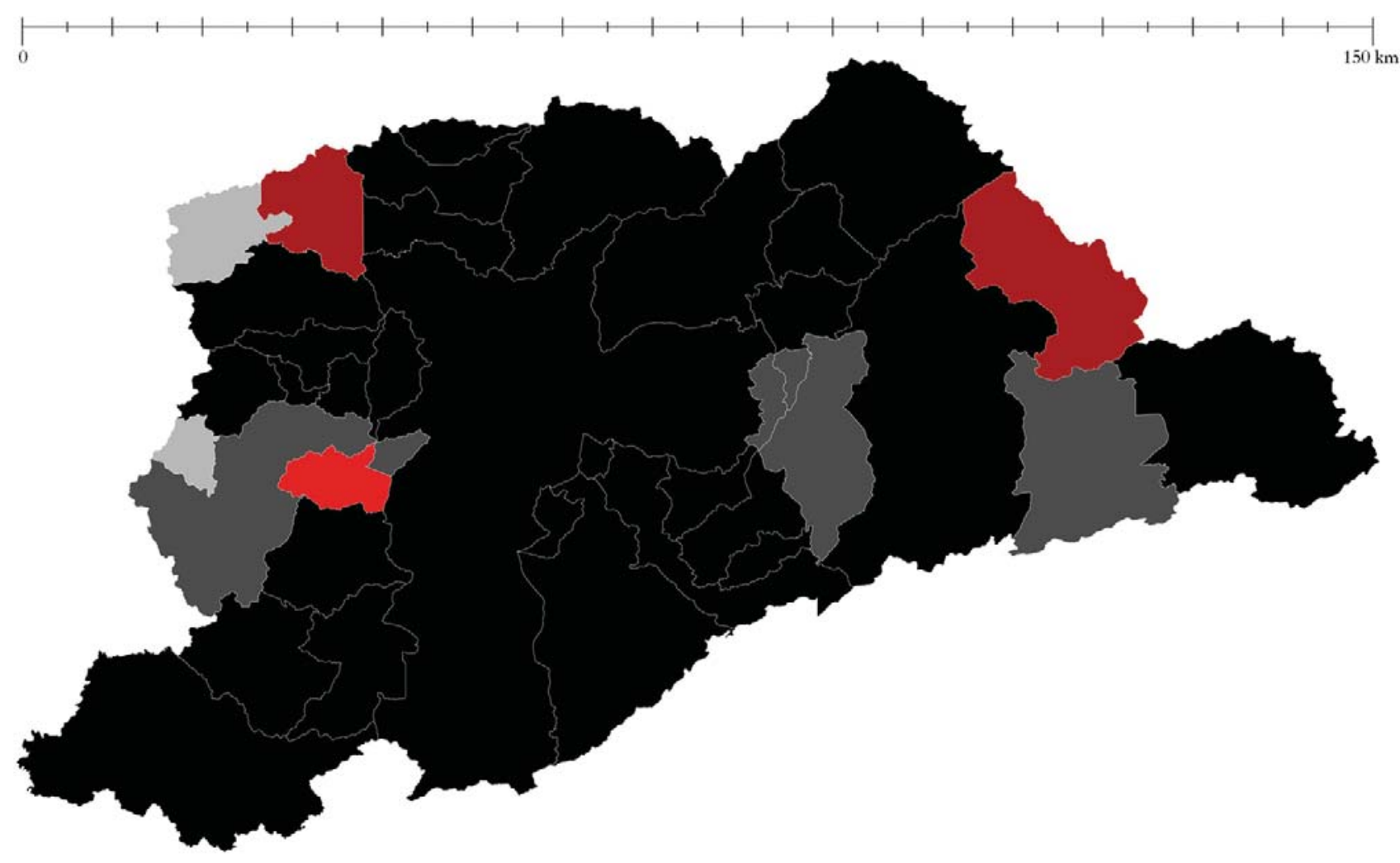

Taxa de conexão de voz

Pior média anual

[referência $\geq 95 \%$ ] [total de chamadas completadas/total de tentativas]

Mapa 32. Pior média anual de conexão de voz para o ano de 2013.

91 a $92 \%$

92 a $93 \%$

93 a $94 \%$

Mapa elaborado pela própria autora.

$94 \% 95$

Fonte: BRASIL, 2014a; CEM, 2007b.

$95 \%$ ou mais 


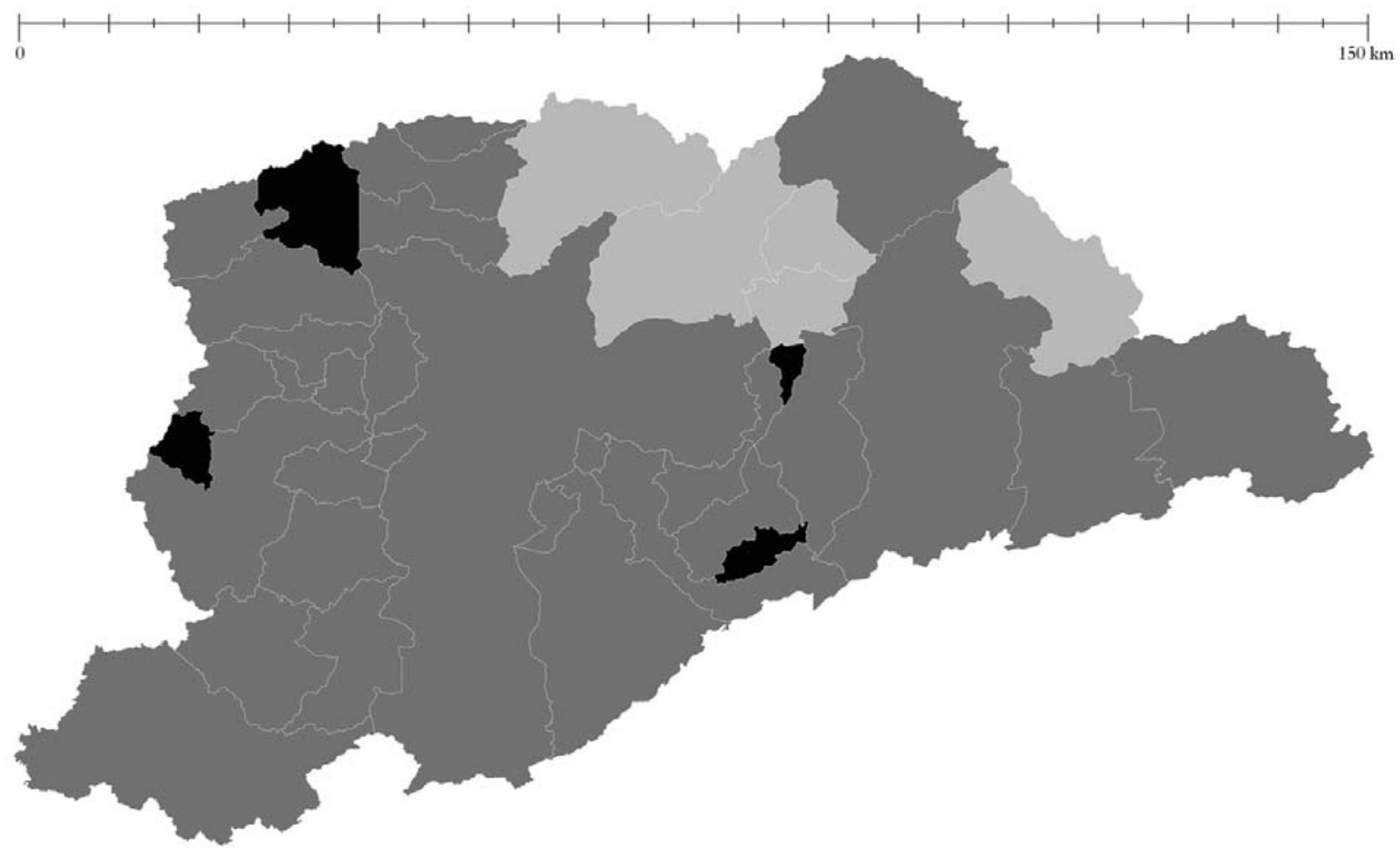

Mapa 33. Melhor média anual de desconexão de voz para o ano de 2013.

Mapa elaborado pela própria autora.

Taxa de desconexão de voz Melhor média anual [referência $\leq \mathbf{2} \%$ ]

[total de chamadas interrompidas

/total de chamadas] 0 a $0,5 \%$

0,5 a $1,0 \%$

1,0 a $2,0 \%$

Fonte: BRASIL, 2014a; CEM, 2007b. 


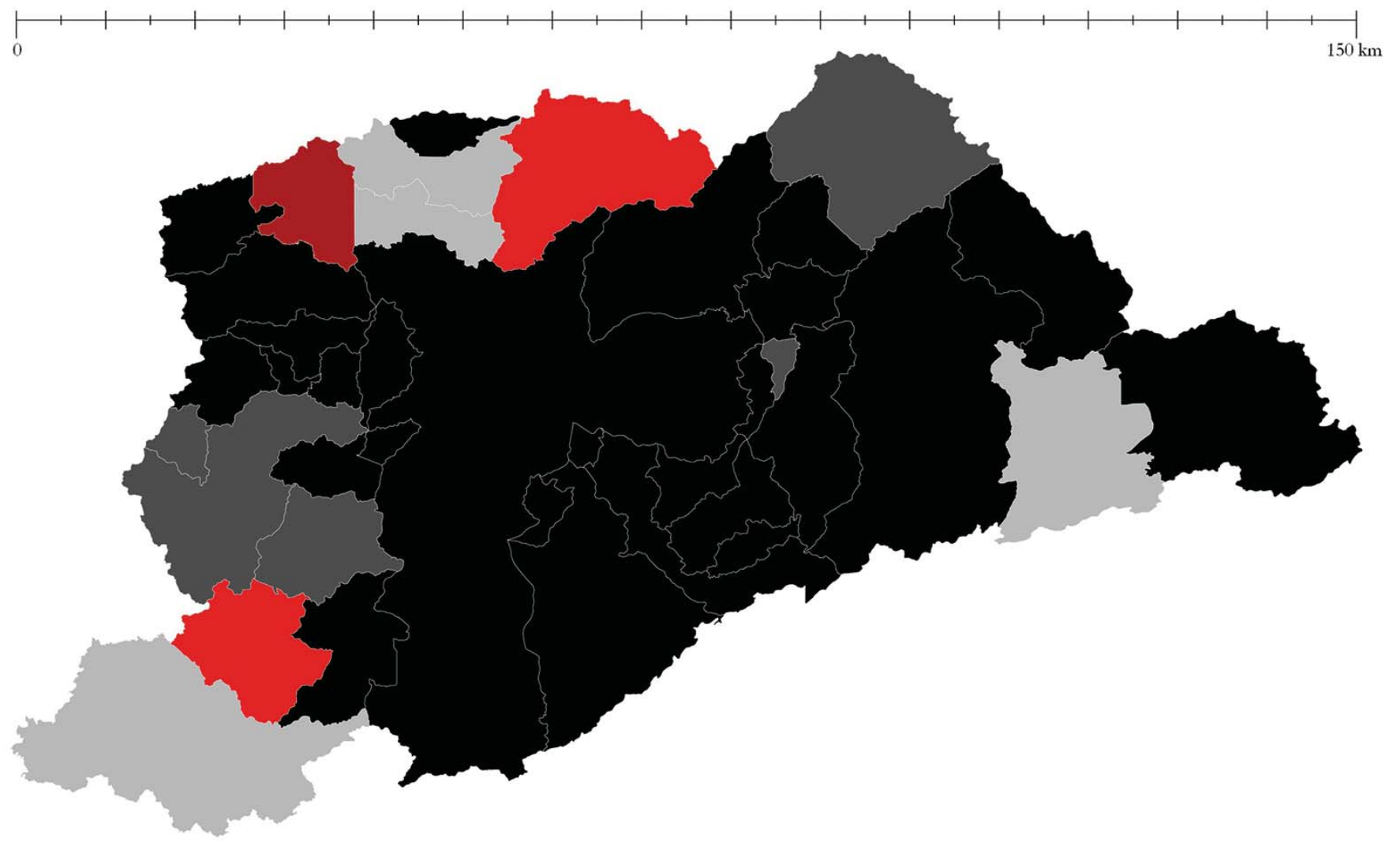

Taxa de desconexão de voz

Pior média anual [referência $\leq 2 \%$ ] [total de chamadas interrompidas/total de chamadas]

$2 \%$ ou inferior

2 a $2,5 \%$

2,5 a $3 \%$

3 a $3,5 \%$

Mapa elaborado pela própria autora.

supeior a $3,5 \%$

Fonte: BRASIL, 2014a; CEM, 2007b. 


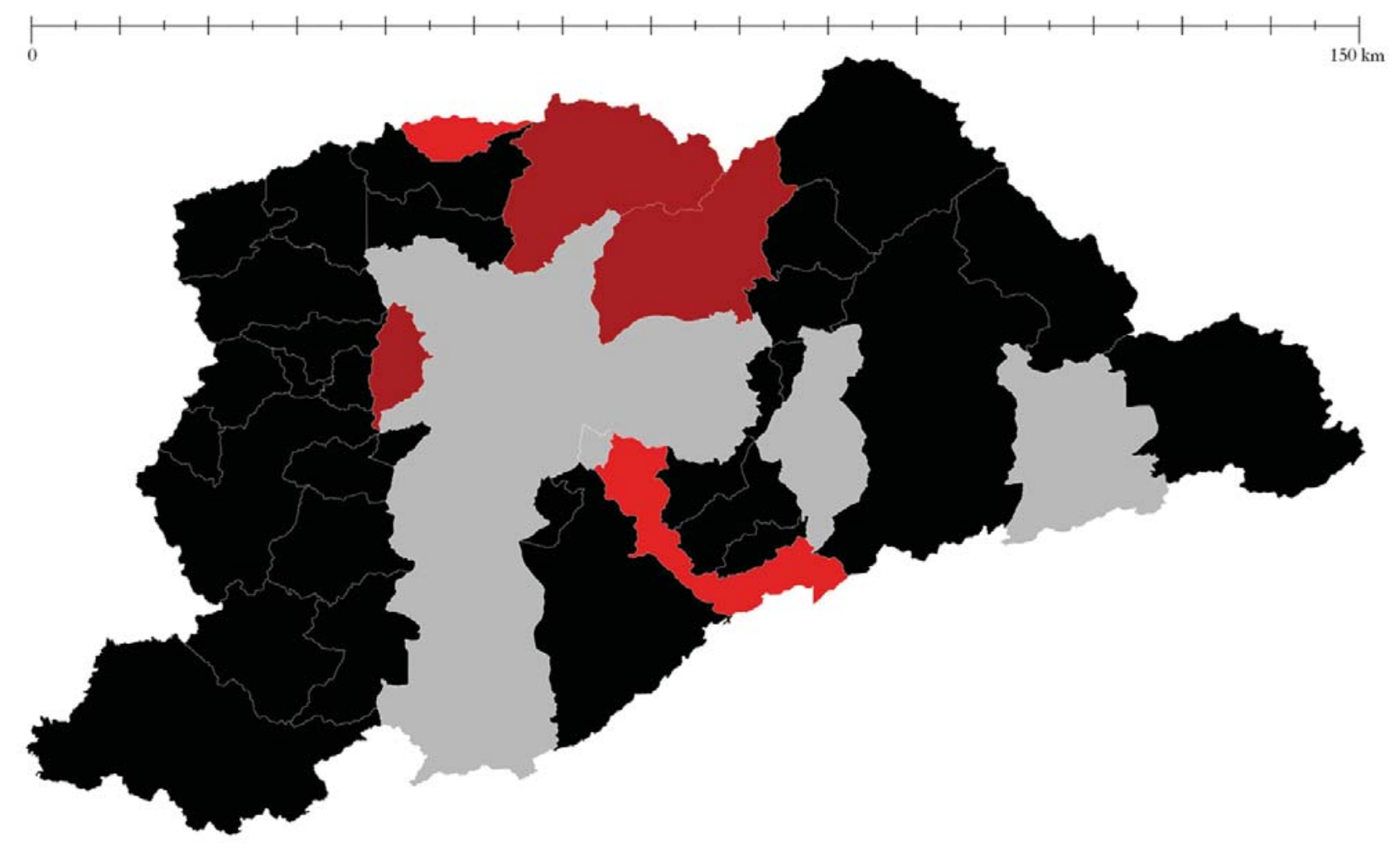

Taxa de desconexão de dados Melhor média anual [referência $\geq 98 \%$ ] [total de conexão de dados/total de tentativas]

Mapa 35. Melhor média anual de conexão de dados para o ano de 2013.

Mapa elaborado pela própria autora.

Fonte: BRASIL, 2014a; CEM, 2007b.

inferior a $97 \%$

97 a $97,5 \%$

97,5 a $98 \%$

$98 \%$ ou superior 


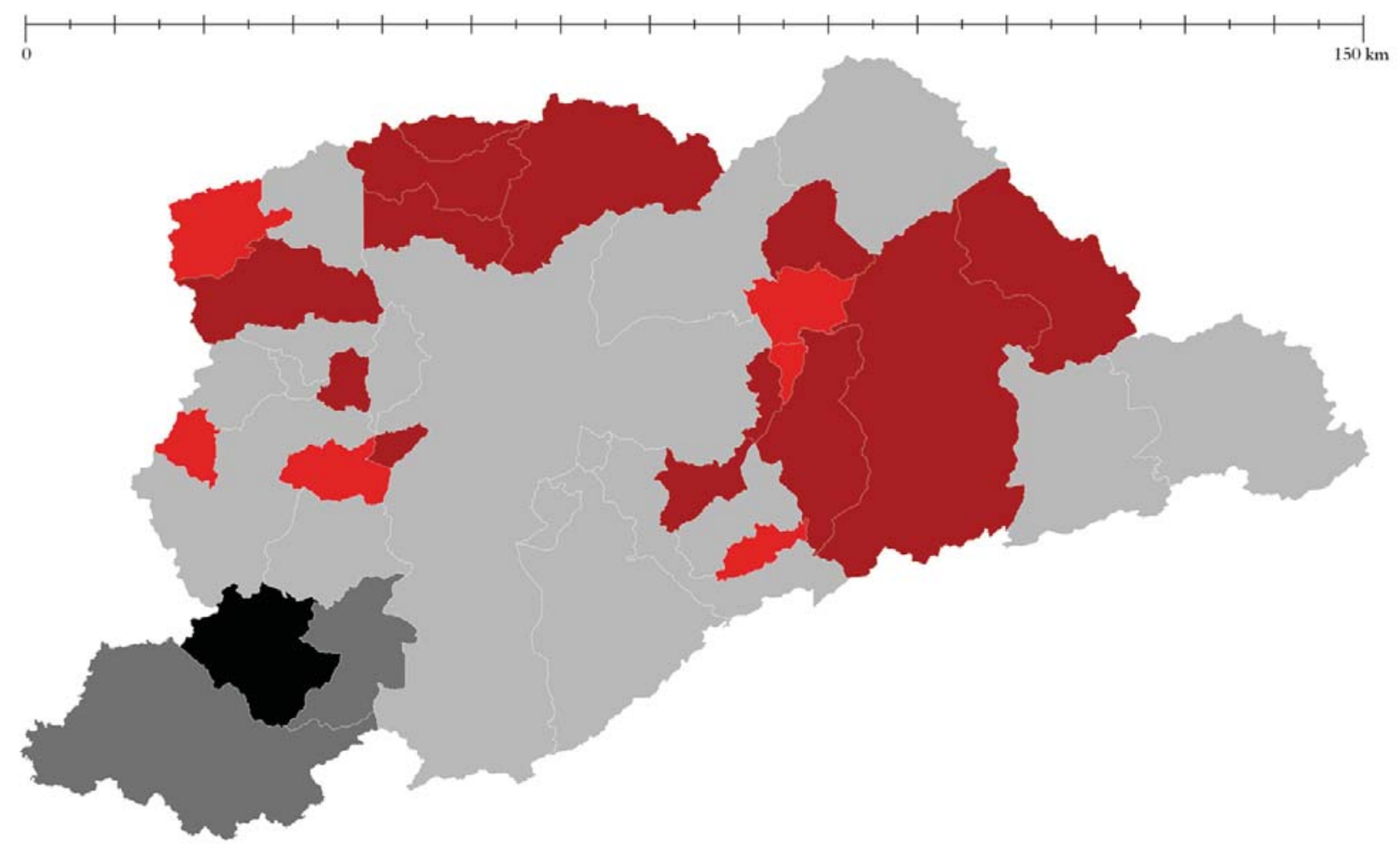

Taxa de conexão de dados Pior média anual [referência $\geq 98 \%$ ] [total de conexão de dados/total de tentativas]

Mapa 36. Pior média anual de conexão de dados para o ano de 2013.

Mapa elaborado pela própria autora.

Fonte: BRASIL, 2014a; CEM, 2007b.

inferior a $90 \%$

90 a $92 \%$

92 a $94 \%$

94 a $96 \%$

superior a $96 \%$ 


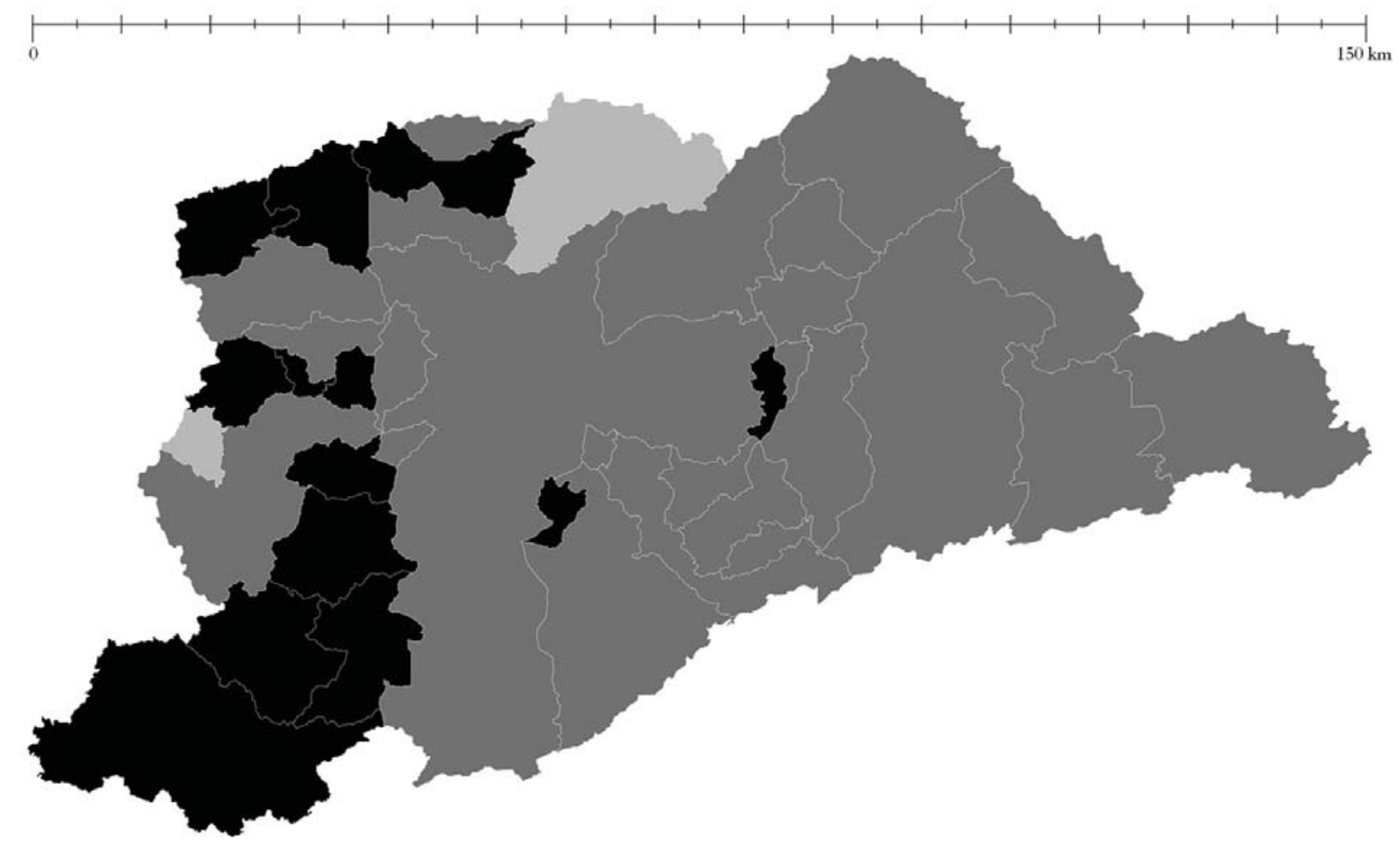

Taxa de desconexão de voz Melhor média anual [referência $\leq 5 \%$ ]

[total de conexões de dados interrompidas/total de conexões]

Mapa 37. Melhor média anual de desconexão de dados para o ano de 2013.

0 a $1,5 \%$

Mapa elaborado pela própria autora.

1,5 a $2,5 \%$

2,5 a $3,5 \%$

Fonte: BRASIL, 2014a; CEM, 2007b. 


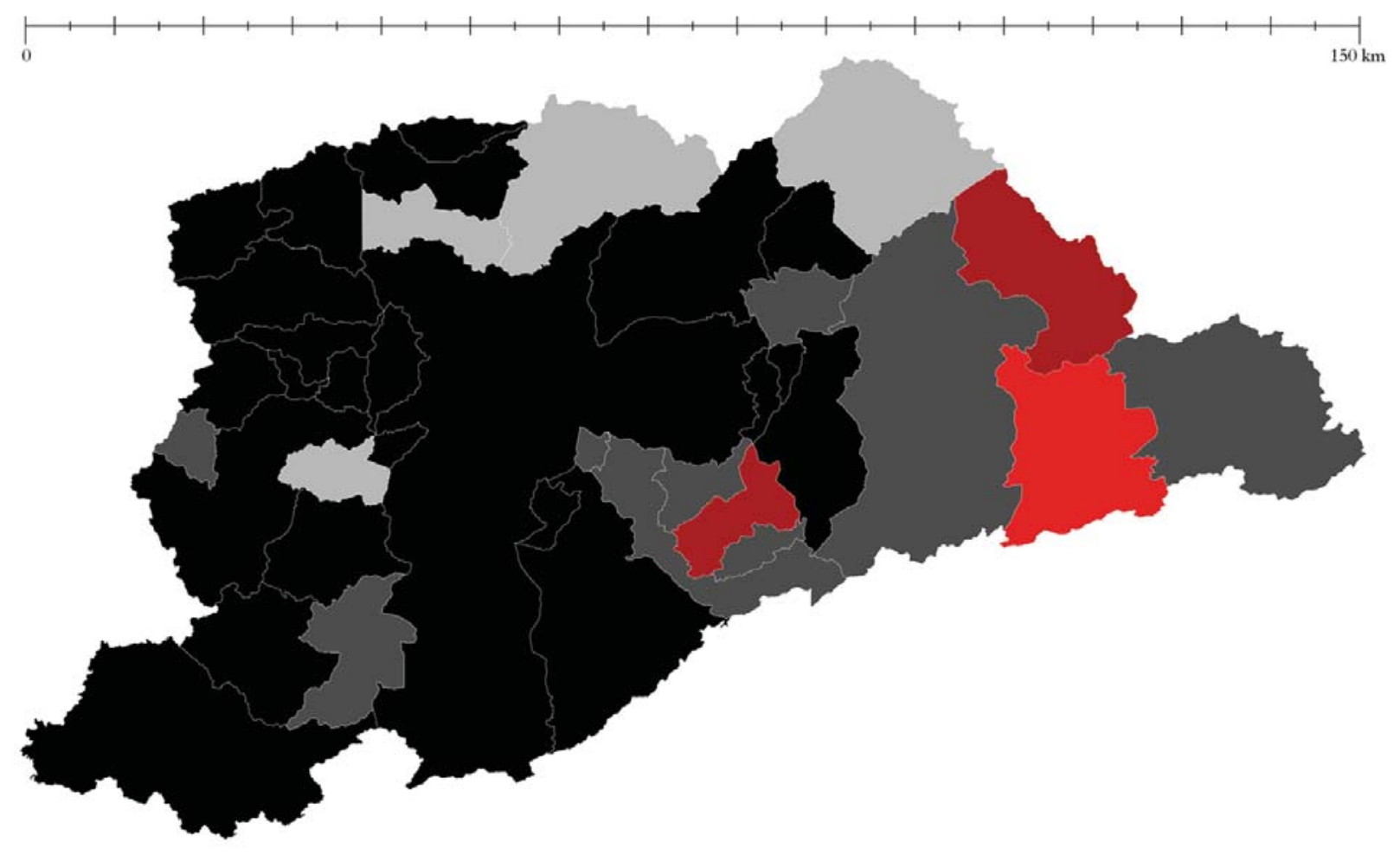

Taxa de desconexão de voz Pior média anual [referência $\leq 5 \%$ ]

[total de conexões de dados interrompidas/total de conexões]

$5 \%$ ou inferior

5 a $7 \%$

7 a $9 \%$

Mapa 38. Pior média anual de desconexão de dados para o ano de 2013.

Mapa elaborado pela própria autora.

9 a $11 \%$

Fonte: BRASIL, 2014a; CEM, 2007b.

superior a $11 \%$ 


\subsubsection{A rede de pavimentação e iluminação pública}

A título de complementação das informações coletadas anteriormente, nesta parte do trabalho são apresentados os dados de qualidade do entorno dos domicílios relativos à área de abrangência dos setores censitários, referentes a uma pesquisa alternativa do Censo do IBGE chamada 'Características Urbanísticas do Entorno dos Domicílios’. Essa pesquisa é inédita e apresenta aspectos importantes para a compreensão dos logradouros do país como um todo, indicando a situação da infraestrutura urbana, com destaque para as dimensões de circulação e meio ambiente.

Nessa análise, foram identificadas as características dos logradouros quanto à existência ou não de iluminação pública, pavimentação, arborização, bueiro, boca de lobo, meio-fio e guias, lixo acumulado em vias públicas, esgoto a céu aberto, calçada e rampas para cadeirante. Devido à extensa base de dados mencionada, e de forma a manter o foco desta pesquisa, foram selecionadas apenas as amostras de iluminação pública e de pavimentação; sistemas considerados críticos, sem os quais o desenvolvimento fica absolutamente comprometido. Vale lembrar que dados quanto à coleta de lixo e de esgoto já foram analisados por meio das pesquisas básicas do Censo, SNIS e Sabesp. Assim, os indicadores aqui analisados incluíram, conforme explicitados na Tabela 10:

- domicílios com pavimentação em seu entorno [\%];

- domicílios com iluminação pública em seu entorno [\%]. 
Tabela 10. Indicadores de qualidade do entorno.

Tabela elaborada pela própria autora.

Fonte: BRASIL, 2014a.

\begin{tabular}{|c|c|c|c|}
\hline ÍNDICE & DESCRIÇÃOO & REFERÊNCIA & CLASSIFICAÇÃO \\
\hline \multirow{5}{*}{ [Censo] } & \multirow{5}{*}{$\begin{array}{c}\text { Domicílios com } \\
\text { pavimentação em seu } \\
\text { entorno }\end{array}$} & 0 a $20 \%$ & Crítico \\
\hline & & 21 a $40 \%$ & Ruim \\
\hline & & 41 a $60 \%$ & Regular \\
\hline & & 61 a $80 \%$ & Aceitável \\
\hline & & 81 a $100 \%$ & Bom \\
\hline \multirow{5}{*}{ [Censo] } & \multirow{5}{*}{$\begin{array}{l}\text { Domicílios com } \\
\text { iluminação pública em } \\
\text { seu entorno }\end{array}$} & 0 a $\mathbf{2 0} \%$ & Crítico \\
\hline & & 21 a $40 \%$ & Ruim \\
\hline & & 41 a $60 \%$ & Regular \\
\hline & & 61 a $80 \%$ & Aceitável \\
\hline & & 81 a $100 \%$ & Bom \\
\hline
\end{tabular}


$\mathrm{Na}$ análise do entorno do Censo, foram excluídos os setores que não dispunham de arruamento regular, devido à necessidade de coleta de informações por face de quadra. Dessa forma, os setores urbanos subnormais (assentamentos informais) e os setores rurais que não apresentassem identificação de quadras foram excluídos da amostra; por isso, há um grande número de setores 'sem dados' identificados nos mapas a seguir (Mapa 39 e Mapa 40).

A partir da análise desses mapas, é possível notar que, assim como nos outros casos, as piores taxas de domicílios com pavimentação e iluminação pública no seu entorno referem-se aos setores localizados nas franjas das áreas urbanizadas, nas periferias do centro expandido, em que estão as menores densidades populacionais, as piores taxas de emprego e as rendas médias mais baixas.

Se voltarmos a observar o Mapa 11 de energia elétrica, este fator não constitui que esses setores estejam incluídos fisicamente na rede infraestrutural de pavimentação e iluminação pública pelo estado. Isto é, em potencial, essa população deve ser uma parcela de consumidores oficiais de energia elétrica, porém isto não implica que ela tenha as mesmas condições de acesso à infraestrutura pública formal. É notável que, muitas vezes, esses setores censitários periféricos tenham acesso à iluminação pública mesmo que não haja pavimentação, ou uma via formal desenhada em seu entorno. Isto é mais frequente que o oposto, a presença de pavimentação sem que haja por sua vez iluminação pública. 
De acordo com a análise, verifica-se que tanto a iluminação pública quanto a pavimentação pública seguem um padrão de acesso disperso, ao contrário de um padrão concentrador. Esse padrão acompanha o crescimento urbano horizontal e as maiores densidades líquidas em áreas periféricas da RMSP. 


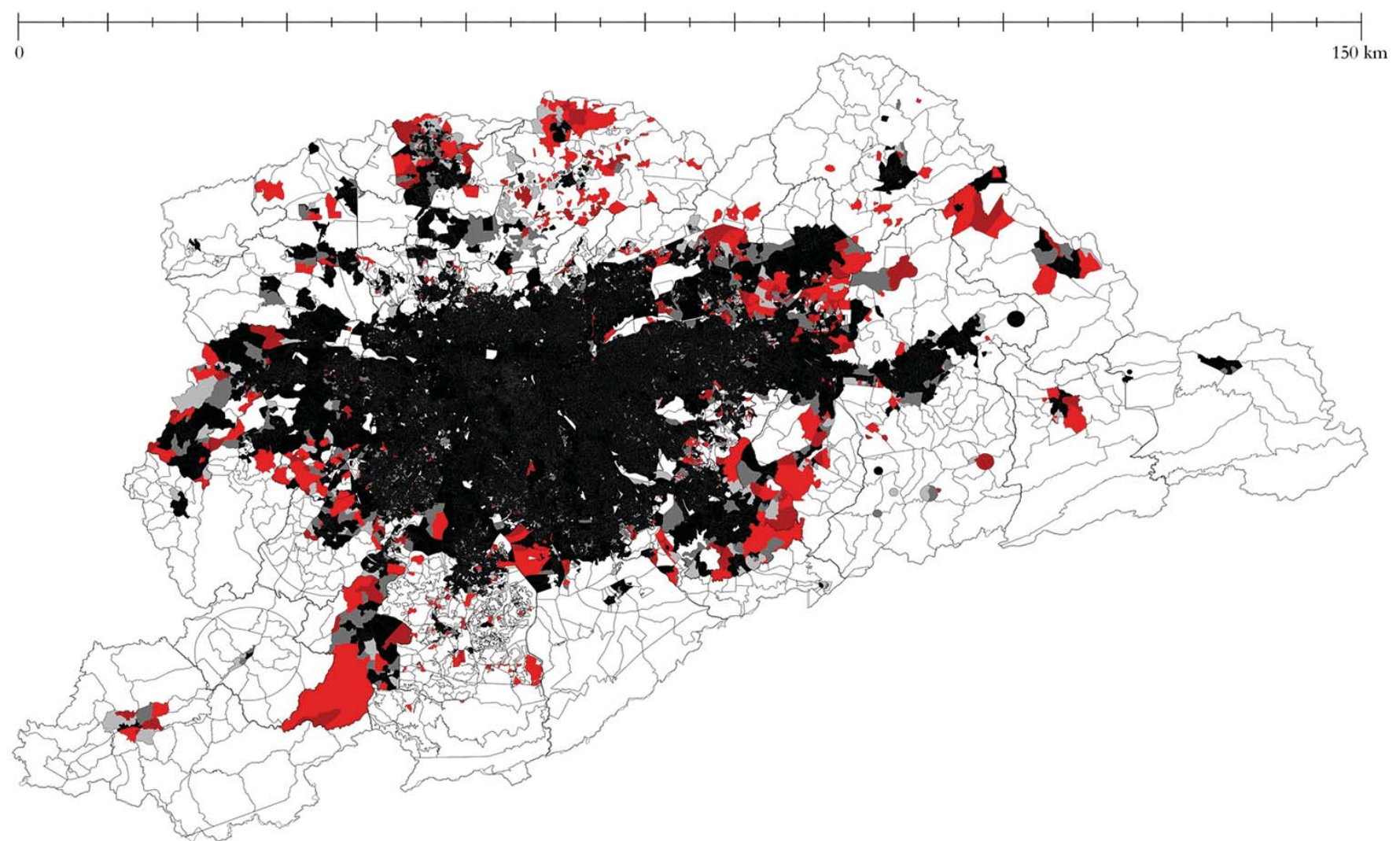

Domicílios com pavimentação

em seu entorno [\%]

$$
0 \text { a } 20
$$

20 a 40

40 a 60

60 a 80

Mapa 39. Domicílios com pavimentação pública em seu entorno.

Mapa elaborado pela própria autora.

80 a 100

sem dados 


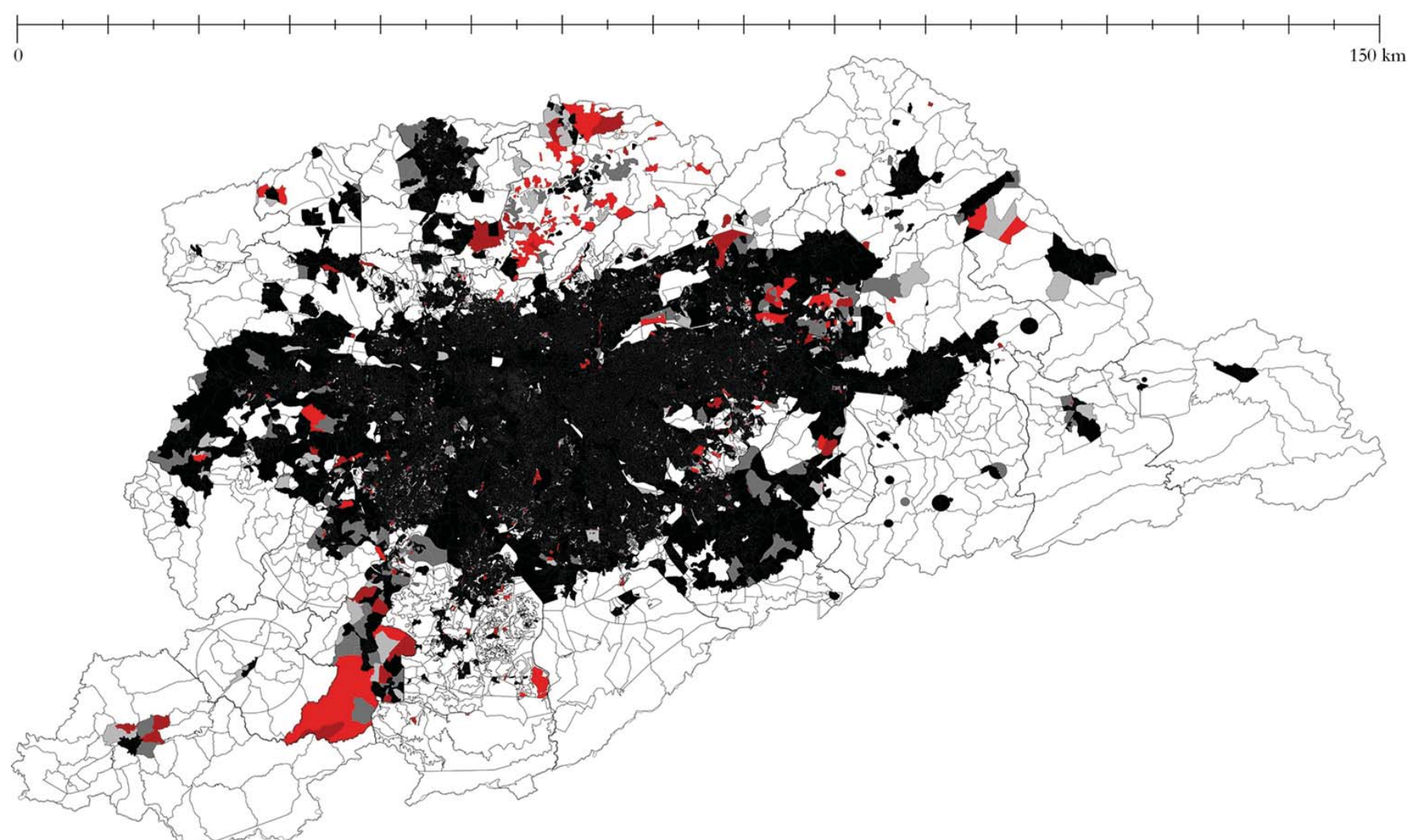

Domicílios com iluminação pública

em seu entorno [\%]
0 a 20
20 a 40
40 a 60
60 a 80
80 a 100
sem dados

Mapa 40. Domicílios com iluminação pública em seu entorno.

Mapa elaborado pela própria autora.

Fonte: IBGE, 2010. 


\subsubsection{A rede de transportes}

A rede de transportes foi, neste trabalho, avaliada como aquela que permite a mobilidade, ou seja, o conjunto de deslocamentos da população no território que, por meio da acessibilidade, encontra a possibilidade física da realização desses movimentos. Essas funções põem em direta correspondência as duas dimensões materiais da sociedade contemporânea, o tempo e o espaço, sendo nesta análise o tempo regulado por consequência do espaço ${ }^{32}$. Assim, a mobilidade é entendida como a gênese da estruturação metropolitana, tendo não só o potencial de induzir o desenvolvimento, mas também o de fortalecê-lo. A heterogeneidade dos espaços metropolitanos, então, é potencialmente resultante da possibilidade - ou da impossibilidade - de conectar espaços distantes, mas não só isso, ela também é efeito das diferentes capacidades de mobilidade, das possibilidades de alcançar lugares específicos.

$\mathrm{Na}$ coleta de dados de transportes, incluíram-se aquelas bases disponibilizadas pela São Paulo Transporte S.A., pela Empresa Metropolitana de Transportes Urbanos de São Paulo, pela Companhia do Metropolitano de São Paulo, pela Companhia Paulista de Trens Metropolitanos e pela Empresa Paulista de Planejamento Metropolitano 
S.A. - Emplasa. Respectivamente, as bases trabalhadas pela autora foram georreferenciadas e compuseram: os pontos e linhas de ônibus do MSP; os pontos de ônibus intermunicipais/metropolitanos; as linhas e os pontos de transporte metroviário e ferroviário; e o traçado do sistema viário. Devido à complexidade da rede de transportes coletivo e individual na RMSP, e ao já abrangente espectro de objetos desta tese, a análise conteve-se ao aspecto da distribuição dos acessos a pontos de metrô, trem e ônibus, assim como à breve análise do traçado viário; não sendo incluídos indicadores quanto ao tempo de viagem, capacidade de suporte das vias, número de usuários, entre outros. A pesquisa bibliográfica complementará os dados considerados faltantes para a análise dessa camada de informações. Esses indicadores de qualidade poderão ser levados adiante nos desdobramentos desta pesquisa.

É importante ressaltar que os dados disponíveis pela pesquisa OD do Metrô foram extensamente trabalhadas, de forma a criar uma compreensão quanto às dinâmicas de viagens atraídas e produzidas pelos modos coletivo ${ }^{33}$ e individual ${ }^{34}$ motorizado, pelos motivos de trabalho, compras, educação e lazer.

${ }^{33}$ De acordo com a definição do Metrô, o modo coletivo contempla as modalidades metrô, trem, ônibus, transporte fretado, transporte escolar e lotação. 
A metodologia utilizada pelo Metrô para compor sua base de dados foi a seguinte:

foram coletados em uma amostra de domicílios, onde todos os moradores responderam sobre todas as viagens realizadas no dia útil anterior ao dia da entrevista. A esses dados aplicou-se o fator de expansão dos dados da amostra para obtenção dos resultados da população total. O esquema amostral adotado para dimensionamento e sorteio da amostra foi $o$ de amostragem estratificada por faixas de consumo de energia elétrica. O consumo de energia elétrica está correlacionado à renda familiar e, por isso, a variável consumo de energia elétrica residencial foi utilizada no esquema amostral. Esse esquema permitiu o sorteio de domicílios estratificados do cadastro de consumidores residenciais de energia elétrica. (informação pessoal) ${ }^{35}$

O diagnóstico por meio das bases avaliadas foi realizado, primeiramente, pela análise visual. Desse modo, foi possível verificar, pela leitura dos

Mapa 41, Mapa 42 e Mapa 43, que, quanto ao transporte coletivo, o ônibus é o meio que mais se encontra disponível na RMSP,

\footnotetext{
${ }^{34}$ De acordo com a definição do Metrô, o modo individual contempla os motoristas e passageiros de automóvel, táxi, motocicleta, bicicleta e caminhada. Nesta pesquisa, foram analisadas as viagens por modo individual motorizado, o que exclui as viagens de bicicleta e a pé.

${ }^{35}$ HIROI, E.M. Metodologia de Pesquisa OD. Mensagem recebida em 26 jun. 2015.
} 
indiferentemente da distribuição social e econômica no território, como classe, renda e disponibilidade de empregos. Assim, esse meio apresenta uma dispersão bem maior do que o alcance do sistema de metrô, sendo esse último presente em áreas mais polarizadas da metrópole, este, sim, concentrado em áreas mais beneficiadas quanto à renda média e aos empregos. Paradoxalmente, a maior proporção de viagens individuais (Mapa 48 e Mapa 49) acontece em regiões com maior oferta de transporte coletivo (Mapa 42 e Mapa 43), e onde residem as classes mais abastadas, como pode ser visto na sobreposição de dados produzida no Mapa 50.

Segundo a última Pesquisa de Mobilidade do Metrô (2012), a utilização do carro é mais intensiva em espaços ocupados pelas classes mais altas, enquanto, por exemplo, o número de viagens a pé tem maior expressão em territórios ocupados por famílias de classes baixas. Segundo a pesquisa, mesmo quando a escolha se faz pelo uso do transporte coletivo, o tempo de locomoção de origem e destino chega a ultrapassar o dobro daquele despendido pelos usuários do transporte individual.

Segundo Requena (apud MARQUES, 2015, p.421):

é razoável sustentar que o sistema paulistano de mobilidade constituiu-se historicamente como reforçador, e não mitigador das desigualdades presentes na metrópole. Se distribuísse oportunidades iguais de deslocamento a todos os viajantes, a mobilidade paulistana poderia arrefecer efeitos de desigualdades geradas em outras áreas cruciais para a vida urbana, como a habitação e a concentração das ofertas de trabalho. 
É clara a ligação entre o desenho do sistema de transporte de massa e os impactos nas dinâmicas socioeconômicas da RMSP. Se sobrepusermos os Mapas 42 e Mapa 43 ao Mapa 44 até o Mapa 49, o que notamos é o número de produção e atração de viagens multiplicadas exponencialmente naquelas zonas que possuem conexões com as linhas de metrô e trem. À medida que se aproximam da área central do MSP, o número de viagens, tanto produzidas quanto atraídas, multiplica.

$\mathrm{O}$ modelo da estrutura viária, devido à história do desenvolvimento urbano da cidade de São Paulo, permanece radial concêntrico, composto por vias radiais e perimetrais (Mapa 42 e Mapa 43). Conforme já discutido, esta pesquisa não irá entrar na discussão da revisão histórica em relação às mudanças perseguidas pela prefeitura e pelo estado quanto a esse modelo. Brevemente, entretanto, vale lembrar o caso do Plano de Avenidas de Prestes Maia, que propunha a concepção de redes na forma de um grid ortogonal que pudessem ser adaptadas às características territoriais da cidade (ANELLI, 2007a). Este fundamentou o Plano Urbanístico Básico - PUB, de 1968, e seus desdobramentos, que concebeu um urbanismo que pudesse relacionar a maior oferta de viagens pelo sistema de transporte de massa com a intensificação planejada do uso do solo ao longo da rede de metrô, de forma a tornar o deslocamento 'mais fácil, rápido e econômico' (ANELLI, 2007b).

Segundo Anelli (ibidem), a ampliação da oferta de locais de moradia, trabalho e serviços por toda a área metropolitana seria possível 
por meio da redução do tempo de viagem; conceito distinto “[...] tanto da ideia da cidade composta por um conjunto de pequenos núcleos urbanos 'autossuficientes' (aonde os habitantes trabalhariam próximo à sua moradia), quanto da concepção de uma cidade mononuclear de expansão ilimitada”. Assim sendo:

ao se espalhar ao longo das redes de mobilidade, a metrópole poderia prescindir do centro que caracteriza a cidade mononuclear, o qual sobreviveria apenas em função do modelo viário radio-concêntrico que vinha sendo implantado desde a década de 1930 de acordo com o Plano de Avenidas de Prestes Maia. (ibidem)

Também é importante notar que nos últimos 15 anos, houve um grande impacto positivo no número de passageiros que fazem uso de modais coletivos (que, nas décadas de 1990, vinham diminuindo); principalmente após a implantação do sistema interligado, da integração tarifária (bilhete único), da separação das faixas exclusivas para a circulação de ônibus em corredores e da construção de novos terminais multimodais. Assim, a análise conjunta desses mapas indica duas tendências contrastantes. Ao mesmo tempo em que se verifica o efeito de dispersão do modal de transporte coletivo de ônibus, acompanhando o crescimento horizontal das áreas urbanizadas, e alcançando com mais homogeinedade as áreas de menor renda da metrópole, o modal metroviário é oferecido de maneira mais concentrada nas áreas de maior renda e empregos. Essas evidências serão retomadas nos próximos subcapítulos que tratam das dinâmicas, articulações e fluxos da metrópole. 


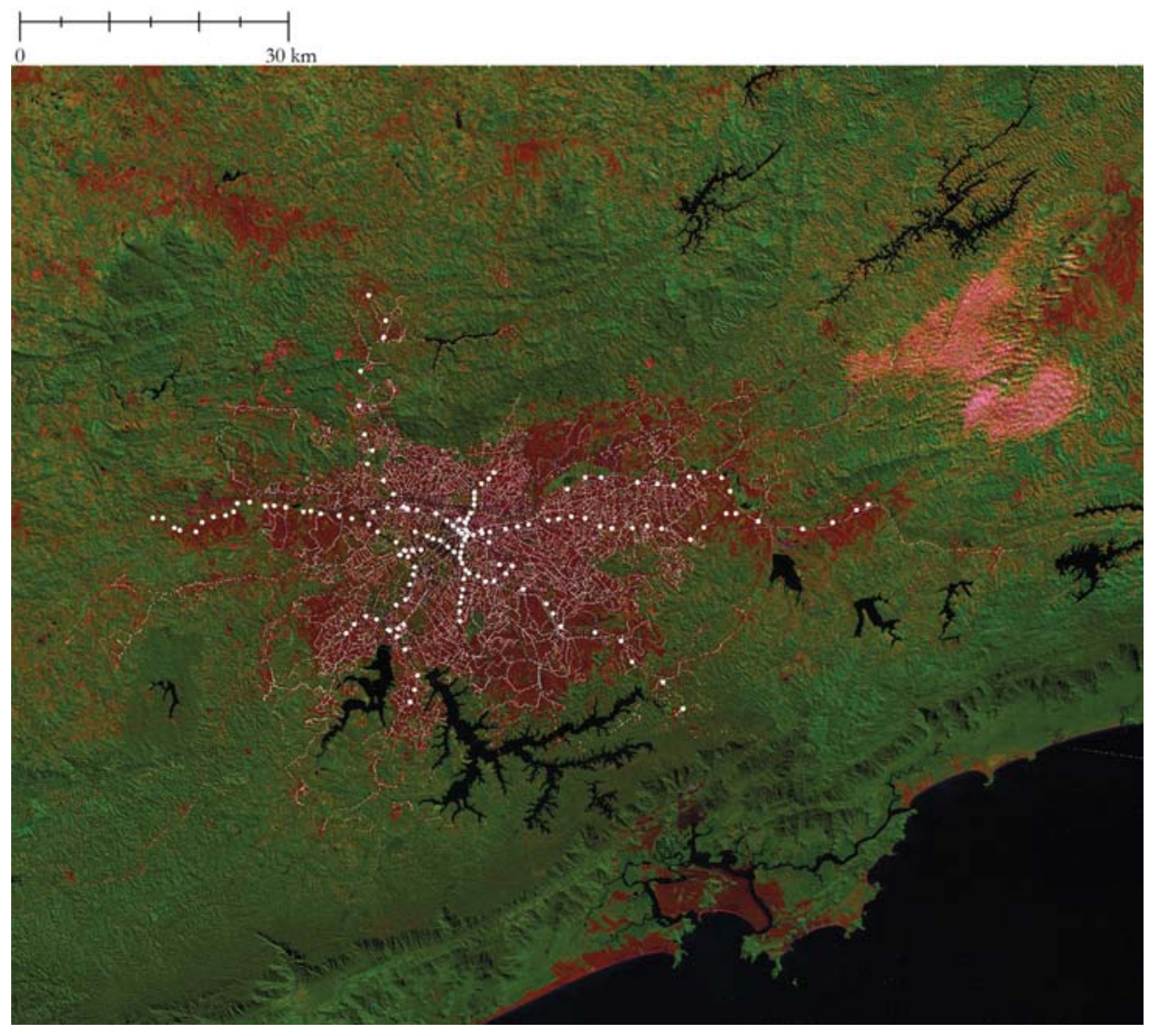

Mapa 41. Paragens de transporte coletivo na RMSP.

Mapa elaborado pela própria autora.

Fonte: SÃO PAULO (ESTADO), EMTU, 2015; SPTRANS, 2015.

Paragens de transporte coletivo [pontos de trem, metrô e ônibus] ponto de ônibus

estaç̃es de metrô e trem O 


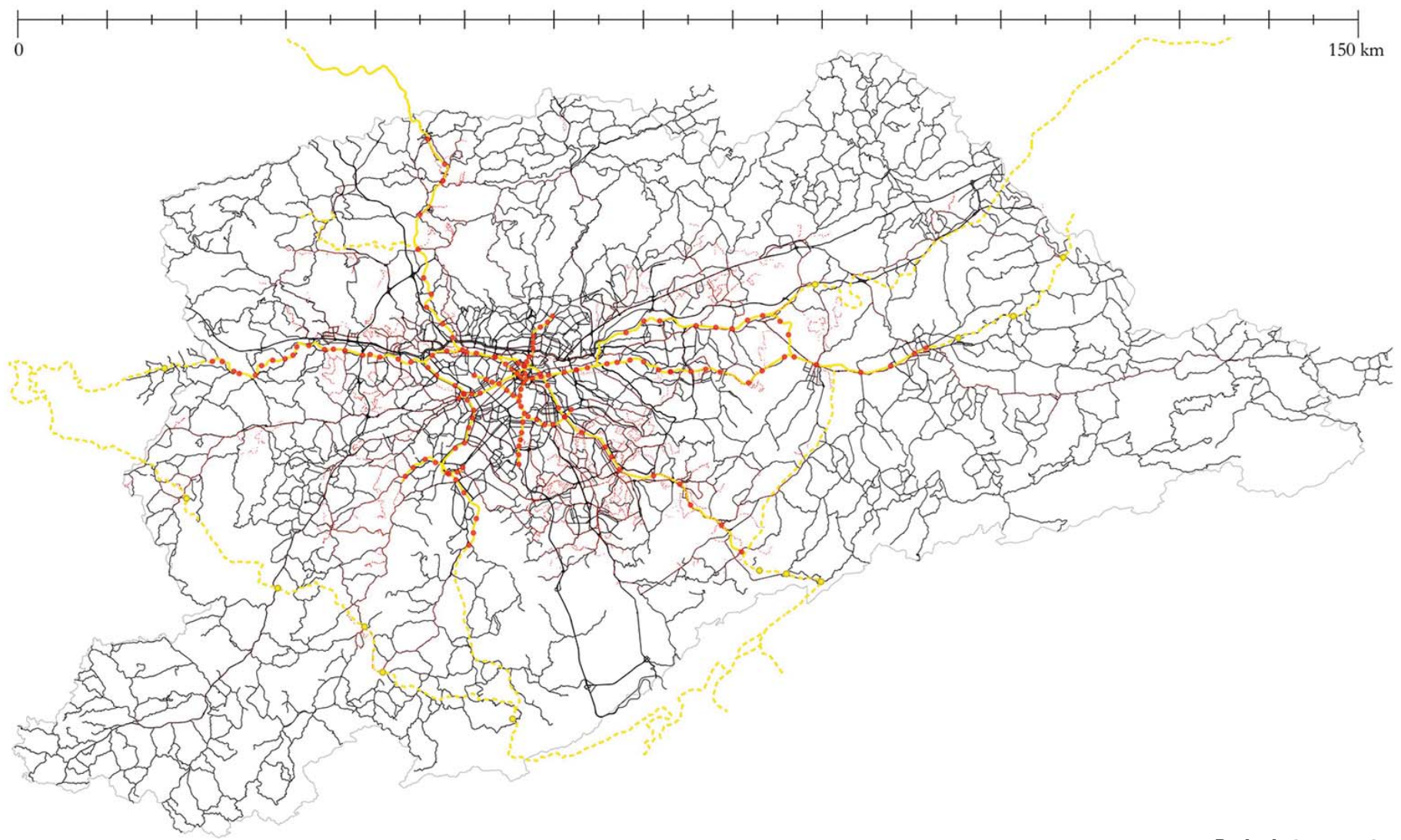

Rede de transporte

[ferroviário, metroviário e rodoviário] pontos de ônibus intermunicipais

estaçōes de metrô e trem estações de carga

Mapa 42. Rede de transportes ferroviário, metroviário e rodoviário da RMSP.

Mapa elaborado pela própria autora.

Fonte: SÃO PAULO (ESTADO), EMTU, 2015; SPTRANS, 2015; EMPLASA, 2015; CEM, $2007 \mathrm{~b}$. linhas de metrô e trem

ferrovia de carga

viário principal 


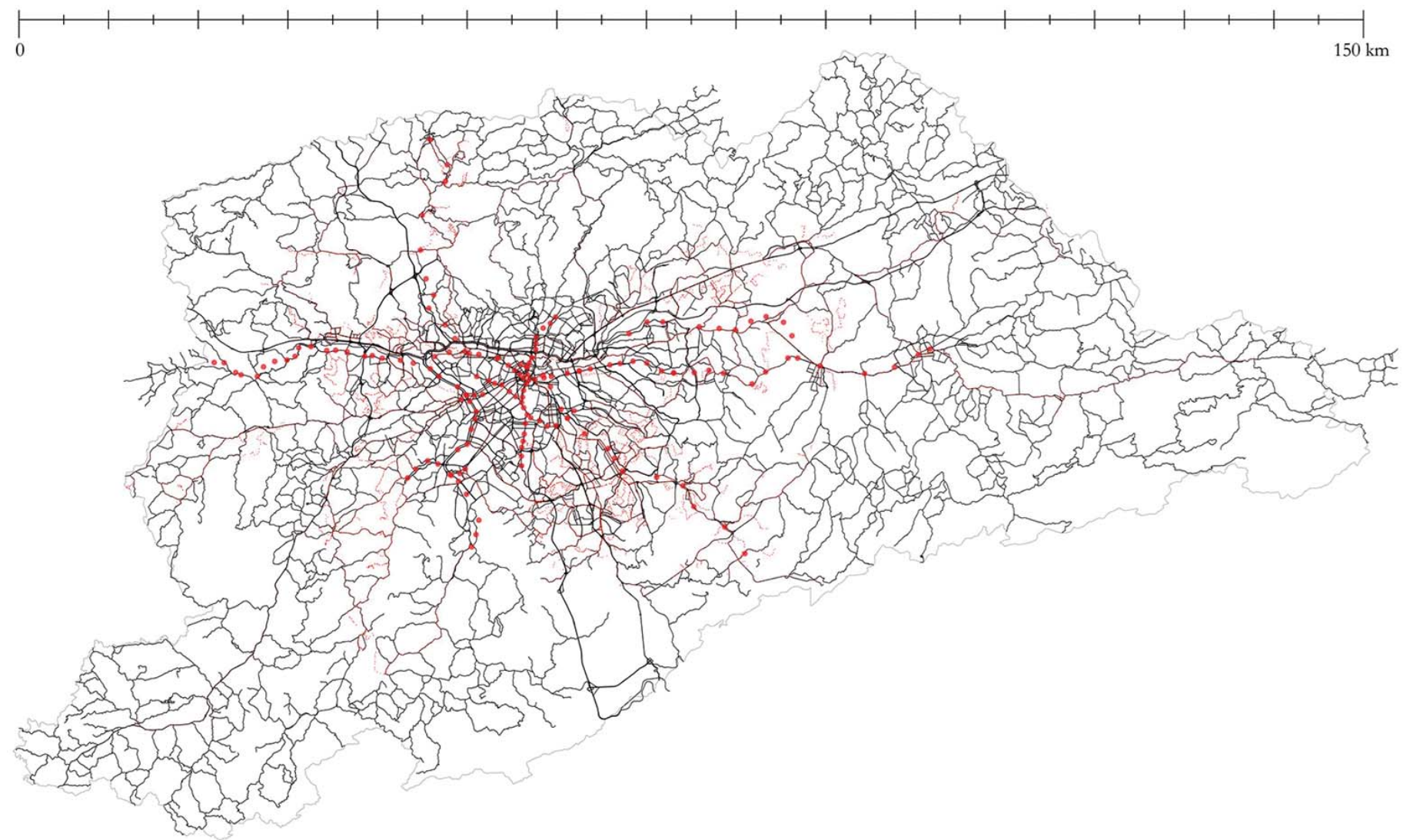

Alcance do sistema de transportes coletivo e individual

Mapa 43. Alcance do sistema de transportes coletivo e individual na RMSP. Mapa elaborado pela própria autora.

Fonte: SÃO PAULO (ESTADO), EMTU, 2015; SPTRANS, 2015; EMPLASA, 2015; CEM, 2007b. 


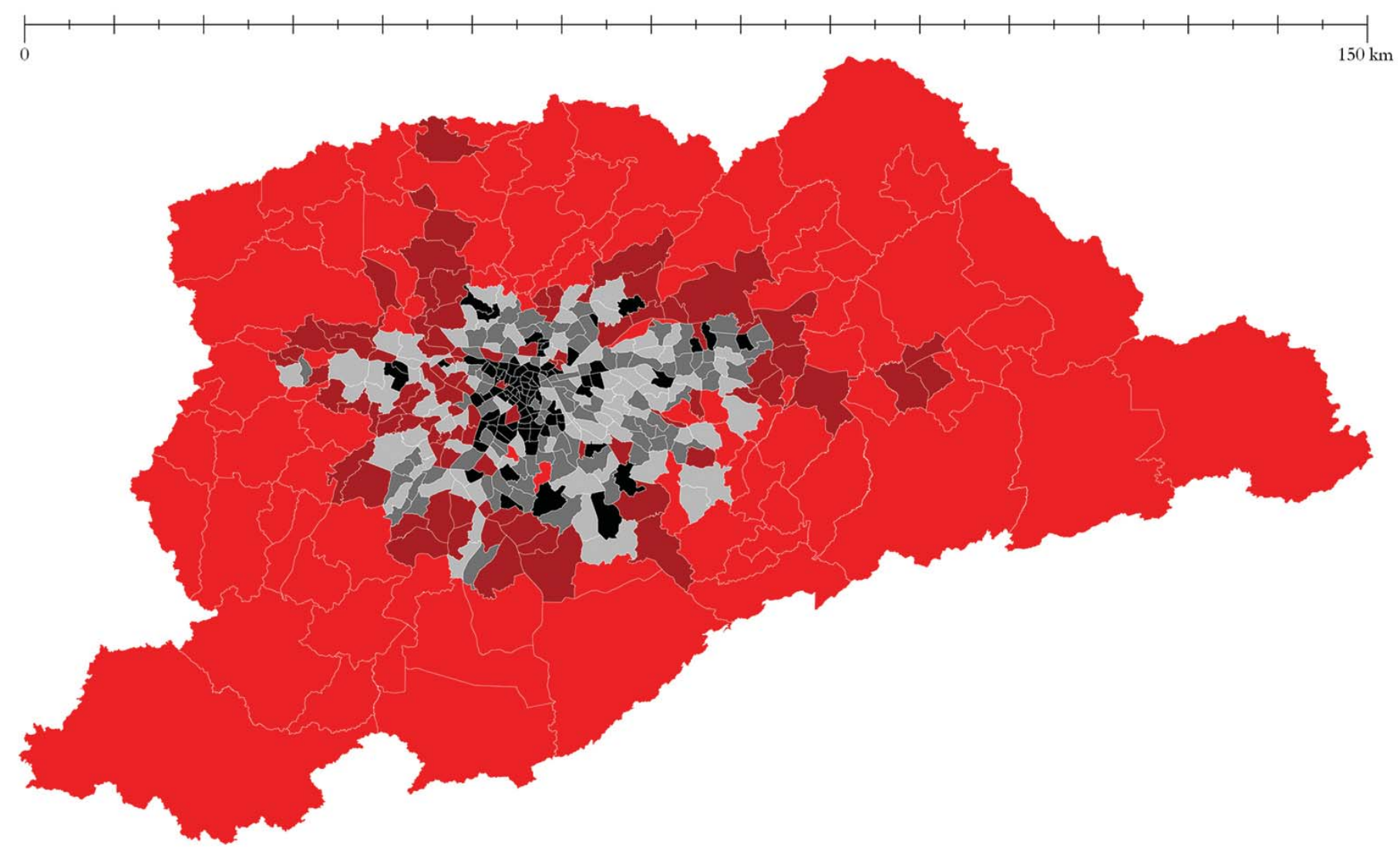

Densidade de viagens produzidas

TOTAL[viagens/ha]

0 a 48

48 a 164

164 a 247

274 a 327

Mapa 44. Densidade de viagens produzidas totais.

Mapa elaborado pela própria autora.

327 a 2.837

Fonte: SÃO PAULO (ESTADO), METRO,2007. 


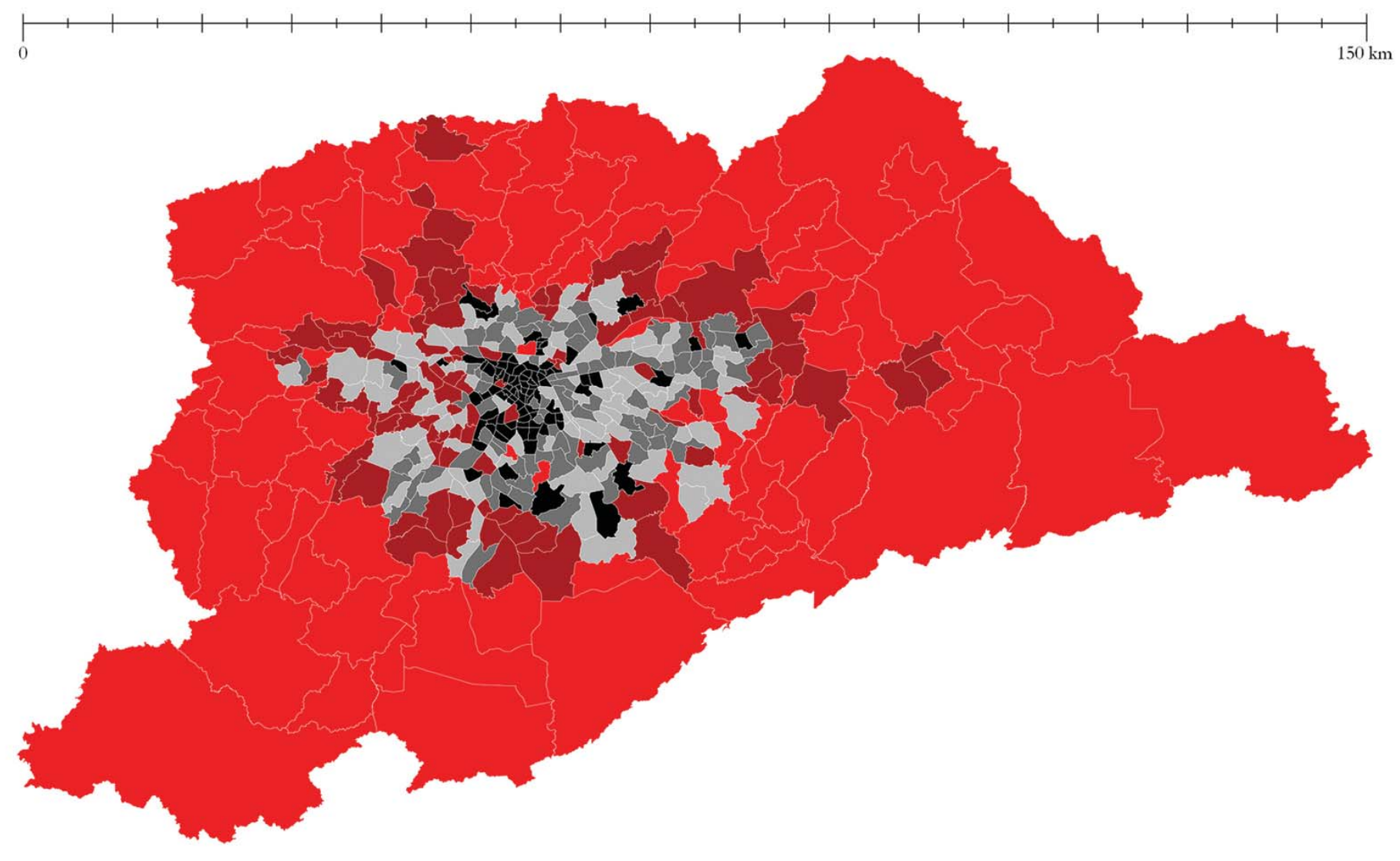

Densidade de viagens atraídas

TOTAL[viagens/ha]

0 a 48

48 a 164

164 a 245

Mapa 45. Densidade de viagens atraídas totais.

245 a 328

Mapa elaborado pela própria autora.

328 a 2.841

Fonte: SÃO PAULO (ESTADO), METRO,2007. 


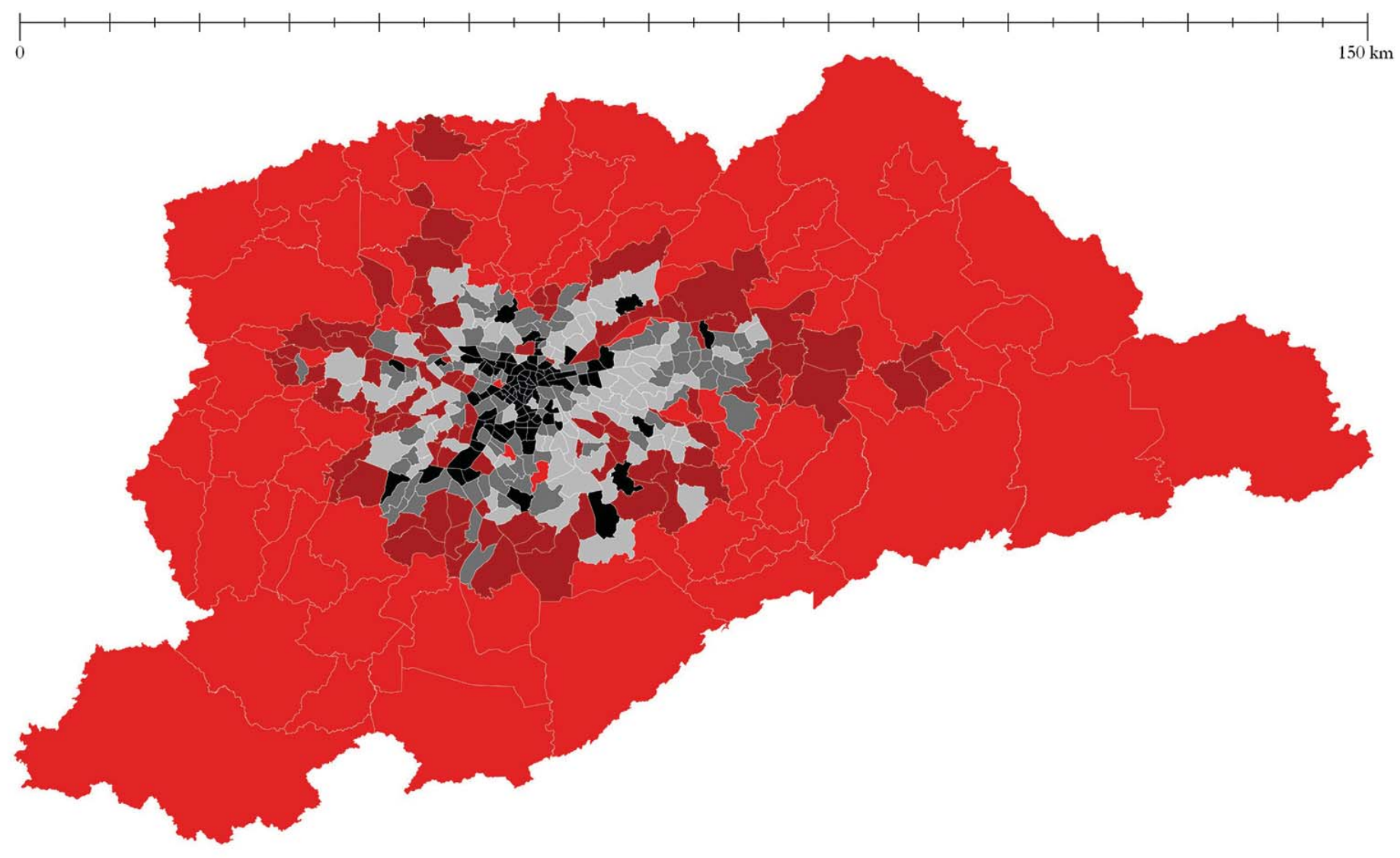

Densidade de viagens produzidas TRANSPORTE COLETIVO [viagens/ha]

0 a 16

16 a 56

Mapa 46. Densidade de viagens produzidas por transporte coletivo.

Mapa elaborado pela própria autora.

56 a 83

83 a 119

Fonte: SÃO PAULO (ESTADO), METRO,2007.

119 a 1.880 


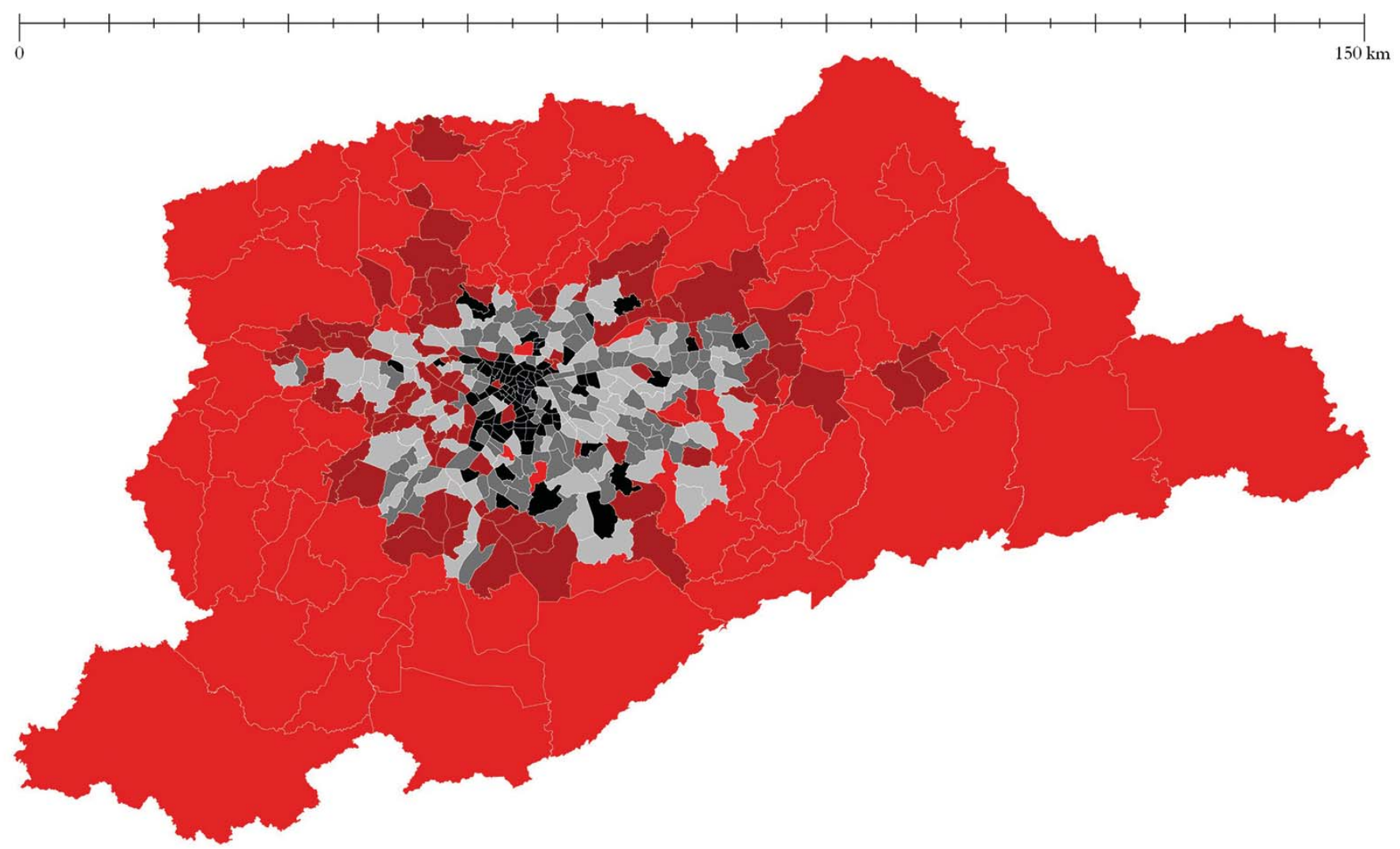

Densidade de viagens atraídas TRANSPORTE COLETIVO [viagens/ha]

0 - 16

16 - 55

$55 \cdot 83$

$83 \cdot 117$

Mapa 47. Densidade de viagens atraídas por transporte coletivo.

Mapa elaborado pela própria autora.

$117-1.876$

Fonte: SÃO PAULO (ESTADO), METRO,2007. 


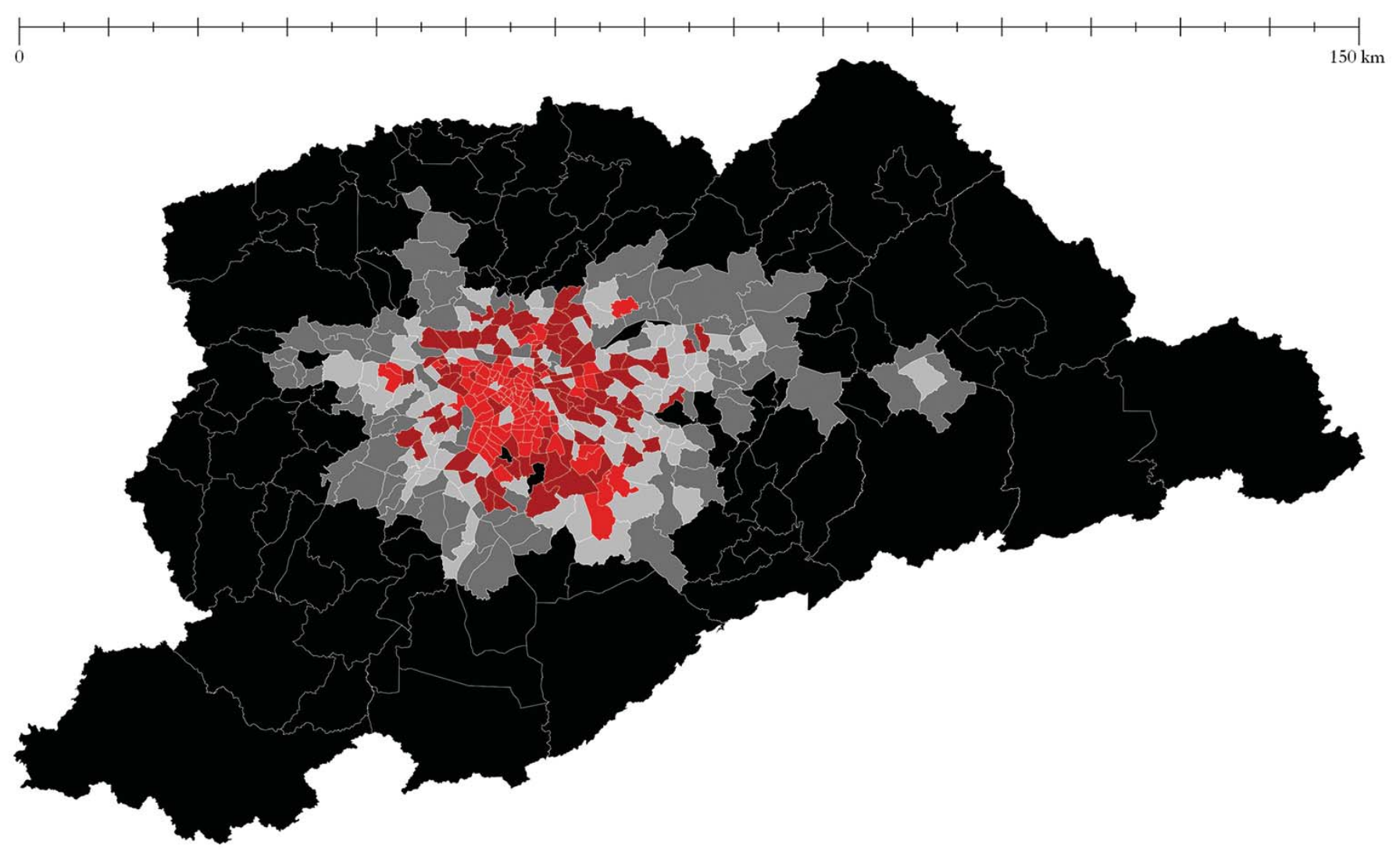

Densidade de viagens produzidas TRANSPORTE INDIVIDUAL MOTORIZADO [viagens/ha]

0 a 12

12 a 42

42 a 74

Mapa 48. Densidade de viagens produzidas por transporte individual motorizado.

74 a 129

Mapa elaborado pela própria autora.

129 a 452

Fonte: SÃO PAULO (ESTADO), METRO,2007. 


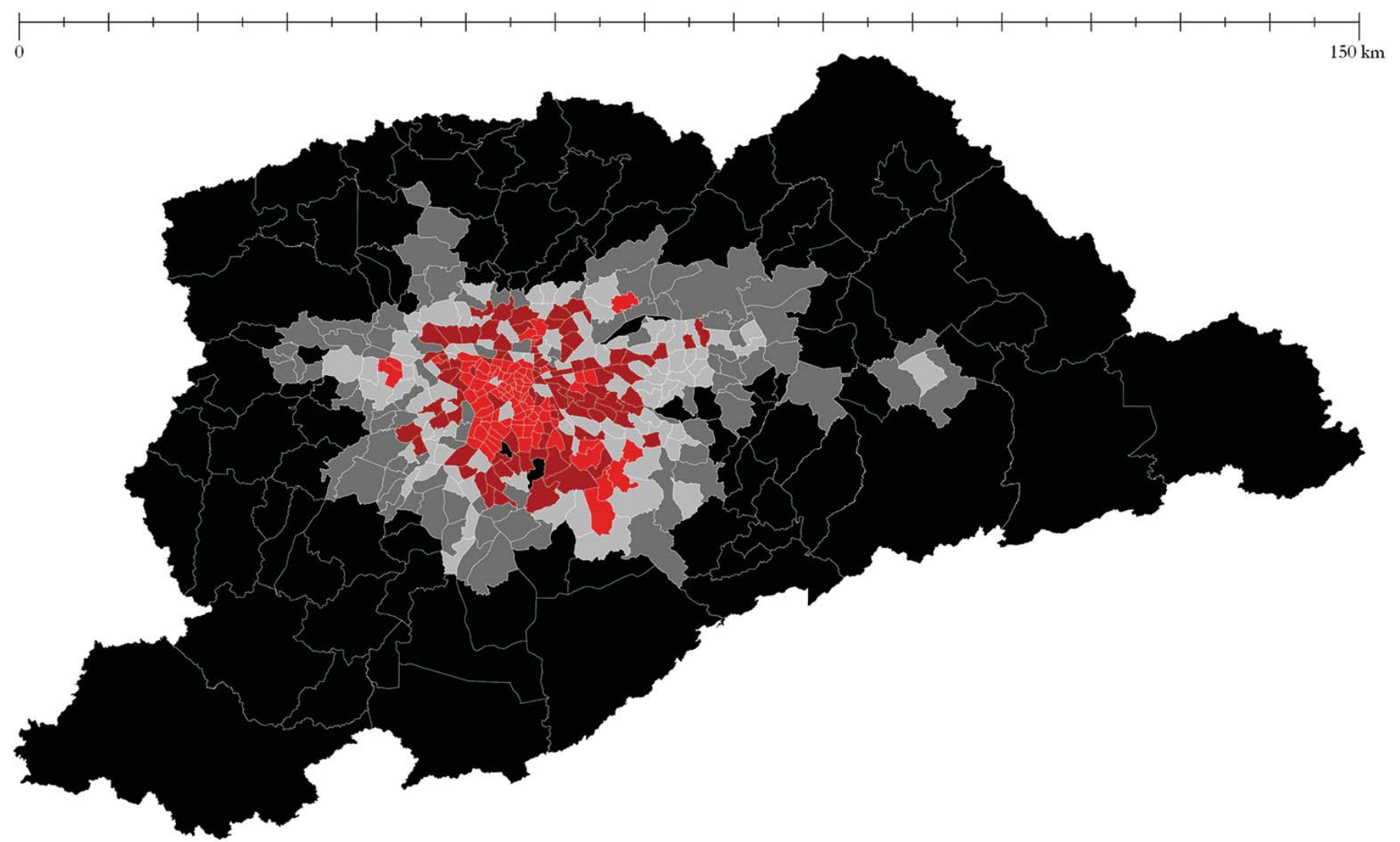

Densidade de viagens atraídas TRANSPORTE INDIVIDUAL MOTORIZADO [viagens/ha]

$0-12$

$12 \cdot 42$

$42 \cdot 74$

Mapa 49. Densidade de viagens atraídas por transporte individual motorizado.

Mapa elaborado pela própria autora.

$74-129$

Fonte: SÃO PAULO (ESTADO), METRO,2007.

$129-452$ 


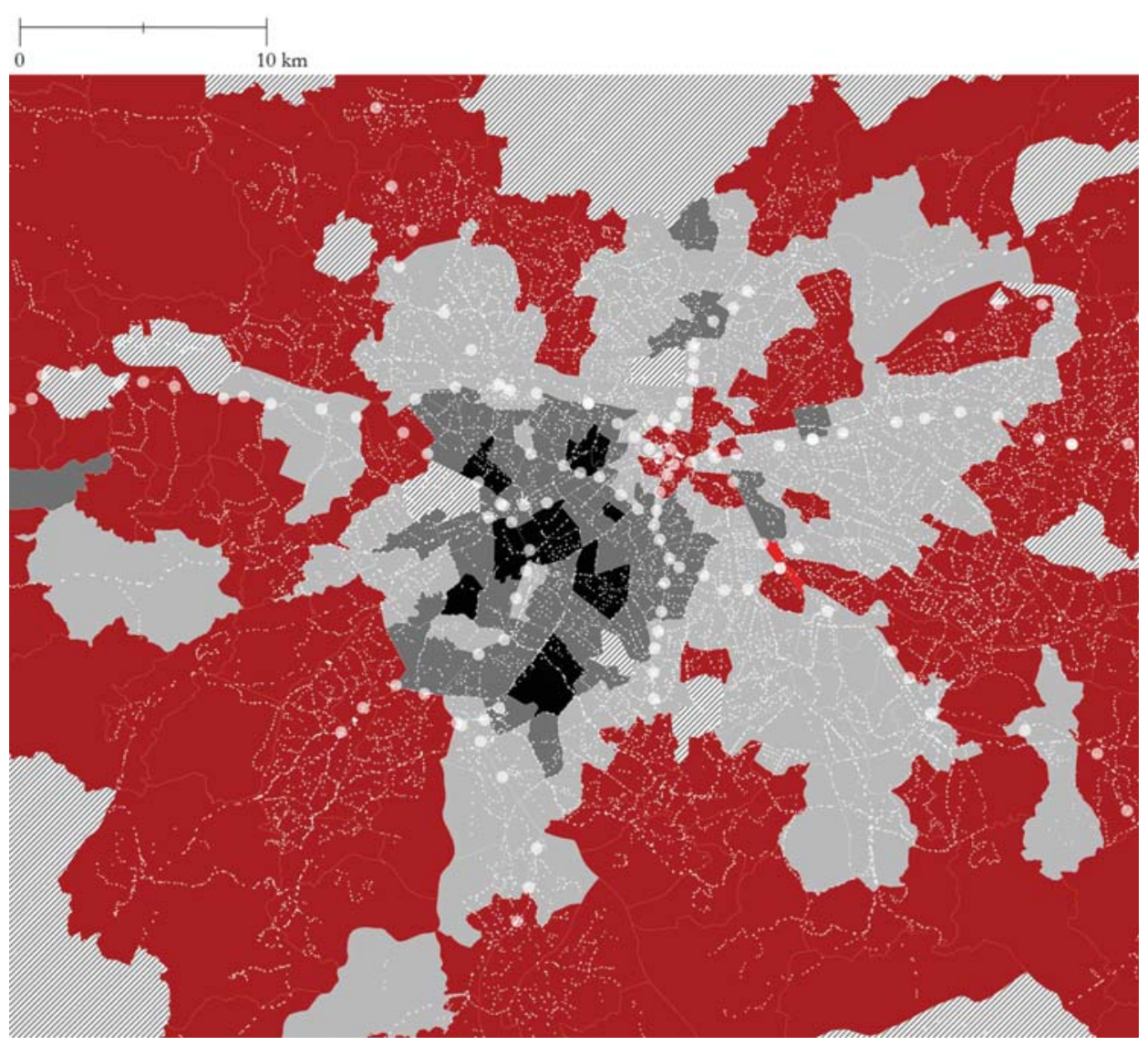

Mapa 50. Paragens de transporte coletivo versus renda média domiciliar na área central da RMSP. Mapa elaborado pela própria autora.

Fonte: SÃO PAULO (ESTADO), EMTU, 2015; SPTRANS, 2015; EMPLASA, 2015; SÃO PAULO (ESTADO), METRO, 2007.

\section{Paragens de transporte coletivo versus Renda média domiciliar [pontos de trem, metrô e ônibus] pontos de ônibus \\ estações de metrô e trem \\ inferior a 1,5 salário mínimo \\ 1,5 a 3 salários mínimos 3 a 5 salários mínimos \\ 5 a 8 salários mínimos superior a 8 salários mínimos}

sem dados 


\subsection{0 espaço dos fluxos da RMSP}

\subsubsection{As dinâmicas}

Conforme explicado no item anterior, a pesquisa OD do Metrô analisou as dinâmicas entre as zonas OD de acordo com os modos e motivos de viagens dos passageiros no dia anterior à pesquisa. Assim, foi possível criar mapas de densidade (número de viagens por dia por hectare) que analisassem quais as localizações que mais concentraram viagens, tanto por seu poder de atração quanto por seu poder de produção. A capacidade que considera o total de viagens por modo, transporte coletivo ou individual, foi descrita no subcapítulo anterior no item $\mathrm{A}$ rede de transportes, mas a capacidade diferenciada em relação às dinâmicas por transporte coletivo e individual e a densidade de viagens produzidas e atraídas pelos diferentes motivos -trabalho, compras, educação e lazer - foram analisadas neste capítulo.

A importância da compreensão dessas diferenciações se deu principalmente devido ao fato desta pesquisa analisar a influência de uma localização (no caso, a menor área de agregação da pesquisa - a zona OD) em relação às dinâmicas abrangidas pela RMSP. Deve-se compreender que esta análise é restrita em seu escopo, já que não é possível abarcar

todas as razões e motivações pelas quais as pessoas se movem no 
território. Entretanto, entende-se que esta é válida para configurar propensões nas dinâmicas pendulares que caracterizam a circulação das pessoas no espaço físico e econômico da metrópole. $\mathrm{O}$ entendimento dessas inclinações, assim como as capacidades infraestruturais das redes da metrópole (analisadas no capítulo anterior), podem conjuntamente configurar uma metodologia original para o desenvolvimento de programas, agendas ou planos, de maior alcance quanto à capacidade de trazer soluções que favoreçam não apenas as dinâmicas locais, mas mais prioritariamente, considerem e distribuam os benefícios numa área de maior abrangência.

Assim, analisou-se ao mesmo tempo, nesta pesquisa, a infraestrutura geral, as dinâmicas e o potencial das articulações de promoverem essa capacidade de 'regular' os fluxos e redistribuírem benefícios. Essas propriedades foram analisadas neste capítulo.

Os maiores fluxos diagnosticados devido aos motivos de trabalho, educação, compras, lazer e saúde por todo o território da RMSP podem ser visualizados na Tabela 11.

A maior densidade de viagens acontece pelos motivos de trabalho, sendo Sé (1.739 viagens por hectare), República (1.693) e Campinas (825) as zonas que mais atraem passageiros. Essas zonas também são aquelas que mais produzem viagens por trabalho para outras localidades da RMSP. Os locais que mais atraem passageiros por motivos educacionais são o Centro Cultural (651), a Liberdade (507) e Fransisco 
Matarazzo (456), sendo que os locais que mais produzem viagens para esses fins são o Centro Cultural (575), a Liberdade (504) e Vila Buarque (406). As compras são o terceiro motivo que mais causa movimento de passageiros na metrópole, sendo os principais destinos deste público o Parque Dom Pedro (257), Oriente (155) e a Sé (144). Essas mesmas localidades se identificam como as principais origens dos passegeiros que se transportam para esse fim.

O motivo de saúde tem como principal destino o Centro Cultural (191), as Clínicas (186) e a Vila Clementino (155), sendo também aqueles locais que mais produzem viagens por esse motivo para as outras localidades; provavelmente, devido aos movimentos diários pendulares dos pacientes que retornam a suas residências ao final das consultas médicas. Para os fins de lazer, as viagens são prioritariamente geradas pela Sé (126), República (101) e Vila Buarque (88) para outras zonas, sendo aquelas que mais atraem passageiros por motivos de lazer a Consolação (86), a República (82) e a PUC (74).

É importante notar a proporção desses deslocamentos gerados pelos motivos elencados em relação à densidade total de viagens por modo coletivo e por modo individual. Nota-se, por exemplo, que, na Sé, $66 \%$ das viagens acontecem por meio do modal coletivo, enquanto apenas $16 \%$ acontecem por deslocamentos individuais motorizados. Do total do modal coletivo, 93\% dos deslocamentos para o destino Sé acontecem em função do trabalho. Observando-se, por exemplo, a zona 
República (também localizada no centro do MSP), percebe-se que, do total de viagens atraídas para essa área por transporte coletivo, $72 \%$ são por trabalho, sendo as atividades de lazer representadas por apenas $4 \%$ dos deslocamentos de outras localidades para esse destino. Apesar da percepção do número de viagens por lazer parecer muito pequeno, a República é o segundo maior polo de atratividade de lazer de toda a metrópole (sendo o primeiro polo, a Consolação, também localizada na área central da MSP).

Para a verificação mais abrangente das dinâmicas por motivo de viagens no território da RMSP, recomenda-se obervar os mapas apresentados a seguir: do Mapa 51 ao Mapa 60. Vale lembrar que, devido à metodologia Quantil utilizada para classificar os dados georreferenciados, explicitada no subcapítulo 3.2, as classes dos diferentes mapas não apresentam as mesmas faixas de dados. Esse fator requer atenção na análise visual cruzada entre os mapas, por exemplo, na comparação visual entre a densidade total de viagens e entre trabalho e lazer. 
Tabela 11. Síntese das zonas OD com maior densidade de viagens atraídas e produzidas.

Fonte: Elaborado pela própria autora a partir dos dados da pesquisa OD (Metrô, 2007).

\begin{tabular}{|c|c|c|c|}
\hline VIAGENS ATRAIDAS & \multirow{3}{*}{$\begin{array}{l}\text { 递 } \\
\text { 똘 } \\
\text { 동 }\end{array}$} & VIAGENS PRODUZIDAS & \multirow{3}{*}{ 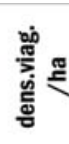 } \\
\hline TOTAIS & & TOTAIS & \\
\hline TRABAIHO & & TRABAIHO & \\
\hline Sé & 1739 & Sé & 1614 \\
\hline República & 1693 & República & 1450 \\
\hline Campinas & 825 & Campinas & 730 \\
\hline EDUCAÇAO & & EDUCAÇAD & \\
\hline Centro cultural & 651 & Centro Cultural & 575 \\
\hline Liberdade & 507 & Liberdade & 504 \\
\hline Fransisco Matarazzo & 456 & Vila Buarque & 406 \\
\hline COMPRAS & & COMPRAS & \\
\hline Pq. Dom pedro & 257 & Pq. Dom Pedro & 253 \\
\hline Oriente & 155 & Sé & 147 \\
\hline Sé & 144 & Oriente & 116 \\
\hline LAZER & & LAZER & \\
\hline Consolação & 86 & Sé & 126 \\
\hline República & 82 & República & 101 \\
\hline PUC & 74 & Vila Buarque & 88 \\
\hline SAUDE & & SAUDE & \\
\hline Centro Cultural & 191 & Clínicas & 166 \\
\hline Clínicas & 186 & Centro Cultural & 165 \\
\hline Vila Clementino & 155 & Vila Clementino & 148 \\
\hline MODO COLETIVO & & MODO COLEIVO & \\
\hline TOTAL & & TOTAL & \\
\hline Sé & 1875 & Sé & 1879 \\
\hline República & 1446 & República & 1469 \\
\hline Centro cultural & 878 & Centro Cultural & 824 \\
\hline MODO INDIVIDUAL & & MODO INDIVIDUAL & \\
\hline TOTAL & & TOTAL & \\
\hline Sé & 451 & São Carlos do Pinhal & 451 \\
\hline Campinas & 450 & Sé & 448 \\
\hline São Carlos do Pinhal & 441 & Campinas & 444 \\
\hline TOTAL & & TOTAL & \\
\hline Sé & 2840 & Sé & 2837 \\
\hline República & 2364 & República & 2359 \\
\hline Centro Cultural & 1435 & São Carlos do Pinhal & 1436 \\
\hline
\end{tabular}




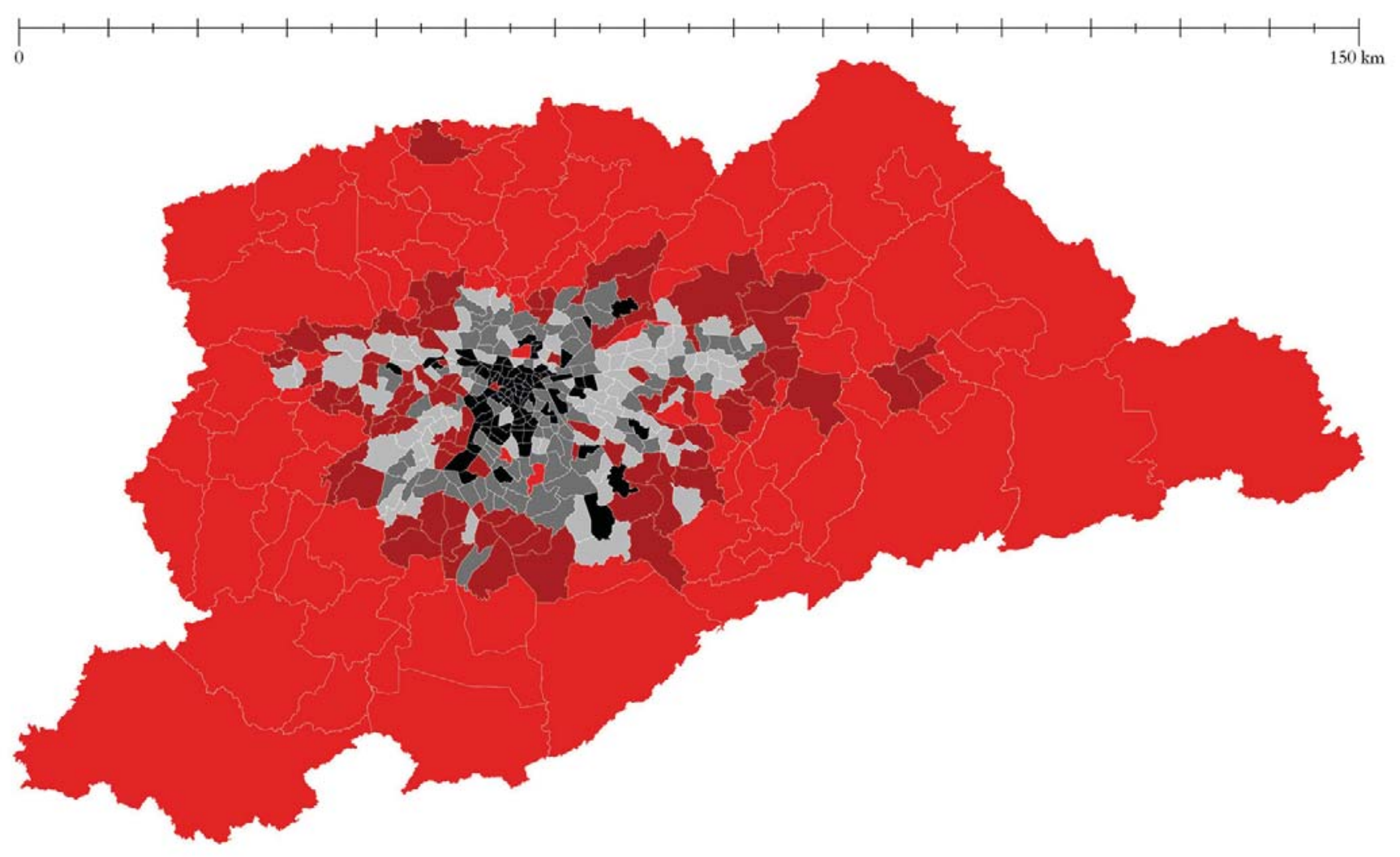

Densidade de viagens produzidas

TRABALHO [viagens/ha]

$0-21$

$21-73$

$73 \cdot 105$

Mapa 51. Densidade de viagens produzidas totais por motivo de trabalho.

Mapa elaborado pela própria autora.

$105-151$

Fonte: SÃO PAULO (ESTADO), METRO,2007.

$151-1.615$ 


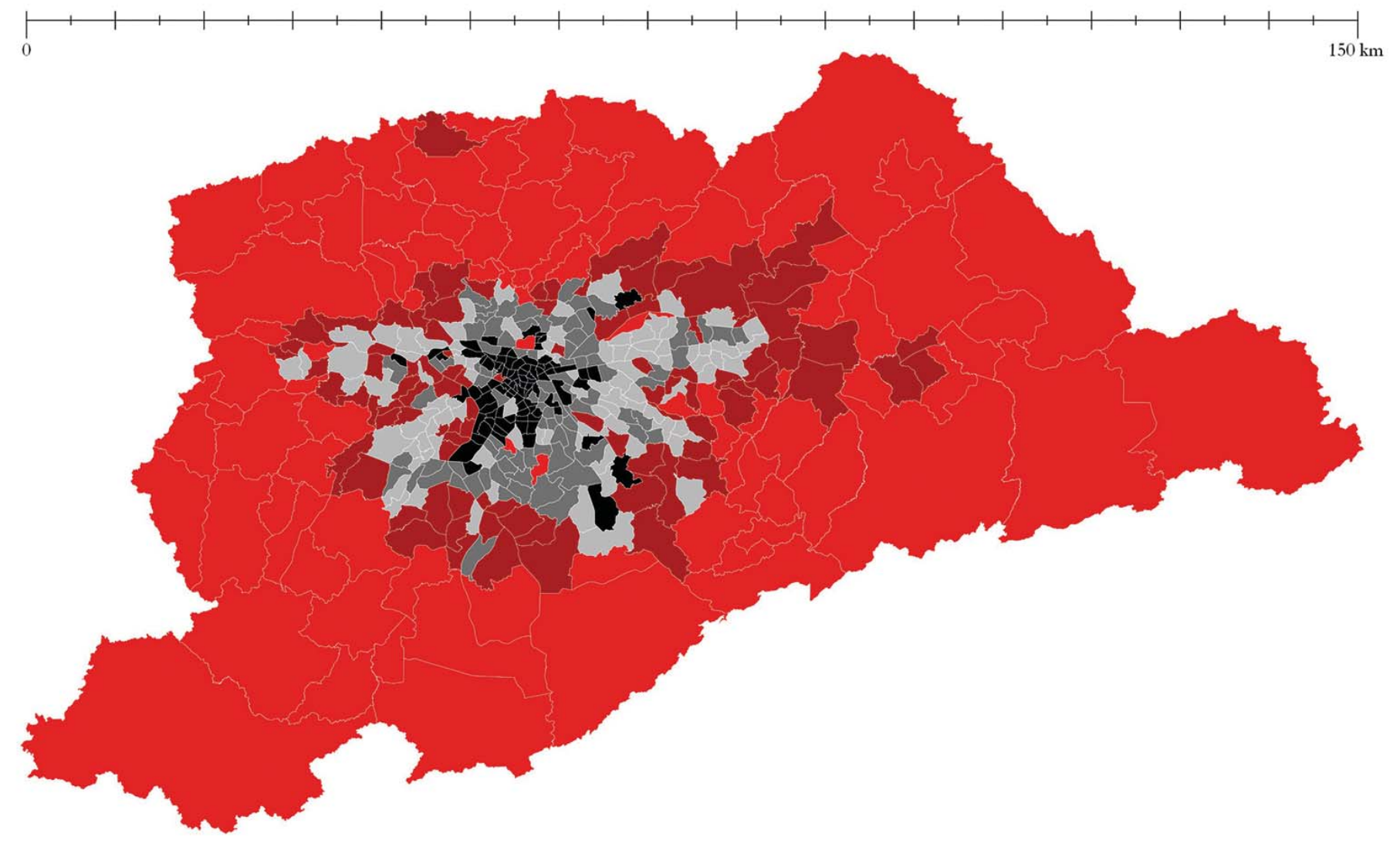

Densidade de viagens atraídas

TRABALHO [viagens/ha]

$0-20$

$20-73$

$73 \cdot 106$

Mapa 52. Densidade de viagens atraídas totais por motivo de trabalho.

Mapa elaborado pela própria autora.

$106 \cdot 148$

Fonte: SÃO PAULO (ESTADO), METRO,2007.

$148 \cdot 1.740$ 


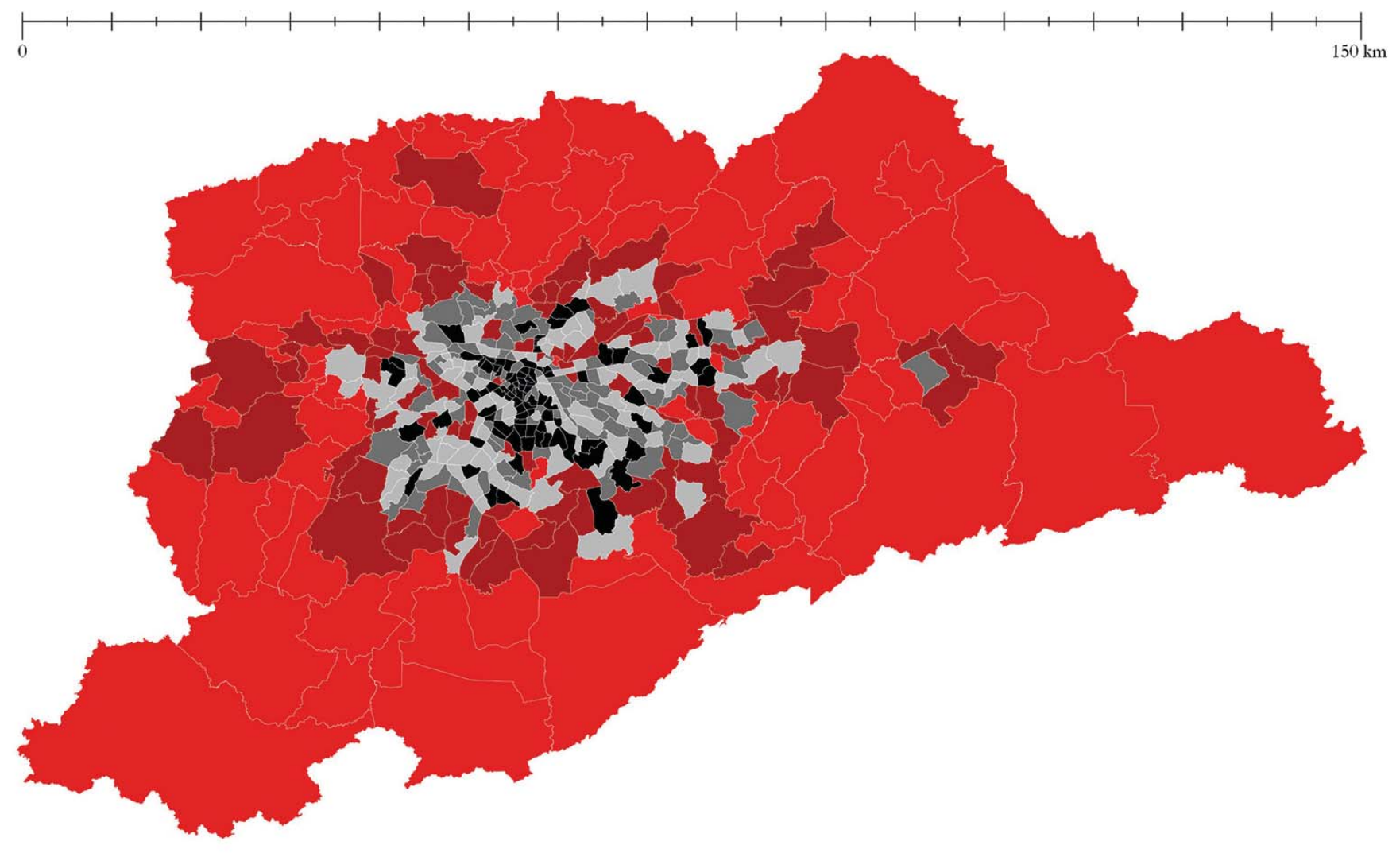

Densidade de viagens produzidas COMPRAS [viagens/ha]

$$
0-0,5
$$

$0,5-4,5$

$4,5-9,5$

Mapa 53. Densidade de viagens produzidas totais por motivo de compras.

Mapa elaborado pela própria autora.

$9,5-17,5$

Fonte: SÃO PAULO (ESTADO), METRO,2007. 


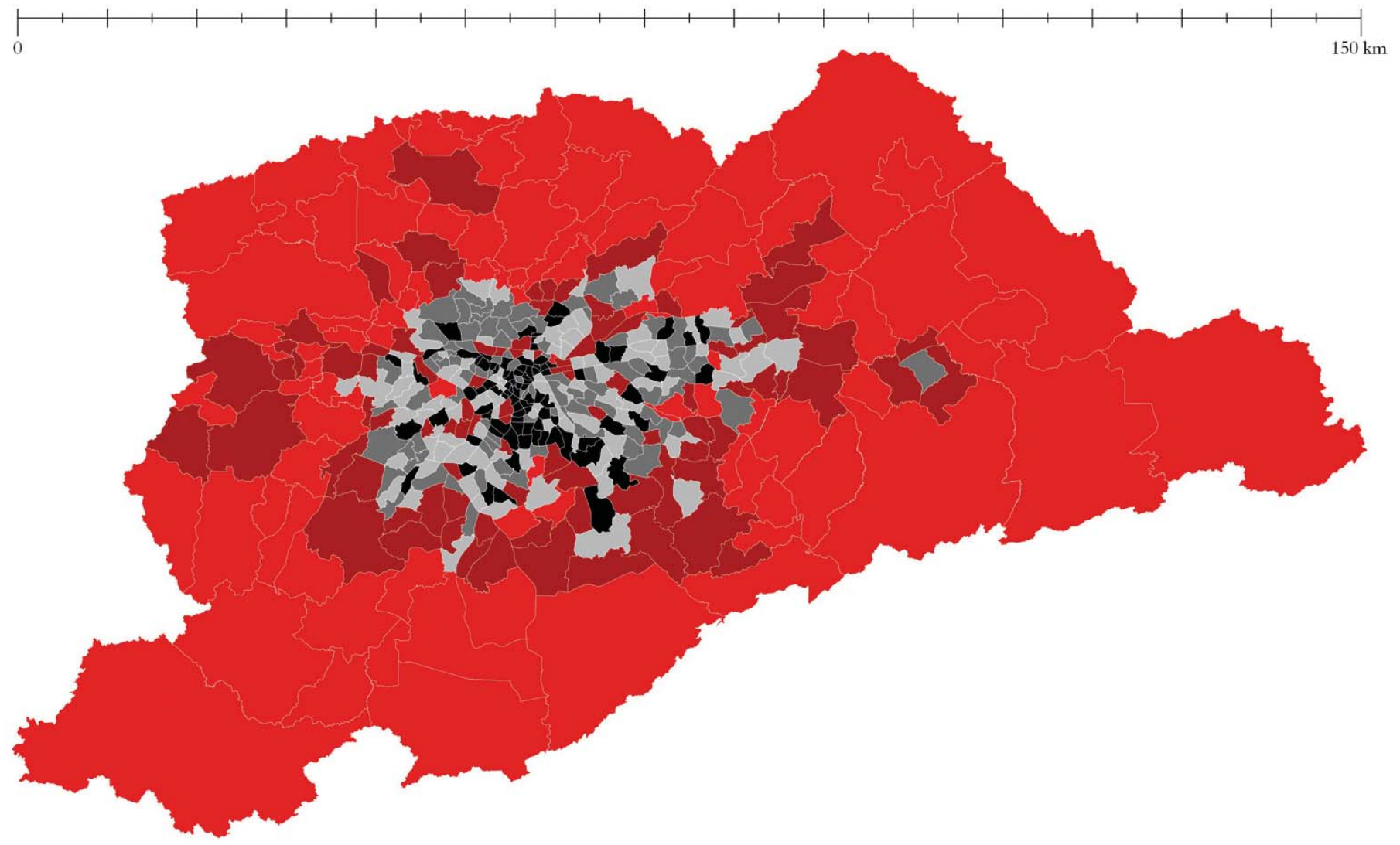

Densidade de viagens atraídas COMPRAS [viagens/ha]

$0-0,7$

$0,7-4,5$

$4,5 \cdot 9,0$

$9,0-18,0$

Mapa 54. Densidade de viagens atraídas totais por motivo de compras.

$18,0-257,0$

Fonte: SÃO PAULO (ESTADO), METRO,2007. 


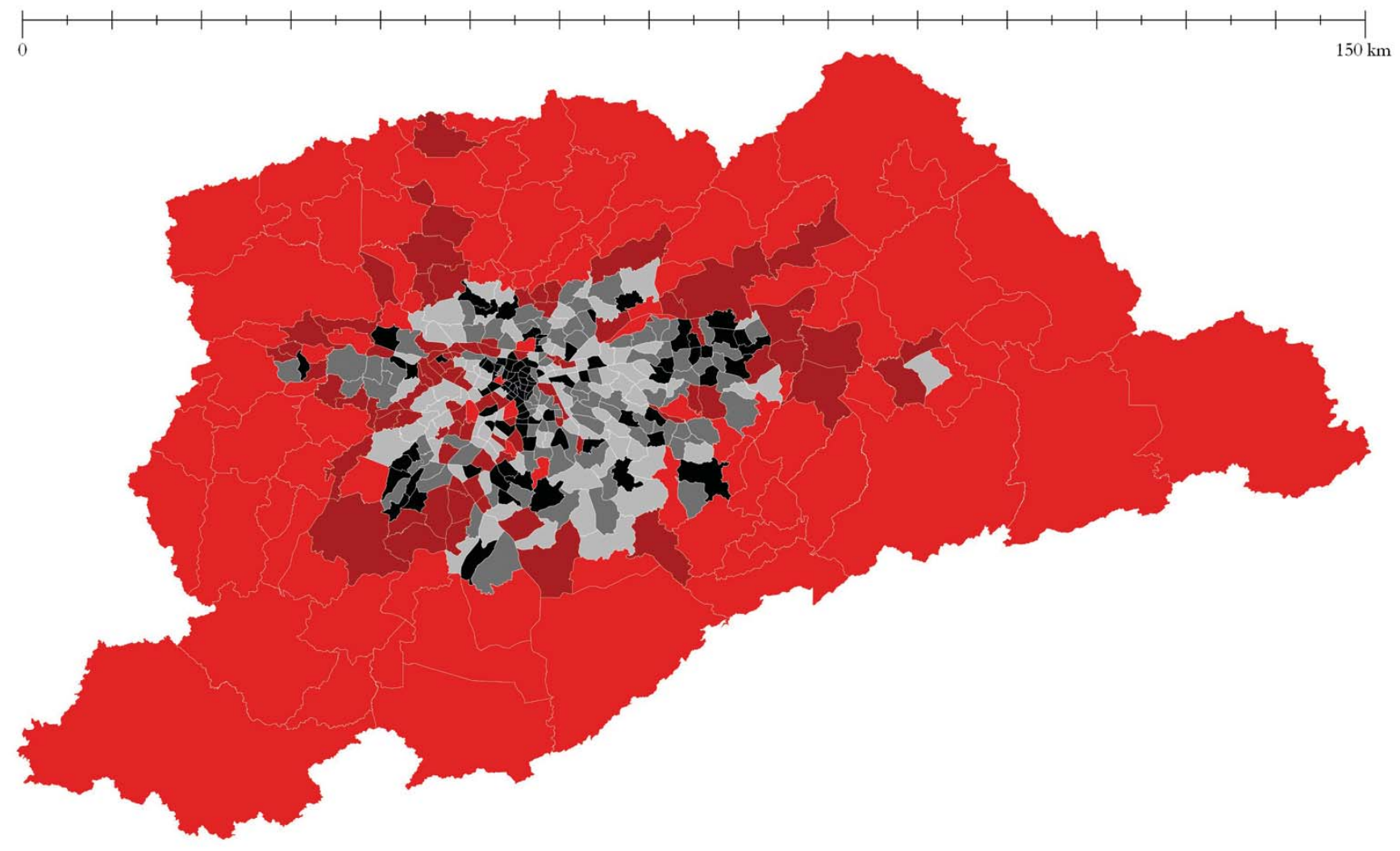

Densidade de viagens produzidas

EDUCAÇÃO [viagens/ha]

0 - 15

$15-48$

$48 \cdot 74$

Mapa 55. Densidade de viagens produzidas totais por motivo de educação.

Mapa elaborado pela própria autora.

$74-110$

Fonte: SÃO PAULO (ESTADO), METR0,2007.

$110 \cdot 575$ 


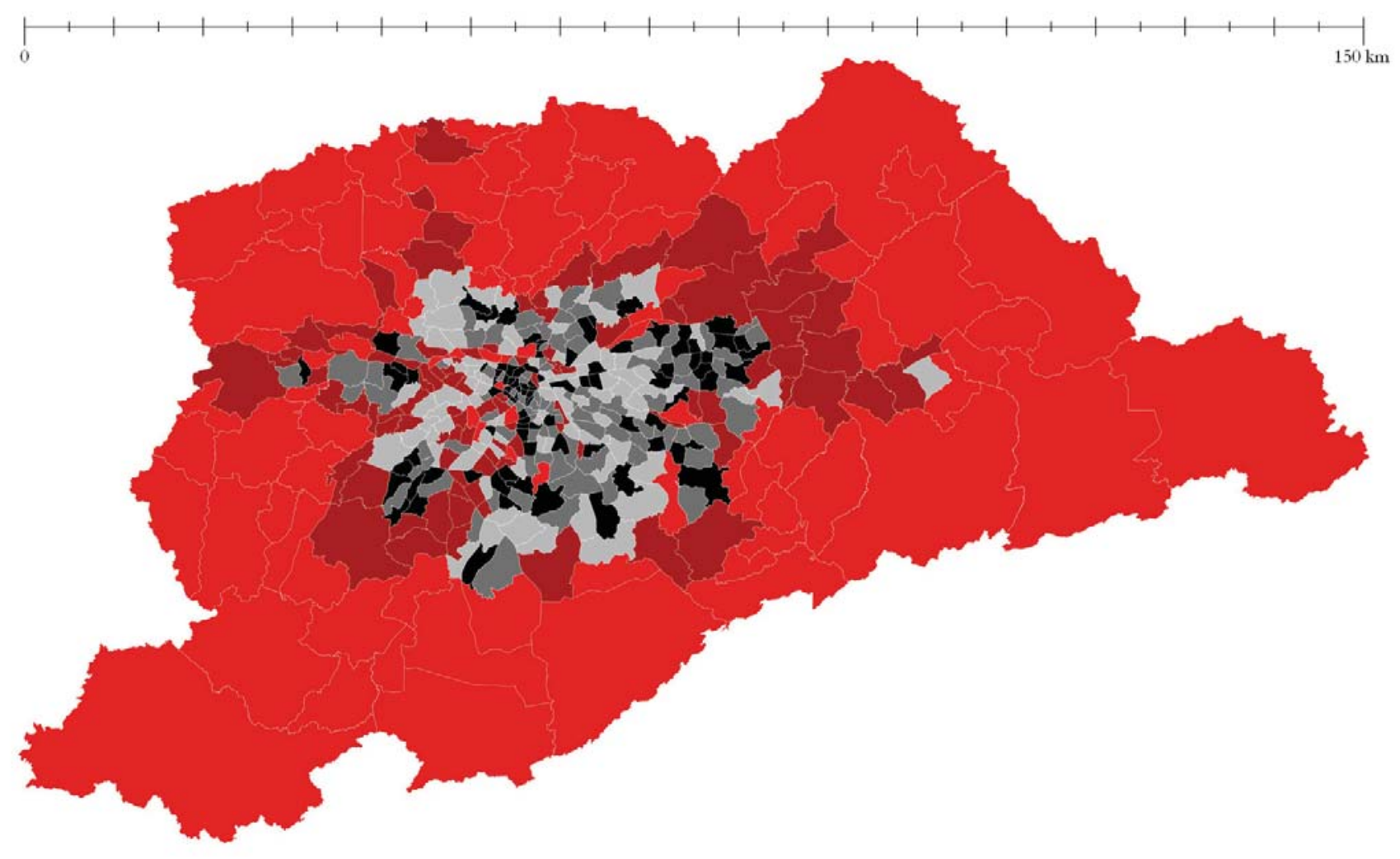

Densidade de viagens atraídas EDUCAÇÃO [viagens/ha]
$0-13$
$13-46$
$46-72$
$72-107$
$107-651$

Mapa 56. Densidade de viagens atraídas totais por motivo de educação.

Mapa elaborado pela própria autora. 


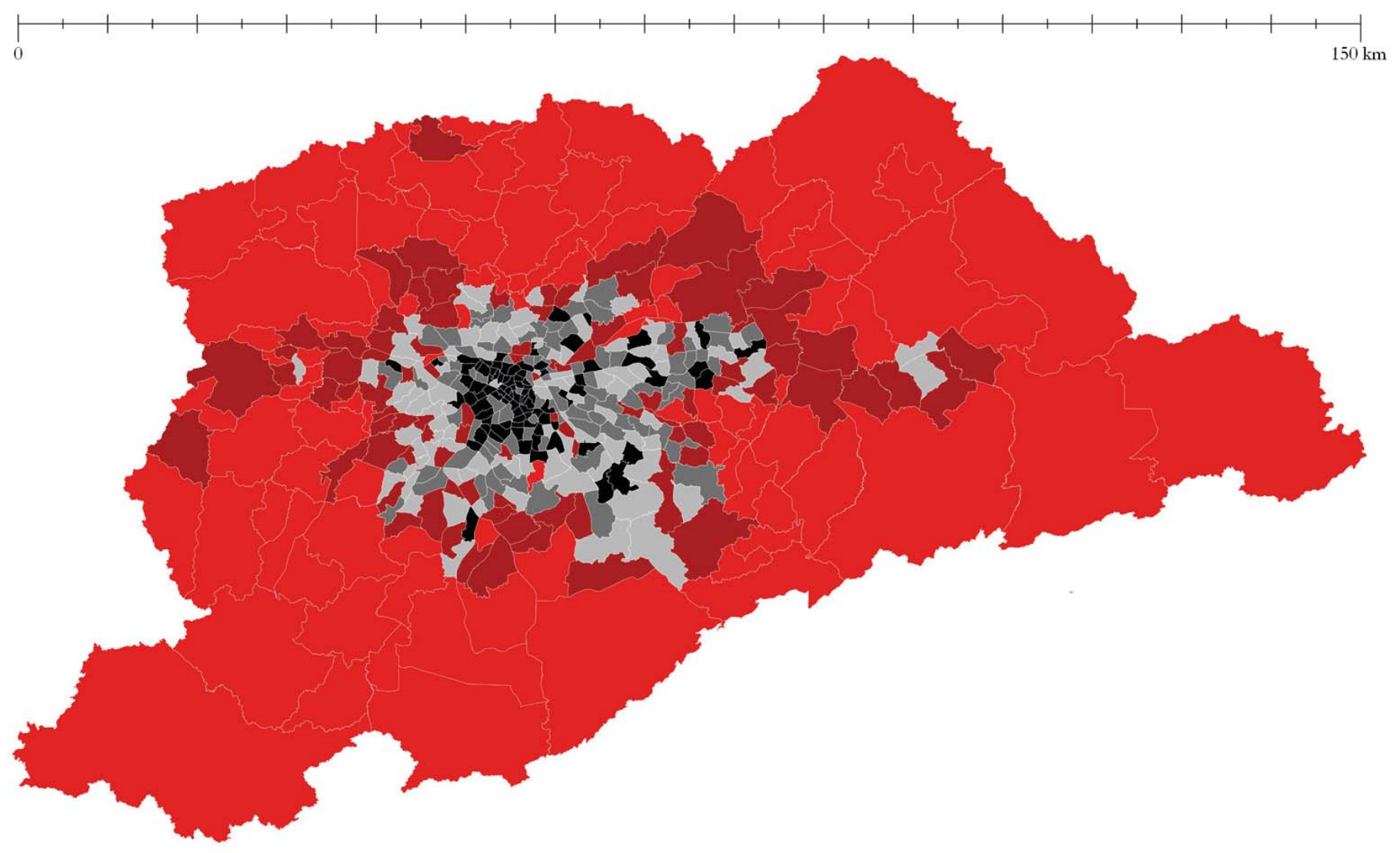

Densidade de viagens produzidas LAZER [viagens/ha]

$0-0,8$

$0,8-4,8$

$4,8 \cdot 10,0$

Mapa 57. Densidade de viagens produzidas totais por motivo de lazer.

$10,0-18,5$

Mapa elaborado pela própria autora.

Fonte: SÃO PAULO (ESTADO), METRO,2007.

$18,5-126,0$ 


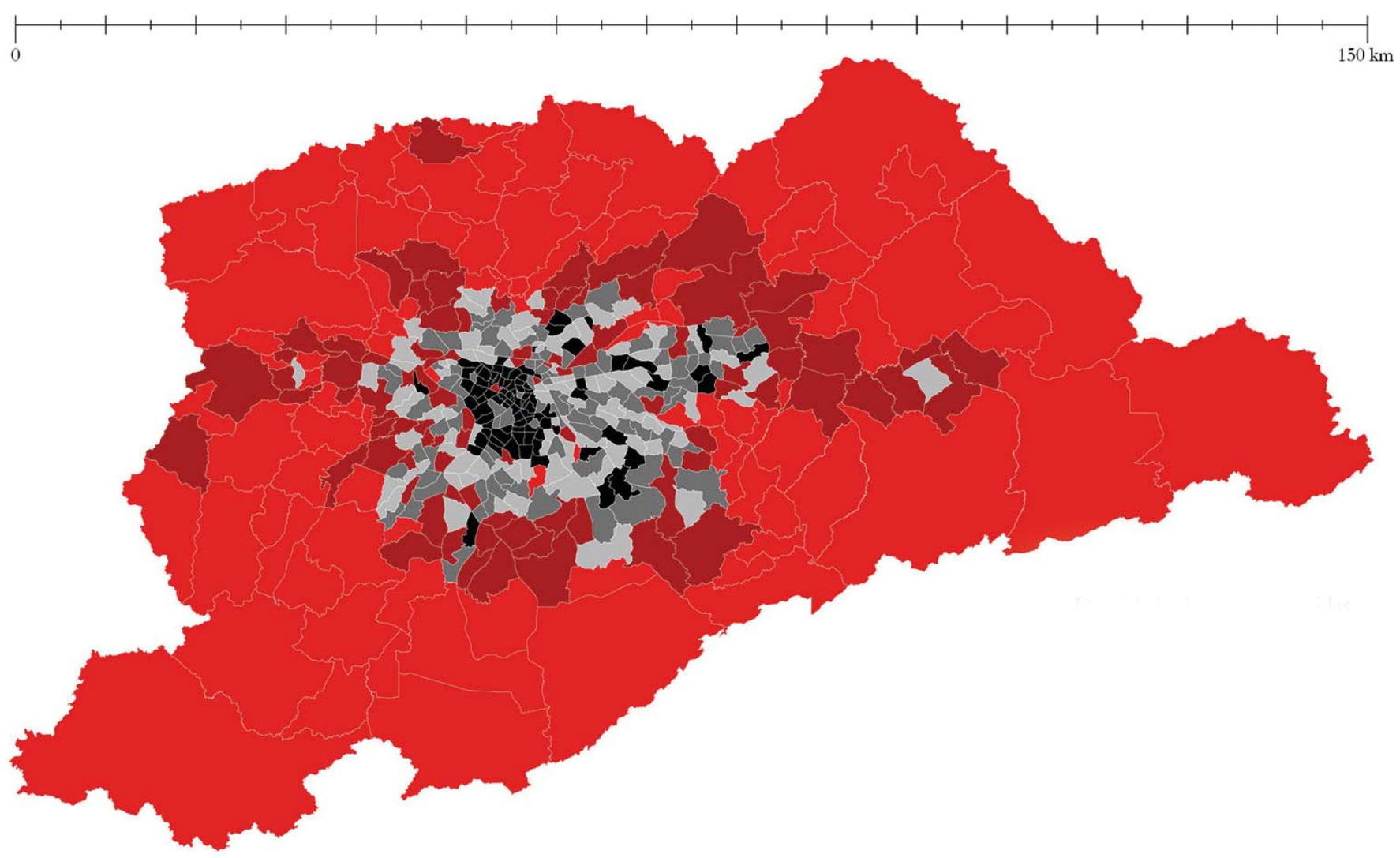

Densidade de viagens atraídas

LAZER [viagens/ha]
0 - 1
$1-5$
$5 \cdot 10$
$10-18$
$18-86$

Mapa 58. Densidade de viagens atraídas totais por motivo de lazer.

Mapa elaborado pela própria autora.

Fonte: SÃO PAULO (ESTADO), METRO,2007. 


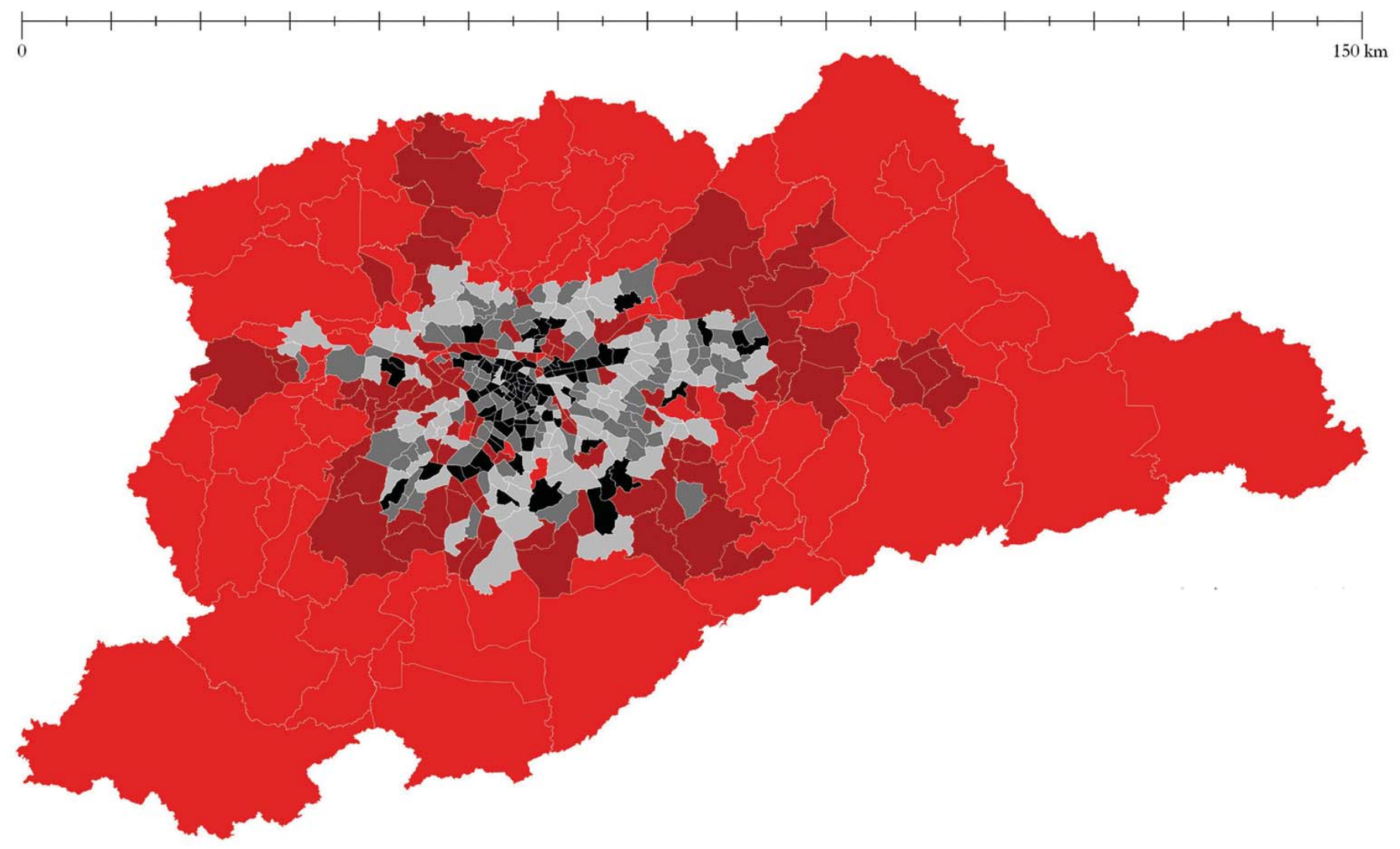

Densidade de viagens produzidas SAÚDE [viagens/ha]

$$
0=0,8
$$

$0,8-4,5$

$4,5 \cdot 8,5$

Mapa 59. Densidade de viagens produzidas totais por motivo de saúde.

Mapa elaborado pela própria autora.

$8,5-15,5$

Fonte: SÃO PAULO (ESTADO), METRO,2007.

$15,5-167,0$ 


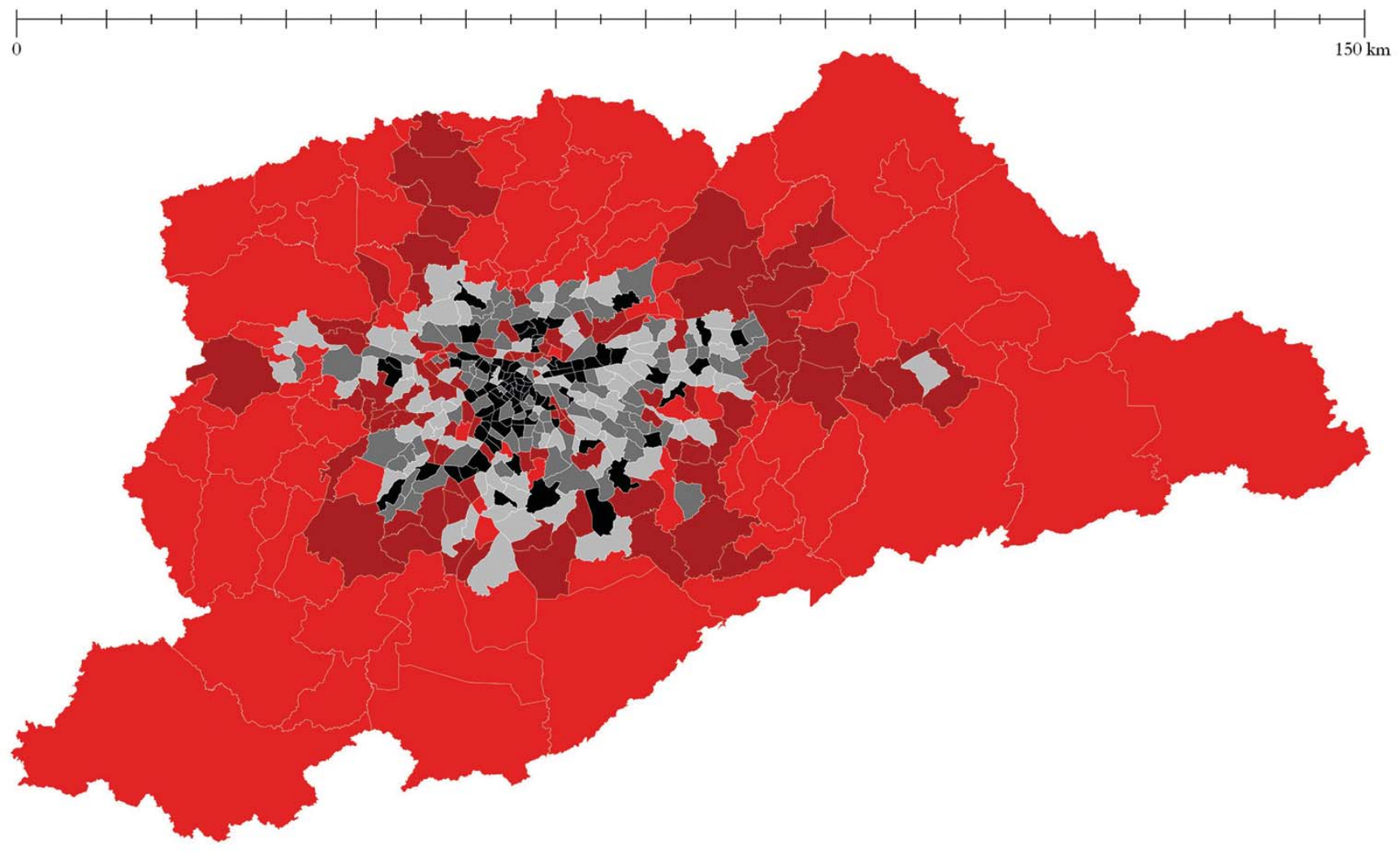

Densidade de viagens atraídas

SAÚDE [viagens/ha]

$$
0-0,8
$$

$0,8-4,3$

$4,3 \cdot 8,0$

Mapa 60. Densidade de viagens atraídas totais por motivo de saúde.

Mapa elaborado pela própria autora.

$8,0-15,0$

Fonte: SÃO PAULO (ESTADO), METRO,2007.

$15,0-191,0$ 


\subsubsection{Os lançamentos}

As informações a respeito dos lançamentos imobiliários residenciais da RMSP foram incluídas de modo bastante sintético nesta pesquisa, na tentativa de se extraírem quaisquer formas de convergências ou simultaneidades quando analisadas conjuntamente com as redes infraestruturais diagnosticadas anteriormente, assim como informações socioeconômicas básicas, como o preço médio dos lançamentos e a renda média do responsável pelos domicílios nas áreas de ponderação dos empreendimentos.

Essas bases foram originalmente sistematizadas pela Embraesp entre o período de 1985 e 2013, porém foram aperfeiçoadas e disponibilizadas pelo CEM, de forma a "subsidiar investigações geostatísticas, de economia urbana e de políticas públicas urbanas”.

Todos esses lançamentos foram georreferenciados e categorizados em lançamentos verticais e horizontais, e sobrepostos às informações de preço da área útil dos lançamentos e de renda média do responsável. A princípio, é possível identificar duas vertentes: as mais altas rendas e o maior número de lançamentos (divididos pela área do distrito), que estão concentrados no núcleo da MSP. Se considerado o número de lançamentos por quilômetro quadrado, a Vila Mariana foi, nestes últimos vinte anos, o distrito com maior número de lançamentos $\left(72 / \mathrm{km}^{2}\right)$, seguido por Perdizes $\left(71 / \mathrm{km}^{2}\right)$, Vila Andrade $\left(64 / \mathrm{km}^{2}\right)$, Itaim 
Bibi $\left(63 / \mathrm{km}^{2}\right)$ e Moema $\left(62 / \mathrm{km}^{2}\right)$ - todos esses distritos estão nas faixas de maior rendimento do chefe de família, em torno de $\mathrm{R} \$ 6.000,00$ (a não ser, no limite inferior por Perdizes, com aproximadamente R \$ 5.260,00, e no limite superior por Moema, com aproximadamente R $8.440,00)^{36}$. Em relação ao preço médio do metro quadrado do lançamento, todos esses distritos estão na faixa média, de $\mathrm{R} \$ 4.000,00 / \mathrm{m}^{2}$ a $\mathrm{R} \$ 4.500,00 / \mathrm{m}^{2}$ (representado pela cor cinza clara no mapa) ${ }^{37}$.

Já em relação aos maiores valores de lançamento por metro quadrado, identifica-se um padrão de natureza diversa. $\mathrm{Na}$ ordem dos maiores para os menores valores, identificam-se os distritos Santo Antônio Paulista, com valor de $\mathrm{R} \$ 7.900,00 / \mathrm{m}^{2}$ (em Ferraz de Vasconcelos), Sapopemba (São Paulo), Jaraguá (São Paulo), Vargem Grande Paulista (Vargem Grande) e Santo André, com valor de R\$ $5.800,00 / \mathrm{m}^{2}$ (Santo André). Desses cinco distritos, dois estão localizados fora do MSP.

Em relação à diferença entre as localizações dos lançamentos verticais e horizontais, é possível identificar uma clara distribuição predominante dos verticais ao centro do MSP, e dos horizontais nas áreas circundantes. Se se acompanhar a linha (que cria uma letra imaginária

\footnotetext{
${ }^{36}$ Esses valores foram corrigidos pelo IGPM de 2013.

${ }^{37}$ Esses valores foram corrigidos pelo IGPM de 2013.
} 
'C') que percorre o percurso dos rios Pinheiros e Tietê, tem-se uma área 'interna', centro do MSP, e uma área 'externa', distritos e municípios do entorno; respectivamente encontra-se o maior número de lançamentos verticais nesse núcleo, e horizontais nas adjacências.

No próximo item serão analisadas as diversas categorias infraestruturais quanto às suas características nos territórios delimitados pelos projetos urbanos demarcados pelas Operações Urbanas Consorciadas e entre outros. 


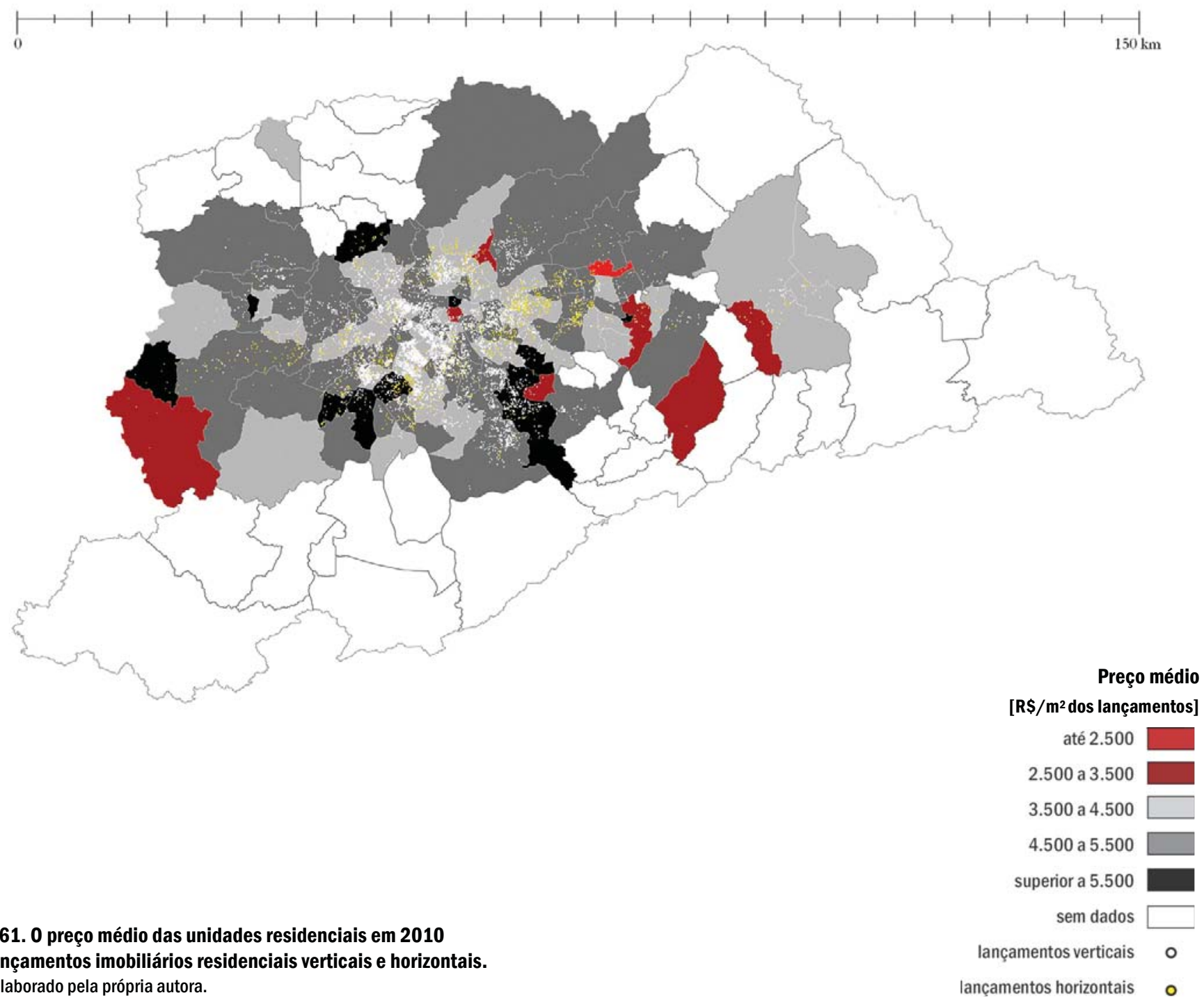

e os lançamentos imobiliários residenciais verticais e horizontais.

ançamentos horizontais

Fonte: CEM, 2014a; CEM,2007a. 


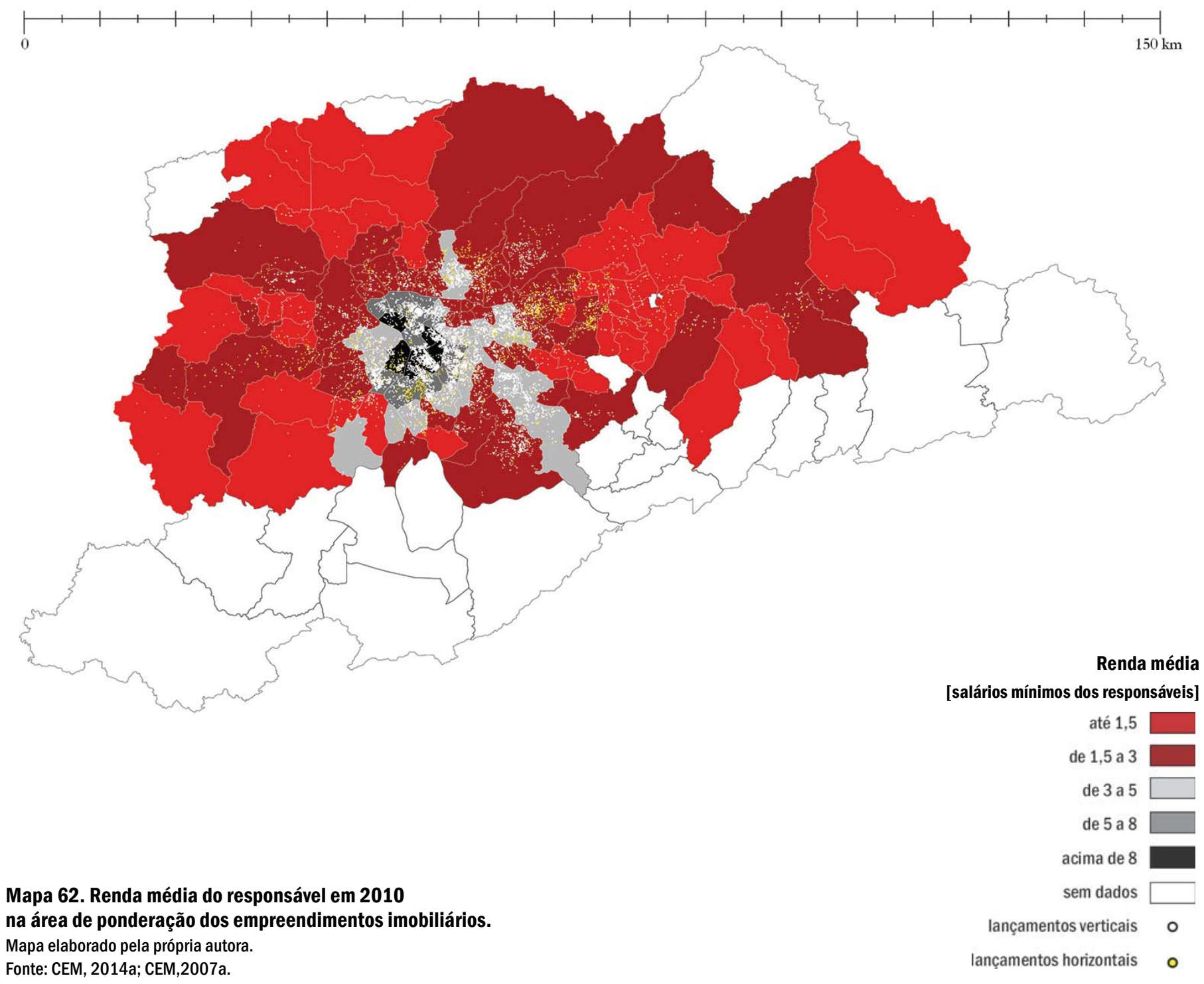




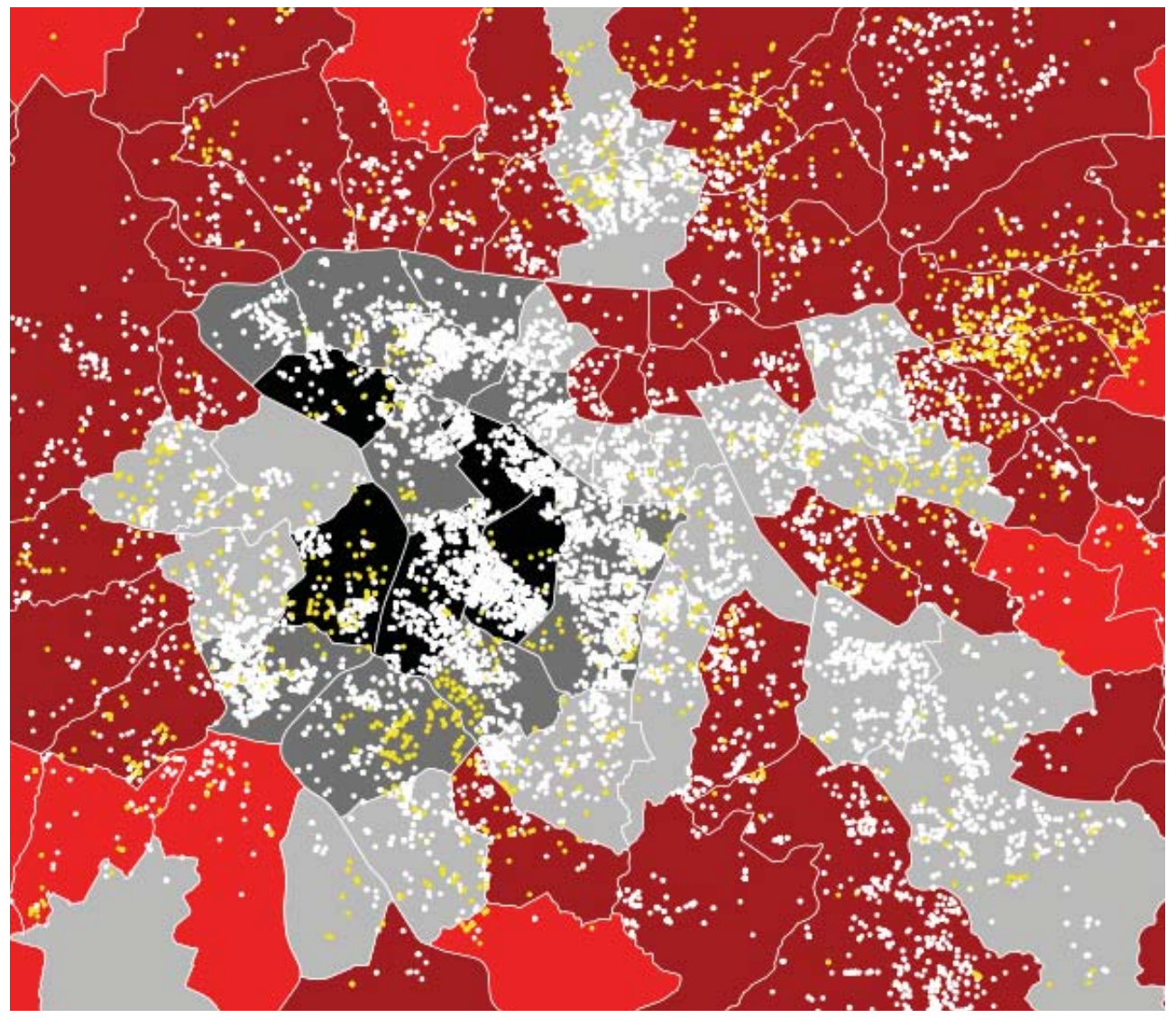

Renda média [salários mínimos dos responsáveis]

até 1,5

de 1,5 a 3

de 3 a 5

de 5 a 8

acima de 8

sem dados

Mapa 63. Ampliação da área central da RMSP indicando os lançamentos verticais (em branco) e horizontais (amarelo). lançamentos verticais Mapa elaborado pela própria autora.

lançamentos horizontais 


\subsubsection{As articulações}

Os projetos urbanos, tal como explorados no capítulo 1, foram examinados neste capítulo de forma a permitir a leitura de suas capacidades em articular as dinâmicas infraestruturais da metrópole. Assim, foi criada uma matriz de associação dos dados que incorporassem, em um eixo (vertical), os projetos urbanos e, no outro (horizontal), os sistemas infraestruturais e seus indicadores e atributos, analisados no subcapítulo 3.2. Essa matriz indica os temas e as classes de agregação de valores verificadas na metrópole paulista, como pode ser analisado nas Tabela 12. As OUCs e o Quadro Socioeconômico. e Tabela 13. As OUCs e a Infraestrutura Urbana.

A identificação dos indicadores e atributos foi feita por meio da delimitação georreferenciada dos perímetros da OUCs - todos indicados no Mapa 65 - e da sobreposição desses desenhos sobre todos os mapas temáticos produzidos nesta pesquisa - do Mapa 1 ao Mapa 63. Devido às complexidades nas operações geográficas, que possibilitariam uma leitura possivelmente mais precisa das informações, foram encontradas restrições que, inversamente, acabariam por gerar suposições incorretas. Essas restrições se deram devido às diversas formas de agregação e classificação de dados coletadas nesta pesquisa (conforme descrito no subcapítulo anterior ' p.228) e na dificuldade de ponderação deles no momento de uma leitura conjugada. 
Assim, o método optado para dar sequência à análise foi o de trabalhar com a leitura visual dos dados, de forma a selecionar os elementos que tivessem, visualmente, maior preponderância dentro dos limites geográficos de cada área de projeto urbano analisado. Logo, foi possível estabelecer uma forma de comparação dos projetos, já que todos os resultados presumidos por base de indicador foram distribuídos e classificados dentro da mesma amostragem, a RMSP. Por meio do estabelecimento dessa escala de atribuição de dados, foi possível identificar a variação dos resultados dessas localizações (OUCs e PPPs), de forma a buscar padrões ou desvios em comparação com as características de todo o entorno.

Os resultados dos indicadores socioeconômicos, tais como indicados nas legendas dos mapas produzidos nesta pesquisa, foram graduados em cinco classes: baixo, médio-baixo, médio, médio-alto e alto. Os indicadores infraestruturais - IRA, IRD, Infiltração das bacias, Abastecimento de Água, Banheiros ligados à rede de esgoto, Cobertura da rede elétrica, Coleta de lixo, Pavimentação e Iluminação no entorno também foram divididos em cinco classes, além de serem distribuídos como: crítico, ruim, regular, bom e ótimo. Indicadores IRFA foram graduados em três classes: crítico, atenção e normal; e os indicadores DEC e FEC, graduados em apenas duas classes: deficiente e suficiente. 


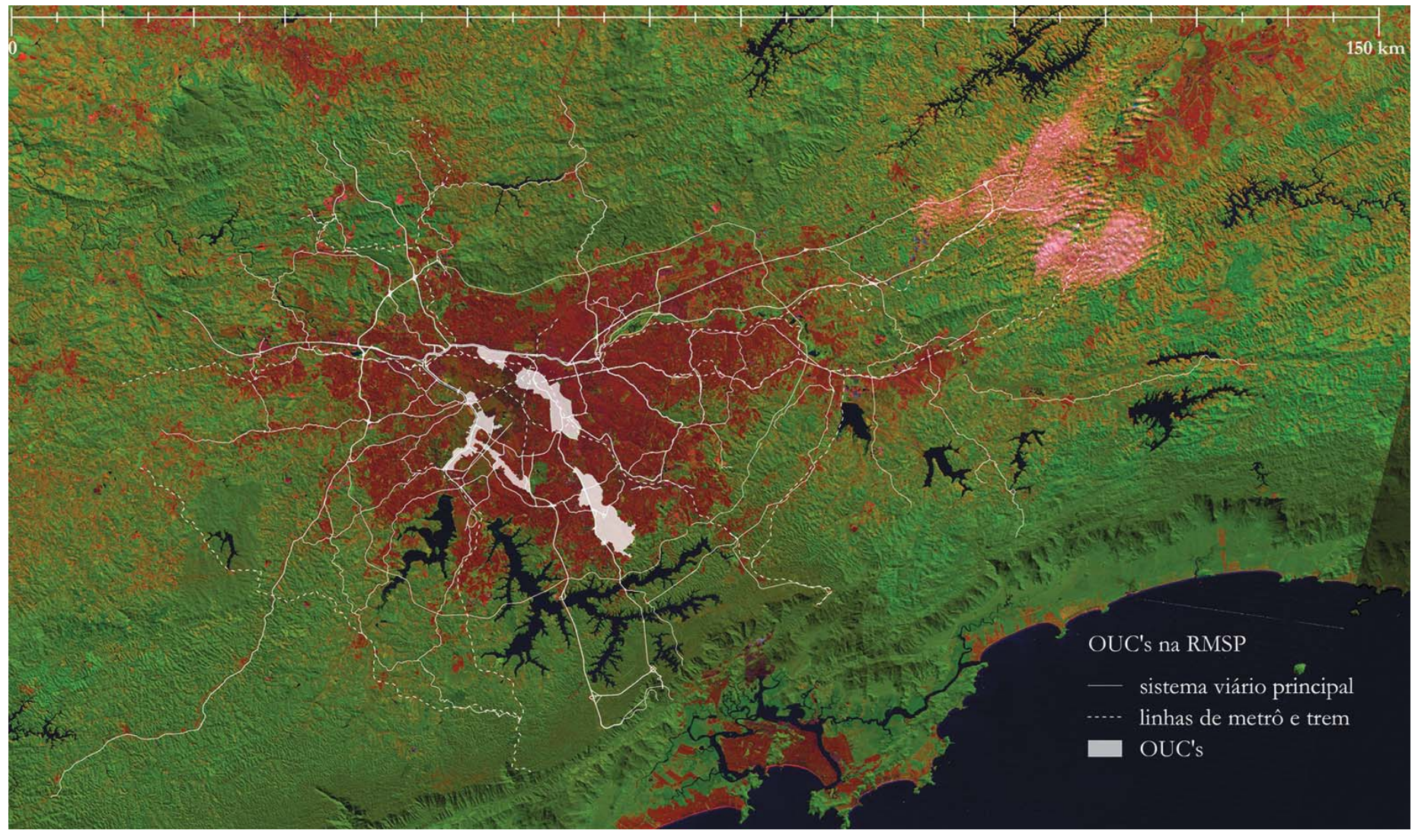

Mapa 64. A RMSP e os Projetos Estratégicos.

Mapa elaborado pela própria autora.

Fonte: SÃO PAULO (CIDADE), SP-URBANISM0, 2015; SÃO PAULO (CIDADE), SP-URBANISM0, 2014; SÃO BERNARDO DO CAMPO (CIDADE), SPU, 2015; EMPLASA, 2015; LANDSAT

TM 5: imagem de satélite. São José dos Campos: Instituto Nacional de Pesquisas Espaciais, 2011. 3 fotografias aéreas. Canais 3,4,5 e composição colorida 5,4 $\mathrm{e}$ 


\section{Resultados}

Na área delimitada para a Operação Urbana Água Branca (Mapa 66), verifica-se a predominância de valores nas faixas máximas de densidade populacional (acima de 150 hab./ha), a taxa de emprego (acima de 1,60 emp./hab.) e a densidade de emprego (acima de 104 emp./ha). Valores relativos à renda dos domicílios e do responsável (entre 5 e 8 salários mínimos) e preço da área útil do lançamento (entre R\$ $4.500 / \mathrm{m}^{2}$ e $\mathrm{R} \$ 5.500 / \mathrm{m}^{2}$ ) também têm predominância nas faixas médioaltas. Quanto aos indicadores infraestruturais relacionados ao abastecimento de água, vê-se a predominância de valores ótimos para o IRA e o IRD, assim como a cobertura do abastecimento por rede pública indicados pela pesquisa do Censo. Vale lembrar que, para o período analisado, apenas um sistema de abastecimento alcançava a região. $\mathrm{O}$ IRFA tem predominâncias diversas dependendo dos lotes analisados, podendo variar entre duas classes, crítico ou ótimo. A taxa de infiltração das bacias apresentou resultados que variaram entre ruim, regular e bom. Os índices DEC foram deficientes e FEC, suficientes. Todos os outros indicadores avaliados foram considerados ótimos.

$\mathrm{Na}$ área delimitada para a Operação Urbana Água Espraiada (Mapa 67), verifica-se que os padrões de densidade populacional predominantes são bastante discrepantes, ora muito baixos (até 18 hab/ha), ora médio-altos (100-150 hab/ha). Já os padrões encontrados 
quanto às taxas e densidade de emprego caem nas faixas médio-altas e altas. A renda dos domicílios indicam a maior faixa (acima de 8 salários mínimos.), enquanto a renda do responsável indicam as faixas média e médio-altas. Quando a renda é avaliada por meio do indicador densidade de renda (renda média dividida por hectares), as faixas que aparentam predominantes parecem ser mais diversas, verificando-se uma heterogeneidade maior de resultados entre as faixas média, média-alta $\mathrm{e}$ alta. A faixa do preço da área útil também indica a faixa média. Os indicadores infraestruturais apresentaram a mesma performance da OUC Água Branca, a não ser pela taxa de infiltração das bacias de esgotamento, que indicaram melhores taxas, e do índice de reclamação de falta d'água, predominantemente em estado de atenção ou normal (em vez de apresentar uma predominância de índices críticos como no caso anterior).

Quanto à Operação Urbana Centro (Mapa 68) e à área delimitada para o projeto Nova Luz (que é de menor tamanho, porém contida na primeira), as faixas predominantes são bastante similares, a não ser pela densidade populacional, que se encontra na faixa mais baixa no segundo caso (Luz). Partes da área delimitada pelo primeiro projeto também possui uma predominância de densidade populacional médiaalta, de igual tamanho a área que apresenta ter densidade muito baixa. As taxas e densidade de emprego são em ambas, altíssimas, porém o paradoxo é que a renda dos domicílios e a renda do responsável 
predominantemente não passam de três salários mínimos. Na OUC Centro, há uma grande predominância de rendas domiciliares abaixo de 1,5 salários. O valor dos lançamentos imobiliários no distrito se encontra na faixa média. A área como um todo apresenta bons indicadores infraestruturais, excetos pelas ruins taxas de infiltração das bacias (que inclui a área da Nova Luz) e para os deficientes resultados DEC/FEC, sendo estes últimos suficientes apenas no perímetro que circunscreve o projeto Nova Luz.

A OUC Faria Lima (Mapa 69) apresenta densidades populacionais médio-altas. As taxas e a densidade de emprego, assim como a renda dos domicílios e do chefe de família são as mais altas das amostras de projetos, sendo o preço dos lançamentos predominantes entre as faixas média e médio-alta. Os indicadores infraestruturais da área que englobava a OUC Faria Lima têm predominância de valores ótimos, a não ser para os indicadores de qualidade de transmissão de energia elétrica, com níveis deficientes de DEC e FEC. No ano estudado, algumas áreas podiam ser alcançadas por sistemas de abastecimento alternativos que não o principal, porém, os níveis IRFA indicaram predominantemente o estado de atenção ou normal. As taxas de infiltração das bacias foram predominantemente regulares ou boas.

A OUC São Bernardo (Mapa 70) apresenta uma densidade populacional média, com taxas e densidade de emprego médio-altas. A renda do domicílio apresenta-se médio-alta, enquanto a renda do 
responsável apresenta-se médio-baixa, o que pode demonstrar que as famílias são compostas por mais de um integrante que compõe a renda familiar. O preço médio da área útil dos lançamentos é predominantemente médio-alto. Os indicadores infraestruturais são, em sua maioria, ótimos e as taxas de infiltração são boas, exceto pela condição pouco contingente dessa região, por ser alcançada apenas por um sistema de abastecimento. O IRA é muito crítico em algumas áreas, ou bons em outras, e os DEC/FEC, marcadamente deficientes.

O projeto de vastas extensões do Arco Tietê (Mapa 71) apresenta densidades populacionais predominantes nas faixas médio e médio-altas, com taxas de emprego altas e densidade médio-altas e altas. A renda dos responsáveis apresenta-se médio-baixa, enquanto a dos domicílios, médio e médio-altas, o que também indica uma tendência de composição da renda por mais de um integrante da família. O preço da área útil apresenta-se predominantemente médio e médio-alto. A infraestrutura da região apresenta indicadores positivos, exceto para os valores discrepantes e deficientes de DEC/FEC.

Apesar da escala da OUC Bairros do Tamanduateí (Mapa 72), que é composta por sete subáreas: Mooca, Parque da Mooca, Ipiranga, Vila Carioca, Cambuci, Henry Ford e Vila Prudente/Vila Zelina; as características socioeconômicas não apresentam discrepâncias muito marcantes. A densidade populacional é, em geral, média, exceto pelo setor Ipiranga e Vila Prudente, com densidade médio-baixa, e do setor 
Mooca, com predominância dividida entre média e média-alta. Quanto às taxas de emprego, pode-se dizer que estas são altas (Mooca, Parque da Mooca, Cambuci e Henry Ford) e média-altas (Ipiranga e Vila Carioca), com exceção da Vila Prudente, com valores médio-baixos. O mesmo ocorre com a densidade de empregos, em geral, média-alta, com exceção da Vila Prudente/Vila Zelina (média-baixa) e Parque da Mooca e Henry Ford (alta). A renda dos responsáveis é predominantemente média, exceto o setor Vila Prudente, média-baixa. Já a renda dos domicílios apresenta-se bastante heterogênea: o setor mais carente neste quesito é o Vila Carioca (média-baixa), seguido pelos setores Cambuci, Vila Prudente e Mooca (média), Ipiranga (média-alta) e Mooca, Parque da Mooca e Henry Ford, com predominância de renda alta. O preço da área útil é, em geral, médio-alto, com setores como o Cambuci e Vila Prudente/Vila Zelina, apresentando valores médios. Os indicadores de infraestrutura apresentam cobertura predominantemente ótima, inclusive apresentando, diferentemente das outras áreas, contingência no sistema de abastecimento de água. Com exceção dessas características, as taxas de infiltração são predominantemente regulares, os IRDs bons, e os DECs muito deficientes.

Quanto aos setores selecionados na primeira etapa da concorrência do projeto Casa Paulista (Mapa 73), é possível verificar uma maior diferenciação dos dados socioeconômicos. De acordo com o Mapa 73 , os lotes 1 e 2 apresentam predominantemente densidade populacional 
baixa e média-alta, os lotes 3 , média e os lotes 4 , média-alta. As taxas e a densidade de emprego, importantemente, variam entre médias e médiaaltas. A renda dos responsáveis varia entre média-baixa e média, sendo a renda domiciliar mais diferenciada transversalmente aos lotes, variando de baixa a, predominantemente, média-alta, assim como o preço da área útil, que varia entre médio-baixo a médio-alto. Os setores da Casa Paulista apresentam dados de cobertura de infraestrutura em geral ótimos, porém apresenta IRDs bons, IRFAs em nível de atenção e, em alguns setores normais, indicadores DEC/FEC deficientes. O lote 4 apresenta taxas críticas de infiltração das bacias, o 3, ruins, porém estes também apresentam uma capacidade contingencial de abastecimento de água.

Por meio desta análise difusa, foi possível evidenciar que as localizações das áreas de operações urbanas consorciadas acabam por seguir algum tipo de padrão se comparadas à totalidade do território da RMSP. No que diz respeito a análises socioeconômicas, a maior parte destes locais apresenta maior predominância de altas taxas de densidades de emprego e a renda média dos responsáveis e dos domicílios são médiabaixas (com exceção da Água Branca, Faria Lima e Água Espraiada, que têm maior nível econômico). Essas localizações também apresentam altas densidades de viagens produzidas e atraídas por transporte coletivo e individual, exceto pela Água Branca, Faria Lima e a OUB Tamanduateí, que não se enquadram em um universo homogêneo nesse quesito. 
Em relação às características físicas e materiais dessas localizações, é possível afirmar que estas apresentam condições mais positivas e homogêneas do que em relação aos atributos encontrados em outras partes da metrópole, exceto pelos indicadores de energia, índices de reclamação de falta d'água e infiltração das bacias de esgotamento, que apresentam predominantemente resultados regulares ou críticos.

Desse modo, por meio da execução da análise cruzada entre as áreas de operação urbana, os dados socioeconômicos e os dados de infraestrutura, juntamente com a análise amostral dos fluxos da metrópole apresentada no próximo subcapítulo, foi possível estabelecer uma relação clara e direta entre a infraestrutura e os projetos de renovação urbana. Essa relação foi aprofundada no Capítulo 4 - O Arquipélago, o grid e os fluxos, a fim de produzir uma interpretação tanto quanto a heterogeinedade da metrópole, do ponto de vista socioeconômico e de cobertura e qualidade dos serviços infraestruturais, como da importância do preenchimento dos objetivos da regeneração urbana. 


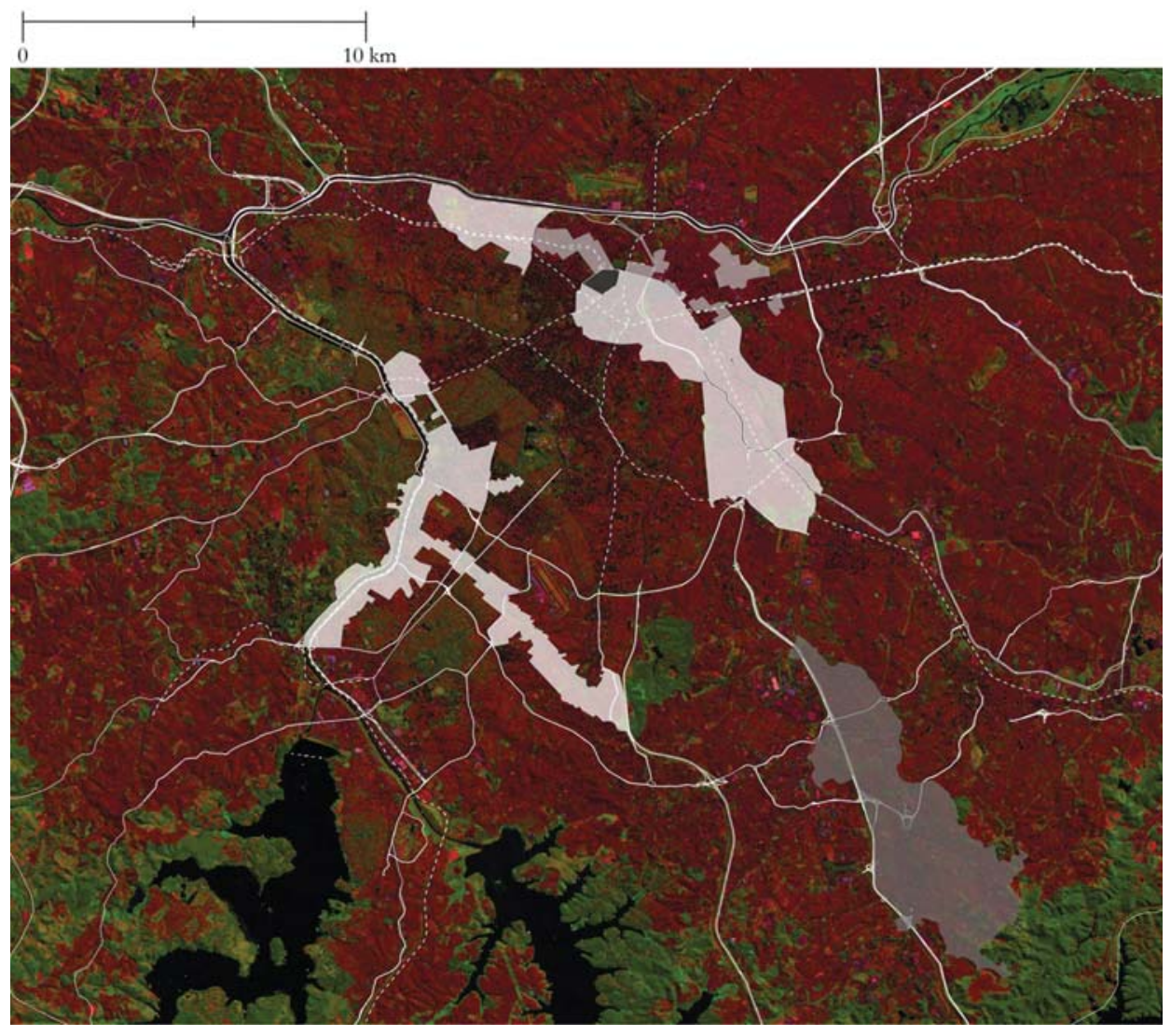

Identificação das OUC's e PPP's

Nova Luz

OUC São Bernardos do Campo

PPP Casa Paulista

OUC São Paulo

Linhas de metrô e trem

Mapa 65. Identificação dos projetos urbanos OUCs e PPPs.

Sistema viário principal

Mapa elaborado pela própria autora.

Fonte: SÃO PAULO (CIDADE), SP-URBANISM0, 2015; SÃ0 PAULO (CIDADE), SP-URBANISMO, 2014; SÃ0 BERNARDO DO CAMPO (CIDADE), SPU, 2015; EMPLASA, 2015 ; LANDSAT

TM 5: imagem de satélite. São josé dos Campos: Instituto Nacional de Pesquisas Espaciais, 2011. 2 fotografias aéreas. Canais 3, 4, 5 e composição colorida 5, 4 e 3. 


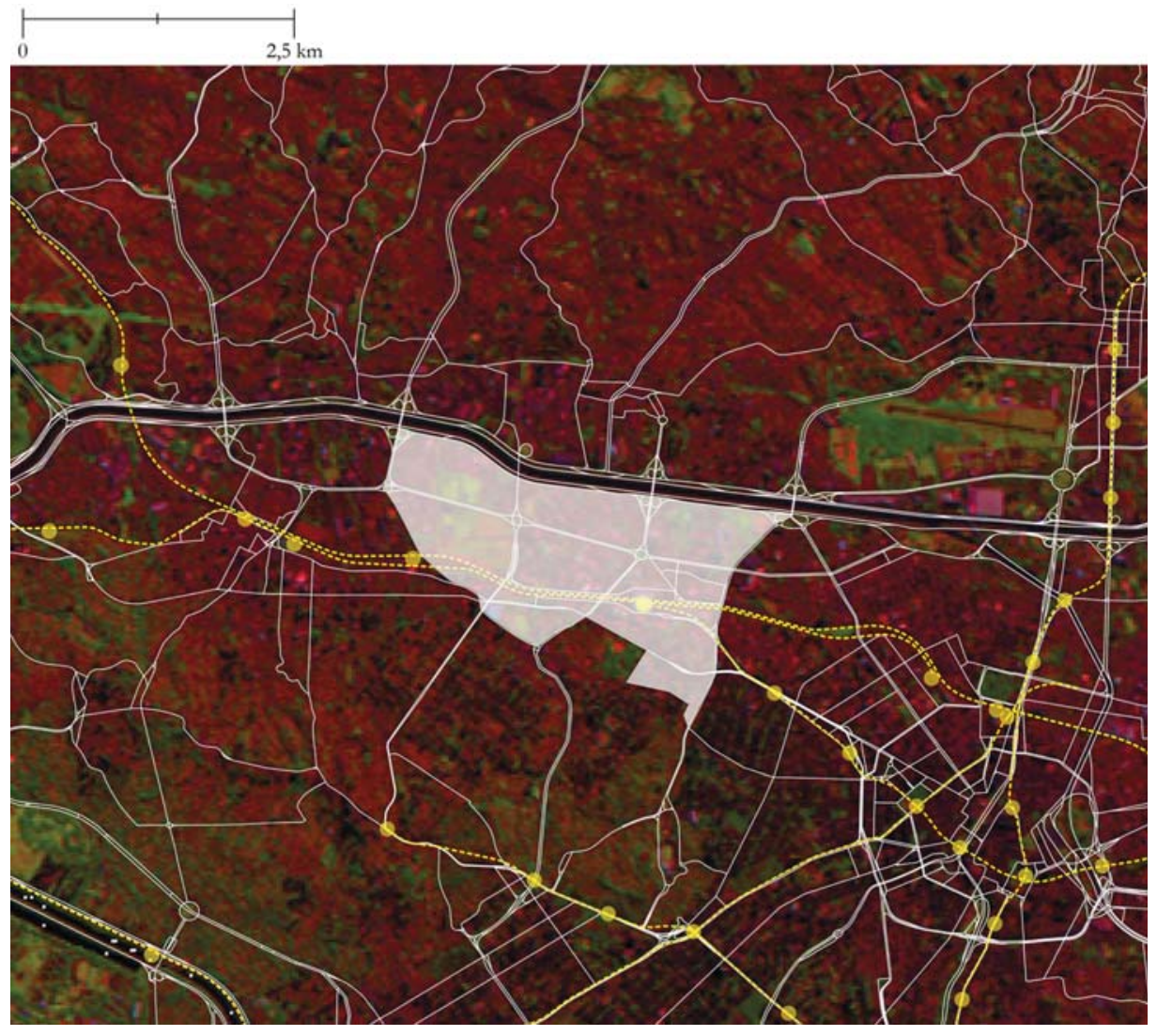

Mapa 66. Identificação da OUC Água Branca.

Mapa elaborado pela própria autora.

Fonte: SÃO PAULO (CIDADE), SP-URBANISMO, 2015; EMPLASA, 2015; LANDSAT TM 5: imagem de satélite. São josé dos Campos: Instituto Nacional de Pesquisas Espaciais, 2011.

2 fotografias aéreas. Canais $3,4,5$ e composição colorida 5,4 e 3.

\section{A OUC Água Branca}

estações de metrô e trem

linhas de metrô e trem a a a

sistema viário

Nota: 0 sistema viário é composto pelas vias macrometropolitanas, metropolitanas, estruturais urbanas e vicinais, segundo classificação da EMPLASA. 


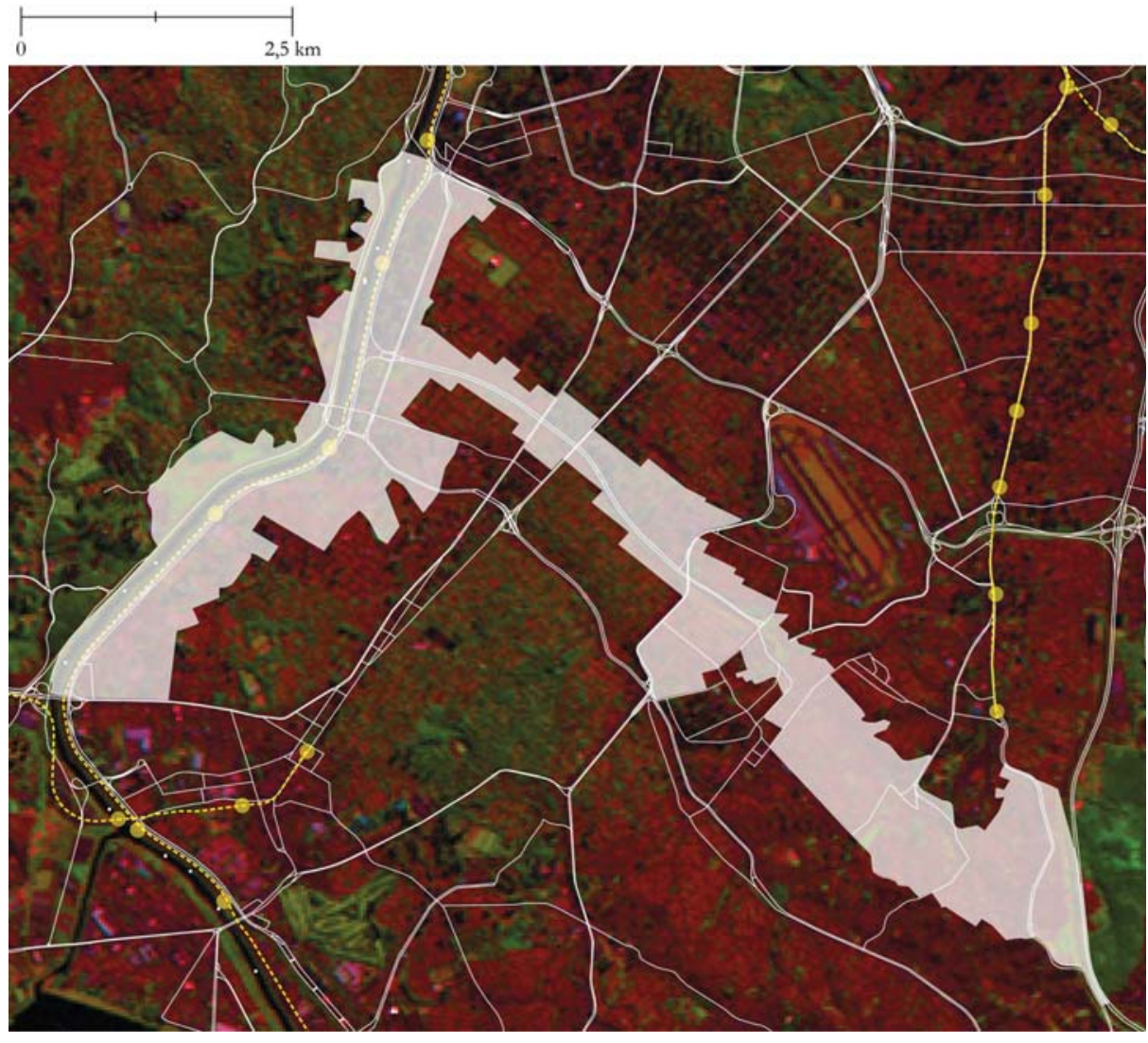

Mapa 67. Identificação da OUC Água Espraiada.

Mapa elaborado pela própria autora.

Fonte: SÃO PAULO (CIDADE), SP-URBANISMO, 2015; EMPLASA, 2015; LANDSAT TM 5: imagem de satélite. São josé dos Campos: Instituto Nacional de Pesquisas Espaciais, 2011.

2 fotografias aéreas. Canais 3, 4, 5 e composição colorida 5, 4 e 3.
A OUC Água Espraiada estaçōes de metrô e trem

linhas de metrô e trem

sistema viário

Nota: 0 sistema viário é composto pelas vias macrometropolitanas, metropolitanas, estruturais urbanas e vicinais, segundo classificação da EMPLASA. 


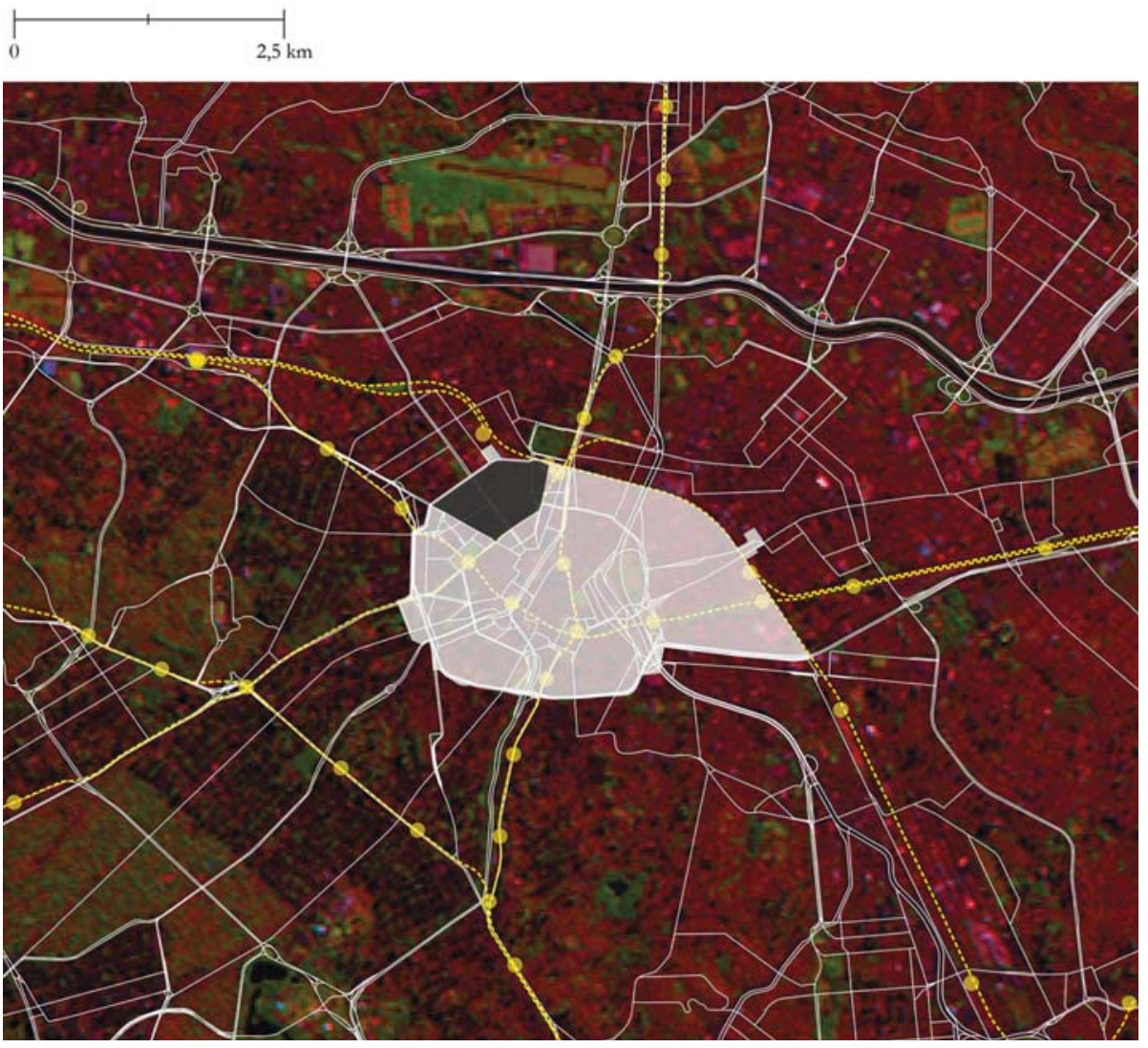

Mapa 68. Identificação da OUC Centro e da área do Projeto Nova Luz.

Mapa elaborado pela própria autora.

Fonte: SÃO PAULO (CIDADE), SP-URBANISM0, 2015; EMPLASA, 2015; LANDSAT TM 5: imagem de satélite. São josé dos Campos: Instituto Nacional de Pesquisas Espaciais, 2011.

2 fotografias aéreas. Canais $3,4,5$ e composição colorida 5,4 e 3 .

\section{A OUC Centro e a Nova Luz} estações de metrô e trem

$$
\begin{aligned}
& \text { sistema viário } \\
& \text { ouc Centro }
\end{aligned}
$$

Nova Luz

Nota: 0 sistema viário é composto pelas vias macrometropolitanas, metropolitanas, estruturais urbanas e vicinais, segundo classificação da EMPLASA. linhas de metrô e trem $=0 \times$ a 


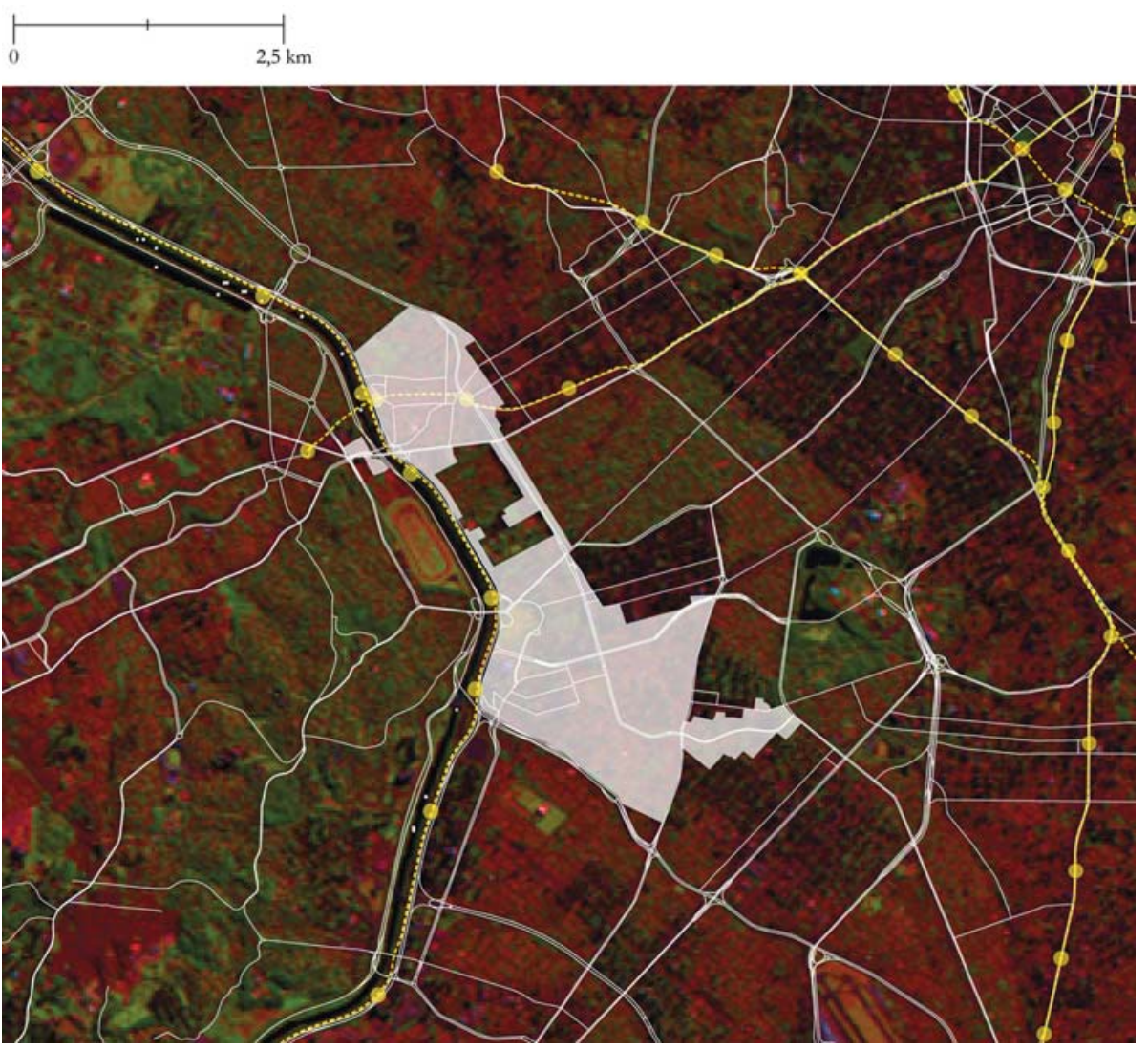

Mapa elaborado pela própria autora.

Fonte: SÃO PAULO (CIDADE), SP-URBANISM0, 2015; EMPLASA, 2015; LANDSAT TM 5: imagem de satélite. São josé dos Campos: Instituto Nacional de Pesquisas Espaciais, 2011. 2 fotografias aéreas. Canais $3,4,5$ e composição colorida 5,4 e 3.

\section{A OUC Faria Lima}

estações de metrô e trem

linhas de metrô e trem

$$
\text { sistema viário }
$$

Nota: 0 sistema viário é composto pelas vias macrometropolitanas, metropolitanas, estruturais urbanas e vicinais, segundo classificação da EMPLASA. 


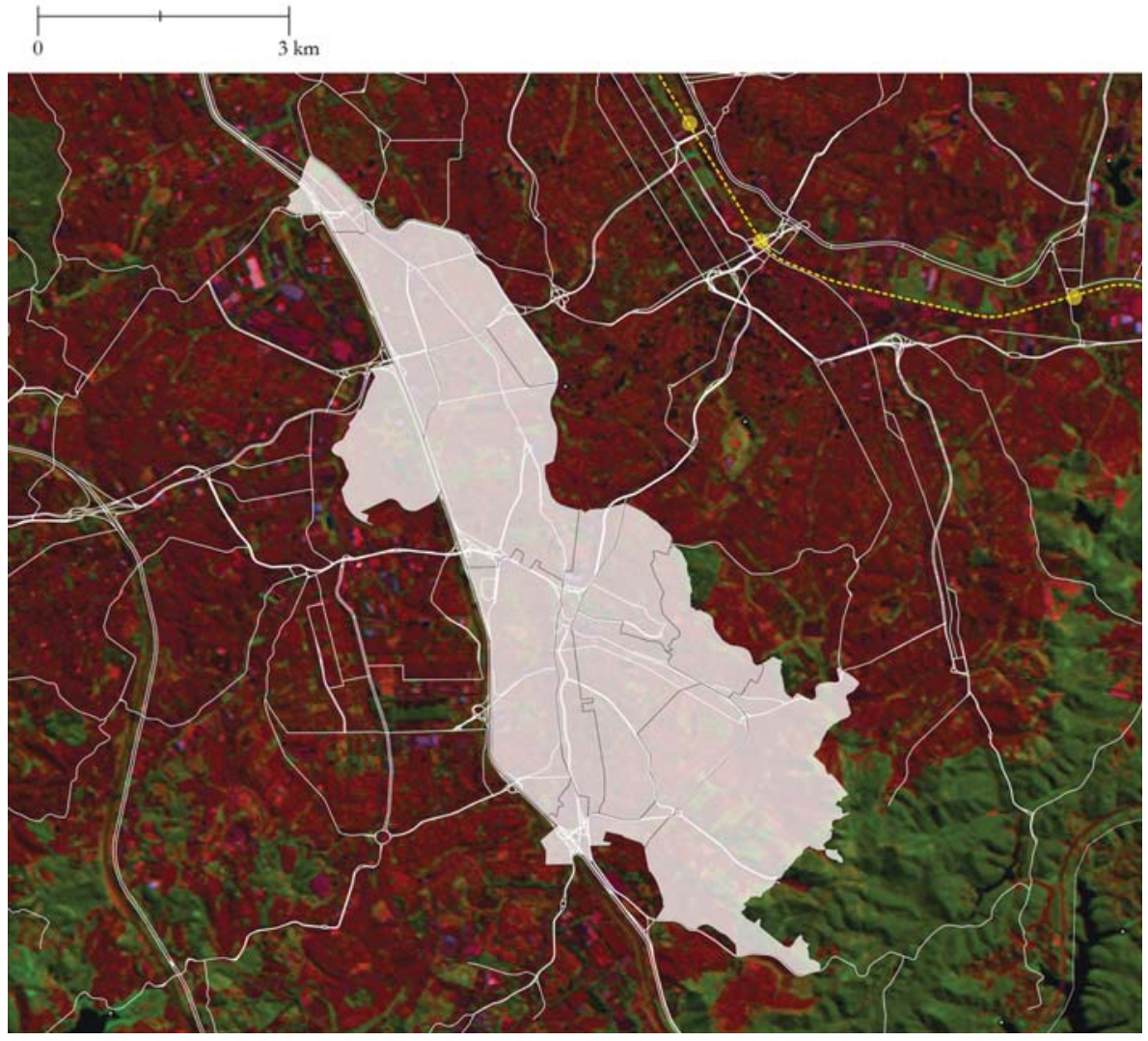

Mapa 70. Identificação da OUC São Bernardo do Campo.

Mapa elaborado pela própria autora.

Fonte: SÃ0 BERNARDO (CIDADE), SPU, 2015; EMPLASA, 2015; LANDSAT TM 5: imagem de satélite. São josé dos Campos: Instituto Nacional de Pesquisas Espaciais, 2011. 2 fotografias aéreas. Canais $3,4,5$ e composição colorida 5,4 e 3
A OUC São Bernardo do Campo estações de trem

linhas de trem

sistema viário

Nota: 0 sistema viário é composto pelas vias macrometropolitanas, metropolitanas, estruturais urbanas e vicinais, segundo classificação da EMPLASA. 


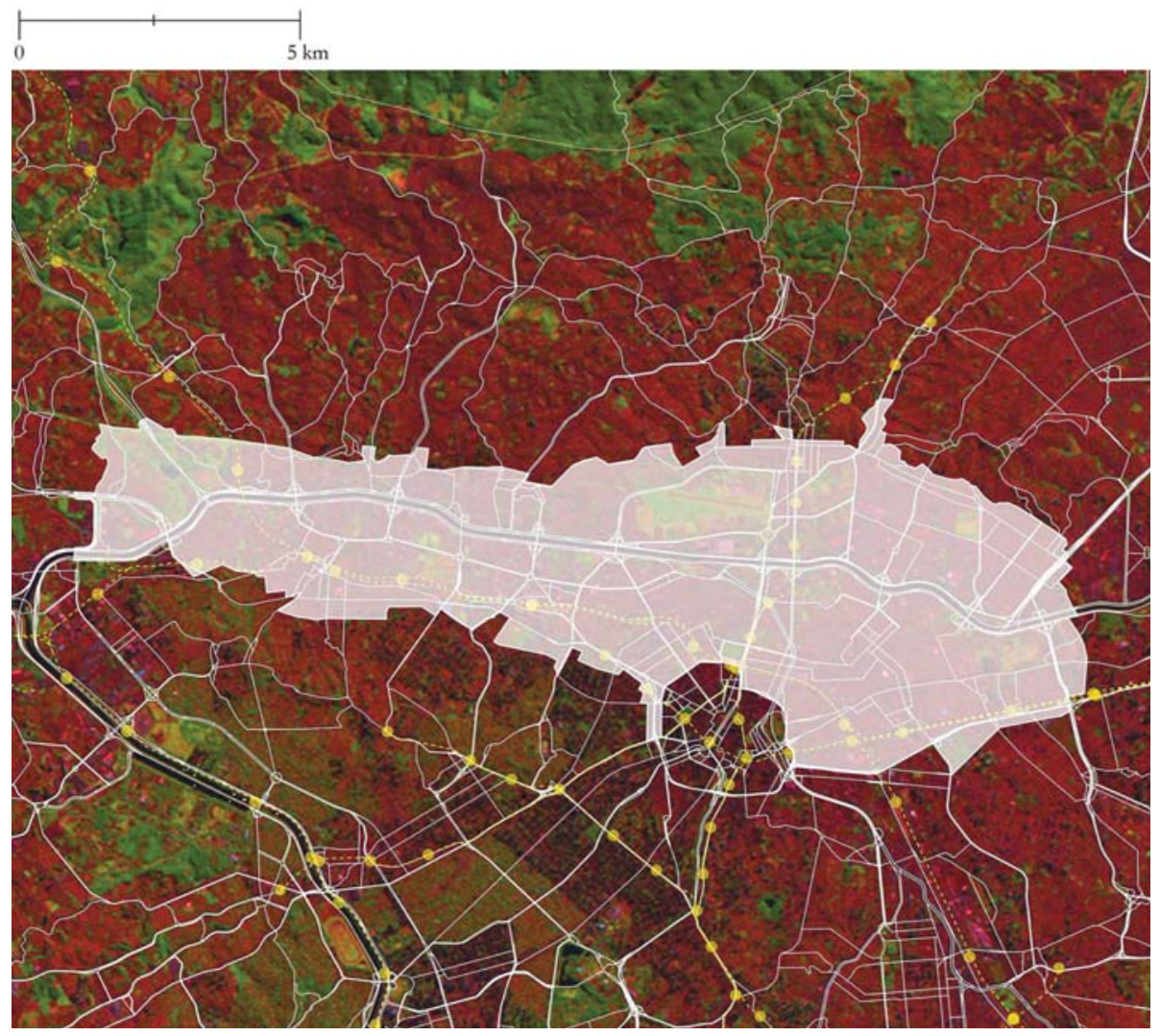

Mapa 71. Identificação da área do projeto Arco do Tietê.

Mapa elaborado pela própria autora.

Fonte: SÃO PAULO (CIDADE), SP-URBANISMO, 2013; EMPLASA, 2015; LANDSAT TM 5: imagem de satélite. São josé dos Campos: Instituto Nacional de Pesquisas Espaciais, 2011. 2 fotografias aéreas. Canais $3,4,5$ e composição colorida 5,4 e 3 .
A OUC Arco do Tietê

estações de metrô e trem

linhas de metrô e trem

sistema viário

Nota: 0 sistema viário é composto pelas vias macrometropolitanas, metropolitanas, estruturais urbanas e vicinais, segundo classificação da EMPLASA. 


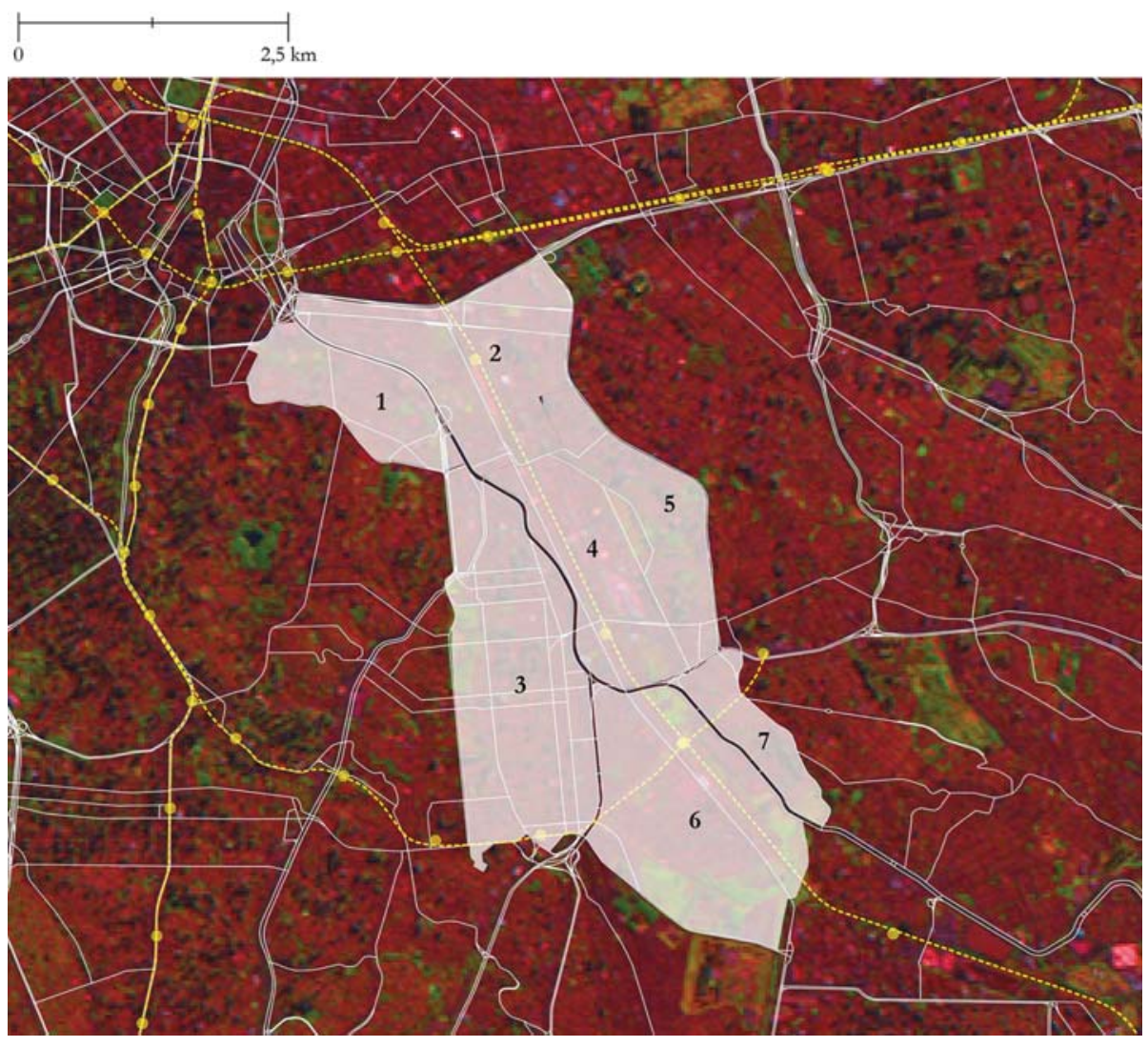

Mapa 72. Identificação da OUC Bairros do Tamanduateí.

Mapa elaborado pela própria autora.

Fonte: SÃO PAULO (CIDADE), SP-URBANISMO, 2015; EMPLASA, 2015; LANDSAT TM 5: imagem de satélite. São josé dos Campos: Instituto Nacional de Pesquisas Espaciais, 2011.

2 fotografias aéreas. Canais $3,4,5$ e composição colorida 5,4 e 3 .

\section{A OUC Bairros do Tamanduateí estações de metrô e trem \\ linhas de metrô e trem $0=0$ \\ sistema viário \\ Cambuci 1 \\ Mooca 2 \\ Ipiranga 3 \\ Henry Ford 4 \\ Parque da Mooca 5 \\ Vila Carioca 6 \\ Vila Prudente e Vila Zelina $\quad 7$}

Nota: 0 sistema viário é composto pelas vias macrometropolitanas, metropolitanas, estruturais urbanas e vicinais, segundo classificação da EMPLASA. 

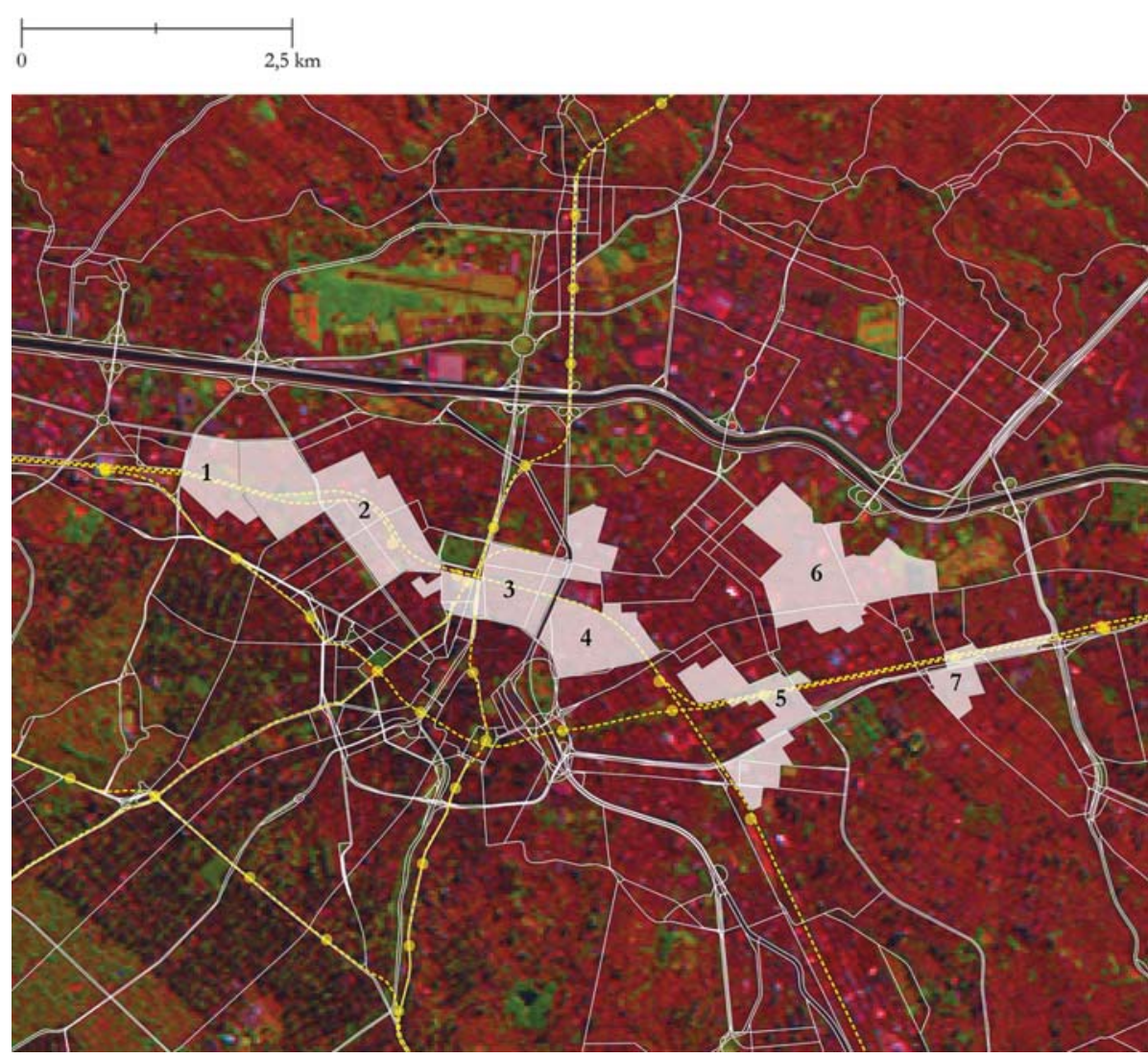

A PPP Casa Paulista

estações de metrô e trem

linhas de metrô e trem

sistema viário

Lote 11

Lote $2 \quad 2$

Lote $3 \mathrm{~A} \quad 3$

Lote 3B 4

Lote3C 5

Lote $4 \mathrm{~A} \quad 6$

Lote 4B 7

Nota: 0 sistema viário é composto pelas vias macrometropolitanas, metropolitanas, estruturais urbanas e vicinais, segundo

Mapa 73. Identificação das PPPs Casa Paulista.

classificação da EMPLASA.

Mapa elaborado pela própria autora.

Fonte: SÃO PAULO (ESTADO), SECRETARIA DA HABITAÇÃ0, 2014; EMPLASA, 2015; LANDSAT TM 5: imagem de satélite. São josé dos Campos: Instituto Nacional de Pesquisas Espaciais, 2011. 2 fotografias aéreas. Canais 3, 4, 5 e composição colorida 5, 4 e 3. 
Tabela 12. As OUCs e o Quadro Socioeconômico.

Fonte: Elaborado pela própria autora.

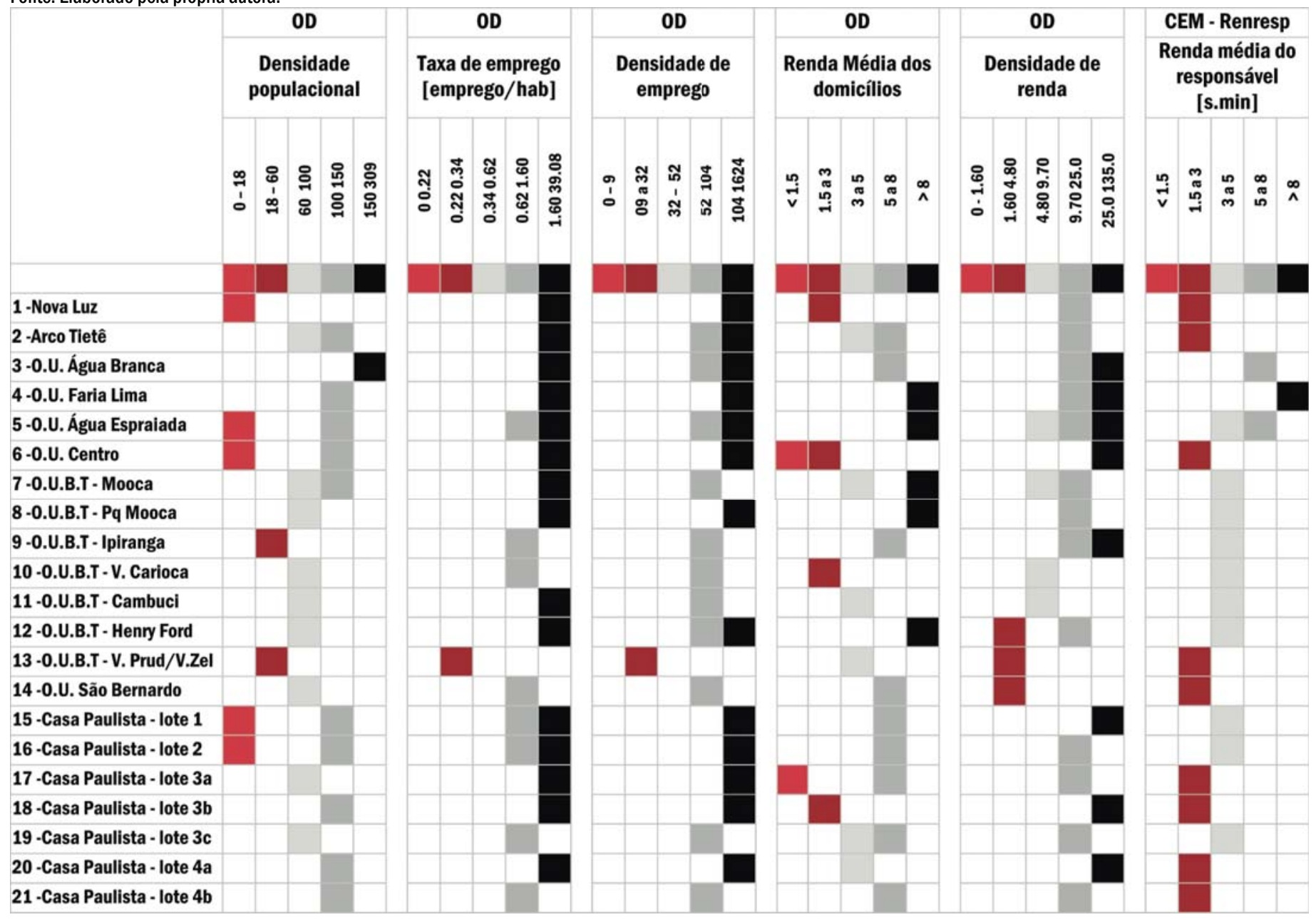




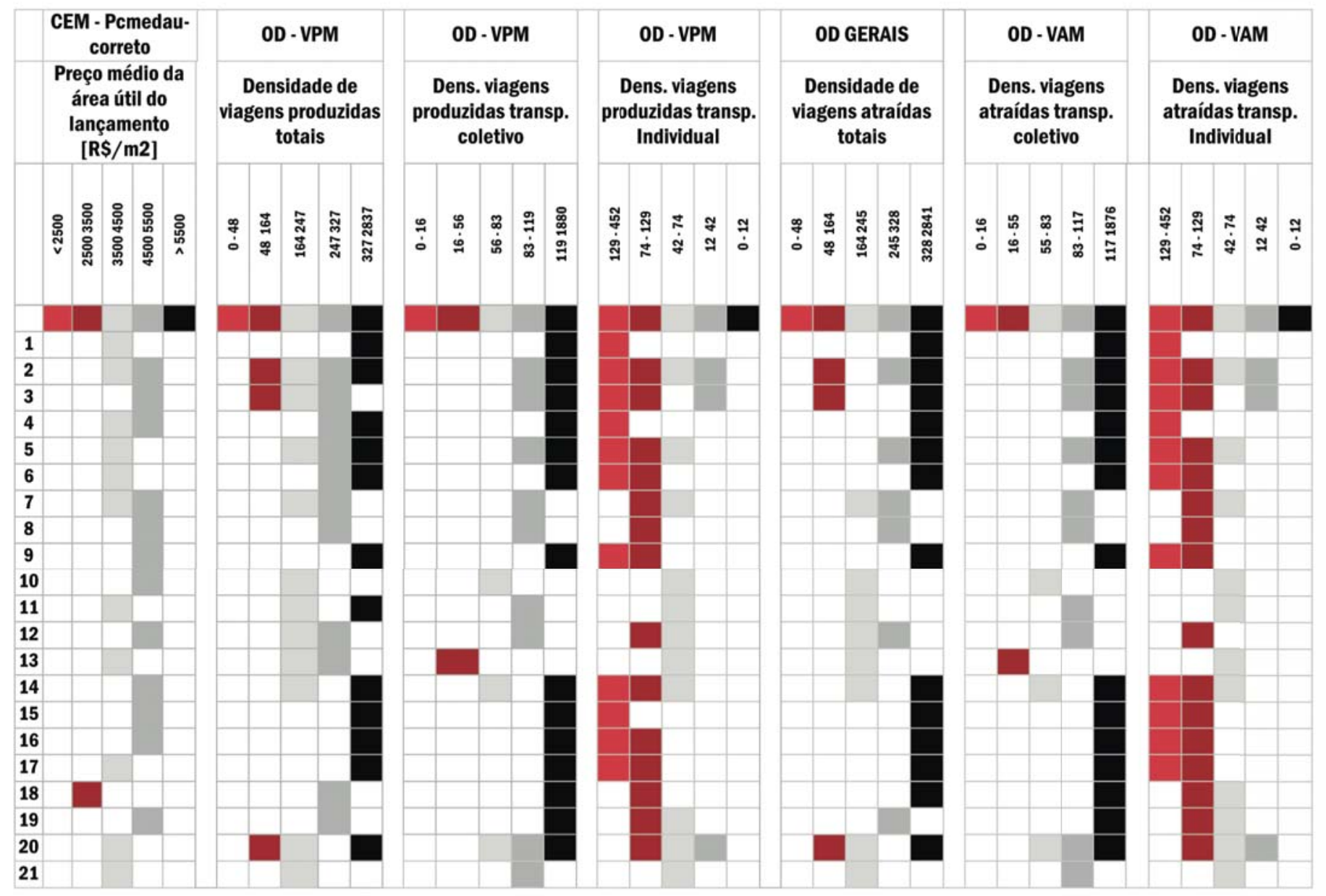


Tabela 13. As OUCs e a Infraestrutura Urbana.

Fonte: Elaborado pela própria autora.

\begin{tabular}{|c|c|c|c|c|c|c|c|c|c|c|c|c|c|c|c|c|c|c|c|c|c|c|c|}
\hline & CON & & & & IBES & & & & & BES & & & & & BES & & & & BES & & & BES & \\
\hline & $\begin{array}{r}\text { Red } \\
\text { a }\end{array}$ & & $\begin{array}{l}\text { Tax } \\
\text { das }\end{array}$ & $\begin{array}{l}\text { a de } \\
\text { bac }\end{array}$ & $\begin{array}{l}\text { infil } \\
\text { ias }\end{array}$ & 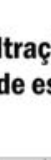 & & & $\begin{array}{l}2 \mathrm{~A}-\mathrm{I} \\
\text { gula }\end{array}$ & $\begin{array}{l}\text { nndic } \\
\text { rida } \\
\text { luçã }\end{array}$ & $\begin{array}{l}\text { e de } \\
\text { de d } \\
0\end{array}$ & & & $\begin{array}{l}\text { RD - } \\
\text { gula } \\
\text { distr }\end{array}$ & $\begin{array}{l}\text { indic } \\
\text { ridac } \\
\text { ibui }\end{array}$ & $\begin{array}{l}\text { e de } \\
\text { de d } \\
\text { ção }\end{array}$ & & & $\begin{array}{l}\text { de } \\
\text { ágalt } \\
\text { águ }\end{array}$ & & & $\begin{array}{l}\text { de s } \\
\text { aste }\end{array}$ & $\begin{array}{l}\text { ist. } \\
\text { sim. }\end{array}$ \\
\hline & 这 & 焄 & $\begin{array}{l}\text { ờ } \\
\text { ¿ें } \\
\text { ợ } \\
0\end{array}$ & 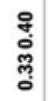 & 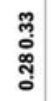 & 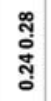 & $\begin{array}{l}\text { స్ํ } \\
\text { ్ํㅇ }\end{array}$ & $\stackrel{8}{2}$ & $\begin{array}{l}\stackrel{8}{ } \\
\dot{2}\end{array}$ & $\begin{array}{l}\text { so } \\
\dot{\phi}\end{array}$ & $\begin{array}{l}\text { क् } \\
\dot{\phi} \\
\dot{\omega}\end{array}$ & $\stackrel{\substack{\infty \\
\wedge}}{0}$ & $\stackrel{R}{i}$ & $\begin{array}{l}\stackrel{8}{~} \\
\dot{\alpha}\end{array}$ & $\begin{array}{l}\text { ڤo } \\
\dot{\phi}\end{array}$ & 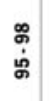 & $\stackrel{\substack{\infty \\
\wedge}}{0}$ & 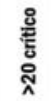 & 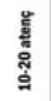 & 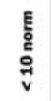 & - & N & m \\
\hline 1-Nova Luz & & & & & & & & & & & & & & & & & & & & & & & \\
\hline 2-Arco Tietê & & & & & & & & & & & & & & & & & & & & & & & \\
\hline 3 -0.U. Água Branca & & & & & & & & & & & & & & & & & & & & & & & \\
\hline 4-0.U. Faria Lima & & & & & & & & & & & & & & & & & & & & & & & \\
\hline 5-0.U. Água Espraiada & & & & & & & & & & & & & & & & & & & & & & & \\
\hline 6-0.U. Centro & & & & & & & & & & & & & & & & & & & & & & & \\
\hline 7-0.U.B.T - Mooca & & & & & & & & & & & & & & & & & & & & & & & \\
\hline 8-0.U.B.T - Pq Mooca & & & & & & & & & & & & & & & & & & & & & & & \\
\hline 9 -0.U.B.T - Ipiranga & & & & & & & & & & & & & & & & & & & & & & & \\
\hline 10 -0.U.B.T - V. Carioca & & & & & & & & & & & & & & & & & & & & & & & \\
\hline 11-O.U.B.T - Cambuci & & & & & & & & & & & & & & & & & & & & & & & \\
\hline 12 -0.U.B.T - Henry Ford & & & & & & & & & & & & & & & & & & & & & & & \\
\hline 13 -0.U.B.T - V. Prud. V.Z & & & & & & & & & & & & & & & & & & & & & & & \\
\hline 14 -0.U. São Bernardo & & & & & & & & & & & & & & & & & & & & & & & \\
\hline 15 -Casa Paulista - lote 1 & & & & & & & & & & & & & & & & & & & & & & & \\
\hline 16 -Casa Paulista - lote 2 & & & & & & & & & & & & & & & & & & & & & & & \\
\hline 17 -Casa Paulista - lote 3a & & & & & & & & & & & & & & & & & & & & & & & \\
\hline 18 -Casa Paulista - lote 3b & & & & & & & & & & & & & & & & & & & & & & & \\
\hline 19 -Casa Paulista - lote 3c & & & & & & & & & & & & & & & & & & & & & & & \\
\hline 20 -Casa Paulista - lote 4a & & & & & & & & & & & & & & & & & & & & & & & \\
\hline 21 -Casa Paulista - lote 4b & & & & & & & & & & & & & & & & & & & & & & & \\
\hline
\end{tabular}




\begin{tabular}{|c|c|c|c|c|c|c|c|c|c|c|c|c|c|c|c|c|c|c|c|c|c|c|c|c|c|c|c|c|c|c|c|c|c|c|}
\hline & & & BGE & & & & & BGE & & & & & IBGE & & & & & BGE & & & & & IBGE & & & & & BGE & & & $\mathbf{S}$ & & $\mathbf{S}$ & \\
\hline & aba & $\begin{array}{l}\text { Dor } \\
\text { tec } \\
\text { sua }\end{array}$ & $\begin{array}{l}\text { n. co } \\
\text { da }\end{array}$ & $\begin{array}{l}\text { m } \\
\text { ito } \\
\text { rede }\end{array}$ & & & $\begin{array}{r}\text { n. co } \\
\text { gado }\end{array}$ & $\begin{array}{l}\text { m b } \\
\text { à re } \\
\text { sgot }\end{array}$ & $\begin{array}{l}\text { anh } \\
\text { de } \\
0\end{array}$ & & Don & $\begin{array}{l}\text { n. at } \\
\text { colet }\end{array}$ & $\begin{array}{l}\text { tendi } \\
\text { ta de }\end{array}$ & $\begin{array}{l}\text { ido } p \\
\text { e lixo }\end{array}$ & & & $\begin{array}{l}\text { Dor } \\
\text { avim }\end{array}$ & $\begin{array}{l}\text { m. co } \\
\text { nent }\end{array}$ & $\begin{array}{l}\text { oção } \\
\text { aço }\end{array}$ & & & $\begin{array}{r}\text { Do } \\
\text { mina }\end{array}$ & $\begin{array}{l}\text { m. c } \\
\text { ção }\end{array}$ & $\begin{array}{l}\text { om } \\
\text { públ }\end{array}$ & & & $\begin{array}{l}\text { m. cét } \\
\text { elét }\end{array}$ & $\begin{array}{l}\text { om e } \\
\text { trica } \\
\text { ibui }\end{array}$ & $\begin{array}{l}\text { energ } \\
\text { de } \\
\text { dora }\end{array}$ & & $\mathrm{DE}$ & & $\mathrm{FE}$ & \\
\hline & ণ্ & $\begin{array}{l}\text { Pִ } \\
\dot{n}\end{array}$ & $\begin{array}{l}8 \\
\dot{g} \\
\dot{q}\end{array}$ & 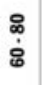 & $\begin{array}{l}\stackrel{8}{1} \\
\dot{\dot{\omega}}\end{array}$ & $\stackrel{\text { ণิ }}{\text { d }}$ & 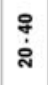 & $\begin{array}{l}\stackrel{\leftrightarrow}{0} \\
\dot{q}\end{array}$ & & $\begin{array}{l}\stackrel{8}{1} \\
\dot{\Phi}\end{array}$ & $\stackrel{\text { ণิ }}{\text { d }}$ & $\begin{array}{l}\stackrel{9}{1} \\
\dot{\alpha}\end{array}$ & $\begin{array}{l}\stackrel{\leftrightarrow}{0} \\
\dot{g}\end{array}$ & 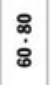 & $\begin{array}{l}\stackrel{8}{\circ} \\
\text { ळे }\end{array}$ & ָ̊ & $\begin{array}{l}\text { \% } \\
\dot{\text { ஸे }}\end{array}$ & $\begin{array}{l}\stackrel{\leftrightarrow}{0} \\
\dot{q}\end{array}$ & $\begin{array}{l}\stackrel{\Phi}{\$} \\
\dot{\Phi}\end{array}$ & $\begin{array}{l}\stackrel{8}{1} \\
\text { வे }\end{array}$ & $\stackrel{\text { ஸి }}{\text { d }}$ & 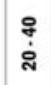 & $\begin{array}{l}\stackrel{\leftrightarrow}{0} \\
\dot{q}\end{array}$ & $\begin{array}{l}\text { Фి } \\
\dot{\iota}\end{array}$ & $\begin{array}{l}\stackrel{8}{1} \\
\text { ் }\end{array}$ & $\stackrel{\text { ণิ }}{0}$ & 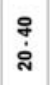 & $\begin{array}{l}\stackrel{0}{\dot{0}} \\
\dot{q}\end{array}$ & $\begin{array}{l}\text { के } \\
\dot{\Phi}\end{array}$ & $\begin{array}{l}\stackrel{8}{1} \\
\dot{\Phi}\end{array}$ & $\frac{\underline{E}}{\bar{n}}$ & $\frac{E}{\bar{v}}$ & $\frac{E}{n}$ & $\underline{\underline{E}}$ \\
\hline & & & & & & & & & & & & & & & & & & & & & & & & & & & & & & & & & & \\
\hline 1 & & & & & & & & & & & & & & & & & & & & & & & & & & & & & & & & & & \\
\hline 2 & & & & & & & & & & & & & & & & & & & & & & & & & & & & & & & & & & \\
\hline 3 & & & & & & & & & & & & & & & & & & & & & & & & & & & & & & & & & & \\
\hline 4 & & & & & & & & & & & & & & & & & & & & & & & & & & & & & & & & & & \\
\hline 5 & & & & & & & & & & & & & & & & & & & & & & & & & & & & & & & & & & \\
\hline 6 & & & & & & & & & & & & & & & & & & & & & & & & & & & & & & & & & & \\
\hline 7 & & & & & & & & & & & & & & & & & & & & & & & & & & & & & & & & & & \\
\hline 8 & & & & & & & & & & & & & & & & & & & & & & & & & & & & & & & & & & \\
\hline 9 & & & & & & & & & & & & & & & & & & & & & & & & & & & & & & & & & & \\
\hline 10 & & & & & & & & & & & & & & & & & & & & & & & & & & & & & & & & & & \\
\hline 11 & & & & & & & & & & & & & & & & & & & & & & & & & & & & & & & & & & \\
\hline 12 & & & & & & & & & & & & & & & & & & & & & & & & & & & & & & & & & & \\
\hline 13 & & & & & & & & & & & & & & & & & & & & & & & & & & & & & & & & & & \\
\hline 14 & & & & & & & & & & & & & & & & & & & & & & & & & & & & & & & & & & \\
\hline 15 & & & & & & & & & & & & & & & & & & & & & & & & & & & & & & & & & & \\
\hline 16 & & & & & & & & & & & & & & & & & & & & & & & & & & & & & & & & & & \\
\hline 17 & & & & & & & & & & & & & & & & & & & & & & & & & & & & & & & & & & \\
\hline 18 & & & & & & & & & & & & & & & & & & & & & & & & & & & & & & & & & & \\
\hline 19 & & & & & & & & & & & & & & & & & & & & & & & & & & & & & & & & & & \\
\hline 20 & & & & & & & & & & & & & & & & & & & & & & & & & & & & & & & & & & \\
\hline 21 & & & & & & & & & & & & & & & & & & & & & & & & & & & & & & & & & & \\
\hline
\end{tabular}




\subsubsection{Os fluxos}

A análise dos fluxos de viagens entre as zonas origem destino do metrô nos indica os efeitos que uma atividade - trabalho, por exemplo pode provocar nas dinâmicas da metrópole devido às diversas naturezas de oferta e demanda na economia de uma região. A observação da alocação desses motivos de viagens em determinada localidade pode nos servir não apenas para diagnosticar uma condição, mas também para indicar possíveis soluções locais que possam surtir efeitos positivos em outras áreas da metrópole. De forma a apreender essa observação de maneira empírica, novamente foram trabalhados os dados da pesquisa OD por meio do desenho georreferenciado dos vetores de viagens entre uma zona e outra.

Devido ao grau de dificuldade e ao tempo necessário para desenhar esses fluxos, com base no conhecimento dos movimentos de pessoas entre as zonas OD explicitadas na seção anterior 'As dinâmicas', foi selecionada para análise a área do projeto Nova Luz. Essa seleção se deu não apenas porque este estudo de caso já havia sido analisado anteriormente como um projeto de reurbanização (no subcapítulo 2.9), mas também pelo fator de viabilidade técnica, por esta estar contida em uma zona OD de pequeno tamanho (diferentemente de outros projetos que envolveriam a agregação de muitas zonas, como o Arco do Tietê). A área do projeto Nova Luz, estando contida na zona OD Santa Ifigênia, foi 
assim analisada como um estudo de caso, de forma que, por essa metodologia, outras áreas e projetos também pudessem ser analisados e assim mais bem compreendidos, e, por sua vez, melhor contrapostos por agendas de projeto e planejamento urbano. Mesmo assim, para o exercício dessa metodologia, também analisaram-se alguns aspectos para das zonas OD que incorporam a área de intervenção da operação urbana Água Branca, tendo sido feito sobre o modo coletivo por motivo de trabalho (nesta foi feita uma média das viagens atraídas para as 4 zonas que compõem a área da OUC Água Branca).

Os fluxos desenhados entre as zonas OD para a zona Santa Ifigênia incluíram todos os modos de viagens (coletivo e individual) pelos motivos de trabalho, educação e lazer. Como já ressaltado, por questões de viabilidade técnica não foi possível incluir todos os motivos nessa análise (como compras, saúde, procura de empregos), no entanto, essa amostragem foi considerada a mais relevante para compreender as dinâmicas locais-regionais nesse caso. As viagens calculadas e desenhadas incluíram todas aquelas produzidas (pelos determinados modos e motivos descritos anteriormente) pela zona Santa Ifigênia para todas as outras zonas $\mathrm{OD}$, e o total de viagens atraídas para zona Santa Ifigênia das zonas OD circundantes. No desenho desses fluxos, fez-se o uso de uma ferramenta gráfica para ilustrar esses vetores de viagens em diferentes espessuras, quanto maior a espessura, maior o número de viagens, e diferentes diâmetros de pontos de origem e destino, seguindo a 
mesma lógica, quanto maior o diâmetro, maior o número de viagens. Os pontos de origem e destino também foram diferenciados em relação às cores utilizadas, vermelhos para zonas de Origem e brancos para zonas de Destino. Os diâmetros desses pontos também respeitaram uma proporção, conforme indicação nas legendas dos mapas a seguir (ver todos os Mapas do intervalo Mapa 74 ao Mapa 87).

Os maiores fluxos diagnosticados devido aos motivos de trabalho, educação e lazer na zona Santa Ifigênia podem ser visualizados na Tabela 14. A maior densidade de viagens acontece pelos motivos de trabalho, sendo que a área em que se inclui o projeto Nova Luz acaba por produzir o maior número de viagens para as zonas República (2.935 viagens por hectare), Cidade Tiradentes (2.254) e Cocaia (1.717). Por sua vez, a Nova Luz atrai o maior número de viagens das zonas Cidade Tiradentes (2.254), Santa Cecília (1.862) e Cocaia (1.717).

O segundo motivo que mais atrai viagens é a educação, sendo que as zonas Santa Cecília (1.824), Tietê (1.016) e Luz (623) são os destinos principais dos passageiros que saem da zona Santa Ifigênia. Essa última atrai a maior densidade de viagens pelo motivo educacional das zonas Santa Cecília (1.320), Luz (676) e Santo Amaro (555). O número de viagens que envolvem o motivo educação, como analisado, representa menos da metade do motivo trabalho.

O motivo de lazer mostra os maiores eixos pendulares de viagens da Santa Ifigênia para a Fazenda Itaim (460), Vila Independência (376) e 
Moinho Velho (307), sendo que os passageiros que mais se destinam à Santa Ifigênia são aqueles provenientes da Fazenda Itaim, (460), Itaquera (460) e Boaçava (363). É claro perceber que, comparadas a outras atividades avaliadas, o motivo de lazer possui o menor impacto nos fluxos de passageiros para a zona.

Assim, os resultados dessa análise amostral indicam o efeito que uma atividade (trabalho, educação e lazer, em diferentes níveis) causa na dinâmica entre as diferentas localizações da metrópole, dependendo da oferta e da demanda por determinado serviço. Deste modo, fica evidente que um plano ou projeto de regeneração urbana deva incorporar em sua metodologia a análise dessas economias, de forma a materializar soluções espaciais que possam promover o reequilíbrio nas condições de acesso a infraestrutura urbana na área de influência da intervenção. 
Tabela 14. Síntese dos fluxos de viagens atraídas e produzidas em relação à zona Santa Ifigênia.

Fonte: Elaborado pela própria autora a partir dos dados da Pesquisa OD (Metrô, 2007).

\begin{tabular}{|c|c|c|c|}
\hline VIAGENS ATRAÍDAS & פ & VIAGENS PRODUZIDAS & פू \\
\hline TOTAIS & 学 & TOTAIS & \\
\hline TRABALHO & $\frac{\omega}{\frac{\omega}{\sigma}}$ & TRABALHO & 递 \\
\hline Cidade Tiradentes & 2.254 & República & 2935 \\
\hline Santa Cecília & 1.862 & Cidade Tiradentes & 2254 \\
\hline Cocaia & 1.717 & Cocaia & 1717 \\
\hline EDUCAÇÃO & & EDUCAÇĀO & \\
\hline Santa Cecília & 1320 & Santa Cecília & 1824 \\
\hline Luz & 676 & Tietê & 1016 \\
\hline Santo Amaro & 555 & Luz & 623 \\
\hline LAZER & & LAZER & \\
\hline Fazenda Itaim & 460 & Fazenda Itaim & 460 \\
\hline Itaquera & 460 & Vila Independência & 376 \\
\hline Boaçava & 363 & Moinho Velho & 307 \\
\hline
\end{tabular}




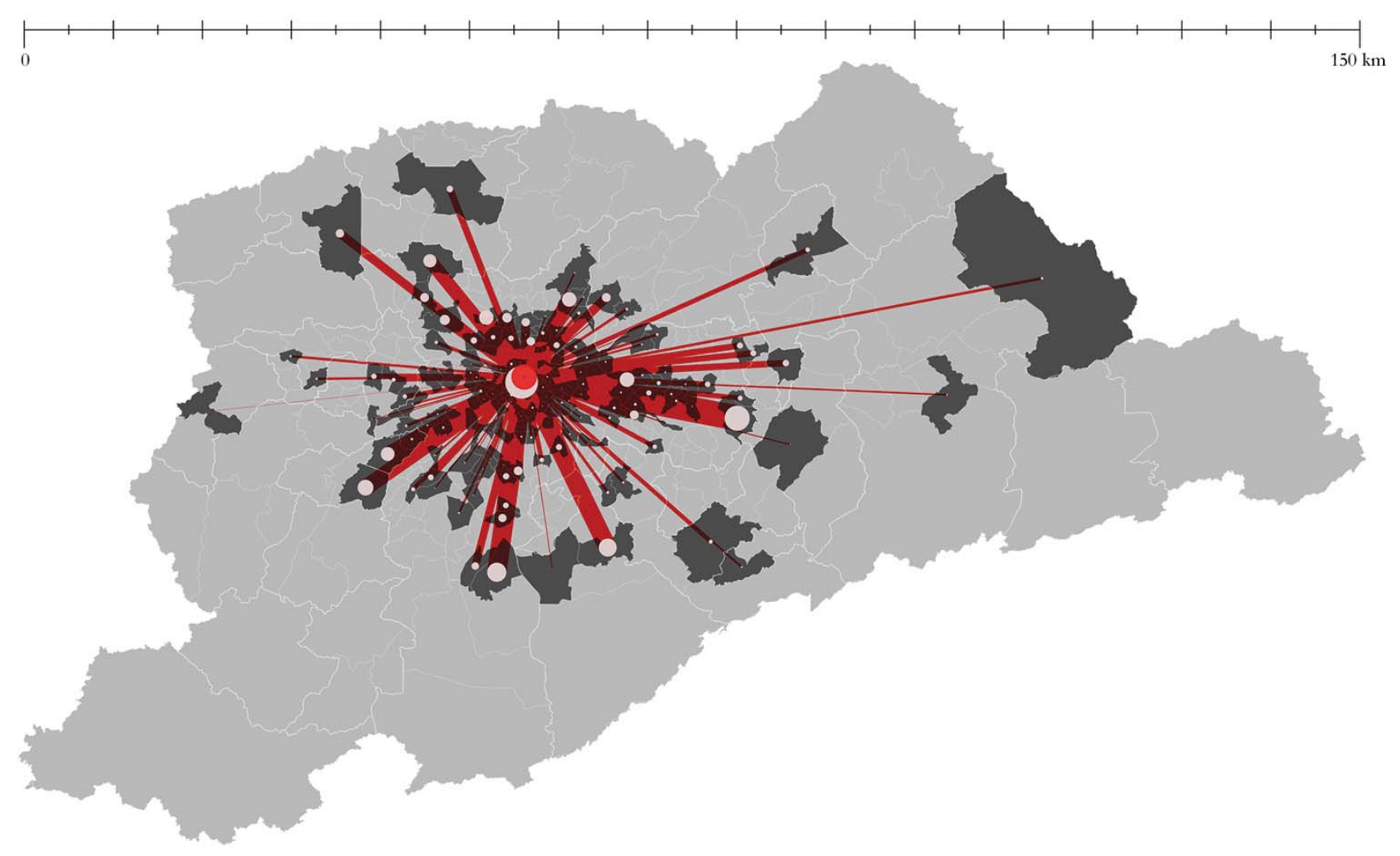

Nova Luz

Vetores de viagens produzidas

TRABALHO

zonas de destino

zona de origem

Mapa 74. Vetores de viagens produzidas por trabalho pela área da Luz.

Mapa elaborado pela própria autora.

Fonte: SÃO PAULO (ESTADO), METRO, 2007; CEM, 2007b.

vetor das viagens

sem viagens

com viagens 


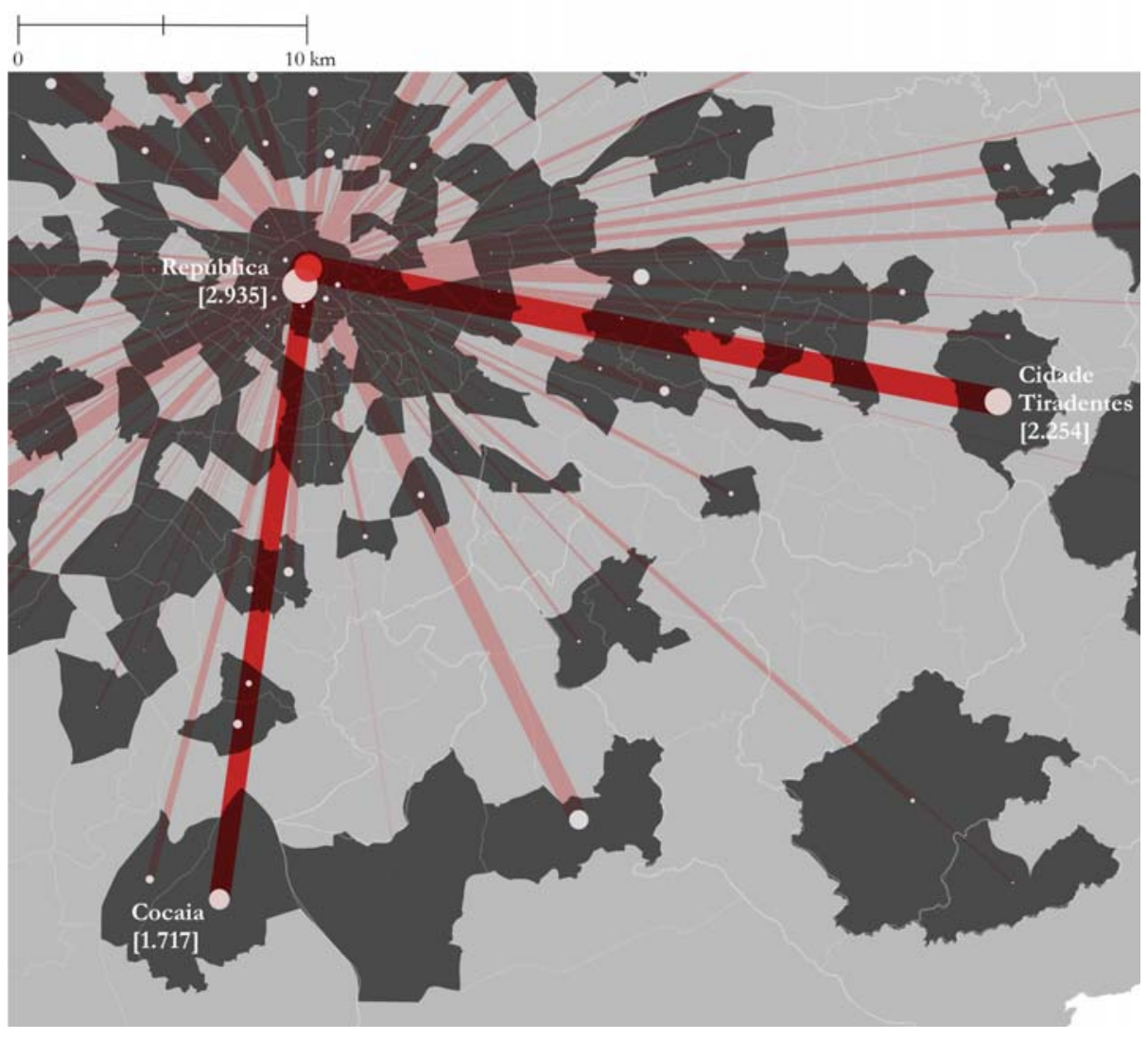

Mapa 75. Principais vetores de viagens produzidas por trabalho pela área da Luz. Mapa elaborado pela própria autora.

Fonte: SÃO PAULO (ESTADO), METRO, 2007; CEM, 2007b.
OUC Nova Luz

Principais vetores de viagens produzidas

TRABALHO

zonas de destino

zona de origem

vetor das viagens

sem viagens

com viagens

3.000

1.500

500 


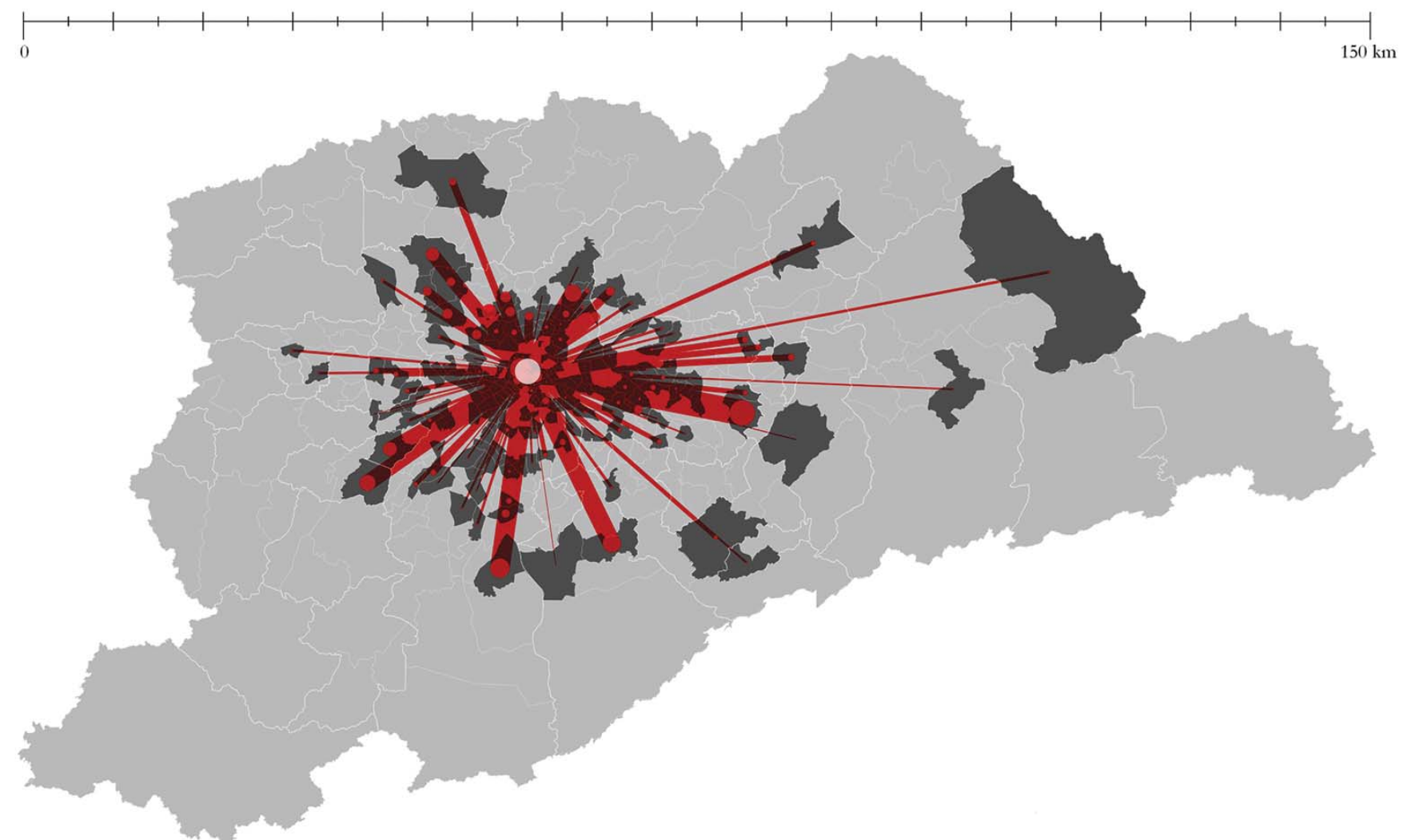

Nova Luz

Vetores de viagens atraídas

TRABALHO

zonas de destino

zona de origem

vetor das viagens

sem viagens

Mapa 76. Vetores de viagens atraídas por trabalho para a área da Luz.

Mapa elaborado pela própria autora.

Fonte: SÃO PAULO (ESTADO), METRO, 2007; CEM, 2007b.

com viagens

sem dados 


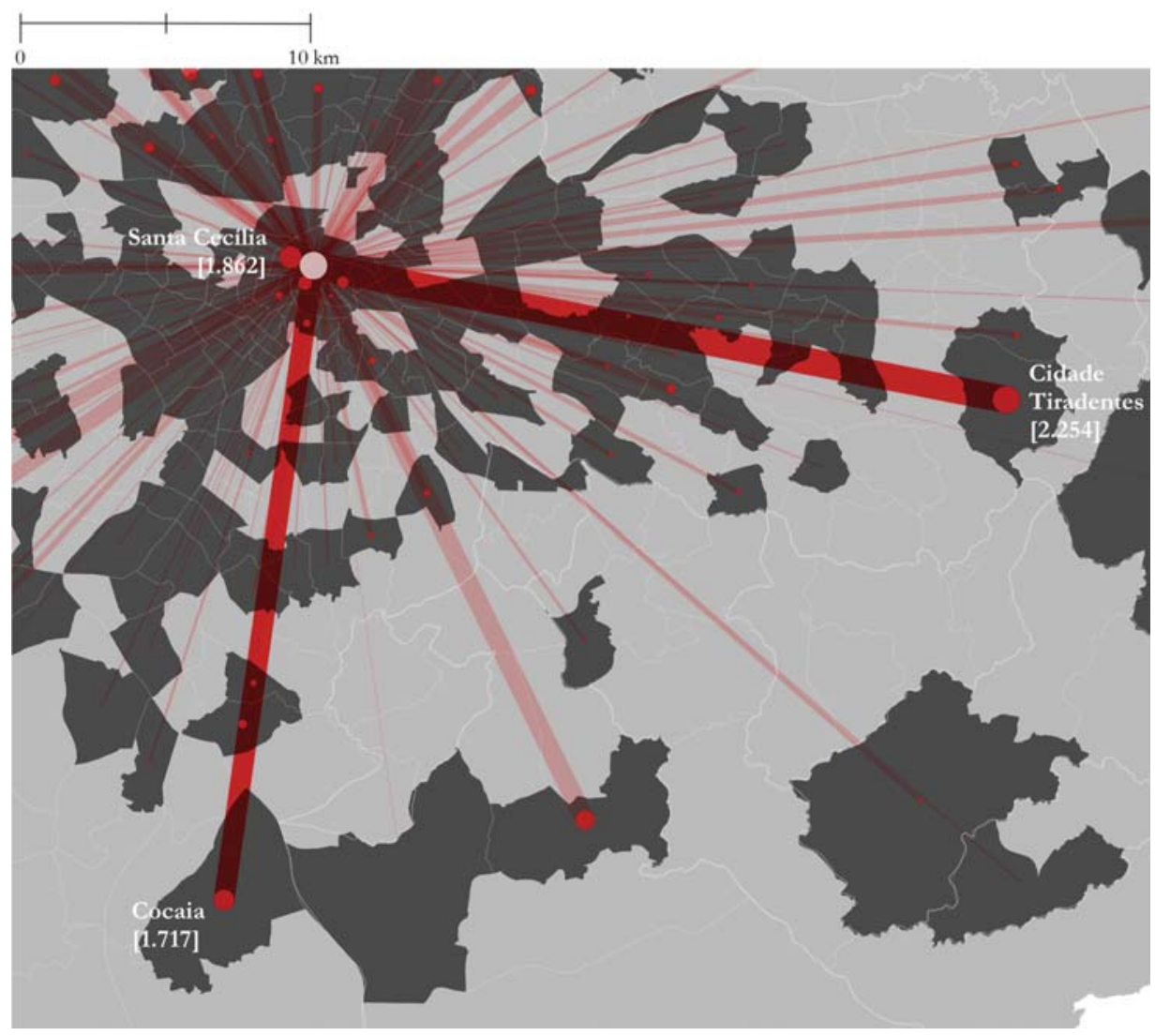

Mapa 77. Principais vetores de viagens atraídas por trabalho para a área da Luz. Mapa elaborado pela própria autora.

Fonte: SÃO PAULO (ESTADO), METRO, 2007; CEM, 2007b.

\section{OUC Nova Luz}

Principais vetores de viagens produzidas

TRABALHO

zonas de destino

zona de origem

vetor das viagens

sem viagens

com viagens

3.000

1.500

500 


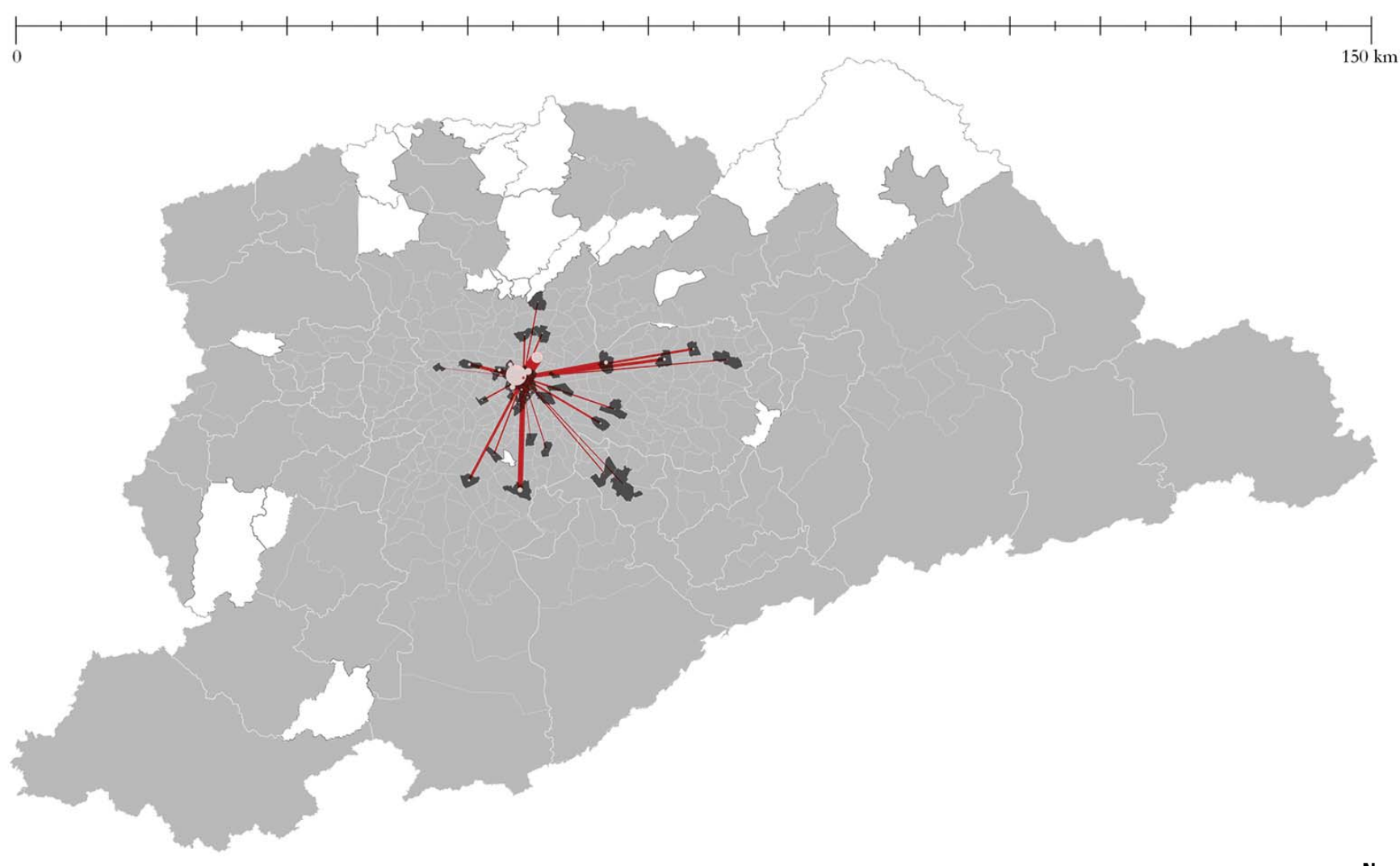

Nova Luz

Vetores de viagens produzidas

EDUCAÇÃo

zonas de destino

zona de origem

vetor das viagens

sem viagens

Mapa 78. Vetores de viagens produzidas por educação para a área da Luz.

Mapa elaborado pela própria autora.

Fonte: SÃO PAULO (ESTADO), METRO, 2007; CEM, 2007b.

com viagens 


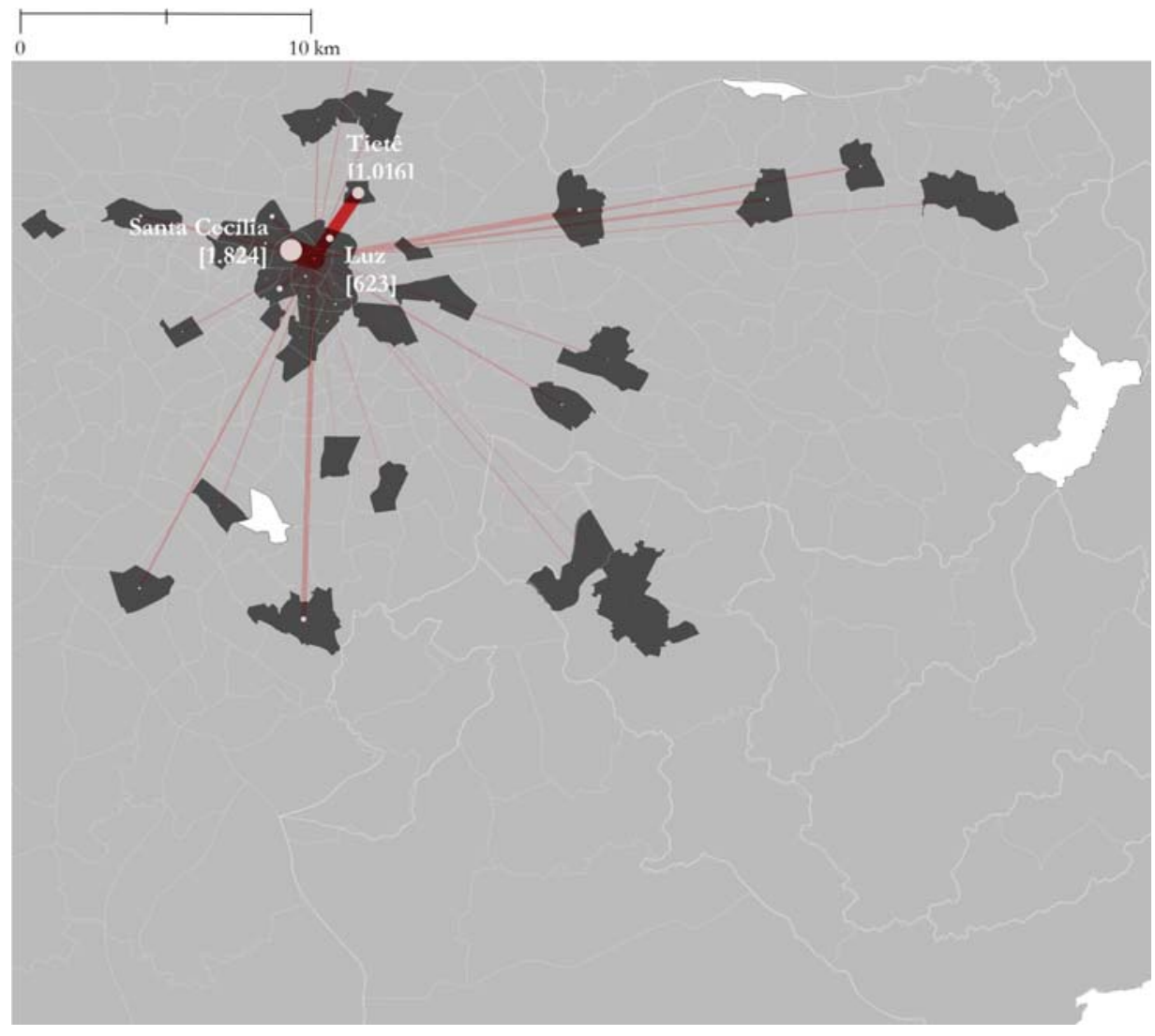

Mapa 79. Principais vetores de viagens produzidas por educação para a área da Luz.

Mapa elaborado pela própria autora.

Fonte: SÃO PAULO (ESTADO), METRO, 2007; CEM, 2007b.
OUC Nova Luz

Principais vetores de viagens produzidas EDUCAÇÃo

zonas de destino
zona de origem
vetor das viagens
sem viagens
com viagens
sem dados
3.000
1.500
500




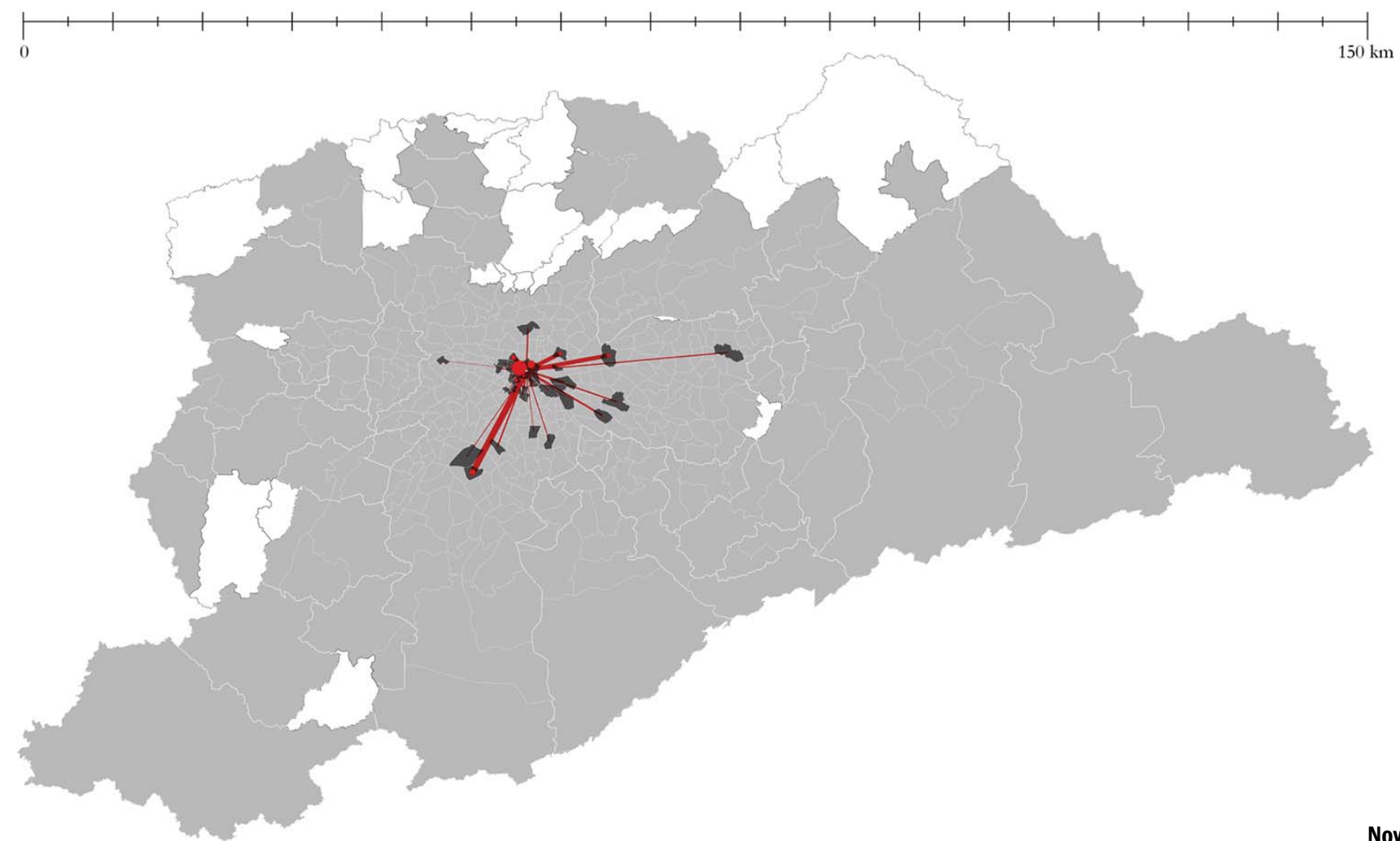

Nova Luz

Principais vetores de viagens atraídas

EDUCAÇÃO

zonas de destino

zona de origem

vetor das viagens

sem viagens

com viagens

Mapa 80. Vetores de viagens atraídas por educação para a área da Luz.

Mapa elaborado pela própria autora.

Fonte: SÃO PAULO (ESTADO), METRO, 2007; CEM, 2007b.

sem dados 


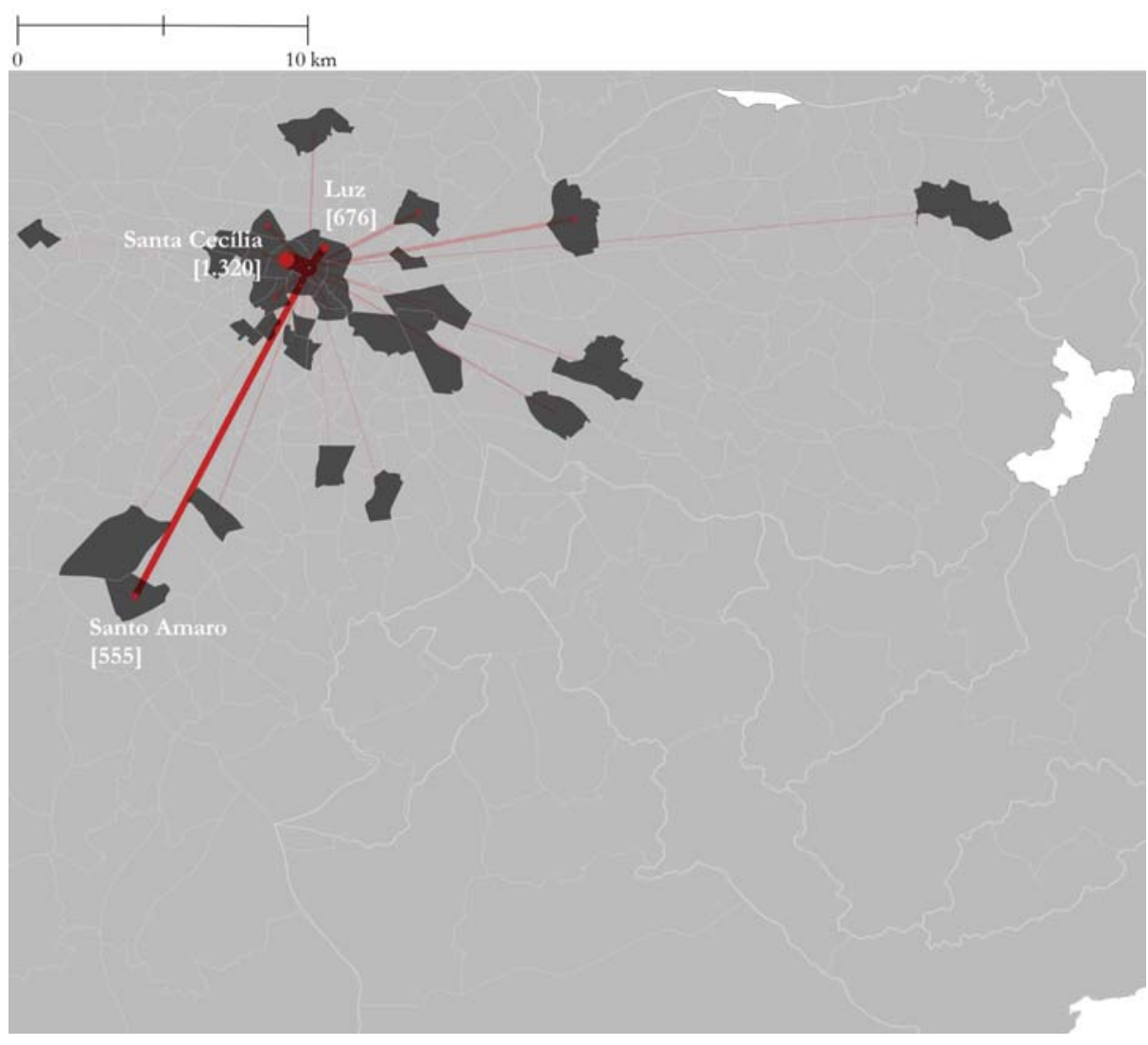

Mapa 81. Principais vetores de viagens atraídas por educação para a área da Luz.

Mapa elaborado pela própria autora.

Fonte: SÃO PAULO (ESTADO), METRO, 2007; CEM, 2007b.
OUC Nova Luz

Principais vetores de viagens atraídas

EDUCAÇÃo

zonas de destino

zona de origem

vetor das viagens

sem viagens

com viagens

sem dados

3.000

1.500 (2)

500 


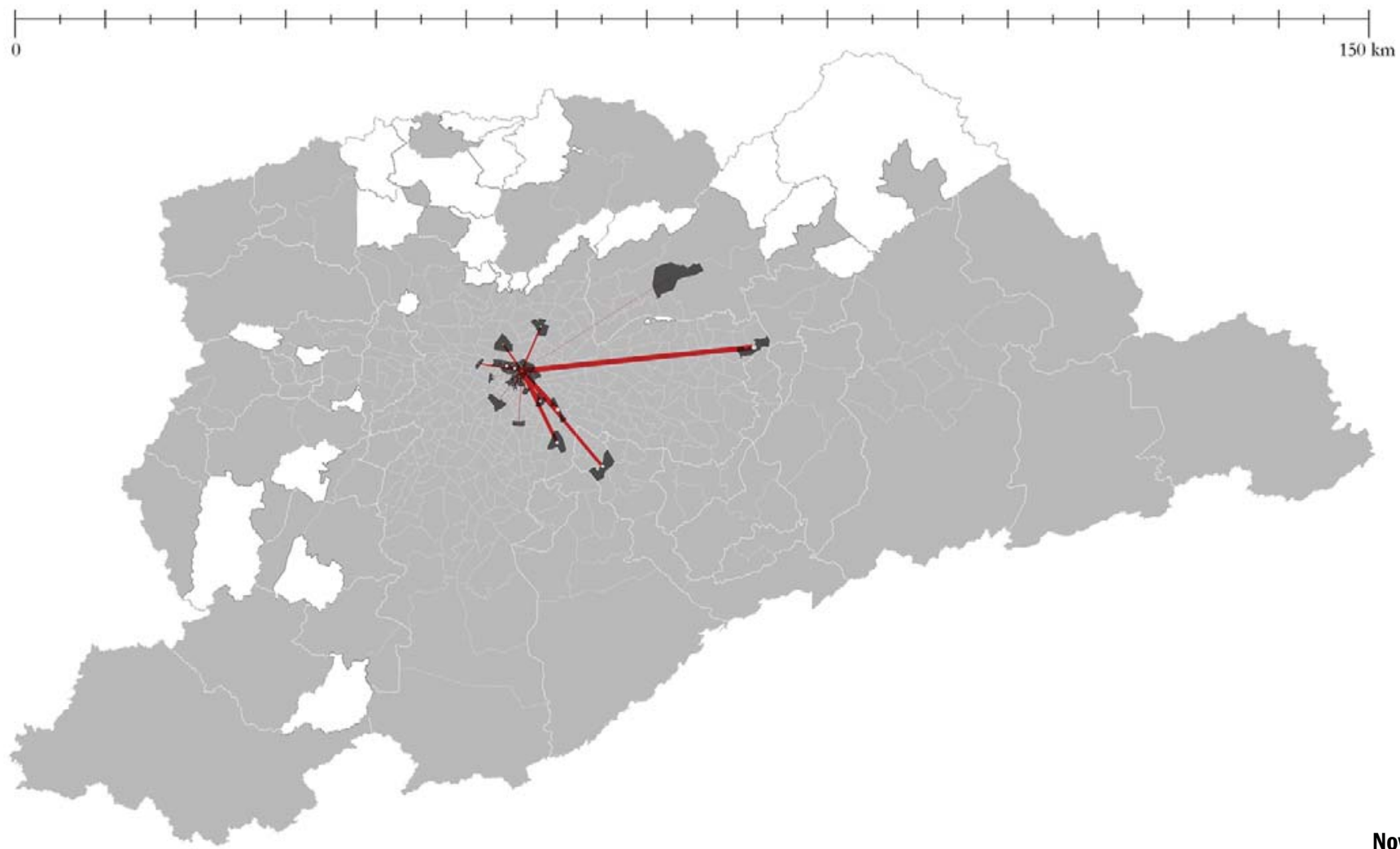

Nova Luz

Vetores de viagens produzidas

LAZER

zonas de destino

zona de origem

vetor das viagens

sem viagens

com viagens

Mapa 82. Vetores de viagens produzidas por lazer para a área da Luz.

Mapa elaborado pela própria autora.

Fonte: SÃO PAULO (ESTAD0), METRO, 2007; CEM, 2007b.

sem dados 


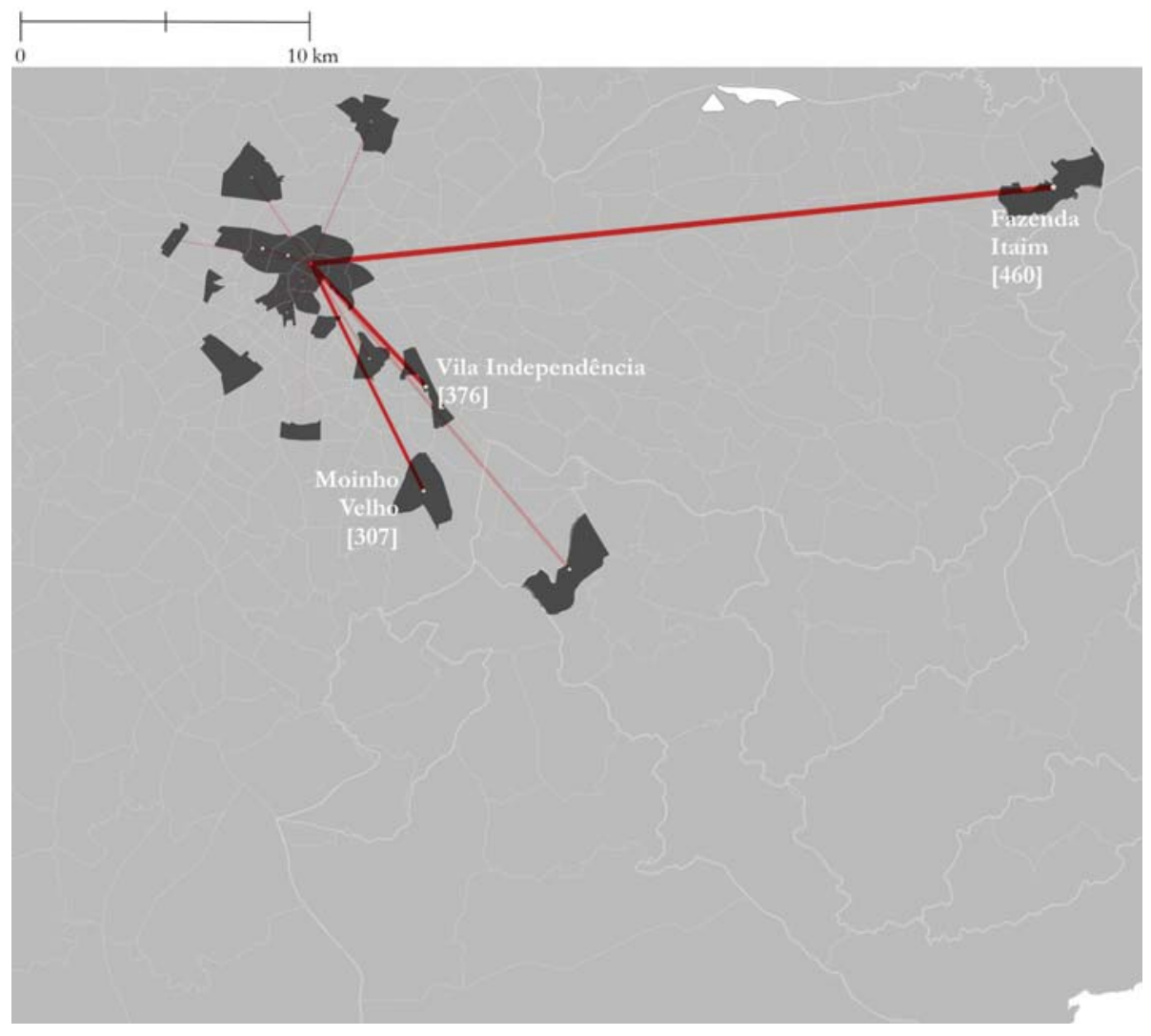

Mapa 83. Principais vetores de viagens produzidas por lazer para a área da Luz.

Mapa elaborado pela própria autora.

Fonte: SÃO PAULO (ESTADO), METRO, 2007; CEM, 2007b.
OUC Nova Luz

Principais vetores de viagens produzidas

LAZER

zonas de destino

zona de origem

vetor das viagens

sem viagens

com viagens

sem dados

3.000

1.500

500 


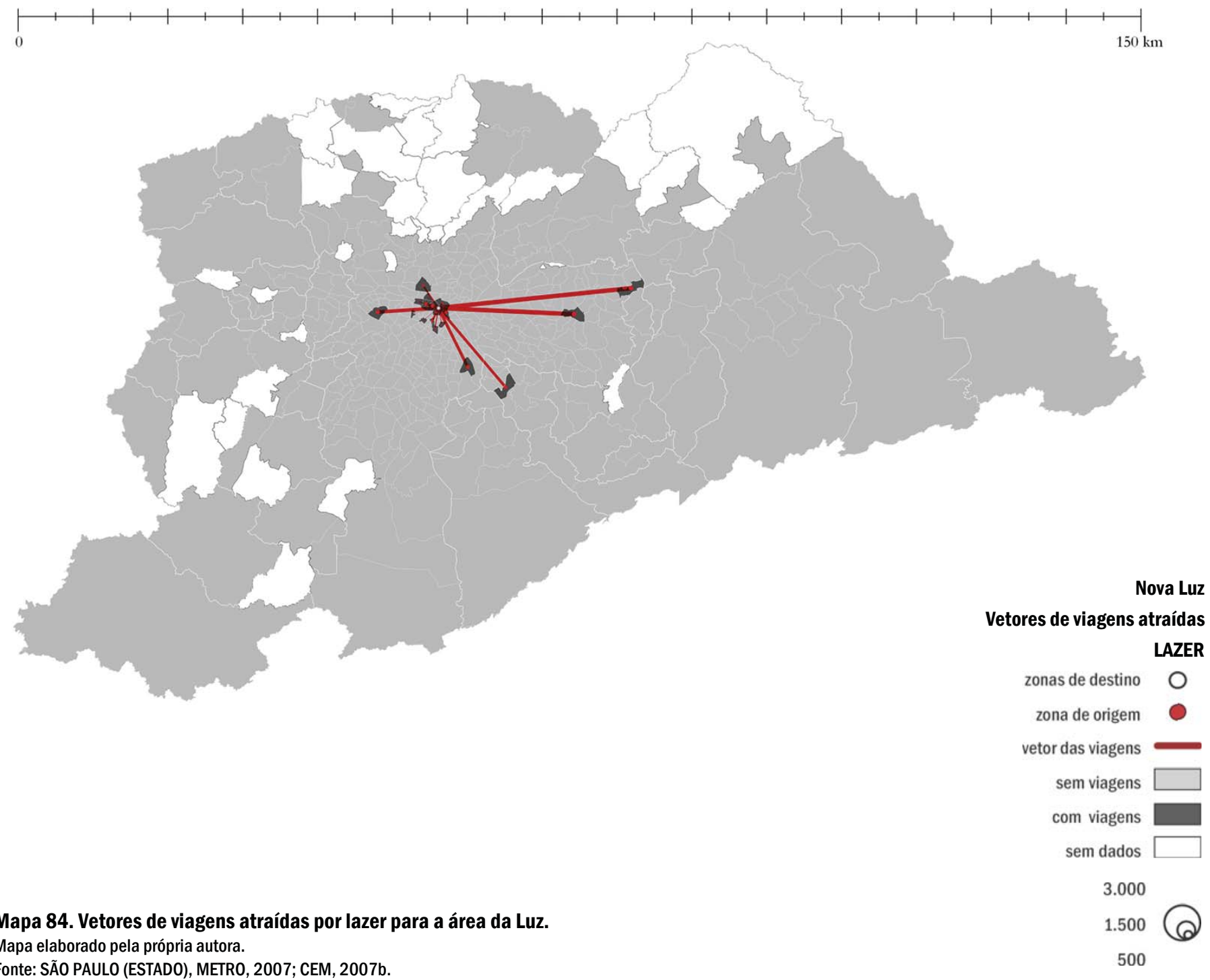




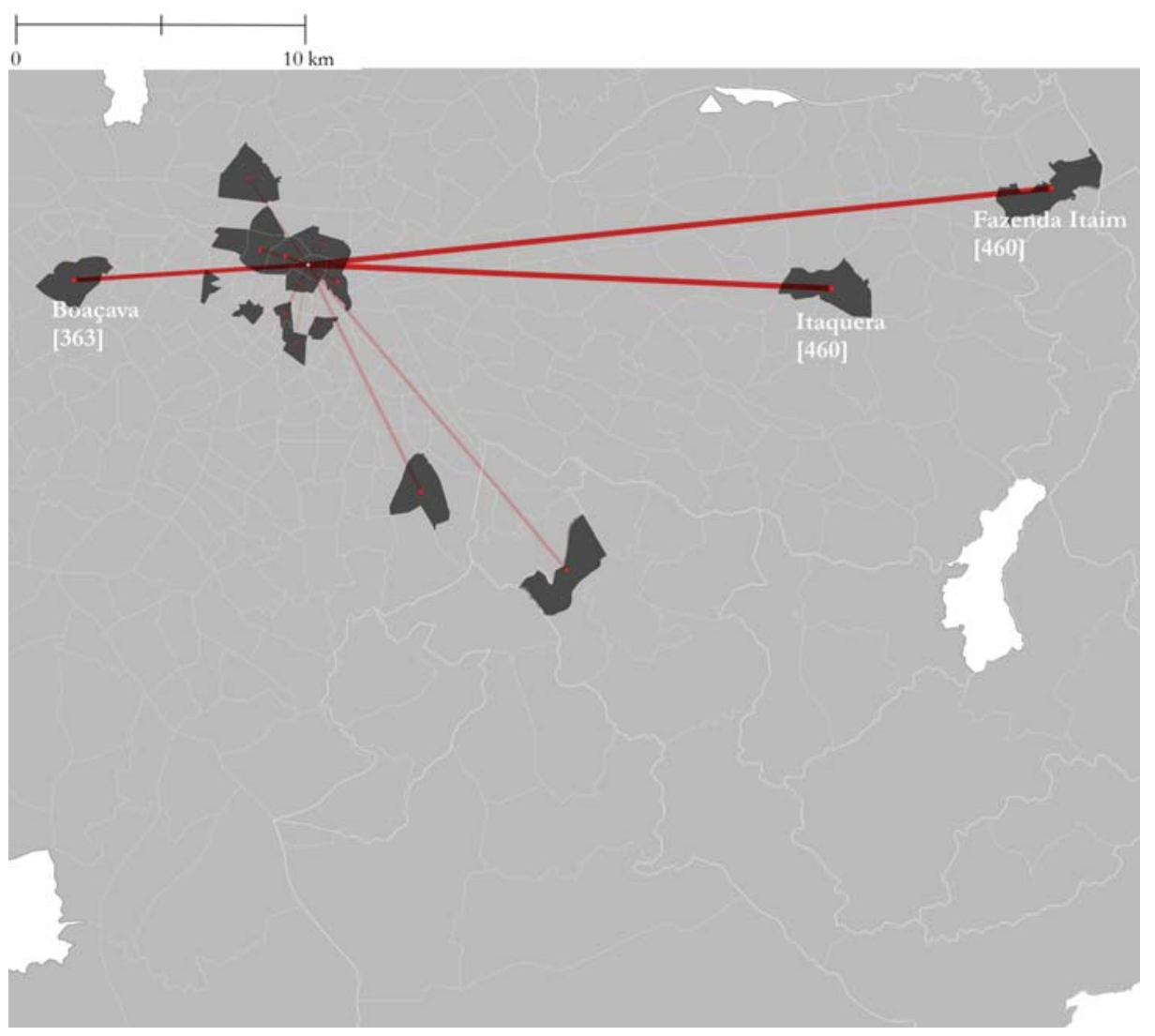

Mapa 85. Principais vetores de viagens atraídas por lazer para a área da Luz.

Mapa elaborado pela própria autora.

Fonte: SÃO PAULO (ESTADO), METRO, 2007; CEM, 2007b.
OUC Nova Luz

Principais vetores de viagens atraídas

LAZER

zonas de destino

zona de origem

vetor das viagens

sem viagens

com viagens

sem dados

3.000

1.500

500 


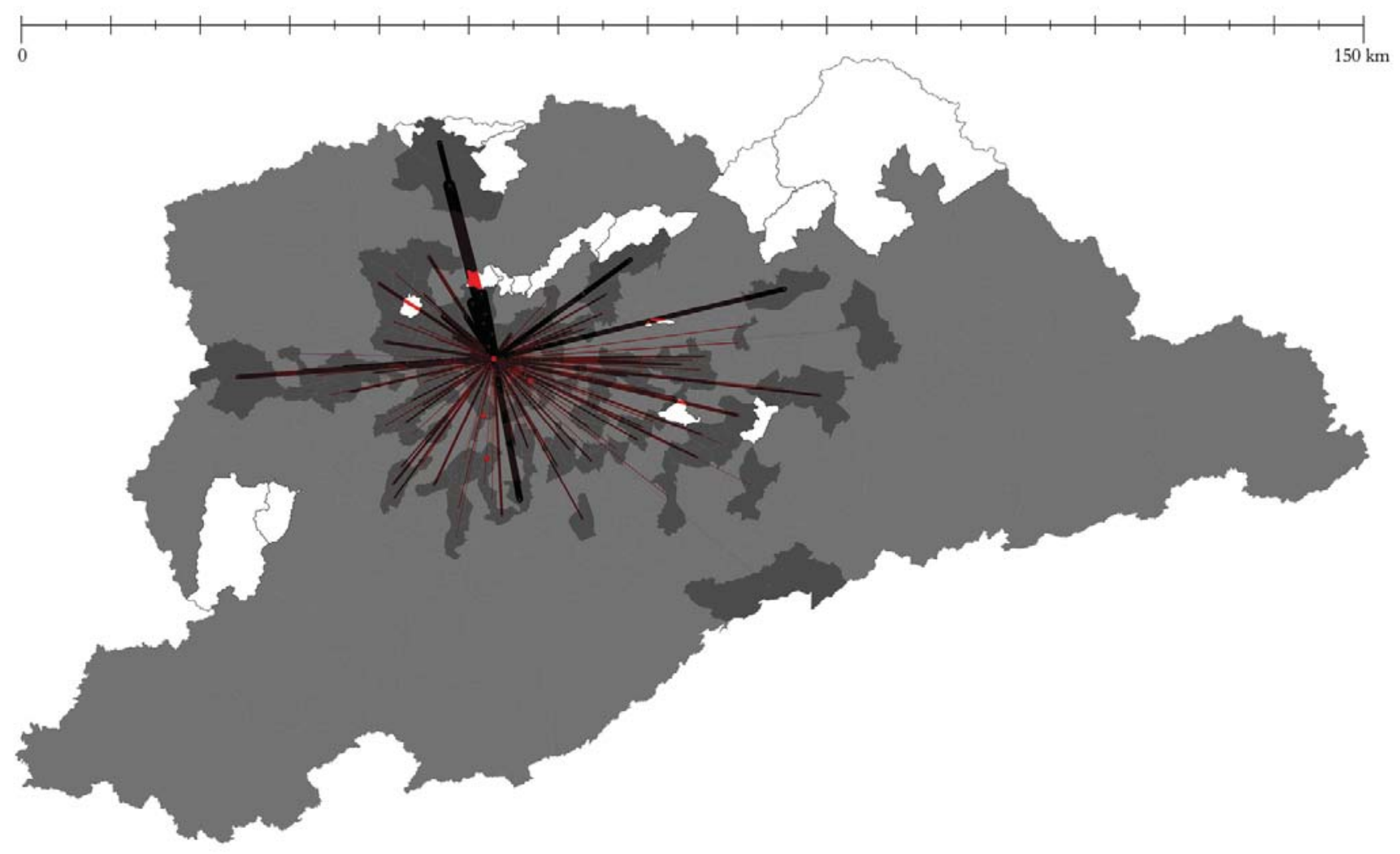

Viagen atraídas por trabalho à área da OU Água Branca

0 - 80 viagens

80 - 329 viagens

329 - 842 viagens Operações Urbanas

Mapa 86. Vetores de viagens atraídas por trabalho na OUC Água Branca.

Mapa elaborado pela própria autora.

Zonas sem dados

Fonte: SÃO PAULO (ESTADO), METRO, 2007; CEM, 2007b. 


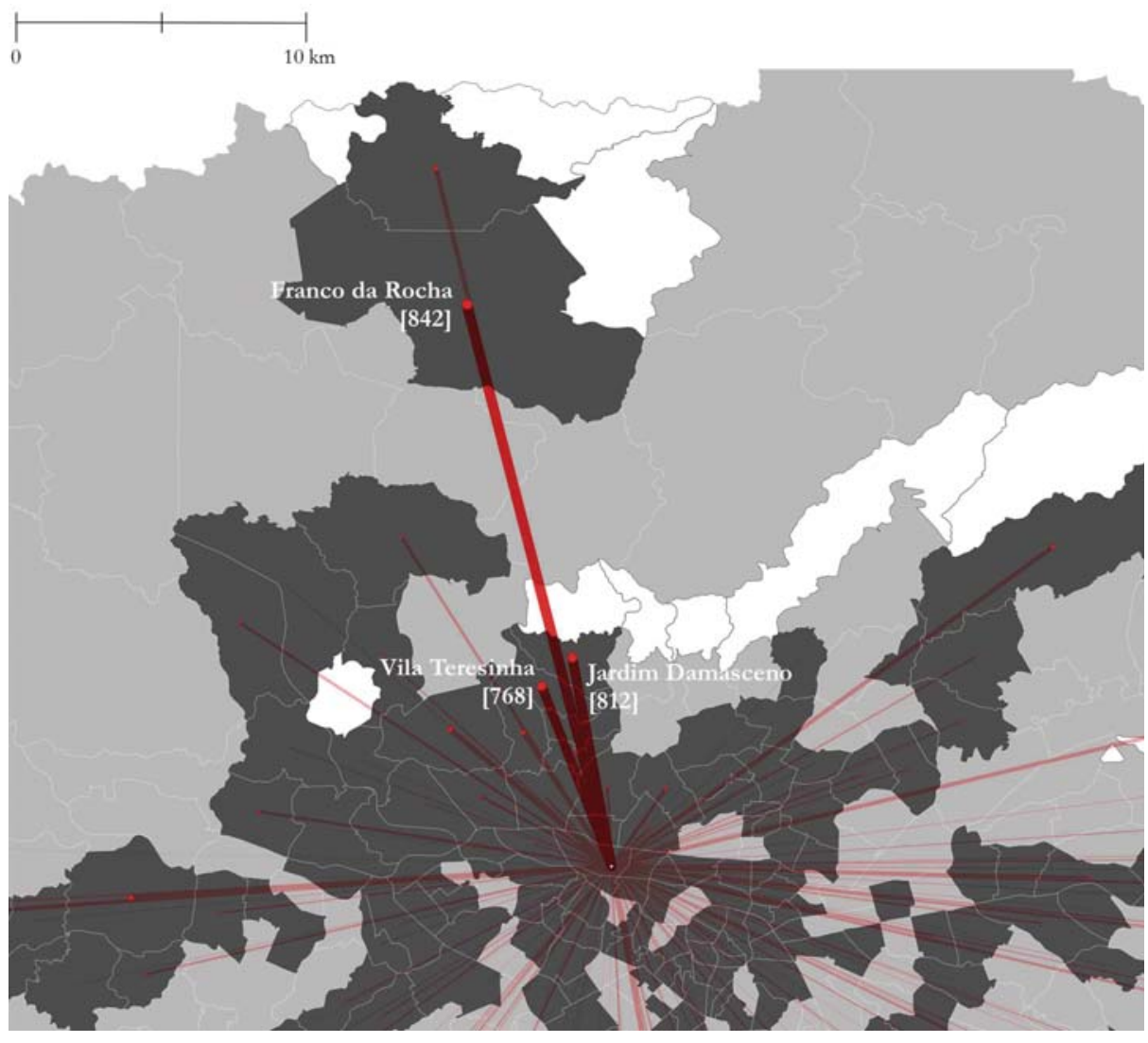

Mapa 87. Principais vetores de viagens atraídas por trabalho na OUC Água Branca.

Mapa elaborado pela própria autora.

Fonte: SÃO PAULO (ESTADO), METRO, 2007; CEM, 2007b

\section{OUC Água Branca}

Principais vetores de viagens atraídas

TRABALHO

zonas de destino

zona de origem

vetor das viagens

sem viagens

com viagens

sem dados

3.000

1.500 (2)

500 


\section{O Arquipélago, o grid e os fluxos}

\section{Efeitos da concentração e da dispersão}

De acordo com as análises empíricas apresentadas no Capítulo 3, foi possível apontar para os padrões de concentração ou dispersão das redes de infraestrutura da RMSP.

A análise da rede de energia, mediante verificação dos indicadores de continuidade de fornecimento, mostra um padrão de 
cobertura dispersa, porém com padrões de qualidade concentradas nas áreas urbanas centrais mais consolidades e de maior renda.

O padrão de cobertura do gás canalizado é disperso, apesar de em menor grau se comparado à rede de energia, porém o número de consumidores entre os municípios que compõem a RMSP, assim como o número e o volume do uso alternativo de gás (por exemplo, para a cogeração), se faz num padrão claramente concentrador, sendo o município de São Paulo aquele que apresenta os maiores volumes e as melhores condições de acesso.

Quanto à rede de abastecimento de água, tem-se um padrão de cobertura bastante disperso, porém, mais uma vez, verifica-se que os padrões de qualidade são bastante piores nas áreas mais periféricas e melhores nas áreas mais centrais.

A rede de coleta de esgoto apresenta um padrão menos abrangente que as primeiras, porém, quanto se trata do tratamento de efluentes e infiltração das bacias, verifica-se um padrão concentrador dos melhores índices de tratamento nas áreas de maior renda. Porém, as estações de tratamento de esgoto são poucas e localizadas, como regra, em áreas menos valorizadas da Metrópole. Como o tratamento não se dá no local da coleta, e essa última por sua vez é ainda incipiente, o padrão desses serviços é relativamente excludente. Vale lembrar que o serviço de esgoto depende do empenho de gestão da cidade como um todo, não sendo do interesse do usuário individual. Uma vez que o esgoto é 
afastado de seu entorno, o indivíduo deixa de se preocupar com o que decorre com seus efluentes.

A análise das redes de telefonia, apesar de mais superficiais, devido à elevada agregação de dados, apresenta uma cobertura dispersa e uma qualidade concentrada nos municípios mais internos a RMSP.

Já a rede de pavimentação e iluminação segue um padrão de acesso disperso, que acompanha o crescimento urbano horizontal e as maiores densidades populacionais líquidas em áreas periféricas da RMSP.

Finalmente, a análise das redes de transporte indica duas tendências contrastantes. Ao mesmo tempo em que se verifica o efeito de dispersão do modal de transporte coletivo de ônibus, acompanhando o crescimento horizontal das áreas urbanizadas, e alcançando com mais homogeneidade as áreas de menor renda da metrópole, o modal metroviário é oferecido de maneira mais concentrada nas áreas de maior renda e empregos. Obviamente, algumas linhas alcançam áreas periféricas, ao exemplo da Linha 3 vermelha (que avança pela Zona Leste), ou da Linha 2 verde (que avança a sudeste), porém, neste caso, o alcançe não é suficiente para promover um acesso deste recurso mais homogêneo em relação ao território da metrópole e às áreas de maior densidade líquida.

Com relação aos dados socioeconômicos, os padrões verificados são altamente concentradores. As maiores taxas de emprego, as maiores rendas médias e o maior número de lançamentos imobiliários são 
verificados nas áreas urbanas mais centrais e consolidadas, com maior cobertura e qualidade de infraestrutura. As maiores densidades populacionais líquidas, entretanto, encontram-se nas áreas periféricas.

Assim, fica claro que as áreas urbanizadas centrais da RMSP concentram as melhores condições de acesso, cobertura e qualidade das redes de serviços infraestruturais, sendo válido também o contrário, ou seja, as áreas mais periféricas, quanto às delimitações da região, concentram as piores condições de acesso, cobertura e qualidade das redes de infraestrutura. Consequentemente, os padrões de distribuição das redes de serviços de infraestrutura acabam se consolidando em torno de um padrão bastante previsível, que acompanha a previsibilidade da definição dos perímetros de reurbanização (as operações urbanas), exatamente naqueles espaços melhor servidos.

Assim, este estudo aponta para um paradoxo, que só pode ser revertido por meio de instrumentos urbanísticos que ofereçam soluções que levem em consideração uma análise mais aprofundada quanto às características socioeconômicas e técnicas, tais como as realizadas no processo desta pesquisa.

Nesse contexto, a importância de um planejamento urbano integrado, concebido na forma de uma agenda de regeneração - que considere como parte indissociável de seu corpo as fontes que geram os recursos naturais que alimentam a cidade e as veias que distribuem esses recursos, tanto por vias aéreas quanto nas suas camadas mais subterrâneas -, se faz fundamental no sentido de apontar para o desenvolvimento de cidades mais democráticas e sustentáveis. 


\section{Justiça urbana}

Por meio da pesquisa conceitual e empírica desta tese, foi possível delinear as heterogeneidades na provisão e qualidade dos serviços urbanos da RMSP, em paralelo com o desenho das características socioeconômicas do território estudado. Compreendeu-se, nesta tese, tal como defendido por Sen (2000), que o desenvolvimento de um país, assim como um território que possui os atributos que sobrepujam os de uma metrópole (macrometrópole), está essencialmente ligado às oportunidades que ele oferece à população de fazer escolhas e exercer sua cidadania. E isso inclui não apenas a garantia dos direitos sociais básicos, como saúde e educação, mas também segurança, liberdade, habitação e cultura $^{38}$. Segundo Sen (ibidem, p.3, tradução nossa):

Vivemos um mundo de opulência sem precedentes, mas também de privação e opressão extraordinárias. O desenvolvimento consiste na eliminação de privações de liberdade que limitam as escolhas e as oportunidades das pessoas de exercer ponderadamente sua condição de cidadão.

De acordo com a revisão bibliográfica, ficou claro que o acesso a classes mínimas de cobertura e qualidade de serviços infraestruturais se

\footnotetext{
${ }^{38}$ É importante observar que reconhece-se que a inserção de novas digressões teóricas no capítulo final de conclusões não é usual em teses. No entanto, a inserção de elementos de justiça social de Sen discutido neste último capítulo justifica-se para contextualizar o conteúdo socialmente distributivo da infraestrutura.
} 
estabelece como um ambiente constitucional que possibilita aos cidadãos o exercício de sua liberdade de escolha e o desenvolvimento de novas oportunidades.

Segundo Green (2012), o sentimento que a pessoa tem o direito a alguma coisa é muito mais poderoso do que simplesmente a necessidade ou a vontade desta de o possuir, pois implica que alguém tem o dever de responder. Direitos são garantias a longo prazo, um conjunto de reivindicações estruturais que permitem às pessoas, particularmente as mais vulneráveis e excluídas da sociedade, de fazerem exigências àquelas que estão no poder. Estas, por sua vez, têm a responsabilidade de respeitar, proteger e cumprir os direitos daqueles mais vulneráveis. Portanto, os direitos estão naturalmente ligados às noções de cidadania, participação e poder.

No entanto, os direitos não são suficientes. Segundo Green (ibidem), nas palavras do economista indiano Amartya Sen, os indivíduos precisam de capacidades - de direitos e da capacidade de exercê-los uma habilidade que é posta em prova quando as pessoas são desprovidas, analfabetas, destituídas, doentes, quando não possuem acesso a informações vitais, ou mesmo, vivem com temor da violência.

Ter o 'direito' de ir à escola, nesse sentido, não é de alguma utilidade, por exemplo, para as meninas que sofrem a pressão das tarefas domésticas, o preconceito no lar ou na comunidade, se são as últimas na 
fila das refeições em família; o que significa que elas acabam por passar os seus dias com fome, limpando ou cuidando de irmãos mais novos. Assim, as capacidades determinam o que as pessoas podem ou não fazer, e o que elas podem ou não ser. A habilidade de atingir segurança material por meio do trabalho produtivo é um aspecto crucial de tais capacidades. (SEN, 2000)

Em seus estudos, Sen revela que, em muitos casos de fome, a falta de abastecimento de alimentos não havia sido significativamente reduzida. Ao contrário, em Bengala (na Índia) por exemplo, a produção de alimentos do ano de maior fome foi constatada como a mais alta em relação aos períodos anteriores. Assim, os fatores que levariam à fome são apontados como fatores sociais e econômicos, tais como salários em declínio, desemprego, o aumento dos preços e a má-distribuição de alimentos, não necessariamente a produção de alimentos.

Claro que a problemática da fome não foi tratada diretamente nesta tese, porém a discussão da falta de recursos como a responsável pela problemática de desenvolvimento se aplica aos argumentos desta tese. Problemas infraestruturais não são necessariamente gerados pela falta do recurso. Por exemplo, para a energia, o problema pode ser produzido no desenho incipiente, pouco contingente, das redes de transmissão e distribuição, como discutido nas entrevistas (capítulo 3.2). 
Uma abordagem que se refere às capacidades das redes, desse modo, se centraria na liberdade positiva, na capacidade real de uma pessoa ter acesso a 'alguma coisa', ou de ser 'alguém', em detrimento de abordagens negativas, que são comuns nas economias de serviços, de se concentrarem em princípios de não interferência. $\mathrm{Na}$ fome de Bengala, citando o mesmo exemplo, a liberdade 'negativa' dos trabalhadores rurais de acesso a compra de mantimentos não foi afetada. No entanto, eles ainda passam fome, porque não são positivamente livres, não possuem as capacidades de escapar da morbidade, eles foram 'ensinados' (ou não instruídos) a não possuírem as funções de cultivar, ou de buscar seu nutrimento.

A revolucionária contribuição de Sen para a economia do desenvolvimento e dos indicadores sociais é o conceito de 'capacidade', desenvolvido em seu artigo Equality of What (da tradução nossa Igualdade de quê). Ele argumenta que os governos devem ser medidos contra as capacidades concretas de seus cidadãos, já que os modelos de desenvolvimento top-down (de cima para baixo) serão sempre trunfo dos direitos humanos, enquanto a definição dos termos não for continuamente posta à prova (o direito é algo que deve ser fornecido aos cidadãos ou simplesmente não pode ser arrancado?).

Nos Estados Unidos, por exemplo, os cidadãos têm o 'direito' hipotético de voto. Para Sen, esse conceito é bastante vazio, pois, para que 
os cidadãos tenham a capacidade de votar, eles deveriam primeiro possuir 'funcionamentos', desde a disponibilidade de educação até a possibilidade de transporte para as urnas, por exemplo. Somente quando esses obstáculos são removidos, pode-se dizer que o cidadão realmente votou por escolha pessoal. Mesmo assim, caberia à cada sociedade a concepção de uma lista de recursos mínimos que devem ser garantidos pela referida sociedade.

Para o exemplo do Brasil, em que não só o cidadão tem direito ao voto, mas também tem a obrigação de fazê-lo, essa discussão é ainda mais relevante e pertinente. Quais os 'funcionamentos', usando o termo de Sen, que garantem que a agenda do partido, ou o candidato votado, tenha sido selecionada por uma escolha pessoal? A questão das capacidades, possibilitadas mediante ao acesso às facilidades, se torna aqui um elemento fundamental que intervém no funcionamento das dinâmicas urbanas.

\section{Interrupções e reprodução da desigualdade}

Seguindo essa lógica, no subcapítulo 2.8 - O papel dos projetos urbanos na [re]estruturação metropolitana - indaga-se: pode a determinação de infraestruturas urbanas tornar-se a força integradora que articula pontos nodais, tornando-se o principal elemento de estímulo 
das dinâmicas metropolitanas? Segundo os estudos teóricos e empíricos realizados ao longo dessa tese, acredita-se que sim.

De modo geral, mediante a análise empírica das localizações dos projetos de operações urbanas (nesta tese definidos como projetos de renovação urbana) versus as características socioeconômicas e de capacidades de acesso a serviços de infraestrutura (conforme subcapítulos 2.9 e 3.3), o planejamento e as políticas parecem favorecer as elites econômicas mais capacitadas. Nos países em desenvolvimento, esse padrão segregacionista é frequentemente associado a uma hegemonia histórica e cultural, o que agrava os aspectos intergeracionais da exclusão urbana que levam ao particionamento espacial e à gentrificação. (UNHABITAT, 2010 p.129 tradução nossa)

Porém, intervenções nas redes de infraestrutura possibilitadas por meio de agendas, planos e projetos coordenados de regeneração urbana, tal como verificado no subcapítulo 2.9 , têm o potencial de articular tecidos fragmentados e segregados às dinâmicas metropolitanas, de forma a inserir comunidades e áreas carentes à economia urbana, sem que necessariamente, novas áreas da metrópole sofram deseconomias e desinvestimentos.

Ao contrário, caso as dinâmicas, as articulações e os fluxos da metrópole não sejam considerados no processo de diagnóstico e concepção de planos de reurbanização ou renovação urbana, 
consequentemente crescerão-se os riscos dos mesmos reproduzirem padrões de desigualdade, de forma a comprometer o desenvolvimento da metrópole, e terem os seus objetivos primeiros dissipados no grid.

Recordando o exemplo britânico analisado no subcapítulo 2.3 Implicações da privatização e a regulação dos serviços públicos, identificou-se que se continua por ignorar a importância dos serviços de infraestrutura providos pelo setor privado no processo de declínio de territórios urbanos, sendo provável que a retirada destes serviços acabaria por minar as áreas de regeneração e, assim, contribuir para a desestabilização de comunidades. Nesse exemplo, percebeu-se que há diálogo insuficiente entre as equipes de projeto de regeneração e aqueles que entregam os serviços dos setores privados; e quando estes estão envolvidos como parceiros nos projetos de regeneração, seu envolvimento é convergente à entrega dos seus serviços. Assim, percebese uma clara dissociação entre as partes, que facilmente pode ser replicada para os projetos de renovação urbana da RMSP.

Esse método insular, que analisa as carências locais de forma confinada, comprova a hipótese desta tese de que projetos de renovação urbana em cidades em desenvolvimento, que integram melhorias em relação à cobertura e qualidade de infraestrutura urbana - diferenciadas em relação ao entorno - tendem a perder as qualidades intrínsecas que os diferenciam, sendo os seus benefícios atenuados e dissipados no território metropolitano. 
Por conseguinte, impõe-se como condição fundamental de preenchimento dos objetivos da regeneração urbana que se garantam condições equânimes de acesso à infraestrutura urbana na área de influência da intervenção.

\section{Os alcançes da autonomia e as perspectivas futuras}

As intervenções locais de regeneração podem ser laboratórios de soluções inovadoras em relação à oferta e demanda de serviços em rede, em uma perspectiva de maior sustentabilidade. A disseminação de soluções descentralizadas como geração distribuída de energia elétrica à base de gás natural ou fontes renováveis, sistemas inteligentes de iluminação pública ou unidades descentralizadas de reuso de água, dentre outros, tende a ser induzida por iniciativas em escala local. Sem prejuízo das necessárias condições de integração entre a área objeto de regeneração e o contexto metropolitano, experiências inovadoras em infraestrutura podem ser viabilizadas precisamente a partir de zonas mais ricas, com maior propensão a pagar pelo custo inicial da inovação.

As experiências inovadoras acima constituem um mix de ações pelo lado da oferta e pelo lado da demanda. Elas não se situam isoladamente nos respectivos domínios de oferta e demanda, mas na interface de articulação recíproca entre ambas. 


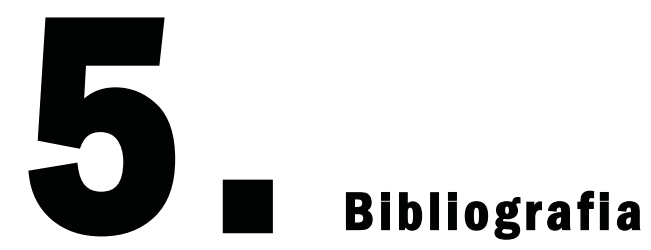


ALBRECHTS, L.; MANDELBAUM, S. The network society: a new context for planning. London: Routledge; 2005. 347 p.

ALVES, H.P. da F. Vulnerabilidade socioambiental na metrópole paulistana: uma análise sociodemográfica das situações de sobreposição espacial de problemas e riscos sociais e ambientais. Revista Brasileira de Estudos de População, São Paulo, v. 23, n. 1, p. 43-51, jun. 2006.

ALVIM, A.T.B.; CASTRO, L.G.R. Avaliação de políticas urbanas: contexto e perspectivas. São Paulo: SciELO Editora Mackenzie; 2010. 145 p.

AMIN, A. Collective culture and the urban public space. City, London, v. 12, n.1, p. 22, 2008.

ANDERSEN, H.S. Urban sores: on the interaction between segregation, urban decay and deprived neighbourhoods. Ashgate Publishing, Ltd.; 2003.

ANELLI, R.L.S. Redes de mobilidade e urbanismo em São Paulo: das radiais/perimetrais do plano de avenidas à malha direcional PUB. Arquitextos, São Paulo, ano 7, n. 082.00, Vitruvius, mar. 2007a. Disponível em: <http://www.vitruvius.com.br/revistas/read/arquitextos/07. 082/259>. Acesso em: 10 jun. 2013.

Urbanização em rede: os corredores de atividades múltiplas do PUB e os projetos de reurbanização da EMURB (1972-82). Arquitextos, São Paulo, ano 8, n. 088.01, Vitruvius, set. 2007b. Disponível em: <http://www.vitruvius.com.br/revistas/read/arquitextos/08. 088/204>. Acesso em: 10 jun. 2013.

\section{ARUP. London Thames Gateway Heat Network.}

Disponível

em:

$<$ http://www.arup.com/Projects/London_Thames_Gate way_Heat_Network.aspx>. Acesso em: 13 abr. 2015.

ATELIER JEAN NOUVEL. Disponível em: <http://www.jeannouvel.com>. Acesso em: 6 abr. 2013.

AURELI, P.V. The possibility of an absolute architecture. Cambridge, Mass.: MIT Press; 2011.

BAKKER, K. Archipelagos and networks: urbanization and water privatization in the South. Geographical Journal. 1, v.169, n. 4, p. 328-41, dez. 2003.

BANCO NACIONAL DE DESENVOLVIMENTO ECONÔMICO E SOCIAL. Seminário Internacional Parceria Público-Privada (PPP). Ministrado por Carlos Lessa. Visitado em 16 nov. 2008.

BERNINI, E.J. J’Accuse. Smart Energy, São Paulo, n. 7, jul./ago. 2011.

Infraestrutura urbana: energia elétrica e a integração das redes infraestruturais. 2012. Entrevista concedida a Andrea Vosgueritchian.

A infraestrutura de redes de serviços públicos urbanos e a cidade inteligente. Metering 
International America Latina, São Paulo, v. 16, p. 12-4, jul. 2012.

Os reguladores e a infraestrutura urbana. O Estado de São Paulo. São Paulo, 9 abr. 2012. Editorial Opinião, p.2.

BETTER BANKSIDE. Disponível em: <http://betterbankside.co.uk/>. Acesso em: 24 jun. 2015.

BOCCUZZI, C. Infraestrutura urbana e smart grids. 2013. Entrevista concedida a Andrea Vosgueritchian.

BRASIL. ANATEL - Agência Nacional de Telecomunicações. Indicadores de telecomunicações. [S.l.]: ANATEL, 2014. Disponível em: <http://sistemas.anatel.gov.br/sqp/qualidade/principal/cons ulta.asp >. Acesso em: out. 2014.

Indicadores de telecomunicações. [S.l.]: ANATEL, 2014. Disponível em: <http://sistemas.anatel.gov.br/sqp/qualidade/principal/cons ulta.asp >. Acesso em: out. 2014.

Indicadores de energia. [S.1]: ANATEL,

$2014 . \quad$ Disponível em: $<$ http://sistemas.anatel.gov.br/sqp/qualidade/principal/cons ulta.asp >. Acesso em: jan. 2014.

BRASIL. Lei Complementar Federal no 14, de 8 de junho de 1973. Estabelece as regiões metropolitanas de São Paulo, Belo Horizonte, Porto Alegre, Recife, Salvador, Curitiba,
Belém e Fortaleza. Diário Oficial da União. Brasília, DF: Senado, 1973.

Constituição (1988). Constituição da República Federativa do Brasil. Brasília, DF: Senado, 1988.

Lei $\mathrm{n}^{\circ}$ 10.257, de 10 de julho de 2001.

Regulamenta os arts. 182 e 183 da Constituição Federal, estabelece diretrizes gerais da política urbana e dá outras providências. Constituição (1988). Constituição da República Federativa do Brasil. Brasília, DF: Senado, 2001.

BRASIL. Ministério das Cidades. Sistema Nacional de Informações sobre Saneamento. Indicadores Municipais. [S.l.]. 2013.2 Disponível em: $<$ http://app.cidades.gov.br/serieHistorica/>. Acesso em: jan. 2015

CALDEIRA, T.P. do R. Cidade de muros: crime, segregação e cidadania em São Paulo. São Paulo: Editora 34/EDUSP, 2000. 408 p.

CARMON, N.; BARON, M. Reducing inequality by means of neighborhood rehabilitation. Urban Studies, n. 31, p. 1.465-79, 1994.

CASTELLS, M. A sociedade em rede. São Paulo: Paz e Terra, 1999.

A questão urbana. São Paulo: Paz e 
A sociedade em rede - A Era da

Informação: Economia, Sociedade e Cultura. v. 1. São Paulo: Paz e Terra, 2009b.

CENTRO DE ESTUdOS DA METRÓPOLE CEM. Contornos perimétricos e dados dos 162 distritos da RMSP (shape) obtidos conforme quadro políticoadministrativo de 01/01/2001. São Paulo: CEM, 2007a. Disponível

em:

$<$ http://www.fflch.usp.br/centrodametropole/716>. Acesso em: nov. 2014.

. Contornos perimétricos e dados dos 39 municípios da RMSP (shape) obtidos conforme quadro político-administrativo de 01/01/2001. São Paulo: CEM, 2007b.

Disponível

em:

<http://www.fflch.usp.br/centrodametropole/716>. Acesso em: nov. 2014.

Base de Lançamentos Imobiliários

Residenciais na Região Metropolitana de São Paulo (1985-2013). São Paulo: CEM, 2014a.

\section{Base de Lançamentos Imobiliários}

Comerciais na Região Metropolitana de São Paulo (19852013). São Paulo: CEM, 2014b.

CESAR, R.C.; FRANCO, L.R.; BRUNA, P.V. Área da Luz: renovação urbana em São Paulo. São Paulo: Perspectiva, 1977.

CHEVAlieR, L. The Assassination of Paris. University Of Chicago Press, 1994.
COMPANHIA DE GÁS DE SÃO PAULO - COMGÁS. Rede de gás da Região Metropolitana de São Paulo (shape). São Paulo: Comgás, 2015 [CD-ROM].

CONDIT, C.W. Chicago 1930-70: building, planning and urban technology. University of Chicago Press, 1974.

COSTA FREIRIA, R. Direito das Águas: aspectos legais e institucionais na perspectiva da qualidade - Ambiental Âmbito Jurídico. Disponível em: <http://www.ambitojuridico.com.br/site/index.php?n_link =revista_artigos_leitura\&artigo_id=1738>. Acesso em: 6 jun. 2015.

COUCH, C. Urban renewal: theory and practice. New York: Palgrave Macmillan, 1990.

COUCH, C.; FRASER, C.; PERCY, S. Urban regeneration in Europe. Oxford: Wiley-Blackwell, 2003.

COUCH, C; SYKES, O.; BÖRSTINGHAUS, W. Thirty years of urban regeneration in Britain, Germany and France: the importance of context and path dependency. Progress in Planning, v. 75, n. 1, p. 1-52, jan. 2011. Print.

COUTARD, O. Réseaux de communications. Marchés et territoires (Nicolas Curien et Gabriel Dupuy). Flux, v. 15, n. 36, p. 83-6, 1999.

The governance of large technical systems. London: Routledge, 1999. 320 p.

COUTARD, O.; RUTHERFORD, J. From networked to post-networked urbanism: new infrastructure 
configurations and urban transitions. France: Supported by the Chaire Ville - École des Ponts ParisTech, 2012.

CURIEN, N.; DUPUY, G. Réseaux de communications. Marchés et territoires. Paris: Presses de l'École Nationale des Ponts et Chaussées, 1997. 176 p.

DAVIS, M. Cidade de quartzo. São Paulo: Boitempo Editorial;, 2009. 432 p.

DE SOTO H. The mystery of capital: why capitalism triumphs in the west and fails everywhere else. Reprint edition. New York, NY: Basic Books, 2003. 288 p.

DEWITT, K. City's redevelopment recalls Lee. Yale Daily News. 27 set. 2005. Disponível em: $<$ http://yaledailynews.com/blog/2005/09/27/citysredevelopment-recalls-lee/>. Acesso em: 22 mai. 2013.

DUPONT, L. Étude sur les Halles. L'Architecture d'Aujourd'hui. jun. n. 352, p. 44-55, 2004.

DUPUY, G. Vers une théorie territoriale des réseaux: une application au transport urbain. Geo, v. 96, n. 538, p. 65879, 1987.

. L'urbanisme des reseaux: theories et methodes. Cidade: A. Colin; 1991. 198 p.

Internet: une approche géographique à l'échelle mondiale. Flux, 1, v. 58, n. 4, p. 5-19, dez. 2004.

EMPRESA PAULISTA DE PLANEJAMENTO METROPOLITANO DE SÃO PAULO - EMPLASA. Mapa de Uso e Ocupação do Solo da Região Metropolitana de São Paulo (shape). São Paulo: EMPLASA, 2015 [CD$\mathrm{ROM}$ ]. Nota de Crédito: "Mapa de Uso e Ocupação do Solo da RMSP, elaborado pela Empresa Paulista de Planejamento Metropolitano S/A - EMPLASA, com financiamento do FEHIDRO".

EZECHIELI, C. Shifting Boundaries: Territories, Networks and Cities. Mimeo, 2008.

FOCAULT, M. Society must be defended: lectures at the Collège de France, 1975-76. Editado por Alessandro Fontana e François Ewald. Traduzido para o inglês por David Macey. New York: Picador, 2003.

FREESTONE, R. Urban Planning [Western] History of. Elsevier Science, p. 16.058-63, 2001.

FROMONOT, F. La campagne des Halles: les nouveaux malheurs de Paris. Paris: La Fabrique éditions, 2005.

GANDY, M. Planning, anti-planning and the infrastructure crisis facing metropolitan Lagos. Urban Studies, v. 43, n.2, 2006.

GIANNOPOUlOS; GILlESPIE, A. Transport and communications in the New Europe, Belhaven. London: 1993.

GOMES, F.A.M. A eletrificação no Brasil. Caderno História e Energia. Eletropaulo. São Paulo, 1986.

GRAHAM, S. Constructing premium network spaces: reflections on infrastructure networks and contemporary urban development. International Journal of Urban and 
Regional Research - Joint Editors and Blackwell Publishers Ltd. mar., v. 24, n. 1, p.183-200 (a), 2000.

Introduction: cities and infrastructure networks. International Journal of Urban and Regional Research - Joint Editors and Blackwell Publishers Ltd. mar., v. 24, n. 1, p. 114-9 (b), 2000.

\section{The Spectre of the Splintering}

Metropolis. Elsevier Science, v. 18, n. 6, p. 365-8, 2001.

Disrupted cities: when infrastructure fails. Routledge, 2009. 208 p.

GRAHAM, S.; MARVIN, S. Splintering Urbanism: Networked Infrastructures, Technological Mobilities and the Urban Condition. Routledge, 2001.

GREEN, D. From poverty to power: how active citizens and effective states can change the world [Internet]. $2^{\text {a }}$ ed. Rugby, UK: Practical Action Publishing in association with Oxfam GB for Oxfam International, 2012.

HALL, S. Building confidence: the emergence of the Bankside urban forest project: process case study. The Author (Unpublished), 2010.

HARVEY, D. The urbanization of capital. Blackwell: Oxford, 1985.

Spaces of hope. Berkeley: University of California Press, 2000.
HUMPHREY, C. Rethinking Infrastructure: Siberian Cities and the Great Freeze of January 2001. Schneider, J.; Susser, I., editors. Wounded cities: destruction and reconstruction in a globalized world Conference. p. 91.110, 2003.

\section{INFORMAÇÕES DOS MUNICÍPIOS PAULISTAS - \\ IMP. SEADE. Disponível em:}

<http://www.imp.seade.gov.br/frontend/>. Acesso em: 1 jul. 2015.

INDEX OF MULTIPLE DEPRIVATION. london.gov.uk. Disponível em:

$<$ http://data.london.gov.uk/datastore/package/indicesmultiple-deprivation-borough>. Acesso em: 17 mai. 2013.

INSTITUTO BRASILEIRO DE GEOGRAFIA E ESTATÍSTICA - IBGE. Base de informações do Censo Demográfico 2010: Resultados do Universo por setor censitário. Rio de Janeiro: IBGE, 2011.

Jacobs J. The Death and Life of Great American Cities. Vintage Books ed. Vintage Books; 1993.

Censo Demográfico 2010. [S.1]. 2010.

Disponível em: <www.censo2010.ibge.gov.br>. Acesso em: mar. 2013.

INSTITUTO DE ENGENHARIA. Simpósio - O Subterrâneo da Cidade e as Redes de Infra-Estrutura Recomendações. São Paulo, Instituto de Engenharia, fevereiro 2006. 
JOURAVLEV, A. Drinking water supply and sanitation services on the threshold of the XXI century. Santiago do Chile: Cepal, 2004.

JUNIOR, G.; CASTRO, A. de; PAGANINI, W. da S. Conceptual aspects of the regulation of water and sewage services in Brazil. Engenharia Sanitária e Ambiental, Rio de Janeiro, v. 14, n. 1, p. 79-88, mar. 2009.

KEATING, W.D. Neighbourhood Revitalization and Community Development. International Encyclopedia of the Social \& Behavioral Sciences, p. 10.494-9, 2001. Web.

KEINER, M., et al. Managing urban futures: sustainability and urban growth in developing countries. CALDEIRA, T.; HOLSTON, J. Brazil. State and urban space in Brazil: from modernist planning to democratic interventions. Hampshire, England: Ashgate, 2005.

LEES, L.; SLATER, T.; WYLY, E. Gentrification. New Ed. New York: Routledge, 2007.

LITTLEFIELD, D. Bankside Urban Forest. Architecture Design, 1, v. 82, n. 1, p. 44-9, jan. 2012.

.(Re)generation: place, memory, identity. Architecture Design, 1, v. 82, n. 1, p. 8-13, jan. 2012.

MARCUSE, P. The Ghetto of Exclusion and the Fortified Enclave New Patterns in the United States. American Behavioral Scientist, 1, v. 41, n. 3, p. 311-26, nov. 1997.
MARQUES, E. (org.). A metrópole de São Paulo no século XXI. Espaços, heterogeneidades e desigualdades. São Paulo: Editora Unesp/CEM, 2015. 458 p.

MARTINI, J.S.C. Infraestrutura urbana: a integração das redes infraestruturais e o modelo do campus da Universidade de São Paulo. 2013. Entrevista concedida a Andrea Vosgueritchian.

MAYOR OF LONDON. London Heat Network Manual. Greater London Authority, London, abr. 2014, Issue n.1.

MERRIFIELD, A. Citizen's agora. The new urban question. Radical Philosophy, n. 179, p.31-5, jun. 2013.

MEYER, R.M.P.; GROSTEIN, M.D.; BIDERMAN C. São Paulo Metrópole. São Paulo: EDUSP, 2004. 290 p.

MEZA, M.T. Reabilitação da região da Luz. Centro histórico de São Paulo: Projetos Urbanos e estratégias de intervenção. Faculdade de Arquitetura e Urbanismo. Universidade de São Paulo, São Paulo, 2007.

Modern Docklands: The background to redevelopment. Survey of London: Poplar, Blackwall and Isle of Dogs [Internet]. London: London County Council, p. 686-91, 1994.

MUMFORD, L. The city in history: its origins, its transformations, and its prospects. New York, Harcourt Brace International, 1968. 
MVRDV.

Disponível

em:

$<$ http://www.mvrdv.nl/\#/projects/243leshalles > . Acesso em: 6 abr. 2013.

OMA. Disponível em: <http://oma.eu/projects/2003/leshalles>. Acesso em: 6 abr. 2013.

OXFORD DICTIONARY OF ENGLISH 3rd edition, Copyright (C 2010 by Oxford University Press

PARIS, M.D. SemPariSeine. Les Halles, The new Heart of Paris. Redevelopment of Les Halles - Paris. 2012. Disponível em: <www.parisleshalles.fr>. Acesso em: 8 mai. 2012.

PENTEADO JUNIOR, A.A. Infraestrutura urbana e a regulação da energia elétrica. 2013. Entrevista concedida a Andrea Vosgueritchian.

PFLIEGER, G., et al. The social fabric of the networked city. Lausanne, EPFL Press/Routledge, 2008. 244 p.

PINHEIRO, A.C.; SADDI, J. Direito, economia e mercados. Rio de Janeiro: Elsevier, 2005.

PORTAL DA PREFEITURA DA CIDADE DE SÃO PAULO. Disponível em: $<$ http://www.prefeitura.sp.gov.br/cidade/secretarias/infraest rutura/sp_obras/operacoes_urbanas/index.php?p=37057>. Acesso em: 25 jun. 2015.

PROGRAMA DE METAS. Programa de Metas. Disponível em: <http://planejasampa.prefeitura.sp.gov.br/metas/>. Acesso em: 24 jun. 2015.
PROJETO NOVA LUZ, São Paulo, Brasil. Projeto Urbanístico Específico (PUE). Subproduto 5.1.: PUE Consolidado. jul. 2011. São Paulo: SMDU, 2011.

\section{Projeto Urbanístico Específico (PUE).}

Subproduto 7.1.: Revisão Final de Conteúdos e Consolidação dos Ajustes Recomendados ao Projeto Urbanístico Específico e do Plano de Urbanização de ZEIS. out. 2012. São Paulo: SMDU, 2012.

Projeto Urbanístico Específico (PUE).

Subproduto 7.2.: Relatório Circunstanciado. out. 2012. São Paulo: SMDU, 2012a.

RACO, M. Assessing the discourses and practices of urban regeneration in a growing region. Geoforum, v. 34, n. 1, p. 37-55, fev. 2003.

RAQUELROLNIK (a). “Nova Luz”. Blog da Raquel Rolnik. Disponível em: <https://raquelrolnik.wordpress.com/tag/nova-luz/>. Acesso em: 13 jan. 2015.

ROBERTS, P.; SYKES, H. Urban regeneration: a handbook. London: Sage Publications Ltd., 1999.

SÃO BERNARDO DO CAMPO (Cidade), SPU - Secretaria de Planejamento Urbano e Ação Regional. Contorno perimétrico da Operação Urbana Consorciada São Bernardo do Campo. São Bernardo do Campo: SPU, 2015.

SÃO PAULO (Cidade), CGE - Centro de Gerenciamento de Emergências da Prefeitura de SP. Base de Dados dos 
Pontos de Alagamento entre 2012 e 2014. São Paulo, 2015 [CD-ROM].

SÃO PAULO (Cidade). Lei Orgânica do Município de São Paulo, de 4 de abril de 1990. São Paulo, 1990.

SÃO PAULO (Cidade). Lei no 13.430, de 13 de setembro de 2002. Esta lei institui o Plano Diretor Estratégico e o Sistema de Planejamento e Gestão do Desenvolvimento Urbano do Município de São Paulo. Plano Diretor Estratégico do Município de São Paulo. São Paulo, SP: Câmara Municipal de São Paulo, 2002. São Paulo, SP: Câmara Municipal de São Paulo, 2002.

SÃO PAULO (Cidade). Lei ${ }^{\circ} 13.399$, de $1^{\circ}$ de agosto de 2002. Esta lei dispõe sobre a criação, estrutura e atribuições das Subprefeituras no Município de São Paulo, estabelece procedimentos para sua implantação e prevê a transferência gradual de órgãos e funções da Administração Direta Municipal. Lei do Município de São Paulo. São Paulo, SP: Câmara Municipal de São Paulo, 2002.

SÃO PAULO (Cidade). Lei $\mathrm{n}^{\circ} 13.885$, de 25 de agosto de 2004. Estabelece normas complementares ao Plano Diretor Estratégico, institui os Planos Regionais Estratégicos das Subprefeituras, dispõe sobre o parcelamento, disciplina e ordena o Uso e Ocupação do Solo do Município de São Paulo. Lei do Zoneamento da Cidade de São Paulo. São Paulo, SP: Câmara Municipal de São Paulo, 2004.

SÃO PAULO (Cidade). Lei no 14.918, de 07 de maio de 2009. Autoriza o executivo a aplicar a concessão urbanística na área da Nova Luz. São Paulo, SP: Câmara Municipal de São Paulo, 2009.

SÃO PAULO (Cidade). Lei $n^{\circ}$ 16.050, de 31 de julho de 2014. Aprova a política de Desenvolvimento Urbano e revoga a Lei no 13.430/2002. Plano Diretor Estratégico do Município de São Paulo. São Paulo, SP: Câmara Municipal de São Paulo, 2014.

SÃO PAULO (Cidade), SMDU (Secretaria Municipal de Desenvolvimento Urbano), SP-Urbanismo (São Paulo Urbanismo). Contornos perimétricos das Operações Urbanas do Município de São Paulo. São Paulo: SMDU, 2015.

\section{Operação Urbana Consorciada Bairros do}

Tamanduateí. Audiências Públicas para Licenciamento Ambiental Prévio. São Paulo: SMDU, 2014. Disponível em: $<$ http://gestaourbana.prefeitura.sp.gov.br/wpcontent/uploads/2014/11/MVC_01_6V_AP_001.pdf $>$. Acesso em: dez. 2014.

Arco Tietê: perímetro proposto para os estudos de viabilidade. São Paulo: SMDU, 2013. Disponível em: $<$ http://www.prefeitura.sp.gov.br/cidade/secretarias/upload /chamadas/arco_tiete-

perimetro_a3_02_otimizado_1360328739.pdf>. Acesso em: jan. 2014.

SÃO PAULO (Estado). Lei Complementar no 1.139 , de 16 de junho de 2011. Reorganiza a Região Metropolitana da 
Grande São Paulo, cria o respectivo Conselho de Desenvolvimento e dá providências correlatas. Legislação do Estado de São Paulo. São Paulo, SP: Palácio dos Bandeirantes, 2011.

SÃO PAULO (Estado), EMTU - Empresa Metropolitana de Transportes Urbanos. Base de dados de pontos de ônibus intermunicipais da Região Metropolitana de São Paulo. São Paulo: EMTU, 2015 [CD-ROM].

SÃO PAUlO (Estado), SABESP - Companhia de Saneamento Básico do Estado de São Paulo. Base de dados de saneamento: setores e sistemas de abastecimento e bacias de escoamento. São Paulo: Sabesp, 2015 [CD-ROM].

SÃO PAULO (Estado), Secretaria da Habitação. Diretrizes para as Intervenções Urbanas - Anexo II do Edital da Concorrência Internacional 001/2014. São Paulo: 2014. Disponível

em: $<$ https://observasp.files.wordpress.com/2014/11/anexo_ii.p df $>$. Acesso em: mai. 2015

SÃO PAULO (Estado), SMA (Secretaria de Estado do Meio Ambiente), Cetesb (Companhia Ambiental do Estado de São Paulo). Base de Dados das Áreas Contaminadas e Reabilitadas da Região Metropolitana de São Paulo. São Paulo: Cetesb, 2015 [CD-ROM].

SÃO PAULO (Estado), STM - Secretaria dos Transportes Metropolitanos, METRO - Companhia do Metropolitano de São Paulo. Pesquisa Origem Destino. São Paulo: STM, 2007.
SÃO PAULO TRANSPORTES - SPTRANS. Base de dados de pontos de ônibus, linhas de ônibus e volume de frota do Município de São Paulo. São Paulo: SPTrans, 2015 [CD-ROM].

\section{SECRETARIA DE DESENVOLVIMENTO URBANO.}

Alckmin sanciona lei que reorganiza a Região Metropolitana de SP. 16 jun. 2011. Disponível em: <http://www.saopaulo.sp.gov.br/spnoticias/lenoticia.php?id $=215129 \& \mathrm{c}=5351 \& \mathrm{q}=$ Alckmin + sanciona+lei+que+reorgani $\mathrm{za}+\mathrm{a}+$ Regi\%E3o+Metropolitana+de+SP $>$. Acesso em: 27 jul. 2011.

SEN, A. Development as Freedom. Reprint edition. New York: Anchor, 2000. 384 p.

A ideia de justiça. São Paulo: Editora Companhia das Letras, 2011. 483 p.

SEURA ARCHITECTES URBANISTES. Disponível em: <http://www.seura.fr/>. Acesso em: 29 mai. 2013 e 4 jun. 2015.

SCHOENBERGER, E. The spatial fix revisited. Antipode, Oxford, v. 36, n. 3, p. 427-33, 2004.

SILVA, J.R. Os esgotos da cidade do Rio de Janeiro. 18571947. CEDAE - Companhia Estadual de Águas e Esgotos. Rio de Janeiro, 1988.

SILVA R.T. The Connectivity of Infrastructure Networks and the Urban Space of São Paulo in the 1990s. International Journal of Urban and Regional Research - 
Blackwell Publishing, Oxford, UK, v. 24, n. 1, p. 139-64, mar. 2000.

Público e privado na oferta de infraestrutura urbana no Brasil. Anuário GEDIM 2002 (Cidades, serviços e cidadania). Rio de Janeiro: Lúmen Júris, p. 53-112, 2002.

\section{Infra-estrutura urbana, tecnologia e} regulação pública no Brasil das décadas de 1880 a 1930. In: La integración del territorio en una idea de Estado, México y Brasil, 1821-1946 ed.México : Instituto de Geografía, UNAM, Instituto de Investigaciones Dr. José Maria Luis Mora, 2007, p. 379-404.

Villes, infrastructures et changements environnementaux. Questions émergentes à partir de l'analyse de São Paulo. In: Institut National de Recherche sur lês Transports et leur Securité. PMG atelier São Paulo, séminaire de travail 23 janvier 2008, Paris. Blocages des mobilités, dês services et de l'urbanisation à São Paulo. Alternatives d'une mégapole, 2008.

Integration of hydraulic infrastructure in metropolitan São Paulo. Prospects of change in a context of growing vulnerability. Geographica Helvetica. , v.66, p.92 - 99, 2011.

SMETS, P.; SALMAN, T. Countering urban segregation: theoretical and policy innovations from around the globe. Urban Studies, 1, v. 45, n. 7, p. 1.307-32. 1, jun. 2008.

SOJA, E.W. Postmodern Geographies. 2 ed. London/New York: Verso, 2011.
SOUTHWARK COUNCIL. Bankside urban forest. Disponível

em: <http://www.southwark.gov.uk/info/200189/frameworks_st rategies_and_programmes_of_work/1230/bankside_urban _forest>. Acesso em: 4 jul. 2015.

SOWA, A. Paris-Les Halles ou comment donner du coeur au ventre. L'Architecture d'Aujourd'hui, Paris, n. 352, p. 56-77, jun. 2004.

SPEAK, S.; GRAHAM, S. Service not included: social implications of private sector restructuring in marginalised neighbourhoods. London: Policy Press, 2000. 56 p.

STICA, F. Um lugar ao centro. 2011. Disponível em: $<$ https://www.youtube.com/watch?v=p36O-P-n4vk>. Acesso em: 28 mar. 2013.

SUTCLIFFE, A. L'Urbanisme des réseaux: théories et méthodes (Gabriel Dupuy). Flux, v. 8, n. 9, p. 60-1, 1992.

SWYNGEDOUW, E. Communication, mobility and the struggle for power over space. In: Transport and Communications Innovation in Europe. London: Belhaven Press, p. 305-325, 1993.

TALLON, A. Urban regeneration in the UK. Oxon: T \& F Books UK, 2009.

THE ARGUMENT FOR URBAN RENEWAL. Life in the model city: stories of urban renewal in New Haven. Disponível

em: 
<http://www.yale.edu/nhohp/modelcity/index.html>.

Acesso em: 3 jan. 2013.

"Urban Regeneration: What Can Be Done and What Should Be Avoided?" In: Istambul, 2004. International Urban Regeneration Symposium: Workshop of Kucukcekmece Distric., 57-62. Istambul: Kucukcekmece Municipality Publication, 2005.

UN-HABITAT. UNHSP. State of the World's Cities 2010/11: Cities for All: Bridging the Urban Divide. London: Earthscan, 2008.

UNITED NATIONS. World Urbanization Prospects: The 2007 Revision. Population Division of the Department of Economic and Social Affairs of the United Nations Secretariat, UN, 2007

UNITED NATIONS. World Population Prospects: The 2008 Revision And World Urbanization Prospects: The 2009 Revision. Population Division of the Department of Economic and Social Affairs of the United Nations Secretariat, UN, 2009.

UTUDJIAN, É. L’Urbanisme souterrain. Paris, 1964.
VELA G. Paris 1954-1999. Données statistiques: Population, logement, emploi. 1er. Arrondissement. Paris: Atelier Parisien d'Urbanisme; 2005.

WILLIAMS, J.; BORROWS, J.; DALY, S. Small water company regulation: choices for commissions. Florida: The NARUC Staff Committee on Water, p. 93, mar. 1998.

WISNIK, G.; et al. "Notas sobre a Sala São Paulo". In: Revista do Programa de Pós Graduação em Arquitetura e Urbanismo da FAUUSP, São Paulo, v. 9, 0.192-202, 2001.

WOODMAN, E. Are developers destroying London's South Bank? 25 out. 2013. Disponível em: <http://www.telegraph.co.uk/culture/art/architecture/10387 199/Are-developers-destroying-Londons-South-

Bank.html>. Acesso em: 29 nov. 2014.

WORPOLE, K. "The law of the forest and the freedom of the streets". openDemocracy. 2015. Disponível em: $<$ https://www.opendemocracy.net/ourkingdom/kenworpole/law-of-forest-and-freedom-of-streets $>$. Acesso em: 29 mai. 2015.

ZOLA, É. The belly of Paris. Oxford: OUP Oxford, 2009.

ZUQUIM, M. de L. Controle do uso do solo na RMSP. São Paulo: FAUUSP, 2009. 